UNIVERSIDADE DE SÃO PAULO

INSTITUTO DE GEOCIÊNCIAS

\title{
EVOLUÇÃO MAGMÁTICA DO PLÚTON PIRACAIA (SP): PARÂMETROS FÍSICO-QUÍMICOS E EVIDÊNCIAS DE MISTURA ENTRE MAGMAS MONZODIORÍTICOS E SIENÍTICOS
}

\author{
Leonardo Frederico Pressi
}

Orientador: Prof. Dr. Valdecir de Assis Janasi

\section{DISSERTAÇÃO DE MESTRADO}

Programa de Pós-Graduação em Mineralogia e Petrologia

\author{
SÃO PAULO
}

2012 
Ficha catalográfica preparada pelo Serviço de Biblioteca e Documentação do Instituto de Geociências da Universidade de São Paulo

Pressi, Leonardo Frederico

Evolução magmática do Plúton Piracaia (SP) : parâmetros físico-químicos e evidências de mistura entre magmas monzodioríticos e sieníticos. / Leonardo Frederico Pressi São Paulo, 2012 .

145 p.. : il.

Dissertação (Mestrado) : IGc/USP

Orient.: Janasi, Valdecir de Assis

1. Petrologia ígnea 2. Geoquímica I Título 


\section{AGRADECIMENTOS}

Primeiramente quero agradecer à USP, CNPq e Fapesp por terem propiciado a estrutura e financiamento para a realização de minha dissertação.

Agradeço ao Valdecir, pela orientação, apoio, incentivo, e pelos grandes ensinamentos éticos, geológicos e científicos.

Agradeço aos professores das disciplinas que cursei, onde muito aprendi, e também aos que conheci pelos corredores, cafés e defesas de teses, onde muitas conversas foram trocadas. Em especial agradeço à Adriana, Boggiani, Irene Lucelene, Rogério, Schorscher, Sílvio, Excelso. Em especial agradeço Adriana, Irene, Lucelene, Rogério e Sílvio pelo auxílio com o mestrado.

Muito importantes foram também os funcionários do Instituto, de todas as esferas (laboratórios, secretaria, biblioteca,...), que sempre se mostraram solícitos e dispostos a colaborar no que fosse necessário. Obrigado Marcos, Paulinho(s), Sandra, Zé Paulo, Tadeu, Ana Paula.

Tão importante quanto o aprendizado acadêmico adquirido ao longo destes três anos, são os inúmeros e indescritíveis momentos de engrandecimento pessoal que me foram proporcionados pelas pessoas com quem convivi de maneira mais próxima. Em especial, agradeço a Casa Brasil (Lua, Kenga, Rafa e Cofre) por terem sido minha família aqui em São Paulo. E que família!!!...quase sempre composta por inúmeros e inusitados membros efêmeros! Lua e Kenga, muito obrigado pelo imenso carinho, amizade, momentos de descontração, ensinamentos tempeirísticos e culinários, e eventuais puxões de orelha!!! Rafa e Cofre, valeu pelo companheirismo e pelos insights filosóficos aleatórios sobre nada e quase tudo.

Muito obrigado aos colegas da Geologia, da graduação e pós-graduação (Jaú, Vivih ,Stephan, Borba, Chava, Sheila, Alex, Marília, Morsa, Elisa, alunos de Petro Ígnea 2009/2010 e Sistema Terra/2010 Ligea,...), pelos momentos agradáveis de convívio diário e de confraternização. Muito obrigado B-9 (Felix, Diana, Pisa, Pedro) por dividirem momentos oscilantemente inspiradores e comumente, mas não exclusivamente, associados à conversas diversas.

Agradeço à Nação Colombiana da USP (John, Johana, Oscar, Karen, Felipe,...) pela amizade, festas, passeios, comilanças e momentos multiculturais. Foi muito bom conhecê-los.

Muito obrigado Albita, por todos os momentos de extraordinária simplicidade, pelo apoio, compreensão e companhia de final-de-semana na USP.

Agradeço ainda ao amigo Fischer, pelos breves momentos de vivência corrida, trabalho intenso e procrastinação, nos meses finais da dissertação. Agradeço também ao DRM-RJ, pelo apoio e flexibilidade para que a dissertação pudesse ser finalizada.

O último agradecimento, que na verdade é o primeiro, é para minha mãe, Dona Adelina, a Admirável Grande Pequena Mulher, pelo amor, apoio e respeito. 


\section{RESUMO}

O presente trabalho investiga processos de interação e mistura parcial de magmas monzodioríticos e sieníticos s.l. no Plúton Piracaia,( $580 \mathrm{Ma})$, que pertence à Província Granítica Itu, de caráter pós-orogênico. O Plúton Piracaia é uma intrusão alongada com cerca de $30 \mathrm{~km}^{2}$, formada por cinco unidades: Monzodioritos grossos (Mdr); Monzodioritos finos (Mdf); Monzonitos heterogêneos $(\mathrm{Mh})$; Sienitos (Sie); quartzo sienitos e quartzo monzonitos (Qsie).

Como base para a caracterização dos processos de interação de magmas, foram estimados os parâmetros físico-químicos dos magmas primários e híbridos identificados no plúton. As temperaturas liquidus foram estimadas a partir da saturação em apatita, e são da ordem de $950-1050^{\circ} \mathrm{C}$ para os magmas mais primitivos $(M d f)$ e $850-900^{\circ} \mathrm{C}$ para os mais diferenciados (quartzo sienitos). As temperaturas solidus, estimadas através das relações de equilíbrio entre hornblenda e plagioclásio, são da ordem de $750^{\circ} \mathrm{C}$ para $M d f$, e $650-700^{\circ} \mathrm{C}$ para Sienitos e quartzo sienitos (Qsie). A profundidade de alojamento do plúton é estimada em $\sim 13-15 \mathrm{~km}$ com base nas pressões estimadas para $M d f$ com base no conteúdo de $\mathrm{Al}$ na hornblenda. A concentração de $\mathrm{H}_{2} \mathrm{O}$ nos magmas foi estimada com base no teor de An do plagioclásio, conhecida a temperatura de cristalização, que indicou valores da ordem de 2,53,3\% para $M d f$, alcançando até $5 \%$ nos quartzo sienitos. Estimativas da $f \mathrm{O}_{2}$ a partir da composição química de cristais de magnetita e ilmenita não puderam ser obtidas, devido a reequilíbrio pósmagmático. Deste modo, foram obtidos valores aproximados com base no conteúdo de ulvoespinélio de cristais de magnetita reconstituídos e no conteúdo da molécula ilmenita dos cristais de ilmenita; em paralelo, foram também utilizadas as razões $\mathrm{Fe} /(\mathrm{Fe} / \mathrm{Mg})$ de anfibólio e biotita. Os resultados revelaram um importante contraste entre as unidades $M d f$ e $M d r$, caracteristicamente oxidadas, com valores próximos aos do buffer NNO, e as demais unidades, onde quartzo sienitos (Qsie) e especialmente Sie mostram-se mais reduzidas. Os baixos valores de susceptibilidade magnética medidos em campo para as unidade Sie e $M h$, que a ela se associa, devem ser reflexos do seu caráter mais reduzido.

Ao longo da história de construção da câmara, que foi alimentada intermitentemente por magmas de composição variada, dois eventos principais de interação de magmas foram identificados, com características distintas: (i) interação de magmas monzodioríticos (Mdf) e sieníticos (Sie), gerando a unidade de Monzonitos heterogêneos $(M h)$, na qual a intensa interdigitação de porções monzodioríticas e sieníticas sugere uma forte atuação mecânica, favorecendo a hipótese de que os magmas tenham se misturado previamente ao alojamento final; e (ii) interação de magmas monzodioríticos $(M d f)$ e quartzo sieníticos (Qsie), gerando diversas estruturas de coexistência, mistura localizada e possivelmente as rochas quartzo monzoníticas da unidade (Qsie); neste caso, a interação entre os magmas possivelmente ocorreu na câmara magmática, como sugerido pelas características das estruturas indicativas de coexistência (enclaves e pillows de composição monzodiorítica).

Palavras-chave: mistura de magmas, condições de cristalização, monzodiorito, sienito, câmara magmática 


\begin{abstract}
The present study investigates the interaction and partial mixing of monzodiorite and syenite s.l. magmas in the Piracaia Pluton ( $580 \mathrm{My})$, which is part of the post-orogenic Itu Granite Province. The Piracaia Pluton is an elongated intrusion with approximately $30 \mathrm{~km}^{2}$, composed by five units: Coarse-grained monzodiorites $(M d r)$; Fine-grained monzodiorites $(M d f)$; Heterogeneous monzonites $(\mathrm{Mh})$; Syenites (Sie); quartz syenites and quartz monzonites (Qsie).

The physico-chemical crystallization parameters of the primary and hybrid magmas identified in the pluton were determined as references for the characterization of the magma interaction processes. The liquidus temperatures were estimated based on apatite saturation, and are in the range of $950-1050^{\circ} \mathrm{C}$ for the most primitive magmas $(M d f)$ and $850-900^{\circ} \mathrm{C}$ for the more differentiated ones (quartz syenites). The solidus temperatures, estimated on the basis of the equilibrium between hornblende and plagioclase, are about $750^{\circ} \mathrm{C}$ for Mdf, and $650-700^{\circ} \mathrm{C}$ for and quartz syenites (Qsie). The depth of emplacement is estimated at $13-15 \mathrm{~km}$, as indicated by pressure estimates for $M d f$, based on the $\mathrm{Al}$-in-hornblende content. The $\mathrm{H}_{2} \mathrm{O}$ concentration of the magmas was estimated based on the An content of plagioclase, with results are in the range of 2.5-3.3\% for $M d f$, reaching up to 5\% in quartz syenites. $f \mathrm{O}_{2}$ estimates based on the composition of coexisting magnetite and ilmenite could not be performed, due to post-magmatic re-equilibration. However, approximate values were obtained based on the ulvospinel content of reconstructed titanomagnetite crystals, and on the content of ilmenite molecule in ilmenite crystals; in parallel, the $\mathrm{Fe} /(\mathrm{Fe} / \mathrm{Mg})$ ratios of amphibole and biotite were also used. The results show an important difference between the $M d f$ and $M d r$ units, which are distinctively oxidized, with values near the NNO buffer, and the other units which have lower $f \mathrm{O}_{2}$, the quartz syenites and especially the syenites being the more reduced units. The lower magnetic susceptibility values measured in the field for the Sie and $M h$ units must reflect their more reduced nature.

During the construction of the magma chamber, which was intermittently recharged by magmas of varied composition, two main events of magma interaction with distinct characteristics were identified: (i) the interaction of monzodiorites ( $M d f$ ) and syenites (Sie), generating the Heterogeneous monzonite unit, in which the interfingering of monzodiorite and syenite portions suggest a strong mechanical interaction, favoring the hypothesis that the magmas were already mixing previously to the final emplacement; (ii) interaction of monzodiorite (Mdf) and quartz syenite (Qsie), generating diverse mingling structures, local hybridization and possibly the quartz monzonite rocks of the unit Qsie; in this case, the magma interaction must have occurred at the magma chamber, as suggested by the type of structures indicative of coexistence (enclaves and monzodiorite pillows).
\end{abstract}

Key words: magma interaction, crystallization parameters, monzodiorite, syenite, magma chamber 
Agradecimentos.

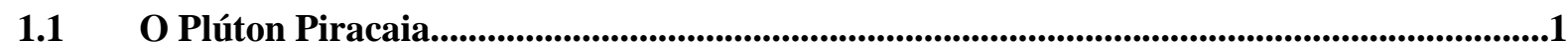

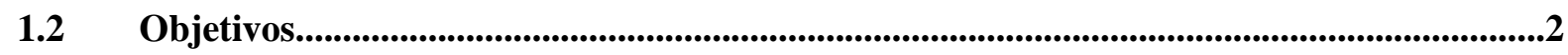

1.3 Mistura de magmas - Aspectos Gerais.................................................................................................3

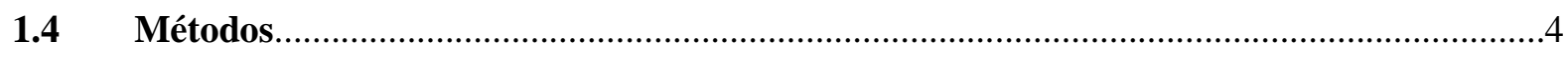

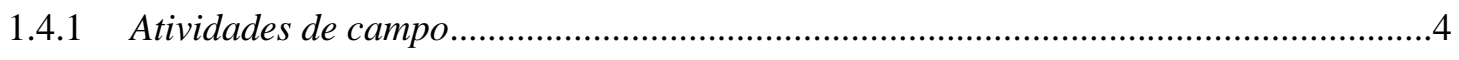

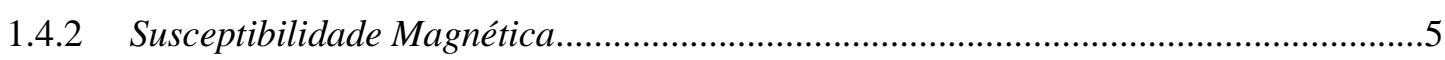

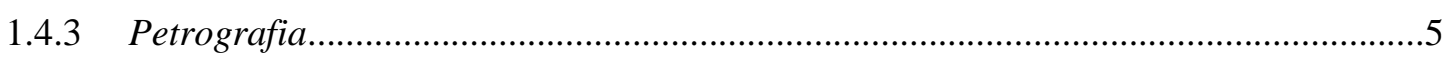

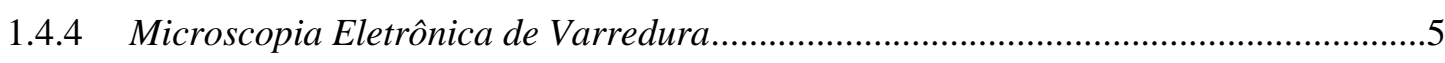

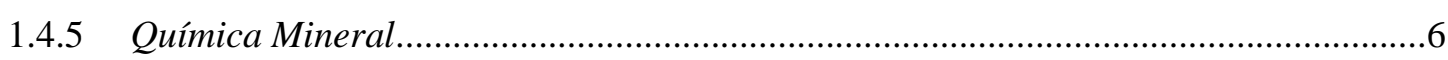

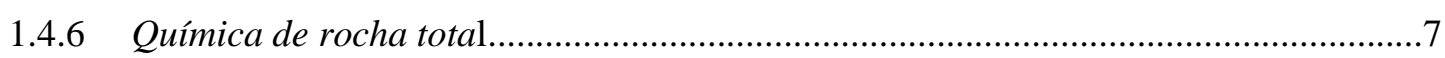

1.5 Contexto Geológico...........................................................................................................................................8

CAPÍTULO III - CARACTERIZAÇÃO GEOLÓGICA DO PLÚTON PIRACAIA...........................13

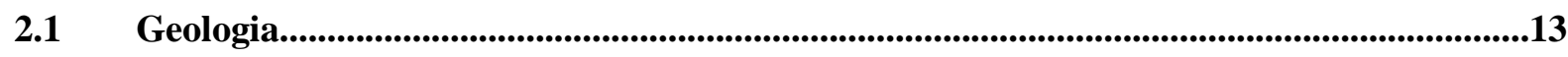

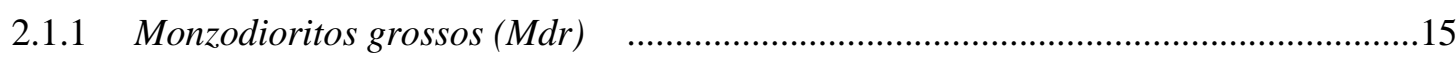

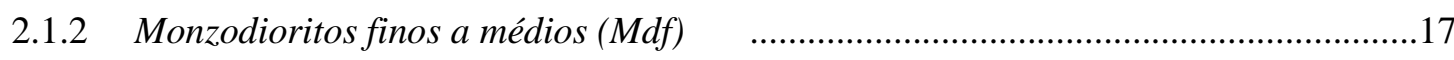

2.1.3 Quartzo sienitos e quartzo monzonitos (Qsie).............................................................. 18

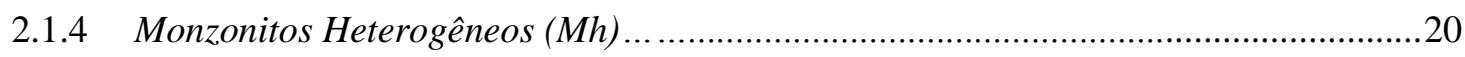

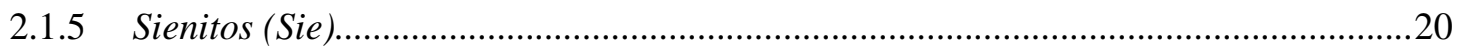

$2.2 \quad$ Petrografia.................................................................................................................................................21

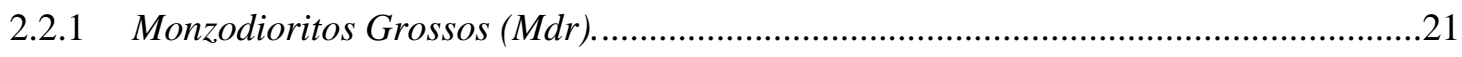

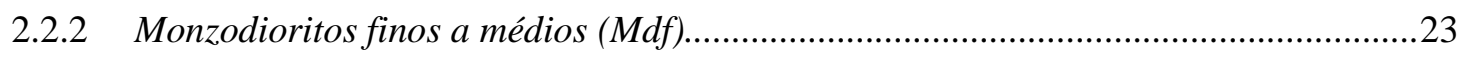




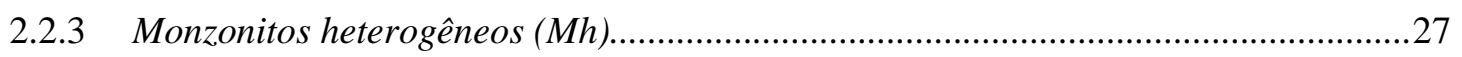

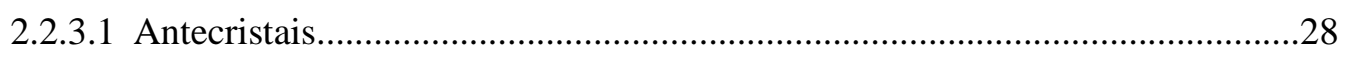

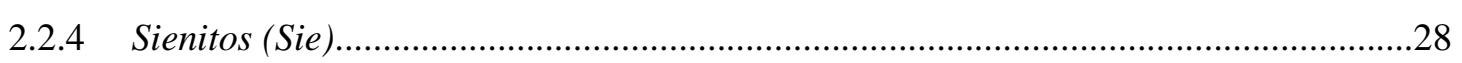

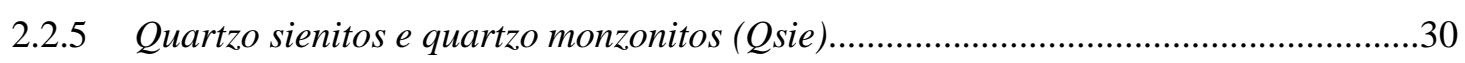

$2.3 \quad$ Mineralogia de opacos.....................................................................................................................31

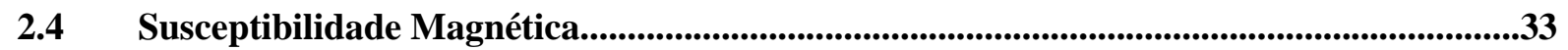

2.5 Química Mineral...........................................................................................................................................34

2.5.1 Hornblenda

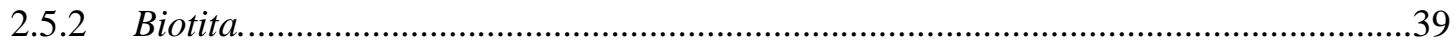

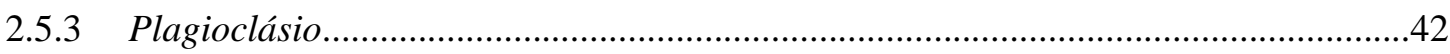

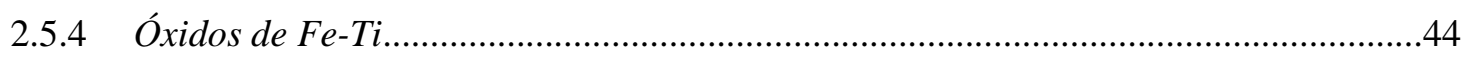

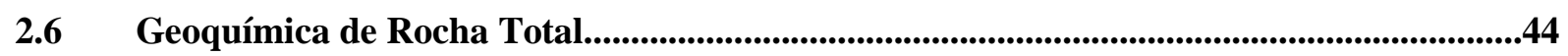

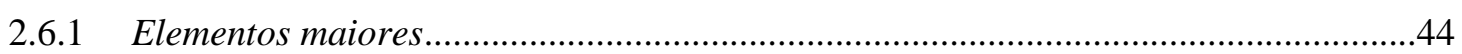

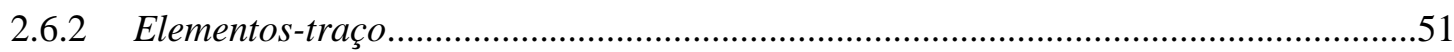

2.6.3 Modelamentos de sequência de cristalização - MELTS...............................................57

2.5 Isótopos de Sr-Nd.........................................................................................................................60

2.6 Aspectos genéticos e ambiente tectônico..............................................................................61

CAPÍTULO III - ESTIMATIVAS DE PARÂMETROS FÍSICO-QUÍMICOS DE

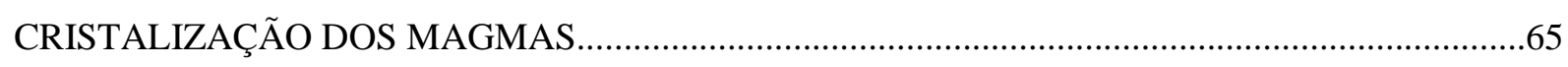

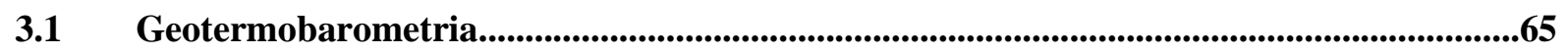

3.2 Termômetros de saturação de fases acessórias..................................................................69

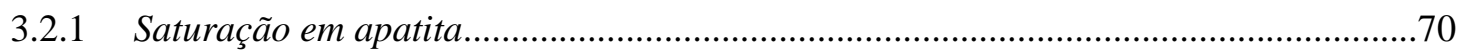

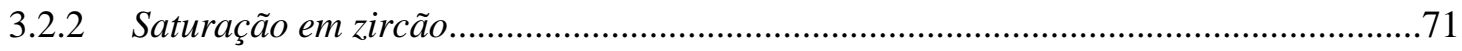

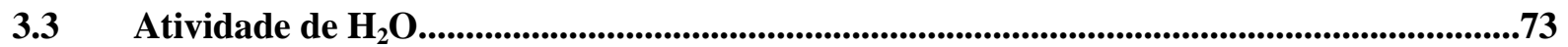

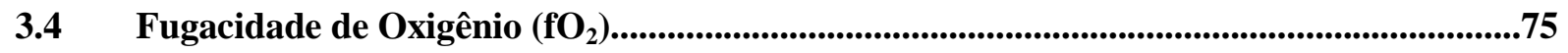

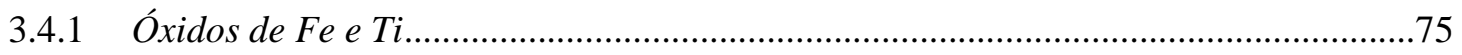

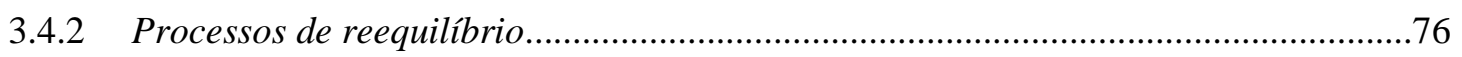

3.4.3 Aplicação de termômetros/oxibarômetros e reconstrução de cristais

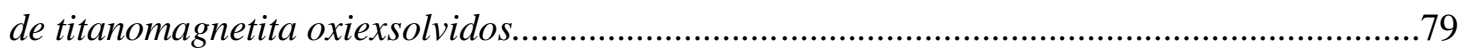

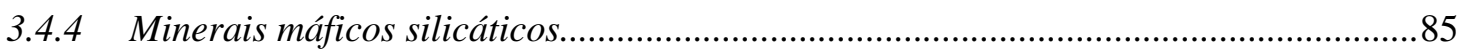

4.1 Evidências de Campo ……........................................................................................................................91

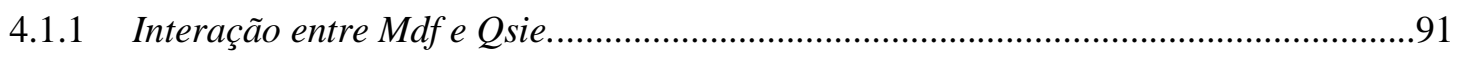




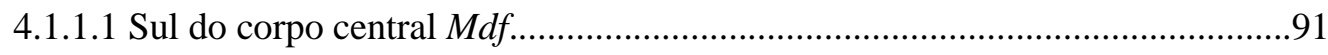

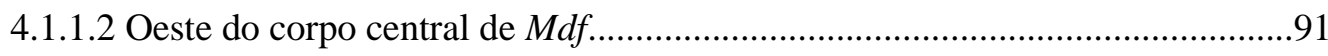

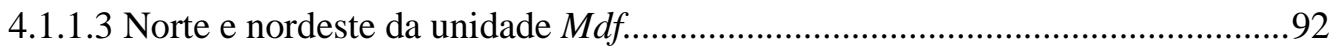

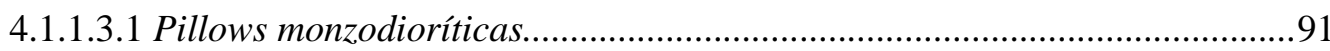

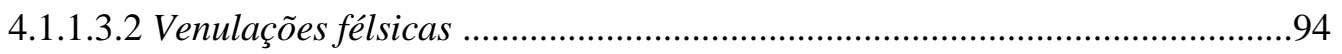

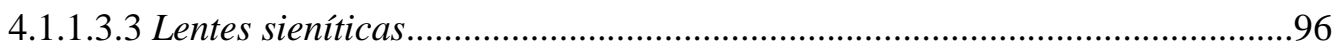

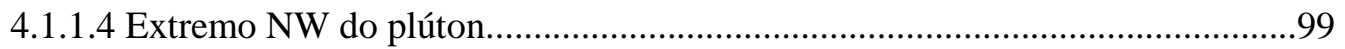

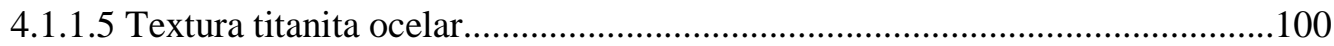

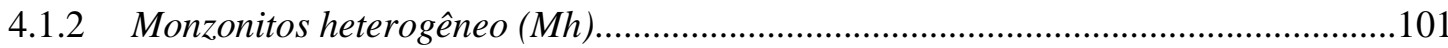

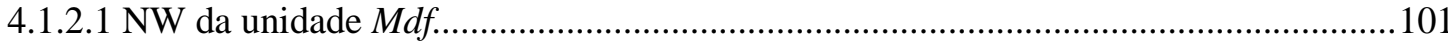

4.1.3 Interação entre Mhe Qsie .....................................................................................102

4.2 Evidências petrográficas de mistura de magmas..........................................................................103

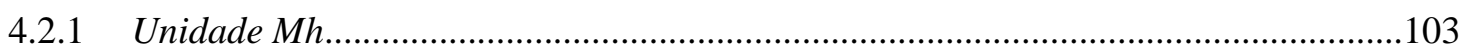

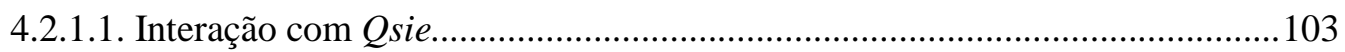

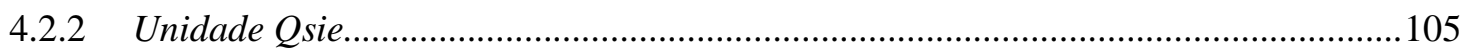

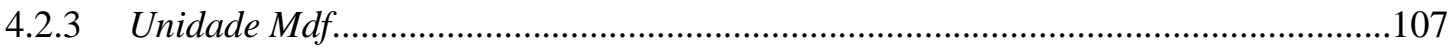

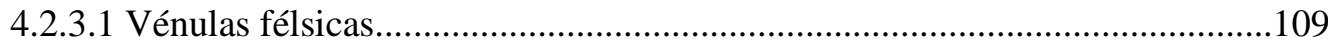

4.2.3.2 Extremo NW do plúton...........................................................................111

4.3 Aspectos geoquímicos dos processos de mistura de magmas................................................111

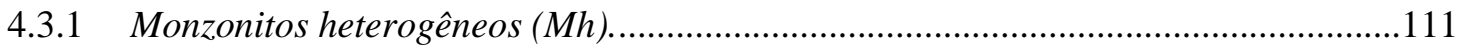

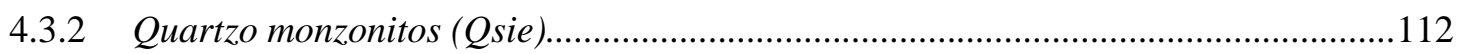

4.4 Heterogeneidades químicas do processo de mistura de magmas........................................115

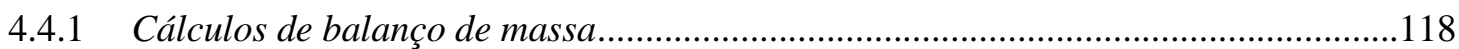

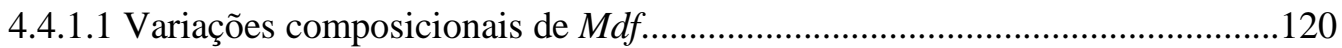

4.4.1.2 Monzonitos heterogêneos $(M h)$ e quartzo monzonitos (Qsie)........................122

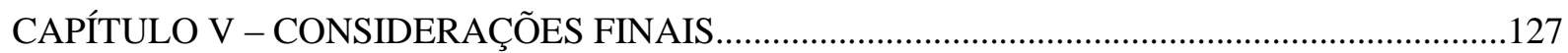

5.1 Considerações sobre a dinâmica de construção da câmara

magmática e cronologia relativa................................................................................................................127

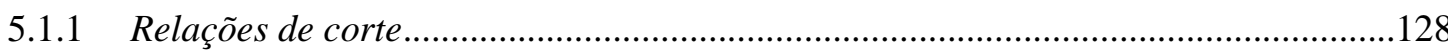

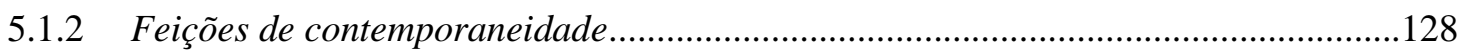

5.1.3 Anisotropia de Susceptibilidade Magnética.................................................................129

5.2 Fatores condicionantes dos processos de mistura de magmas.............................................131

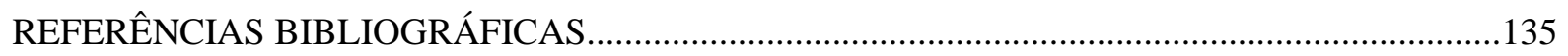




\section{ÍNDICE DE FIGURAS}

Figura 1. Esboço geológico do embasamento cristalino de parte da região sudeste do Brasil. Salienta-se na cor roxo os plútons pertencentes à Província Granítica Itu (simplificado de Janasi et al. (2009). 9

Figura 2. Esboço do contexto geológico local da região de Piracaia e Atibaia. Destaca-se a proximidade do Plúton Piracaia com o limite entre a Nappe Socorro-Guaxupé e o Domínio Apiaí-São Roque.

Figura 3. Mapa geológico do Plúton Piracaia, segundo Janasi \& Ulbrich (1987).

Figura 4. Mapa geológico do Plúton Piracaia, com as modificações nas unidades e contatos redefinidos, segundo o presente trabalho. Constam em azul os pontos mencionados no texto e em preto as foliações medidas em campo. Modificado de Janasi \& Ulbrich (1987) e Salmoni (2007)......

Figura 5. Unidades $M d r$ e $M d f$ : (A) monzodiorito grosso ( $M d r$ ) com textura equigranular grossa e estrutura maciça (PI-542); (B) associação entre monzodiorito grosso (Mdr) (porção inferior da foto) e monzodiorito fino $(M d f)$ (porção superior da foto) com contatos irregulares, onde observa-se uma venulação félsica centimétrica na interface entre as litologias (PI-589); (C) Monzodiorito (Mdf), apresentando venulações félsicas dispersas (PI-500); (D) detalhe da foto "C", destacando a textura inequigranular fina a média.

Figura 6. Unidade Qsie: (A) quartzo sienito leucocrático, com textura equigranular grossa, apresentando foliação incipiente (PI-410); (B) quartzo sienito com elevado conteúdo de máficos (IC 10), cortando a unidade $M h$ (PI-427); (C) quartzo monzonito com elevado IC ( 20) e máficos predominantemente restritos à matriz (PI-624).

Figura 7. Monzonitos heterogêneos $(M h)$ e Sienitos (Sie): (A) textura heterogênea típica da unidade $M h$, com porções félsicas de composição sienítica e porções máficas monzodioríticas. Salienta-se a presença de cristais subcentimétricos idiomórficos de hornblenda (PI-437); (B) Mh com lentes sieníticas irregulares (PI400); (C) matacão de Sie, apresentando lentes féldspáticas centimétricas, orientadas segundo o plano de foliação (PI-602); (D) detalhe do sienito PI-602, onde é possível visualizar melhor a textura inequigranular fina a média.

Figura 8. Fotomicrografias das unidades $M d r$ e $M d f$ : (A) e (B), polarizadores paralelos e cruzados, respectivamente, de monzodiorito grosso $(M d r)$, com estrutura maciça. Observam-se alguns cristais de plagioclásio com zoneamento normal descontínuo e a presença de cristais idiomórficos de augita (amostra PI-589A); (C) e (D) polarizadores paralelos e cruzados, respectivamente, de monzodiorito equigranular fina $(M d f)$ com foliação magmática incipiente, marcada pelo alinhamento de cristais tabulares de plagioclásio (amostra PI-588A); (E) e (F) polarizadores paralelos, respectivamente, de monzonito (Mdf) apresentando textura equigranular fina e baixo IC. Observam-se cristais de augita, apresentando reação parcial para anfibólio (amostra PI-588B).

Figura 9. Fotomicrografias das unidades $M d f$ e $M h$ : (A) e (B) polarizadores paralelos e cruzados, respectivamente, de monzodiorito fino $(M d f)$ com foliação de estado sólido, evidenciada pela orientação e recristalização de biotita. Nota-se também uma recristalização incipiente dos feldspatos e a presença de pequenos cristais de epidoto, associados à biotita ao longo dos planos de foliação (amostra PI-546-7L); (C) e (D) polarizadores paralelos e cruzados, respectivamente, de monzonito heterogêneo $(M h)$, onde destacase o contraste entre porções sieníticas (Sie) e monzodioríticas (Mzd) (amostra PI-400A); (E) e (F) polarizadores paralelos e cruzados, respectivamente, de monzonito heterogêneo com cristais e agregados e cristais de hornblenda e antecristais de plagioclásio (amostra PI-400B).

Figura 10. Fotomicrografias das unidades Sie e Qsie: (A) textura inequigranular fina a média, típica da unidade de sienitos (Sie). Destaca-se a presença de cristal idiomórfico de allanita (amostra PI-26B); (B) quartzo sienito (Qsie), com hornblenda e ricas em quartzo, que apresenta-se fortemente recristalizado (amostra PI-427); (C) quartzo sienito com forte foliação de estado sólido, destacando-se a recristalização incipiente de feldspato alcalino, com o desenvolvimento de buldging, conferindo o aspecto de uma textura seriada (amostra PI-529); (D) quartzo monzonito (Qsie) com textura inequigranular média a grossa, com agregados de biotita entre cristais de feldspato, e allanita, acessório característico da unidade (amostra PI584). Todas as fotomicrografias a polarizadores cruzados. 
Figura 11. Imagens de Microscopia Eletrônica de Varredura (elétrons secundários) exibindo as relações texturais de cristais de magnetita e ilmenita. (A) cristal subédrico de magnetita em quartzo sienito (Qsie); (B) cristais próximos de magnetita e ilmenita em monzodiorito $(M d r)$; (C) cristais de magnetita e ilmenita em associação do tipo composto, em $M d r$; (D) cristais de magnetita e ilmenita em associação do tipo treliça, em quartzo monzonito (Qsie); (E) cristais de magnetita e ilmenita em associação do tipo sanduíche, em $M d f ;(F)$ cristais de magnetita e ilmenita em associação do tipo treliça e patch, quartzo sienito (Qsie)...

Figura 12. Mapa geológico do Plúton Piracaia com medidas de susceptibilidade magnética de pontos de suas diferentes unidades.

Figura 13. Diagramas de classificação para anfibólios cálcicos das diferentes unidades que compõem o Plúton Piracaia: (A) para cristais com $\mathrm{Na}+\mathrm{K}>0,5$ e (B) para cristais com $\mathrm{Na}+\mathrm{K}<0,5$.

Figura 14. Variações da razão $\mathrm{Fe} /(\mathrm{Fe}+\mathrm{Mg})$ dos anfibólios, pela substituição simples entre $\mathrm{Mg}^{2+}$ e $\mathrm{Fe}^{2+}$.

Figura 15. Variações químicas nos anfibólios do Plúton Piracaia relacionadas aos mecanismos de substituição: (A) edenítica; (B) tschermakítica; (C) Ti-tschermakítica.

Figura 16. Correlação entre o conteúdo de Ti e a variação da razão $\mathrm{Fe} /(\mathrm{Fe}+\mathrm{Mg})$ nos anfibólios entre as diferentes unidades do Plúton Piracaia.

Figura 17. Correlação entre o conteúdo de $\mathrm{Al}^{\text {tot }}$ e a variação na razão $\mathrm{Fe} /(\mathrm{Fe}+\mathrm{Mg})$ nos anfibólios do Plúton Piracaia.

Figura 18. Diagrama de classificação das biotitas do Plúton Piracaia, onde destaca-se a variação na razão $\mathrm{Fe} /(\mathrm{Fe}+\mathrm{Mg})$ entre as diferentes unidades.

Figura 19. Diagramas de correlação para as biotitas das diferentes unidades que compõem o Plúton Piracaia, onde observa-se em (A) que os conteúdos e Si e Al mantêm-se praticamente constantes, em (A) e (B), respectivamente.

Figura 20. Variação nas concentrações de Ti nas biotitas das diferentes unidades que compõem o Plúton Piracaia

Figura 21. Variação composicional dos plagioclásios de diferentes unidades do Plúton Piracaia: (A) monzodioritos (Mdr e $M d f$ ); (B) Monzonitos heterogêneos (Mh) e Sienitos (Sie); (C) quartzo monzonitos e quartzo sienitos (Qsie).

Figura 22. Diagrama TAS, mostrando o amplo intervalo de $\mathrm{SiO}_{2}$ e as elevadas concentrações de álcalis apresentadas pelas unidades que compõem o Plúton Piracaia.

Figura 23. Diagrama R1 - R2 (De La Roche et al. 1980), onde as rochas do Plúton Piracaia apresentam-se deslocadas para a esquerda em relação à sua classificação mineralógica, devido ao seu elevado conteúdo de álcalis.

Figura 24. Índice de alcalinidade de Peacock para as rochas que compõem o Plúton Piracaia (linha tracejada).

Figura 25. Diagrama de $\mathrm{SiO}_{2}$ vs $\mathrm{K}_{2} \mathrm{O}$ (Peccerillo \& Taylor (1976) evidenciando o elevado conteúdo de $\mathrm{K}_{2} \mathrm{O}$ das rochas do Plúton Piracaia.

Figura 26. Diagrama AFM para as diferentes unidades que compõem o Plúton Piracaia.

Figura 27. Diagrama de Miyashiro (1974), evidenciando o elevado conteúdo de $\mathrm{FeO}_{\mathrm{t}}$ de todas as unidades que compõem o Plúton Piracaia.

Figura 28. Índice de saturação em alumina (Frost et al., 2001), evidenciando o caráter metaluminoso das rochas do Plúton Piracaia.

Figura 29. Índice MALI proposto por Frost et al. (2001), onde as amostras de todas as unidades do Plúton Piracaia situam-se no campo das rochas alcalinas (alkalic). 
Figura 30. Rochas do Plúton Piracaia plotadas no diagrama de correlação entre o *Fe $(\mathrm{FeO} /(\mathrm{FeO} / \mathrm{MgO}))$ e $\mathrm{SiO}_{2}$ proposta por Frost et al. (2001), cujos limites entre os campos ferroan e magnesian (linha laranja) foram modificados por Frost \& Frost (2008). A linha preta corresponde à divisão de basaltos cálcioalcalinos e toleíticos de Miyashiro (1974).

Figura 31. Composições de elementos maiores e menores das unidades que compõem o Plúton Piracaia, dispostos em diagramas binários, utilizando $\mathrm{SiO}_{2}$ como índice de diferenciação.

Figura 32. Composições de elementos traços das unidades que compõem o Plúton Piracaia, dispostos em diagramas binários, utilizando $\mathrm{SiO}_{2}$ como índice de diferenciação.

Figura 33. Diagramas de ETR para as rochas das diferentes unidades que compõem o Plúton Piracaia, normalizados para o condrito de Sun \& McDonough (1989).

Figura 34. Diagramas multielementares para as rochas das diferentes unidades que compõem o Plúton Piracaia, normalizados para o Manto Primitivo de Sun \& McDonough (1989),

Figura 35. Modelamentos de sequência de cristalização para monzodioritos ( $M d r$ e $M d f$ ) do Plúton Piracaia utilizando o software MELTS. A amostra PI-257 refere-se a um monzodiorito grosso (Mdr); as amostras PI-589B, PI-5c e PI-621 são monzodioritos finos (Mdf); e as amostras PI-358a e PI-614 são monzonitos $(M d f)$.

Figura 36. Modelamentos de sequência de cristalização para a unidade Qsie do Plúton Piracaia, utilizando o software MELTS. As amostras PI-429, PI-537, PI-582 e PI-270 correspondem a quartzo monzonitos e as amostras PI-410 e PI-427 correspondem a quartzo sienitos.

Figura 37. Modelamentos de sequência de cristalização utilizando o software MELTS para as unidades de Sienitos (Sie) (amostras PI-26b e PI-602) e Monzonitos heterogêneos (Mh) (PI-400a e PI437a) do Plúton Piracaia.

Figura 38. Diagrama ${ }^{87} \mathrm{Sr} /{ }^{86} \mathrm{Sr}$ versus $\varepsilon \mathrm{Nd}_{(\mathrm{t})}$ para as rochas das diferentes unidades que compõem o Plúton Piracaia.

Figura 39. Diagramas de identificação de ambiente tectônico com as rochas que compõem o Plúton Piracaia, segundo Whalen et al., (1987).

Figura 40. Rochas do Plúton Piracia plotadas em diagramas discriminantes para rochas com afinidade cálcio-alcalina e granitos do tipo-A (Dall'Agnoll \& Oliveira, 2007).

Figura 41. Estimativas de temperatura e pressão de cristalização para as rochas do Plúton Piracaia.

Figura 42. Temperaturas de saturação em apatita para as diferentes unidades que compõem o Plúton Piracaia

Figura 43. Temperaturas de saturação em zircão para as diferentes unidades que compõem o Plúton Piracaia.

Figura 44. Variações nas concentrações de $\mathrm{Mg}$ e $\mathrm{Mn}$ entre magnetita e ilmenita coexistentes de rochas das diferentes unidades que compõem o Plúton Piracaia. Teste para verificação de equilíbrio segundo Bacon \& Hirschmann (1988), onde a linha tracejada representa a tendência de correlação ideal (1:1) esperada para cristais em equilíbrio.

Figura 45. Variações nas concentrações de $\mathrm{MnO}$ entre os diferentes tipos texturais de ilmenita, referentes a amostras das diferentes unidades que compõem o Plúton Piracaia.

Figura 46. Imagens de Microscopia Eletrônica de Varredura (elétrons retroespalhados) dos cristais selecionados para reconstituição, das diferentes unidades que compõem o Plúton. 
Figura 47. Estimativas de $f \mathrm{O}_{2}$ para as unidades $M d r$ e $M d f$ obtidas a partir da reconstituição de cristais de titanomagnetita e ilmenitas coexistentes, segundo o termômetro/oxibarômetro de Spencer \& Lindsley (1981).

Figura 48. Estimativa de $f \mathrm{O}_{2}$, a partir do conteúdo de ulvoespinélio de cristais reconstituídos de titanomagnetita, de algumas unidades que compõem o Plúton Piracaia.

Figura 49. Estimativas de $f \mathrm{O}_{2}$ a partir da composição de ilmenita de monzodioritos ( $M d r$ e $M d f$ ) e Sienitos (Sie), segundo Spencer \& Lindsley (1981). A temperatura estipulada para os monzodioritos refere-se à solidus apontadas pelos modelamentos no software MELTS, enquanto que para os Sienitos utilizou-se as estimativas de liquidus e solidus.

Figura 50. Correlação entre os conteúdos de $\mathrm{Al}($ tot) com as razões $\mathrm{Fe} /(\mathrm{Fe}+\mathrm{Mg})$ de biotita e hornblenda das diferentes unidades que compõem o Plúton Piracaia.

Figura 51. Correlação entre os conteúdos de $\mathrm{Mn}$ e $\mathrm{Ti}$ e as razões $\mathrm{Fe} /(\mathrm{Fe}+\mathrm{Mg})$ de biotitas das diferentes unidades que compõem o Plúton Piracaia.

Figura 52. Correlação entre os conteúdos de $\mathrm{Mn}$ e Ti e as razões $\mathrm{Fe} /(\mathrm{Fe}+\mathrm{Mg})$ de hornblendas das diferentes unidades que compõem o Plúton Piracaia.

Figura 53. Estimativa qualitativa de $f \mathrm{O}_{2}$, a partir da composição da hornblenda de rochas das diferentes unidades que compõem o Plúton, segundo Anderson \& Smith (1995).

Figura 54. Estimativas de $f \mathrm{O}_{2}$ para as unidades que compõem o Plúton Piracaia, utilizando a razão $\mathrm{Fe} /(\mathrm{Fe}+\mathrm{Mg})$ da biotita, a partir do método Wones \& Eugster (1965).

Figura 55. Comparação entre as razões $\mathrm{FeO} /(\mathrm{FeO}+\mathrm{MgO})$ de rocha total e as razões $\mathrm{Fe} /(\mathrm{Fe}+\mathrm{Mg})$ das biotitas das diferentes unidades que compõem o Plúton Piracaia.

Figura 56. Evidências de mistura heterogênea entre as unidades Mdf e Qsie. (A) Pillows e enclaves monzodioríticos imersos em quartzo monzonito, no contato sul entre Mdf e Qsie (PI-624); (B) cristais idiomórficos de feldspato alcalino dispersos em matriz monzodiorítica, no extremo oeste da unidade $M d f$ (PI-545); (C) pillows monzodioríticas circundadas por material félsico híbrido, evidenciado pela variação no conteúdo de máficos (PI-551); (D) detalhe da foto $\mathrm{C}$, mostrando a íntima associação espacial entre pillows com forte contraste reológico. Na porção central da foto observa-se pillow com contatos irregulares, fragmentando-se parcialmente, cercada de pillows com contatos bem definidos e abruptos.

Figura 57. (A) e (B) Pillows monzodioríticas empilhadas e achatadas, circundadas por rochas félsicas híbridas, próximas ao contato entre $M d f$ e Qsie. (B) é uma foto de detalhe da foto (A), correspondendo à área do retângulo, onde delineou-se o formato das pillows, visando destacá-las.

Figura 58. Heterogeneidades texturais das vênulas félsicas contidas na unidade $M d f$ : (A) vênula apresentando contatos abrupto e gradacional. No lado direito da foto, junto ao contato abrupto, a vênula tem composição quartzo sienítica, que grada para quartzo monzonitos e novamente para monzodioritos em direção ao lado direito da foto; (B) vênula quartzo sienítica com abundantes cristais de hornblenda, que formando concentrações centimétricas; (C) vênula félsica delineada pela linha tracejada, muito rica em cristais de hornblenda e titanita. As setas vermelhas indicam a localização de algumas zonas ricas em cristais de titanita, que tendem a circundar as porções externas da vênula. Salienta-se também a textura grossa apresentada pela porção quartzo sienítica situada na porção central; (D) vênulas félsicas caracterizando estrutura em chama (flame-like), com concentração de hornblenda em sua porção superior. As fotos (A), (C) e (D) correspondem a estruturas encontradas na Pedreira de Piracaia, enquanto a foto (B) refere-se ao ponto PI-546.

Figura 59. Pillows monzodioríticas em meio à lente métrica de quartzo sienito (Qsie). Nota-se que as pillows assimilam pequenas "gotas" de quartzo sienito próximo ao contato. O quartzo sienito, por sua vez, apresenta inúmeros enclaves máficos, fortemente estirados e assimilados (PI-546).

Figura 60. Lente quartzo sienítica próximo ao contato entre $M d f$ e $Q$ sie, na porção NE do plúton (PI-546). Notar a marreta $(\sim 30 \mathrm{~cm})$ como escala. As fotos C, D e E mostram detalhes do afloramento. (C) mostra 
pillows no contato entre a lente quartzo sienítica e o monzodiorito. O contato é abrupto, porém irregular-; (D) salienta a existência de falhas sin-plutônicas afetando parte do conjunto. A seta vermelha aponta vênulas não deslocadas pela falha; (E) mostra duas gerações de vênulas félsicas de diferentes espessuras se entrecortando

Figura 61. Interdigitação entre $Q$ sie e $M d f$ no extremo NW do plúton (PI-515). As fotos B e C mostram detalhes do afloramento (foto A), evidenciando o estiramento e fragmentação do quartzo sienito. A existência de dobras assimétricas sugere sentido de movimento lateral direito e demonstra a atuação de campo tensional durante o alojamento dos magmas.

Figura 62. Pillows monzodioríticas fortemente achatadas, adquirindo formato lenticular (PI-515) situadas no extremo NW do plúton.

Figura 63. Bolsões félsicos em monzodioritos $(M d f)$, com cristais idiomórficos de titanita em seu centro, caracterizando a textura titanita-ocelar, que segundo Hibbard (1991) é gerada por sucessivos eventos de mistura de magmas (PI-500).

Figura 64. Evidências de interação entre $M h$ e Sie. Na foto A observa-se a heterogeneidade do processo de mistura, evidenciado pelas variações no IC e mistura heterogênea. Em B observa-se veio de sienito com formato sigmoidal, evidenciando maior contraste reológico entre os magmas (PI-512).

Figura 65. Fotomicrografias dos $M h$ menos heterogêneos: (A) e (B) $M h$ onde há predomínio de magma monzodiorítico, evidenciado pela elevado IC e presença de antecristais de plagioclásio. Evidências de mistura são marcadas pela abundância de feldspato alcalino na matriz, e pela presença de allanita (PI-532, polarizadores paralelos e cruzados, respectivamente); (C) $M h$ pobre em bolsões félsicos. Contudo, ainda se observa o contraste textural e composicional entre porções félsicas e máficas (PI-405, polarizadores paralelos); (D) $M h$ cortado por veio quartzo sienítico, que apresenta textura grossa, abundante titanita e quartzo intersticial (PI-534, polarizadores cruzados); (E) $M h$ com hornblenda com núcleo corroído próximo ao contato com a vênula quartzo sienítica da foto D, polarizadores paralelos; (F) veio sienítico cortando $M h$ ( PI-512, polarizadores cruzados.

Figura 66. Heterogeneidades texturais presentes na unidade Qsie: (A) e (B) quartzo monzonito, com textura fina contendo antecristais de plagioclásio. Destaca-se a ocorrência de esparsos cristais de feldspato alcalino de grande dimensão (PI-537, polarizadores paralelos e cruzados, respectivamente); (C) e (D) agregados de biotita da matriz em quartzo monzonitos, com abundantes inclusões de zircão e apatita. Observam-se também cristais de allanita próximos (PI-582, polarizadores paralelos e cruzados, respectivamente); (E) quartzo monzonitos com cristais de plagioclásio, tabulares e zonados, situados próximos a agregados de biotita (PI-582, polarizadores cruzados); (F) quartzo sienito com abundantes cristais de hornblenda (PI-427, polarizadores cruzados)......

Figura 67. Feições de interação entre $M d f$ e Qsie: (A) e (B) justaposição entre $M d f$ e $Q$ sie, onde praticamente não se observa mistura, evidenciando um elevado contraste reológico entre ambos (PI-515, polarizadores paralelos e cruzados, respectivamente). A porção monzodiorítica é representada pela sigla "Mzd"; (C) e (D) monzodiorito com baixo IC, quartzo intersticial em abundância e esparsos cristais de allanita, interpretado como produto de mistura com Qsie (PI-614, polarizadores paralelos e cruzados, respectivamente); (E) vênula rica em hornblenda cortando monzodioritos, no contato entre as unidades $M d f$ e Qsie ao sul do plúton (PI-538, polarizadores cruzados); (F) finas vênulas quartzo sieníticas (setas) dispersas em $M d f$ (PI-5a, polarizadores paralelos).

Figura 68. Foto de campo e fotomicrografias de uma venulação félsica e monzodioritos adjacentes presentes na Pedreira de Piracaia: (A) Foto de campo da venulação félsica amostrada; (A1-A5) fotomicrografias das diferentes porções da vênula: (A1) Acumulações de hornblenda e titanita com inclusões de apatita no contato da vênula com o monzodiorito; (A2) porção sienítica, com textura média a grossa e cristais euédricos de titanita; (A3) porção monzonítica, com textura média a fina, rica em hornblenda e allanita; (A4) porção monzonítica,com maior concentração de biotita, próximo ao contato inferior com o monzodiorito; (A5) monzodiorito no contato inferior da vênula, com textura fina e escassos cristais maiores de hornblenda. Salienta-se que esta porção amostrada está mais abaixo e não aparece na foto; (B) aglomerado de máficos da porção monzonítica (A-2) da vênula, com hornblenda, biotita, titanita, apatita e cristais de zircão associados. A linha tracejada na foto (A) representa a possível interface entre os magmas, a partir da qual houve mistura heterogênea e formação de um contato gradacional. 
Figura 69. Diagrama de ETR para a unidade $M h$, e unidades $M d f$ e Sie, que representam os extremos composicionais da mistura. Normalizado para o condrito de Sun \& McDonough (1989).

Figura 70. Diagrama multielementar para a unidade $M h$ e unidades $M d f$ e Sie que representam os extremos composicionais da mistura. Normalizado para o Manto Primitivo de Sun \& McDonough (1989).

Figura 71. Diagrama de ETR para quartzo monzonitos (Qsie), e Mdf e quartzo sienitos (Qsie), que representam os extremos composicionais da mistura. Normalizado para o vondrito de Sun \& McDonough (1989).

Figura 72. Diagrama multielementar para quartzo monzonitos (Qsie), e $M d f$ e quartzo sienitos (Qsie), que representam os extremos composicionais da mistura. Normalizado para o Manto Primitivo de Sun \& McDonough (1989).

Figura 73. Diagrama de ETR para as diferentes porções de uma vênula félsica e monzodioritos adjacentes (superior e inferior). Normalizado para o condrito de Sun \& McDonough (1989).

Figura 74. Diagrama multielementar para as diferentes porções da uma vênula félsica e monzodioritos adjacentes (superior e inferior) apresentados na Figura 70, encontrados na Pedreira de Piracaia. Normalizado para o Manto Primitivo de Sun \& McDonough (1989).

Figura 75. Diagramas de correlação C $(M h-S i e)$ vs. C $(M d f-$ Sie $)$ segundo Fourcade \& Allegre (1981) para a geração de Monzonitos Heterogêneos $(M h)$. Em (A) diagrama para elementos maiores, plotados em wt(\%); em (B) diagrama para elementos traço, onde: V/10; Zr/10; Sr/100 e Ba/1000.

Figura 76. Diagramas de correlação C (quartzo monzonitos - quartzo sienitos) vs. C (Mdf-quartzo sienito) segundo Fourcade \& Allegre (1981) para a geração de Quartzo monzonitos (Qsie). Em (A) diagrama para elementos maiores, plotados em wt(\%); em (B) diagrama para elementos traço, onde: V/10; Zr/10; Sr/100 $\mathrm{e} \mathrm{Ba} / 1000$.

Figura 77. Modelamentos de cristalização fracionada e em equilíbrio, partindo dos monzodioritos (Mdf) mais primitivos (PI-589B), segundo as proporções de minerais fornecidas pelos cálculos de balanço de massa para elementos maiores para se chegar até monzodioritos moderadamente evoluídos (PI-75), que ocorre com aproximadamente $52 \%$ de cristalização. Os modelamentos foram realizados com incrementos de $10 \%$, onde as setas pontilhadas indicam o percentual de cristalização de $50 \%$. As linhas de evolução em azul representam cristalização em equilíbrio e em verde cristalização fracionada. As curvas em preto sinalizam a variação composicional pelo fracionamento de augita, plagioclásio e biotita. Em (A) utilizou-se um $\mathrm{Kd}=10$ para a biotita, enquanto em (B) utilizou-se um $\mathrm{Kd}=6.36$. A proporção de fases fracionadas, recalculadas para $100 \%$, foi de: $46.2 \%$ de plagioclásio, $12.8 \%$ de clinopiroxênio, $41 \%$ de biotita.

Figura 78. Modelamentos de cristalização fracionada e em equilíbrio a partir dos monzodioritos ( $M d f)$ mais primitivos (PI-589B), utilizando as proporções de minerais fornecidas pelos modelamentos realizados através do software MELTS. Em (A) utilizou-se $\mathrm{Kd}=10$ para o Ba na biotita, enquanto em (B) utilizou-se $\mathrm{Kd}=6,36$

Figura 79. Modelamentos de cristalização fracionada e em equilíbrio a partir das proporções fornecidas pelos modelamentos realizados no software MELTS, para rochas relativamente evoluídas da unidade $M d f$ (monzonito PI-358a). Em (A) utilizou-se $\mathrm{Kd}=10$ para o Ba na biotita, enquanto em (B) utilizou-se $\mathrm{Kd}=$ 6,36 .

Figura 80. Modelamentos de mistura entre monzodioritos (Mdf) (PI-589B) e a unidade de Sienitos (Sie) e quartzo sienitos da unidade (Qsie). Importante observar a grande dispersão das rochas híbridas $(M h$ e quartzo monzonitos).

Figura 81. Mapas de foliação e lineação magnética para as diferentes unidades que compõem o Plúton Piracaia (extraído de Raposo et al., 2011).

Figura A01. Mapa com a localização dos pontos com análises de química mineral e química de rocha total 


\section{ÍNDICE DE TABELAS}

Tabela 1. Coeficientes de partição utilizados nos modelamentos de elementos traço

Tabela A01. Composição química, em percentagem de peso, de anfibólios das rochas

do Plúton Piracaia $(\mathrm{O}=23)$.

Tabela A02. Composição química, em percentagem de peso, de biotitas das rochas do Plúton Piracaia.

Tabela A03. Composição química, em percentagem de peso, para plagioclásios das rochas do Plúton Piracaia.

Tabela A04. Composição química, em percentagem de peso, para magnetitas das rochas do Plúton Piracaia $(\mathrm{O}=4)$

Tabela A04. Composição química, em percentagem de peso, para ilmenitas das rochas do Plúton Piracaia $(\mathrm{O}=6)$

Tabela A05. Composição química (óxidos \% peso; traços, ppm) das rochas do Plúton Piracaia por Fluorescência de RaiosX).

Tabela A06. Composição química de elementos traços para das rochas do Plúton Piracaia pelo método de ICPMS

Tabela A07. Dados de isótopos de Sr e Nd para as rochas do Plúton Piracaia. Razões iniciais calculadas para $580 \mathrm{Ma}$

Tabela A08. Estimativas de pressão e temperatura de cristalização para as rochas do Plúton Piracaia.

Tabela A09. Estimativas de concentração de $\mathrm{H}_{2} \mathrm{O}$ para as rochas do Plúton Piracaia.

Tabela A10. Estimativas de $f \mathrm{O}_{2}$ a partir de cristais de magnetita e ilmenita de rochas do Plúton Piracaia.

Tabela A11. Composição dos cristais de magnetita reconstituídos de rochas do Plúton Piracaia

Tabela A12. Estimativas de $f \mathrm{O}_{2}$ a partir de cristais reconstituídos de magnetita e ilmenita de rochas do Plúton Piracaia.

Tabela A13. Tabela A13. Modelamento de cristalização fracionada para Mdf a partir elementos maiores

Tabela A14. Modelamentos de elementos maiores para a geração de

Monzonitos heterogêneos $(M h)$ por cristalização fracionada e mistura de magmas

Tabela A15. Modelamentos de elementos maiores para a geração de quartzo monzonitos (Qsie) por cristalização fracionada e mistura de magmas.

Tabela A16. Modelamentos de elementos maiores para a geração de monzonitos $(M d f)$ por cristalização fracionada e mistura de magmas

Tabela A17. Modelamentos de elementos maiores para a geração de Sienitos (Sie) e quartzo sienitos (Qsie) por cristalização fracionada. 


\section{ANEXOS}

ANEXO 1 Tabelas de análises químicas de minerais

ANEXO 2 Tabelas de análises químicas de rocha total

ANEXO 3 Tabela de análises isotópicas de $\mathrm{Sr}$ e $\mathrm{Nd}$

ANEXO 4 Tabelas de estimativas de parâmetros físico - químicos de cristalização dos magmas

ANEXO 5 Tabelas de modelamentos de cristalização fracionada e de mistura de magmas a partir de elementos maiores

ANEXO 6 Mapa com a localização dos pontos com análises de química mineral e química de rocha total 


\section{CAPÍTULO I - INTRODUÇÃO}

\subsection{O Plúton Piracaia}

O Plúton Piracaia abriga em seus cerca de $30 \mathrm{~km}^{2}$ uma grande diversidade litológica (i.e. monzodioritos, monzonitos, quartzo monzonitos, sienitos, quartzo sienitos). O plúton apresenta formato elipsoidal, em resposta à atuação de um campo tensional durante o posicionamento dos magmas, que ocorreu em um contexto tardi a pós-orogênico. A atuação deste campo tensional condicionou a interação entre magmas monzodioríticos, sieníticos e quartzo sieníticos em diferentes escalas, gerando magmas híbridos e uma grande diversidade de estruturas, cuja análise propicia uma interpretação da sequência de intrusões dos magmas, durante a construção do plúton.

Os primeiros trabalhos específicos sobre o plúton devem-se a Cavalcante \& Kaefer (1974), que apresentaram um esboço geológico e delinearam seus contatos, e a Campos Neto \& Arthur (1983), que identificaram sete associações litológicas.

Uma importante contribuição ao conhecimento do plúton foi desenvolvida por Janasi (1986) e Janasi \& Ulbrich (1987), através de um mapeamento detalhado e extensa caracterização geoquímica e também isotópica. Foram identificadas 29 fácies, agrupadas em sete associações litológicas, e as variações composicionais foram consideradas como produto essencialmente de processos de cristalização fracionada, em dois estágios, a partir dos magmas monzodioríticos mais primitivos. Contudo, os autores já descreveram relações de contato entre rochas de composição contrastada, indicativas de coexistência entre os magmas. Estas feições também foram observadas por Gomes \& Platevoet (1994) e Gomes (1995), que descreveram estruturas do tipo pillow.

Wernick et al. (1997) e Wernick \& Menezes (2001) sugerem a existência de diversos pulsos de magmas durante a construção do plúton. Porém consideram que a cristalização fracionada a partir dos magmas mais primitivos é o principal processo petrogenético atuante no plúton, que teria ocorrido em diversos estágios, até atingir as composições referentes às rochas mais evoluídas.

São importantes também os trabalhos de Artur et al. (1994) e Artur (2003), que apresentam dados de tipologia de zircão para as rochas que compõem o plúton.

Trabalhos subsequentes (Salmoni, 2007; Janasi et al., 2007; Oliveira, 2009) já identificam a existência de fontes distintas para os magmas que construíram o plúton, assim como a origem híbrida para um dos tipos de monzonitos encontrados, embora não descartem a atuação concomitante de processos de cristalização fracionada. 


\subsection{Objetivos}

Este projeto propõe o estudo das estruturas de interação entre magmas intermediários (monzodioríticos) e félsicos (sieníticos e quartzo sieníticos) no Plúton Piracaia, a partir de levantamentos de campo e estudos petrográficos, para caracterizar os produtos mineralógicos e texturais desta interação. Estimativas dos parâmetros físico-químicos dos magmas (temperaturas liquidus e solidus, pressão de cristalização, $\alpha \mathrm{H}_{2} \mathrm{O}, f \mathrm{O}_{2}$ ) serão feitas de modo a compreender o seu comportamento quando da coexistência, permitindo elaborar modelos físicos para o processo. Da mesma forma, nas rochas que apresentam evidências de hibridismo (monzonitos heterogêneos e quartzo monzonitos) serão estudados os aspectos geoquímicos dos processos de mistura de magmas, a partir das variações dos conteúdos de elementos maiores e traços.

Através de termômetros de saturação de fases acessórias se buscará estimar as temperaturas liquidus dos magmas. Os minerais de interesse são zircão e apatita, e serão utilizados os modelos de solubilidade para Zr e P desenvolvidos por Watson \& Harrison (1983) e Harrison \& Watson (1984).

As estimativas de temperatura e pressão de cristalização dos magmas visam complementar os resultados apresentados por Salmoni (2007). O barômetro utilizado será o de Anderson \& Smith (1995), que baseia-se no conteúdo de Al na hornblenda. Já os termômetros serão os propostos por Blundy \& Holland (1990) e Holland \& Blundy (1994).

A atividade de $\mathrm{H}_{2} \mathrm{O}\left(\alpha \mathrm{H}_{2} \mathrm{O}\right)$ será estimada através dos modelos desenvolvidos por Lange et al. (2009), que estabelece uma relação entre o aumento do teor de An do plagioclásio com o aumento da temperatura e concentração de $\mathrm{H}_{2} \mathrm{O}$ dos magmas.

As condições de fugacidade de $\mathrm{O}_{2}\left(f \mathrm{O}_{2}\right)$ serão estimadas a partir das relações composicionais de cristais de magnetita e ilmenita, coexistentes e em equilíbrio, calculadas através do termômetro/oxibarômetro desenvolvido por Spencer \& Lindsley (1981). Em paralelo também será feita uma abordagem baseada nas relações entre $\mathrm{Fe}$ e $\mathrm{Mg}$ de minerais máficos (hornblenda e biotita), uma vez que sob condições de maior fugacidade a razão $\mathrm{Fe} /(\mathrm{Fe}+\mathrm{Mg})$ tende a diminuir.

Serão realizados ainda, modelamentos geoquímicos visando melhor entender os processos de mistura, assim como suas possíveis heterogeneidades. Os cálculos de balanço de massa, para elementos maiores e traço ( $\mathrm{Ba}, \mathrm{Sr}$ e $\mathrm{Rb}$ ), simularão a gênese das diferentes unidades a partir de processos de cristalização (em equilíbrio e fracionada) e de mistura de magmas.

Para elementos maiores os cálculos serão realizados a partir dos cálculos de Stormer \& Nichols (1978), enquanto para os elementos-traços os modelos de cristalização serão baseados nos trabalhos de Neuman et al. (1957) e Wood \& Frasier (1976), e os de mistura no trabalho de Langmuir et al. (1978). 


\subsection{Mistura de magmas - Aspectos Gerais}

O processo de interação entre magmas, inicialmente proposto por Bunsen (1851, apud Best, 2003) e intensamente discutido a partir da década de 1970, é hoje considerado um importante processo evolutivo em petrologia ígnea. Classificações recentes, como a de Barbarin (1999) propõem que a grande maioria das rochas graníticas apresentam algum grau de mistura entre magmas, de modo que grande parte da diversidade composicional dos magmas pode ser atribuída a processos de mistura.

De acordo com Philpotts \& Ague (2009) uma série de produtos pode ser gerada a depender do tipo e extensão do processo de interação entre os magmas. Se por um lado pode não haver mistura nenhuma, onde os magmas apenas coexistem (mingling), no outro extremo podem ocorrer processos de mistura homogênea, que geram magmas híbridos cujas evidências da mistura se manifestam apenas como cristais em desequilíbrio com o melt. Contudo, a interação entre magmas mais comumente produz híbridos por processos de mistura heterogêneos, que se destacam por suas variações texturais e geoquímicas.

Os contrastes entre as propriedades físicas dos magmas (temperatura, viscosidade, densidade) são fatores determinantes para o tipo e a extensão dos processos de mistura. Outros fatores importantes são os volumes relativos, o percentual de cristalização dos magmas, e em câmaras magmáticas a taxa de injeção e a existência de fluxos turbulentos, ou mesmo a atuação de tensão externa.

Quando dois magmas de composição contrastada (e.g. máficos e félsicos) interagem, a troca de calor faz com que a viscosidade do magma de menor temperatura (mais félsico) diminua à medida que sua temperatura aumenta, até que seja atingida a temperatura de equilíbrio. Uma vez atingido o equilíbrio térmico, a viscosidade do magma félsico pode ser maior ou menor que a do magma máfico, a depender de suas proporções relativas. A uma proporção específica, os dois magmas apresentam viscosidades iguais. Esta proporção, que varia em cada caso, foi denominada por Sparks and Marshall (1986) de limite de inversão reológica.

Os contrastes de densidade determinam se a injeção de um magma em uma câmara préexistente tenderá a ascender ou se acumular na base da câmara. Contudo, grandes contrastes de densidade podem ser compensados caso a taxa de injeção dos magmas seja elevada, desencadeando o desenvolvimento de fluxos turbulentos, que por sua vez favorecem a interação entre os magmas.

Durante a mistura ocorrem trocas químicas entre os magmas, através de mecanismos de difusão. Contudo, a efetividade da difusão apresenta limitações, principalmente quanto à distância, uma vez que a atuação de processos difusivos restringe-se a distâncias relativamente pequenas, da ordem de centímetros. O tempo também é um fator limitante, mesmo em ambiente plutônico, pois os coeficientes de difusão diminuem exponencialmente com a redução da temperatura.

A probabilidade de que ocorram processos de mistura homogênea é maior quanto menor for o contraste composicional entre os membros-finais. Ainda assim, Sparks \& Marshall (1986) afirmam que a homogeneização do sistema (i.e. mistura homogênea) somente será atingida caso os magmas 
estejam predominantemente líquidos no momento da interação. Embora se considere que seja possível a geração de um magma híbrido homogêneo com padrões composicionais lineares e intermediários entre os membros-finais da mistura (Perugini et al., 2003), o que vem sendo observado sistematicamente é que dificilmente atinge-se o equilíbrio para todos os elementos, em especial os elementos traço (Perugini et al., 2006; Menendez \& Ortega 1999; Petrelli et al., 2011).

De todo modo os processos de mistura tendem a ser intensificados pela combinação de processos físicos e químicos. A atuação de fatores dinâmicos, no que se refere ao fluxo e dispersão dos magmas, é considerada indispensável para o desenvolvimento de uma mistura mais efetiva (Koyagushi, 1986; Perugini et al., 2003 e 2006). Estes mecanismos dinâmicos, embora ocorram também em câmaras magmáticas, tendem a ser mais efetivos durante a ascensão e transporte dos magmas a níveis crustais mais rasos (Blake \& Campbell, 1986; Zorpi et al., 1989; Collins et al., 2000).

\subsection{Métodos}

\subsubsection{Atividades de campo}

Durante a realização do presente trabalho foram realizadas três atividades de campo principais, totalizando 12 dias. A primeira ocorreu entre 11 e 15 de agosto de 2009; a segunda entre 26 de novembro e 01 de dezembro de 2009; e a terceira entre 08 e 11 de fevereiro de 2010, todas auxiliadas por colegas de pós-graduação e graduação.

Os dois primeiros campos visaram o reconhecimento das diferentes unidades, assim como cobrir a maior área possível do plúton. O terceiro campo teve como objetivo principal elucidar algumas questões importantes, principalmente com relação aos locais com evidências de mistura de magmas. Foram visitados ao todo 124 pontos (PI-500 a PI-624). Utilizou-se como base o mapa geológico na escala 1:25000, desenvolvido por Janasi (1986) e modificado por Salmoni (2007). Ferramentas adicionais foram as cartas topográficas do IBGE na escala 1:10000 e os software Google Earth e ArcGis 9.3.

Ao longo do período de mestrado foram realizadas duas outras atividades de campo, uma acompanhando a aluna Fernanda de Carvalho Oliveira na coleta de dados para a realização de seu Trabalho de Formatura; e a outra acompanhando a Professora Maria Irene B. Raposo, para a coleta da amostras para as análises de Anisotropia de Susceptibilidade Magnética (ASM). 


\subsubsection{Susceptibilidade Magnética}

As medidas de susceptibilidade magnética absoluta foram obtidas através de um aparelho portátil Exploranium modelo KT-9. Foi utilizado o modo "pin", que segundo o manual do produto registra a susceptibilidade magnética real, até uma profundidade de $\sim 20 \mathrm{~mm}$, com erros absolutos da ordem de $1 \%$.

Foras obtidas cinco medidas em cada afloramento e em alguns casos em amostras de mão, onde o valor considerado representa a média das medidas.

\subsubsection{Petrografia}

Foram confeccionadas 60 laminas petrográficas, que se somaram ao acervo construído pelo orientador desde seu mestrado, e complementado em orientações subsequentes.

A petrografia foi realizada utilizando-se um microscópio Olympus modelo BX50, com objetivas de 1.25X, 4X, 10X e 40X. Dentre as lâminas confeccionadas, cerca de 20 foram polidas para caracterização da mineralogia de opacos, que também foi realizada através do mesmo microscópio.

No presente trabalho não foram realizadas análises modais. Considerou-se que os dados obtidos por Janasi (1986) são representativos para as diferentes unidades, uma vez que muitos dos pontos foram revisitados durante as três atividades de campo.

\subsubsection{Microscopia Eletrônica de Varredura}

As análises de Microscopia Eletrônica de Varredura (MEV) foram realizadas visando caracterizar as relações texturais de minerais opacos, não identificáveis ao microscópio de luz refletida. Este método consiste em excitar a amostra com um feixe de elétrons de alta energia, obtendo-se como resultado elétrons secundários, elétrons retroespalhados, raios $\mathrm{X}$ característicos e catodoluminescência. Através dos elétrons secundários e elétrons retroespalhados, obtém-se um imageamento de detalhe das amostras. A análise semi-quantitativa para elementos maiores dos pontos analisados é possível através de um sistema EDS (espectrômetro de dispersão de energia) acoplado.

Foram realizadas duas seções de 4 horas cada, no Laboratório de Microscopia Eletrônica da UFRGS (CME-UFRGS), através de um Microscópio JEOL - JSM 5800. Utilizou-se uma voltagem de aceleração de 20 kV, em lâminas petrográficas metalizadas com Carbono. 


\subsubsection{Química Mineral}

Análises quantitativas de minerais foram realizadas no Laboratório de Microssonda Eletrônica do IGc-USP, através de um equipamento JEOL JXA-8600S, provido de cinco espectrômetros de dispersão de comprimento de onda (WDS), cada um com dois cristais analisadores (TAP/STE), TAP/PET, PET/LiF e LiF/PET). O equipamento tem automação de fabricação NORAN e sistema Voyager 3.6.1. Foram realizadas correções de efeito de matriz (numero atômico, absorção de massa e fluorescência secundária) segundo o procedimento PROZA (Bastin et al., 1984).

As análises foram feitas em lâminas polidas, cobertas com uma película de C de aproximadamente $25 \eta \mathrm{m}$ de espessura, e são obtidas pela emissão de um feixe de elétrons de baixa energia, gerado por um filamento de tungstênio e acelerado por um eletrodo, resultando em um diâmetro de aproximadamente $1 \mu \mathrm{m}$. A composição química é determinada pela comparação da intensidade de radiação $\mathrm{X}$ dos átomos da amostra excitados pelo feixe com aquela emanada de uma substância de composição química conhecida tomada como padrão. A análise qualitativa é realizada pelo sistema EDS e quantitativa pelo sistema WDS.

Foram analisados os minerais: biotita, plagioclásio, hornblenda, magnetita e ilmenita. Ao todo foram realizados cinco dias de análises. Foram analisados pelo menos três cristais de cada amostra, onde em cada cristal foram feitas pelo menos três análises. Os dados foram manuseados através do software Minpet, sendo que foi incluído o banco de dados para os mesmos minerais, construído pelo orientador, exceto os minerais opacos.

As análises foram realizadas com um feixe eletrônico de $15 \mathrm{kV}$ de voltagem de aceleração e $20 \eta \mathrm{A}$ de corrente. $\mathrm{O}$ diâmetro do feixe para plagioclásios foi de 5 ou $10 \mu \mathrm{m}, 5 \mu \mathrm{m}$ para biotita e anfibólio e tipicamente $1 \mu \mathrm{m}$ para os opacos. Os tempos de contagem foram de 10 segundos para $\mathrm{Si}$, $\mathrm{Al}, \mathrm{Ti}, \mathrm{Fe}, \mathrm{Mg}, \mathrm{Mn}, \mathrm{Ca}, \mathrm{K}, \mathrm{Na}, \mathrm{F}, \mathrm{Cl}$ e de 30 segundos para os menores $\mathrm{Ni}, \mathrm{Zn}, \mathrm{Nb}, \mathrm{Cr}, \mathrm{Ba}$.

Para as estimativas de pressão e temperatura foram analisados três pares de cristais plagioclásio-hornblenda para cada amostra. Foram analisados tanto cristais de plagioclásio tabulares, zonados e de grande dimensão, como também cristais da matriz. Nos cristais tabulares zonados, foram analisadas três porções dos cristais: os núcleos, porções intermediárias e bordas.

Os cristais de magnetita e ilmenita selecionados haviam sido previamente analisados por Microscopia Eletrônica de Varredura (MEV) com sistema EDS acoplado. As análises de MEV visaram melhor caracterizar as relações texturais entre ilmenita e magnetita, assim como identificar processos de exsolução. Alguns cristais de ilmenita apresentavam finas lamelas de exsolução de hematita, de modo que nestes cristais o feixe da microssonda foi alterado para $20 \mu \mathrm{m}$. Como o intuito das análises de opacos era identificar relações de equilíbrio entre magnetita e ilmenita visando determinar as condições de fugacidade de oxigênio dos magmas, foram também analisados três pares de cristais magnetita-ilmenita. 


\subsubsection{Química de rocha total}

Foram selecionadas 21 amostras das diferentes unidades para análises químicas de elementos maiores e traços. Foram realizadas também análises de 3 porções de uma vênula félsica, juntamente com duas análises dos monzodioritos adjacentes à vênula.

As amostras foram preparadas no Laboratório de Tratamento de Amostras (LTA) do Instituto de Geociências da USP (IGc-USP). A fragmentação inicialmente se deu com o uso de marreta e prensa hidráulica, separando-se as porções alteradas. Preferiu-se não utilizar o britador de mandíbulas de aço para diminuir a possibilidade de contaminação das amostras. Após o quarteamento as amostras foram cominuídas utilizando-se panela de ágata e moinho planetário de ágata, até se atingir a fração de 200 mesh.

Durante toda a preparação utilizou-se álcool líquido e ar comprimido para a limpeza dos equipamentos, antes e após a sua utilização, também visando minimizar, a possibilidade de contaminação das amostras.

Elementos maiores e traço foram analisados no Laboratório de Fluorescência de raios $\mathrm{X}$ do IGc-USP, através de equipamento automático Phillips PW 2400. Para tanto, confeccionaram-se pastilhas fundidas para a análise de elementos maiores e pastilhas prensadas para os elementos-traço. As pastilhas fundidas são confeccionadas a partir da mistura de $1 \mathrm{~g}( \pm 0,001)$ de pó da amostra com $9 \mathrm{~g}$ $( \pm 0,001)$ de fundentes metaborato e tetraborato de lítio, levados ao fogo a uma temperatura de $1000^{\circ} \mathrm{C}$ em cadinhos de platina. As pastilhas prensadas são confeccionadas após a micronização de 7,5 g da amostra e adição de parafina, em proporção de $20 \%$ em relação ao peso da amostra.

Foram selecionadas 10 das 21 amostras, mais as três porções da vênula félsica e dois monzodioritos adjacentes, para análise de elementos traço por espectrometria de massa com plasma indutivamente acoplado (ICP-MS). As análises foram realizadas no Laboratório de Química e ICP do IGc-USP, através de um de espectrômetro do tipo quadrupolo, modelo ELAN 6100DRC da PerkinElmer/Sciex. As amostras foram preparadas segundo a metodologia descrita em Navarro (2004), através de digestão ácida em bombas do tipo Parr, usando $\mathrm{HNO}_{3} 14 \mathrm{~N}$ e $\mathrm{HF} 40 \%$, a partir de uma alíquota de $40 \mathrm{mg}$ de amostra. A digestão se dá sob temperatura em torno de $200^{\circ} \mathrm{C}$, por aproximadamente 5 dias, atingindo pressões de até 10 atm, de modo a garantir a completa dissolução de minerais acessórios, em especial o zircão.

Os resultados para ambos os métodos, juntamente com o banco de dados construído pelo orientador, foram tratados através dos softwares Excel, Petrograph e GCD Kit, para a normalização, confecção de diagramas e modelamentos geoquímicos.

O mapa do plúton com a localização dos todos os pontos com análises químicas de rocha total e química mineral é apresentado no Anexo 6. 


\subsection{Contexto Geológico}

O Plúton Piracaia, localizado a cerca de $80 \mathrm{~km}$ a nordeste da cidade de São Paulo-SP, faz parte da Província Granítica Itu (PGI), que segundo Janasi et al. (2009) representa uma associação de plútons graníticos pós-orogênicos ( 590-580 Ma), que formam um cinturão predominantemente linear e estende-se por aproximadamente $\sim 350 \mathrm{~km}$ com uma orientação N60E, intrudindo o extremo sul do Terreno Apiaí-Guaxupé. Os granitos da PGI apresentam assinatura geoquímica do tipo A e são predominantemente sub-alcalinos, cristalizados sob condições oxidantes e contemporâneos com granitos cálcio-alcalinos alto $\mathrm{K}$ do tipo $\mathrm{I}$, dentre os quais rochas básicas a intermediárias ricas em $\mathrm{K}$, como as do Plúton Piracaia evidenciam a contribuição de um manto litosférico metassomatizado a este magmatismo.

A PGI intrude o extremo sul do Terreno Apiaí-Guaxupé (Figura 1), que é formado pela Nappe Socorro-Guaxupé (NSG) e pelo Domínio Apiaí-São Roque (DASR). O Terreno Apiaí-Guaxupé tem sua origem relacionada ao processo de subducção e colisão entre os Crátons Paranapanema e São Francisco, que se completou entre 630-610 Ma com o desenvolvimento de um sistema de nappes de alta pressão (Campos Neto \& Caby, 1999). Neste contexto, o DASR juntamente com a NSG representam as margens continentais ativas de idade Criogeniana-Ediacarana, desenvolvidas diacronicamente ao longo da borda da Placa Paranapanema.

O DASR é composto predominantemente por rochas metamórficas de baixo grau relacionadas a sequências metavulcano-sedimentares mesoproterozóicas e uma unidade plataformal carbonática neoproterozóica (Campos Neto, 2000). Estas sequências são cortadas por granitos sin-orogênicos cálcio-alcalinos de alto K, com idades aproximadas entre 615-605 Ma (Janasi et al., 2001; Prazeres Filho et al., 2003).

A NSG representa um pacote alóctone de uma seção de aproximadamente $15 \mathrm{~km}$ de espessura, compreendendo níveis de crosta inferior a média, subdivididos em: Unidade Granulítica Inferior, Unidade Diatexítica Intermediária e Unidade Migmatítica Superior (Campos Neto, 2000). É cortada por granitos sin-orogênicos de arco magmático, charnockitos e granitos anatéticos. Estes granitos são aparentemente um pouco mais antigos dos que ocorrem no DASR, com idades entre 625-610 Ma, que coincidem com o intervalo de duração do pico metamórfico regional (Campos Neto, 2000). 


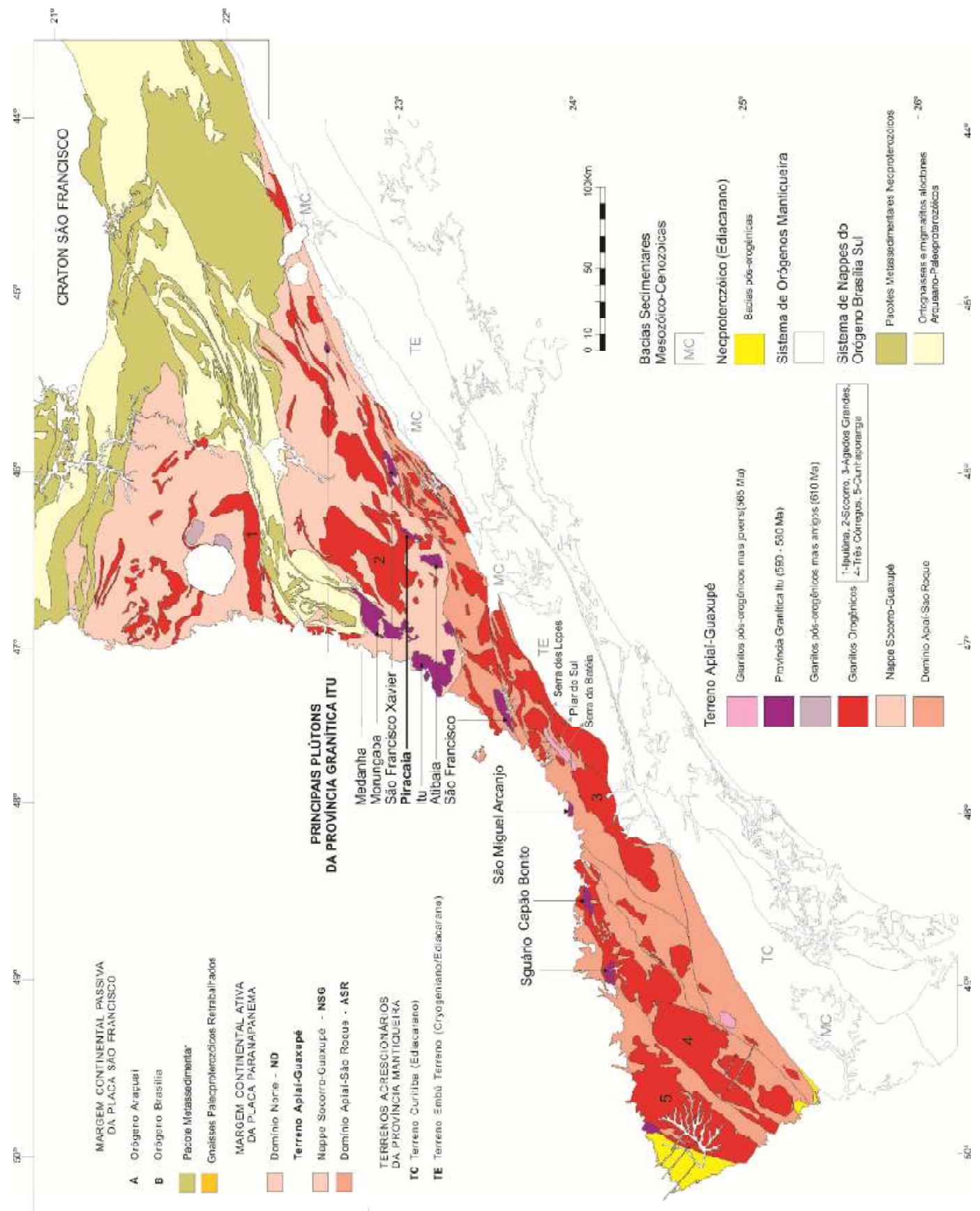

Figura 1. Esboço geológico do embasamento cristalino de parte da região sudeste do Brasil. Salienta-se na cor roxo os plútons pertencentes à Província Granítica Itu (simplificado de Janasi et al. (2009).

A NESG e o DASR registram também um magmatismo mais recente, entre 590-580 Ma, que se posiciona em níveis crustais relativamente rasos, após o deslocamento vertical principal da nappe (Heilbron et al., 2004), que corresponde à PGI. A PGI dispõe-se paralelamente ao contato com o Domínio Embu, que é delimitado ao norte pela Falha de Taxaquara e ao sul pela Falha de Cubatão. O Terreno Embu representa um terreno acrescionado segundo um regime transpressional dextral, logo após a colisão entre as Placas do Paranapanema e São Francisco. Esta acresção lateral pode ter gerado 
um alívio de pressão, que associado ao soerguimento de crosta e elevado gradiente térmico relacionados ao processo orogenético, contribuíram para a geração dos magmas da PGI (Janasi et al., 2009).

O limite norte entre a NESG e DASR é controlado pela zona de cisalhamento de Jundiuvira, que apresenta sentido de movimentação lateral esquerdo. O Plúton Piracaia localiza-se a cerca de 10 $\mathrm{km}$ deste limite, intrudindo o domínio da NESG ao longo de uma zona de falhas que se situa entre as zonas de cisalhamento de Extrema e São Bento do Sapucaí, e também condiciona a intrusão do Sienogranito Atibaia (Figura 2).

O Plúton Piracaia, datado em 578 \pm 3 Ma (U-Pb em zircão, Janasi et al., 2009), intrude rochas do Complexo Metamórfico Piracaia (CMP), e rochas graníticas do Complexo Granítico Socorro, com as quais os contatos são essencialmente tectônicos. Rochas do CMP ocorrem também como tetos pendentes (roof pendants) nas porções centro-leste e sudeste do plúton.

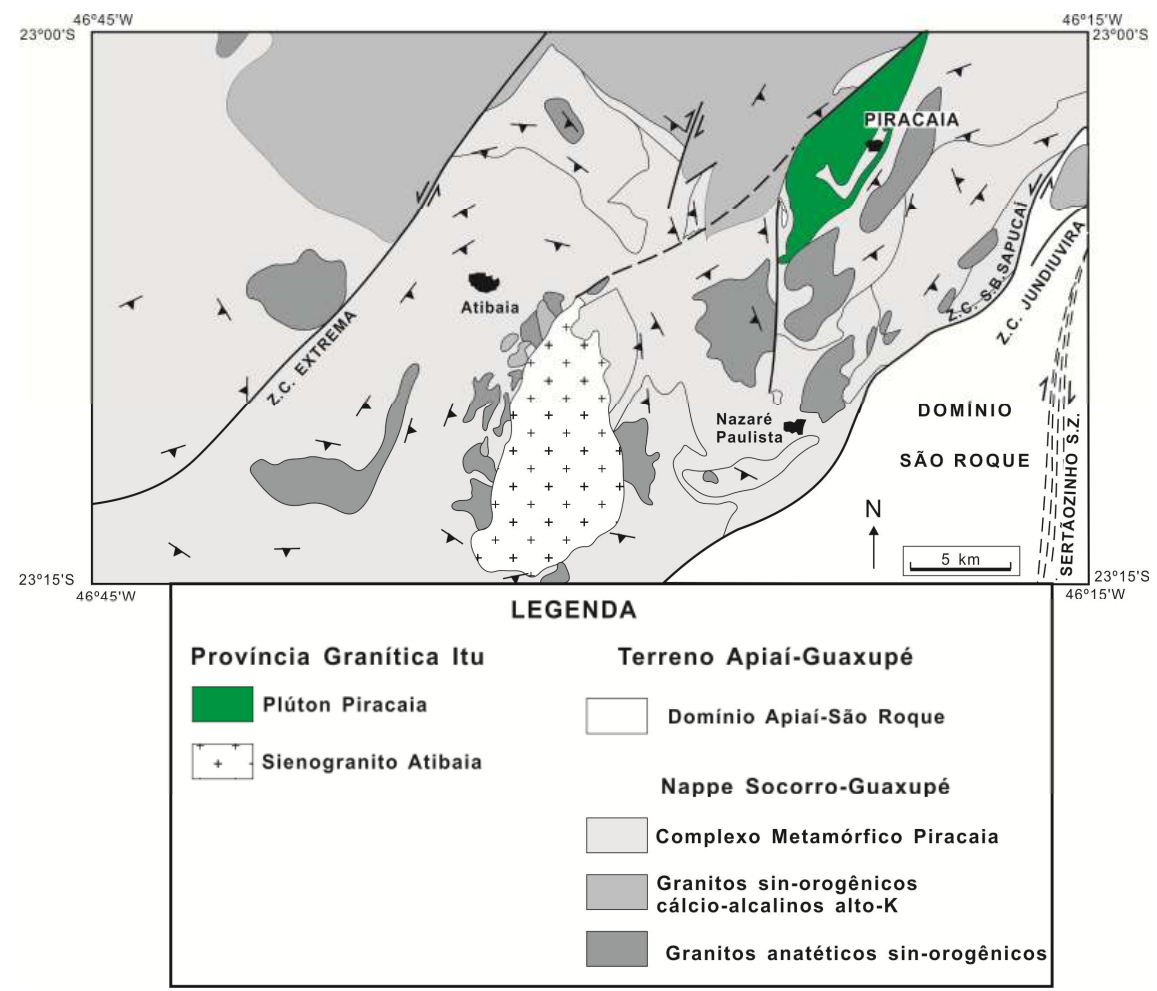

Figura 2. Esboço do contexto geológico local da região de Piracaia e Atibaia. Destaca-se a proximidade do Plúton Piracaia com o limite entre a Nappe Socorro-Guaxupé e o Domínio Apiaí-São Roque.

O Complexo Metamórfico Piracaia representa uma unidade metassedimentar pré-brasiliana, que compreende xistos e gnaisses, ambos migmatizados, porém com intensidade variável. Uma coluna estratigráfica foi proposta para por Campos Neto et al. (1983): a unidade basal é formada por biotita gnaisse (tonalítico a granítico) de afinidade desconhecida (ortognaisse?) que ocorre principalmente a leste do Plúton Piracaia (Figura 2). Acima dela, aparece uma unidade espessa de granada-biotita gnaisse, com camadas decimétricas de rocha cálcio-silicática e anfibolito, derivada do metamorfismo 
de grauvacas (Janasi, 1999). A unidade superior é dominada por metapelitos (sillimanita-granadabiotita xisto), com intercalações menores de mica-quartzo xisto e quartzitos micáceos.

As rochas do Complexo Socorro que fazem contato com o Plúton Piracaia ao longo de sua porção oeste. São granitos a tonalitos megaporfiríticos, por vezes fortemente foliados, caracterizando uma estrutura protomilonítica, com feldspatos estirados (augen). Já os granitos situados a sudeste são biotita granitos anatéticos, leucocráticos e de cor rosada, conhecidos como granitos do tipo Quatro Cantos.

Artur et al. (1993) e Artur (2003), propuseram reunir todo o conjunto de rochas plutônicas da região no chamado Complexo Granitóide Socorro, no qual incluíram também o Plúton Piracaia. O ordenamento temporal proposto é: Associação Magmática Nazaré Paulista; Associação Magmática Socorro I; Associação Magmática Charnoquítica; Associação Magmática Socorro II; e Associação Magmática Piracaia; onde as diferentes associações apresentariam uma superposição temporal parcial.

O Plúton Piracaia intrude rochas das Associações Nazaré Paulista e Socorro I, sendo que os granitos megaporfiríticos mais tardios da Associação Socorro I apresentam idades de $595 \pm 12 \mathrm{Ma}$ (Töpfner, 1996 apud Artur, 2003). Deste modo, a diferença temporal entre estes granitos tardios e o Plúton Piracaia coincide com intervalo entre as fases orogênicas (625-605 Ma) e pós-orogênicas ( 590-580 Ma) propostos por Janasi et al. (2009), que é de aproximadamente $15 \mathrm{Ma}$. 


\section{CAPÍTULO II - CARACTERIZAÇÃO GEOLÓGICA DO PLÚTON PIRACAIA}

\subsection{Geologia}

O Plúton Piracaia apresenta formato elipsoidal, medindo cerca de $15 \mathrm{~km}$ de comprimento e no máximo $2,5 \mathrm{~km}$ de largura, ocupa uma área de aproximadamente $30 \mathrm{~km}^{2}$, com orientação aproximadamente N30E. O plúton apresenta heterogeneidades estruturais, texturais e modais que são muitas vezes perceptíveis em escala de afloramento ou mesmo escala de mão. Foliações magmática e de estado sólido são comumente observadas, coincidem com a orientação do plúton e apresentam ângulo de mergulho elevado.

Através de um mapeamento detalhado, 29 diferentes fácies foram identificadas por Janasi (1986) e Janasi \& Ulbrich (1987). Tal variação faciológica reflete em grande parte processos puramente magmáticos. Contudo, alguns dos critérios utilizados nesta subdivisão estão relacionados a aspectos estruturais, no que se refere ao desenvolvimento de feições deformacionais à medida que a foliação magmática evolui para uma componente de estado sólido.

As 29 fácies foram agrupadas por Janasi (1986) e Janasi \& Ulbrich (1987) em sete unidades, que são:

(a) Monzodioritos muito finos escuros (Mde);

(b) Monzodioritos finos $(M d f, M d f(t))$ e médios $(M d m)$ e equivalentes metamorfisados, gnáissicos $(\operatorname{Mdf}(g), \operatorname{Mdm}(g))$;

(c) Monzodioritos grossos arroxeados $(M d r)$;

(d) Monzonitos médios a finos cinzentos $(M f c)$ e equivalentes metamorfisados, gnáissicos $(M f c(g))$;

(e) Monzonitos "microporfiríticos" $(M p)$;

(f) Sienitos cinzentos médios (Sie);

(g) Quartzo monzonitos e quartzo sienitos grossos ( $Q m e, Q m m, Q m l, Q s l$ e Aqs).

No presente trabalho propõem-se modificações em relação à distribuição de unidades apresentadas por Janasi (1986) e Janasi \& Ulbrich (1987) (Figura3). Na Figura 4, apresenta-se a redefinição de contatos e redistribuição de unidades propostas, juntamente com a localização dos pontos visitados. Dentre as mudanças, salientam-se:

- A unidade de (Sie), cujos contatos foram delineados por Janasi (1986) baseando-se em critérios aerofotogeológicos e que ocupava uma área de aproximadamente $4 \%$ do plúton, mostrou-se impossível de ser representada em mapa. A litologia pôde ser observada apenas em alguns afloramentos, sob a forma de matacões, localizados principalmente no extremo norte do plúton. O restante de sua área original corresponde à unidade de Monzonitos Microporfiríticos, segundo Janasi (1986), e que passou a ser chamada em 
trabalhos subsequentes de Monzonitos heterogêneos $(M h)$. Contudo, salienta-se a importância da unidade Sie devido às diversas feições estruturais e químicas que evidenciam sua participação em processos de mistura com monzodioritos que resultaram na unidade de Monzonitos heterogêneos $(M h)$;

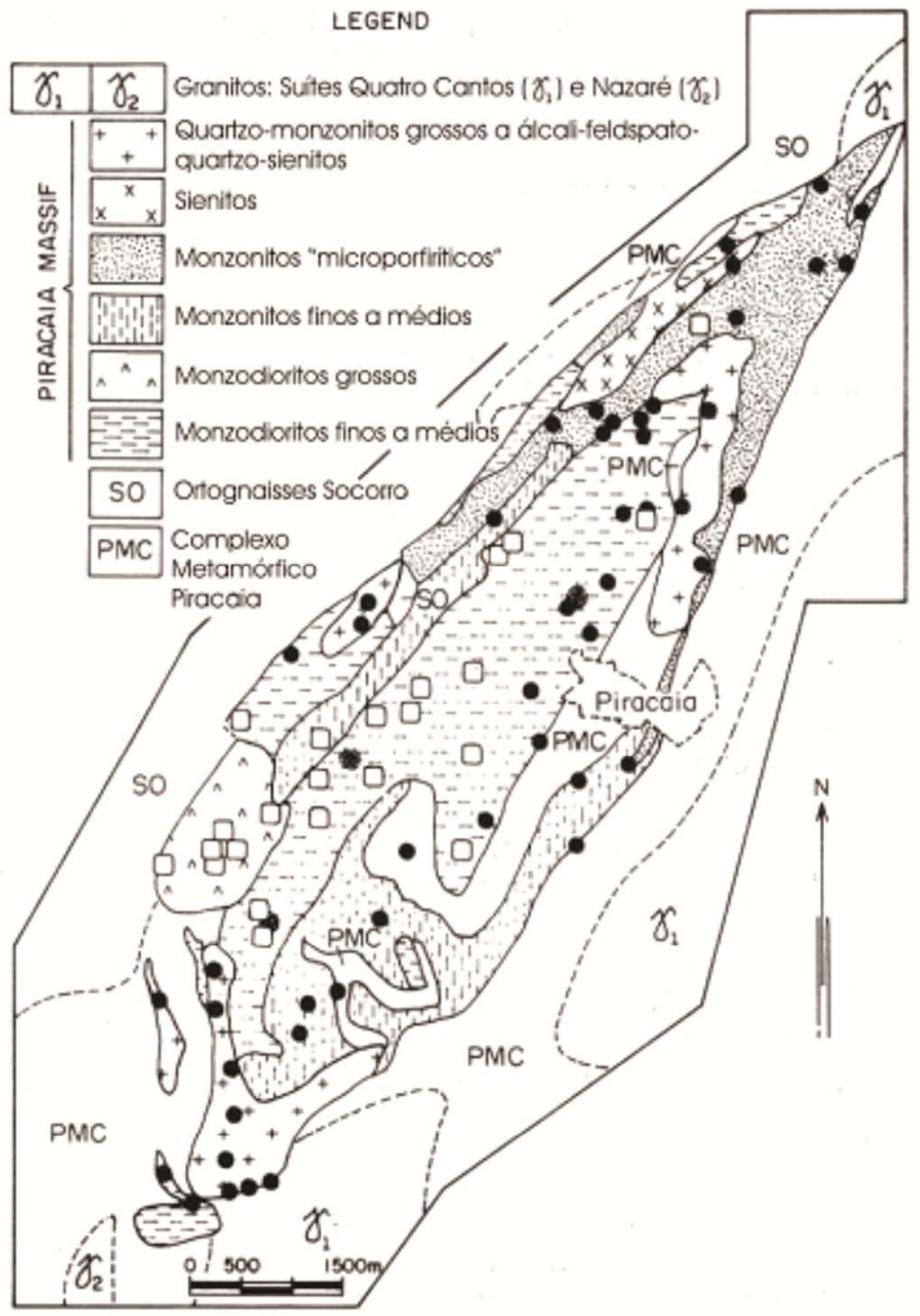

Figura 3. Mapa geológico do Plúton Piracaia, segundo Janasi \& Ulbrich (1987). 
- Embora Janasi (1986) reconheça que "cada unidade mapeável raramente corresponde à área de predomínio de um único fácies", optou-se pela não representação de áreas de domínio entre os fácies Monzodiorito fino $(M d f)$ e Monzodiorito médio $(M d m)$ no mapa geológico, por entender-se que os dois tipos texturais ocorrem predominantemente associados ao longo de toda a unidade, mesmo tendo Janasi 1986 observado que "o que se observa são áreas de predomínio dos tipos finos e médios".

- Da mesma forma, optou-se por inserir a unidade de Monzonitos médios a finos cinzentos $(M f c)$ junto à unidade de Monzodioritos finos a médios $(M d f)$, uma vez que ambas ocorrem intimamente associadas. Contudo, se reconhece que a ocorrência dos Monzonitos esteja aparentemente restrita às regiões atribuídas à unidade $M f c$ por Janasi (1986), isto é, ao longo das bordas oeste, leste e sudeste da unidade de Monzodioritos finos e médios;

- A unidade de Monzodioritos muito finos escuros (Mde) também foi incluída na unidade de monzodioritos finos a médios ( $M d f)$, considerando sua semelhança composicional e ocorrência restrita.

Tendo sido feitas as observações sobre as principais mudanças, faz-se necessário uma breve descrição das unidades.

\subsubsection{Monzodioritos grossos (Mdr)}

A unidade $M d r$ localiza-se exclusivamente na porção SW do plúton. Suas características principais são a textura grossa e estrutura maciça (Figura 5A). Duas fácies são reconhecidas: a fácies escura, predominante, tem composição diorítica a monzodiorítica e IC entre 25 e 45; já a fácies clara é monzodiorítico a monzonítico, com IC entre 15-25. A quantidade e qualidade das exposições não permitem estabelecer as relações de contato mútuo.

Também não foi possível definir com clareza a relação das rochas de textura grossa com algumas ocorrências em diferentes locais da unidade de monzodioritos de textura fina que apresentam forte foliação magmática. Contudo, feições observadas em alguns pontos são sugestivas de que os monzodioritos finos sejam intrusivos. O ponto PI-609 é um exemplo, localizado na porção central da unidade, em uma área de relevo relativamente suave, afloram algumas cristas alinhadas de 1 ou 2 metros de espessura, paralelas à foliação magmática. Já no ponto PI-589, localizado próximo ao contato com a unidade $M d f$, monzodioritos grossos e finos ocorrem justapostos, com contato abrupto, porém não retilíneo (Figura 5B). 


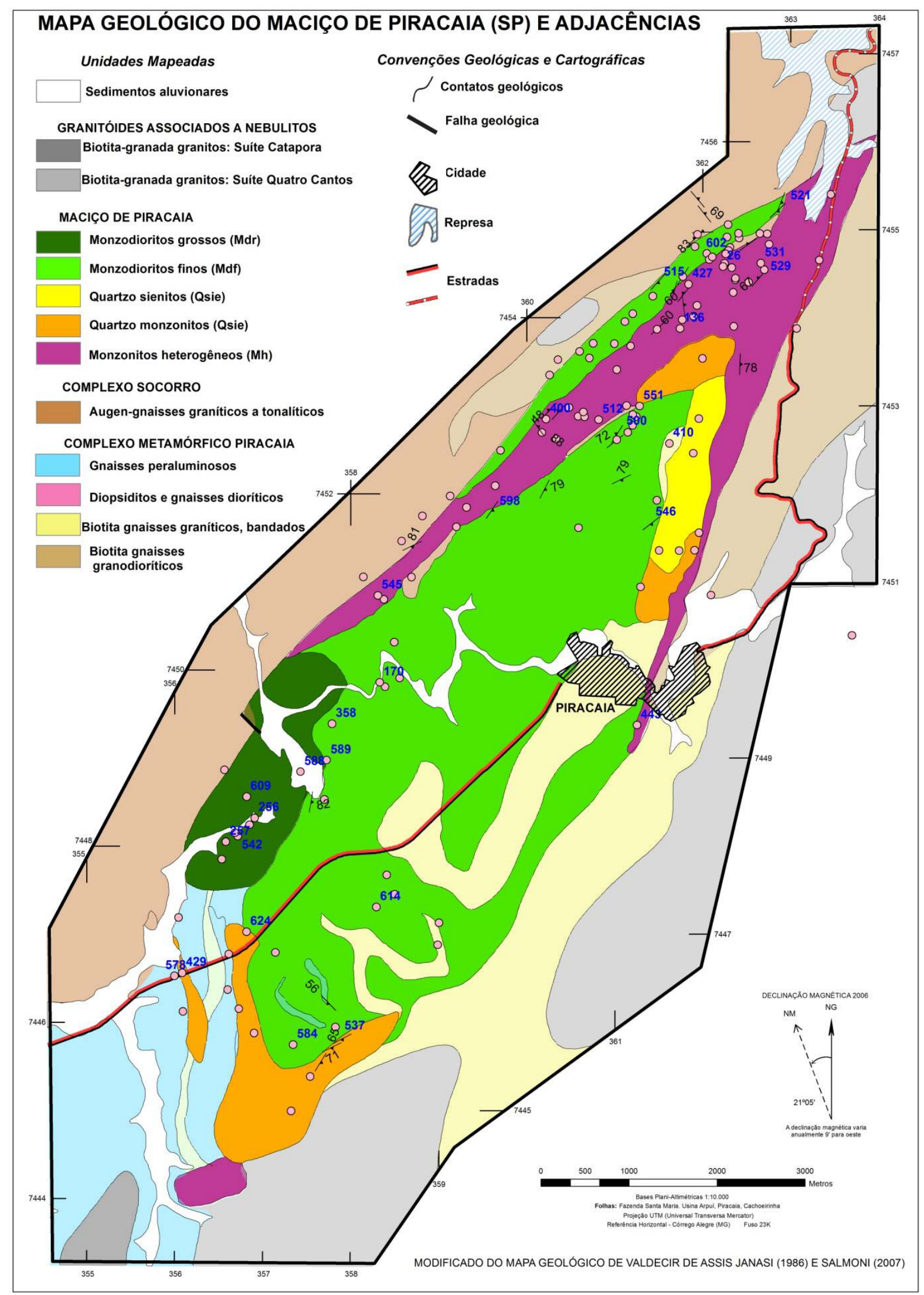

Figura 4. Mapa geológico do Plúton Piracaia, com as modificações nas unidades e contatos redefinidos, segundo o presente trabalho. Constam em azul os pontos mencionados no texto e em preto as foliações medidas em campo. Modificado de Janasi \& Ulbrich (1987) e Salmoni (2007). 


\subsubsection{Monzodioritos finos a médios (Mdf)}

Os $M d f$ representam a unidade de maior expressão no plúton. Ocupam sua parte central e ocorrem também sob a forma de uma fina "faixa" ao longo da borda NW. As rochas da unidade exibem variações mineralógicas, modais e texturais, que em parte refletem processos puramente ígneos e em parte estão relacionadas à atuação de um campo tensional, responsável pelo desenvolvimento de uma foliação de estado sólido.

A unidade apresenta rochas que abrangem um grande intervalo composicional, que pode ser expresso pela variação no conteúdo de máficos (IC entre 45 e 25), compreendendo monzodioritos e monzonitos. Predominam monzodioritos, texturalmente heterogêneos em escala de afloramento, uma vez que são comuns alternâncias entre porções finas e médias. Embora os termos finos sejam mais abundantes, por vezes caracterizando uma textura equigranular fina, as rochas desta unidade tipicamente apresentam textura inequigranular fina a média (Figura 5C e D).

Destaca-se ainda a ocorrência restrita de monzodioritos com textura muito fina, quase a afanítica; dentre as quais ocorrem variações porfiríticas, com fenocristais tabulares de plagioclásio e biotita. Estes monzodioritos destacam-se pelo elevado conteúdo de máficos (IC>35).

A centro-sul do corpo central, assim como próximo à borda W-NW, ocorrem monzonitos, (unidade $M f c$ de Janasi, 1986). Identificam-se dois tipos texturais, um com textura equigranular fina e outro com textura inequigranular fina a média. São mineralogicamente semelhantes aos monzodioritos, porém mais félsicas, apresentando um conteúdo maior de feldspato alcalino, IC entre 15 e 25 , e quartzo inferior a 5\%. Monzonitos e monzodioritos ocorrem intimamente associados, mesmo em escala de afloramento. Por vezes apresentam relações de corte, cuja geometria complexa não permite inferir a cronologia relativa.

As rochas situadas na porção centro-oeste e sudoeste do corpo central em geral apresentam estrutura maciça e apenas por vezes se observa foliação magmática. Nas demais porções do corpo (porção leste e em toda a sua porção norte), as rochas passam a apresentar forte foliação, com componente de estado sólido importante.

Em alguns poucos pontos de monzonitos $(M d f)$ e quartzo monzonitos ( $Q s i e)$ observa-se a ocorrência de enclaves monzodioríticos com textura muito fina, de pequena dimensão e com contatos abruptos com as hospedeiras.

É comum ainda a existência de venulações félsicas centimétricas, relacionadas à unidade Qsie, que apresentam grande diversidade textural e composicional, compreendendo monzonitos, quartzo monzonitos, sienitos e quartzo sienitos. Estas venulações apresentam contatos que variam de abruptos a interdigitados e gradacionais, evidenciando diferentes contrastes reológicos em relação aos monzodioritos. 

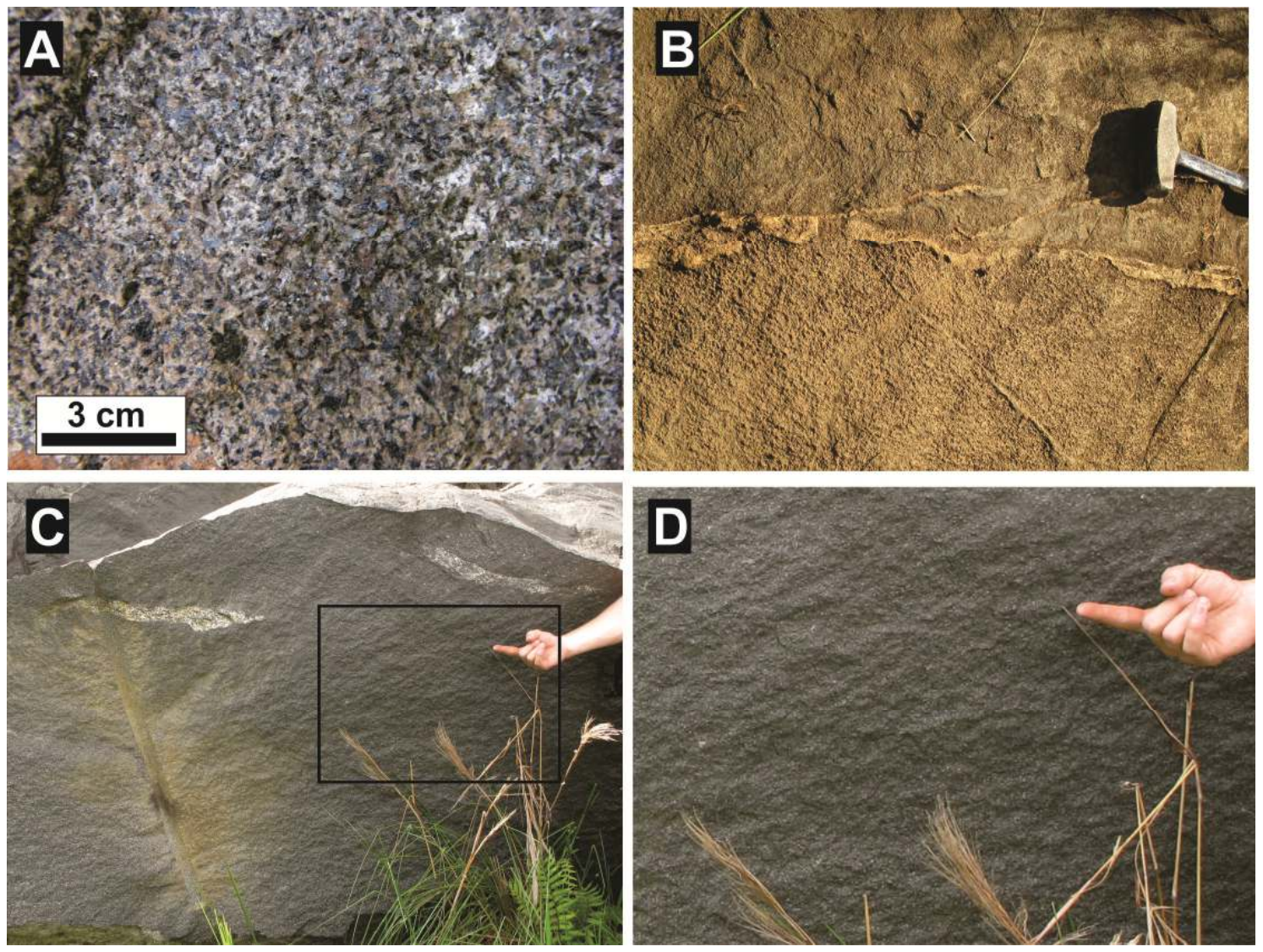

Figura 5. Unidades $M d r$ e $M d f$ : (A) monzodiorito grosso ( $M d r$ ) com textura equigranular grossa e estrutura maciça (PI-542); (B) associação entre monzodiorito grosso (Mdr) (porção inferior da foto) e monzodiorito fino $(M d f)$ (porção superior da foto) com contatos irregulares, onde observa-se uma venulação félsica centimétrica na interface entre as litologias (PI-589); (C) Monzodiorito (Mdf), apresentando venulações félsicas dispersas (PI500); (D) detalhe da foto "C", destacando a textura inequigranular fina a média.

As venulações são também encontradas nas demais unidades que compõem o plúton. Contudo, são muito mais abundantes em $M d f$, em especial próximo ao contato com os dois corpos principais de Qsie, como observado por Janasi (1986). Nestes locais é comum que os monzodioritos ocorram circundados por estas rochas félsicas, caracterizando estruturas do tipo "pillow" (Wiebe,1988; Wiebe et al., 2001).

\subsubsection{Quartzo sienitos e quartzo monzonitos (Qsie)}

A unidade Qsie ocorre como dois corpos principais e ocupa uma área total de aproximadamente $5 \mathrm{~km}^{2}$, o que equivale a aproximadamente $18 \%$ plúton. Um dos corpos localiza-se na porção NE do plúton, entre a unidade de Monzonitos heterogêneos $(M h)$ e o corpo central de Monzodioritos finos a médios $(M d f)$. Apresenta formato alongado e de certa forma "bordeja" a unidade de monzodioritos. Quartzo sienitos com textura equigranular grossa e IC $<10$ são os litotipos mais abundantes (Figura 6A e B). Contudo, em suas bordas norte e sul ocorrem quartzo monzonitos com textura média a grossa, e IC $\sim 20$. 

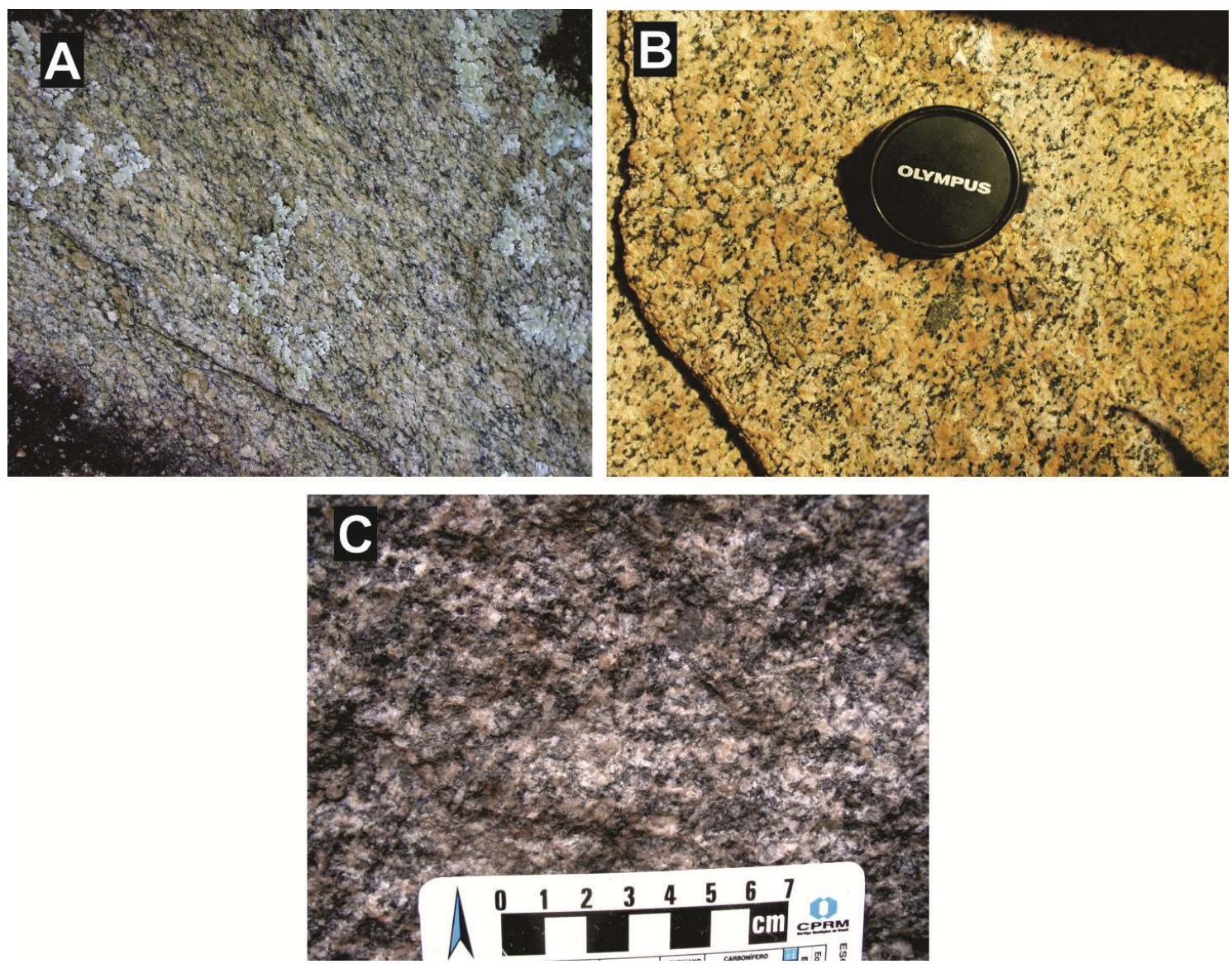

Figura 6. Unidade Qsie: (A) quartzo sienito leucocrático, com textura equigranular grossa, apresentando foliação incipiente (PI-410); (B) quartzo sienito com elevado conteúdo de máficos (IC 10), cortando a unidade Mh (PI427); (C) quartzo monzonito com elevado IC ( 20) e máficos predominantemente restritos à matriz (PI-624).

O segundo corpo situa-se no extremo sul do plúton e seu formato em planta lembra um "V". Predominam quartzo monzonitos com textura inequigranular média a grossa e IC $\sim 10$. Contudo, ao longo do contato com os monzodioritos centrais, as rochas apresentam IC mais elevado ( 20) e textura inequigranular média a fina, com feldspatos subédricos e minerais máficos predominantemente restritos à matriz (Figura 6C). Quartzo sienitos são observados apenas em esparsos pontos situados no extremo sul da ocorrência.

Há ainda um pequeno corpo, isolado, no extremo SW do plúton, que se caracteriza pelo elevado conteúdo de minerais máficos (IC 20) e pela textura localmente porfirítica (PI-578).

As rochas desta unidade apresentam forte foliação de estado sólido, em especial a ocorrência a $\mathrm{NE}$, cuja textura pode ser classificada como protomilonítica. 


\subsubsection{Monzonitos Heterogêneos (Mh)}

Esta unidade foi denominada por Janasi (1986) de Monzonitos Microporfiríticos em decorrência de sua feição característica, que é a presença de bolsões félsicos imersos em uma matriz fina (Figura 7A e B). Em trabalhos subsequentes Salmoni (2007) e Janasi et al. (2009), a unidade foi renomeada, passando a chamar-se Monzonitos heterogêneos $(M h)$, ao observar-se que tal feição estrutural é decorrente de processos heterogêneos de mistura de magmas, onde os bolsões félsicos têm composição de sieníticas (semelhante à da unidade Sie) e a matriz fina, escura, é de composição monzodiorítica (semelhante a $M d f$ ).

A unidade ocupa grande parte da porção norte do plúton, embora internamente a ela existam algumas pequenas ocorrências de $M d f$. A abundância de bolsões félsicos é variável ao longo da unidade e as rochas mostram-se heterogêneas mesmo em escala de afloramento. Por vezes inclusive observam-se veios sieníticos preservados.

A unidade caracteristicamente apresenta foliação de estado sólido e é cortada por veios e lentes métricas de quartzo monzonitos e quartzo sienitos da unidade Qsie. Salmoni (2007) inclusive tentativamente delineou uma área onde a associação entre $M h$ e Qsie é mais expressiva. Contudo, as etapas de campo desenvolvidas no presente trabalho mostraram que as lentes são abundantes ao longo de toda a unidade.

\subsubsection{Sienitos (Sie)}

Apesar de ter sido observado que esta unidade não pode ser representada em mapa na escala adotada, sua descrição faz-se importante tendo em vista o papel que desempenha na gênese da unidade de Monzonitos heterogêneos. As rochas desta unidade têm textura inequigranular fina a média, com IC $<10$, onde hornblenda é o mineral máfico principal. Apresentam foliação de estado sólido (Figura 7C e D) e por vezes contêm lentes feldspáticas de granulação mais grossa.

As rochas desta unidade foram encontradas em apenas três pontos. Dois deles situam-se próximos entre si e ocorrem como matacões, na porção NW da unidade de $M h$, sendo que um deles apresenta dimensões em torno de $10 \mathrm{~m}^{2}$ (PI-26 e PI-602). Estes pontos localizam-se em uma área relevo íngreme e com poucos afloramentos acessíveis devido à cobertura vegetal, de modo que é possível que haja outras ocorrências próximas. O terceiro ponto (PI-443) localiza-se no extremo E do plúton, junto à extremidade da unidade $M h$, onde as rochas afloram como cristas fortemente alinhadas segundo a orientação do plúton. 

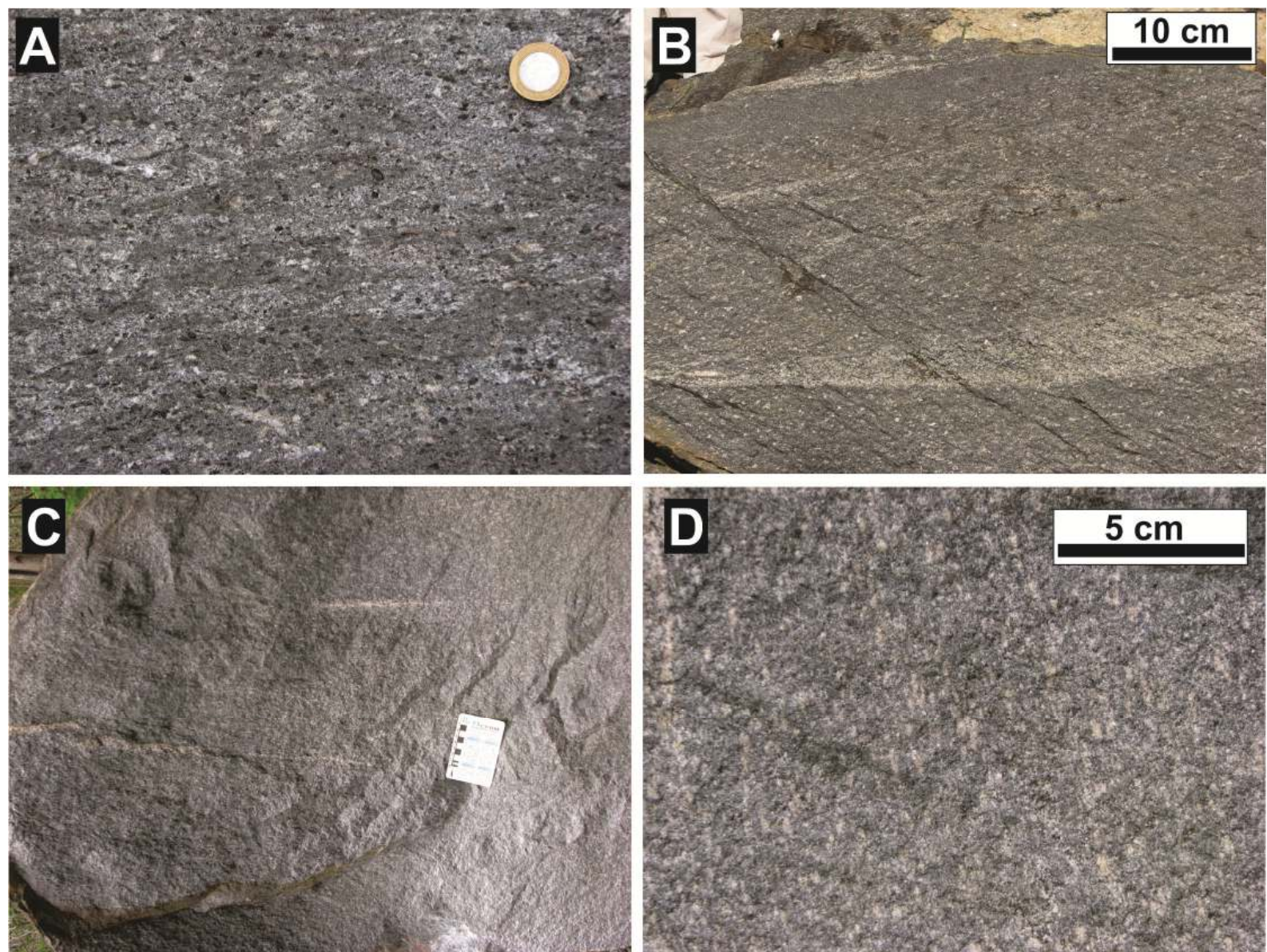

Figura 7. Monzonitos heterogêneos $(M h)$ e Sienitos (Sie): (A) textura heterogênea típica da unidade $M h$, com porções félsicas de composição sienítica e porções máficas monzodioríticas. Salienta-se a presença de cristais subcentimétricos idiomórficos de hornblenda (PI-437); (B) Mh com lentes sieníticas irregulares (PI-400); (C) matacão de Sie, apresentando lentes féldspáticas centimétricas, orientadas segundo o plano de foliação (PI-602); (D) detalhe do sienito PI-602, onde é possível visualizar melhor a textura inequigranular fina a média.

\subsection{Petrografia}

Assim como na descrição faciológica, uma descrição petrográfica detalhada das unidades é encontrada em Janasi (1986). Por este motivo, é feita adiante uma breve caracterização, salientando os aspectos principais de cada unidade.

\subsubsection{Monzodioritos Grossos (Mdr)}

São rochas homogêneas e caracteristicamente exibem textura equigranular grossa. Apresentam uma grande variação modal, abrangendo de dioritos a monzonitos; o IC situa-se no intervalo 15-45. Biotita é o mineral máfico mais abundante. Ocorre tipicamente como palhetas, têm cor marrom (pleocroísmo amarelo; marrom escuro) e por vezes forma agregados. Augita está presente em todas as rochas. Sua cristalização é precoce e os cristais normalmente apresentam reação para anfibólio em suas bordas (Figura 8A e B). 

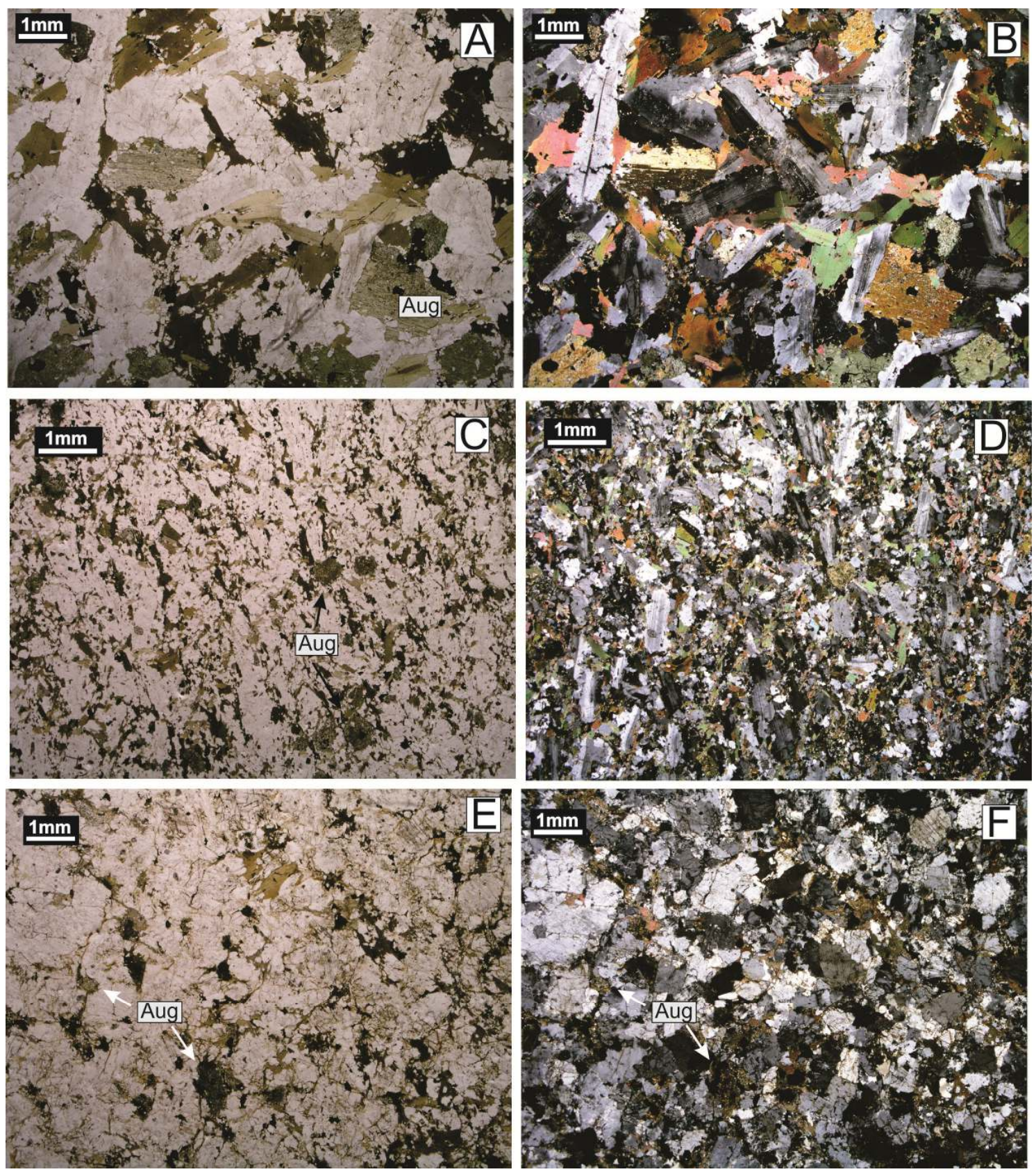

Figura 8. Fotomicrografias das unidades $M d r$ e $M d f$ : (A) e (B), polarizadores paralelos e cruzados, respectivamente, de monzodiorito grosso $(M d r)$, com estrutura maciça. Observam-se alguns cristais de plagioclásio com zoneamento normal descontínuo e a presença de cristais idiomórficos de augita (amostra PI589A); (C) e (D) polarizadores paralelos e cruzados, respectivamente, de monzodiorito equigranular fina $(M d f)$ com foliação magmática incipiente, marcada pelo alinhamento de cristais tabulares de plagioclásio (amostra PI588A); (E) e (F) polarizadores paralelos, respectivamente, de monzonito ( $M d f$ ) apresentando textura equigranular fina e baixo IC. Observam-se cristais de augita, apresentando reação parcial para anfibólio (amostra PI-588B). 
Cristais de plagioclásio tabulares de grande dimensão (até $1 \mathrm{~cm}$ ) são abundantes. Frequentemente apresentam forte zonação e por vezes formam agregados do tipo "synneusis", onde os cristais geralmente se unem segundo o plano de geminação polissintética. O zoneamento é do tipo normal descontínuo e caracteriza-se por um núcleo de labradorita $\left(\mathrm{An}_{48-58}\right)$, com geminação polissintética e bordas não geminadas de oligoclásio $\left(\mathrm{An}_{25-33}\right)$. O feldspato alcalino é pouco abundante nas rochas monzodioríticas. Ocorre quase que exclusivamente na matriz e muitas vezes é intersticial. Já as rochas monzoníticas podem conter cristais maiores (até $4 \mathrm{~mm}$ ), que igualam-se aos plagioclásios em dimensão.

Quartzo é um mineral importante apenas nas rochas monzoníticas, embora ocorra de modo escasso nos monzodioritos. É sempre intersticial e acessório. Apatita é o acessório principal. Sua cristalização é precoce, formando grandes cristais idiomórficos que tendem a ocorrer junto aos agregados de biotita, frequentemente como inclusões. Outros acessórios importantes são zircão e minerais opacos. Os minerais opacos, cuja cristalização também é precoce, comumente ocorrem como inclusões em augita e biotita. Zircão é um pouco mais tardio e frequentemente se situa junto a agregados de biotita.

As rochas desta unidade não apresentam foliação magmática ou deformação no estado sólido. Contudo, em alguns pontos observam-se evidências de processos cumuláticos, caracterizados por uma grande quantidade de agregados de plagioclásio em synneusis, por vezes também com cristais de biotita levemente encurvados. Nestes casos são mais abundantes também a apatita e inclusões de minerais opacos em augita e biotita.

\subsubsection{Monzodioritos finos a médios (Mdf)}

Considerando esta unidade é a mais volumosa dentre as que compõem o plúton, e é composta por rochas que apresentam variações composicionais, texturais e estruturais entre si, primeiramente será feita uma descrição de seus aspectos comuns. Subsequentemente serão exploradas as especificidades encontradas nas diferentes porções do corpo central da unidade, que é onde são encontradas as principais variações.

O IC de $M d f$, embora varie entre 25-45, normalmente situa-se entre 30 e 40 . Estas rochas apresentam augita ou hornblenda, acompanhadas de biotita (pleocroísmo amarelo; marrom escuro), que é sempre o mineral máfico mais abundante (Figura 8C e D). Cristais tabulares de plagioclásio zonados e núcleos cálcicos $\left(\mathrm{An}_{60-30}\right)$ são típicos, e comumente representam fenocristais. $\mathrm{O}$ feldspato alcalino, em geral microclínio pertítico, é restrito à matriz e comumente intersticial. Apatita é o acessório principal, tem cristalização precoce, e ocorre inclusa principalmente em minerais máficos. Por vezes apresenta-se acicular, inclusa em feldspatos da matriz. Minerais opacos também são precoces e normalmente ocorrem inclusos ou associados aos minerais máficos. Zircão é um pouco 
mais tardio e também é comum em associação aos minerais máficos. Quartzo é raro e sempre intersticial.

As rochas presentes nas porções centro-oeste e sudoeste do corpo central destacam-se por não apresentarem evidências de deformação. Observa-se também uma variedade textural maior do que nas demais porções do corpo. Ocorrem rochas inequigranulares finas a médias, rochas equigranulares muito finas e rochas porfiríticas, onde a variação textural refere-se essencialmente ao modo de ocorrência do plagioclásio. A presença de augita, que não ocorre no restante do corpo, também é marcante nestas porções. Apresenta alteração para anfibólio em diferentes intensidades. A alteração em alguns casos restringe-se à matriz, enquanto por vezes observam-se apenas pseudomorfos de augita.

As rochas com textura muito fina, equigranulares ou porfiríticas, são pouco abundantes. As porfiríticas têm matriz fina $(0,2-0,3 \mathrm{~mm})$ e os fenocristais são de plagioclásio, que ocorrem como cristais ripiformes, normalmente medindo entre 1 e $2 \mathrm{~mm}$, e com zoneamento normal. Os núcleos apresentam $\mathrm{An}_{38-52}$, porém mais comumente se situam no limite labradorita-andesina. Já as bordas variam entre $\mathrm{An}_{25-38}$, mas em geral situam-se no limite andesina-oligoclásio. As rochas equigranulares exibem textura fanerítica fina, medindo em média 0,2-0,3 $\mathrm{mm}$. Os plagioclásios tendem a ser equidimensionais e a não apresentar zoneamento.

Os monzodioritos com textura inequigranular fina a média são as rochas mais abundantes de $M d f$, e ocupam as porções sudeste, leste e a centro-norte do corpo central, assim como a pequena lente no extremo noroeste do plúton. Destaca-se que em todos estes locais as rochas caracteristicamente apresentam hornblenda estável, sendo que relictos de augita são muito raramente observados. Contêm cristais tabulares de plagioclásio, zonados e com borda homogênea irregular, com o mesmo aspecto, dimensão e composição dos fenocristais presentes nas rochas porfiríticas. Tem-se a impressão de que estes fenocristais estão tipicamente presentes nas rochas monzodioríticas, de modo que a textura transiciona de porfirítica para fanerítica inequigranular à medida que a matriz apresenta aumento de granulação. Os cristais maiores de plagioclásio apresentam composições que abrangem todo o intervalo entre andesina-labradorita e oligoclásio-andesina. Já a composição dos plagioclásios da matriz é semelhante nos três tipos texturais e idêntica à da borda dos fenocristais, ou seja, próximas ao limite oligoclásio-andesina.

Rochas monzoníticas são encontradas apenas no corpo central, e situam-se em sua porção centro-sul. Apresentam a mesma mineralogia principal das rochas monzodioríticas, das quais diferem principalmente pelo maior conteúdo de feldspato alcalino e menor IC (20-25) (Figura 8E e F). São identificados dois tipos de monzonitos: rochas com textura equigranular fina que contém augita; e rochas com textura inequigranular fina a média, sem augita. Em ambas o feldspato alcalino (microclínio e ortoclásio) é normalmente anédrico e apresenta micropertitas, e o quartzo é sempre intersticial e inferior a 5\%. As rochas do primeiro tipo destacam-se por conterem com augita, em geral 
pouco alterada para hornblenda. Cristais tabulares de plagioclásio zonados também estão presentes nestas rochas, por vezes caracterizando uma textura levemente inequigranular. Apresentam núcleos de andesina cálcica $\left(\mathrm{An}_{47-49}\right)$. Já as bordas e a matriz são de oligoclásio cálcico $\left(\mathrm{An}_{25-29}\right)$. Contrastam em relação aos monzodioritos por não apresentarem composições intermediárias. As rochas do segundo tipo são menos abundantes e normalmente apresentam hornblenda e biotita, embora por vezes contenham apenas biotita. São distintas também por apresentarem allanita, que não é observada nos outros monzonitos ou em nenhuma outra rocha de $M d f$.

Com relação aos enclaves monzodioríticos observados em alguns pontos de monzonitos $(M d f)$ e quartzo monzonitos (Qsie), identifica-se a existência de dois tipos texturais, embora não sejam abundantes e disponha-se de poucas amostras. Um deles apresenta textura porfirítica, com um conteúdo de fenocristais de até $30 \%$, representados essencialmente por plagioclásio ripiforme de até 3 $\mathrm{mm}$, fortemente zonados e por vezes orientados. Em raros casos, ocorrem também biotita e augita. Análises dos fenocristais de plagioclásio de uma amostra (PI-170a) obtidos por Janasi (1986) mostram núcleos com composição labradorítica $\left(\mathrm{An}_{55-60}\right)$ e bordas e matriz próximas ao limite andesinaoligoclásio $\left(\mathrm{An}_{32-34}\right)$. O segundo tipo textural é equigranular, embora apareçam raros fenocristais de plagioclásio com o mesmo hábito e tamanho dos descritos acima. A matriz de ambos os tipos de enclaves é fina (0,1-0,2 mm) e composta por plagioclásio $\left(\mathrm{An}_{25-28}\right)$, biotita, augita e minerais opacos, que exibem contatos poligonais. Feldspato alcalino é geralmente intersticial e observam-se pertitas finas na sua parte central.

\subsubsection{Evidências deformacionais e implicações mineralógicas}

São diversas as evidências relacionadas ao desenvolvimento de uma foliação de estado sólido. Embora se observe que algumas porções do corpo central de $M d f$ apresentam-se mais deformadas, não é possível identificar zonas de progressão da deformação. Os planos de foliação são em grande parte marcados pela orientação e recristalização de cristais de biotita (pleocroísmo castanho-esverdeado), que frequentemente circundam cristais e agregados de cristais de feldspatos. Cristais maiores de plagioclásio podem apresentar extinção ondulante, subgrãos e recristalização nas bordas. Dos fenocristais tabulares, típicos desses magmas, restam apenas os núcleos, que são identificáveis por apresentarem variável intensidade de saussuritização. Os feldspatos da matriz apresentam dois tipos de recristalização; uma de alta temperatura, evidenciada por rotação de subgrão, e outra que parece ser superimposta e tardia, evidenciada por buldging e é comumente acompanhada pela recristalização da biotita (Figura 9A e B). O quartzo, quando presente, apresenta textura granoblástica, recristalizado por rotação de subgrão. 

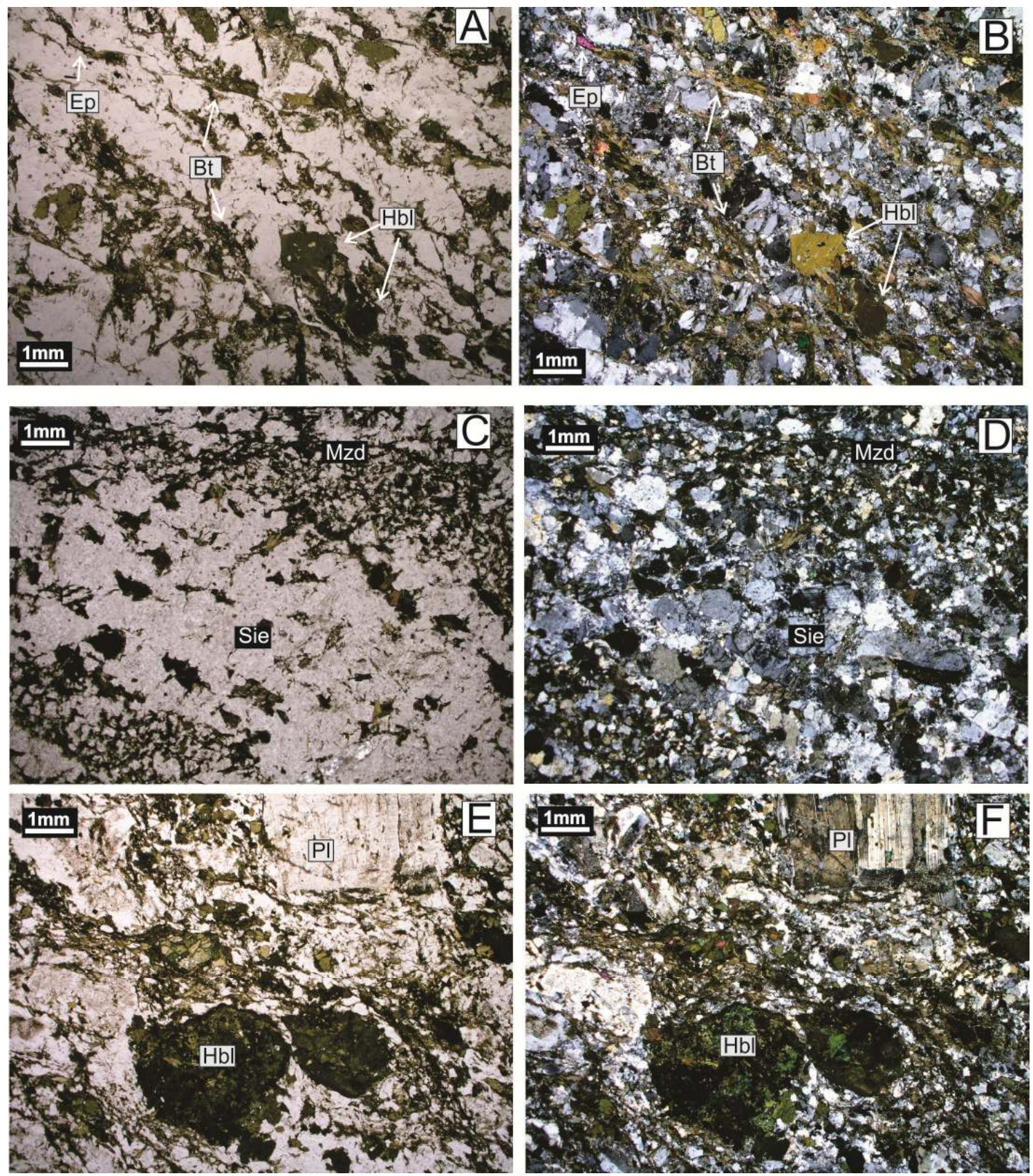

Figura 9. Fotomicrografias das unidades $M d f$ e $M h$ : (A) e (B) polarizadores paralelos e cruzados, respectivamente, de monzodiorito fino $(M d f)$ com foliação de estado sólido, evidenciada pela orientação e recristalização de biotita. Nota-se também uma recristalização incipiente dos feldspatos e a presença de pequenos cristais de epidoto, associados à biotita ao longo dos planos de foliação (amostra PI-546-7L); (C) e (D) polarizadores paralelos e cruzados, respectivamente, de monzonito heterogêneo $(M h)$, onde destaca-se o contraste entre porções sieníticas (Sie) e monzodioríticas (Mzd) (amostra PI-400A); (E) e (F) polarizadores paralelos e cruzados, respectivamente, de monzonito heterogêneo com cristais e agregados e cristais de hornblenda e antecristais de plagioclásio (amostra PI-400B). 
Existe relação entre a estabilidade dos minerais máficos e a atuação de um campo tensional regional sobre os magmas, onde o aumento da deformação aparentemente é acompanhado pelo aumento na atividade de fluidos do sistema. As rochas deformadas nunca apresentam augita como mineral estável, que de fato é observada como raros relictos no interior da hornblenda apenas nas rochas onde a deformação é menor. Com o aumento da deformação passa a ser comum a presença de cristais límpidos de hornblenda sem qualquer vestígio de augita. Em alguns locais onde a deformação é mais intensa, os cristais de hornblenda são totalmente recristalizados, formando biotita.

Titanita, mineral raramente observado nas rochas não deformadas e que quando presente é de pequena dimensão e anédrico, passa a ser um acessório importante. Ocorre como cristais subédricos a euédricos, em meio à matriz feldspática e por vezes orientada segundo o plano de foliação. Ocorre também como cristais xenomórficos, nos núcleos e bordas de hornblenda e biotita e circundando cristais de ilmenita. Observa-se ainda o aparecimento de cristais euédricos a subédricos de epidoto medindo até $0,5 \mathrm{~mm}$, sempre associados aos demais minerais máficos, mais comumente junto aos agregados de biotita que marcam os planos de foliação (Figura 9B).

\subsubsection{Monzonitos heterogêneos $(\mathrm{Mh})$}

A unidade $M h$, como mencionado na descrição faciológica, compreende rochas com uma textura fortemente heterogênea, caracterizada por bolsões subcentimétricos e lentes centimétricas félsicos, imersos em uma matriz fina (0,1-0,2 mm), predominantemente máfica. Os bolsões félsicos são de composição sienítica, em grande parte compostos por microclínio e plagioclásio sódico, configurando uma granulação fina a média (Figura 9C e D). Contudo, é característica a presença de cristais euédricos de grande dimensão ou agregados de pequenos cristais de hornblenda, que tendem a localizar-se no centro dos bolsões ou adjacentes aos mesmos (Figura 9E e F). Embora sua abundância seja variável, os bolsões podem representar até $50 \%$ da rocha. A matriz tem composição monzodiorítica e granulação fina, muito semelhante às rochas da unidade $M d f$. Embora os bolsões e a matriz sejam intimamente interdigitados, por vezes se observa que os contatos entre eles são abruptos.

O IC da rocha varia entre 20 e 30 e microclínio sempre predomina em relação ao plagioclásio. Biotita é o mineral máfico mais abundante (pleocroísmo amarelo; marrom escuro). Comumente são observados cristais tabulares de plagioclásio zonados, fortemente saussuritizados, que macroscopicamente podem ser confundidos com os bolsões félsicos. Estes cristais atingem até $5 \mathrm{~mm}$ e são maiores que os tipicamente encontrados nas rochas de $M d f$, que normalmente medem entre 1 e 2 mm. Os núcleos mais cálcicos apresentam composição no limite andesina-labradorita $\left(\mathrm{An}_{34-51}\right)$. Já as bordas e cristais da matriz apresentam $\mathrm{An}_{2-26}$, onde oligoclásio é a composição predominante, e albita é menos frequente. 
Titanita é o acessório principal e tende a ocorrer nos bolsões félsicos, e tende a ser anédrica. Allanita, embora pouco abundante, está sempre presente e tende a ocorrer dentro ou próxima aos bolsões félsicos. Zircão ocorre de modo esparso.

Esta unidade tipicamente apresenta foliação de estado sólido, evidenciada principalmente pela orientação e recristalização de biotita, que passa a apresentar pleocroísmo castanho-esverdeado. A biotita que por vezes ocorre nas bordas de hornblenda também parece estar associada ao processo de recristalização. Cristais maiores de microclínio e cristais tabulares de plagioclásio por vezes apresentam subgrãos e recristalização incipiente em suas bordas, caracterizando buldging. Os feldspatos da matriz apresentam recristalização mais intensa, com rotação de sub-grão. Epidoto, embora não abundante, ocorre ao longo dos planos de foliação, associado à biotita.

\subsubsection{Antecristais}

Assumindo uma origem híbrida para estes monzonitos, o grande contraste textural e apresentado pelos cristais tabulares de plagioclásio, associado à composição de seus núcleos fortemente cálcicos, que é muito distinta em relação aos cristais de menor dimensão e da matriz, dá margem à discussão sobre o termo mais adequado para descrevê-los, se fenocristais, xenocristais, ou antecristais. A concepção do termo antecristal como apresentada por Davidson et al. (2007) e Jerram \& Martin (2008) permite elucubrações sobre esta questão. Segundo os autores, antecristais têm sua cristalização iniciada em progenitores do magma final, tendo sido reincorporados a este magma final. Estes cristais diferem de xenocristais por estarem diretamente relacionados ao sistema magmático em questão, podendo ser reciclados através de diversos eventos de repreenchimento e reincorporados em estágios finais da erupção ou colocação dos magmas.

No que se refere à unidade Monzonitos heterogêneos de Piracaia, os cristais tabulares de plagioclásio não seriam corretamente denominados de fenocristais, pois não cristalizaram a partir de um magma monzonítico, mas sim a partir de um magma monzodiorítico ou diorítico, previamente ao evento de mistura. O termo xenocristal também não é adequado, pois o magma monzodiorítico a partir do qual cristalizaram contribui para a composição final da rocha, ou seja, eles têm vínculo genético com a rocha onde estão inseridos. É este vínculo genético, embora apresentem composição contrastante em relação à rocha onde estão inseridos, que torna mais propícia a utilização do termo antecristal para descrever estes cristais.

\subsubsection{Sienitos (Sie)}

Rochas desta unidade ocorrem sempre associados à unidade $M h$. Apresentam cor cinza claro e textura inequigranular fina a média (Figura 10A). Microclínio é levemente mais abundante em relação ao plagioclásio e por vezes apresenta tamanho destacado (até $2 \mathrm{~mm}$ ) com bordas irregulares. A matriz 
é composta por cristais de microclínio e plagioclásio sódico $\left(\mathrm{An}_{2-6}\right)$ com contatos poligonais. Contudo, observam-se composições um pouco mais cálcicas $\left(\mathrm{An}_{9-11}\right)$, em raros cristais isolados ou em núcleos irregulares em cristais de microclínio. O IC é $\sim 15$. Hornblenda verde-azulada é o mineral máfico principal e ocorre como cristais equidimensionais ou pouco alongados, bem distribuídos pela rocha. A biotita ocorre predominantemente como cristais esverdeados (pleocroísmo amarelo; verde), embora se observem raros cristais de cor marrom (pleocroísmo amarelo; marrom escuro), que podem apresentar tons esverdeados nas bordas.

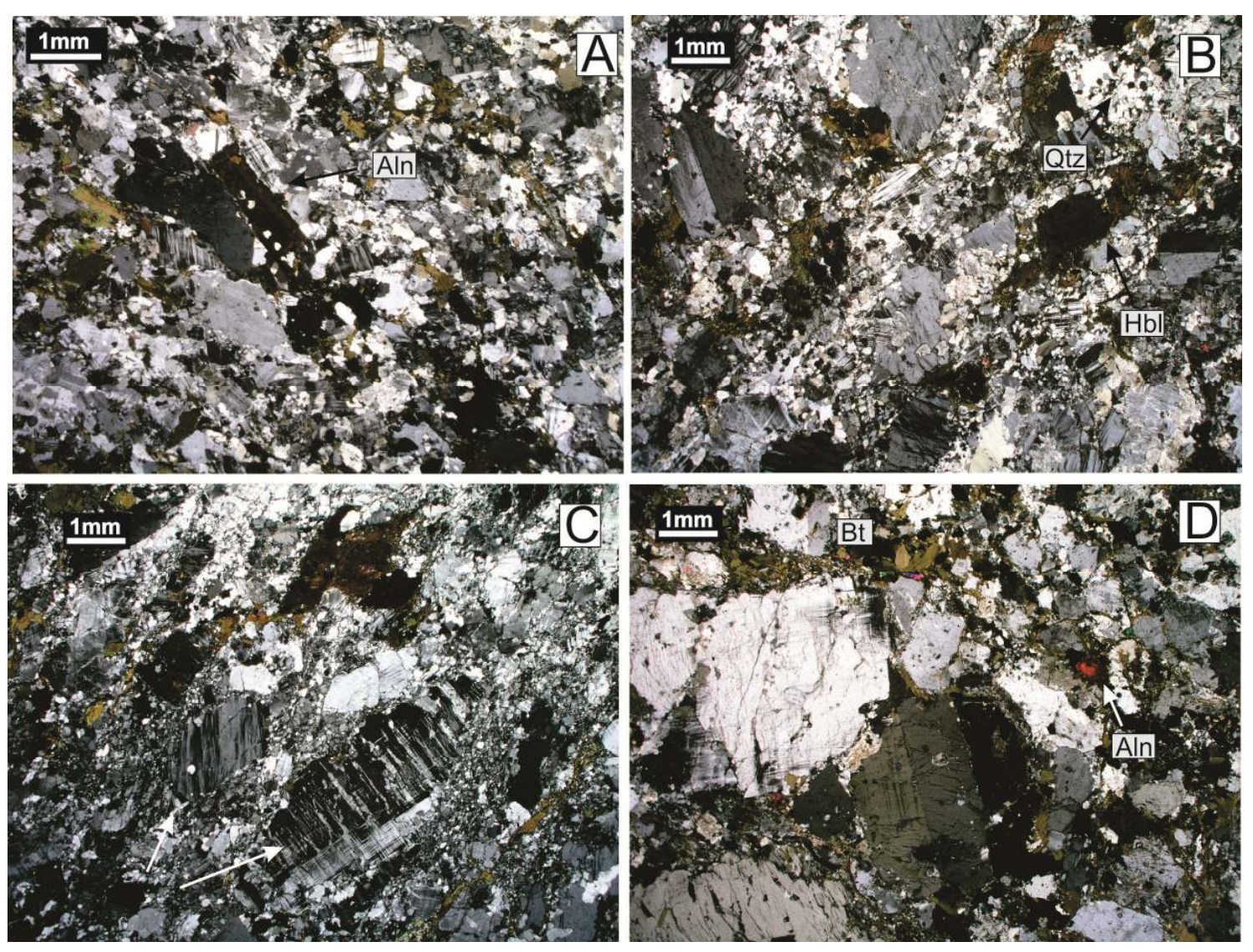

Figura 10. Fotomicrografias das unidades Sie e Qsie: (A) textura inequigranular fina a média, típica da unidade de sienitos (Sie). Destaca-se a presença de cristal idiomórfico de allanita (amostra PI-26B); (B) quartzo sienito (Qsie), com hornblenda e ricas em quartzo, que apresenta-se fortemente recristalizado (amostra PI-427); (C) quartzo sienito com forte foliação de estado sólido, destacando-se a recristalização incipiente de feldspato alcalino, com o desenvolvimento de buldging, conferindo o aspecto de uma textura seriada (amostra PI-529); (D) quartzo monzonito (Qsie) com textura inequigranular média a grossa, com agregados de biotita entre cristais de feldspato, e allanita, acessório característico da unidade (amostra PI-584). Todas as fotomicrografias a polarizadores cruzados. 
Allanita é o principal mineral acessório, ocorrendo como cristais prismáticos euédricos de até $2 \mathrm{~mm}$. Zircão e apatita são comuns como inclusões em biotita. Titanita xenomórfica é observada localmente, assim como epidoto, que está sempre associado à biotita.

Os sienitos também apresentam evidências deformacionais, similares às descritas para monzonitos heterogêneos e $M d f$, onde os planos de foliação são marcados pela recristalização de biotita, e os feldspatos apresentam recristalização incipiente.

\subsubsection{Quartzo sienitos e quartzo monzonitos (Qsie)}

As características distintivas apresentadas pelas rochas desta unidade são as texturas hipidiomórfica grossa (quartzo sienitos) e inequigranular média a grossa (quartzo monzonitos), a grande quantidade de feldspato alcalino, a presença de quartzo e o baixo IC. Os termos predominantes são quartzo sienitos e quartzo monzonitos leucocráticos (IC < 10) (Figura 10C), enquanto em menor quantidade ocorrem quartzo monzonitos mais máficos, com IC $\sim 20$. A matriz é escassa nas rochas leucocráticas, enquanto nas mais máficas pode atingir até 35\% (Figura 10D).

O microclínio é o mineral mais abundante e também o que apresenta maior dimensão. Normalmente mede entre 2-5 mm, embora eventualmente sejam observados cristais de até $1 \mathrm{~cm}$. São cristais idiomórficos, pertíticos e com contatos predominantemente bem definidos com a matriz. Biotita (pleocroísmo amarelo; castanho esverdeado) é o mineral máfico principal e tende a formar agregados. Hornblenda, que é rara em quartzo sienitos, apresenta-se como cristais subédricos de cor verde-azulada (Figura 10B). Ocorre como cristais isolados ou agrupados, ou ainda reliquiar junto aos agregados de biotita.

O plagioclásio tende a ser mais abundante nas rochas com maior IC. São encontrados cristais tabulares, com geminação polissintética, fracamente zonados, normalmente medindo entre 1,5 e $2 \mathrm{~mm}$ e com composição de oligoclásio $\left(\mathrm{An}_{18-23}\right)$. Menos frequentemente são observados cristais de até $1 \mathrm{~cm}$, zonados e com núcleo saussuritizado, que podem constituir agregados em "synneusis”. Por vezes são encontrados ainda cristais com núcleo de oligoclásio e borda albítica, mais frequentes em rochas com baixo IC. Já a composição dos plagioclásios da matriz varia de oligoclásio sódico a albita.

Allanita e zircão representam os minerais acessórios principais e são mais abundantes em relação às demais unidades do plúton. A apatita, embora presente em pequena quantidade, forma cristais prismáticos bem desenvolvidos e situa-se predominantemente associada aos minerais máficos Observa-se ainda titanita, em geral xenomórfica e formada a partir da ilmenita, e epidoto, associado principalmente à biotita recristalizada.

As rochas desta unidade sempre apresentam evidências de deformação, embora a intensidade seja variável, observando-se buldging em feldspatos e rotação de sub-grão no quartzo (Figura 10B e C). Texturas protomiloníticas são comuns, especialmente no corpo situado a NE da unidade $M d f$. Em 
alguns pontos os feldspatos apresentam-se em grande parte recristalizados, conferindo à rocha o aspecto de uma textura seriada.

\subsection{Mineralogia de opacos}

Minerais opacos são acessórios importantes nas amostras de todas as unidades, e são representados essencialmente por magnetita e ilmenita. Embora em geral sejam de cristalização precoce, existem diferenças quanto à ocorrência e abundâncias relativas.

Os monzodioritos ( $M d r$ e $M d f$ ) exibem magnetita e ilmenita, que formam cristais subédricos a euédricos, e embora se apresentem inclusos tanto em augita e biotita como em feldspatos, ocorrem preferencialmente associados aos minerais máficos (Figura 11A e B). Associações entre os dois minerais são observadas geralmente quando inclusos nas fases precoces (augita e biotita). Nestes casos, as relações texturais são do tipo composto, treliça, sanduíche e patch (segundo Haggerty, 1976; Dall'Agnoll et al., 1997) (Figura 11C-F), evidenciando a atuação de processos secundários de oxiexsolução, o que será discutido no item 3.4.3. Cristais individuais de ambos minerais, principalmente ilmenita, tendem a ocorrer apenas na matriz, de forma intersticial. Por vezes verifica-se ainda a existência de cristais anédricos de ilmenita, formados a partir da desestabilização da biotita. Os minerais opacos representam até $4 \%$ da rocha, onde magnetita é amplamente mais abundante, independentemente do tipo textural considerado. Destaca-se que não se observa ilmenita em algumas amostras de $M d f$ com foliação de estado sólido. Nestas amostras é comum a existência de pequenos cristais de sulfetos, que tendem a ocorrer ao longo dos planos de foliação.

Ilmenita e magnetita são menos abundantes nos quartzo monzonitos e quartzo sienitos de Qsie. Em geral, são mais abundantes nos quartzo monzonitos, que chegam a apresentar até $2 \%$, enquanto nos quartzo sienitos são sempre inferiores a $1 \%$. Nesta unidade a magnetita é levemente mais abundante que ilmenita, e as relações texturais entre os minerais são as mesmas que em $M d r$ e $M d f$.Tendem a ocorrer próximos aos minerais máficos (hornblenda e biotita) ou inclusos nos mesmos, caracterizando-se como cristais precoces, especialmente nos quartzo monzonitos, mas também formam cristais anédricos, intersticiais.

Nos Monzonitos heterogêneos $(M h)$ ilmenita é o mineral opaco preponderante, onde magnetita ocorre de modo subordinado. Juntos geralmente representam aproximadamente $1 \%$ da rocha e ocorrem associados aos minerais máficos e feldspatos. Em algumas amostras destaca-se a ocorrência de sulfetos (pirita e calcopirita), embora sejam menos abundantes que os óxidos.

A unidade de Sienitos (Sie) destaca-se por conter essencialmente ilmenita, geralmente subédrica, quando inclusa em feldspatos, ou intersticial. Por vezes observa-se ilmenita martitizada. Cristais de magnetita são observados em pontos isolados, como pequenos cristais. Sulfetos (pirita e calcopirita) são um pouco mais abundantes, e também formam pequenos cristais, aleatoriamente distribuídos. 
413_2

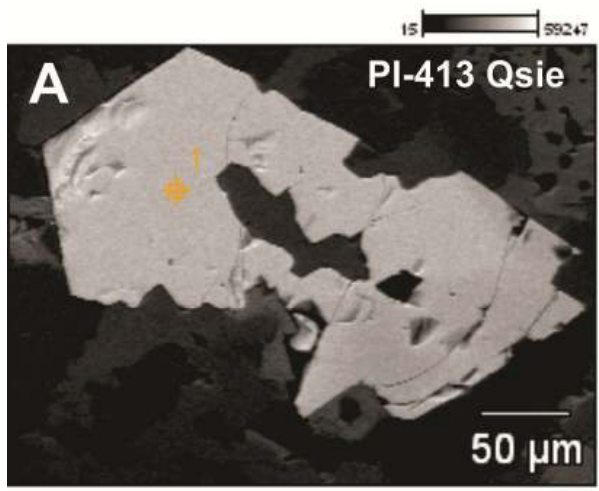

256_1_1

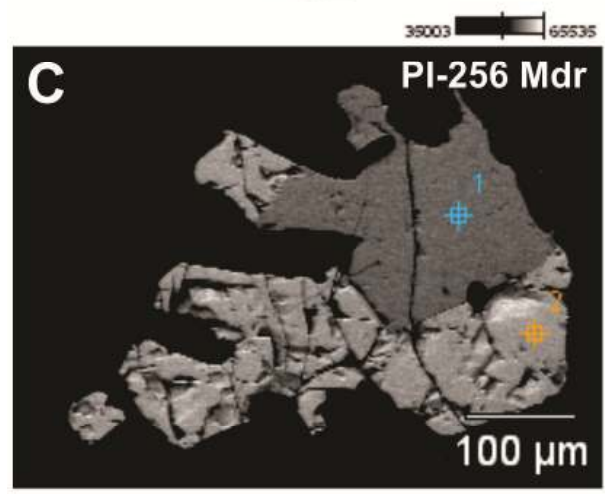

75_4_1

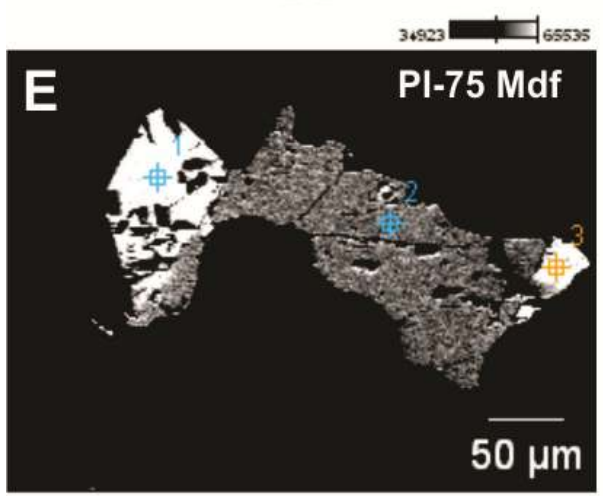

25623

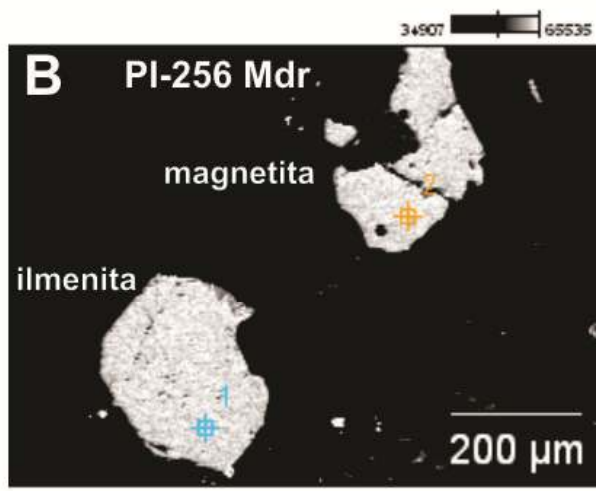

270_7

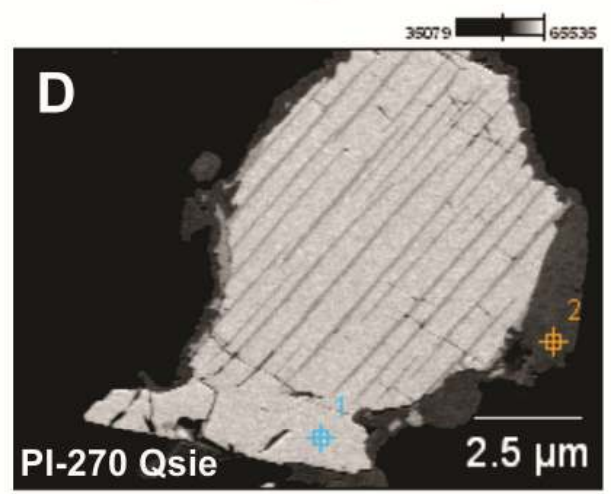

413_2_2

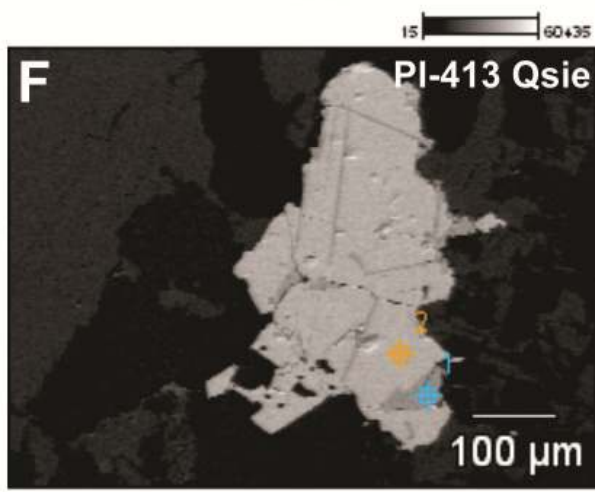

Figura 11. Imagens de Microscopia Eletrônica de Varredura (elétrons secundários) exibindo as relações texturais de cristais de magnetita e ilmenita. (A) cristal subédrico de magnetita em quartzo sienito (Qsie); (B) cristais próximos de magnetita e ilmenita em monzodiorito $(M d r)$; (C) cristais de magnetita e ilmenita em associação do tipo composto, em $M d r$; (D) cristais de magnetita e ilmenita em associação do tipo treliça, em quartzo monzonito (Qsie); (E) cristais de magnetita e ilmenita em associação do tipo sanduíche, em $M d f$; (F) cristais de magnetita e ilmenita em associação do tipo treliça e patch, quartzo sienito (Qsie). 


\subsection{Susceptibilidade Magnética}

As diferentes unidades são distinguíveis em termos de susceptibilidade magnética. As unidades $M d r$ e $M d f$ destacam-se por serem as rochas de mais alta susceptibilidade, atingindo até $95 \mathrm{x}$ $10^{-3} \mathrm{SI}$, o que reflete seu maior conteúdo de magnetita (Figura 12). A susceptibilidade é menor em $M d f$, e decresce à medida que as rochas tornam-se mais félsicas. As maiores susceptibilidades são encontradas em geral na porção centro-sul do corpo central, próximo à $M d r$, uma vez que é lá que se encontram as rochas mais primitivas da unidade.

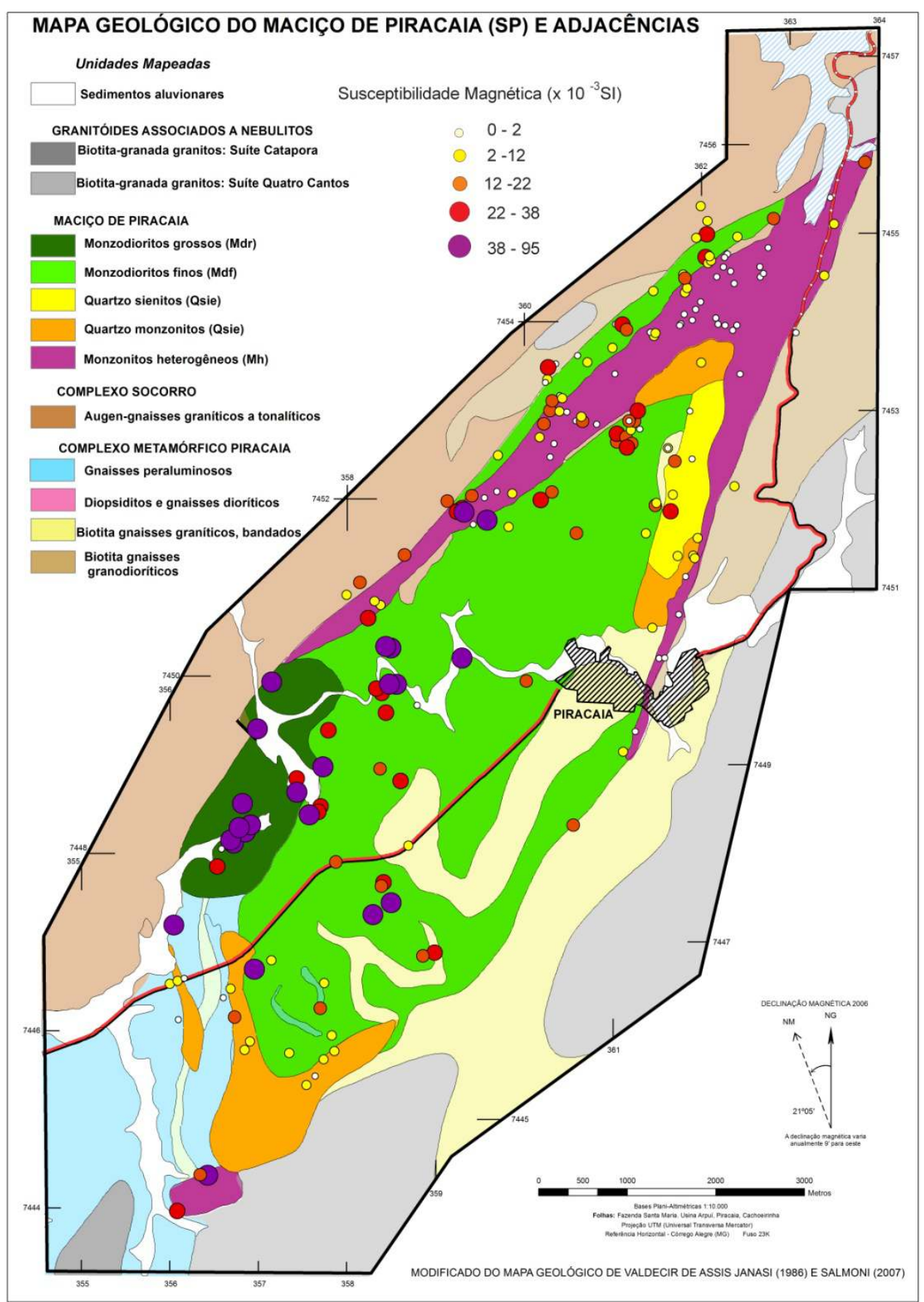

Figura 12. Mapa geológico do Plúton Piracaia com medidas de susceptibilidade magnética de pontos de suas diferentes unidades. 
Por outro lado, as unidades mais félsicas caracteristicamente apresentam susceptibilidades baixas. As mais altas susceptibilidades são encontradas em quartzo monzonitos (Qsie), onde atingem no máximo $24 \times 10^{-3} \mathrm{SI}$. Contudo na unidade Qsie são normalmente inferiores a $10 \times 10^{-3} \mathrm{SI}$. Já as rochas de $M h$ se destacam por apresentarem susceptibilidade quase nula, uma vez que magnetita é praticamente ausente nestas rochas. Com relação à Sie, não se dispõe de análises estatisticamente representativas, uma vez que se encontram poucos afloramentos. Contudo, nos dois pontos medidos as medidas são consistentemente baixas, idênticas as obtidas para a unidade $M h$.

Salienta-se que os intervalos de susceptibilidade apresentados na Figura 12 foram definidos manualmente após análise do histograma de pontos, construído através do software ARCGIS.

\subsection{Química Mineral}

\subsubsection{Hornblenda}

No presente trabalho, análises de anfibólio foram priorizadas em amostras de monzodioritos, uma vez que um grande acervo de dados para as unidades mais evoluídas foi previamente obtido por Salmoni (2007). Os resultados das análises são apresentados na Tabela A01.

A fórmula estrutural dos anfibólios pode ser expressa, segundo Deer et. al., (1992) e Klein \& Hurlbut, (2002):

$$
\begin{gathered}
\mathrm{A}_{0-1} \mathrm{~B}_{2} \mathrm{C}_{5} \mathrm{~T}_{8} \mathrm{O}_{22}(\mathrm{OH}, \mathrm{F})_{2}, \text { onde } \\
\mathrm{T}=\mathrm{Si}, \mathrm{Al}^{\mathrm{IV}}, \mathrm{Cr}^{3+} \mathrm{Ti}^{4+} ; \\
\mathrm{C}=\mathrm{Mg}, \mathrm{Fe} 2+, \mathrm{Mn}^{\mathrm{Al}}{ }^{\mathrm{VI}}, \mathrm{Cr}, \mathrm{Ti}, \mathrm{Fe} 3+; \\
\mathrm{B}=\mathrm{Ca}, \mathrm{Na}, \mathrm{Fe} 2+, \mathrm{Mn}, \mathrm{Mg} ; \\
\mathrm{A}=\mathrm{Na}, \mathrm{K}
\end{gathered}
$$

A nomenclatura utilizada segue a proposta da IMA (International Mineralogical Association). $\mathrm{O}$ método de cálculo utilizado para a estimativa de $\mathrm{Fe}^{+2}$ e $\mathrm{Fe}^{+3}$ foi o de 13 cátions menos $\mathrm{Ca}$, $\mathrm{Na}$ e $\mathrm{K}$ (13-CNK), uma vez que Martins (2001) e Gualda \& Vlach (2005) concluem ser este o mais adequado para anfibólios composicionalmente ricos em cálcio. Todos os cristais de Piracaia apresentam $\mathrm{Ca}^{\mathrm{B}}>$ 1.5 e Na ${ }^{\mathrm{B}}<0.5$, e são portanto, anfibólios cálcicos.

Os resultados mostram ocupação variável do sítio $\mathrm{A}$, tanto em amostras de uma mesma unidade como em cristais de uma mesma amostra, o que requer a utilização de dois diagramas de classificação (Figura 13A e B). Os cristais com Na+K > 0,5 são predominantemente classificados como hastingsita e ferro-edenita, e alguns poucos cristais de monzodioritos são classificados como magnesio-hastingsita e edenita. Já os cristais com $\mathrm{Na}+\mathrm{K}<0,5$ são classificados como ferrotschermakita, ferro-hornblenda e magnesio-hornblenda. Em geral as unidades não são distinguíveis 
nestes diagramas de classificação, à exceção dos cristais classificados como magnesio-hornblenda, que são encontrados apenas nas amostras de monzodioritos e vênulas félsicas.

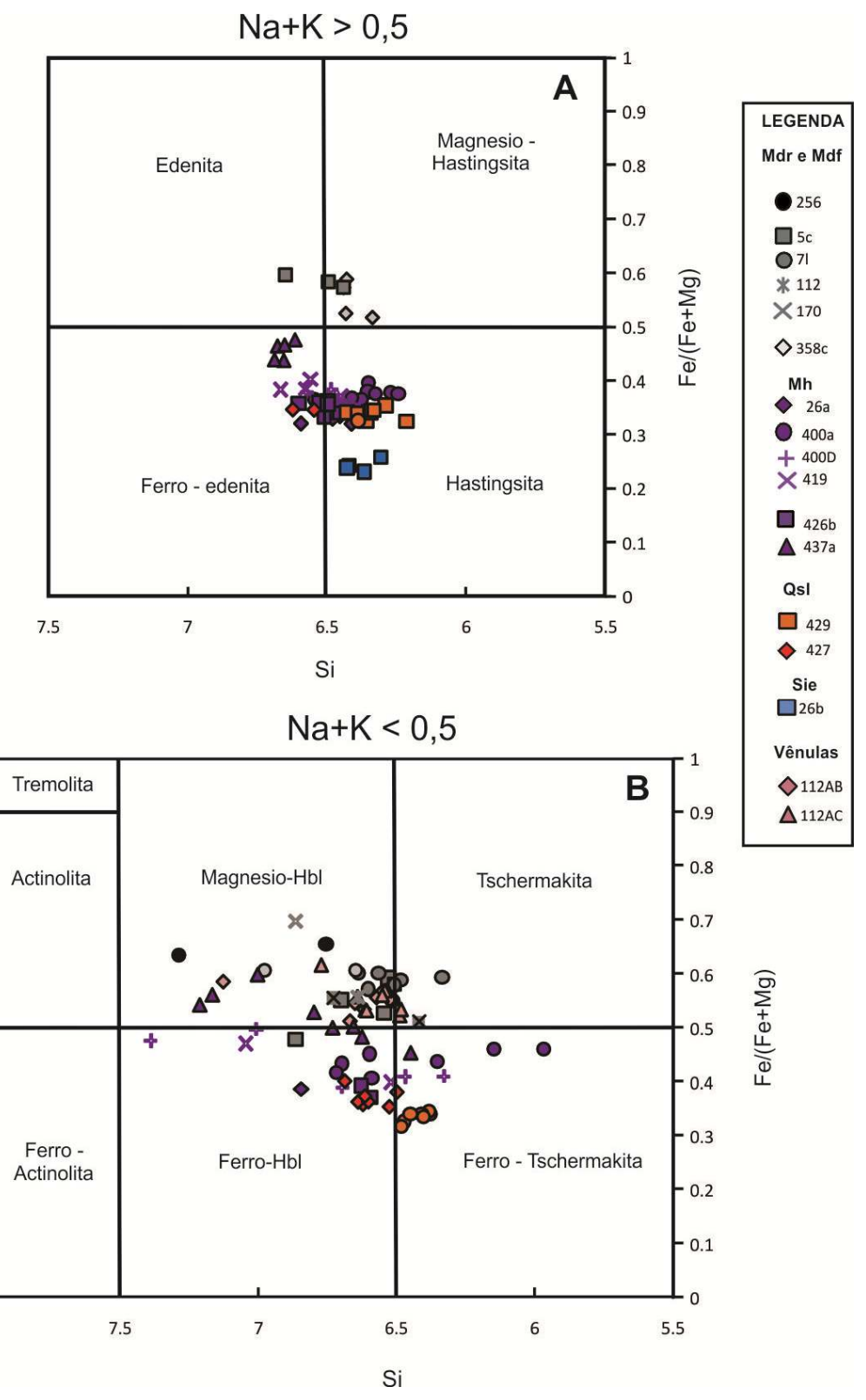

Figura 13. Diagramas de classificação para anfibólios cálcicos das diferentes unidades que compõem o Plúton Piracaia: (A) para cristais com $\mathrm{Na}+\mathrm{K}>0,5$ e (B) para cristais com $\mathrm{Na}+\mathrm{K}<0,5$.

A principal variação apresentada entre as unidades refere-se à substituição simples entre $\mathrm{Mg} \mathrm{e}$ $\mathrm{Fe}^{+2}$, onde verifica-se o aumento da razão $\mathrm{Fe} /(\mathrm{Fe} / \mathrm{Mg}$ ) do anfibólio com a diferenciação (Figura 14). Os anfibólios dos monzodioritos ( $M d r$ e $M d f$ ) e vênulas félsicas são composicionalmente semelhantes, onde a razão $\mathrm{Fe} /(\mathrm{Fe} / \mathrm{Mg})$ varia entre 0,34 e 0,48. No outro extremo situam-se os anfibólios de Sie, com razão $\mathrm{Fe} /(\mathrm{Fe} / \mathrm{Mg}$ ) em torno de 0,77, e os da unidade Qsie, que variam entre 0,60 e 0,67. Os anfibólios de $M h$ apresentam grande variação, com composições que abrangem todo o intervalo entre os monzodioritos e as unidades félsicas $(0,40$ a 0,68$)$. 


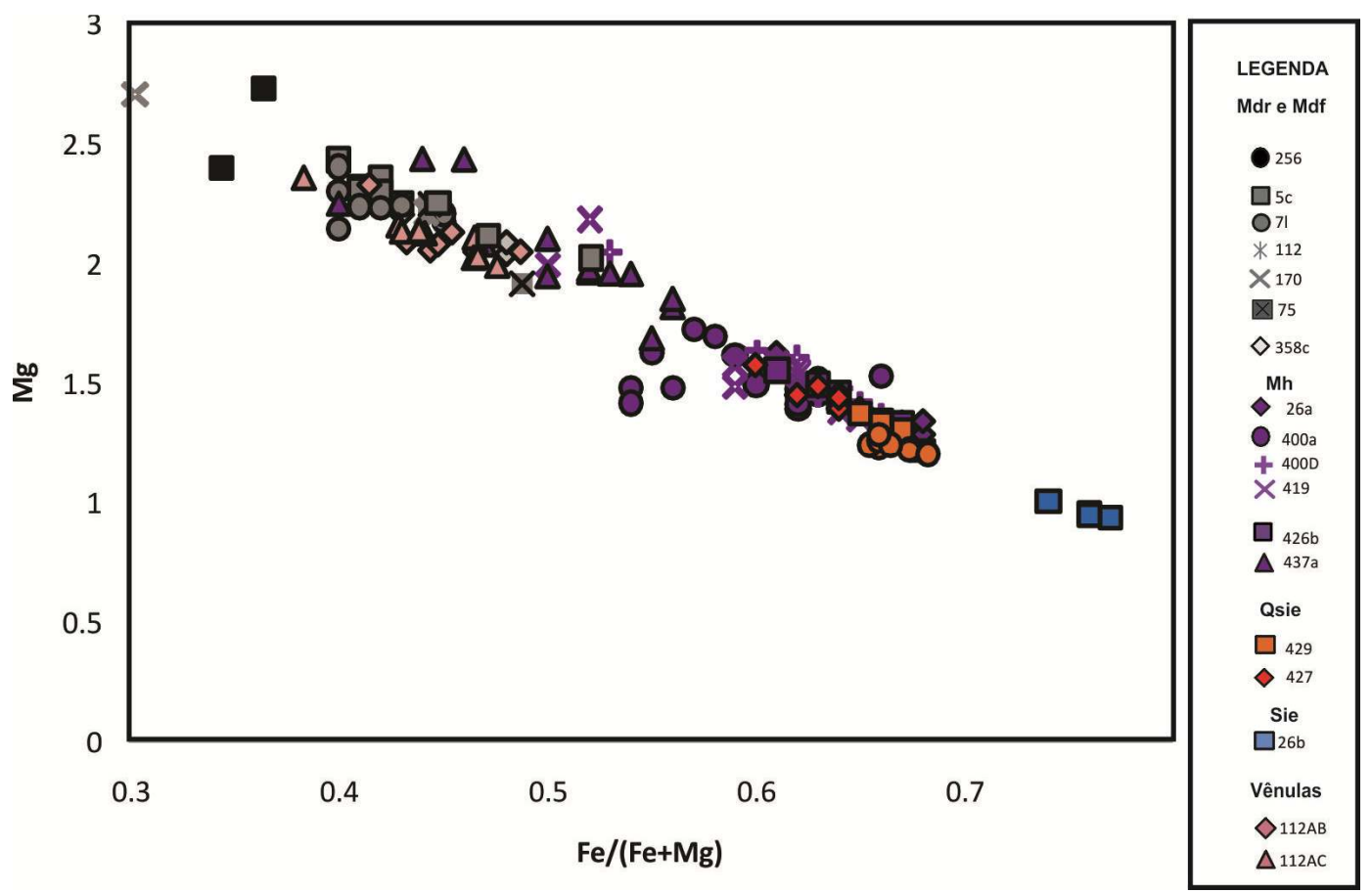

Figura 14. Variações da razão $\mathrm{Fe} /(\mathrm{Fe}+\mathrm{Mg})$ dos anfibólios, pela substituição simples entre $\mathrm{Mg}^{2+} \mathrm{e} \mathrm{Fe}^{2+}$.

Secundariamente observam-se variações relacionadas aos mecanismos substituição acopladas:

$$
\begin{array}{ll}
\square^{\mathrm{A}}+\mathrm{Si} \leftrightarrow(\mathrm{Na}+\mathrm{K})^{\mathrm{A}}+\mathrm{Al}^{\mathrm{IV}} & (\text { troca edenítica); } \\
\mathrm{Si}+\left(\mathrm{Mg}, \mathrm{Fe}^{2+}, \mathrm{Mn}\right) \leftrightarrow \mathrm{AlI}^{\mathrm{V}}+\mathrm{Al}^{\mathrm{VI}} & (\text { tschermakítica); } \\
\mathrm{Mg}^{2+}+2 \mathrm{Si} \leftrightarrow \mathrm{Ti}+2 \mathrm{Al}^{\mathrm{IV}} & \text { (Ti-tschermakítica) }
\end{array}
$$

Observa-se que a troca edenítica ocorreu de forma mais efetiva, embora o conteúdo de Si varie pouco entre as unidades (Figura 15A). Por outro lado, as trocas tschermakítica e Ti-tschermakítica foram mais restritas (Figura 15B e C). Na Figura 16 observa-se que o conteúdo de Ti mantém-se praticamente constante entre as diferentes unidades. São exceção algumas amostras de monzonitos heterogêneos, que apresentam conteúdos de Ti um pouco mais baixos, e o quartzo monzonito PI-429, cujos elevados conteúdos destacam-se entre todas as amostras. $\mathrm{O}$ conteúdo de $\mathrm{Al}^{\text {tot }}$ também varia pouco, como pode ser observado na Figura 17. Salienta-se a semelhança composicional existente entre os anfibólios das vênulas félsicas e monzodioritos.

Embora os mecanismos de troca sejam sensíveis a variações nas condições de temperatura e pressão, observa-se que em geral as trocas refletem dominantemente as variações químicas existentes entre os magmas. 

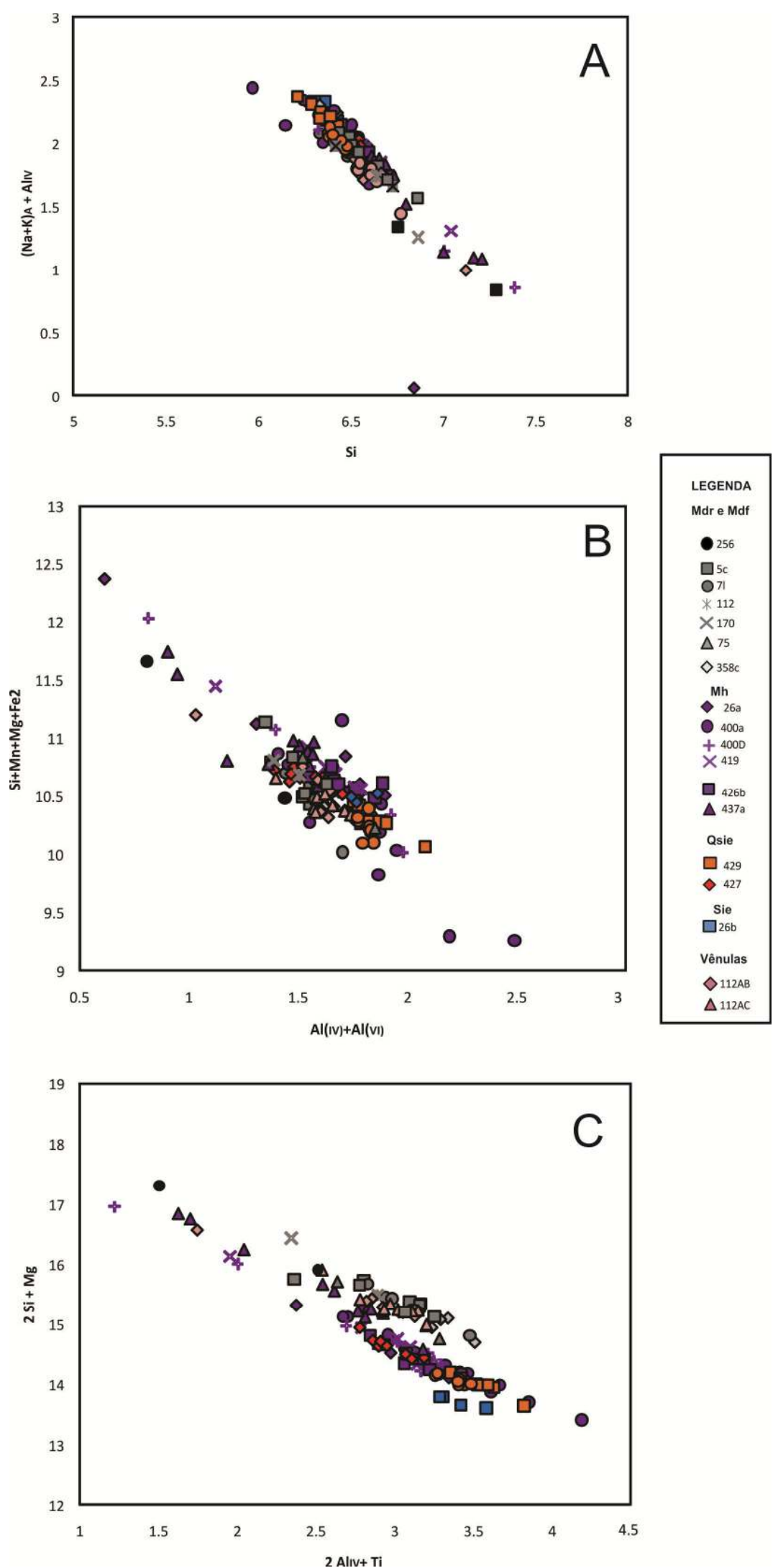

Figura 15. Variações químicas nos anfibólios do Plúton Piracaia relacionadas aos mecanismos de substituição: (A) edenítica; (B) tschermakítica; (C) Ti-tschermakítica. 


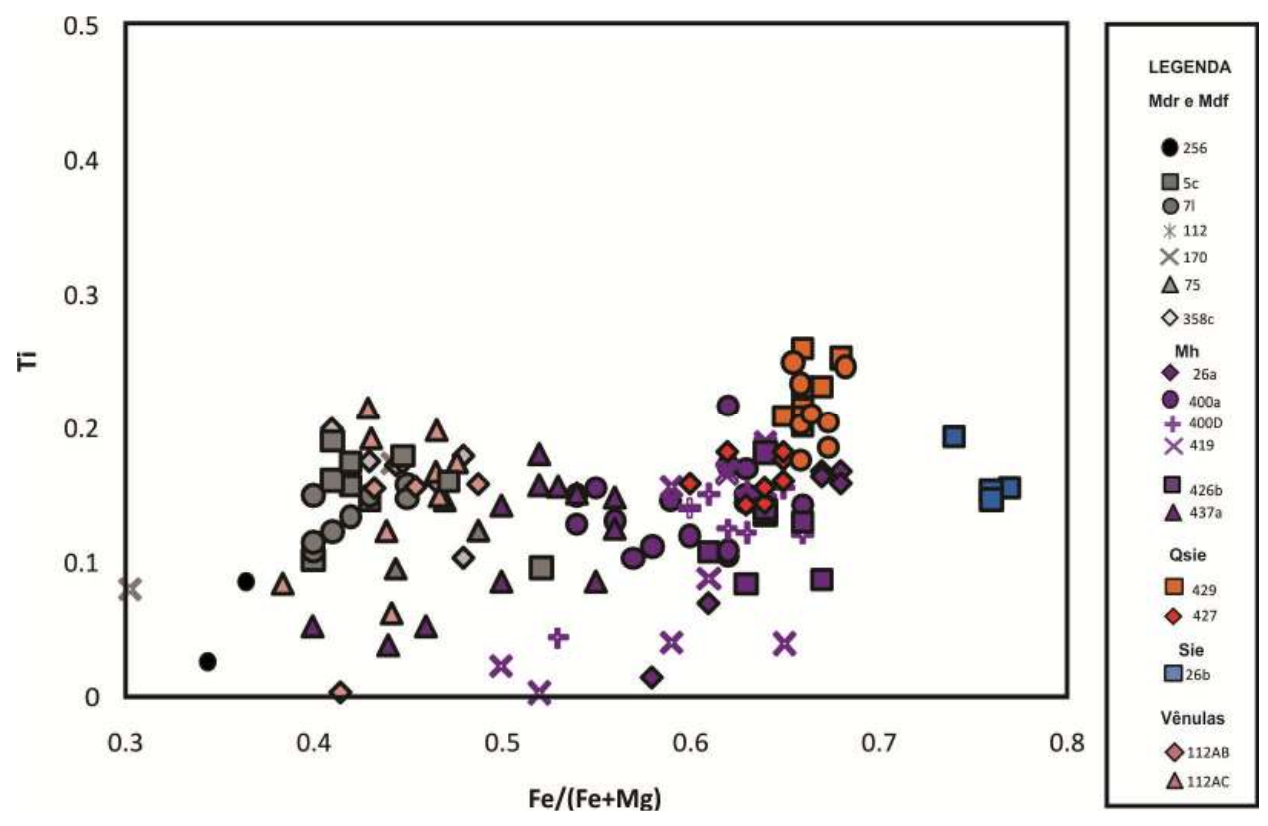

Figura 16. Correlação entre o conteúdo de Ti e a variação da razão $\mathrm{Fe} /(\mathrm{Fe}+\mathrm{Mg})$ nos anfibólios entre as diferentes unidades do Plúton Piracaia.

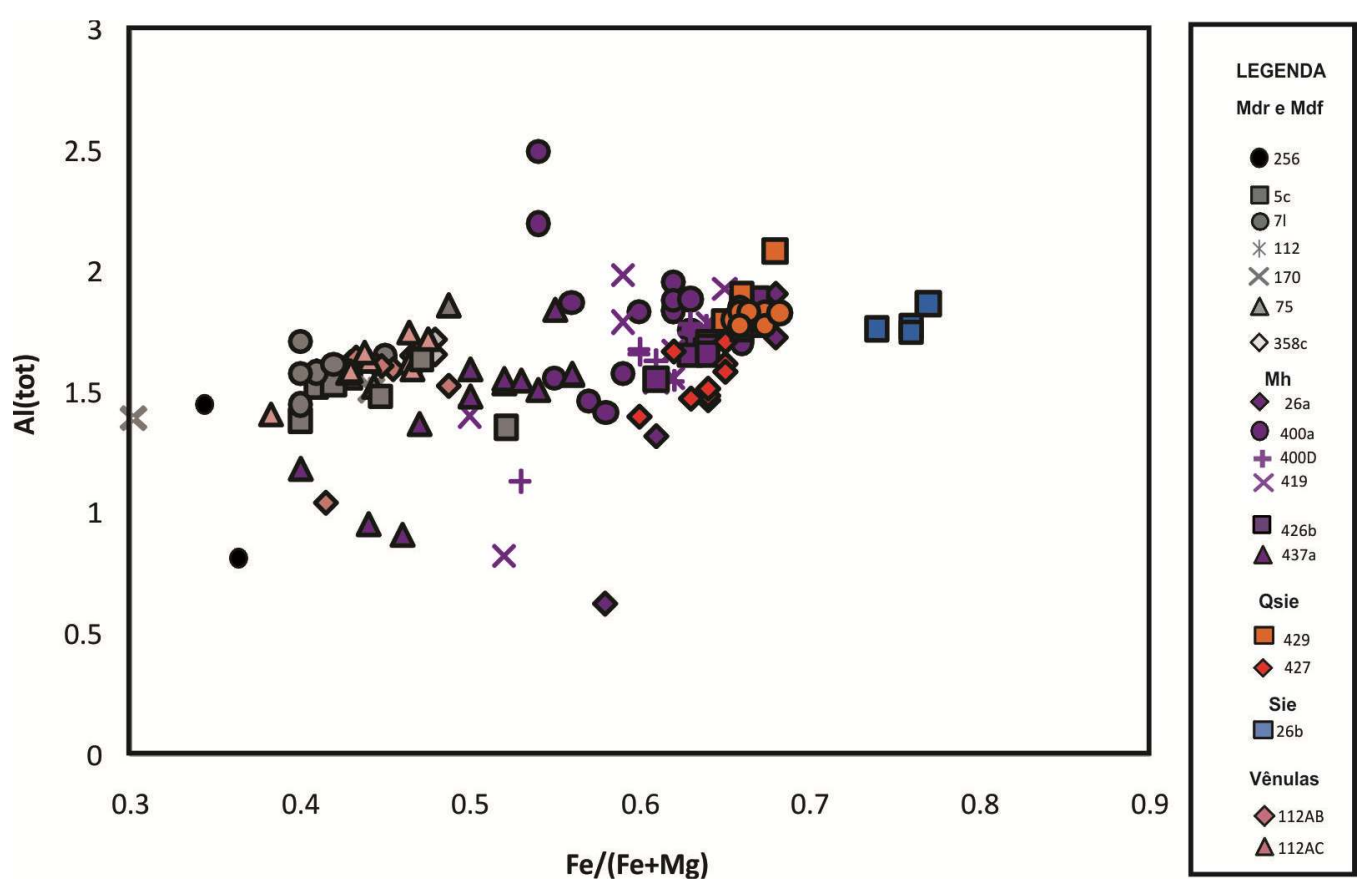

Figura 17. Correlação entre o conteúdo de $\mathrm{Al}^{\text {tot }}$ e a variação na razão $\mathrm{Fe} /(\mathrm{Fe}+\mathrm{Mg})$ nos anfibólios do Plúton Piracaia. 


\subsubsection{Biotita}

A fórmula estrutural da biotita foi calculada na base de 22 oxigênios e pode ser expressa, segundo Deer et al. (1992), por:

$$
\begin{gathered}
\mathrm{X}_{2} \mathrm{Y}_{4-6} \mathrm{Z}_{8} \mathrm{O}_{20}(\mathrm{OH}, \mathrm{F})_{4} \text {, onde: } \\
\mathrm{X}=\mathrm{Na}, \mathrm{K} ; \\
\mathrm{Y}=\mathrm{Mg}, \mathrm{Fe}^{2+,} \mathrm{Mn}, \mathrm{Al}^{\mathrm{VI}}, \mathrm{Ti} \mathrm{Fe}^{3+;} \\
\mathrm{Z}=\mathrm{Si}, \mathrm{Al}^{\mathrm{IV}}
\end{gathered}
$$

Os resultados das análises de biotita são apresentados na Tabela A02. Embora os cristais de todas as unidades sejam ricos na molécula annita, observa-se uma grande variação na razão $\mathrm{Fe} /(\mathrm{Fe}+\mathrm{Mg}$ ) que, assim como para o anfibólio, aumenta com a diferenciação (Figura 18). A variação nos monzodioritos ( $M d r$ e $M d f$ ) varia de 0,42 em $M d r$ até 0,57 em rochas de composição monzonítica da unidade $M d f$. O intervalo composicional da unidade $M h$ também é amplo, entre 0,55 e 0,69. Esta variação apresentada por $M h$ possivelmente reflete a variação no grau de mistura entre $M d f$ e Sie, onde as amostras com mais baixa razão $\mathrm{Fe} /(\mathrm{Fe}+\mathrm{Mg})$ são as que apresentam maior similaridade com os monzodioritos, como será discutido no item 4.1.2 . Já em quartzo monzonitos variam entre 0,63 e 0,79 e em quartzo sienitos entre 0,66 e 0,80 .

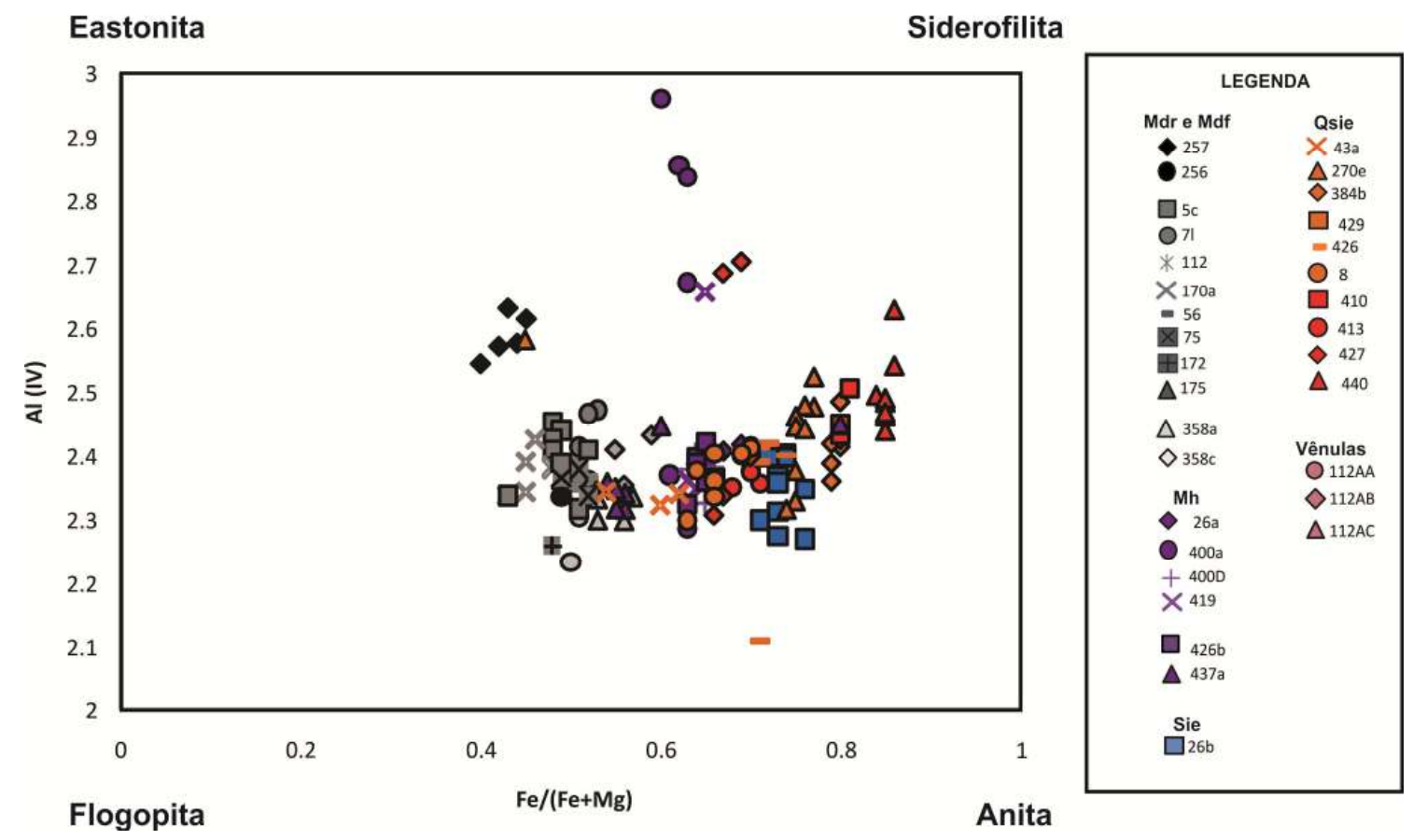

Figura 18. Diagrama de classificação das biotitas do Plúton Piracaia, onde destaca-se a variação na razão $\mathrm{Fe} /(\mathrm{Fe}+\mathrm{Mg})$ entre as diferentes unidades. 
Na Figura 19A e B, observa-se que os conteúdos de $\mathrm{Si}$ e $\mathrm{Al}^{\mathrm{IV}}$ mantêm-se praticamente constantes entre as diferentes unidades. $\mathrm{O}$ conteúdo de $\mathrm{Al}^{\mathrm{IV}}$ é inclusive mais uniforme do que $\mathrm{o} \mathrm{Al}_{2} \mathrm{O}_{3}$, em análises de rocha total. Contudo, quando considera-se o $\mathrm{Al}^{\text {tot }}$, observa-se uma leve tendência de enriquecimento com a diferenciação, à exceção da amostra PI-26b (unidade Sie), cuja concentração é menor.
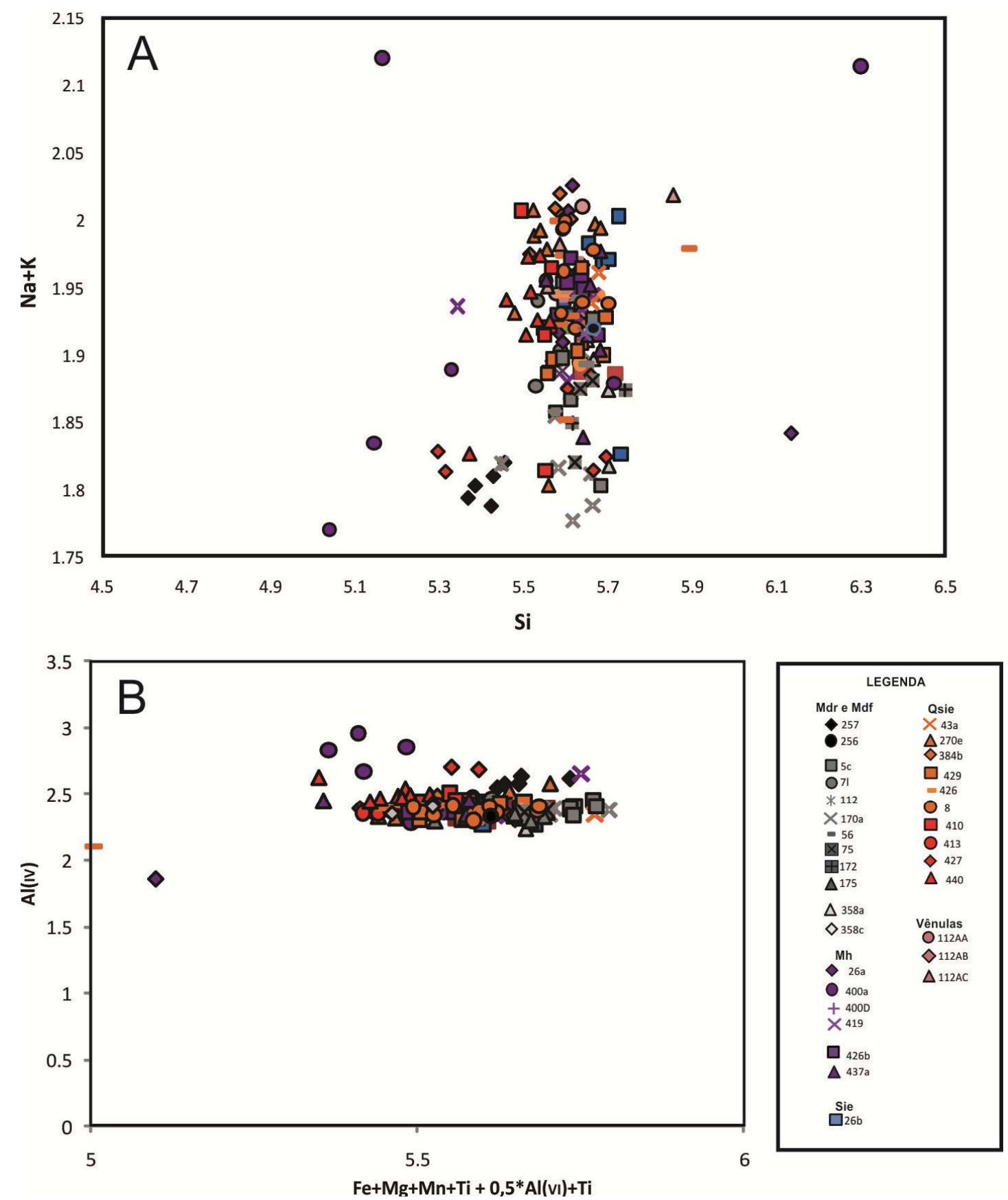

Figura 19. Diagramas de correlação para as biotitas das diferentes unidades que compõem o Plúton Piracaia, onde observa-se em (A) que os conteúdos e Si e Al mantêm-se praticamente constantes, em (A) e (B), respectivamente. 
Assim como para o anfibólio, as biotitas de monzodioritos e vênulas félsicas associadas são semelhantes composicionalmente. Contudo, existem diferenças no conteúdo de Ti, que é mais baixo nas vênulas e se aproxima ao de Sie e quartzo sienitos (Qsie). Considerando-se todas as unidades, observa-se que conteúdo de Ti decresce com a diferenciação, embora os monzodioritos sejam marcadamente mais enriquecidos (Figura 20). As biotitas dos monzodioritos tendem ainda a ser mais enriquecidas em $\mathrm{BaO}$ em relação às demais unidades.

Salienta-se que as análises obtidas por Janasi (1986) foram realizadas tanto em cristais primários como recristalizados. Contudo, não se observam mudanças composicionais significativas entre os dois conjuntos de cristais.

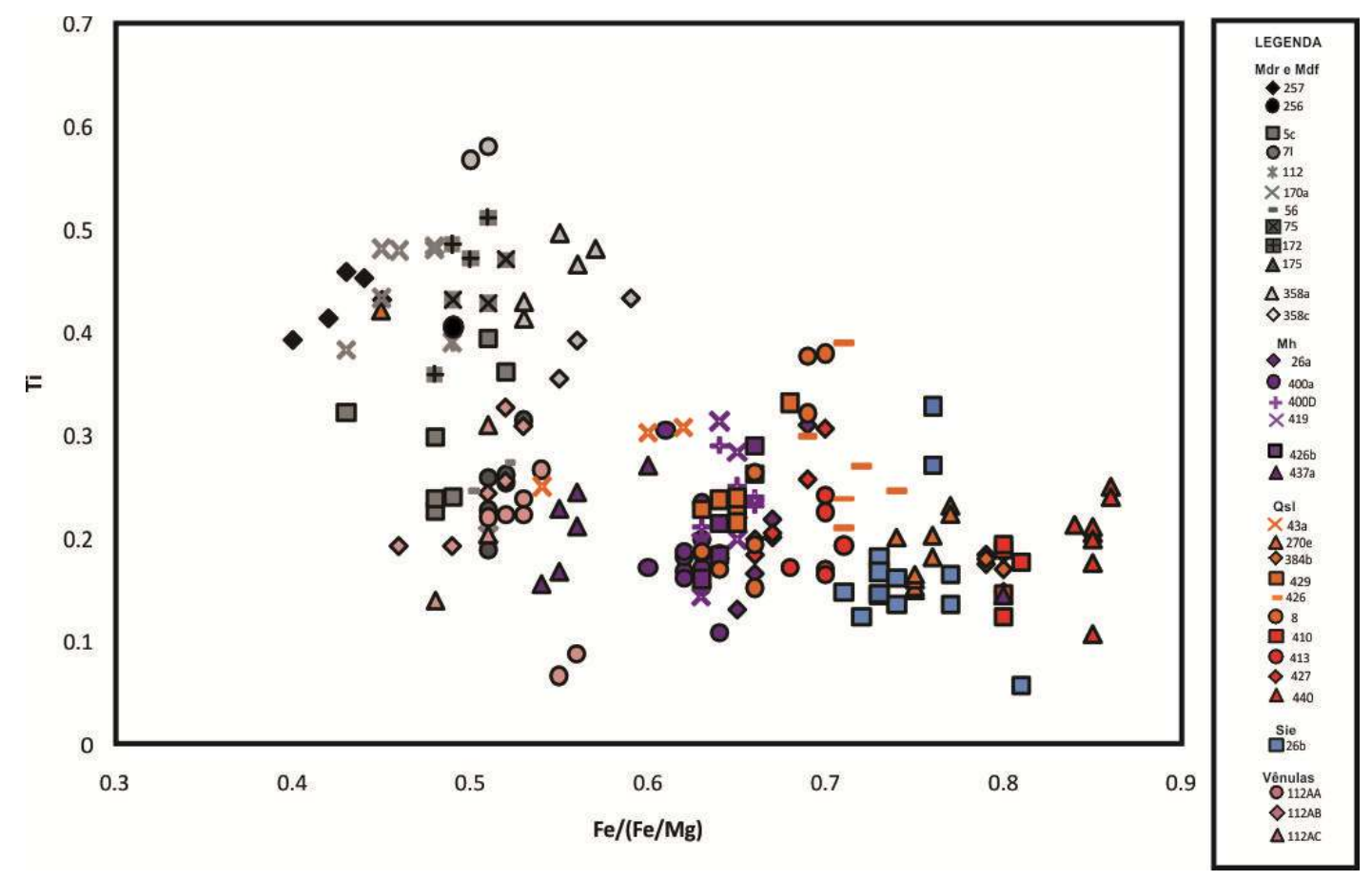

Figura 20. Variação nas concentraç̃os de Ti nas biotitas das diferentes unidades que compõem o Plúton Piracaia. 


\subsubsection{Plagioclásio}

Os resultados das análises de plagioclásio são apresentados na Tabela A03. O cálculo para os membros finais (Ab-An-Or) mostra que o componente Ortoclásio é sempre inferior a 2,5\%, e varia pouco entre as unidades. Contudo, nas rochas mais félsicas o conteúdo é inferior a 1\%, como pode ser observado na Figura 21. Os componentes anortita e albita variam bastante, mesmo dentro das

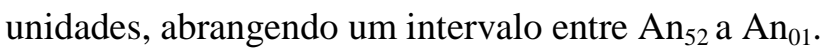

As composições mais cálcicas são encontradas em fenocristais de enclaves monzodioríticos de $M d f$ e nos Monzodioritos grossos $(M d r)$. Em $M d r$ os cristais podem ser homogêneos, ou apresentar forte zonação entre núcleo e borda, onde a composição se situa próximo ao limite andesinalabradorita. Estes cristais ocorrem também nas rochas mais diferenciadas da unidade, sendo que inclusive as composições mais cálcicas $\left(\mathrm{An}_{53-59}\right)$ são encontradas em rochas monzoníticas (Janasi, 1986). Nos cristais zonados, a composição das bordas situa-se no campo do oligoclásio.

Em $M d f$, os plagioclásios são mais sódicos e classificados como oligoclásio. Contudo, os cristais tabulares de grande dimensão, mais frequentes em rochas monzodioriíticas, atingem composições dentro do campo da andesina. As bordas destes cristais apresentam composições similares às da matriz.

Os $M h$ também apresentam conjuntos de cristais composicionalmente distintos. Os antecristais (cristais tabulares zonados de grande dimensão) são composicionalmente muito parecidos com os cristais de $M d r$ e cristais tabulares de $M d f$. Os núcleos atingem composições próximas ao campo da labradorita, enquanto as bordas são classificadas como oligoclásio. Por outro lado, os cristais da matriz tendem a ser mais sódicos que as bordas e situam-se próximo ao limite oligoclásio-albita.

Os cristais da amostra de Sie são de pequena dimensão e mostram-se composicionalmente homogêneos. São cristais essencialmente sódicos, onde o conteúdo de An é predominantemente inferior a $10 \%$, de modo que podem ser classificados como albita.

Quartzo monzonitos e quartzo sienitos (Qsie) predominantemente apresentam $A n<20$, onde bordas de cristais maiores e matriz são classificados com albita. Uma exceção é o quartzo monzonito PI-429, que contém grandes cristais de plagioclásio saussuritizado, cujos núcleos situam-se no campo da andesina. 

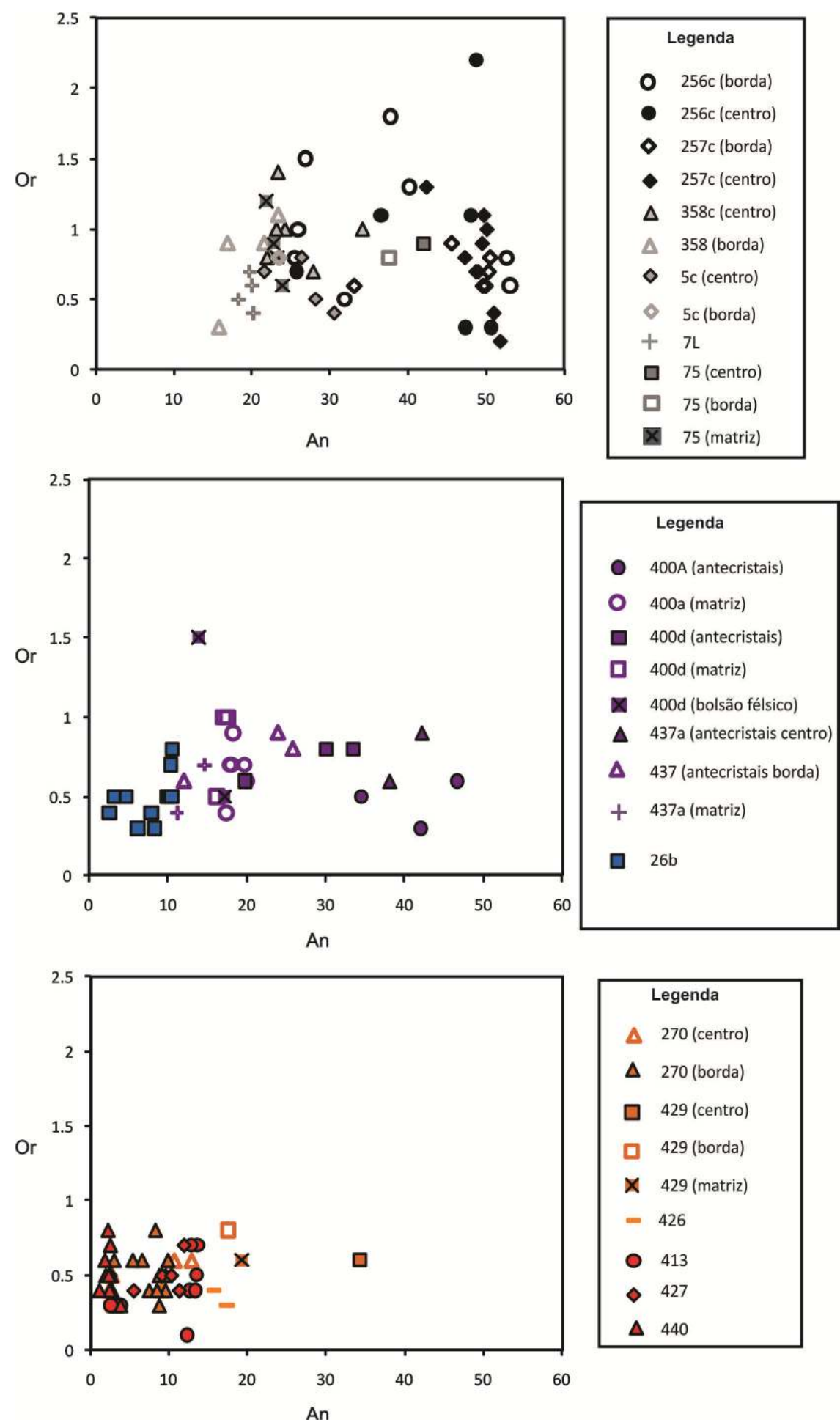

Figura 21. Variação composicional dos plagioclásios de diferentes unidades do Plúton Piracaia: (A) monzodioritos ( $M d r$ e $M d f$ ); (B) Monzonitos heterogêneos (Mh) e Sienitos (Sie); (C) quartzo monzonitos e quartzo sienitos (Qsie). 


\subsection{4 Óxidos de Fe-Ti}

Foram selecionados cristais de magnetita e ilmenita em amostras de todas as unidades, visando caracterizar possíveis variações químicas de cristais primários, assim como identificar eventuais processos de oxi-exsolução. Foram analisados desde associações de cristais tipicamente relacionados a processos secundários de oxiexsolução, i.e. associações do tipo treliça, como associações do tipo composto e também cristais individuais, porém próximos, de magnetita e ilmenita.

Os cálculos de fórmula estrutural foram realizados utilizando 4 oxigênios para magnetita e 6 oxigênios para ilmenita. Os resultados, apresentados na Tabela A04, mostram que independentemente da unidade ou tipo de associação considerada, a composição dos cristais é praticamente pura, tanto para ilmenita como magnetita.

Nos cristais de magnetita, o conteúdo máximo da molécula ulvoespinélio é predominantemente inferior a $1 \%$ e nunca atinge $2 \%$. Já o componente ilmenita é superior a $85 \%$ na ampla maioria dos cristais de ilmenita, onde os conteúdos mais baixos são encontrados em amostras de monzodioritos. Em sienitos ( Sie) e quartzo sienitos (Qsie), o componente ilmenita é sempre superior a $95 \%$. Esta homogeneidade composicional, muito próxima à dos membros finais, especialmente para os cristais de magnetita, sugere a atuação de processos de oxiexsolução. A possível existência destes processos, assim como eventuais alternativas para a obtenção de estimativas de fugacidade de oxigênio dos magmas, serão discutidas no item 3.4.3.

\subsection{Geoquímica de Rocha Total}

\subsubsection{Elementos maiores}

As unidades que compõem o Plúton Piracaia apresentam grande variabilidade composicional, podendo ser expressa pelo teor de $\mathrm{SiO}_{2}$, que abrange um intervalo entre 45 e 69\% 77\% (Tabelas A05 e A06). Existem também variações significativas dentro das diferentes unidades. A maior diferença refere-se aos monzodioritos ( $M d r$ e $M d f$ ), que se situam desde os limites entre as rochas ultrabásicas e básicas (45\%), até o campo das rochas intermediárias (60\%).

$M d r$ e $M d f$ caracteristicamente apresentam olivina e nefelina normativos, o que já sugere um caráter alcalino para os magmas mais primitivos. Nestas unidades apenas as amostras mais diferenciadas (monzonitos com quartzo, monzonitos e raros monzodioritos) apresentam hiperstênio no cálculo de norma e nenhuma apresenta quartzo. Por outro lado, quartzo monzonitos e quartzo sienitos (Qsie) caracteristicamente apresentam quartzo normativo $>6 \%$. Sie e $M h$ também apresentam quartzo e hiperstênio normativos, onde o quartzo é inferior a $1 \%$. 
No diagrama TAS, que relaciona o conteúdo de álcalis com $\mathrm{SiO}_{2}$, observa-se que todas as unidades de Piracaia situam-se no campo das rochas alcalinas (Figura 22). Esse enriquecimento em álcalis também é perceptível no diagrama R1-R2 de De La Roche et al. (1980), onde os monzodioritos mais primitivos situam-se no campo dos sienodioritos e evoluem até o campo dos sienitos (Figura 23).

TAS (Cox et al. 1979)

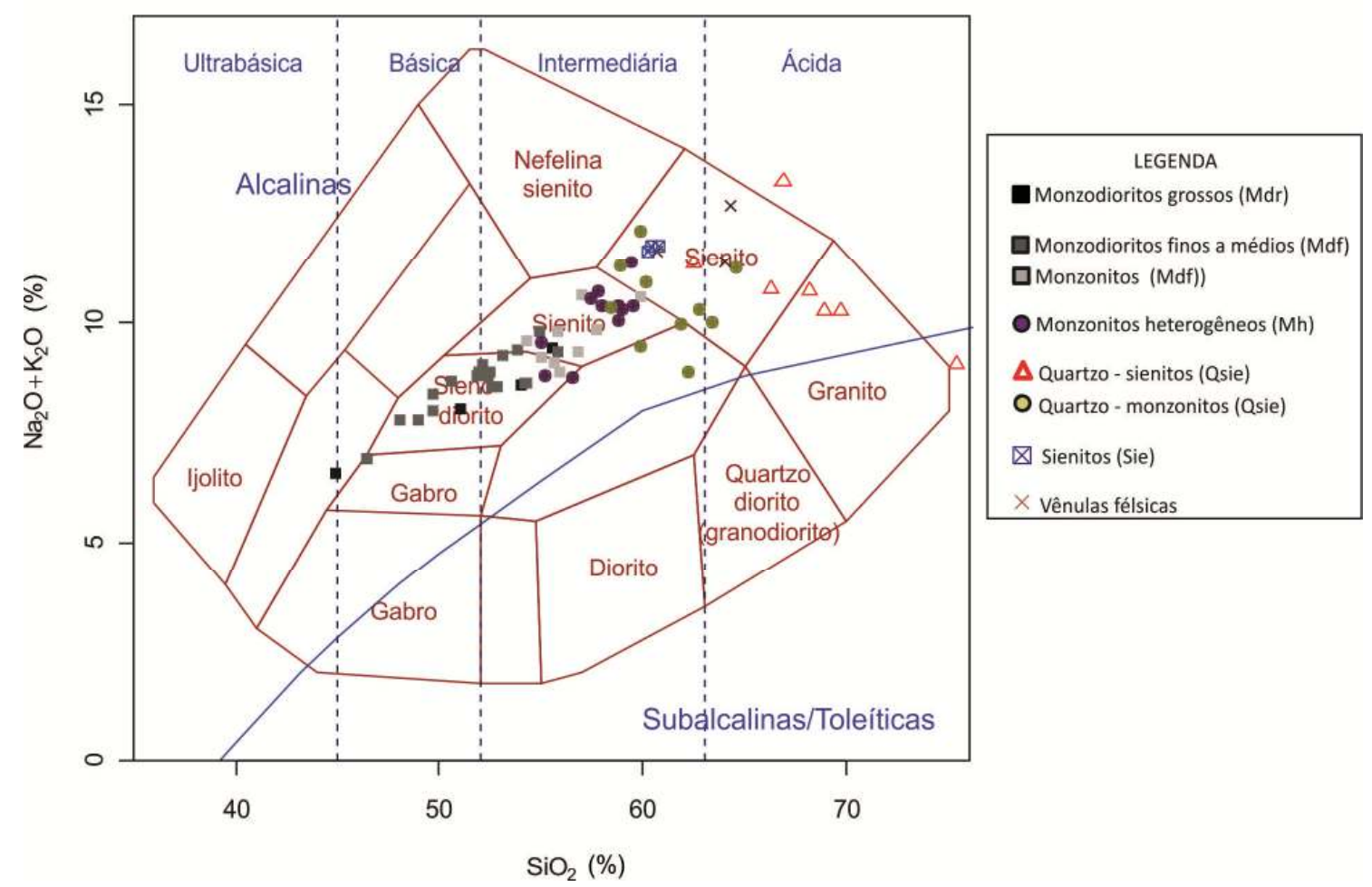

Figura 22. Diagrama TAS, mostrando o amplo intervalo de $\mathrm{SiO}_{2}$ e as elevadas concentrações de álcalis apresentadas pelas unidades que compõem o Plúton Piracaia.

As rochas apresentam Índice de alcalinidade de Peacock de aproximadamente 48, o que as situa no campo das rochas alcalinas (Figura 24). No mesmo diagrama, observa-se que as rochas da unidade Qsie apresentam grande dispersão e não formam uma tendência bem definida.

Já o diagrama $\mathrm{K}_{2} \mathrm{O}$ vs. $\mathrm{SiO}_{2}$ de Peccerillo \& Taylor (1976) mostra que o enriquecimento em álcalis se deve em grande parte às elevadas concentrações de $\mathrm{K}_{2} \mathrm{O}$, onde as rochas podem ser classificadas como de afinidade shoshonítica (Figura 25).

Embora o conteúdo de álcalis seja elevado, sua concentração é inferior à de $\mathrm{Al}_{2} \mathrm{O}_{3}$, de modo que as rochas de todas as unidades são classificadas como metaluminosas, segundo o Indice de Saturação em Alumínio (ISA) de Shand (1943). Apenas os quartzo sienitos mais diferenciados de Qsie, que ocorrem como veio tardios, apresentam ISA pouco superiores a 1 e são levemente peraluminosos. 


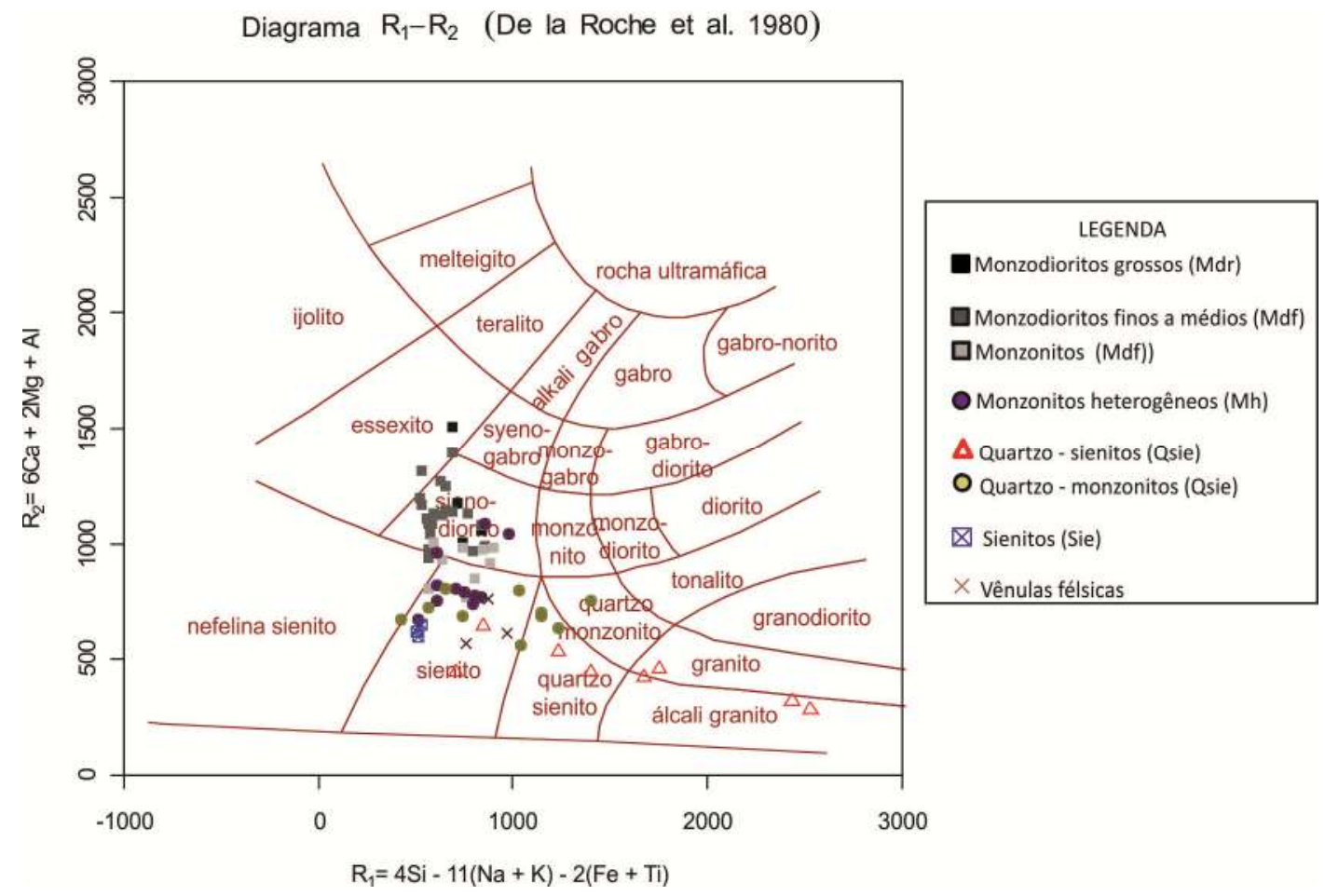

Figura 23. Diagrama R1 - R2 (De La Roche et al. 1980), onde as rochas do Plúton Piracaia apresentam-se deslocadas para a esquerda em relação à sua classificação mineralógica, devido ao seu elevado conteúdo de álcalis.

No diagrama AFM (Figura 26), observa-se que todas as unidades apresentam uma tendência de evolução que desloca-se de $\mathrm{F}$ para $\mathrm{A}$, o que evidencia o caráter precoce dos óxidos de $\mathrm{Fe}$ (magnetita). Quando considerados apenas os monzodioritos ( $M d r$ e $M d f$ ), observa-se que estas rochas apresentam o mesmo padrão de evolução. O diagrama AFM mostra ainda, que as rochas de todas unidades apresentam elevado conteúdo de $\mathrm{Fe}$, o que é melhor percebido no diagrama $\left(\mathrm{FeO}_{\mathrm{t}}+\mathrm{MgO}\right)$ vs. $\mathrm{SiO}_{2}$ de Miyashiro (1974), onde as concentrações de Piracaia se comparam às de rochas toleíticas (Figura 27).

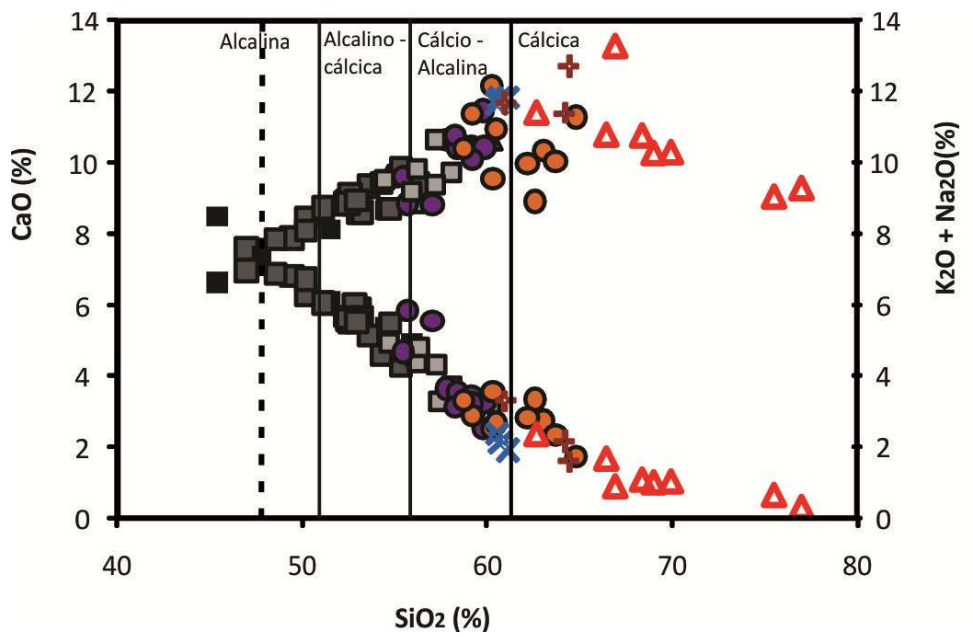

\begin{tabular}{|l|}
\hline \multicolumn{1}{c|}{ LEGENDA } \\
Monzodioritos grossos (Mdr) \\
$\square$ Monzodioritos finos a médios (Mdf) \\
$\square$ Monzonitos (Mdf)) \\
OMonzonitos heterogêneos (Mh) \\
$\Delta$ Quartzo - sienitos (Qsie) \\
O Quartzo - monzonitos (Qsie) \\
* Sienitos (Sie) \\
+ Vênulas félsicas
\end{tabular}

Figura 24. Índice de alcalinidade de Peacock para as rochas que compõem o Plúton Piracaia (linha tracejada). 


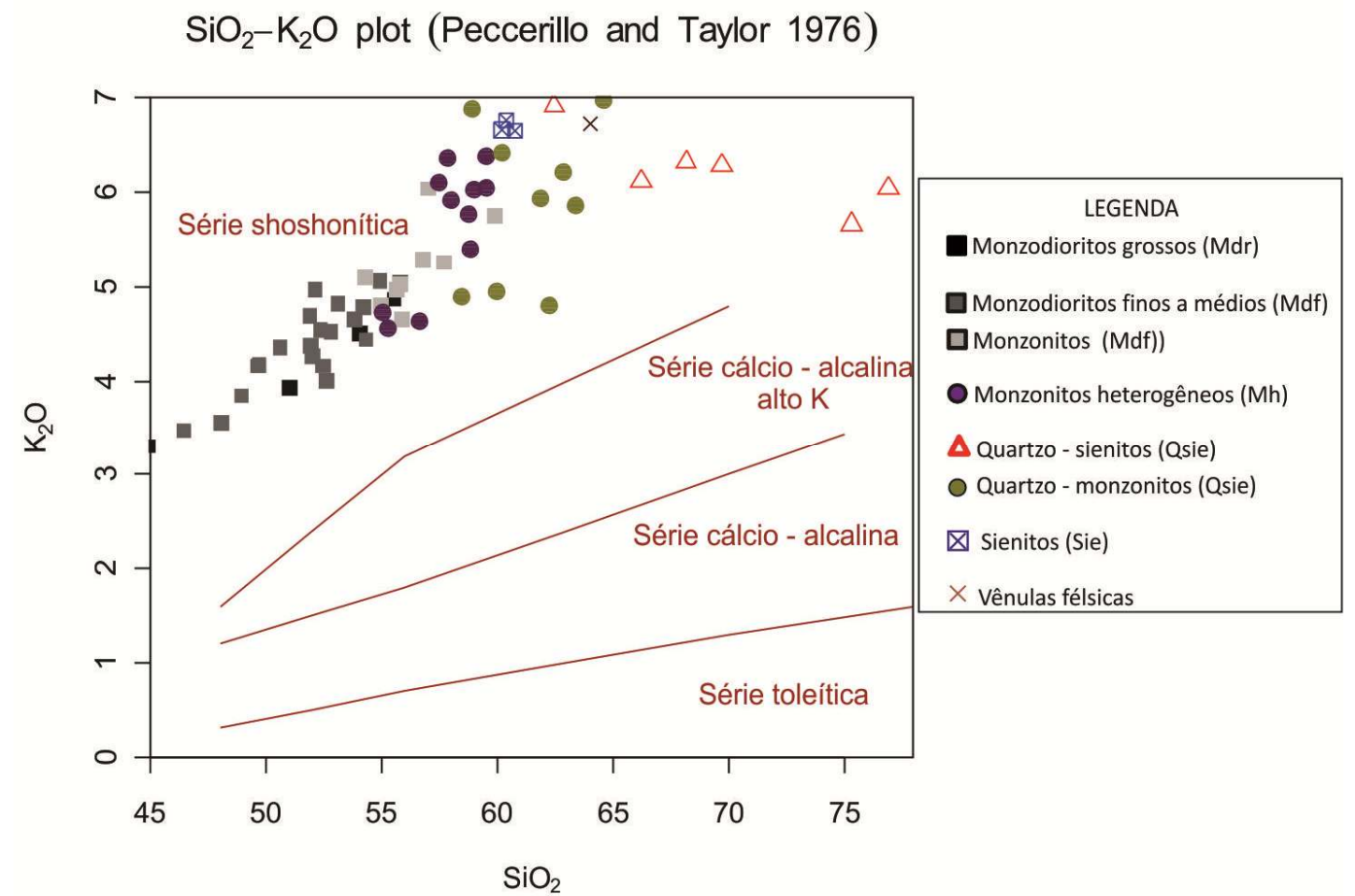

Figura 25. Diagrama de $\mathrm{SiO}_{2}$ vs $\mathrm{K}_{2} \mathrm{O}$ (Peccerillo \& Taylor (1976) evidenciando o elevado conteúdo de $\mathrm{K}_{2} \mathrm{O}$ das rochas do Plúton Piracaia.

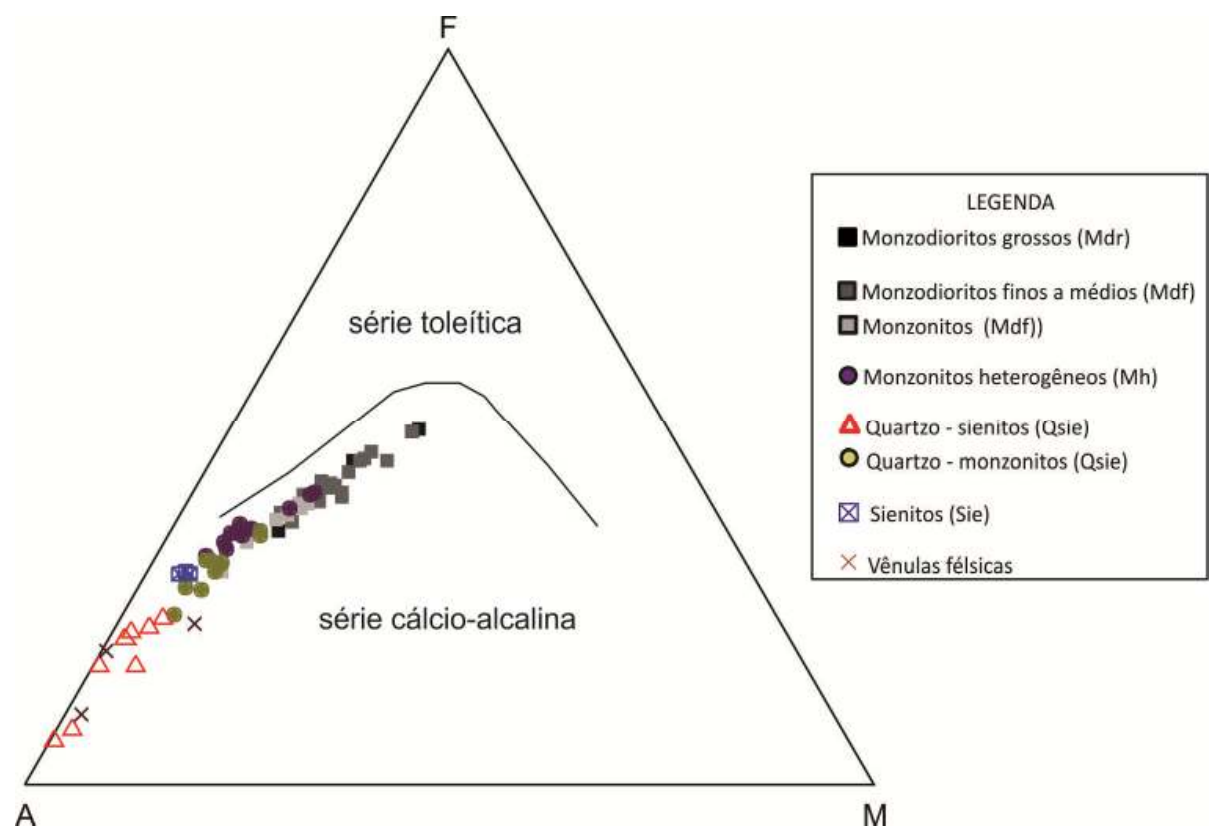

Figura 26. Diagrama AFM para as diferentes unidades que compõem o Plúton Piracaia. 


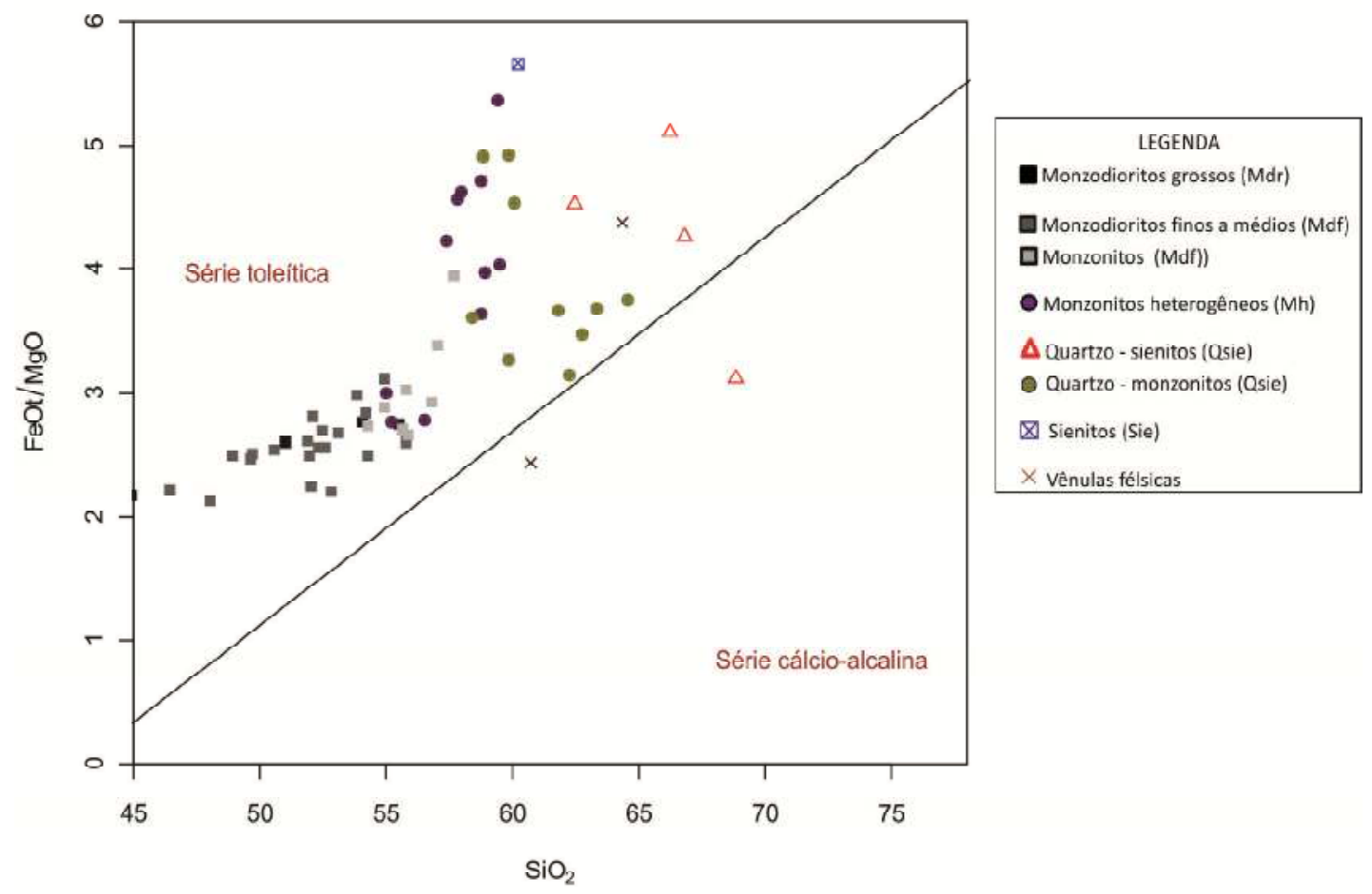

Figura 27. Diagrama de Miyashiro (1974), evidenciando o elevado conteúdo de $\mathrm{FeO}_{\mathrm{t}}$ de todas as unidades que compõem o Plúton Piracaia.

O caráter metaluminoso, a afinidade alcalina e as elevadas concentrações de Fe das rochas de Piracaia ficam evidentes também quando utilizados os diagramas classificatórios desenvolvidos por Frost et al. (2001) e Frost \& Frost (2008). O Índice de Saturação em Alumina (ASI) apresentado por Frost et al. (2001) (Figura 28) diferencia-se do índice clássico proposto por Shand (1943), ao incorporar também o elemento $\mathrm{P}$, onde $\mathrm{ASI}=[\mathrm{Al} /(\mathrm{Ca}-1.67 \mathrm{P}+\mathrm{Na}+\mathrm{K})]$. Os resultados são idênticos aos fornecidos pelo ISA clássico, onde apenas as amostras mais diferenciadas de Qsie e as venulações félsicas são levemente peraluminosos.

$\mathrm{O}$ índice MALI $\left(\mathrm{Na}_{2} \mathrm{O}+\mathrm{K}_{2} \mathrm{O}-\mathrm{CaO}\right.$ vs. $\left.\mathrm{SiO}_{2}\right)$, que se assemelha ao índice de alcalinidade de Peacock, tem a vantagem de poder ser utilizado mesmo que as rochas de uma determinada associação não sejam cogenéticas. Contudo, sua aplicabilidade restringe-se a rochas com teor de $\mathrm{SiO}_{2}>51 \%$, de modo que os monzodioritos mais primitivos situam-se fora dos campos delimitados pelos autores (Figura 29). Ainda assim, as amostras das unidades $M d r$ e $M d f$ apresentam um padrão linear e evoluem paralelamente aos campos composicionais delimitados no diagrama, o que permite extrapolar estes campos para menores concentrações de $\mathrm{SiO}_{2}$, onde os monzodioritos classificam-se como rochas alcalinas (alkalic), assim como todas as rochas das demais unidades. As únicas exceções são duas amostras de quartzo sienitos leucocráticos (Qsie), que ocorrem como veios tardios, e pelo seu elevado teor de $\mathrm{SiO}_{2}$ são classificadas como álcali-cálcicas (alkali-calcic). 


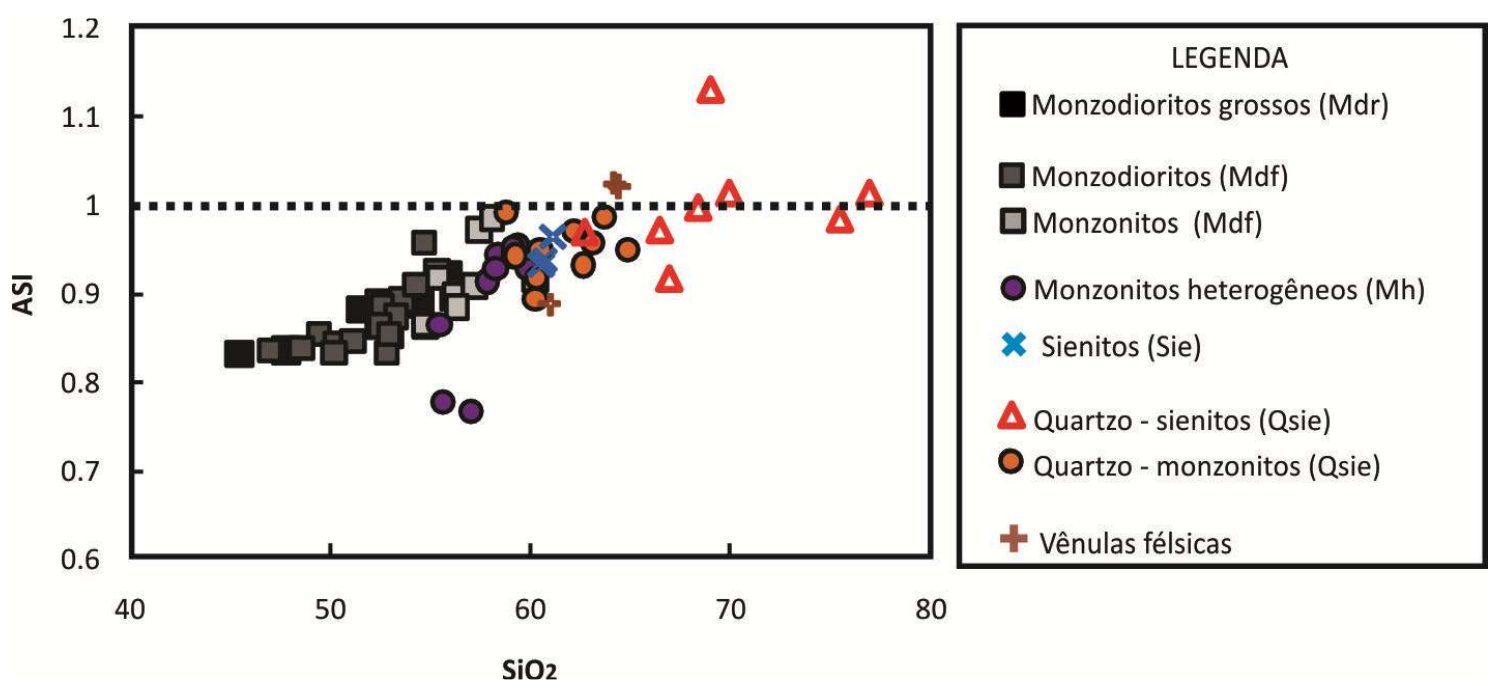

Figura 28. Índice de saturação em alumina (Frost et al., 2001), evidenciando o caráter metaluminoso das rochas do Plúton Piracaia.

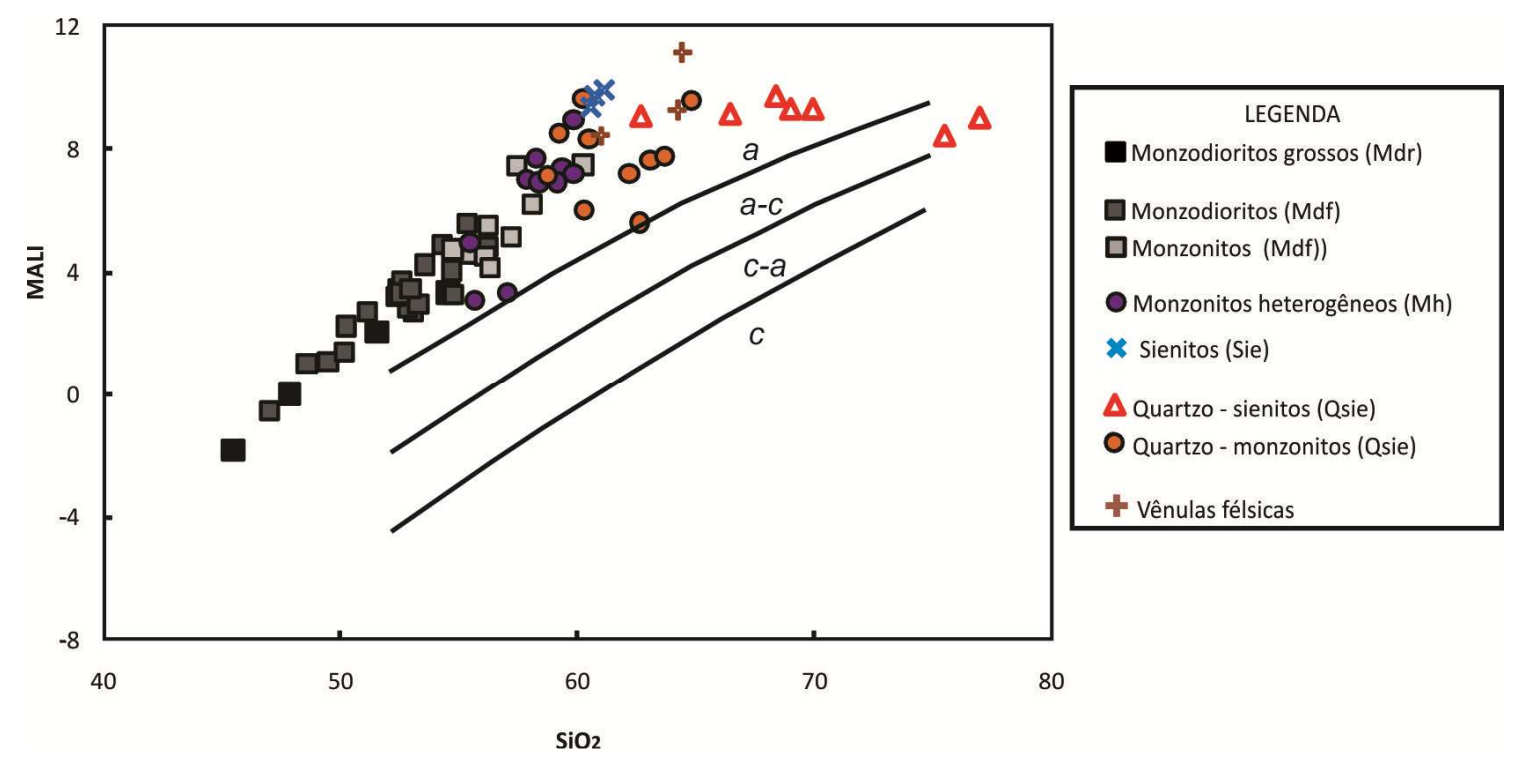

Figura 29. Índice MALI proposto por Frost et al. (2001), onde as amostras de todas as unidades do Plúton Piracaia situam-se no campo das rochas alcalinas (alkalic).

No que se refere às relações entre $\mathrm{FeO}_{\mathrm{t}}$ e $\mathrm{MgO}$, expressas por Frost et al. (2001) como $\mathrm{Fe}^{*}$ $\left(\mathrm{FeO}_{\mathrm{t}} / \mathrm{FeO}_{\mathrm{t}}+\mathrm{MgO}\right)$ e cujos campos composicionais foram modificados por Frost \& Frost (2008), todas as unidades de Piracaia podem classificadas como ferroan, embora os monzodioritos predominantemente situem-se no limite entre os campos (Figura 30). 


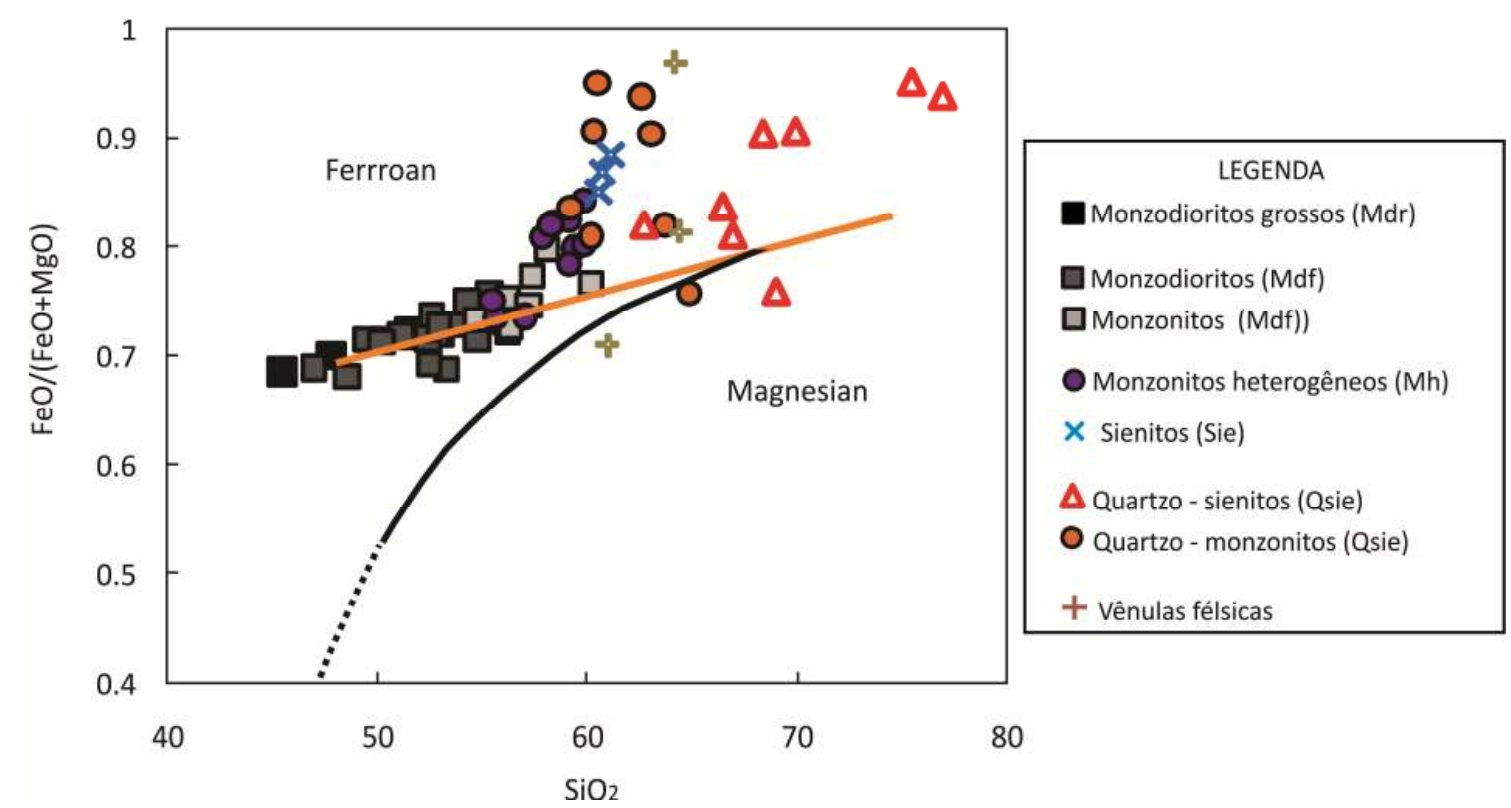

Figura 30. Rochas do Plúton Piracaia plotadas no diagrama de correlação entre o * Fe $(\mathrm{FeO} /(\mathrm{FeO} / \mathrm{MgO}))$ e $\mathrm{SiO}_{2}$ proposta por Frost et al. (2001), cujos limites entre os campos ferroan e magnesian (linha laranja) foram modificados por Frost \& Frost (2008). A linha preta corresponde à divisão de basaltos cálcio-alcalinos e toleíticos de Miyashiro (1974).

Frost et al. (2001) sugerem que o enriquecimento em Fe das rochas do tipo ferroan deve-se a trajetórias de evolução redutoras. Embora em Piracaia isto seja possível para os sienitos e quartzo sienitos, o mesmo não vale para os monzodioritos, que cristalizaram sob condições oxidantes, como evidenciados pela tendência de evolução no diagrama AFM e cristalização precoce da magnetita. De modo que para a grande maioria das amostras, o fato de serem classificadas como ferroan reflete simplesmente que as concentrações de Fe dos magmas são elevadas, e não que o enriquecimento esteja relacionado às condições de fugacidade de $\mathrm{O}_{2}$ vigentes durante o processo de cristalização.

O Índice de alcalinidade e o Índice de Saturação em Sílica de Frost \& Frost (2008) foram desenvolvidos visando aprimorar o sistema classificatório proposto por Frost et al. (2001), de modo a incluir rochas alcalinas. O índice de alcalinidade (AI), que representa uma modificação do Índice Agpaítico de Shand, é expresso por: AI = Al-(Na+K). Em Piracaia verifica-se IA >0, o que caracteriza as rochas como metaluminosas.

Já o Índice de Saturação em Sílica (FSSI) é calculado a partir dos resultados dos cálculos de NORMA e expresso por $\mathrm{Q}-[\mathrm{Lc}+2(\mathrm{Ne}+\mathrm{Kp})] / 100$. Todos os monzodioritos $(M d r$ e $M d f)$ e Sienitos (Sie) apresentam FSSI <1 e são portanto, subsaturados. O mesmo vale para a maioria dos Monzonitos heterogêneos, sendo que os demais apresentam FSSI levemente positivos, próximos ao limite de subsaturação. Já quartzo monzonitos e quartzo sienitos, caracteristicamente apresentam FSSI >1, à exceção de duas amostras de quartzo monzonitos (PI-429 e PI-8), que mineralogicamente destacam-se por serem mais máficas que as demais. 
Quando os dados de todas as unidades são dispostos em diagramas binários, utilizando $\mathrm{SiO}_{2}$ como índice de diferenciação (Figura 31), observa-se que apenas $\mathrm{K}_{2} \mathrm{O}, \mathrm{Al}_{2} \mathrm{O}_{3}$ e $\mathrm{Na}_{2} \mathrm{O}$ não apresentam correlação negativa com o aumento de $\mathrm{SiO}_{2}$. Enquanto $\mathrm{K}_{2} \mathrm{O}$ apresenta uma tendência bem definida de enriquecimento, observam-se padrões dispersos para $\mathrm{Al}_{2} \mathrm{O}_{3}$ e $\mathrm{Na}_{2} \mathrm{O}$.

Quanto ao $\mathrm{Al}_{2} \mathrm{O}_{3}$, as concentrações, embora oscilantes, se mantêm praticamente constantes com o aumento de $\mathrm{SiO}_{2}$, para as unidades $M d r, M d f$, Mh e Sie. Já as rochas de Qsie apresentam concentrações levemente mais baixas, caracterizando uma tendência mal definida de enriquecimento com o aumento de $\mathrm{SiO}_{2}$.

No que se refere ao $\mathrm{Na}_{2} \mathrm{O}$, os sienitos (Sie) destacam-se por serem as rochas com concentrações mais elevadas. Não se identificam tendências evolutivas para as unidades $M d r, M d f$ e $M h$, onde os teores de todas as amostras concentram-se entre 4 e $5 \%$, em um intervalo de aproximadamente $10 \%$ de $\mathrm{SiO}_{2}$. Quartzo monzonitos e quartzo sienitos de Qsie não apresentam internamente uma tendência bem definida, à exceção das amostras mais diferenciadas de quartzo sienito, que apresentam concentrações mais baixas de $\mathrm{Na}_{2} \mathrm{O}$.

\subsubsection{Elementos-traço}

Quando considerados os elementos traço, nos diagramas binários em geral observa-se, como esperado, que as rochas mais primitivas são mais enriquecidas em elementos compatíveis, ao contrário das mais evoluídas, que tendem a apresentar maiores concentrações de elementos incompatíveis (Figura 32). Contudo, salientam-se algumas diferenças entre as unidades.

$M d r$ e $M d f$ destacam-se pelas elevadas concentrações de $\mathrm{Ba}$ e $\mathrm{Sr}$, onde é bem marcada uma tendência de empobrecimento com a diferenciação. Por outro lado, $\mathrm{Rb}, \mathrm{Nb}$ e Zr são os elementos com tendências de enriquecimento melhor definidas.

Percebe-se algumas diferenças entre as rochas mais diferenciadas, especialmente entre sienitos e quartzo sienitos. Enquanto os quartzo sienitos (Qsie) apresentam concentrações mais elevadas de Th, Sienitos (Sie) são mais enriquecidos em Nb, Zn e moderadamente também em Zr. Contudo, a dispersão é grande entre quartzo sienitos. $\mathrm{O} \mathrm{Nb}$ merece destaque, uma vez que a unidade $M h$ acompanha o aumento apresentado por Sie. As concentrações deste elemento, por outro lado, diminuem nos quartzo monzonitos e quartzo sienitos, à medida que as rochas da unidade tornam-se mais félsicas. 

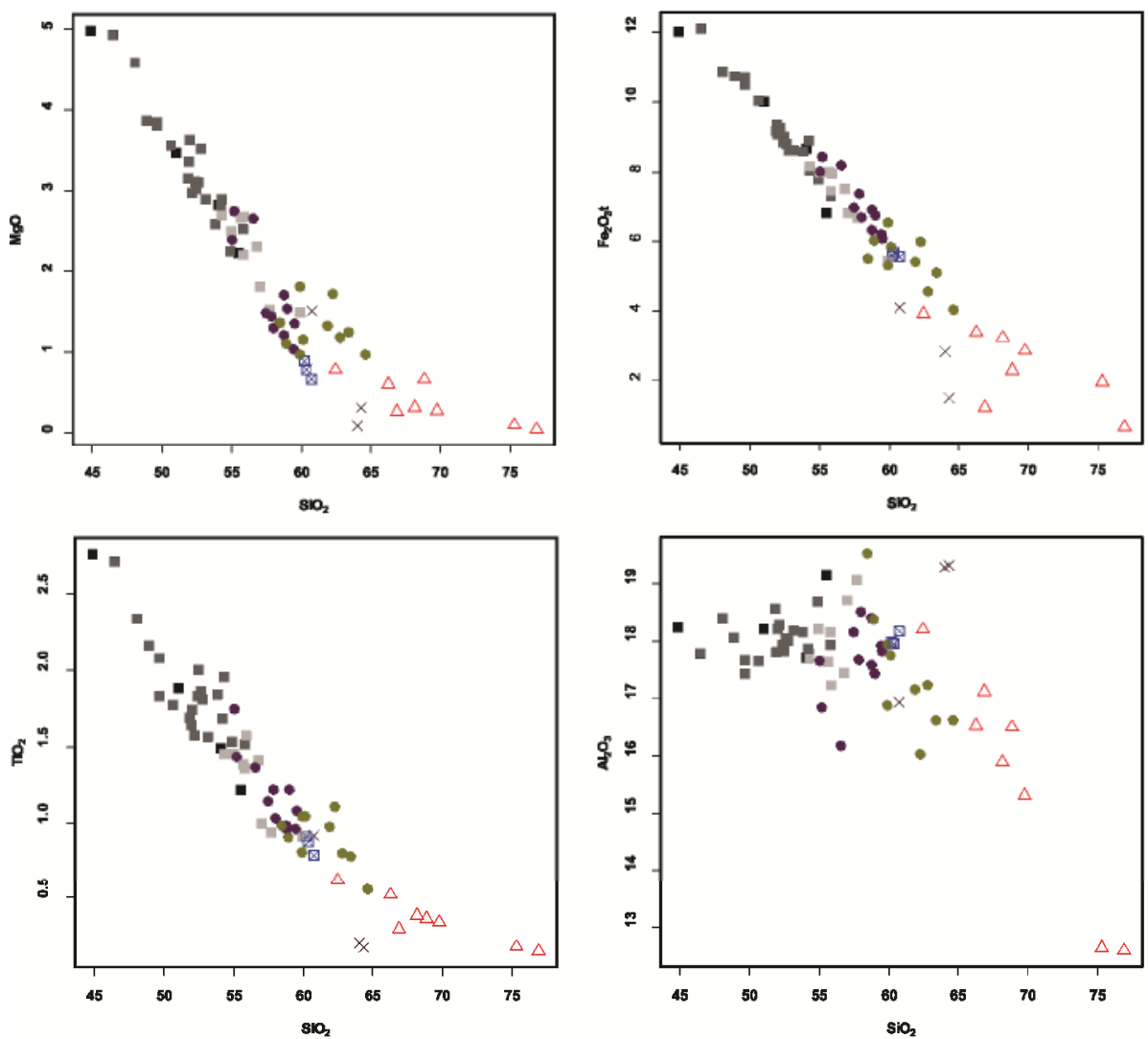

\section{LEGENDA}

Monzodioritos grossos (Mdr)

Monzodioritos (Mdf)

Monzonitos (Mdf)

Monzonitos heterogëneos (Mh) \Sienitos (Sie)

$\triangle$ Quartzo sienitos (Qsie)

Q Quartzo monzonitos (Qsie)

$X$ Vênulas félsicas
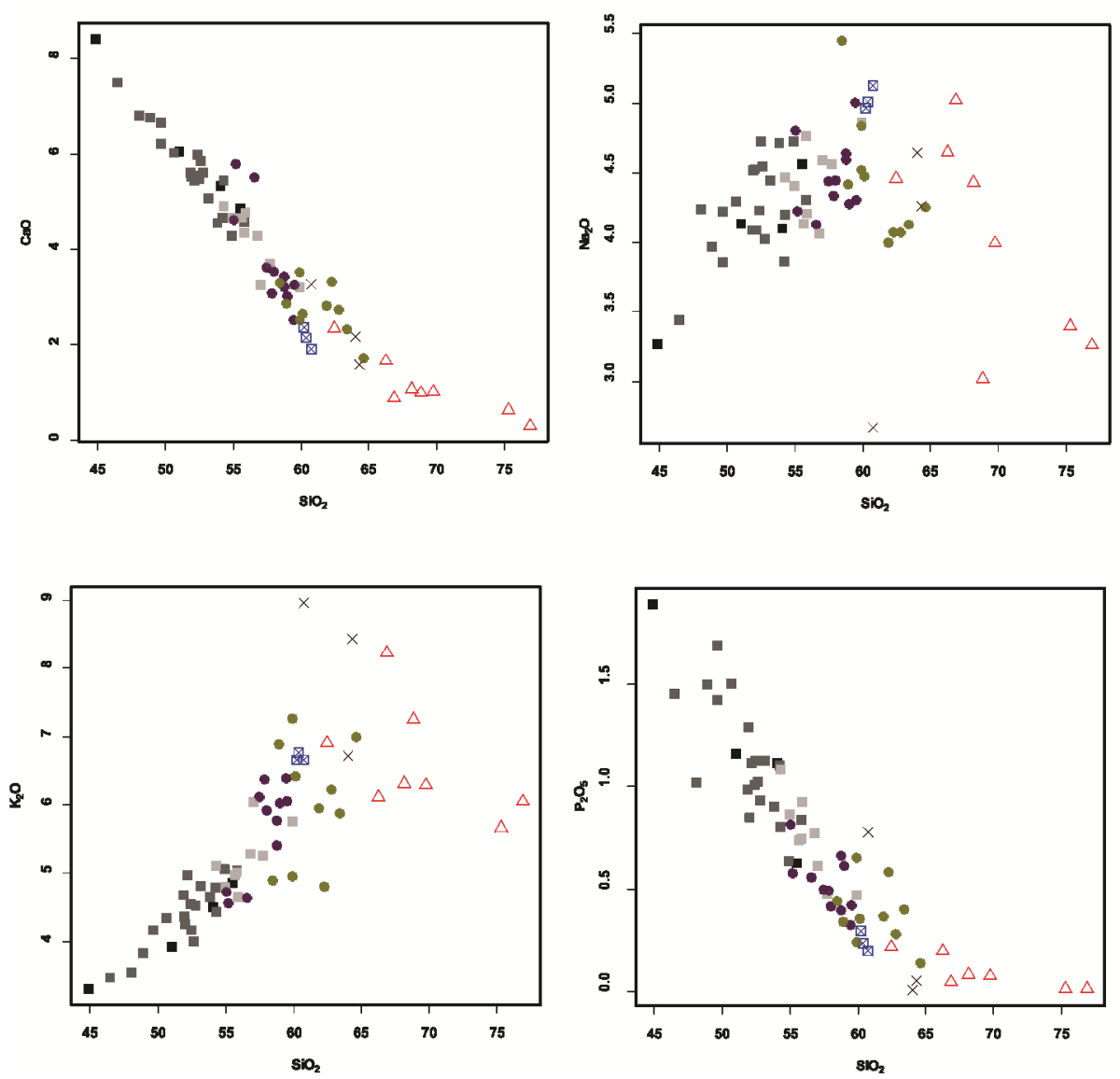

Figura 31. Composições de elementos maiores e menores das unidades que compõem o Plúton Piracaia, dispostos em diagramas binários, utilizando $\mathrm{SiO}_{2}$ como índice de diferenciação. 
Com relação aos elementos terras raras (ETR) (Figura 33), todas as amostras apresentam um moderado enriquecimento de ETR leves em relação aos pesados. O fracionamento mostra-se menos pronunciado nos monzodioritos e $M h$, onde a razão $(\mathrm{La} / \mathrm{Yb})_{\mathrm{N}}$ varia entre 15 e 23 para $M d r$ e $M d f$ e entre 14 e 20 para $M h$. Observa-se também que algumas amostras de monzodioritos, tanto de $M d r$ como $M d f$, apresentam leve anomalia positiva de Eu, enquanto em algumas amostras de $M h$ as anomalias são levemente negativas.

O fracionamento é maior nos quartzo monzonitos e quartzo sienitos (Qsie), onde a razão $(\mathrm{La} / \mathrm{Yb})_{\mathrm{N}}$ varia entre 10 e 47. Comparando as rochas mais evoluídas, verifica-se que quartzo sienitos são mais enriquecidos em ETR leves do que sienitos, que por sua vez apresentam maiores concentrações de ETR pesados, resultando em razões $(\mathrm{La} / \mathrm{Yb})_{\mathrm{N}}$ mais baixas, que são de 19 para sienitos e 44 para a amostra de quartzo sienito. Mh e Sie mostram padrões composicionais muito semelhantes, porém Sie apresenta concentrações levemente mais elevadas. Observa-se ainda, que algumas amostras de Sie, e Qsie, e uma ou outra de $M h$ apresentam anomalias negativas de Eu.

Quando plotadas em diagramas multielementares (Figura 34) ficam mais claros os padrões característicos de cada unidade e salientam-se, em especial, as diferenças entre os monzodioritos e as rochas mais félsicas (Sienitos e quartzo sienitos). Contudo, antes de destacar as diferenças se faz importante salientar o elevado conteúdo de $\mathrm{K}$ de todas as unidades. Esta anomalia positiva é ressaltada pelas concentrações predominantemente baixas de U, Th (à exceção da unidade Qsie), e menos pronunciadamente também de $\mathrm{Nb}$ e Ta.

Uma característica distintiva de $M d r$ e $M d f$ são os maiores teores de $\mathrm{Ba}, \mathrm{Sr}, \mathrm{P}, \mathrm{Ti}$ e moderadamente também o Eu em relação às demais unidades, enquanto as concentrações de Th, $\mathrm{U}, \mathrm{Zr}$ e Hf são relativamente baixas. Por outro lado, Sie e quartzo sienitos (Qsie) em geral são ricos em Th, U e HFSE (especialmente Zr e Hf), e têm concentrações relativamente baixas de Sr, Ti e P. Destaca-se ainda a grande variação nas razões $\mathrm{Ba} / \mathrm{Rb}$ entre as unidades, que são muito altas em monzodioritos e baixas nas unidades félsicas. Em $M d r$ e $M d f$ variam entre 73 e 27, enquanto Sie e quartzo sienitos (Qsie) apresentam razões inferiores a 15. Mh e quartzo monzonitos (Qsie) apresentam razões levemente mais altas, porém também muito semelhantes entre si, normalmente variando entre 11 e 23 .

O padrão composicional dos $M h$ é predominantemente intermediário entre Sie e $M d f$, enquanto o dos quartzo monzonitos (Qsie) é intermediário entre quartzo sienitos (Qsie) e Mdf. Contudo, U e Th são exceção em $M h$, cujas concentrações são mais elevadas em relação a monzodioritos e sienitos. Já quartzo monzonitos (Qsie) destacam-se pela grande variação nos conteúdos de ETR, Rb, Zr e Nb, sendo que muitas amostras apresentam concentrações mais elevadas do que $M d f$ e quartzo sienitos (Qsie). 

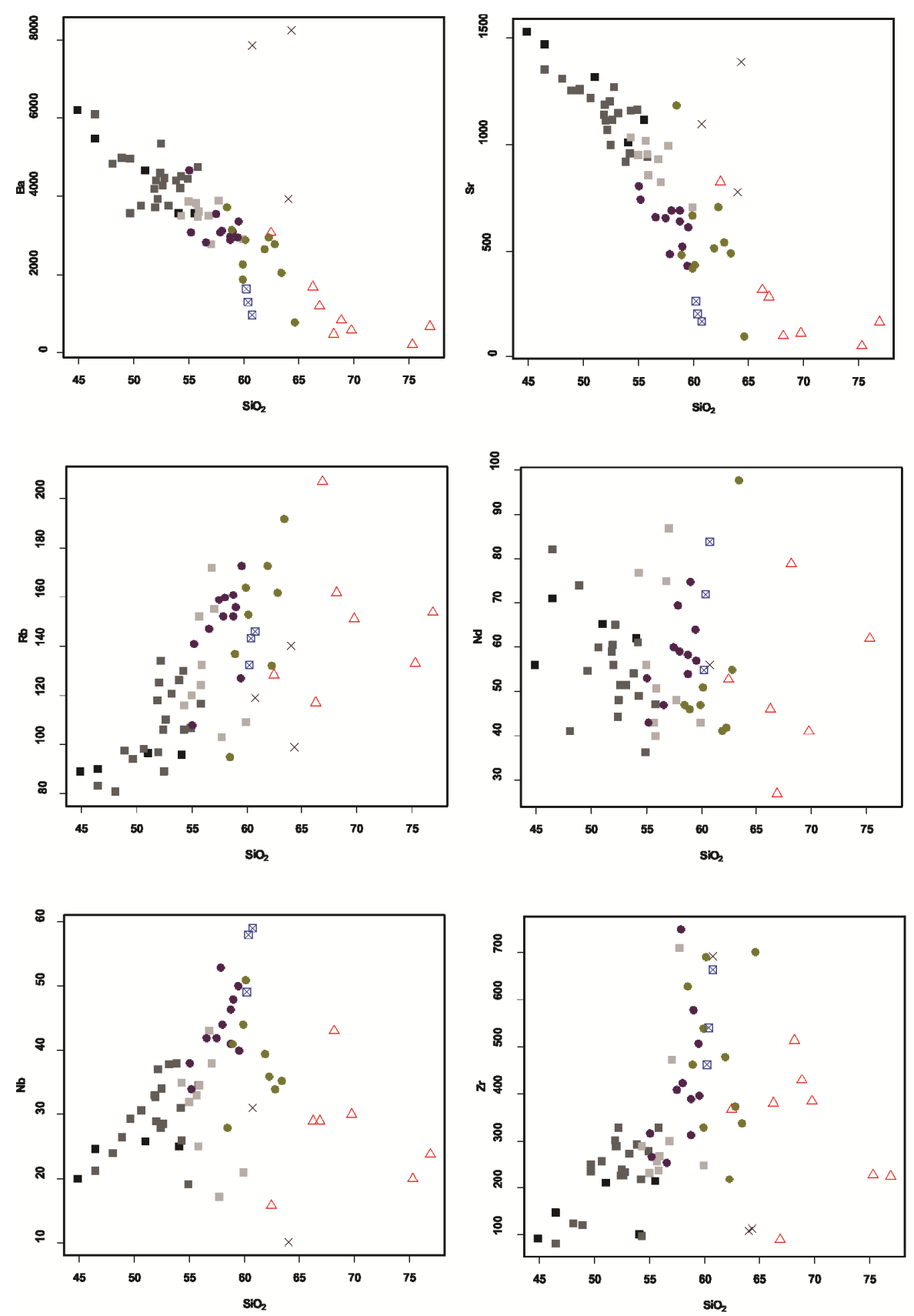

$X$ Vênulas féssicas
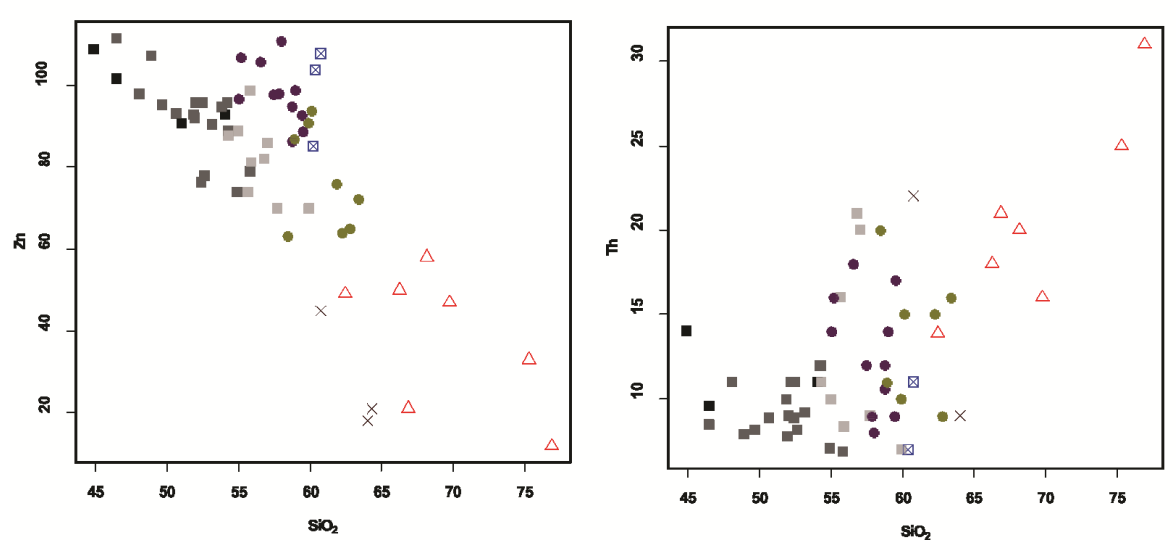

Figura 32. Composições de elementos traços das unidades que compõem o Plúton Piracaia, dispostos em diagramas binários, utilizando $\mathrm{SiO}_{2}$ como índice de diferenciação. 

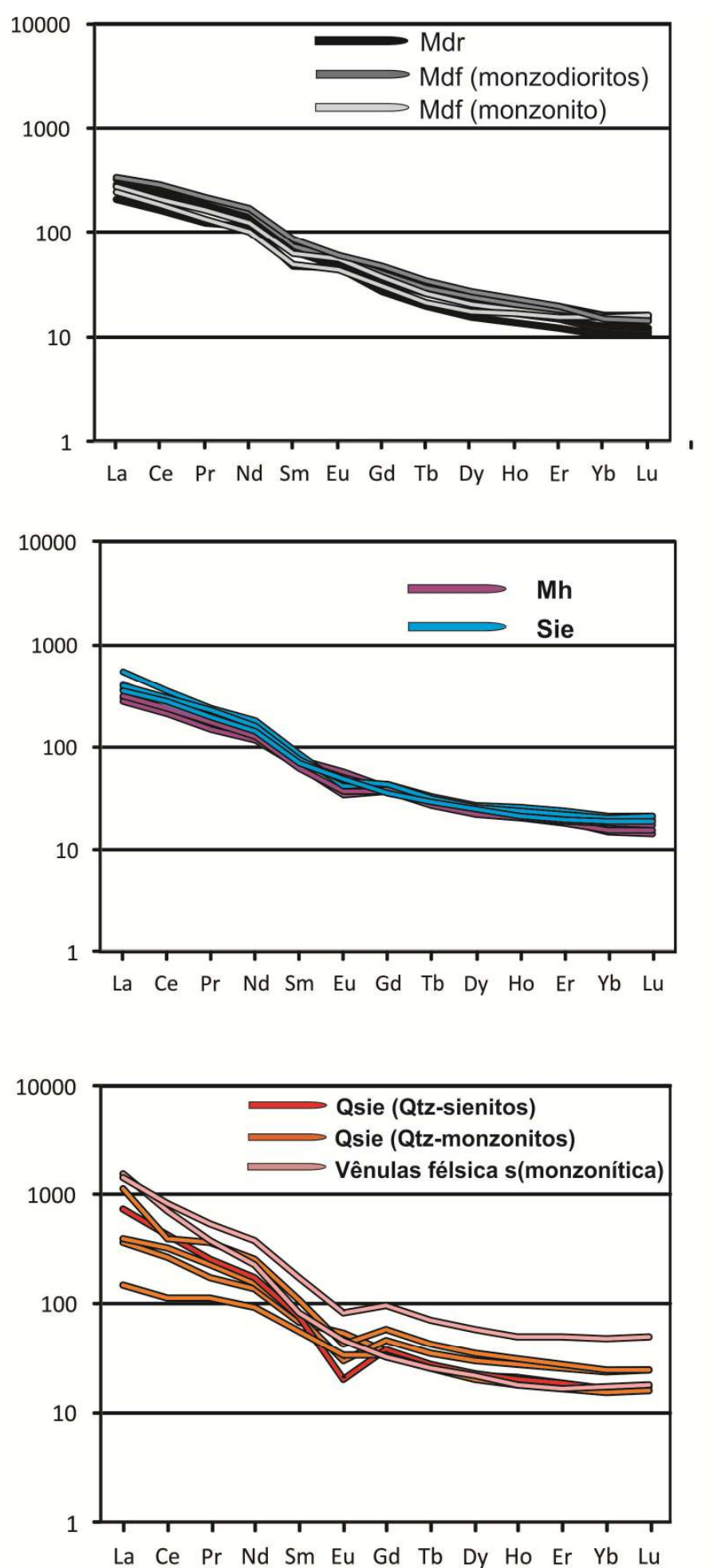

Figura 33. Diagramas de ETR para as rochas das diferentes unidades que compõem o Plúton Piracaia, normalizados para o condrito de Sun \& McDonough (1989). 

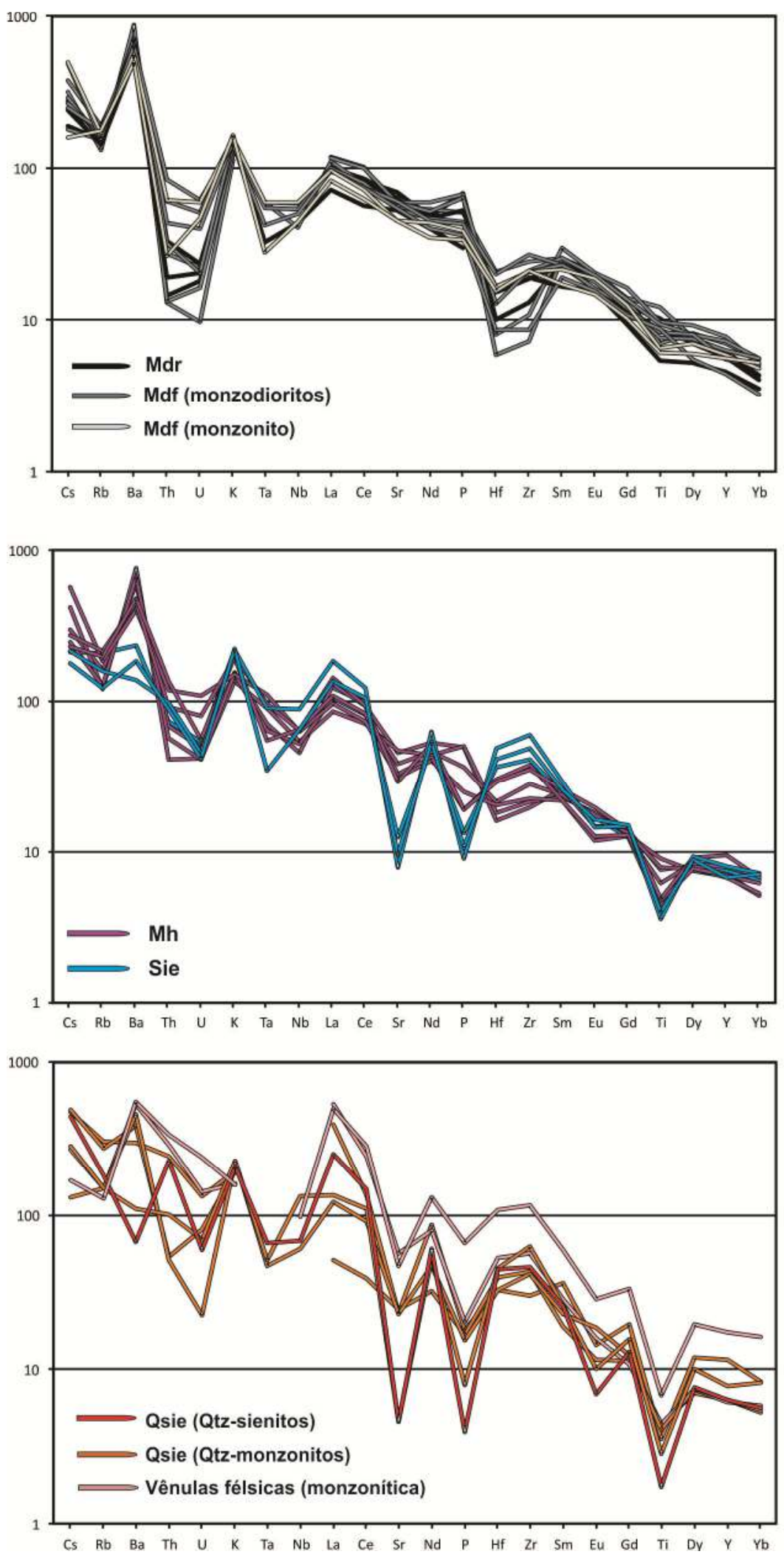

Figura 34. Diagramas multielementares para as rochas das diferentes unidades que compõem o Plúton Piracaia, normalizados para o Manto Primitivo de Sun \& McDonough (1989), 


\subsubsection{Modelamentos de sequência de cristalização - MELTS}

Foi modelada a cristalização de amostras representativas de todas as unidades, a partir das concentrações de elementos maiores de amostras representativas, utilizando o software MELTS (Ghiorso \& Sack, 1995). Foram incluídas amostras de monzonitos heterogêneos e quartzo monzonitos, mesmo considerando uma possível origem híbrida para estas rochas. O software exige que sejam fornecidas estimativas de temperatura liquidus e fugacidade de oxigênio dos magmas para que os modelamentos sejam executados. As temperaturas inseridas foram as estimativas de saturação em apatita e os buffers de fugacidade foram os condizentes com a mineralogia característica das diferentes rochas: buffer NNO para monzodioritos e quartzo monzonitos e buffer QFM para monzonitos heterogêneos, sienitos e quartzo sienitos.

Foram modeladas 6 amostras de monzodioritos (Mdr e Mdf); 2 de Sienitos (Sie); 2 de Monzonitos heterogêneos $(M h) ; 2$ de quartzo sienitos e 4 de quartzo monzonitos (Qsie).

Os resultados, em geral, são coerentes com o observado através da análise petrográfica e alguns deles permitiram algumas elucidações adicionais, que inicialmente não haviam sido percebidas, em especial com relação aos minerais opacos. Em $M d r$ e $M d f$ os modelamentos apontaram a cristalização de ilmenita apenas nos estágios finais de cristalização. Revisando as lâminas, percebeu-se que de fato cristais individuais de ilmenita são observados apenas de modo intersticial. E que os cristais inclusos nas fases precoces ocorrem sempre associados à magnetita. Assim sendo, os modelamentos sugerem que estas associações de cristais são possivelmente decorrentes de processos de oxiexsolução de cristais primários de titanomagnetita.

Contudo, algumas diferenças importantes foram encontradas, e referem-se: à apatita, que embora precoce e relativamente abundante em todas as unidades, foi uma fase predominantemente ausente os modelamentos de monzonitos heterogêneos, sienitos, quartzo monzonitos e quartzo sienitos; e à titanita, mineral acessório de cristalização tardia em todas as unidades, que não apareceu em nenhuma das amostras modeladas.

Em $M d r$ e $M d f$ magnetita, apatita e clinopiroxênio são sempre as primeiras fases a cristalizar (Figura 35). A magnetita mostra-se a fase liquidus, e é acompanhada por apatita nas amostras mais primitivas. Biotita e plagioclásio são os minerais seguintes na sequência de cristalização. Feldspato alcalino aparece depois, em um intervalo de temperatura entre 25 e $75^{\circ} \mathrm{C}$ mais baixas. Salienta-se que a diferença de temperatura entre a cristalização da biotita e feldspato alcalino são maiores nas amostras mais primitivas. Ilmenita aparece nos estágios finais, assim como o anfibólio, porém este último não surgiu em todas as amostras modeladas. 

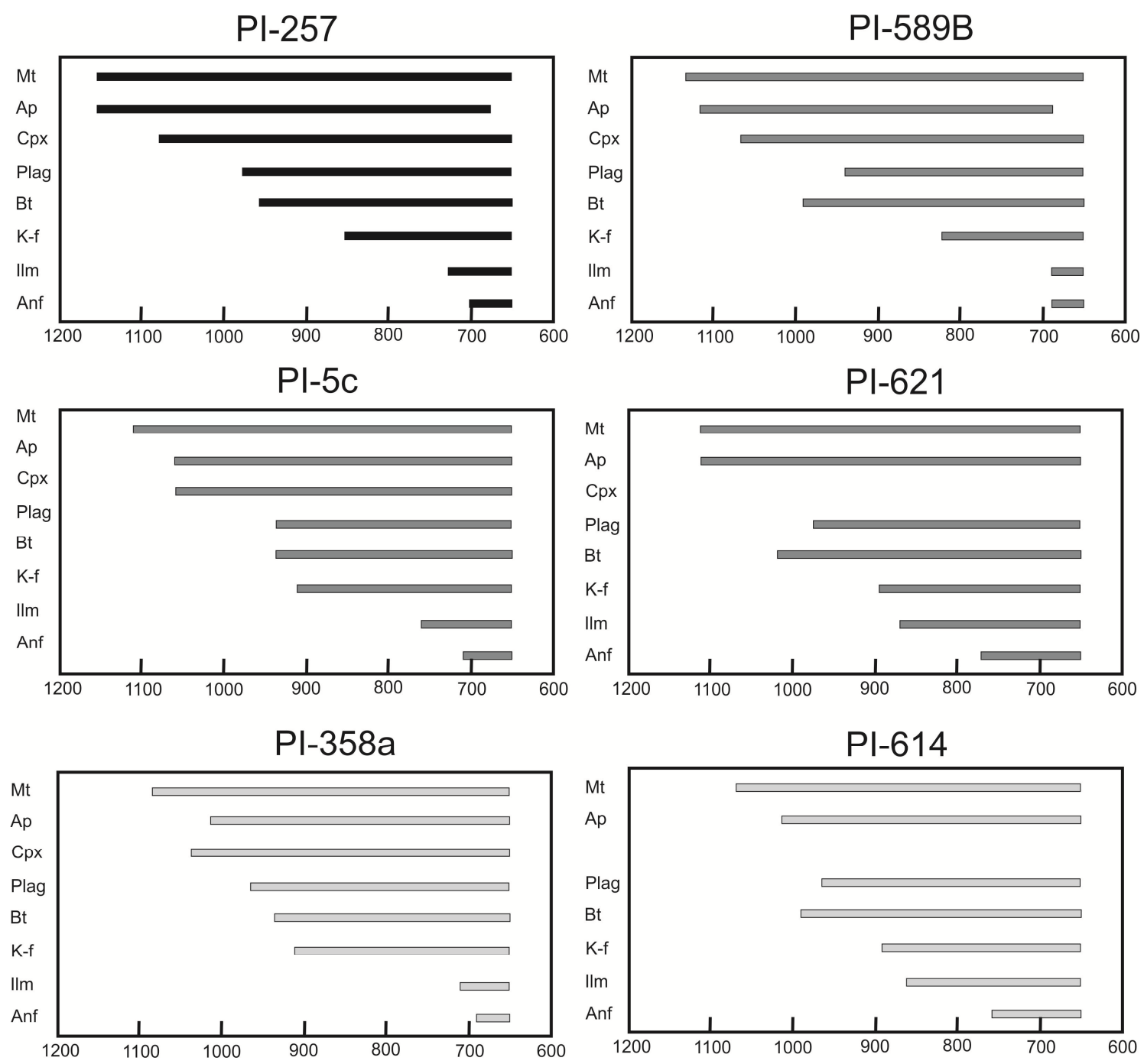

Figura 35. Modelamentos de sequência de cristalização para monzodioritos $(M d r$ e $M d f)$ do Plúton Piracaia utilizando o software MELTS. A amostra PI-257 refere-se a um monzodiorito grosso (Mdr); as amostras PI589B, PI-5c e PI-621 são monzodioritos finos (Mdf); e as amostras PI-358a e PI-614 são monzonitos (Mdf).

Os modelamentos dos quartzo monzonitos destacam-se por em geral mostrarem a cristalização praticamente simultânea de plagioclásio e feldspato alcalino (Figura 36), que ocorre próximo a $900^{\circ} \mathrm{C}$. Subsequentemente cristaliza-se a ilmenita. Outra característica importante é a cristalização precoce de magnetita e biotita. Anfibólio aparece em três amostras, assim como o quartzo, este últimos nos estágios finais da cristalização. Destaca-se que a cristalização de biotita e feldspato alcalino tendem a ocorrer à temperaturas semelhantes.

Uma das amostras de quartzo sienito (PI-427) apresenta comportamento idêntico aos quartzo monzonitos, embora os feldspatos iniciem a cristalização a uma temperatura cerca de $50^{\circ} \mathrm{C}$ mais baixa, ou seja, $850^{\circ}$ C. Já a outra (PI-410), que é mais félsica, apresenta feldspato alcalino como fase liquidus. Biotita e plagioclásio só iniciam sua cristalização após aproximadamente $125^{\circ} \mathrm{C}$ (Figura 36), e a cristalização de feldspato alcalino inicia-se anteriormente à biotita. 
Os modelamentos para as duas amostras de $M h$ também diferem entre si (Figura 37), principalmente com relação à cristalização do anfibólio, que é precoce em PI-437A e tardia em PI400a. A magnetita é fase liquidus, assim como plagioclásio e feldspato alcalino cristalizam em temperaturas semelhantes (aproximadamente $900^{\circ} \mathrm{C}$ ), em ambas as amostras. Já a biotita inicia a cristalização cerca de $50^{\circ} \mathrm{C}$ antes do feldspato alcalino.
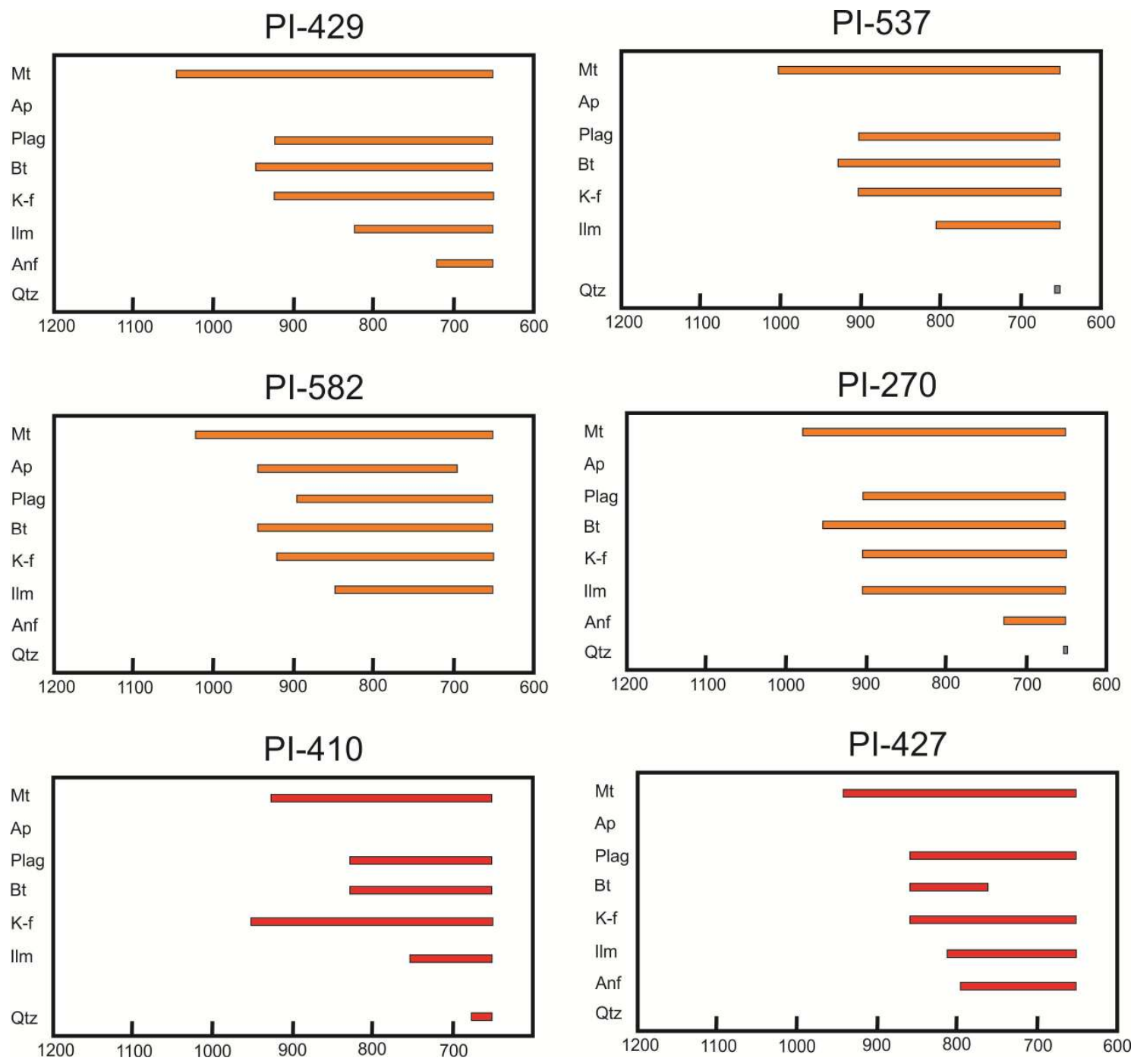

Figura 36. Modelamentos de sequência de cristalização para a unidade Qsie do Plúton Piracaia, utilizando o software MELTS. As amostras PI-429, PI-537, PI-582 e PI-270 correspondem a quartzo monzonitos e as amostras PI-410 e PI-427 correspondem a quartzo sienitos.

Já os Sie mostram ilmenita como fase liquidus na amostra PI-26b. Subsequentemente cristalizam biotita, feldspato alcalino, plagioclásio e anfibólio. Na amostra PI-602 magnetita é precoce e ilmenita inicia a cristalização apenas em torno de temperaturas $200^{\circ} \mathrm{C}$ mais baixas. Em ambas a cristalização de plagioclásio e feldspato alcalino ocorre a temperaturas semelhantes, em geral um pouco acima $900^{\circ} \mathrm{C}$, e coincide com a temperatura observada em $M h$ para estes minerais. Já a biotita cristaliza também a $900^{\circ} \mathrm{C}$ na amostra PI-602 e a uma temperatura aproximadamente $30^{\circ} \mathrm{C}$ mais elevada na amostra PI-26b. 

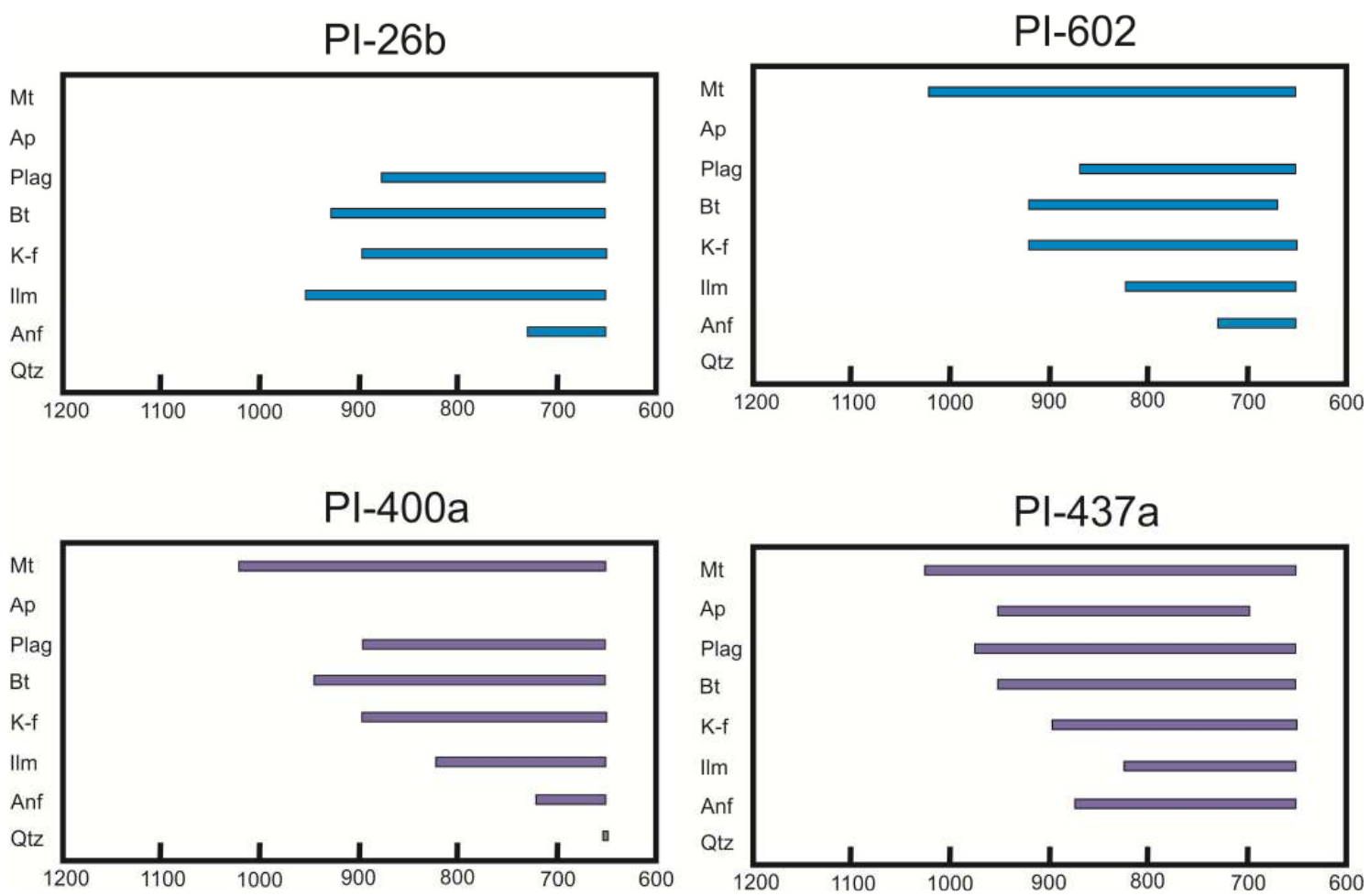

Figura 37. Modelamentos de sequência de cristalização utilizando o software MELTS para as unidades de Sienitos (Sie) (amostras PI-26b e PI-602) e Monzonitos heterogêneos (Mh) (PI-400a e PI437a) do Plúton Piracaia.

\subsection{Isótopos de $\mathrm{Sr}-\mathrm{Nd}$}

Dados isotópicos para os sistemas $\mathrm{Rb}-\mathrm{Sr}$ e $\mathrm{Sm}-\mathrm{Nd}$ apresentados em Janasi et al. (2009),

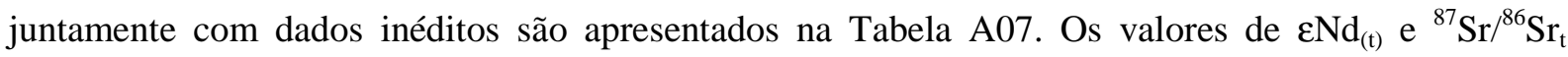
apresentados foram recalculados para $580 \mathrm{Ma}$, idade obtida a partir do método U-Pb em zircão (Janasi et al., 2009).

Os resultados para o sistema $\mathrm{Rb}-\mathrm{Sr}$ apontam uma similaridade entre as unidades, onde razões ${ }^{87} \mathrm{Sr}^{86} \mathrm{Sr}_{\mathrm{t}}$ situam-se entre 0,705 e 0,706 (Figura 38). Entre o conjunto, salientam-se apenas os $M h$, por apresentarem razões levemente maiores em relação às demais.

Por outro lado, os resultados para o sistema Sm-Nd mostram diferenças importantes-entre as unidades, especialmente quando se comparam $M d f$ com $M h$ e Sie.

As duas amostras de $M d f$ analisadas apresentam $\varepsilon \mathrm{Nd}_{(\mathrm{t})}$ de $-8,5$. Já a amostra de Sie representa o valor mais negativo do conjunto analisado, com $\varepsilon \mathrm{Nd}_{(\mathrm{t})}=-10.5$, enquanto nos $M h$ o $\varepsilon \mathrm{Nd}_{(\mathrm{t})}$ é intermediário entre os dois extremos, variando entre -8.7 e -9.6.

Os quartzo monzonitos e a amostra de quartzo sienito (Qsie) são as rochas menos negativas do conjunto: os valores de $\varepsilon \mathrm{Nd}_{(\mathrm{t})}$ calculados são de -6.0 a -7.3 para os quartzo monzonitos, enquanto o quartzo sienito tem $\varepsilon \mathrm{Nd}_{(\mathrm{t})}=-7.1$. 
A similaridade nas razões de $\mathrm{Sr}$ e $\varepsilon \mathrm{Nd}_{(\mathrm{t})}$ das rochas da unidade $Q$ sie com $M d f$ não permite excluir um vínculo entre estas unidades. Já as diferenças dos $M d f$ com a amostra de Sie é significativa e pode apontar para uma fonte mais antiga para estes últimos.

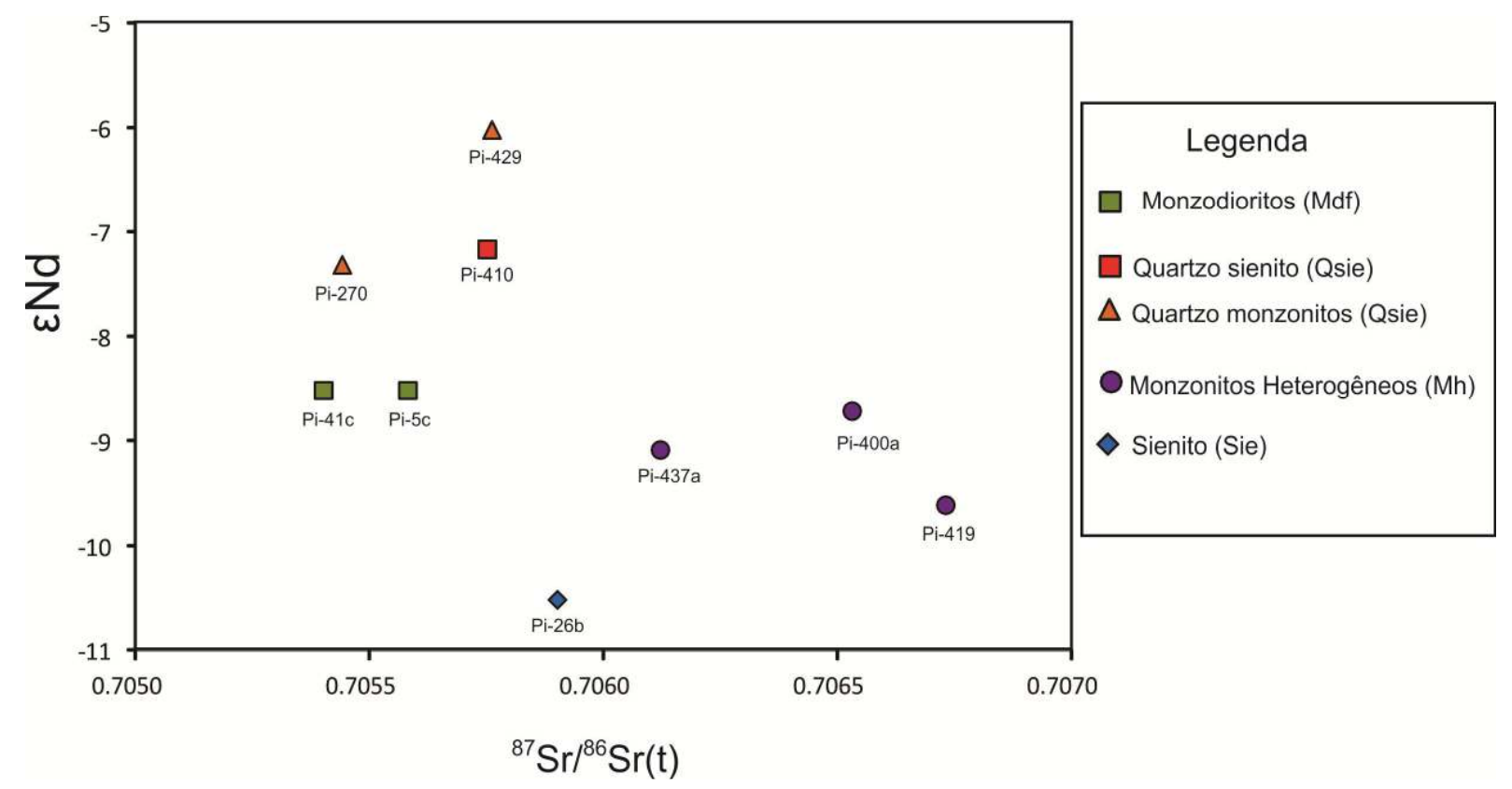

Figura 38. Diagrama ${ }^{87} \mathrm{Sr} /{ }^{86} \mathrm{Sr}$ versus $\varepsilon \mathrm{Nd}_{(\mathrm{t})}$ para as rochas das diferentes unidades que compõem o Plúton Piracaia.

\subsection{Aspectos genéticos e ambiente tectônico}

O elevado conteúdo de elementos LILE (K, Sr e Ba) presente nos monzodioritos, juntamente com suas baixas razões ${ }^{87} \mathrm{Sr}^{86}{ }^{86} \mathrm{Sr}_{(\mathrm{t})}(\sim 0.705)$ e $\varepsilon \mathrm{Nd}_{(\mathrm{t})}$ fortemente negativo (-8.5) sugerem para uma fonte mantélica metassomatizada, cujo enriquecimento é atribuído a eventos prévios de subducção (Janasi et al., 1993; Janasi et al., 2009). A percolação de fluidos relacionados à desidratação da placa subductante percola o manto adjacente, formando horizontes de clinopiroxenito, com variável abundância de fases hidratadas, como flogopita e pargasita. Segundo Janasi et al. (1993) o mecanismo de geração destes magmas poderia ser explicada pelo modelo de vein-plus-wall rock melting (Foley, 1992), onde ocorre fusão destes horizontes piroxeníticos e das paredes formadas pelo manto harzbugítico que os hospeda.

As rochas félsicas (Sienitos e quartzo sienitos) apresentam elevadas concentrações de HFSE e baixos conteúdos de $\mathrm{Sr}$, que sugerem uma similaridade com granitos do tipo A. Esta similaridade verifica-se também quando utilizados os diagramas propostos por Whalen et al. (1987), embora as concentrações dos elementos $\mathrm{Y}, \mathrm{Zn}$ e em algumas amostras também o $\mathrm{Zr}$ sejam distintas em relação aos granitos do tipo A típicos (Figura 39). 

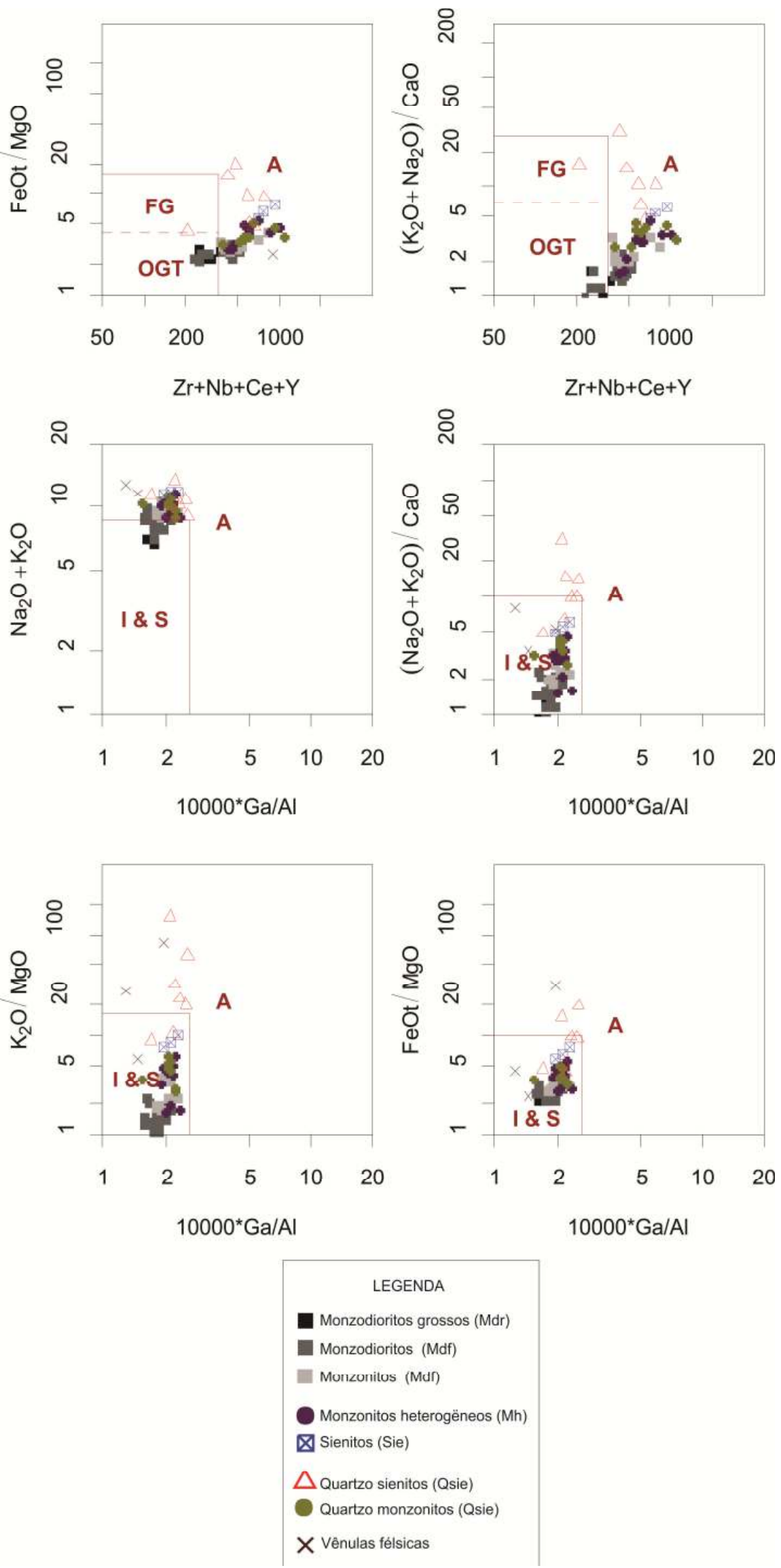

Figura 39. Diagramas de identificação de ambiente tectônico com as rochas que compõem o Plúton Piracaia, segundo Whalen et al., (1987). 
Frost et al. (2001) e Dall'Agnoll \& Oliveira (2007) reconhecem que elementos maiores podem ser utilizados na identificação de granitos do tipo A. Quando inseridas nos diagramas desenvolvidos por Dall'Agnoll \& Oliveira (2007), que visam distinguir granitos de afinidade cálcioalcalinas de granitos do tipo A, observa-se que as rochas félsicas de Piracaia situam-se essencialmente fora do campo dos granitos de tipo A por apresentarem concentrações mais elevadas de $\mathrm{Al}_{2} \mathrm{O}_{3}$ (Figura $40 \mathrm{~A}, \mathrm{~B}$ e C). Apenas no diagrama que considera o conteúdo de álcalis $\left(\mathrm{K}_{2} \mathrm{O}\right.$ e $\left.\mathrm{N}_{2} \mathrm{O}\right)$ observa-se que os quartzo sienitos (Qsie) situam-se no campo dos granitos tipo A oxidado (Figura 40D).

Com relação aos diagramas classificatórios desenvolvidos por Frost et al. (2001), os autores identificam que granitos do tipo A são predominantemente ferroan alkalic e ferroan alkali-calcic. Por estes critérios as rochas félsicas podem ser classificadas como de tipo A.
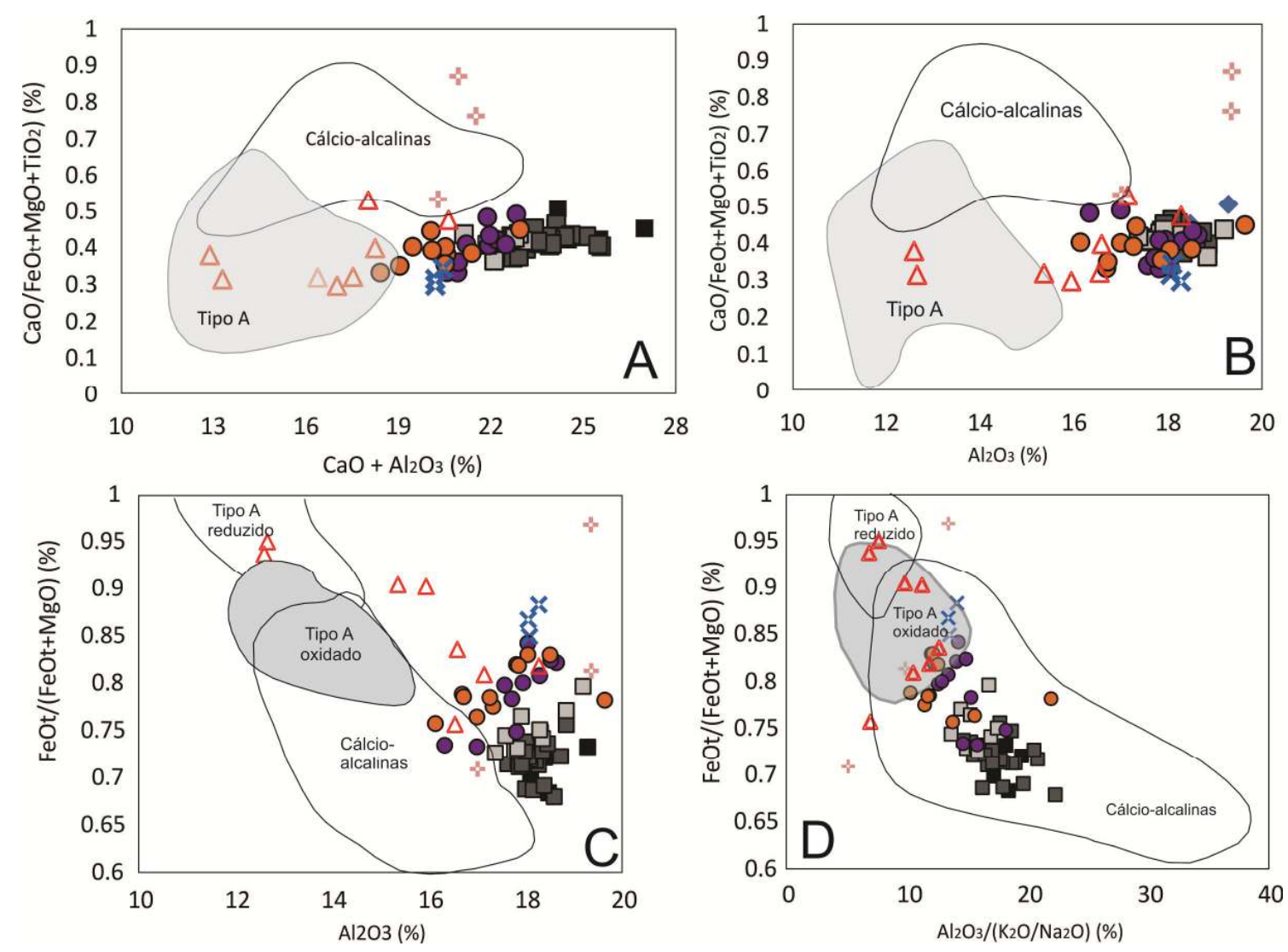

Figura 40. Rochas do Plúton Piracia plotadas em diagramas discriminantes para rochas com afinidade cálcioalcalina e granitos do tipo-A (Dall'Agnoll \& Oliveira, 2007). 
A semelhança de rochas pertencentes à Provincia Granítica Itu com granitos do tipo A foi identificada por Wernick (2000) e Janasi et al. (2009), onde salienta-se o caráter oxidado apresentado por alguns plútons. Segundo Janasi et al. (2009), os magmas mais primitivos encontrados em Piracaia podem ser os responsáveis por estas características, uma vez que os monzodioritos apresentam conteúdos de elementos HFSE ( $\mathrm{Nb}$ e Ta) e representam magmas fortemente oxidados. Os possíveis processos sugeridos seriam: (i) que a base da crosta foi enriquecida por fluidos relacionados aos magmas monzodioríticos, sendo posteriormente fundida; (ii) que os magmas graníticos poderiam ser gerados pela refusão destes magmas monzodioríticos, alojados na base da crosta pelo mecanismo de underplating; (iii) ou que os magmas crustais félsicos teriam se misturado com os magmas monzodioríticos em porções profundas da crosta, ou durante sua ascensão até níveis crustais mais rasos. 


\section{CAPÍTULO III - ESTIMATIVAS DE PARÂMETROS FÍSICO-QUÍMICOS DE CRISTALIZAÇÃO DOS MAGMAS}

Os magmas podem ser caracterizados através de suas variáveis intensivas, que são parâmetros considerados invariantes em qualquer ponto do sistema em questão. Dentre as mais importantes merecem destaque a densidade, viscosidade, temperaturas liquidus e solidus, juntamente com as condições de pressão vigentes durante sua cristalização. De igual importância são os conteúdos de algumas espécies químicas, tais como $\mathrm{O}_{2}, \mathrm{H}_{2} \mathrm{O}, \mathrm{S}, \mathrm{Si}$, uma vez que podem interferir em outras varáveis como, por exemplo, a temperatura solidus e viscosidade, assim como fornecer evidências importantes relacionadas à fonte dos magmas.

Considerando que câmaras magmáticas podem ser sistemas geológicos abertos, são muitos os fatores que podem alterar as variáveis intensivas. O magmatismo relacionado a zonas de cisalhamento em um contexto tardi a pós-orogênico, em especial, está sujeito à injeção de magmas de composição distinta cuja interação inevitavelmente implicará em modificações das propriedades físicas dos mesmos. Merece destaque também o aporte externo de fluidos e assimilação das rochas encaixantes.

No presente trabalho buscou-se: estimar as temperaturas liquidus das diferentes rochas que compõem o Plúton Piracaia, através de cálculos de saturação de zircão e apatita; obter estimativas de atividade de $\mathrm{H}_{2} \mathrm{O}\left(a \mathrm{H}_{2} \mathrm{O}\right)$; e complementar as estimativas de $\mathrm{P}-\mathrm{T}$ de cristalização e fugacidade de $\mathrm{O}_{2}$ $\left(f \mathrm{O}_{2}\right)$ previamente realizadas por Salmoni (2007).

\subsection{Geotermobarometria}

Uma revisão sobre os métodos desenvolvidos visando à obtenção de estimativas de pressão e temperatura de cristalização dos magmas é apresentada por Anderson (1996) e Anderson et al. (2008). Em intrusões de caráter metaluminoso, como é o caso de Piracaia, os métodos que envolvem o par hornblenda-plagioclásio são os mais amplamente utilizados.

Com relação aos termômetros, as calibrações mais recentes são as propostas por Blundy \& Holland (1990) e Holland \& Blundy (1994).

A calibração de Blundy \& Holland (1990) é desenvolvida a partir dos equilíbrios:

$$
\begin{aligned}
& \text { edenita }+4 \text { quartzo }=\text { tremolita }+ \text { albita } \\
& \text { pargasita }+4 \text { quartzo }=\text { hornblenda }+ \text { albita }
\end{aligned}
$$


Os autores recomendam que seu uso seja restrito a magmas com temperaturas entre 500 e $1100^{\circ} \mathrm{C} \mathrm{e}$ que os conteúdos de Si da hornblenda seja menor que 7,8 átomos por fórmula unitária e o plagioclásio seja menos cálcico que $\mathrm{An}_{92}$.

Os cálculos relacionados à equação I foram revistos por Holland \& Blundy (1994), que propuseram uma nova calibração considerando também o equilíbrio:

$$
\text { edenita }+ \text { albita }=\text { richterita }+ \text { anortita } \quad \text { (III) }
$$

Embora ambas sejam sensíveis ao conteúdo de $\mathrm{Fe}^{3+}$ da hornblenda, para o uso da calibração Holland \& Blundy (1994) recomenda-se que seja utilizado o método de recálculo proposto pelos autores, que considera uma média entre estimativas máximas e mínimas, semelhante ao desenvolvido por Leake (1997). Tendo isto em vista, Martins (2001) sugere o uso do método de Blundy \& Holland (1990), por ser menos susceptível a variações relacionadas à normalização de balanço de carga.

Contudo, Anderson et al (1996) e Bachman \& Dungan (2002) observam que as diferenças na estimativa do $\mathrm{Fe}^{3+}$ não afetam significativamente os resultados e que, à exceção de intrusões rasas, as temperaturas fornecidas pelo método de Holland \& Blundy (1994) são as que mais se aproximam às obtidas por outros termômetros.

O principal barômetro hoje utilizado para rochas graníticas cálcio-alcalinas típicas é o Al-emhornblenda. Inicialmente desenvolvido por Hammarstrom \& Zen (1986) e Hollister et al. (1987), ancora-se no princípio de que o conteúdo de $\mathrm{Al}$ da hornblenda aumenta com o aumento da pressão confinante. O método foi aprimorado por Anderson \& Smith (1995) que, ao basear-se nos trabalhos experimentais Johnson \& Rutherford (1989) e Schmidt (1992), incorporam o efeito da temperatura sobre o conteúdo de $\mathrm{Al}$ da hornblenda, e propõem a relação:

$$
P( \pm 0,6 \mathrm{kbar})=4,76 \mathrm{Al}-3,01-\left\{\left[T\left({ }^{\circ} \mathrm{C}\right)-675\right] / 85\right\} \times\left\{0,530 \mathrm{Al}+0,005294\left[T\left({ }^{\circ} \mathrm{C}\right)-675\right]\right\}
$$

onde $\mathrm{Al}=\mathrm{Al}^{\mathrm{IV}}+\mathrm{Al}^{\mathrm{VI}}$. Contudo, Anderson \& Smith (1995) observam que o método não é aplicável a magmas com baixa $f \mathrm{O}_{2}$, uma vez que sob essas condições a razão $\mathrm{Mg} / \mathrm{Fe}$ da hornblenda é diminuída, consequentemente aumentando a quantidade de $\mathrm{Al}$ da hornblenda de modo independente da pressão, fornecendo resultados superestimados. Desta forma, propõem que seu uso se restrinja a anfibólios com razões $\mathrm{Fe} /(\mathrm{Fe} / \mathrm{Mg})$ inferiores a 0,65 . Os autores sugerem ainda que os plagioclásios das rochas analisadas devem idealmente apresentar teores de $\mathrm{An}_{25-35}$, uma vez que a troca tschermakítica também pode favorecer o aumento de $\mathrm{Al}$ da hornblenda.

No presente trabalho, para efeito de comparação, as estimativas de temperatura solidus foram realizadas utilizando-se dos métodos de Blundy \& Holland (1990) e Holland \& Blundy (1994). Já as 
estimativas de pressão de cristalização foram calculadas pelo método de Anderson \& Smith (1995) utilizando-se as temperaturas fornecidas pelos dois métodos acima citados.

No Plúton Piracaia a hornblenda é uma fase abundante na unidade $M h$ e em grande parte dos monzodioritos da unidade Mdf. Salmoni (2007), ao investigar as condições P-T das unidades mais félsicas pelos métodos acima citados, já observou a dificuldade para a obtenção de estimativas na unidade Qsie, uma vez que se observa anfibólio de modo restrito em quartzo monzonitos e raramente em quartzo sienitos. Contudo, considerando as abundantes feições de interação que evidenciam a contemporaneidade entre $Q s i e, M d f$ e $M h$, assume-se que as estimativas de pressão possam ser extrapoladas para o plúton como um todo. Os resultados são apresentados na Tabela A08 e Figura 31. Foram desconsideradas as estimativas de temperatura abaixo de $650^{\circ} \mathrm{C}$.

Observa-se uma coerência entre os métodos de Blundy \& Holland (1990) e Holland \& Blundy (1994) nas estimativas de temperatura, onde os resultados apresentam uma diferença geralmente inferior a $40^{\circ} \mathrm{C}$. Da mesma forma, não se observaram variações significativas quando analisados os núcleos e bordas de cristais. Assume-se então que os cristais de hornblenda não sofreram processos de reequilíbrio tardi a pós-magmático.

Para a unidade $M d f$, foram feitas estimativas em três amostras, sendo dois monzodioritos e um monzonito. Segundo o método de Holland and Blundy (1994), as temperaturas de cristalização situamse em torno de $750^{\circ} \mathrm{C}$. As estimativas mais baixas, entre 670 e $720^{\circ} \mathrm{C}$, foram obtidas para a amostra PI-500-71.

As estimativas de pressão para a unidade $M d f$ apresentam significativa dispersão, com valores máximos e mínimos de 6,1 e 2,6 kbar, respectivamente. Contudo, a grande maioria dos resultados situa-se entre 3,5 e 4,0 kbar.

Na unidade $M h$ reaplicou-se o barômetro às análises realizadas por Salmoni (2007), considerando que as estimativas então apresentadas foram obtidas através do método de Blundy \& Holland (1990). Os cálculos foram realizados a partir de pares Hbl-Plag com dois tipos principais de associação textural: entre cristais de hornblenda e plagioclásio de pequena dimensão, pertencentes à matriz; e a grandes cristais de hornblenda associados a cristais de plagioclásio também de grande de dimensão e zonados (interpretados como antecristais).

Observa-se uma pequena diferença entre os dois conjuntos. No grupo dos grandes cristais de anfibólio e antecristais de plagioclásio, as temperaturas variam entre 664 e $798^{\circ} \mathrm{C}$ e as pressões entre 2,4 e 4,9 kbar. Contudo, predominam temperaturas no intervalo $680-700^{\circ} \mathrm{C}$ e pressões em torno de 4,5 kbar. Já considerando os pares pertencentes à matriz, as temperaturas variam entre 637 e $720^{\circ} \mathrm{C}$ e as pressões entre 3,7 e 5,8 kbar. Em geral as temperaturas deste grupo são levemente mais baixas e se situam em torno de $670^{\circ} \mathrm{C}$. Já a pressão é levemente mais alta e situa-se predominantemente no intervalo 5,0-5,5 kbar. As estimativas para cristais pertencentes a dois ocelos da amostra PI-400D forneceram temperaturas de 683 e $690^{\circ}$ e 4,3 e 4,9 kbar, respectivamente. 
Estes resultados são entre 50 e $70^{\circ} \mathrm{C}$ mais baixos e aproximadamente $1 \mathrm{kbar}$ mais elevados em relação aos obtidos por Salmoni (2007) e devem-se às diferenças de cálculo entre os métodos de Blundy \& Holland (1990) e Holland \& Blundy (1994), como pode ser observado na Tabela A08.

As estimativas também foram realizadas para quatro conjuntos de cristais da amostra PI-26b, pertencentes à unidade Sie. Contudo, os resultados de temperatura são um pouco baixos, entre 579 e $704^{\circ} \mathrm{C}$. Assume-se que tais resultados são imprecisos, considerando que estão abaixo das temperaturas de cristalização de magmas sieníticos. Embora a composição dos anfibólios esteja dentro dos critérios estabelecidos pelos autores, o erro pode estar relacionado ao baixo teor de An dos plagioclásios destas rochas. As estimativas de pressão, entre 3,8 e 5,0 kbar, embora coincidam com as das demais unidades, devem ser consideradas com restrição, uma vez que a razão $\mathrm{Fe} /(\mathrm{Fe}+\mathrm{Mg})$ dos anfibólios é superior ao estabelecido por Anderson \& Smith (1995).

Análises de Salmoni (2007), referentes a duas amostras da unidade Qsie, um quartzo monzonito (PI-429) e um quartzo sienito (PI-427), também foram recalculadas. Os resultados são temperaturas de 659 e $669^{\circ} \mathrm{C}$ e pressões de 4,0 e 4,10 kbar para a amostra de quartzo sienito; e de 719 a $785^{\circ} \mathrm{C}$ e 4,8 a 6,1 kbar para o quartzo monzonito.

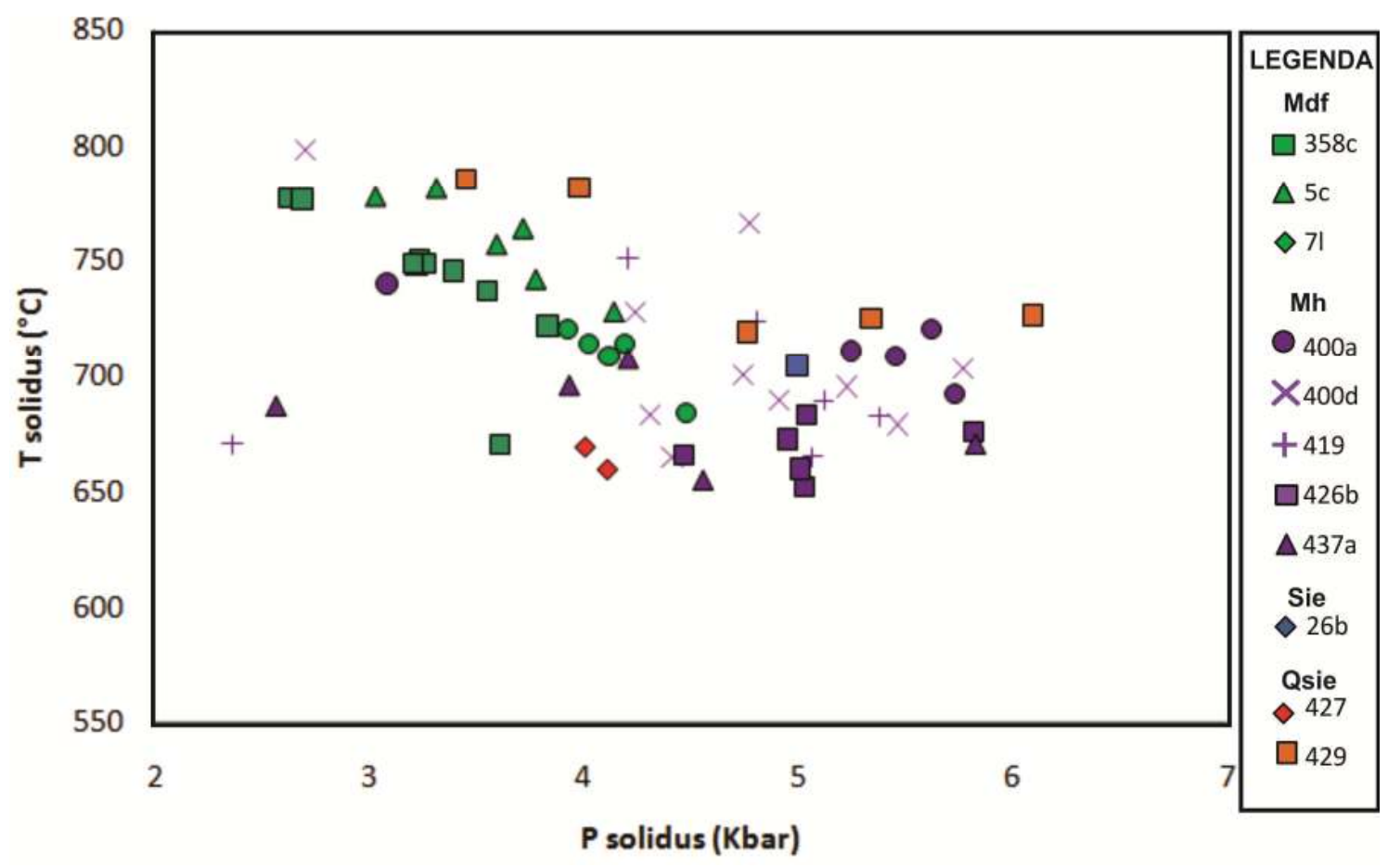

Figura 41. Estimativas de temperatura e pressão de cristalização para as rochas do Plúton Piracaia.

Os critérios estabelecidos por Anderson \& Smith (1995) impõem importantes restrições nas estimativas de pressão de todas as unidades. A primeira delas refere-se aos plagioclásios. Os plagioclásios analisados em sua maioria apresentam teores de $A n<25$ e, portanto estão abaixo do 
limite ideal para a aplicabilidade do barômetro. Cristais com composição adequada são encontrados apenas em monzodioritos ( $M d f$ e $M d r$ ) e nos antecristais de $M h$.

A segunda restrição refere-se ao estado de oxidação, uma vez que estimativas de pressão tendem a ser superestimadas caso a fugacidade dos magmas seja baixa. Anderson \& Smith (1995) sugerem que o método deva ser aplicado a rochas cujos anfibólios apresentem \#Fe $<65$. Situam-se acima deste limite a amostra PI-26b, da unidade de Sie e também o quartzo monzonito PI-429 da unidade Qsie. O quartzo sienito PI-427, também de Qsie, e algumas amostras de Mh estão próximos a esse limite e se situam acima ou abaixo a depender do método utilizado para cálculo do conteúdo de $\mathrm{Fe}^{2+}$

Mesmo tendo em vista as restrições acima, considera-se que os resultados são confiáveis. As pressões obtidas para a unidade $M d f$ a partir de cristais com $A n<25$ não diferem significativamente das obtidas a partir de cristais com composição adequada. Da mesma forma, as estimativas para amostras com \#Fe $>65$ situam-se dentro da margem de erro do método.

Levando em consideração que as estimativas são obtidas através de iterações que compensam pressão e temperatura, de modo que quanto maior a pressão, menor a temperatura, e vice-versa, considera-se como mais adequados os resultados intermediários. Admite-se, portanto, que a colocação dos magmas que compõem o Plúton Piracaia se deu a pressões entre 3,5 e 4,0 kbar, o que equivale a uma profundidade de 13 a $15 \mathrm{~km}$, aproximadamente.

\subsection{Termômetros de saturação de fases acessórias}

Os termômetros de saturação de fases acessórias representam uma importante ferramenta para a caracterização e compreensão de sistemas ígneos, principalmente pelo potencial de fornecer estimativas de temperaturas próximas às condições liquidus dos magmas. Contudo, devem ser utilizados em associação a uma análise petrográfica criteriosa, considerando que é preciso garantir que os minerais em questão não sejam xenocristais, antecristais ou de origem cumulática e que tenham cristalizado nos estágios iniciais do sistema magmático.

Cientes de que a maioria das rochas graníticas apresenta zircão e apatita como minerais acessórios, Watson \& Harrison (1983) e Harrison \& Watson (1984) desenvolveram modelos de solubilidade visando estimar as temperaturas de saturação destes minerais. 


\subsubsection{Saturação em apatita}

Harrison \& Watson (1984), ao apresentarem resultados experimentais e baseando-se em trabalhos prévios, concluem que os principais fatores que afetam a saturação de apatita são a temperatura e conteúdo de $\mathrm{SiO}_{2}$ do magma. Variações de outros componentes, como por exemplo, $\mathrm{Ca}$, $\mathrm{F}$ e $f \mathrm{O}_{2}$ parecem ser insignificantes, levando os autores a supor que a estabilidade da apatita depende principalmente da atividade de $\mathrm{P}_{2} \mathrm{O}_{5}$. Nem mesmo o conteúdo $\mathrm{H}_{2} \mathrm{O}$ exerce forte influência nas concentrações de $\mathrm{P}_{2} \mathrm{O}_{5}$ necessárias para que a saturação seja atingida. Isto talvez possa ser explicado, segundo os autores, pelo fato de a apatita não ser um mineral silicático.

O método desenvolvido por Harrison \& Watson (1984) utiliza-se de todos os dados experimentais até então disponíveis. Aplica-se a magmas com temperaturas de $800^{\circ}$ a $1500^{\circ} \mathrm{C}$, conteúdo de $\mathrm{H}_{2} \mathrm{O}$ de 0 a $10 \%$, e restringe-se a um intervalo de $\mathrm{SiO}_{2}$ entre 45 e $75 \%$. A relação entre temperatura, teor de $\mathrm{SiO}_{2}$ e saturação em apatita é descrita pela equação:

$$
\ln D_{\text {ap }}=\left[\left(8400+\left(\left(\mathrm{SiO}_{2}-0,5\right) 2,64 \times 10^{4}\right)\right) / T\right]-\left[3,1+\left(12,4\left(\mathrm{SiO}_{2}-0,5\right)\right)\right]
$$

Embora a solubilidade de apatita seja maior em magmas básicos comuns, nos quais a sua cristalização pode só ocorrer quando pelo menos $1 / 3$ do sistema tenha cristalizado (Piccoli \& Candella, 2002), as elevadas concentrações de $\mathrm{P}_{2} \mathrm{O}_{5}$ das rochas de Piracaia, especialmente as monzodioríticas, juntamente com a análise petrográfica, permitem afirmar que as temperaturas obtidas para todas as unidades estão próximas às condições liquidus (Figura 42).

As estimativas da temperatura de saturação em apatita para os monzodioritos são, como esperado, mais elevadas em relação às demais rochas do plúton e situam-se no intervalo de 927 a $1055^{\circ} \mathrm{C}$. Não se observam diferenças entre os tipos texturais fino e grosso; as rochas de composição monzonítica também apresentam temperaturas dentro deste intervalo.

Embora se disponha de apenas três análises de rochas da unidade Sie, as estimativas obtidas, entre 875 e $917^{\circ} \mathrm{C}$, são coerentemente inferiores às das rochas monzodioríticas.

Os $M h$ apresentam temperaturas entre 921 e $1013^{\circ} \mathrm{C}$. Contudo, a maioria das amostras apresenta temperaturas em torno de $950^{\circ} \mathrm{C}$ e apenas duas situam-se na faixa dos $1000^{\circ} \mathrm{C}$. O intervalo de temperaturas predominante, em torno de $950^{\circ} \mathrm{C}$, é intermediário entre as temperaturas dos monzodioritos e das rochas da unidade Sie.

Com relação à unidade $Q$ sie, as rochas quartzo sieníticas apresentam temperaturas entre $800 \mathrm{e}$ $939^{\circ} \mathrm{C}$. Já os quartzo monzonitos têm temperaturas mais elevadas, entre 883 e $1035^{\circ} \mathrm{C}$. Merece destaque o fato de que as maiores temperaturas nem sempre foram obtidas nas amostras com maior concentração de $\mathrm{P}_{2} \mathrm{O}_{5}$, como pode ser observado na Figura 42 . 

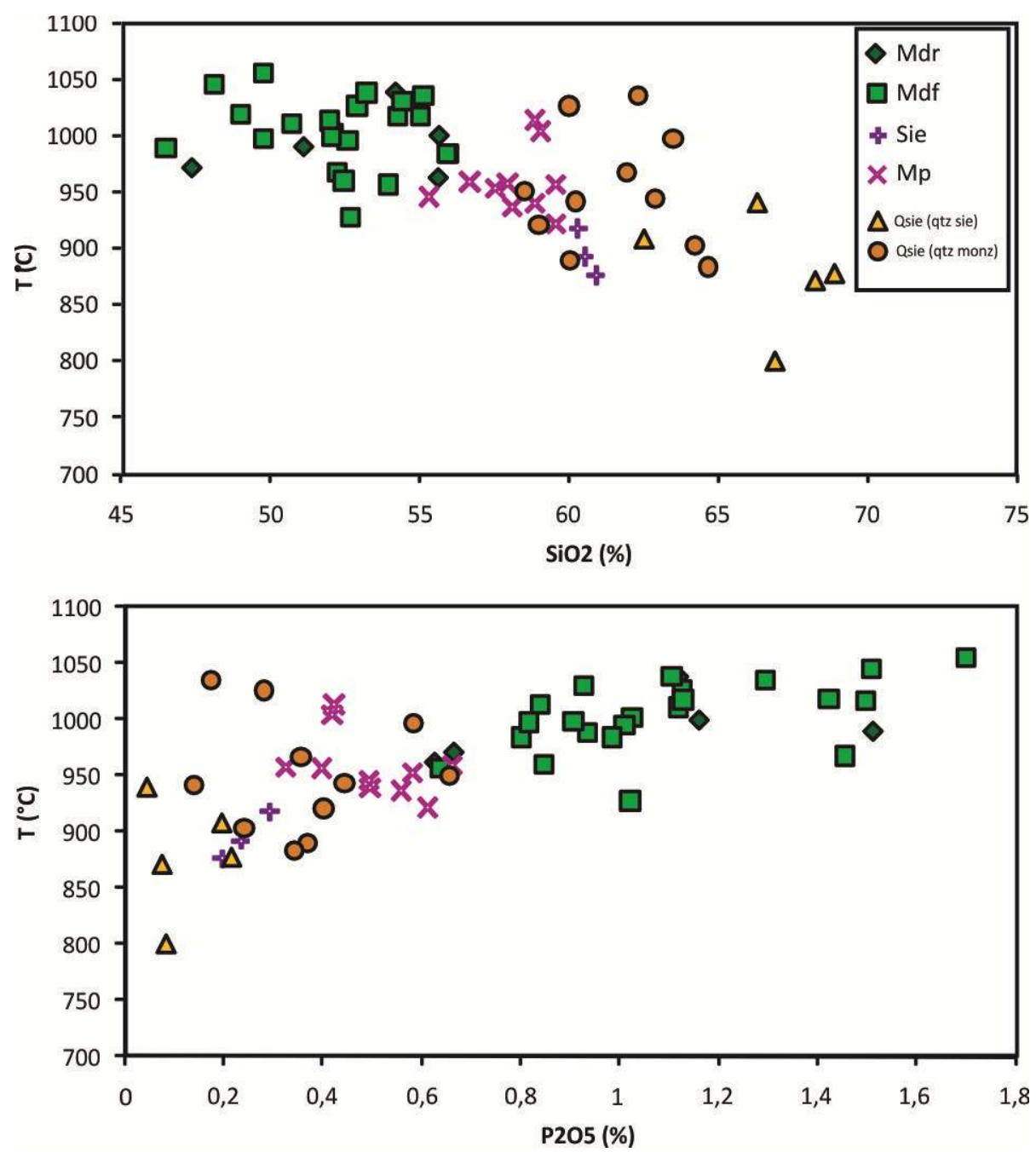

Figura 42. Temperaturas de saturação em apatita para as diferentes unidades que compõem o Plúton Piracaia .

\subsubsection{Saturação em zircão}

O termômetro de Watson \& Harrison (1983) foi desenvolvido a partir da constatação feita por trabalhos anteriores de que a solubilidade do zircão está diretamente relacionada à composição dos magmas, e que a uma mesma temperatura este mineral está mais propenso à dissolução em magmas básicos do que em magmas ácidos. A relação entre o aumento da solubilidade com a composição do magma pode ser expressa pela razão $M=(\mathrm{Na}+\mathrm{K}+2 \mathrm{Ca}) /(\mathrm{Al} \cdot \mathrm{Si})$. Quanto maior a razão $M$, maior a solubilidade do zircão. O modelo, definido pela equação:

$$
\ln D_{\mathrm{Zr}}=\{-3,80-[0,85(M-1)]\}+12900 / T
$$

foi desenvolvido a partir de dados referentes à magmas graníticos tipicamente derivados de fusão crustal e sua aplicação é recomendada para rochas cujo $M$ situa-se no intervalo $0,9-1,7$. Os autores salientam ainda que condições de pressão e conteúdo de $\mathrm{H}_{2} \mathrm{O}$ não devem influenciar na solubilidade do 
zircão e consequentemente nas estimativas de temperatura de saturação, a não ser que o conteúdo de $\mathrm{H}_{2} \mathrm{O}$ seja inferior a $1,5-2 \%$.

No Plúton Piracaia apenas as rochas da unidade Qsie apresentam $M$ dentro do intervalo adequado; mesmo nesta unidade, os valores de $M$ se situam próximo ao limite superior, e em muitas amostras inclusive estão levemente acima (Figura 43). As temperaturas resultantes são de 804 a $900^{\circ} \mathrm{C}$, não existindo diferença entre quartzo monzonitos e quartzo sienitos. Estes resultados coincidem com as temperaturas de saturação em apatita para os quartzo sienitos (800-939 $\left.{ }^{\circ} \mathrm{C}\right)$. Em Sie a razão $M$ é de aproximadamente 2 e as temperaturas de saturação em zircão $\left(841-885^{\circ} \mathrm{C}\right)$ estão relativamente próximas às obtidas para apatita $\left(875-917^{\circ} \mathrm{C}\right)$.
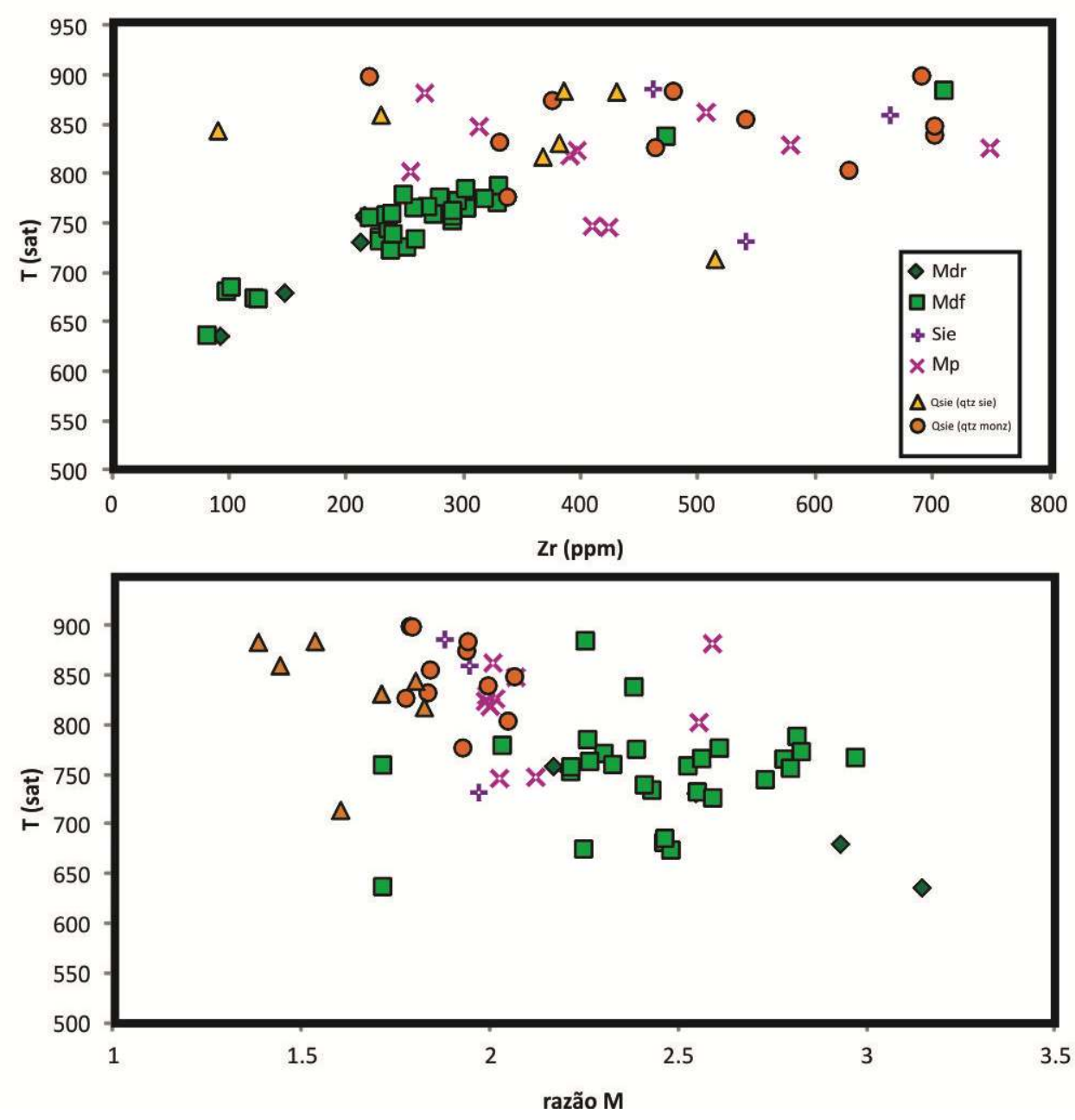

Figura 43. Temperaturas de saturação em zircão para as diferentes unidades que compõem o Plúton Piracaia. 
As unidades $M d r, M d f$ e $M h$ apresentam razões $M$ entre 2,16 e 3,14. Caso a aplicabilidade do método possa ser estendida a rochas básicas a intermediárias, estas razões evidenciam que os magmas não se apresentavam saturados em zircão a temperaturas próximas à liquidus. Elevadas razões $M$ evidenciariam ainda a potencialidade do magma de dissolver cristais de zircão herdados (Watson \& Harrison, 1983), que podem ocorrer quando os teores de $\mathrm{Zr}$ do magma são baixos e se houver contribuição de fontes crustais ao magmatismo, ou assimilação das rochas encaixantes.

Para a unidade $M h$, as estimativas de temperatura de saturação em zircão são de 818 a $881^{\circ} \mathrm{C}$. Já para as unidades $M d r$ e $M d f$, variam entre 636 e $885^{\circ} \mathrm{C}$, onde as mais altas correspondem às rochas de composição monzonítica Em geral, estas temperaturas são significativamente mais baixas que as de saturação em apatita $\left(921-1013^{\circ} \mathrm{C}\right.$ para $M h$ e $927-1055^{\circ} \mathrm{C}$ para $M d r$ e $\left.M d f\right)$. Isto sugere que a contribuição externa (cristais herdados) deve ser restrita e que estes magmas saturaram em zircão relativamente tarde. Salienta-se ainda que as estimativas para algumas amostras de monzodioritos são inferiores às temperaturas solidus calculadas para a unidade $M d f$.

\subsection{Atividade de $\mathrm{H}_{2} \mathrm{O}$}

Diversos modelos termodinâmicos que descrevem as relações plagioclásio-líquido foram desenvolvidos após a constatação de que o teor de anortita do plagioclásio aumenta em conjunto com a temperatura e concentração de $\mathrm{H}_{2} \mathrm{O}$ dos magmas. Embora estes modelos sejam aplicáveis como higrômetros e termômetros/geobarômetros (Housh \& Luhr, 1991; Putirka, 2005), por outro lado são limitados no que se refere à identificação da contribuição dos diferentes parâmetros intensivos.

O modelo desenvolvido por Lange et al. (2009) inova ao permitir a individualização dos efeitos de pressão, temperatura e composição do líquido sobre a partição dos componentes de albita e anortita entre plagioclásio e o magma. Contudo, as calibrações ainda não abrangem todo o espectro composicional das rochas ígneas. Pode ser aplicado a magmas com temperaturas entre $825-1230^{\circ} \mathrm{C}$, teor de sílica entre 45 e $75 \%$, concentrações de $\mathrm{H}_{2} \mathrm{O}$ entre 0 e $7 \%$, plagioclásios com $\mathrm{An}_{37-93}$ e cristalizados a pressões entre 0 e 300 Mpa. Os autores salientam ainda que este termômetro/higrômetro apresenta melhores resultados quando a temperatura ou a concentração de $\mathrm{H}_{2} \mathrm{O}$ é obtida através de algum outro método.

A aplicabilidade do método de Lange et al.(2009) em Piracaia é restrita, uma vez que o teor de An é menor que 37 em grande parte das rochas, em especial nas unidades mais félsicas. Apenas os cristais maiores da unidade $M d r$; fenocristais da unidade $M d f$ e antecristais da unidade $M h$ apresentam composição adequada. De todo modo, aplicou-se o método também para os cristais com An<37 e compararam-se os resultados. 
As estimativas foram realizadas para condições de pressão de cristalização entre 3 e 5 kbar. A primeira constatação é que as concentrações de $\mathrm{H}_{2} \mathrm{O}$ seriam maiores a pressões mais elevadas, se mantidas a temperatura e composição do magma. Os resultados são apresentados na Tabela A09.

Para a unidade $M d r$, os conteúdos de $\mathrm{H}_{2} \mathrm{O}$ estimados variam de 2,0 a 2,6\% na amostra PI-257c $\left(\mathrm{An}_{42-49}\right)$ e de 3,4 a 4,1\% na amostra PI-256 $\left(\mathrm{An}_{41-50}\right)$, que apresenta composição monzonítica. Contudo, análises realizadas por Janasi (1986) também na amostra PI-256, porém em núcleos mais cálcicos $\left(\mathrm{An}_{50-59}\right)$, resultam em conteúdos de $\mathrm{H}_{2} \mathrm{O}$ de até $4,6 \%$.

Amostras de $M d f$ mostram resultado semelhante. As rochas monzodioríticas $\left(\mathrm{An}_{45-61}\right)$ apresentam concentrações entre 2,5 e 3,3\%. Teores um pouco mais elevados (até 3,4\%) são observados na amostra PI-358a $\left(\mathrm{An}_{42-48)}\right.$, cuja composição é monzonítica, assim como observado em $M d r$. Cristais da amostra $\mathrm{PI}-5 \mathrm{c}$ com $\mathrm{An}_{24-31}$ fornecem concentrações de $\mathrm{H}_{2} \mathrm{O}$ inferiores, entre 1,5 e $2,1 \%$. De qualquer modo, estas estimativas são relativamente altas para rochas desta composição. Conteúdos de $\mathrm{H}_{2} \mathrm{O}$ como estes podem baixar significativamente as temperaturas solidus e corroboram as temperaturas de cristalização obtidas através do par hornblenda-plagioclásio.

As estimativas para unidade $M h$ foram obtidas a partir de grandes cristais tabulares (antecristais) de duas amostras. Para a amostra PI-400a $\left(\mathrm{An}_{42-46}\right)$ as concentrações de $\mathrm{H}_{2} \mathrm{O}$ são de 4,1 a 4,6\%, enquanto para a amostra PI-437a $\left(\mathrm{An}_{38-42}\right)$ são de 2,5 a 3,0\%. Contudo, o significado destes resultados é questionável, se considerarmos que a gênese da unidade $M h$ está relacionada a processos de mistura predominantemente heterogêneos. Neste contexto, os cristais mais cálcicos (antecristais) teriam se formado a partir do magma monzodiorítico. Para a obtenção de estimativas do magma híbrido, uma melhor abordagem é a de que sejam considerados os cristais da matriz, que podem ter se formado após o evento de mistura. Contudo, estes cristais apresentam An<37. As estimativas a partir destes variam entre 2,8 e $3,2 \%$ para a amostra PI-400a $\left(\mathrm{An}_{17-19}\right)$ e de 1,1 a $1,5 \%$ para a amostra PI437a $\left(\mathrm{An}_{11-14}\right)$.

Para as unidades Sie e Qsie, as estimativas puderam ser feitas apenas em cristais com An<37. Para a amostra PI-26b da unidade Sie, que apresenta $\mathrm{An}_{3-10}$, as estimativas do teor de $\mathrm{H}_{2} \mathrm{O}$ variam entre 3,5 e 4,2\%. Na unidade Qsie, duas amostras de quartzo sienitos com $\mathrm{An}_{2-13}$ fornecem concentrações de $\mathrm{H}_{2} \mathrm{O}$ entre 2,7 e $5,0 \%$. Já para quartzo monzonitos, as estimativas feitas também a partir de duas amostras $\left(\mathrm{An}_{2-34}\right)$, apresentam resultados entre 3,4 e 4,3\% de $\mathrm{H}_{2} \mathrm{O}$. Os resultados são coerentemente mais elevados, se considerada a composição mais félsica destes magmas. Contudo, devido às limitações do método, sua interpretação deve ser tomada com cautela. 


\subsection{Fugacidade de Oxigênio $\left(f \mathrm{O}_{2}\right)$}

A fugacidade é uma expressão termodinâmica do potencial químico de um componente em um sistema em equilíbrio. No caso dos magmas, as concentrações de oxigênio podem ser expressas através da fugacidade, uma vez que a diferença entre a fugacidade e a pressão total de oxigênio é muito pequena em relação às variações observadas nos sistemas magmáticos. A determinação das condições redox é importante uma vez que elas condicionam o comportamento de diversos elementos químicos, entre eles alguns importantes constituintes de minerais formadores de minérios metálicos, especialmente elementos como $\mathrm{Fe}$, Sn e outros, que podem ocorrer em mais de um estado de oxidação nos magmas.

As condições de redução-oxidação dos magmas podem ser expressas com relação a buffers de fugacidade, que correspondem a reações de equilíbrio de fases onde as relações entre $\mathrm{fO}_{2}$ e outras variáveis importantes, como a temperatura, são conhecidas experimentalmente. A fugacidade de todos os buffers aumenta com o aumento de temperatura; consequentemente, a estabilidade de minerais que contenham $\mathrm{Fe}$ na estrutura é diretamente dependente da $f \mathrm{O}_{2}$ e da temperatura do magma (Best, 2003).

\subsection{1 Óxidos de Fe e Ti}

$\mathrm{O}$ reconhecimento de que rochas plutônicas podem ser distinguidas em função de sua mineralogia de opacos e que as diferenças podem ser atribuídas principalmente às condições de fugacidade de oxigênio dos magmas já foram observados nos trabalhos de Czamanske \& Mihalik (1972). Ishihara (1977), ao estudar rochas do arquipélago do Japão, propôs a distinção hoje clássica entre granitóides das séries da magnetita e da ilmenita e atribuiu as baixas fugacidades de $\mathrm{O}_{2}$ dos granitos da série da ilmenita à interação com rochas sedimentares e metassedimentares.

As estimativas de fugacidade de $\mathrm{O}_{2}$ dos magmas foram pioneiramente desenvolvidas considerando as relações de equilíbrio entre magnetita e ilmenita. $\mathrm{O}$ primeiro geotermômetrooxibarômetro foi desenvolvido por Buddington \& Lindsley (1964) e parte da premissa de que o Ti inicialmente cristaliza-se como $\mathrm{Fe}_{2} \mathrm{TiO}_{4}$ (ulvoespinélio), e posteriormente forma titanomagnetita, a depender das condições de $f_{2}$. A aplicabilidade deste geotermômetro é restrita a cristais com composição no intervalo $\mathrm{Mt}_{90} \mathrm{Usp}_{10}$ a $\mathrm{Mt}_{20} \mathrm{Usp}_{80}$ e Hem $\mathrm{H}_{15} \mathrm{Ilm}_{85}$ a Hem $\mathrm{Hlm}_{97}$.

A realização de experimentos subseqüentes propiciou o aprimoramento das formulações matemáticas e a revisão dos métodos, de modo a abranger de forma mais ampla os buffers, condições de temperatura e também o efeito de constituintes menores dos óxidos, merecendo destaque os trabalhos de Spencer \& Lindsley (1981) e Stormer (1983). Dentre os trabalhos mais recentes destacase o método de Ghiorso \& Evans (2008), assim como o programa ILMAT, apresentado por Lepage (2003) e atualizações subsequentes, que permite a realização de cálculos através dos principais termômetros/oxibarômetros até então desenvolvidos. 


\subsubsection{Processos de reequilíbrio}

A constatação de que a solução-sólida entre magnetita e ilmenita é restrita e a observação de que a composição dos óxidos de Fe-Ti é muito distinta em rochas vulcânicas e plutônicas impõe limitações quanto à aplicação de termômetros/oxibarômetros. Os óxidos de Fe-Ti de rochas plutônicas tendem a apresentar reequilíbrios subsolidus, na presença de fluidos oxidantes. Os processos de equilíbrio podem ser do tipo óxido-silicato; óxido-óxido; ou intraóxido; onde a composição dos óxidos envolvidos tende a migrar para a de membros finais puros. O processso intraóxido em cristais de titanomagnetita, denominado de oxiexsolução por Buddington \& Lindsley (1964), atua de forma promover a remobilização do Ti e formar ilmenita.

São diversas as relações texturais entre (titano)magnetita e ilmenita, que podem ser primárias ou pós-magmáticas (Buddington \& Lindsley, 1964; Haggerty, 1976; 1981; Dall'Agnol et al., 1997). Sua distinção se faz importante uma vez que se buscam relações de equilíbrio primário para que os geotermômetros/oxibarômetros possam ser aplicados. Haggerty $(1976$; 1981) fazem uma síntese das relações texturais típicas de processos de oxiexsolução, como ilmenita em treliça, cristais do tipo composto e cristais do tipo sanduíche.

Caso seja identificada a existência de processos de reequilíbrio, uma alternativa para a aplicação do geotermômetros/oxibarômetros é a reconstituição dos cristais originais de titanomagnetita. Uma alternativa para as rochas que sofreram reequilíbrio pós-magmático é a reconstrução dos cristais originais de titanomagnetita, a partir da composição da magnetita hospedeira e ilmenita oxiexsolvida. Os métodos de reconstrução mais comumente utilizados são por contagem de pontos ou análises de imagens digitais com o uso de software (Dall'Agnoll et al., 1997; Azzone, 2008).

No caso de Piracaia, foram realizadas sessões de Microscopia Eletrônica de Varredura e de Microssonda Eletrônica em óxidos de Fe-Ti em diversas relações texturais, visando caracterizar e identificar a diferença composicional existente entre cristais primários e reequilibrados. Este reconhecimento se faz importante principalmente no que se refere aos cristais de magnetita dos tipos individual e composto, considerando que estes podem ser primários ou secundários.

No que se refere às ilmenitas, o teor de $\mathrm{MnO}$ pode auxiliar na identificação de reequilíbrio pós-magmático. A partição de $\mathrm{Mg} / \mathrm{Mn}$ entre magnetita e ilmenita é um potencial critério, como estabelecido Bacon \& Hirschmann (1988), onde magnetitas e ilmenitas em equilíbrio devem apresentar razões $\mathrm{Mg} / \mathrm{Mn}$ iguais ou muito próximas. Contudo, este método é em grande parte válido apenas para rochas vulcânicas. As magnetitas e ilmenitas de Piracaia apresentam razões $\mathrm{Mg} / \mathrm{Mn}$ muito distintas e à exceção da amostra PI-75 de $M d f$, se situam fora da margem de erro estipulada por Bacon \& Hirschmann (1988), o que evidencia a possível atuação de processos de reequilíbrio (Figura 44). 


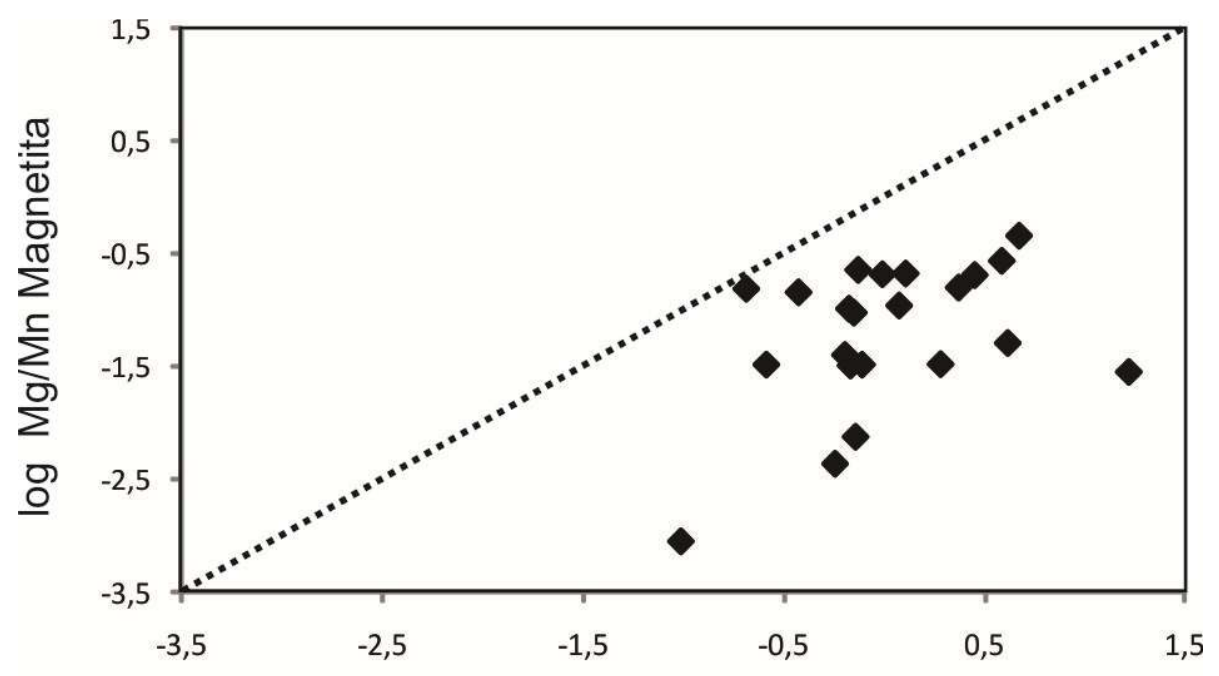

$\log \mathrm{Mg} / \mathrm{Mn}$ Ilmenita

Figura 44. Variações nas concentrações de $\mathrm{Mg}$ e $\mathrm{Mn}$ entre magnetita e ilmenita coexistentes de rochas das diferentes unidades que compõem o Plúton Piracaia. Teste para verificação de equilíbrio segundo Bacon \& Hirschmann (1988), onde a linha tracejada representa a tendência de correlação ideal (1:1) esperada para cristais em equilíbrio.

Para rochas plutônicas, Dall'Agnol et al. (1997) observam que cristais de ilmenita formados por oxiexsolução tendem a apresentar concentrações de $\mathrm{MnO}$ mais elevadas em relação a cristais primários. Tal constatação baseou-se na observação, feita no Granito Jamon, de que cristais do tipo treliça, patch e sanduíche, formados exclusivamente por oxiexsolução, são mais ricos em Mn do que os cristais considerados primários, do tipo composto e individual.

Em Piracaia, pode-se distinguir tipos texturais de ilmenita com alto e baixo teor de $\mathrm{MnO}$ nas amostras PI-5c, PI-358c, PI-75 da unidade Mdf e na amostra PI-413 da unidade Qsie (Figura 45). Reconhece-se, portanto, a possível existência de cristais primários, que potencialmente podem ser usados na obtenção de estimativas de $f \mathrm{O}_{2}$, associados aos cristais reconstituídos de titanomagnetita. Nas demais amostras, considerando que os teores $\mathrm{MnO}$ são os mesmos independentemente do tipo textural, é possível que todos os cristais de ilmenita tenham sido reequilibrados, e assim não poderiam ser usados para cálculos de $f \mathrm{O}_{2}$. 

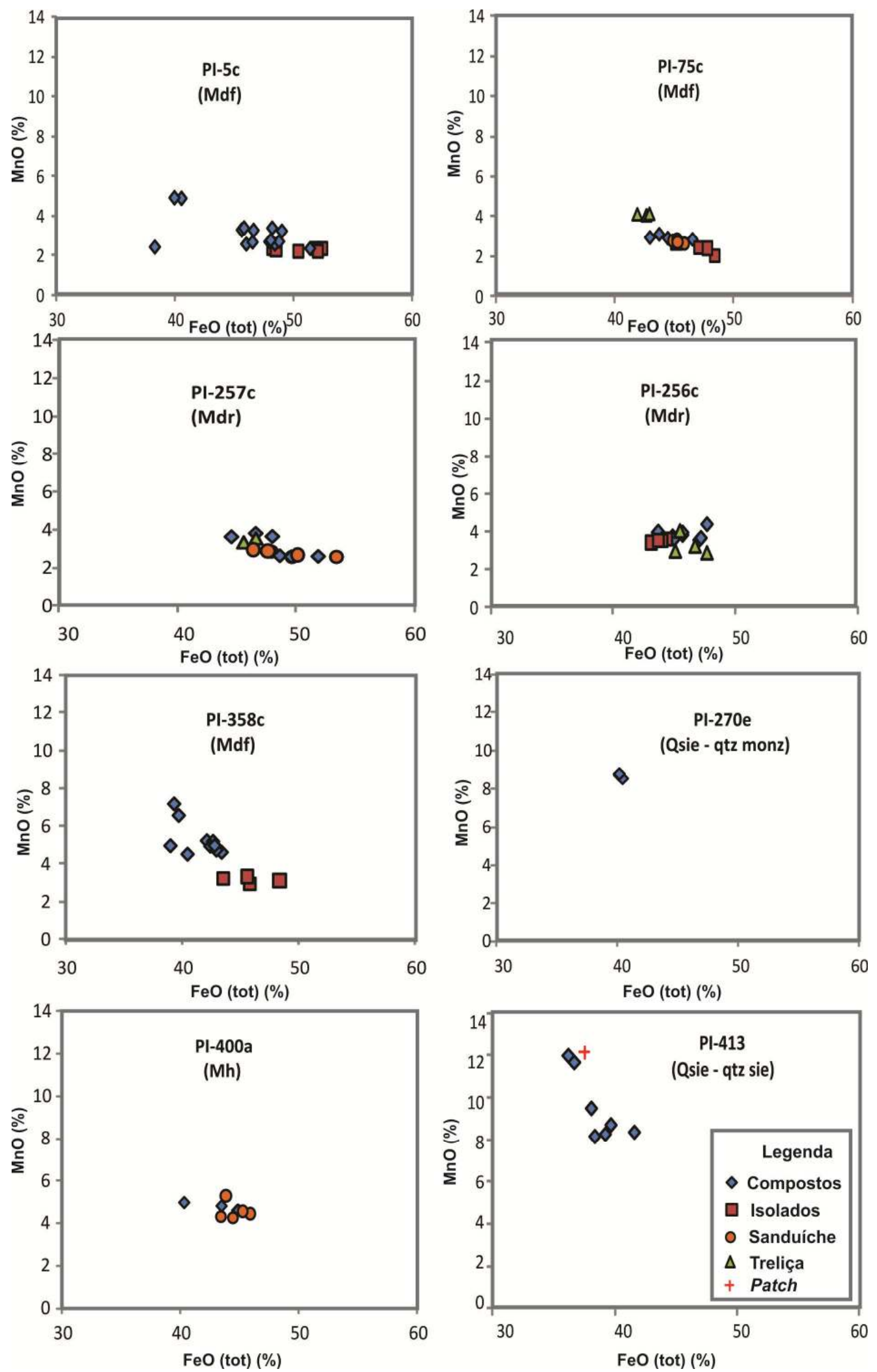

Figura 45. Variações nas concentrações de $\mathrm{MnO}$ entre os diferentes tipos texturais de ilmenita, referentes a amostras das diferentes unidades que compõem o Plúton Piracaia. 
3.4.3 Aplicação de termômetros/oxibarômetros e reconstrução de cristais de titanomagnetita oxiexsolvidos

O baixo teor do componente ulvoespinélio das magnetitas de Piracaia, em geral $<2 \%$, situa-se fora do limite estipulado por Buddington \& Lindsley (1964) para aplicação de termômetros/oxibarômetros, o que já representa uma forte evidência da atuação de processos de oxiexsolução. Ainda assim, foram realizados cálculos através a partir do programa ILMAT, para associações texturais de magnetita com cristais de ilmenita do tipo individual e composto. Como pode ser observado na Tabela A10, os resultados fornecem temperaturas muito baixas, o que reforça a hipótese de que os cristais de magnetita sofreram oxiexsolução.

No presente trabalho, a reconstituição dos cristais de titanomagnetita foi realizada para rochas de todas as unidades que compõem o plúton, associando a composição de magnetita e ilmenita obtida por Microssonda Eletrônica às imagens dos cristais oxiexsolvidos, obtidas através de Microscopia Eletrônica de Varredura. Seguiu-se a metodologia descrita em Azzone (2008): “As porcentagens em área de ilmenita exsolvida e da magnetita hospedeira obtida pelas imagens de elétrons retroespalhados são assumidas como percentagem volumétrica. Tais porcentagens podem então ser convertidas para uma fração de peso multiplicando-as pelas densidades da magnetita hospedeira e da ilmenita exsolvida. Para o cálculo das densidades utiliza-se o trabalho de Lindsley (1965) que apresenta os volumes molares das séries de soluções sólidas magnetita-ulvoespinélio e hematitailmenita em função da composição química. Desta forma, pode-se por meio da análise de cada fase calcular sua densidade, e multiplicando-se pelo respectivo percentual de volume assumido tem-se a concentração relativa de hospedeiro e da lamela em fração de peso. Multiplica-se esta fração em peso pelos dados em porcentagem de peso de cada elemento da análise de cada componente. As porcentagens em peso de cada elemento obtidas são então integradas (somadas) gerando uma composição teórica de um cristal de magnetita rico em ulvoespinélio e homogêneo." A determinação das porcentagens relativas de magnetita e ilmenita foi realizada utilizando-se do software Corel PhotoPaint. As imagens dos cristais reconstituídos são apresentadas na Figura 46, e suas composições na Tabela A11. 

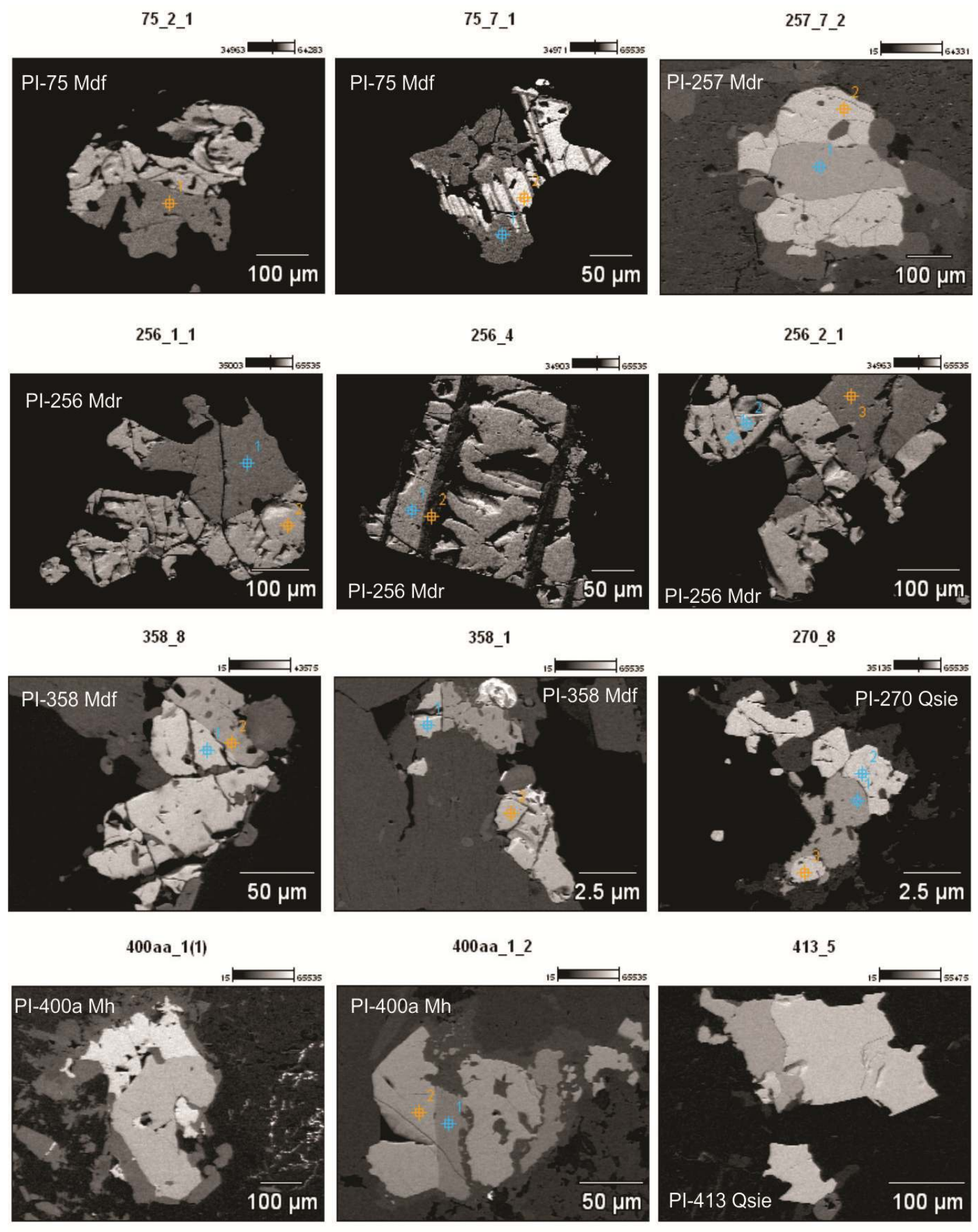

Figura 46. Imagens de Microscopia Eletrônica de Varredura (elétrons retroespalhados) dos cristais selecionados para reconstituição, das diferentes unidades que compõem o Plúton.

As estimativas a partir dos cristais reconstituídos também foram feitas utilizando o programa ILMAT e foram considerados os resultados do termômetro/oxibarômetro de Spencer \& Lindsley (1981). Foram utilizados os cristais de titanomagnetita reconstituídos em associação com ilmenitas do tipo individual e composto, que apresentavam mais baixo teor de MnO. Mesmo nestes casos, as temperaturas obtidas são em geral menores que as estimativas de temperatura de cristalização 
magmática, como pode ser observado na Tabela A12 e Figura 47. Isto implica em três possibilidades: que a reconstituição dos cristais de titanomagnetita não foi satisfatória; que os cristais de ilmenita, sem exceção, também sofreram reequilíbrio pós-magmático; ou que magnetita e ilmenita iniciaram sua cristalização em momentos distintos da evolução do magma e, portanto os conjuntos de cristais utilizados para os cálculos não se encontravam em equilíbrio.

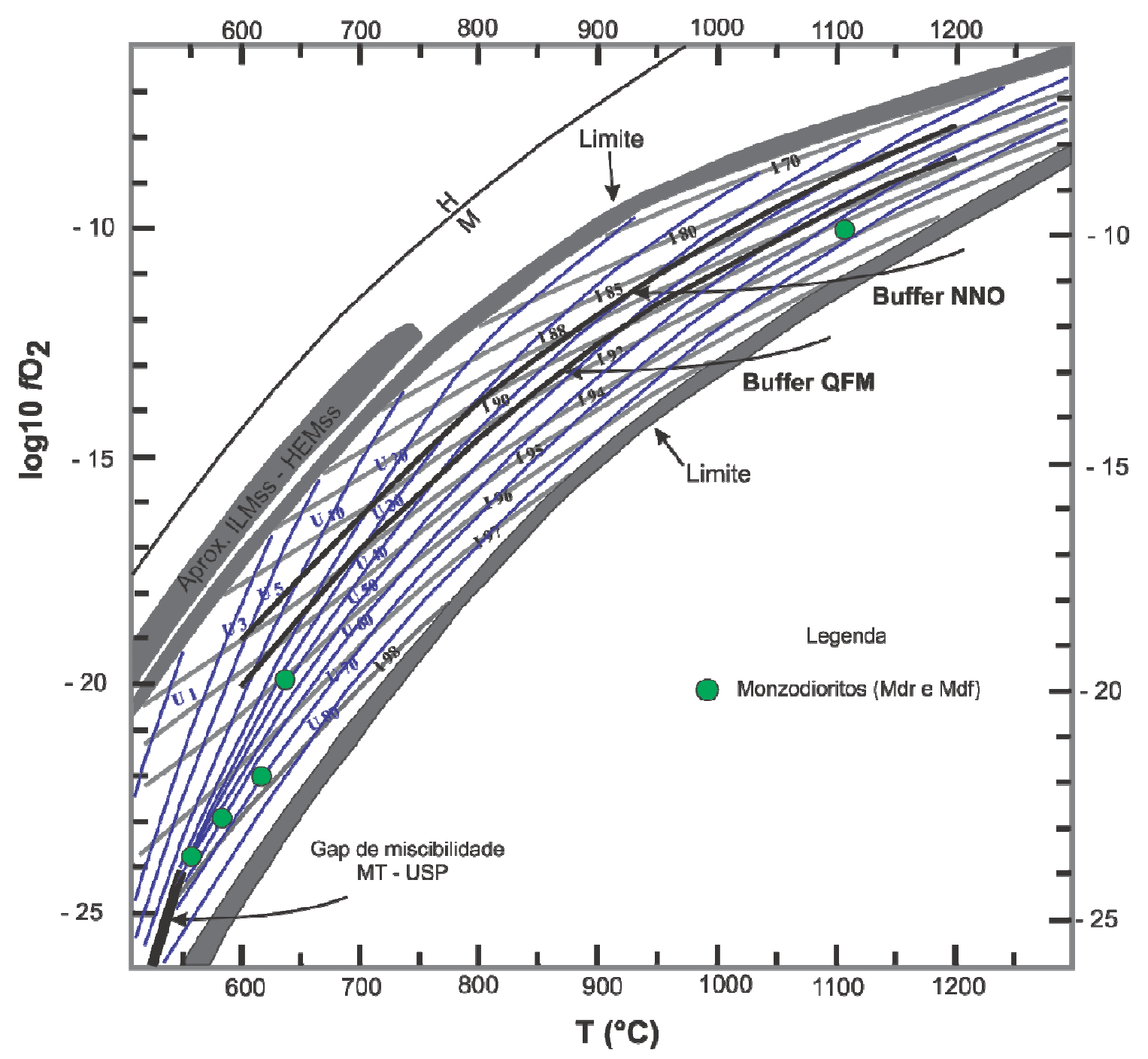

Figura 47. Estimativas de $f \mathrm{O}_{2}$ para as unidades $M d r$ e $M d f$ obtidas a partir da reconstituição de cristais de titanomagnetita e ilmenitas coexistentes, segundo o termômetro/oxibarômetro de Spencer \& Lindsley (1981).

Os modelamentos de cristalização realizados utilizando o software MELTS auxiliam na elucidação deste problema. Os resultados para as diferentes unidades apontaram a ilmenita como uma das últimas fases a cristalizar, ao contrário da magnetita, que se apresenta como fase liquidus em todas as rochas de Piracaia, à exceção da unidade Sie. Uma segunda análise petrográfica para conferência mostra que cristais individuais de ilmenita ocorrem exclusivamente em estágios tardios, enquanto a magnetita é de fato precoce. Tal constatação sugere que todas as ocorrências de ilmenita em associações do tipo composto sejam o reflexo de processos de oxiexsolução de cristais de 
titanomagnetita. Do mesmo modo, os resultados insatisfatórios obtidos a partir da reconstrução de cristais de titanomagnetita oxiexsolvidos combinados com cristais individuais de ilmenita devem refletir o fato de que magnetita e ilmenita iniciaram sua cristalização em momentos distintos da evolução dos magmas.

Por outro lado, nos casos onde houve reequilíbrio, o trabalho de Spencer \& Lindsley (1981) propicia uma estimativa da $f \mathrm{O}_{2}$, obtida graficamente, arbitrando-se a temperatura e utilizando-se a composição da ilmenita ou titanomagnetita, separadamente. Na Figura 48 estão plotados os conteúdos de ulvoespinélio de alguns cristais de titanomagnetita reconstruídos de Piracaia. A temperatura utilizada representa o momento onde a cristalização de titanomagnetita se inicia segundo os modelamentos fornecidos pelo software MELTS, que é muito próxima às temperaturas liquidus calculadas pelo programa. Embora as interpretações sejam limitadas, principalmente pelo pequeno numero de cristais e amostras de cada unidade, os resultados apontam para condições relativamente oxidantes para todas as unidades que apresentam magnetita. $M d r$ e $M d f$ mostram-se os magmas mais oxidados, com valores de $f \mathrm{O}_{2}$ a ordem de $10^{-8}$ bars à temperaturas liquidus (em torno de $1100^{\circ} \mathrm{C}$ ), o que representa cerca de 1-2 unidades log acima do buffer NNO. A amostra de Mh PI-400a forneceu valor de $f \mathrm{O}_{2}$ um pouco mais baixo, em torno de $10^{-9}$ bars a $1050^{\circ} \mathrm{C}$, também acima de NNO. Contudo, esta é uma amostra atípica, uma vez que as rochas de $M h$ raramente apresentam magnetita. É possível que estes cristais tenham se cristalizado no magma monzodiorítico, previamente ao evento de mistura que deu origem à unidade. Os valores obtidos para a unidade Qsie, com temperaturas liquidus da ordem de $950^{\circ} \mathrm{C}$, situam-se entre os buffers NNO-QFM. Os Sienitos (Sie) não podem ser plotados neste diagrama por não apresentarem magnetita, o que evidencia que estes magmas sejam os mais reduzidos presentes no plúton.

Considerações a respeito da composição das ilmenitas podem ser feitas exclusivamente para os monzodioritos ( $M d r$ e $M d f$ ) e para os sienitos Sie, pois são as únicas rochas nas quais se dispõem de dados de cristais individuais. Na Figura 49 os círculos correspondem aos cristais do tipo individual. Já as setas representam o intervalo composicional de cristais dos tipos composto e individual, que foram plotadas para efeito de comparação. A temperatura utilizada para os monzodioritos representa a média das estimativas solidus obtidas, considerando que as evidências petrográficas e modelamentos sugerem sua cristalização tardia. Observa-se um amplo intervalo de $f \mathrm{O}_{2}$ (entre $10^{-15}$ e $10^{-19}$ bars); os valores mais altos situados sobre o buffer NNO, e os mais baixos até três unidades log abaixo do buffer QFM. Tais condições, ainda que imprecisas, sugerem uma trajetória redutora para a cristalização dos magmas monzodioríticos. 


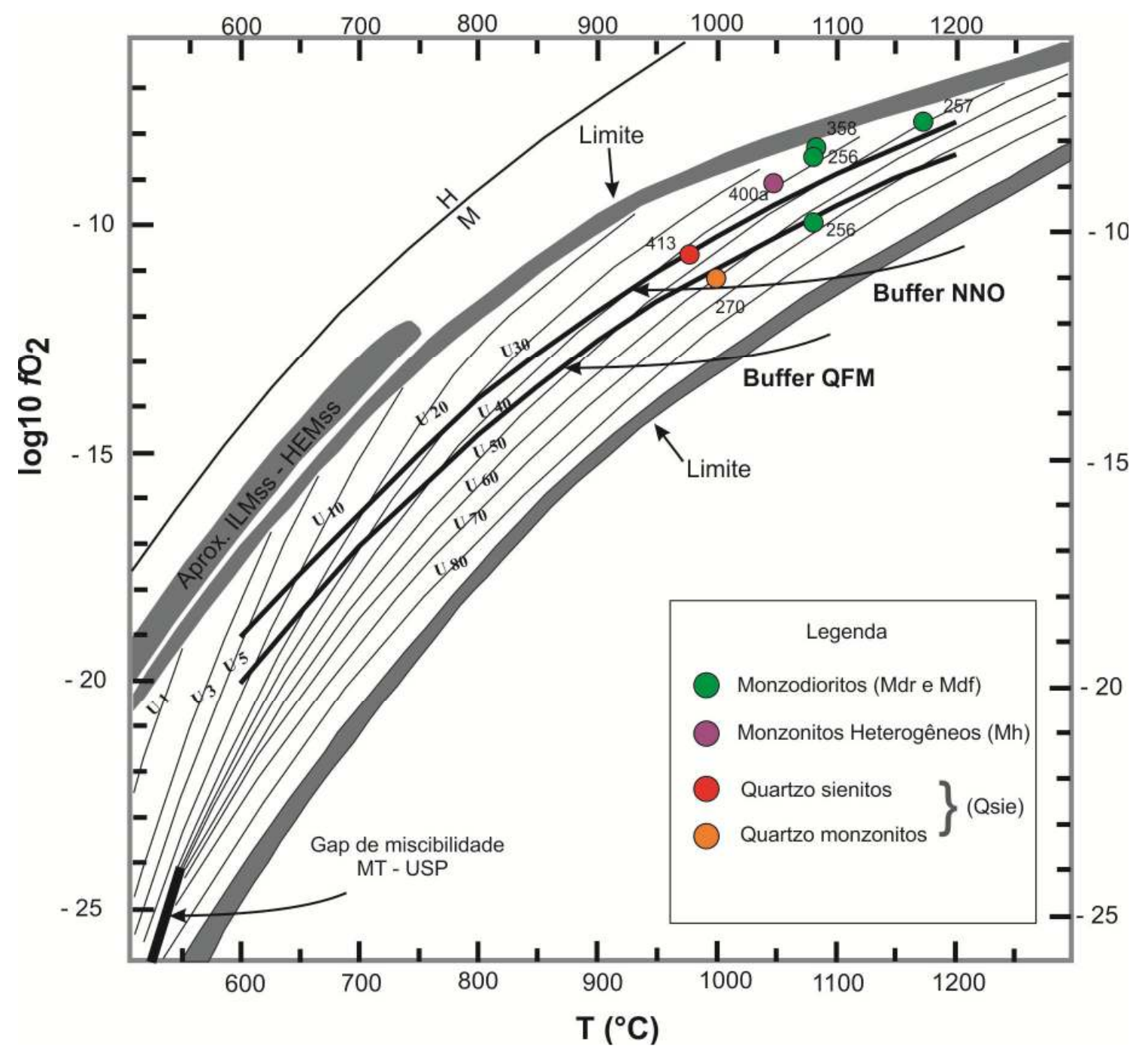

Figura 48. Estimativa de $f \mathrm{O}_{2}$, a partir do conteúdo de ulvoespinélio de cristais reconstituídos de titanomagnetita, de algumas unidades que compõem o Plúton Piracaia.

Para a unidade Sie, que apresenta ilmenita como fase liquidus segundo os modelamentos obtidos no programa MELTS, utilizou-se a temperatura onde a cristalização teria se iniciado, assim como a estimativa de temperatura solidus. Em ambos os casos, as condições de $f \mathrm{O}_{2}$ estariam muito abaixo do buffer QFM, compreendendo um intervalo entre $10^{-15}$ e $10^{-20}$ bars. Estes resultados são imprecisos, mas mostram que os magmas sieníticos (Sie) são menos oxidados em relação aos monzodioritos ( $M d r$ e $M d f)$. 


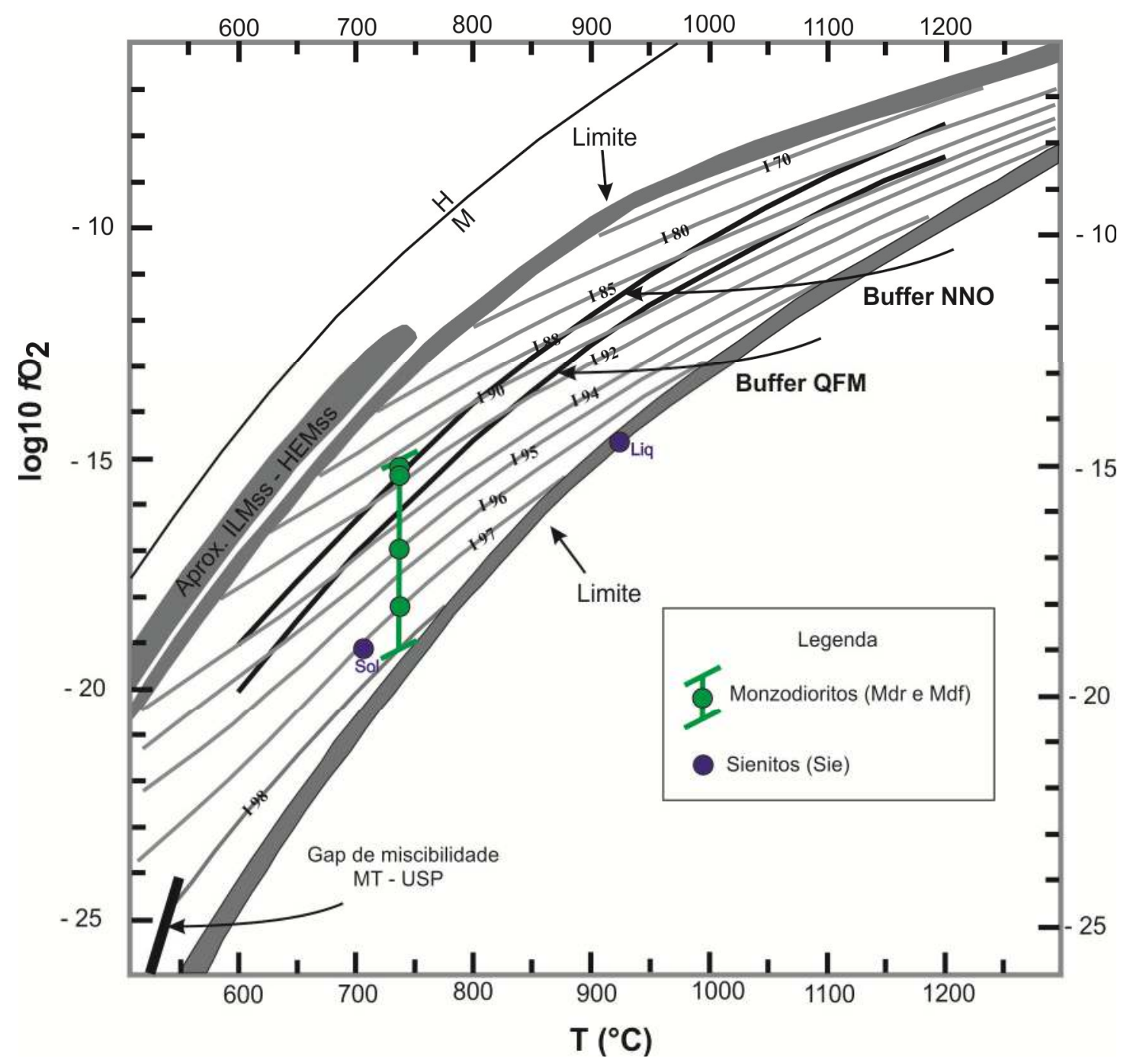

Figura 49. Estimativas de $f \mathrm{O}_{2}$ a partir da composição de ilmenita de monzodioritos (Mdr e $M d f$ ) e Sienitos (Sie), segundo Spencer \& Lindsley (1981). A temperatura estipulada para os monzodioritos refere-se à solidus apontadas pelos modelamentos no software MELTS, enquanto que para os Sienitos utilizou-se as estimativas de liquidus e solidus. 


\subsection{Minerais máficos silicáticos}

Wones \& Eugster (1965) identificaram que a biotita pode apresentar tendências de enriquecimento em $\mathrm{Fe}$ ou $\mathrm{Mg}$ a depender das condições de $f \mathrm{O}_{2}$ vigentes durante a cristalização. Sob condições mais oxidantes as razões $\mathrm{Fe} /(\mathrm{Fe}+\mathrm{Mg})$ tendem a diminuir, uma vez que a entrada de $\mathrm{Mg}$ na estrutura do mineral é favorecida pois maior proporção do Fe deve apresentar valência 3+. Czamanske \& Wones (1973) extrapolaram esta inferência para outros minerais ferromagnesianos importantes, como hornblenda, piroxênio e também biotita, analisados através de microssonda eletrônica.

Avaliando as composições de biotita e anfibólio das diferentes unidades que compõem o Plúton Piracaia, mostradas nas Figura 50, 51 e 52, pode-se inferir que os monzodioritos ( $M d r$ e $M d f$ ) são os magmas comparativamente mais oxidados. No outro extremo, estão os sienitos da unidade Sie e quartzo sienitos da unidade $Q$ sie, estes últimos com razões $\mathrm{Fe} /(\mathrm{Fe}+\mathrm{Mg})$ um pouco mais elevadas. As rochas híbridas, monzonitos heterogêneos $(M h)$ e quartzo monzonitos (Qsie) apresentam composição intermediária e consequentemente também $f \mathrm{O}_{2}$.
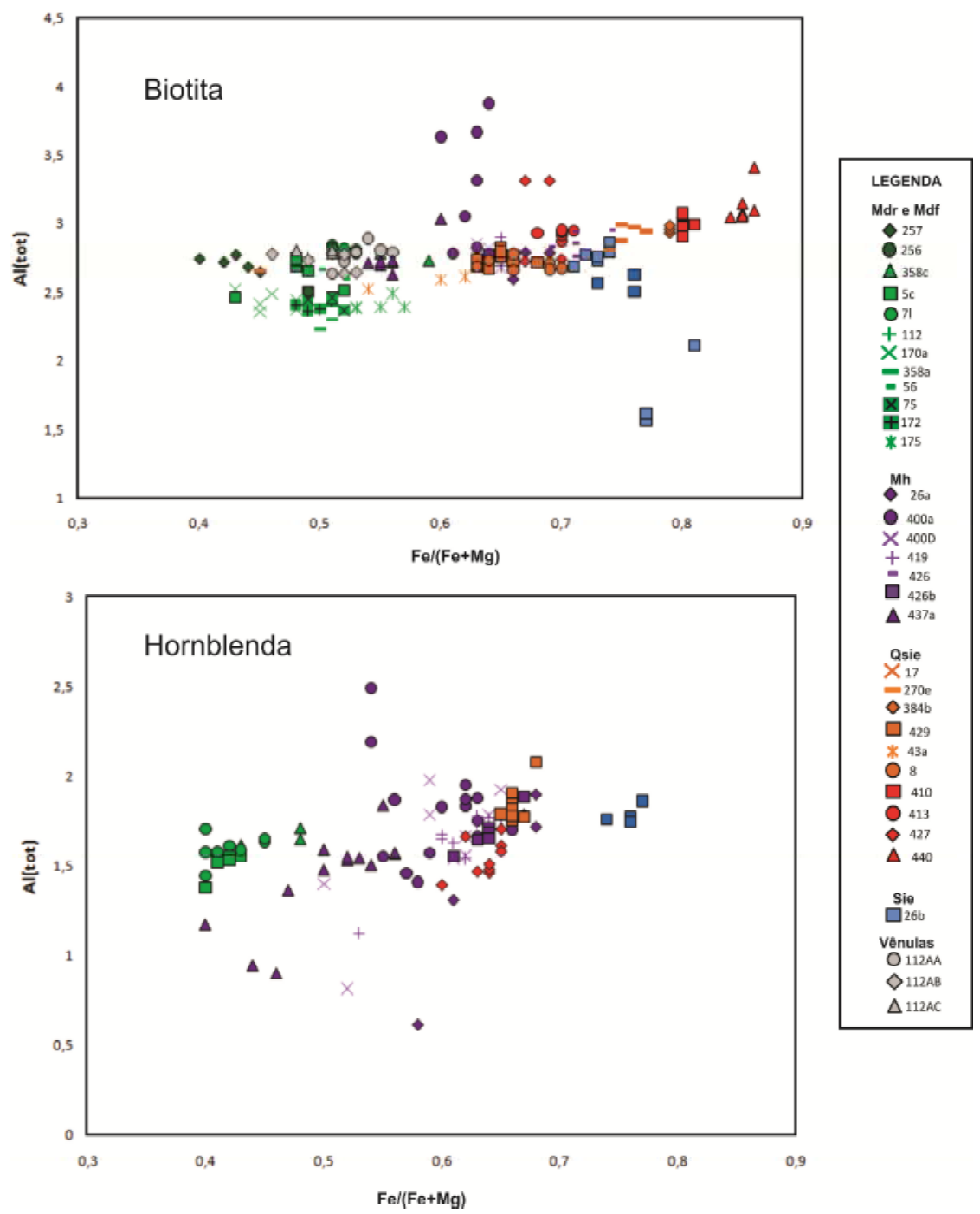

Figura 50. Correlação entre os conteúdos de $\mathrm{Al}($ tot $)$ com as razões $\mathrm{Fe} /(\mathrm{Fe}+\mathrm{Mg})$ de biotita e hornblenda das diferentes unidades que compõem o Plúton Piracaia. 
Czamanske \& Wones (1973) e Lalonde \& Bernard (1993) observaram também que, nas rochas por eles estudadas, as biotitas com conteúdos de $\mathrm{Al}_{\text {tot }}$ mais elevados se associam a rochas com $f \mathrm{O}_{2}$ mais baixas. Czamanske \& Wones (1973) admitiram que o aumento de Al poderia estar relacionado à maior atividade de sílica dos magmas. Lalonde \& Bernard (1993), por outro lado, estudaram duas ocorrências distintas, do ponto de vista de ambiente tectônico e características químicas, e sugeriram uma relação entre baixa $f_{2}$ e o caráter peraluminoso dos magmas. As biotitas com elevado conteúdo de Al cristalizaram em magmas que são ao mesmo tempo peraluminosos e reduzidos, devido a uma importante contribuição de rochas sedimentares.

No Plúton Piracaia as proporções de Al na biotita se mantêm constantes independentemente da unidade considerada, como pode ser observado na Figura 50. Tal comportamento parece simplesmente refletir a composição dos magmas que compõem o plúton, uma vez que também não se observam grandes variações nos teores de $\mathrm{Al}_{2} \mathrm{O}_{3}$ nas análises químicas de rocha total.

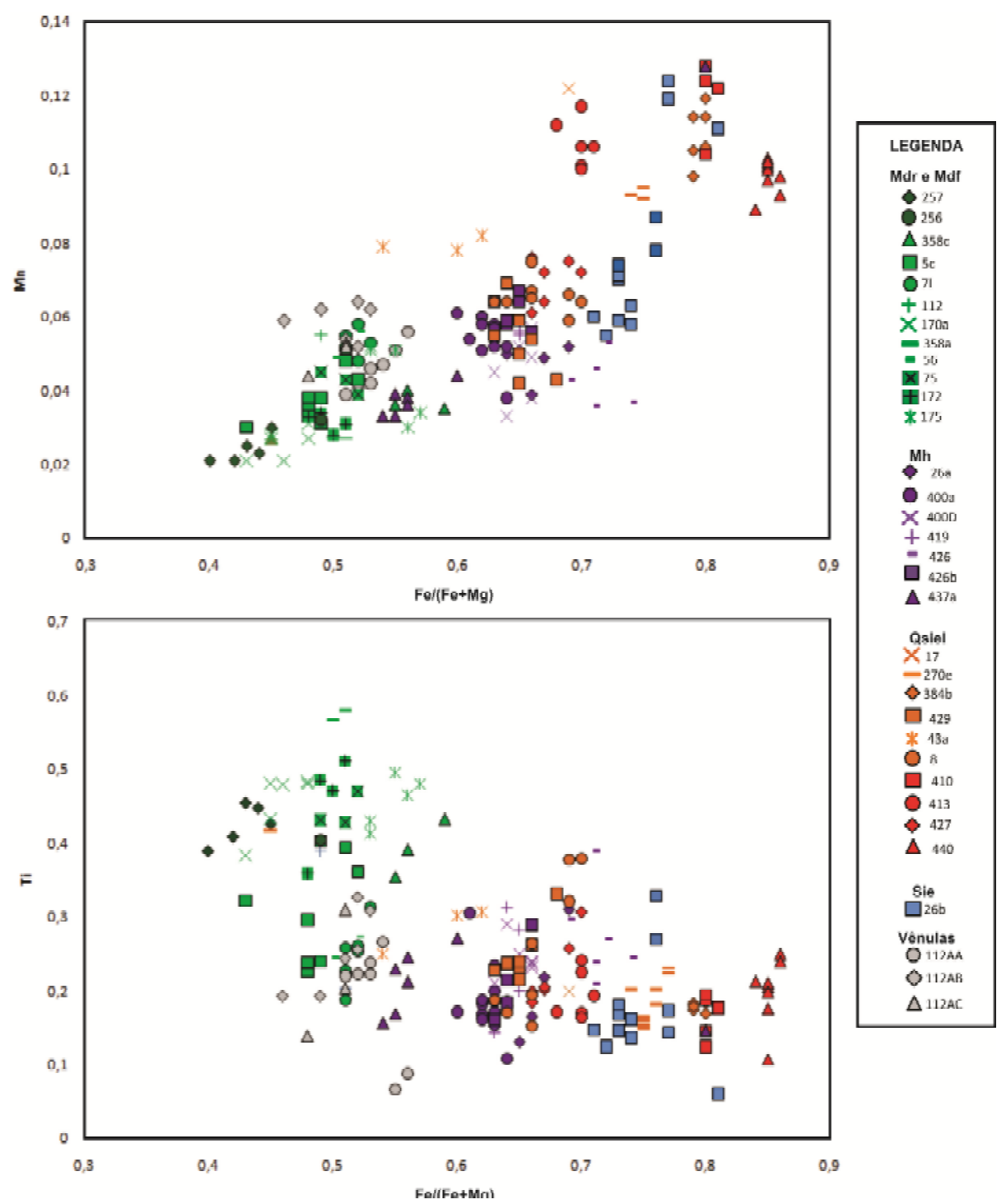

Figura 51. Correlação entre os conteúdos de $\mathrm{Mn}$ e Ti e as razões $\mathrm{Fe} /(\mathrm{Fe}+\mathrm{Mg})$ de biotitas das diferentes unidades que compõem o Plúton Piracaia. 
As rochas estudadas por Czamanske \& Wones (1973), pertencentes ao Complexo Ígneo de Finnmarka, exemplificam o aumento na fugacidade de oxigênio com a diferenciação magmática. Além da diminuição da razão $\mathrm{Fe} /(\mathrm{Fe}+\mathrm{Mg})$, há também decréscimo de Ti e Mn nos anfibólios e biotita com o aumento da $f_{2}$. Nas Figura 51 e 52 observa-se que tal correlação é verificada apenas nos anfibólios de Piracaia, onde (Ti e Mn são mais altos nas rochas mais reduzidas. Contudo a correlação não é tão bem definida para o Ti. Já as biotitas apresentam comportamento oposto, com maior conteúdo de Ti nas rochas com maior $\mathrm{fO}_{2}$ (os monzodioritos), o que deve refletir a maior temperatura de cristalização dessas rochas.

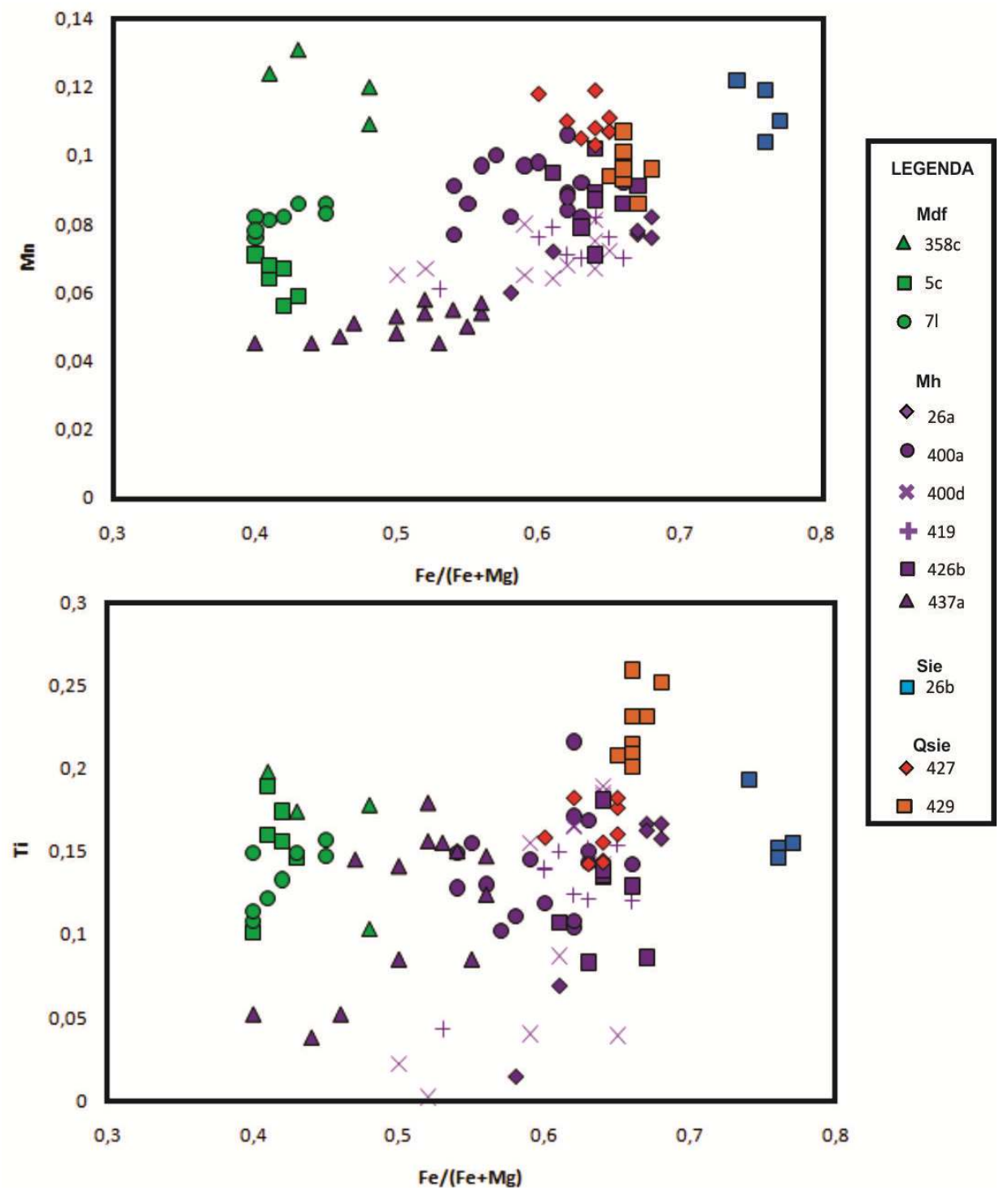

Figura 52. Correlação entre os conteúdos de $\mathrm{Mn}$ e $\mathrm{Ti}$ e as razões $\mathrm{Fe} /(\mathrm{Fe}+\mathrm{Mg})$ de hornblendas das diferentes unidades que compõem o Plúton Piracaia. 
Anderson \& Smith (1995) ao estudarem a influência da $f \mathrm{O}_{2}$ sobre as estimativas de pressão, utilizaram um grande acervo de dados químicos de hornblenda de plútons anorogênicos. Isto permitiu aos autores estabelecer uma divisão qualitativa das condições redox, a partir da razão $\mathrm{Fe} /(\mathrm{Fe}+\mathrm{Mg})$ e do conteúdo de $\mathrm{Al}^{\mathrm{IV}}$. As divisões são mostradas na Figura 53, onde estão plotadas as amostras de Piracaia. De modo coerente com o que foi inferido a partir dos óxidos, as rochas monzodioríticas ( $M d f$ e $M d r$ ) situam-se no campo de alta $f \mathrm{O}_{2}$ e os Sienitos (Sie) situam-se no campo de baixa $f \mathrm{O}_{2}$. As demais unidades situam-se em posição intermediária entre elas.

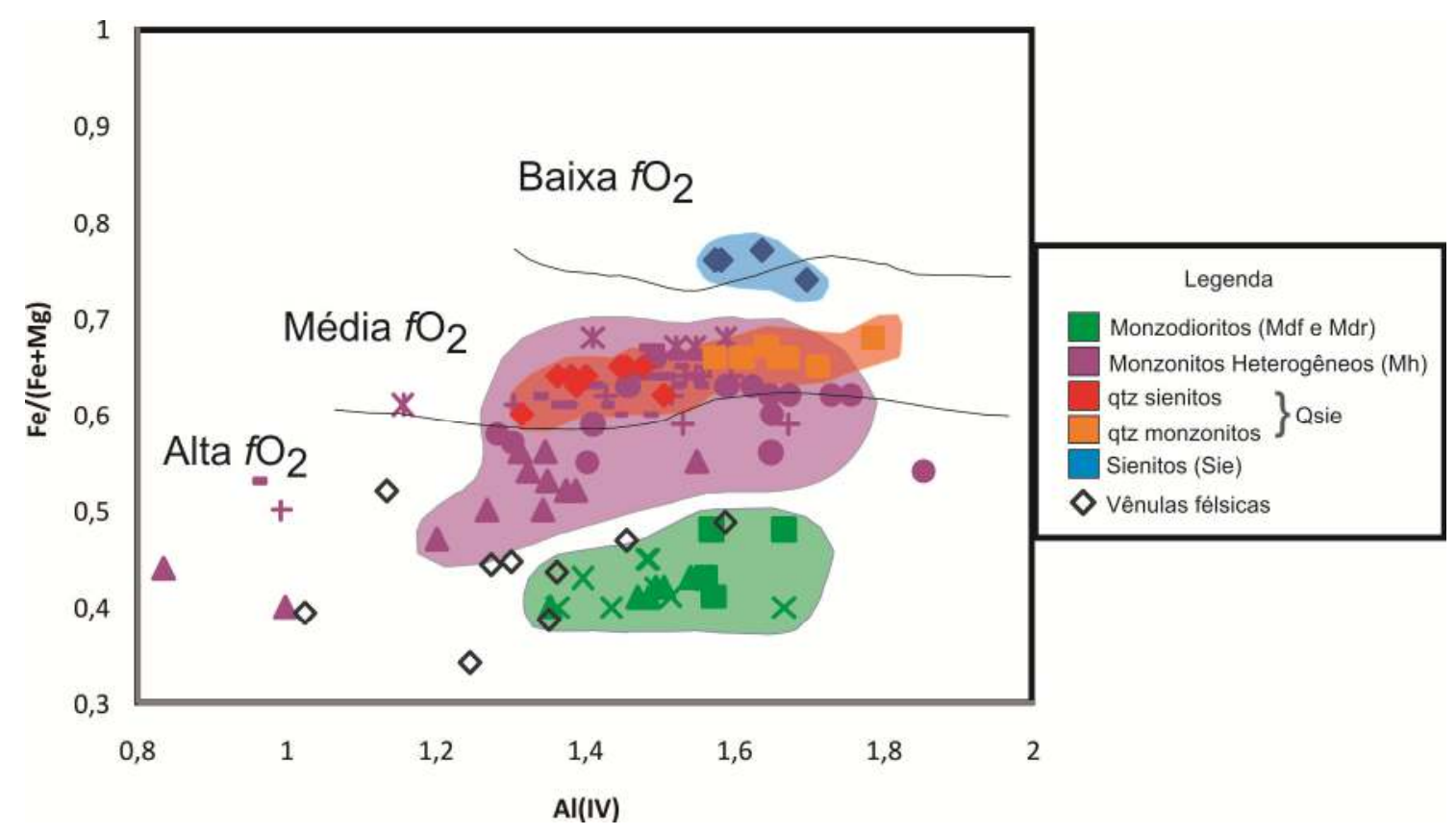

Figura 53. Estimativa qualitativa de $f \mathrm{O}_{2}$, a partir da composição da hornblenda de rochas das diferentes unidades que compõem o Plúton, segundo Anderson \& Smith (1995).

Ainda considerando a razão $\mathrm{Fe} /(\mathrm{Fe}+\mathrm{Mg})$ da biotita, Wones \& Eugster (1965) ao realizarem experimentos a diferentes buffers a uma pressão de 2,07 kbar, estabeleceram um método qualitativo para determinar a fugacidade de oxigênio do sistema. Entretanto, considerando que a biotita é um mineral relativamente precoce nas rochas de Piracaia, as temperaturas onde sua cristalização se inicia situam-se acima dos limites superiores calibrados por Wones \& Eugster (1965). Porém, utilizando-se as estimativas de temperatura solidus, podem-se estimar as condições vigentes ao final da cristalização. Observa-se na Figura 54 que as rochas de Piracaia em sua maioria situam-se acima do buffer NNO. Mdr e $M d f$ são, também neste caso, os mais oxidados, com fugacidades entre $10^{-11}$ e $10^{-14}$ bars. Sie e quartzo sienitos (Qsie) estariam no outro extremo, apresentando fugacidades de até $10^{-17}$ bars, situando-se próximo ou abaixo do limite entre os buffers NNO-QFM. Contudo, salienta-se ainda o amplo intervalo apresentado tanto por quartzo sienitos como quartzo monzonitos da unidade Qsie. As rochas de $M h$ apresentariam fugacidades intermediárias, entre $\log 10^{-13}$ e $\log 10^{-16}$ bars. 


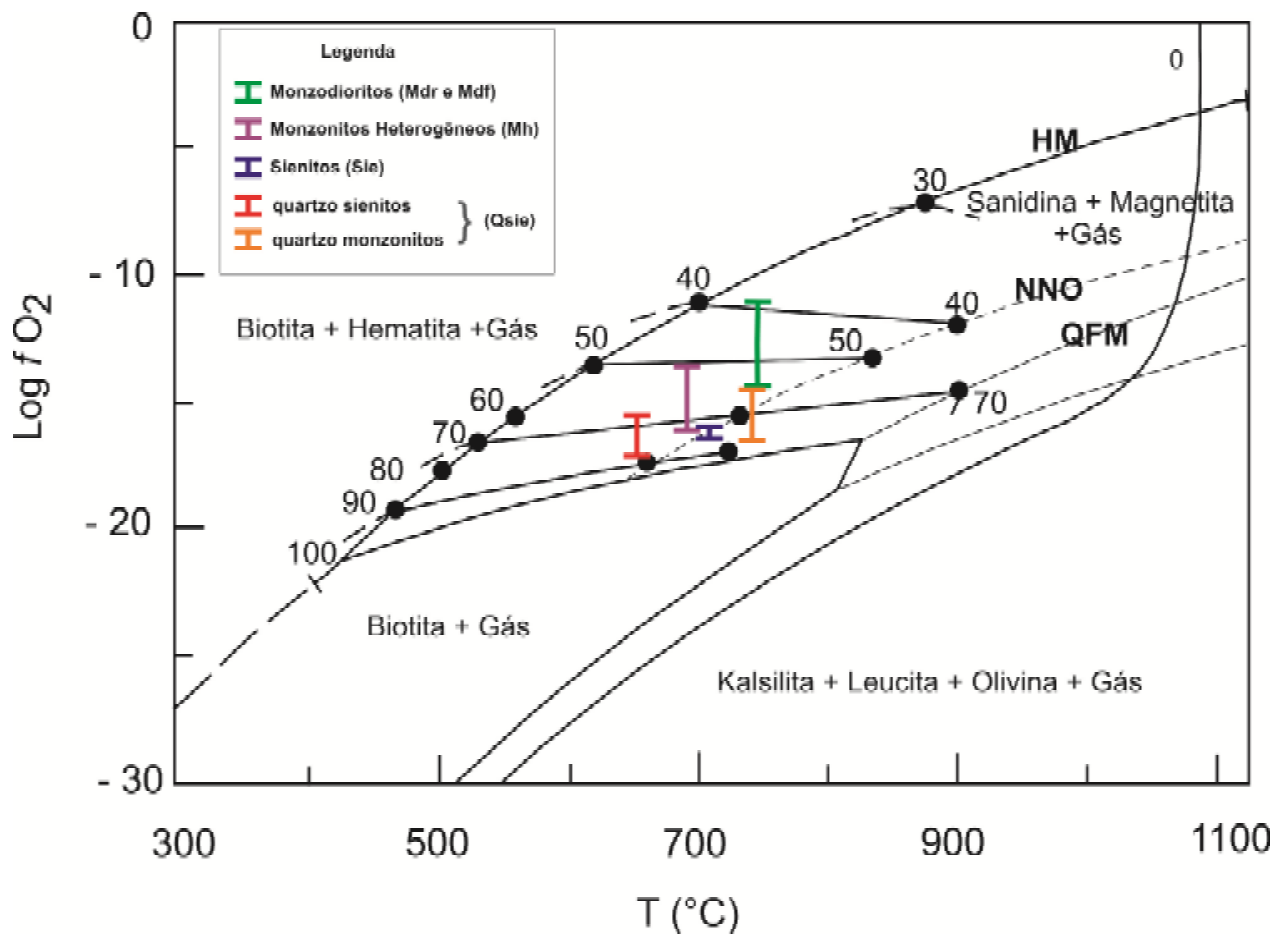

Figura 54. Estimativas de $f \mathrm{O}_{2}$ para as unidades que compõem o Plúton Piracaia, utilizando a razão $\mathrm{Fe} /(\mathrm{Fe}+\mathrm{Mg})$ da biotita, a partir do método Wones \& Eugster (1965).

Anderson et al. (2008) comparam as razões $\mathrm{Fe} /(\mathrm{Fe}+\mathrm{Mg})$ das biotitas com as razões $\mathrm{FeO} / \mathrm{FeO}+\mathrm{MgO}$ da rocha total de uma grande quantidade de plútons graníticos mesoproterozóicos das séries da ilmenita e magnetita. Os autores propõem que em rochas da série da magnetita a $\mathrm{fO}_{2}$ é o principal fator que influencia a razão $\mathrm{Fe} / \mathrm{Mg}$ de biotita e outros silicatos máficos, uma vez que em geral não há correlação composicional entre biotita e rocha total. Já nas rochas da série da ilmenita a composição da biotita é condicionada pela composição do magma, uma vez que todo o Fe disponível tende a apresentar estado de valência +2 .

A Figura 55 mostra que em Piracaia as razões $\mathrm{Fe} /(\mathrm{Fe}+\mathrm{Mg})$ da biotita de todas as unidades apresentam correlação positiva quando comparadas com a composição da rocha total. Isto sugere que o fator composicional dos magmas é um condicionante importante em Piracaia, apesar das diferenças de fugacidade, dada a ampla variação observada. 


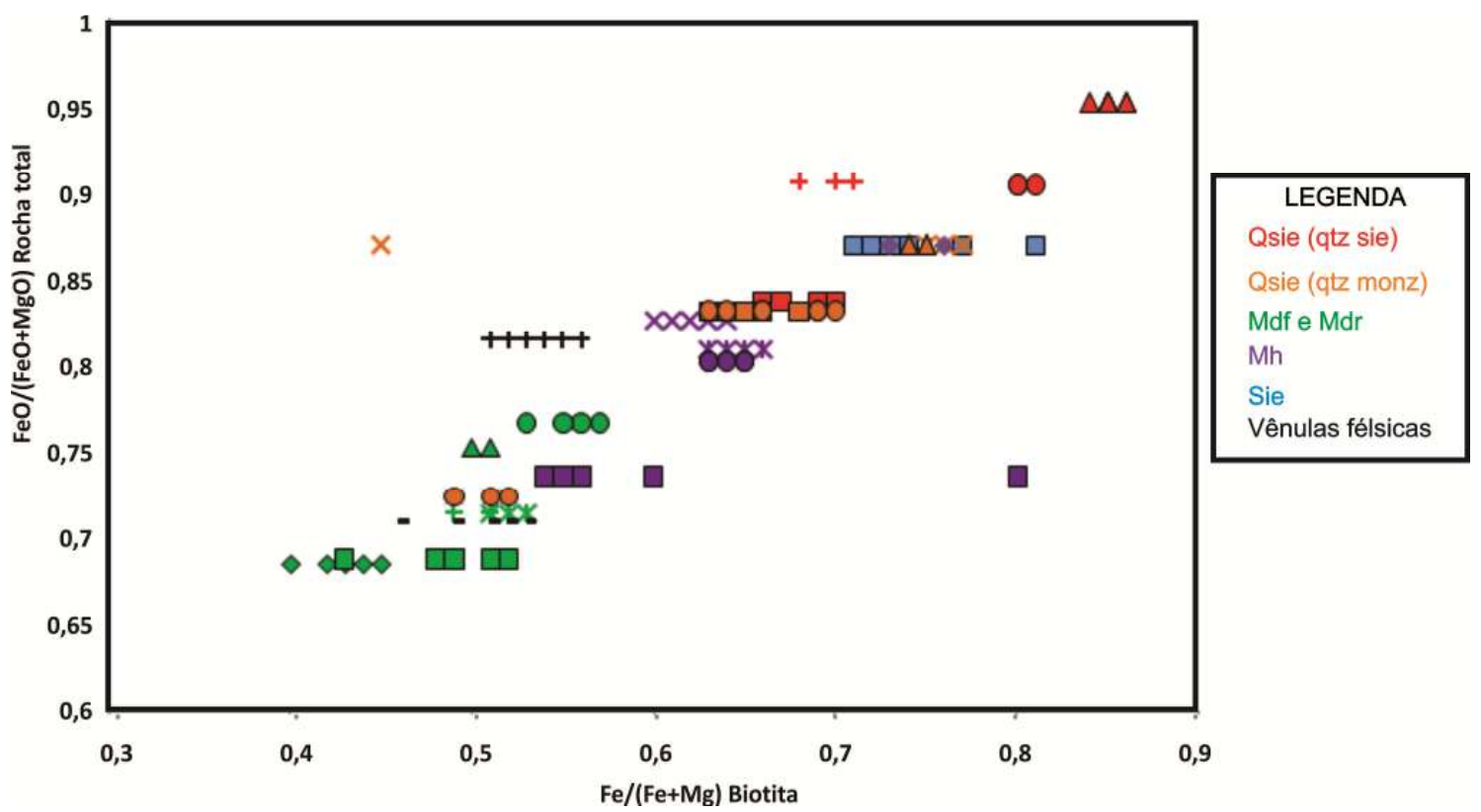

Figura 55. Comparação entre as razões $\mathrm{FeO} /(\mathrm{FeO}+\mathrm{MgO})$ de rocha total e as razões $\mathrm{Fe} /(\mathrm{Fe}+\mathrm{Mg})$ das biotitas das diferentes unidades que compõem o Plúton Piracaia. 


\section{CAPÍTULO IV - EVIDÊNCIAS DE PROCESSOS DE MISTURA DE MAGMAS}

O Plúton Piracaia, composto por cinco diferentes unidades, apresenta diversas feições que evidenciam a contemporaneidade e interação de magmas composicionalmente distintos.

\subsection{Evidências de Campo}

\subsubsection{Interação entre Mdf e Qsie}

Os $M d f$ representam a unidade de maior expressão no plúton e é ao longo das bordas do corpo central de $M d f$, próximos ao contato com as duas ocorrências de Qsie, que são mais abundantes as feições indicativas de contemporaneidade e interação entre os magmas.

\subsubsection{Sul do corpo central de $M d f$}

As estruturas que evidenciam contemporaneidade são representadas por interdigitação entre monzodioritos e quartzo sienitos, caracterizando processos de mistura heterogênea, em escala métrica a decamétrica, Observa-se também, embora de modo menos abundante, a presença de enxames de enclaves e pillows de composição monzodioriorítica invadindo quartzo monzonitos. Um exemplo é o ponto PI-624, onde ocorrem diversos matacões com enclaves centimétricos e pillows decimétricas imersos em quartzo monzonitos (Figura 56A). Os enclaves e pillows por vezes encontram-se estirados, porém raramente se observam feições de fragmentação e mistura com o quartzo monzonito. Entretanto, em muitos matacões que não apresentam enclaves ou pillows o conteúdo de minerais máficos da matriz do quartzo monzonito é mais elevado que o comum, conferindo à rocha um IC da ordem de 20-25, mais alto que o típico desta unidade.

\subsubsection{Oeste do corpo central de $M d f$}

No extremo oeste da unidade de $M d f$ encontra-se outra ocorrência de quartzo monzonitos, onde Janasi (1986) tentativamente delineou um pequeno corpo mapeável. Nesta porção comumente encontram-se rochas que apresentam cristais de feldspato alcalino milimétricos, idiomórficos, imersos em uma matriz máfica (IC 20), com textura equigranular fina (Figura 56B). A distribuição dos cristais de feldspato alcalino é irregular, e por vezes encontram-se esparsos cristais imersos em uma rocha que modalmente classifica-se como monzodiorito. Contudo, nas porções onde o feldspato alcalino é mais abundante (até 40\%), as rochas se assemelham aos quartzo monzonitos encontrados próximo ao contato entre $M d f$ e $Q$ sie no sul do plúton. Nestes locais a biotita é o mineral máfico principal e hornblenda não ocorre. 

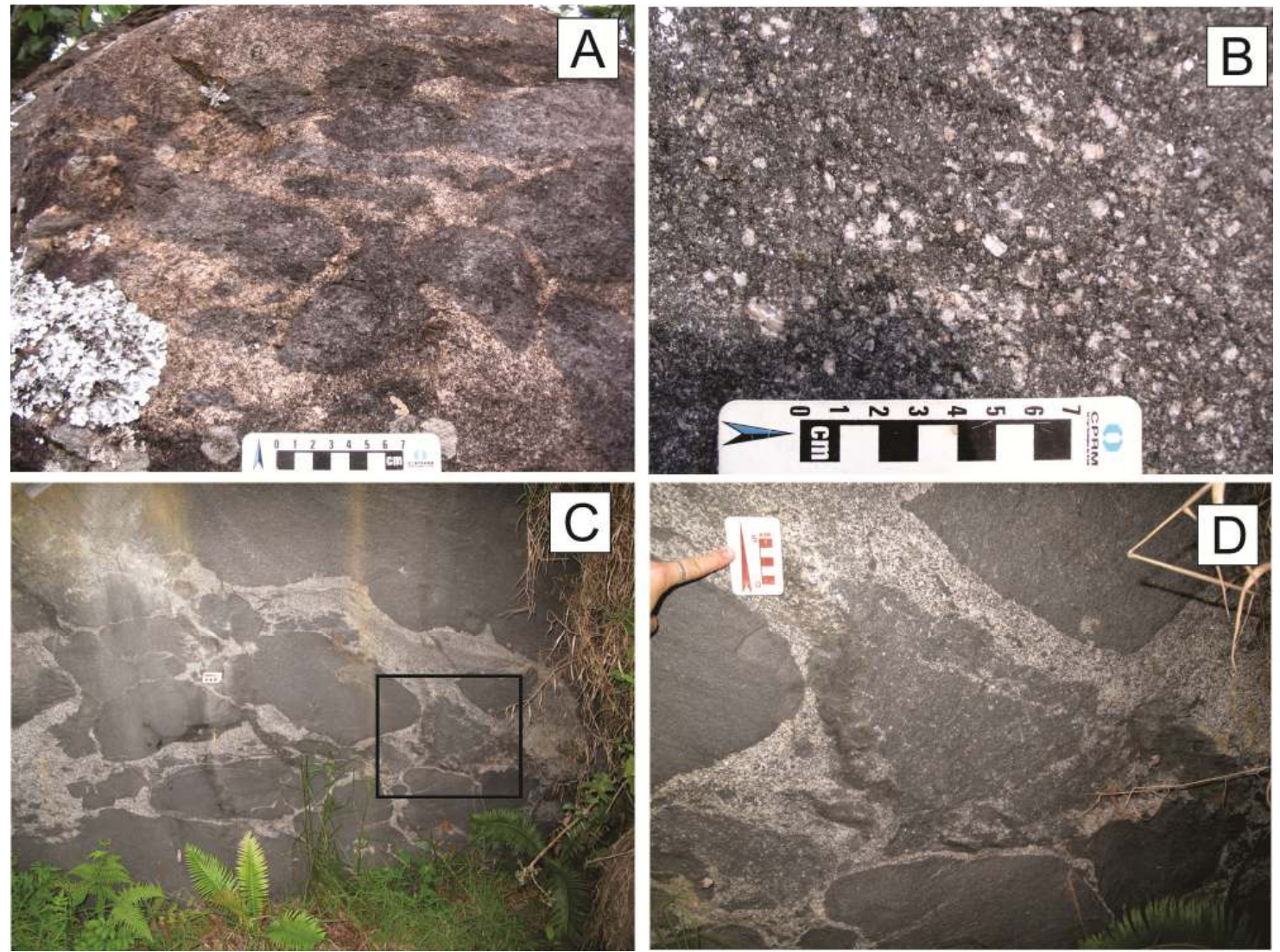

Figura 56. Evidências de mistura heterogênea entre as unidades Mdf e Qsie. (A) Pillows e enclaves monzodioríticos imersos em quartzo monzonito, no contato sul entre Mdf e Qsie (PI-624); (B) cristais idiomórficos de feldspato alcalino dispersos em matriz monzodiorítica, no extremo oeste da unidade $M d f$ (PI545); (C) pillows monzodioríticas circundadas por material félsico híbrido, evidenciado pela variação no conteúdo de máficos (PI-551); (D) detalhe da foto C, mostrando a íntima associação espacial entre pillows com forte contraste reológico. Na porção central da foto observa-se pillow com contatos irregulares, fragmentando-se parcialmente, cercada de pillows com contatos bem definidos e abruptos.

\subsubsection{Norte e nordeste da unidade $M d f$}

É nas porções norte e nordeste que se encontram as mais belas e o maior número de feições de interação entre $M d f$ e $Q$ sie. É difícil afirmar se nestas porções a interação entre os magmas foi de fato mais intensa, ou se simplesmente a qualidade e número de exposições é maior. O fato é que nesta área ocorrem inúmeros matacões cortados, resquícios de antigas pedreiras artesanais, que por serem cortados salientam e facilitam a visualização das diversas estruturas. É nesta porção que se situa também a Pedreira de Piracaia, ainda em atividade e que apresenta cortes extensos que expõem belas estruturas.

\subsection{Pillows monzodioríticas}

É comum no extremo norte da unidade central de $M d f$, a existência de pillows de composição monzodiorítica, similares às descritas no contato sul entre $M d f$ e Qsie. Contudo, observam-se diferenças em alguns aspectos importantes, (i.e. dimensão, forma, distribuição). No norte-nordeste as pillows atingem dimensões decimétricas a métricas e em geral ocorrem circundadas por material 
félsico, que nunca atinge espessura maior que $50 \mathrm{~cm}$. Por vezes observa-se um grande número de pillows intimamente associadas, com pouco material félsico ocupando os interstícios entre as mesmas. Nestas circunstâncias, as pillows tendem a apresentar-se empilhadas e achatadas (Figura 57). O material félsico mais comumente apresenta composição quartzo sienítica a quartzo monzonítica, porém varia também para composições monzoníticas e sienitíticas, que apresentam evidências de mistura com os monzodioritos (ver item 4.1.1.3.2)
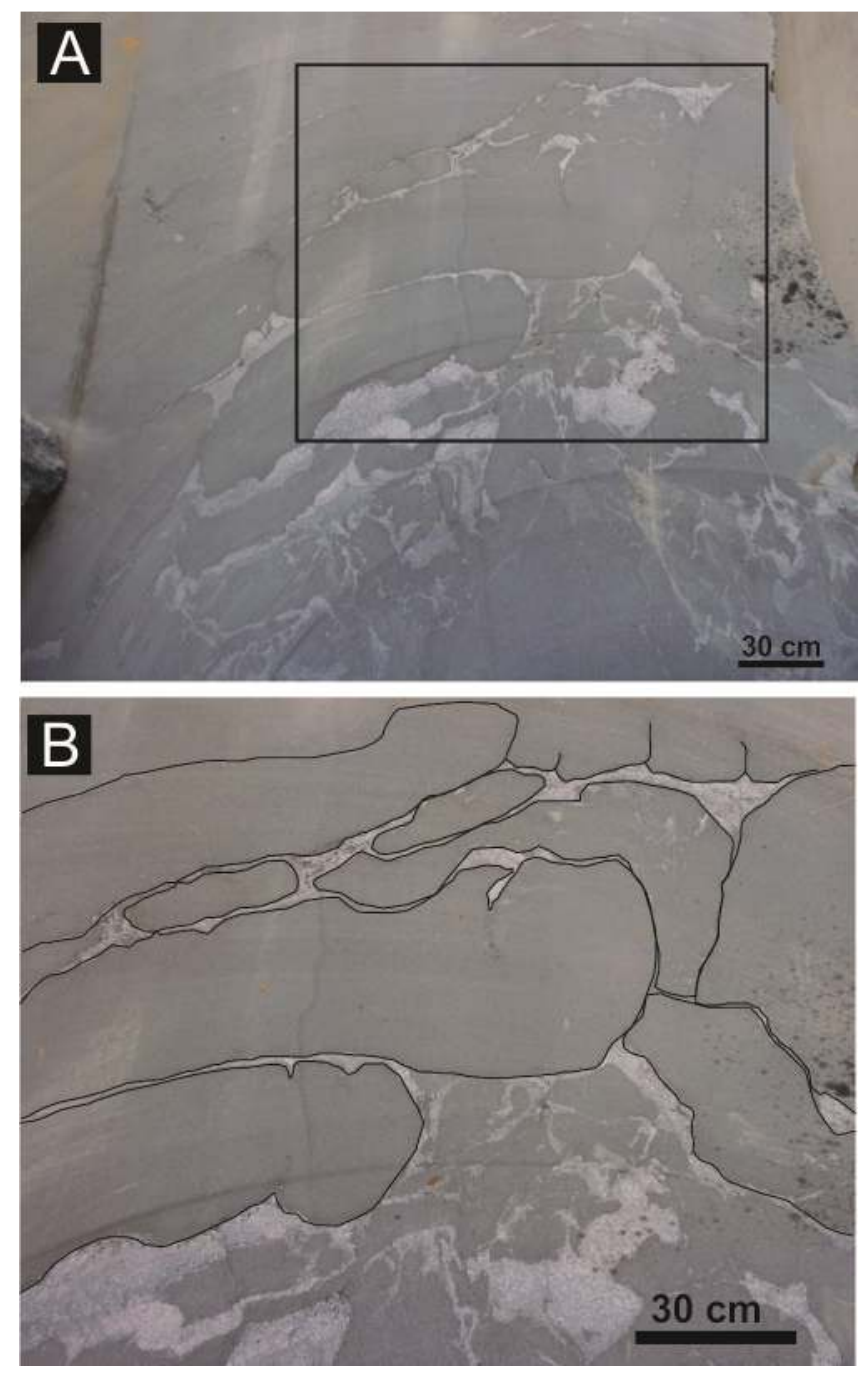

Figura 57. (A) e (B) Pillows monzodioríticas empilhadas e achatadas, circundadas por rochas félsicas híbridas, próximas ao contato entre $M d f$ e $Q s i e$. (B) é uma foto de detalhe da foto (A), correspondendo à área do retângulo, onde delineou-se o formato das pillows, visando destacá-las.

Feições semelhantes são descritas em diversos plútons, de contextos tectônicos distintos (Wiebe, 1988; Wiebe et al., 2001; Turnbull et al., 2010). Os autores as consideram diagnósticas de câmaras magmáticas félsicas em cristalização invadidas por pulsos de magma máfico. De acordo com o modelo, o contraste reológico dificulta a atuação de processos de mistura efetivos e favorece fragmentação do magma máfico sob a forma de pillows e enclaves. Considerando ainda sua maior 
densidade, o magma máfico tende a acumular-se na base da câmara, causando o empilhamento e achatamento das pillows por sobrecarga.

No ponto PI-551, localizado aproximadamente $100 \mathrm{~m}$ a norte da Pedreira, encontram-se grandes matacões, onde também são observadas pillows monzodioríticas em abundância. Embora tenham as mesmas dimensões das descritas na Pedreira, neste afloramento fica mais clara a existência de pillows muito próximas que exibem grandes contrastes reológicos entre si.

$\mathrm{Na}$ Figura 56C e D encontram-se lado a lado uma pillow típica, apresentando bordas arredondadas, porém com contatos abruptos, e uma pillow com contatos difusos e parcialmente fragmentada, misturando-se com o material félsico inter-pillow. Observa-se também que o próprio material félsico apresenta-se heterogêneo, com bandas onde o conteúdo de minerais máficos é marcadamente maior.

Existem duas hipóteses para a origem destas feições. A primeira é a de que ocorreram múltiplos pulsos de magma monzodiorítico e que as pillows com diferenças reológicas representam pulsos distintos. A segunda é a de que em uma câmara magmática composta por magmas de composição distinta e dinamicamente ativa, o processo de mistura/interação não é homogêneo. A existência de correntes de convecção ou simplesmente o fluxo magmático poderia colocar lado a lado pillows que tenham interagido em diferentes graus com o magma félsico residente na câmara. $\mathrm{O}$ mesmo raciocínio pode ser estendido para o material félsico existente entre as pillows, de modo que a existência de múltiplos pulsos não se faz necessária.

\subsection{Venulações félsicas}

Como discutido nos itens 2.1.2 e 4.1.1.3.2, a unidade $M d f$ apresenta abundantes venulações centimétrias félsicas, sendo por vezes cortada pelas mesmas. As melhores exposições são encontradas na porção norte da ocorrência central de $M d f$, em especial a Pedreira de Piracaia, onde observa-se uma grande diversidade estrutural e textural (Figura 58). Aleatoriamente distribuídas e composicionalmente compreendendo monzonitos, quartzo monzonitos, sienitos e quartzo sienitos, as vênulas apresentam diversos contrastes reológicos em relação aos monzodioritos hospedeiros. Os contatos podem ser retos e abruptos; ou irregulares e até mesmo gradacionais.

Estas venulações foram mais recentemente estudadas por Salmoni (2007), Oliveira (2009) e Pressi et al. (2010), que buscaram compreender os processos envolvidos na sua gênese. A aparente falta de conexão com corpos maiores de quartzo sienito e a maior semelhança composicional dos cristais de hornblenda com os presentes em $M d f$ em relação aos da unidade Qsie, levaram Janasi (1986) e Salmoni (2007) a atribuir a gênese das vênulas a processos de segregação in situ (filter pressing). 

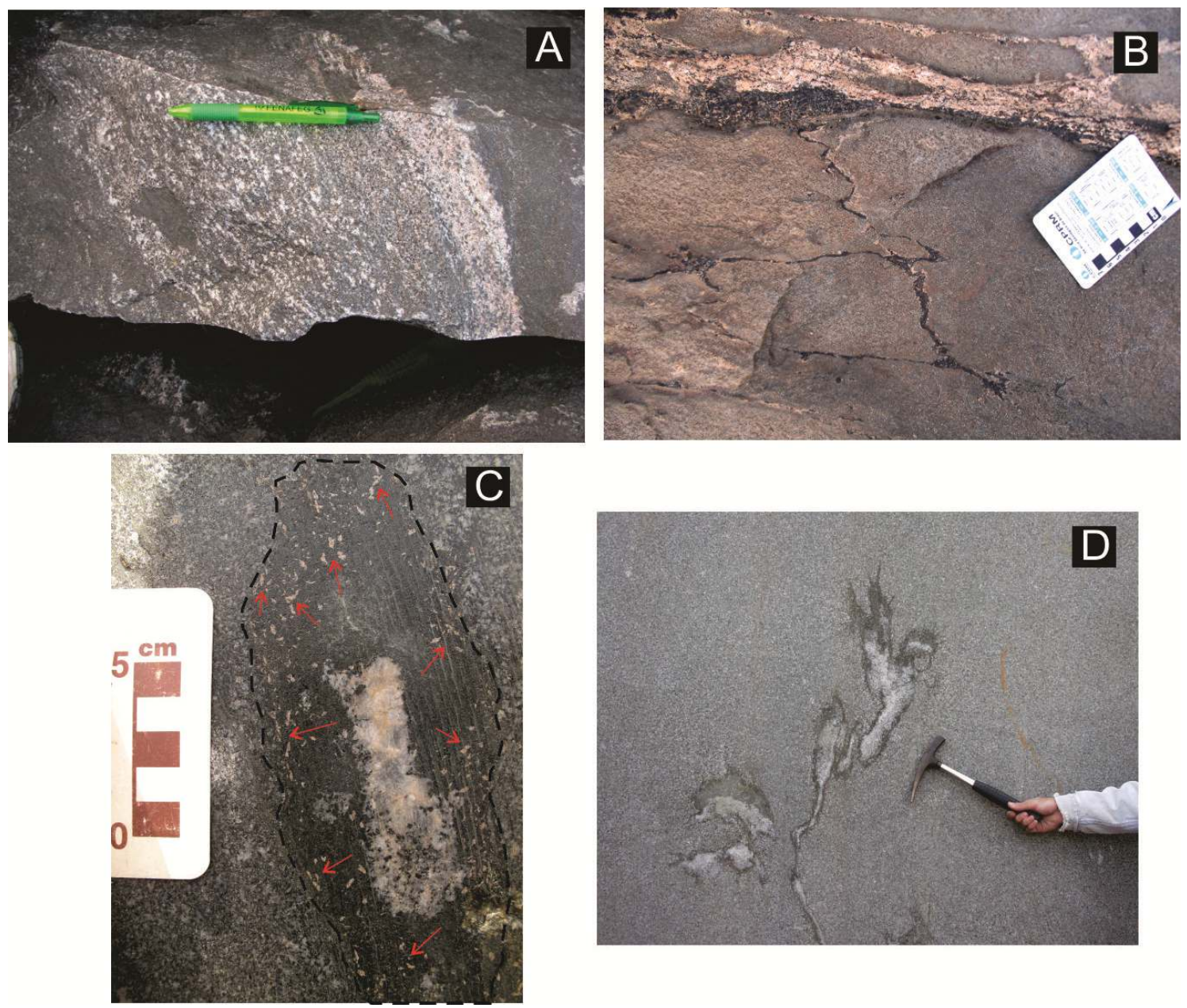

Figura 58. Heterogeneidades texturais das vênulas félsicas contidas na unidade $M d f$ : (A) vênula apresentando contatos abrupto e gradacional. No lado direito da foto, junto ao contato abrupto, a vênula tem composição quartzo sienítica, que grada para quartzo monzonitos e novamente para monzodioritos em direção ao lado direito da foto; (B) vênula quartzo sienítica com abundantes cristais de hornblenda, que formando concentrações centimétricas; (C) vênula félsica delineada pela linha tracejada, muito rica em cristais de hornblenda e titanita. As setas vermelhas indicam a localização de algumas zonas ricas em cristais de titanita, que tendem a circundar as porções externas da vênula. Salienta-se também a textura grossa apresentada pela porção quartzo sienítica situada na porção central; (D) vênulas félsicas caracterizando estrutura em chama (flame-like), com concentração de hornblenda em sua porção superior. As fotos (A), (C) e (D) correspondem a estruturas encontradas na Pedreira de Piracaia, enquanto a foto (B) refere-se ao ponto PI-546.

Oliveira (2009) e Pressi et al. (2010) sugerem a hipótese de mistura de magmas, ao descreverem as variações texturais e composicionais existentes nas venulações com contatos gradacionais. Observou-se que nestes casos um dos contatos apresenta-se abrupto e o outro gradacional. Esta assimetria nos contatos é acompanhada pela mudança na composição das vênulas, que transicionam de quartzo sienitos ou sienitos com quartzo, tornando-se progressivamente mais máficos e ricos em plagioclásio, até que se atinja a composição monzodiorítica típica da unidade $M d f$ (Figura 58A). Wiebe \& Collins (1998) e Bateman (1995) observam feições similares em diferentes escalas, relacionadas a eventos de repreenchimento de câmaras félsicas por magmas máficos. As porções inferiores do magma máfico, seja este caracterizado por pillows ou lentes, tendem a resfriar-se 
rapidamente em contato com o magma residente na câmara. Já as porções superiores tendem a interagir mais fortemente com o magma félsico, durante o assentamento gravitacional. Quanto maior o volume de magma máfico envolvido no processo maior a interação, uma vez que as porções internas podem sofrer processos de diferenciação in situ, o que facilita o processo de interação com o magma félsico, devido ao menor contraste composicional. Este processo caracterizaria, portanto, uma assimetria entre contatos superiores, abruptos, e inferiores, gradacionais.

Outra característica importante apresentada pelas venulações se relaciona à cristalização de grandes cristais idiomórficos de hornblenda, e em menor quantidade também titanita, que podem ocorrer de forma concentrada (Figura 58B), por vezes formando agregados onde juntos ocupam até 90\% das vênulas (Figura 58C). Em alguns casos observa-se que os cristais de hornblenda tendem a ocorrer no contato superior entre o material félsico e as pillows monzodioríticas, por vezes projetandose para o interior das mesmas, em associação a estruturas do tipo chama (flame-like) (Figura 58D). Tal feição também é observada por outros autores, onde a formação destes cristais é atribuída ao escape de voláteis do magma félsico e reação na interface com o magma máfico (Turnbull et al., 2010).

\subsection{Lentes sieníticas}

Distante aproximadamente $550 \mathrm{~m}$ a sudeste da pedreira, e junto ao contato NE entre $M d f$ e o corpo de quartzo sienitos (Qsie), encontra-se o afloramento de maior dimensão de todo o plúton (PI546), um lajeado que ocupa uma área de aproximadamente 125 × $200 \mathrm{~m}$. Muitas das estruturas descritas na Pedreira de Piracaia estão também presentes neste afloramento, como pillows monzodioríticas e abundantes venulações félsicas à quais podem estar associadas concentrações de cristais de hornblenda idiomórfica.

A proporção de magma quartzo sienítico parece ter sido maior, possivelmente pela proximidade do contato com a unidade Qsie. No afloramento encontram-se pelo menos três lentes de quartzo sienito em meio a $M d f$, medindo entre 1,5 e $2 \mathrm{~m}$ de espessura, e orientadas segundo a foliação. Estas lentes apresentam assimetria entre seus contatos, de modo similar ao observado nas venulações da Pedreira, onde um apresenta-se abrupto e o outro gradacional. Contudo, é difícil identificar a terminação da lente onde o contato é gradacional, assim como não fica clara a transição composicional entre quartzo sienito, quartzo monzonito e monzodiorito, em parte porque a superfície "suja" do lajeado dificulta a visualização das estruturas. Ainda assim, observa-se que o quartzo sienito apresenta pillows monzodioríticas e grande quantidade de enclaves máficos, estes últimos fortemente estirados e fragmentados, misturando-se à matriz (Figura 59). 


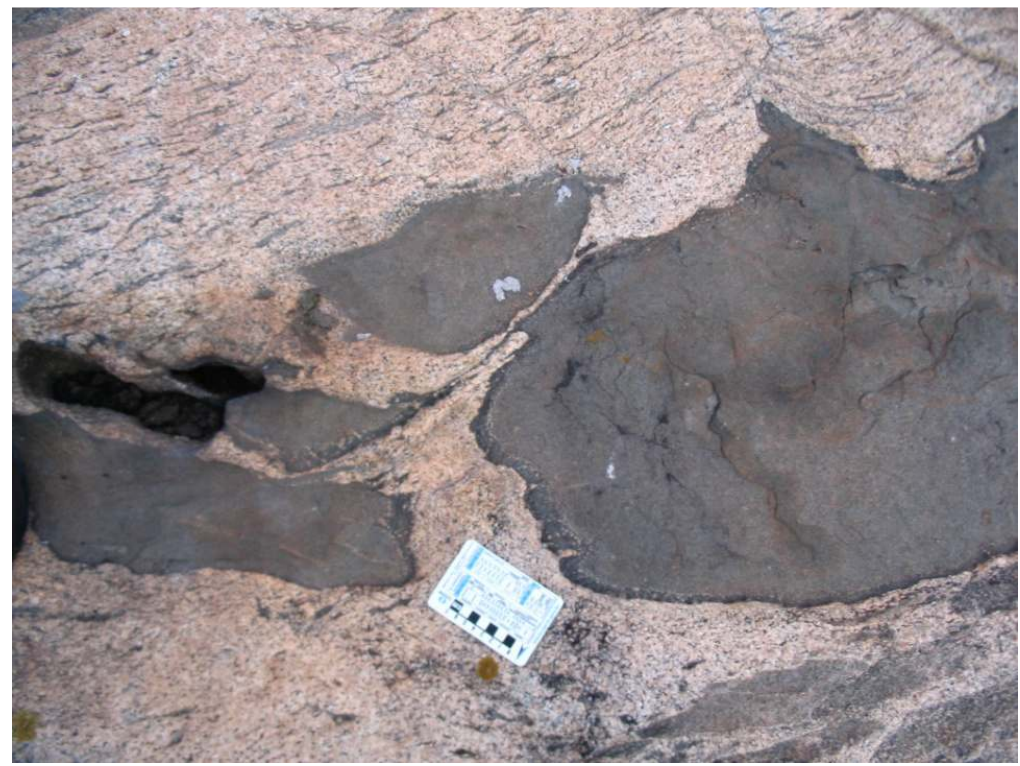

Figura 59. Pillows monzodioríticas em meio à lente métrica de quartzo sienito (Qsie). Nota-se que as pillows assimilam pequenas "gotas" de quartzo sienito próximo ao contato. O quartzo sienito, por sua vez, apresenta inúmeros enclaves máficos, fortemente estirados e assimilados (PI-546).

$\mathrm{Na}$ Figura 60 apresenta-se uma das lentes de quartzo sienito. Na foto pode-se visualizar apenas a extremidade da lente que apresenta contato abrupto com o monzodiorito (porção inferior da lente na foto). Ainda assim, a irregularidade do contato e a presença de algumas pilllows na interface, evidenciam a interação dos magmas em estado plástico (Figura 60 C).

Na Figura 60 observa-se também a existência de vênulas de pequena espessura $(<5 \mathrm{~cm})$, cuja proximidade e orientação similar por vezes caracterizam "enxames de vênulas". Estes enxames podem ser cortados por vênulas de maior espessura, evidenciando mais de um evento de geração de vênulas félsicas (Figura 60 B e E).

Observam-se ainda diversas falhas, que deslocam algumas vênulas enquanto outras próximas mantêm-se intactas, evidenciando seu caráter sin-plutônico (Figura 60 B e D) Estas falhas apresentam orientação aproximada 090/76, dispondo-se praticamente perpendiculares ao plano de foliação principal das rochas, e são também encontradas em outros pontos da unidade $M d f$.

Duas gerações de venulações félsicas são observadas também no ponto PI-598. A primeira delas corresponde a vênulas com no máximo $5 \mathrm{~cm}$ de espessura, pouco espaçadas entre si, e com contatos irregulares com o monzodiorito. O segundo tipo refere-se a vênulas espessas, de até $20 \mathrm{~cm}$ de espessura, com contatos retos com o monzodiorito, e que corta as do primeiro tipo. 

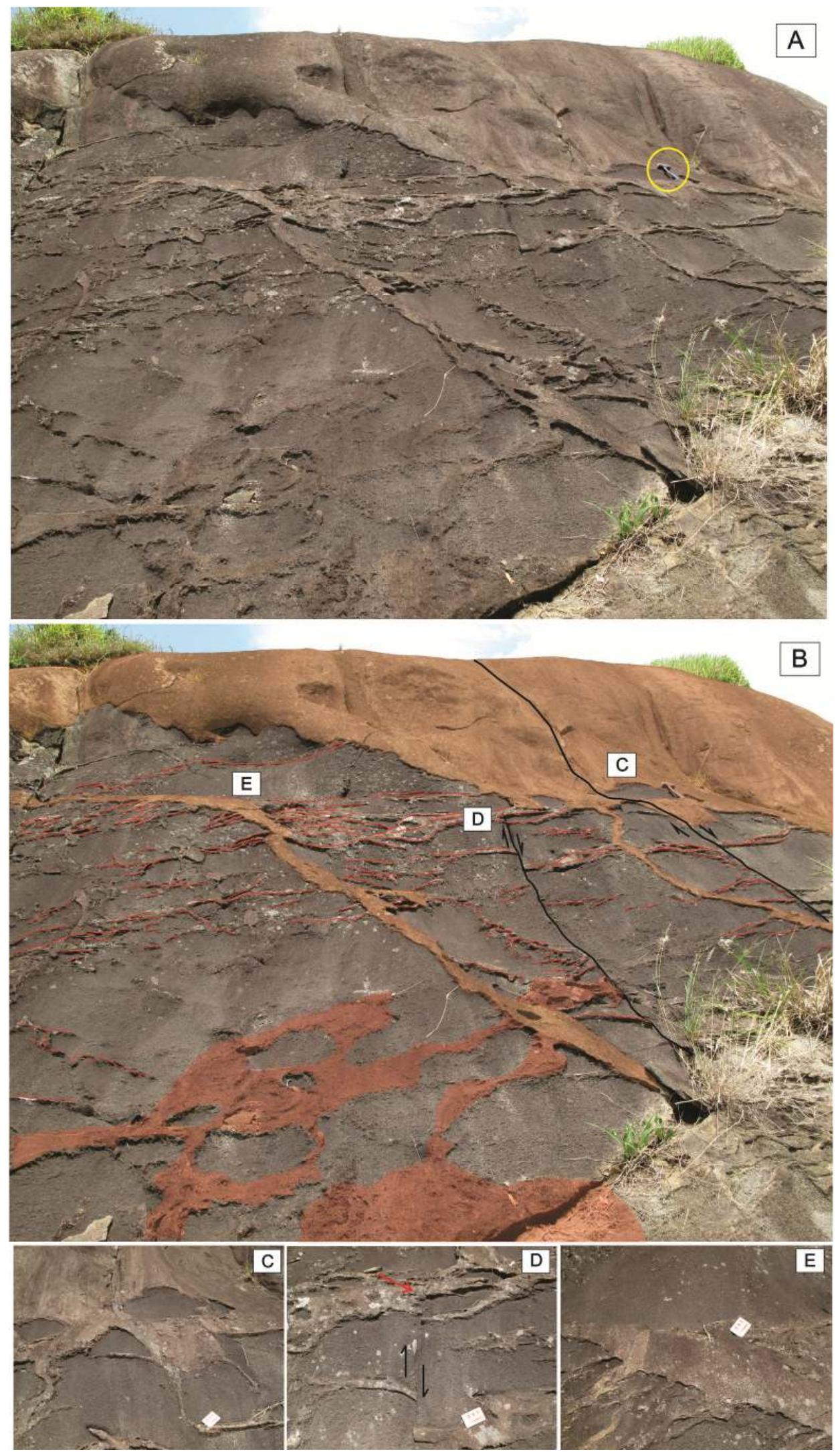

Figura 60. Lente quartzo sienítica próximo ao contato entre $M d f$ e $Q$ sie, na porção NE do plúton (PI-546). Notar a marreta $(\sim 30 \mathrm{~cm})$ como escala. As fotos C, D e E mostram detalhes do afloramento. (C) mostra pillows no contato entre a lente quartzo sienítica e o monzodiorito. O contato é abrupto, porém irregular-; (D) salienta a existência de falhas sin-plutônicas afetando parte do conjunto. A seta vermelha aponta vênulas não deslocadas pela falha; (E) mostra duas gerações de vênulas félsicas de diferentes espessuras se entrecortando. 


\subsubsection{Extremo NW do plúton}

No extremo NW do plúton, entre a unidade $M h$ e as encaixantes, ocorre um estreito corpo de $M d f$ com $200 \mathrm{~m}$ de espessura por aproximadamente $3 \mathrm{~km}$ de comprimento. Nesta porção ocorre intensa interdigitação entre $M d f$ e $Q$ sie, onde pillows monzodioríticas e vênulas quartzo sieníticas são abundantes (Figura 61A). As pillows ocorrem fortemente achatadas e estiradas segundo a foliação, adquirindo formato lenticular com proporção 5:1 (Figura 62). As vênulas quartzo sieníticas também apresentam estiramento e fragmentação, porém não ocorre mistura entre $Q$ sie e $M d f$. São comuns também vênulas dobradas, evidenciando sentido de movimento lateral direito (Figura 61B e C).

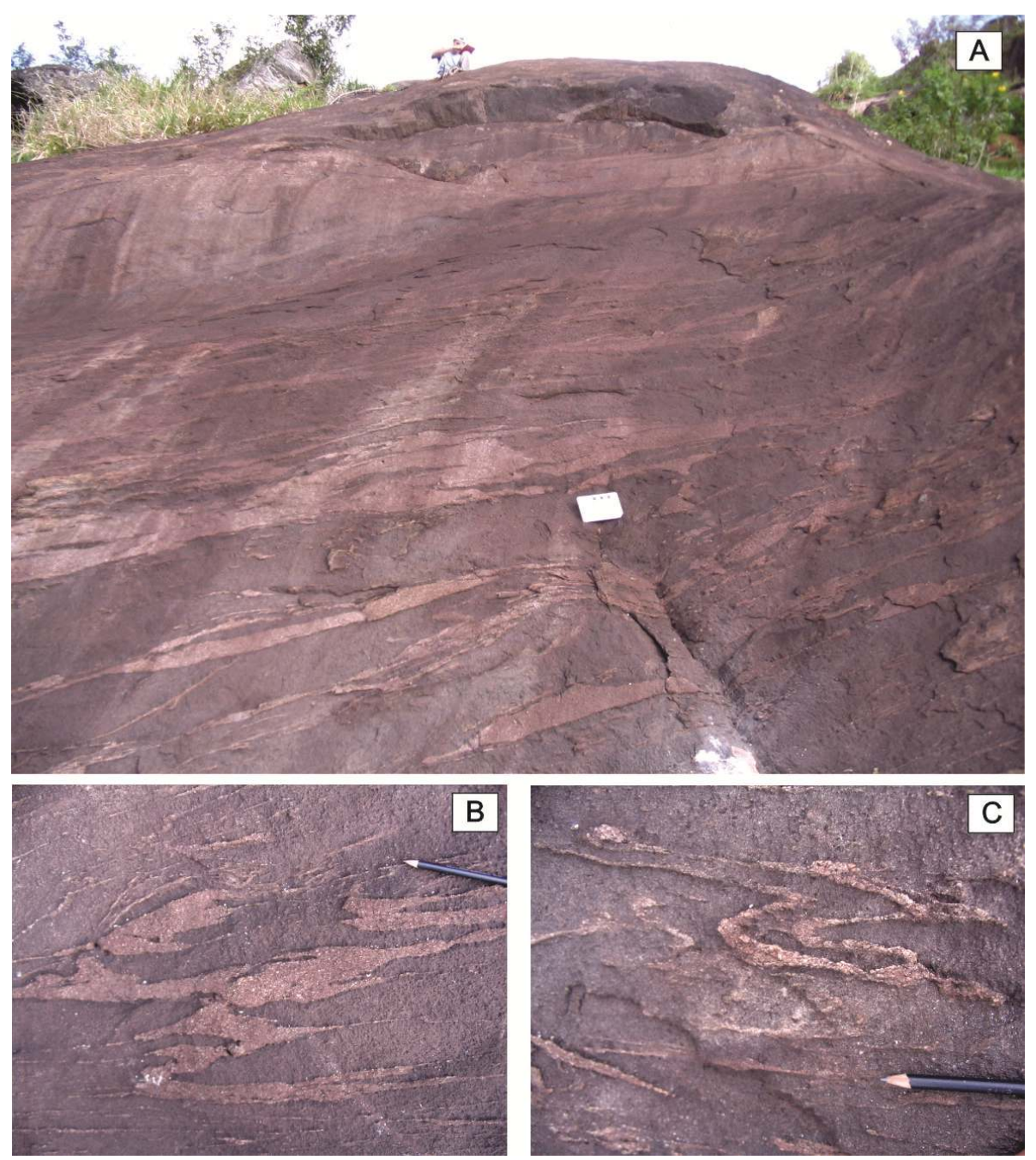

Figura 61. Interdigitação entre $Q$ sie e $M d f$ no extremo NW do plúton (PI-515). As fotos B e C mostram detalhes do afloramento (foto A), evidenciando o estiramento e fragmentação do quartzo sienito. A existência de dobras assimétricas sugere sentido de movimento lateral direito e demonstra a atuação de campo tensional durante o alojamento dos magmas. 


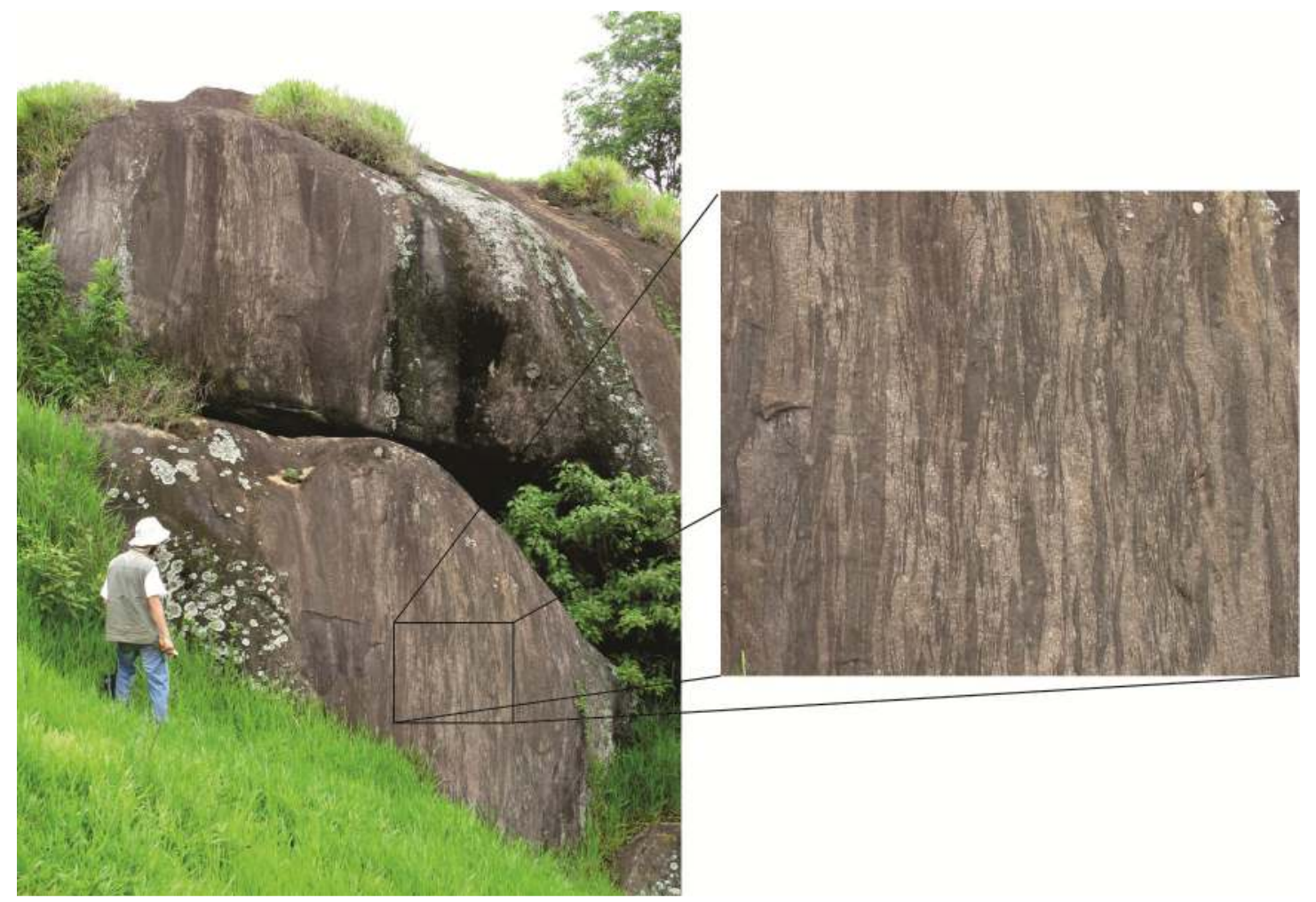

Figura 62. Pillows monzodioríticas fortemente achatadas, adquirindo formato lenticular (PI-515) situadas no extremo NW do plúton.

\subsubsection{Textura titanita-ocelar}

$\mathrm{Na}$ Pedreira de Piracaia e também a norte dela, encontram-se alguns matacões de monzodiorito com textura peculiar. Neles, o monzodiorito apresenta matriz com textura equigranular fina característica, porém contém inúmeros bolsões félsicos com cristais individuais de titanita em seu centro (Figura 63). Os bolsões variam entre 2 e $5 \mathrm{~mm}$ e podem representar até $15 \%$ da rocha. A titanita é geralmente subédrica ou euédrica e por vezes ocorrem cristais de hornblenda associados. Esta textura é descrita por Hibbard (1991) e interpretada como o produto de eventos sucessivos de mistura de magmas. A formação os bolsões com titanita em seu centro representaria um primeiro estágio de interação entre magmas máficos e félsicos e uma posterior recarga de magma máfico na câmara dispersaria os bolsões, deixando-os imersos em uma matriz máfica. 


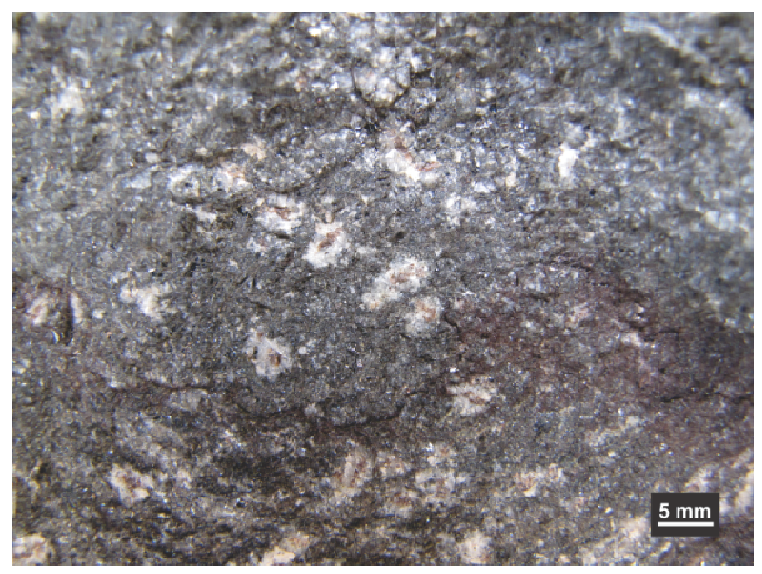

Figura 63. Bolsões félsicos em monzodioritos (Mdf), com cristais idiomórficos de titanita em seu centro, caracterizando a textura titanita-ocelar, que segundo Hibbard (1991) é gerada por sucessivos eventos de mistura de magmas (PI-500).

\subsubsection{Monzonitos heterogêneos $(M h)$}

As características típicas desta unidade, apresentadas nos itens 2.1.4 e 2.2.3, evidenciam processos de mistura heterogêneos entre $M d f$ e Sie. A matriz fina, de composição monzodiorítica, assim como os antecristais tabulares de plagioclásio, são típicos de $M d f$. Já os bolsões félsicos, de composição sienítica e isentos de quartzo, assim como a presença de allanita, são típicos de Sie. Por outro lado, a formação dos grandes cristais e agregados de hornblenda pode ser atribuída à interação entre os magmas.

A identificação macroscópica de $M h$ é relativamente fácil quando a presença de bolsões sieníticos é abundante, uma vez que eles contrastam com a matriz fina, monzodiorítica. Contudo, a distribuição destes bolsões não é homogênea, o que reflete variações nas proporções de mistura entre os magmas sienítico e monzodiorítico. É comum inclusive haver variações de distribuição de bolsões sieníticos em um mesmo afloramento. Em locais onde os bolsões são pouco abundantes, a textura equigranular fina e o aspecto macroscopicamente homogêneo das rochas as tornam parecidas com os monzodioritos da unidade $M d f$. Contudo, a susceptibilidade magnética, que é caracteristicamente baixa em $M h$, pode auxiliar na distinção.

\subsubsection{NW da unidade $M d f$}

Em um único ponto (PI-512) localizado próximo ao contato NW entre $M d f$ e $M h$ são encontrados indícios de interação entre magmas da unidade Sie em Mh. O afloramento é composto por alguns matacões de dimensões métricas, resquícios de antiga atividade de extração artesanal para rocha ornamental, onde monzonitos típicos da unidade $M h$ ocorrem interdigitados com sienitos da unidade Sie (Figura 64). Alternam-se porções onde as rochas apresentam contato abrupto e locais onde ocorrem estruturas indicativas de processos de mistura predominantemente heterogêneo. Em alguns matacões observa-se ainda a presença de veios centimétricos de sienito, cortando $M h$. O estiramento e 
formato sigmoidal do veio evidenciam claramente sua intrusão em um estado ainda plástico de $M h$, assim como a atuação de um campo tensional sobre a câmara magmática, com um sentido de movimento lateral direito.
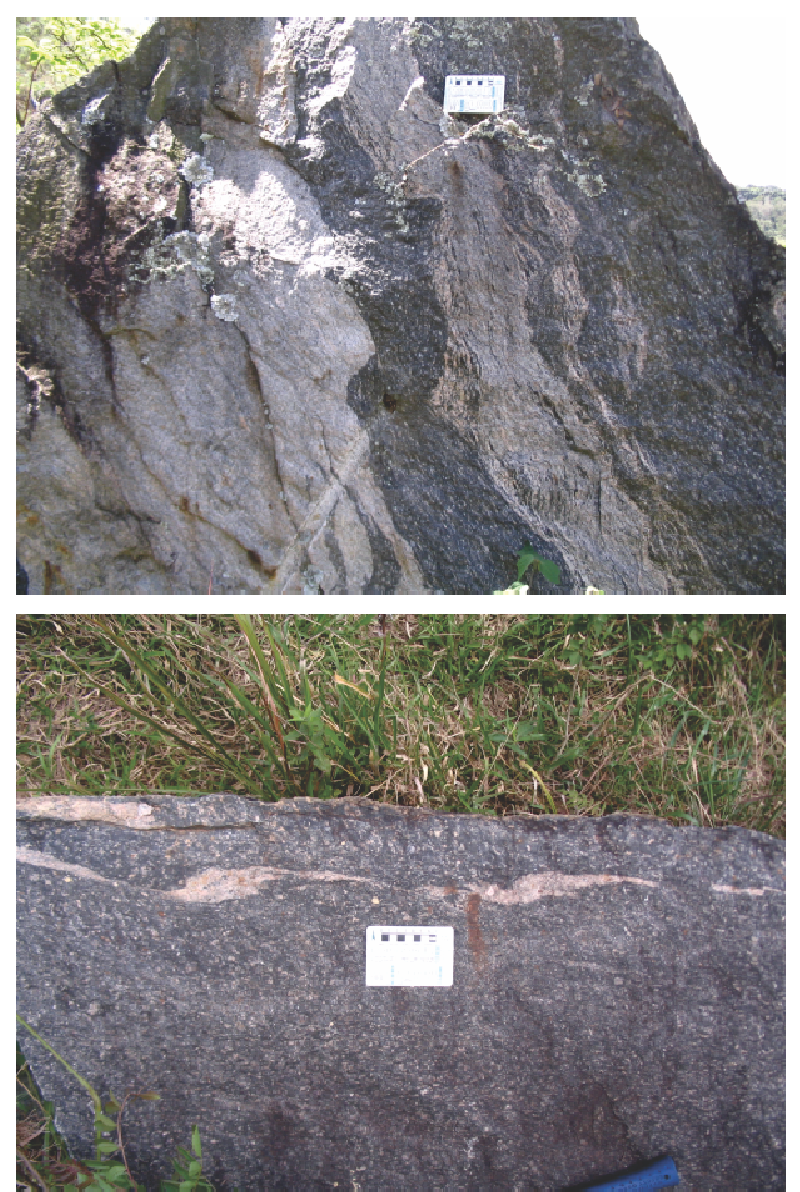

Figura 64. Evidências de interação entre $\mathrm{Mh}$ e Sie. Na foto A observa-se a heterogeneidade do processo de mistura, evidenciado pelas variações no IC e mistura heterogênea. Em B observa-se veio de sienito com formato sigmoidal, evidenciando maior contraste reológico entre os magmas (PI-512).

\subsubsection{Interação entre Mhe Qsie}

A unidade $M h$ é comumente cortada por veios centimétricos e lentes métricas de quartzo sienito. Os quartzo sienitos que formam as lentes representam as rochas mais diferenciadas da unidade Qsie. São leucocráticos (IC < 10) e relativamente ricos em quartzo. A textura é grossa, equigranular, e seus contatos com $M h$ são predominantemente retos e abruptos.

Já os veios podem apresentar contatos que refletem reologia variável. Em muitos locais os contatos são irregulares e por vezes os veios fragmentam-se e misturando-se heterogeneamente com $M h$, formando lentes e bolsões centimétricos de Qsie imersos em $M h$. Nestes casos a distinção macroscópica em relação às feições típicas de $M h$ é difícil ou mesmo impossível de ser feita. 


\subsection{Evidências petrográficas de mistura de magmas}

\subsubsection{Unidade $\mathrm{Mh}$}

As principais características da unidade, que são o contraste reológico entre os magmas, e a ocorrência de grandes cristais e agregados de cristais de hornblenda, já evidentes macroscopicamente, destacam-se ainda mais ao microscópio petrográfico. Em especial, se destaca a intensa interdigitação entre porções monzodioríticas e sieníticas, que normalmente atinge a escala milimétrica sem que os magmas percam suas propriedades mineralógicas e texturais.

A análise petrográfica salienta também algumas características da unidade que não são facilmente observadas macroscopicamente. Muitos dos antecristais de plagioclásio, que chegam a medir $1 \mathrm{~cm}$, são maiores dos que os tipicamente encontrados em $M d f$, e podem ser macroscopicamente confundidos com os bolsões sieníticos. (Figura 65A e B).

Ao microscópio salientam-se também os minerais acessórios. Titanita e allanita são os mais abundantes, e tendem a ocorrer como cristais subédricos a euédricos. Em casos raros, observam-se cristais de hornblenda que apresentam resquícios de clinopiroxênio em seu núcleo, evidenciando uma história pretérita de cristalização no magma monzodiorítico.

Nos locais onde as rochas apresentam menor abundância de bolsões félsicos e grandes cristais de hornblenda, a análise petrográfica mostra que o caráter heterogêneo do processo de mistura é mantido, uma vez que normalmente se distinguem áreas de predomínio textural félsico e máfico (Figura 65 C). Nas porções onde o processo de mistura é mais efetivo ou a proporção de $M d f$ é maior, o caráter híbrido da rocha é identificado pelo elevado conteúdo de feldspato alcalino e também pelos abundantes cristais de plagioclásio com baixo teor de An $(<10)$. Cristais e agregados de cristais de hornblenda, assim como allanita, embora menos abundantes, estão sempre presentes (Figura $65 \mathrm{~A} \mathrm{e}$ C).

\subsubsection{Interação com Qsie}

Considerando que a principal característica textural da unidade $M h$ é a presença de bolsões e lentes félsicas, nos casos onde a mistura entre $M h$ e veios de Qsie é mais intensa, somente ao microscópio é possível identificar este processo. A interação com Qsie é identificada principalmente pela presença de quartzo e pela textura, que passa a ser média a grossa (Figura 65D). Contudo, quartzo é sempre pouco abundante $(<7 \%)$ e intersticial. Por vezes observa-se também que os cristais de hornblenda de $M h$ apresentam núcleos parcialmente corroídos próximo ao contato com os veios quartzo sieníticos (Figura $65 \mathrm{E}$ ). 

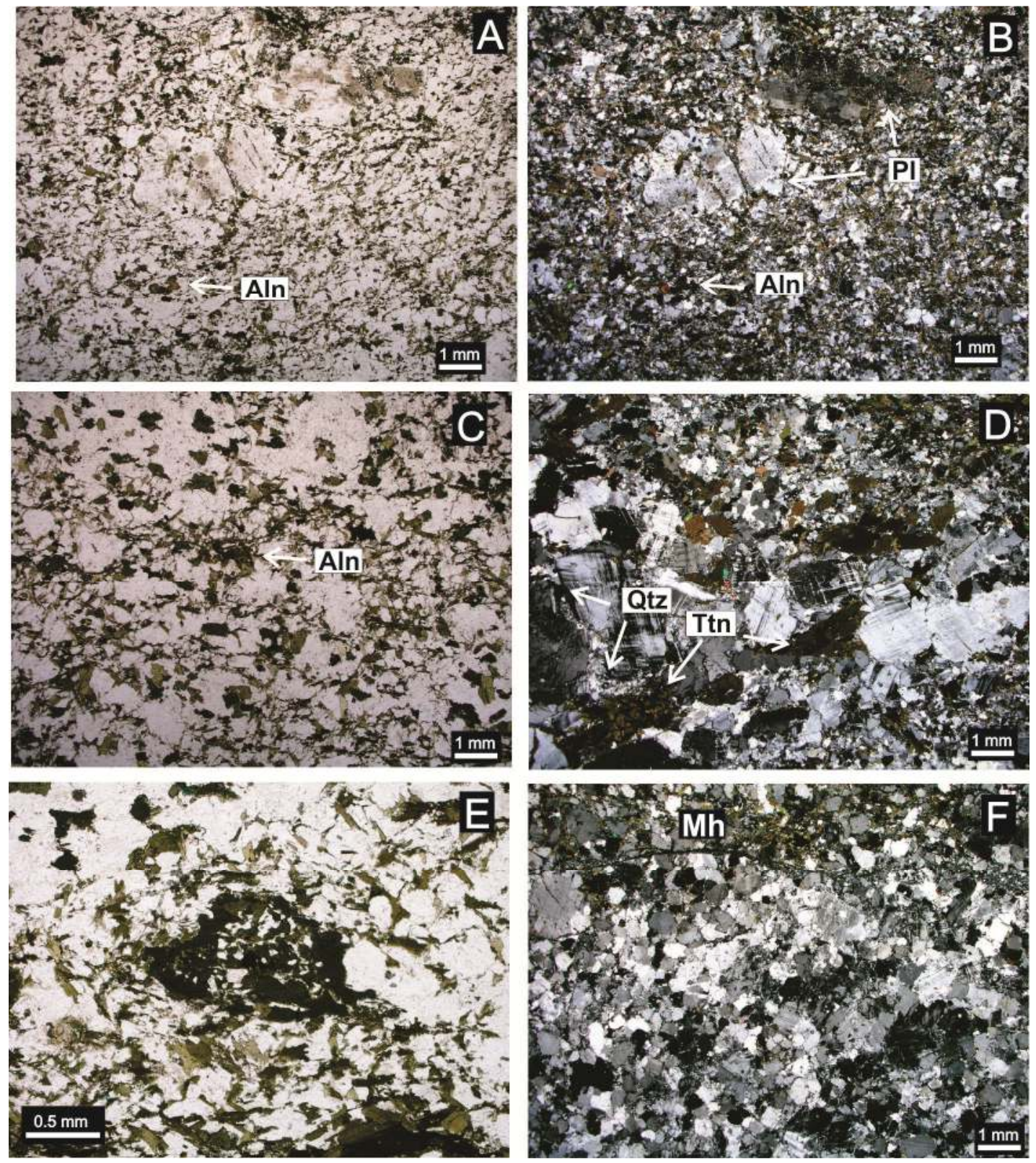

Figura 65. Fotomicrografias dos $M h$ menos heterogêneos: (A) e (B) $M h$ onde há predomínio de magma monzodiorítico, evidenciado pela elevado IC e presença de antecristais de plagioclásio. Evidências de mistura são marcadas pela abundância de feldspato alcalino na matriz, e pela presença de allanita (PI-532, polarizadores paralelos e cruzados, respectivamente); (C) $M h$ pobre em bolsões félsicos. Contudo, ainda se observa o contraste textural e composicional entre porções félsicas e máficas (PI-405, polarizadores paralelos); (D) $M h$ cortado por veio quartzo sienítico, que apresenta textura grossa, abundante titanita e quartzo intersticial (PI-534, polarizadores cruzados); (E) $M h$ com hornblenda com núcleo corroído próximo ao contato com a vênula quartzo sienítica da foto D, polarizadores paralelos; (F) veio sienítico cortando Mh ( PI-512, polarizadores cruzados. 


\subsubsection{Unidade Qsie}

Com relação ao corpo de quartzo monzonitos situados ao sul do plúton, e aos quartzo monzonitos que bordejam os quartzo sienitos da porção nordeste, diversas evidências apontam para uma origem híbrida. Embora sejam menos diversas quando comparadas à $M h$, estas evidências estão sempre presentes. Como discutido no item 2.1.3, nos quartzo monzonitos o plagioclásio é mais abundante quanto maior o IC. Esta correlação está diretamente associada à variação nas proporções relativas entre magmas monzodioríticos e quartzo sieníticos. Em alguns locais, mesmo os quartzo sienitos apresentam algumas feições que indicam uma pequena interação com magmas monzodioríticos.

Os quartzo monzonitos caracteristicamente apresentam inequigranular onde os minerais máficos tendem a formar agregados e se restringirem à matriz. Embora ocorra hornblenda em alguns pontos, o mais comum é que contenham apenas biotita. São abundantes as inclusões de apatita e zircão, sendo que este último que frequentemente forma halos pleocróicos (Figura 66C e D) A allanita, mineral acessório típico da unidade Qsie e abundante nos quartzo monzonitos, e ocorre aleatoriamente dispersa pela rocha, porém muitas vezes próxima aos agregados de máficos.

Nos quartzo monzonitos que contêm hornblenda, o IC é notadamente maior ( 20). Estas rochas apresentam um conteúdo elevado de grandes cristais de feldspato alcalino, cuja dimensão atinge $1,5 \mathrm{~cm}$. Se considerada apenas a matriz, onde os minerais máficos tendem a concentrar-se, o IC passa a $\sim 25-30$.

Próximo ao contato com a unidade $M d f$, os quartzo monzonitos podem apresentar textura inequigranular média a fina. A presença de cristais de feldspato alcalino idiomórficos de até $1 \mathrm{~cm}$ irregularmente distribuídos confere à rocha um caráter porfirítico incipiente (Figura 66A e B). Contudo, considerando que o conteúdo de plagioclásio se situa em torno de $30 \%$, pode-se assumir que estas são rochas onde a participação de magma monzodiorítico é maior. Deste modo, interpreta-se que os cristais maiores de feldspato alcalino não representariam fenocristais, mas cristais formados no magma quartzo sienítico, previamente ao evento de mistura. 

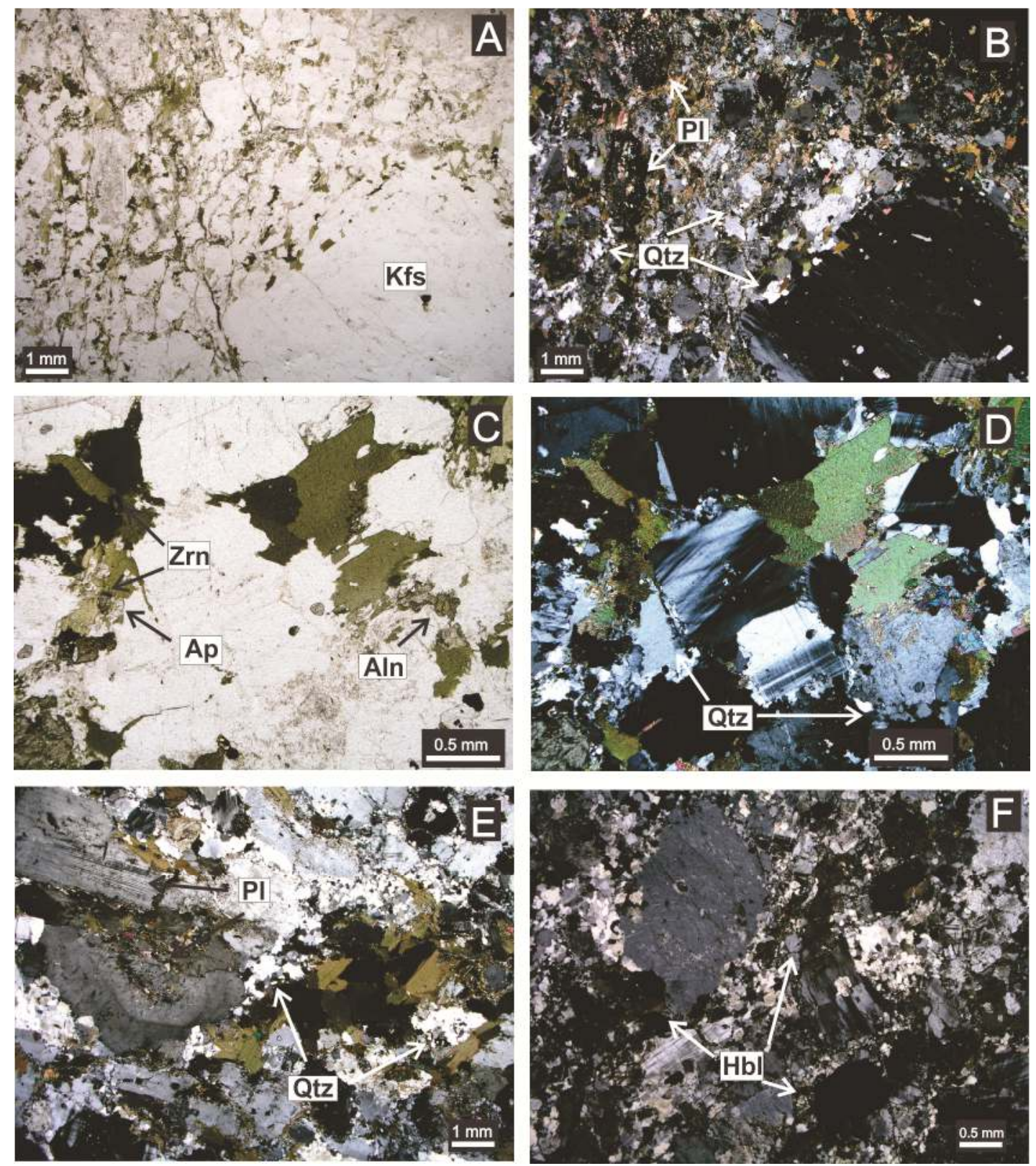

Figura 66. Heterogeneidades texturais presentes na unidade Qsie: (A) e (B) quartzo monzonito, com textura fina contendo antecristais de plagioclásio. Destaca-se a ocorrência de esparsos cristais de feldspato alcalino de grande dimensão (PI-537, polarizadores paralelos e cruzados, respectivamente); (C) e (D) agregados de biotita da matriz em quartzo monzonitos, com abundantes inclusões de zircão e apatita. Observam-se também cristais de allanita próximos (PI-582, polarizadores paralelos e cruzados, respectivamente); (E) quartzo monzonitos com cristais de plagioclásio, tabulares e zonados, situados próximos a agregados de biotita (PI-582, polarizadores cruzados); (F) quartzo sienito com abundantes cristais de hornblenda (PI-427, polarizadores cruzados). 
Outra característica importante é a presença de cristais de plagioclásio com composição oligoclásio-andesina, muitas vezes tabulares, geminados e zonados. Estes cristais se assemelham aos encontrados nas unidades $M d r, M d f$ e mesmo $M h$ (Figura 66E) e não são encontrados em quartzo sienitos, de modo que podem estar relacionados aos magmas monzodioríticos.

Algumas rochas quartzo sieníticas também apresentam evidências que podem estar relacionadas a processos de interação com $M d f$. Estas evidências referem-se essencialmente ao maior conteúdo de máficos, que pode chegar a 10\%, onde destaca-se a presença de hornblenda (Figura 66F). Os máficos tendem a formar agregados e restringirem-se à matriz, e assim como nos quartzo monzonitos, a biotita é o mineral máfico principal. Inclusões de apatita e zircão também são observadas, porém são menos abundantes.

\subsubsection{Unidade $M d f$}

No sul da ocorrência central de $M d f$, em porções distantes das venulações félsicas ou mesmo onde elas são pouco abundantes, os monzodioritos apresentam-se mais félsicos, por vezes modalmente classificados como monzonitos, e a granulação aumenta, passando a inequigranular fina a média. Contudo, estas rochas não são composicionalmente uniformes e comumente se observa a justaposição de porções mais félsicas e mais máficas, até mesmo em amostra de mão.

A alternância textural entre porções finas e médias é verificada em outras partes da unidade $M d f$, e poderia ser uma característica inerente dessas rochas. Porém, a análise petrográfica aponta que nas porções mais félsicas se destaca o elevado conteúdo de feldspato alcalino e quartzo. Embora menos abundante, a allanita está sempre presente (Figura $67 \mathrm{C}$ e D). Este mineral nunca é encontrado nas rochas monzodioríticas típicas da unidade, nem mesmo nas mais diferenciadas (monzoníticas). Considerando que este é um mineral acessório típico das unidades mais evoluídas (Sie e Qsie) e somando-se a abundância de feldspato alcalino e quartzo, juntamente com a proximidade do corpo de quartzo monzonitos ao sul, pode-se interpretar que estas feições decorrem de processos de interação com Qsie.

Estas feições se concentram na área onde Janasi (1986) tentativamente delineou a unidade de monzonitos acinzentados $(M f c)$. Contudo, em diversos locais das porções centro-sul e sudoeste de $M d f$, como no ponto PI-5 por exemplo, observam-se vênulas quartzo sieníticas milimétricas, ricas em hornblenda, dispersas na matriz monzodiorítica (Figura 67F). As vênulas frequentemente se fragmentam e o que se observa são agregados de cristais ou mesmo cristais individuais, que se destacam da matriz pela sua maior dimensão. 

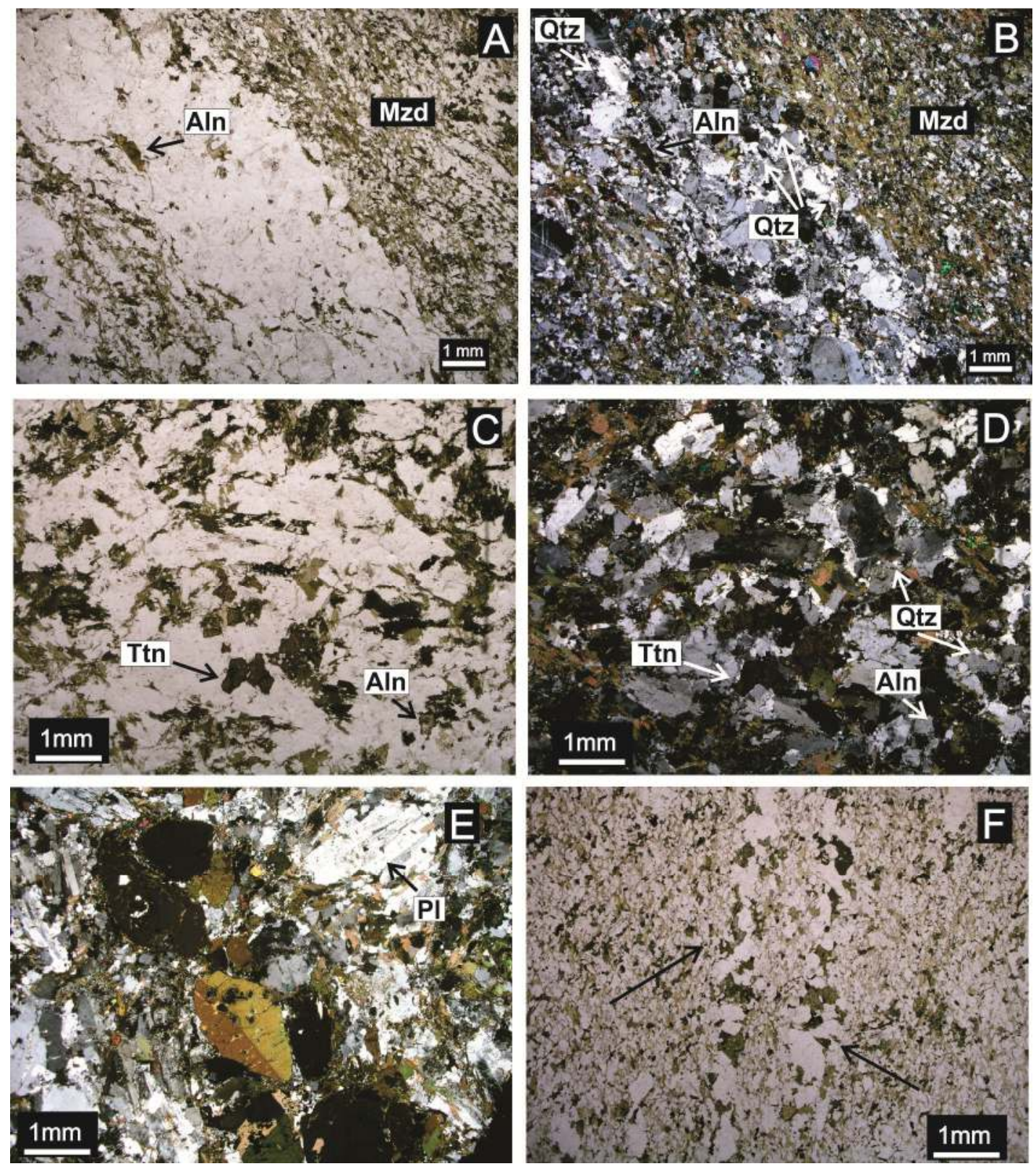

Figura 67. Feições de interação entre $M d f$ e $Q$ sie: (A) e (B) justaposição entre $M d f$ e $Q$ sie, onde praticamente não se observa mistura, evidenciando um elevado contraste reológico entre ambos (PI-515, polarizadores paralelos e cruzados, respectivamente). A porção monzodiorítica é representada pela sigla "Mzd"; (C) e (D) monzodiorito com baixo IC, quartzo intersticial em abundância e esparsos cristais de allanita, interpretado como produto de mistura com Qsie (PI-614, polarizadores paralelos e cruzados, respectivamente); (E) vênula rica em hornblenda cortando monzodioritos, no contato entre as unidades Mdf e Qsie ao sul do plúton (PI-538, polarizadores cruzados); (F) finas vênulas quartzo sieníticas (setas) dispersas em $M d f$ (PI-5a, polarizadores paralelos). 


\subsubsection{Vênulações félsicas}

Embora as vênulas apresentem uma grande heterogeneidade textural e modal, esta diversidade pode ser interpretada como inerente à variação do processo de mistura entre magmas monzodioríticos $(M d f)$ e quartzo sieníticos (Qsie), assim como o retrabalhamento das mesmas por sobrecarga e fluxo magmático. Deste modo, a descrição de vênulas não retrabalhadas, que apresentam contatos desde abrupto até gradacional e existe clara transição composicional entre quartzo sienitos ou sienitos com quartzo, passando por quartzo monzonitos ou monzonitos com quartzo, e gradando até monzodioritos, auxilia na compreensão dos processos de mistura heterogênea atuantes. Como exemplo, faz-se abaixo a descrição das diferentes porções de uma vênula félsica, que preserva todo o conjunto de variações texturais, estruturais e composicionais das vênulas encontradas na Pedreira de Piracaia.

A porção sienítica da vênula é composta essencialmente por feldspato alcalino (Figura 68 A2). O teor de quartzo é geralmente inferior a $5 \%$. Apresentam baixo IC $(<5)$, onde biotita é o máfico principal, seguida pela hornblenda. Allanita e titanita são também acessórios importantes, ocorrendo como grandes cristais, subédricos a euédricos. Zircão é raro. Em seu contato superior com os monzodioritos apresenta grande concentração de cristais de hornblenda, formando uma faixa centimétrica composta quase que exclusivamente por hornblenda (Figura 68 A-1).

A porção monzonítica apresenta contatos graduais com a porção sienítica. O IC é de aproximadamente 25, onde se destaca a abundância de hornblenda idiomórfica (até 20\%), allanita e zircão (Figura 68 A-3). São comuns agregados de minerais máficos, ricos em apatita e zircão (geralmente incluso em hornblenda e biotita (Figura 68B). A quantidade de hornblenda diminui progressivamente em direção ao contato inferior da vênula, de modo inversamente proporcional ao aumento de biotita (Figura 68 A-4). O mesmo ocorre com o plagioclásio, que é mais abundamente quanto mais próximo ao monzodiorito.

Os monzodioritos acima e abaixo da vênula apresentam composição e textura semelhantes (Figura 68 A-5). A textura é fina e o IC 35. Biotita é o mineral máfico predominante. Hornblenda é anédrica, tem pequena dimensão e abundância inferior a $8 \%$. Apatita e titanita são os acessórios principais. Não se observa allanita. Contudo, próximo ao contato com a porção monzonítica da vênula ocorrem alguns bolsões félsicos e cristais idiomórficos de hornblenda.

Pode-se interpretar que as porções monzoníticas onde são mais abundantes os cristais de allanita e zircão como uma zona de interface e mistura entre os magmas monzodioríticos e quartzo sieníticos. A possibilidade de que a interação entre os magmas favoreceu a cristalização destes minerais será discutida no item 4.4. 


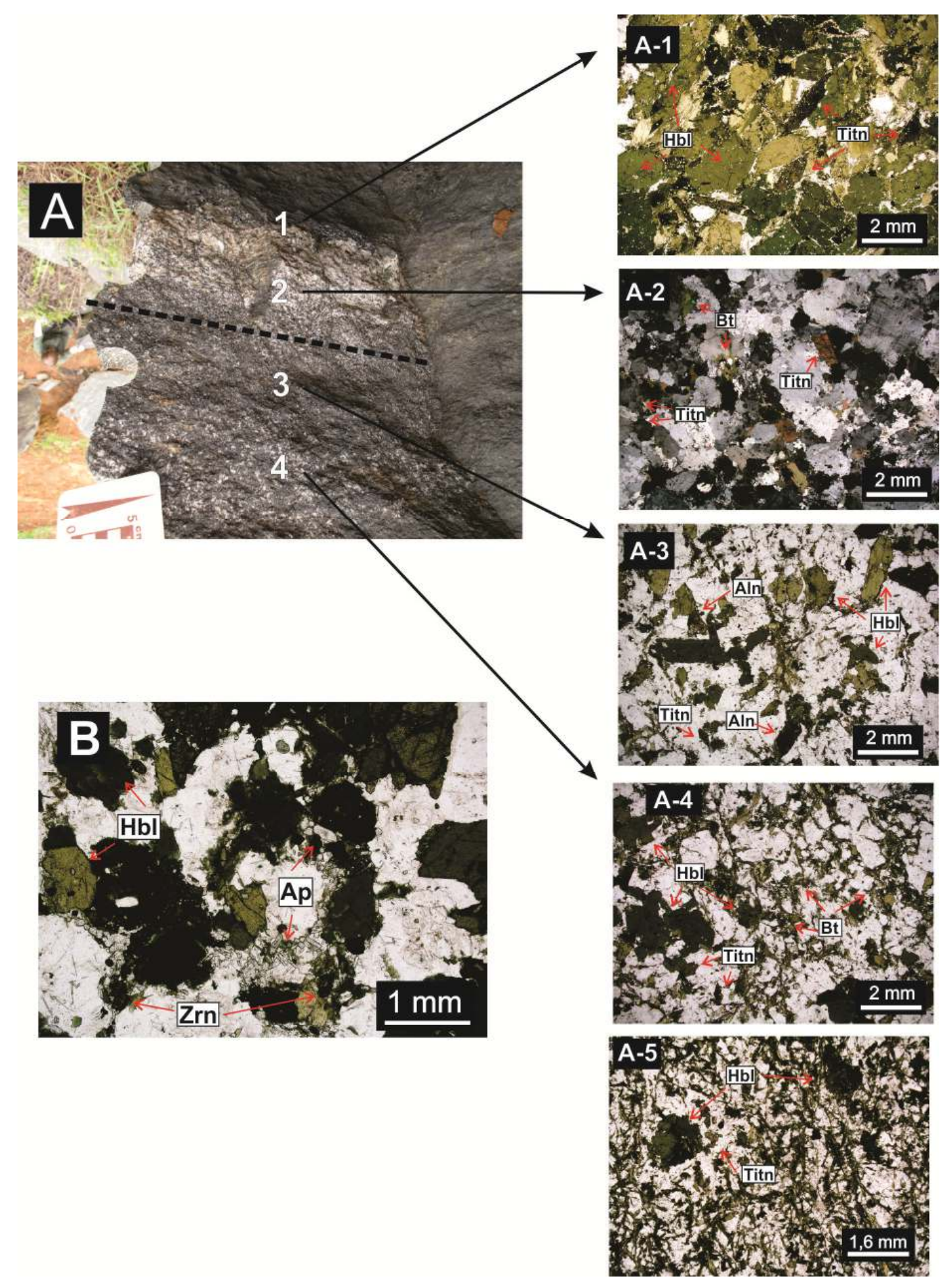

Figura 68. Foto de campo e fotomicrografias de uma venulação félsica e monzodioritos adjacentes presentes na Pedreira de Piracaia: (A) Foto de campo da venulação félsica amostrada; (A1-A5) fotomicrografias das diferentes porções da vênula: (A1) Acumulações de hornblenda e titanita com inclusões de apatita no contato da vênula com o monzodiorito; (A2) porção sienítica, com textura média a grossa e cristais euédricos de titanita; (A3) porção monzonítica, com textura média a fina, rica em hornblenda e allanita; (A4) porção monzonítica,com maior concentração de biotita, próximo ao contato inferior com o monzodiorito; (A5) monzodiorito no contato inferior da vênula, com textura fina e escassos cristais maiores de hornblenda. Salienta-se que esta porção amostrada está mais abaixo e não aparece na foto; (B) aglomerado de máficos da porção monzonítica (A-2) da vênula, com hornblenda, biotita, titanita, apatita e cristais de zircão associados. A linha tracejada na foto (A) representa a possível interface entre os magmas, a partir da qual houve mistura heterogênea e formação de um contato gradacional. 


\subsubsection{Extremo NW do plúton}

Como descrito no item 4.1.1.1, no extremo NW do plúton ocorre uma lente de monzodioritos, onde se observa uma intensa interdigitação entre $M d f$ e $Q$ sie, sob a forma de vênulas cortando $M d f$ e pillows de $M d f$ circundadas por Qsie.

A análise petrográfica reforça a observação macroscópica de que, apesar da intensa interdigitação, porções monzodioríticas e quartzo sieníticas tendem a manter seu caráter composicional e textural preservado, sendo raros os locais onde se observa fragmentação e mistura heterogênea mais efetiva (Figura 67 A e B).

\subsection{Aspectos geoquímicos dos processos de mistura de magmas}

Considerando que as evidências estruturais e texturais permitem inferir uma origem híbrida para monzonitos heterogêneos e quartzo monzonitos, faz-se importante descrever os aspectos geoquímicos relacionados aos processos de mistura. As evidências referem-se essencialmente aos elementos traço, uma vez que para os elementos maiores as rochas das diferentes unidades apresentam tendências de evolução lineares, que não permitem alcançar conclusões mais aprofundadas sobre os processos petrogenéticos atuantes.

\subsubsection{Monzonitos heterogêneos (Mh)}

As rochas da unidade Monzonitos heterogêneos, quando dispostas em diagramas binários, de ETR e multielementares, apresentam composições que predominantemente se situam entre os padrões composicionais de monzodioritos finos e sienitos (Figura 69 e 70). Contudo, alguns elementos não seguem este padrão. As concentrações U e Th, em especial, são mais elevadas nos monzonitos heterogêneos em relação a Mdfe Sie (Figura 70). 


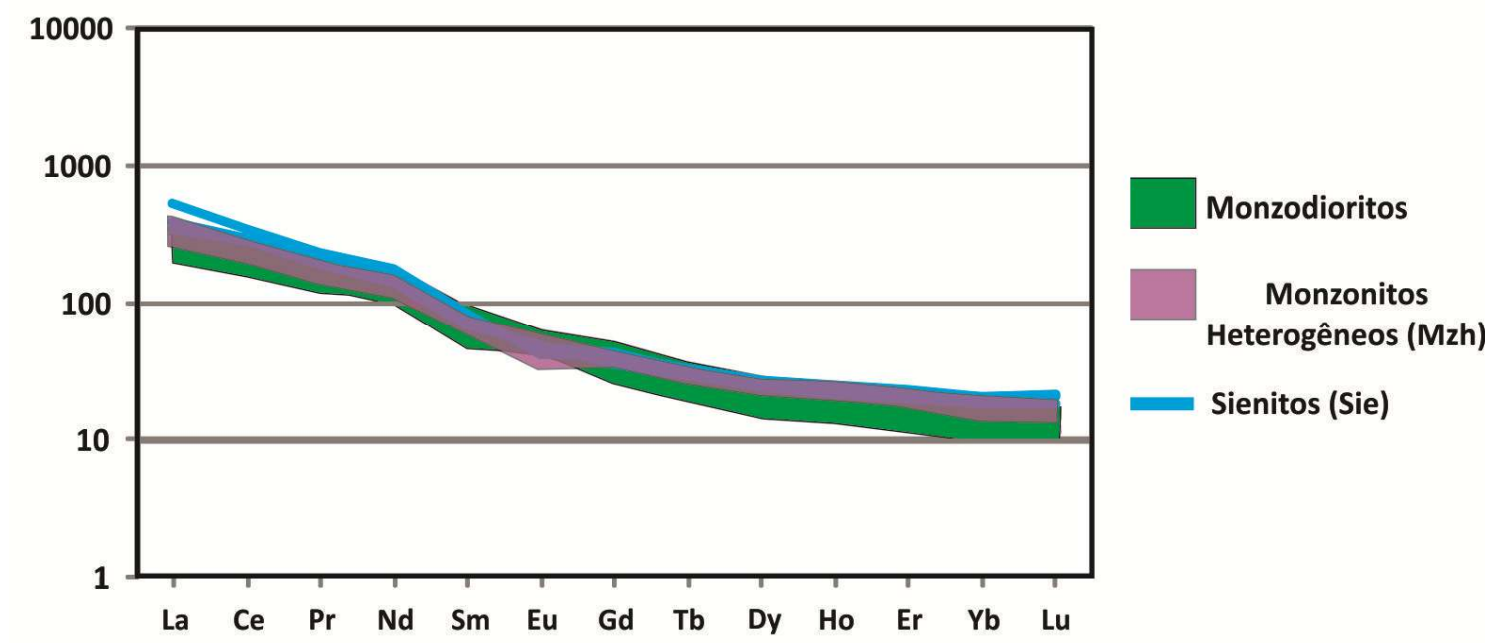

Figura 69. Diagrama de ETR para a unidade $M h$, e unidades $M d f$ e Sie, que representam os extremos composicionais da mistura. Normalizado para o condrito de Sun \& McDonough (1989).

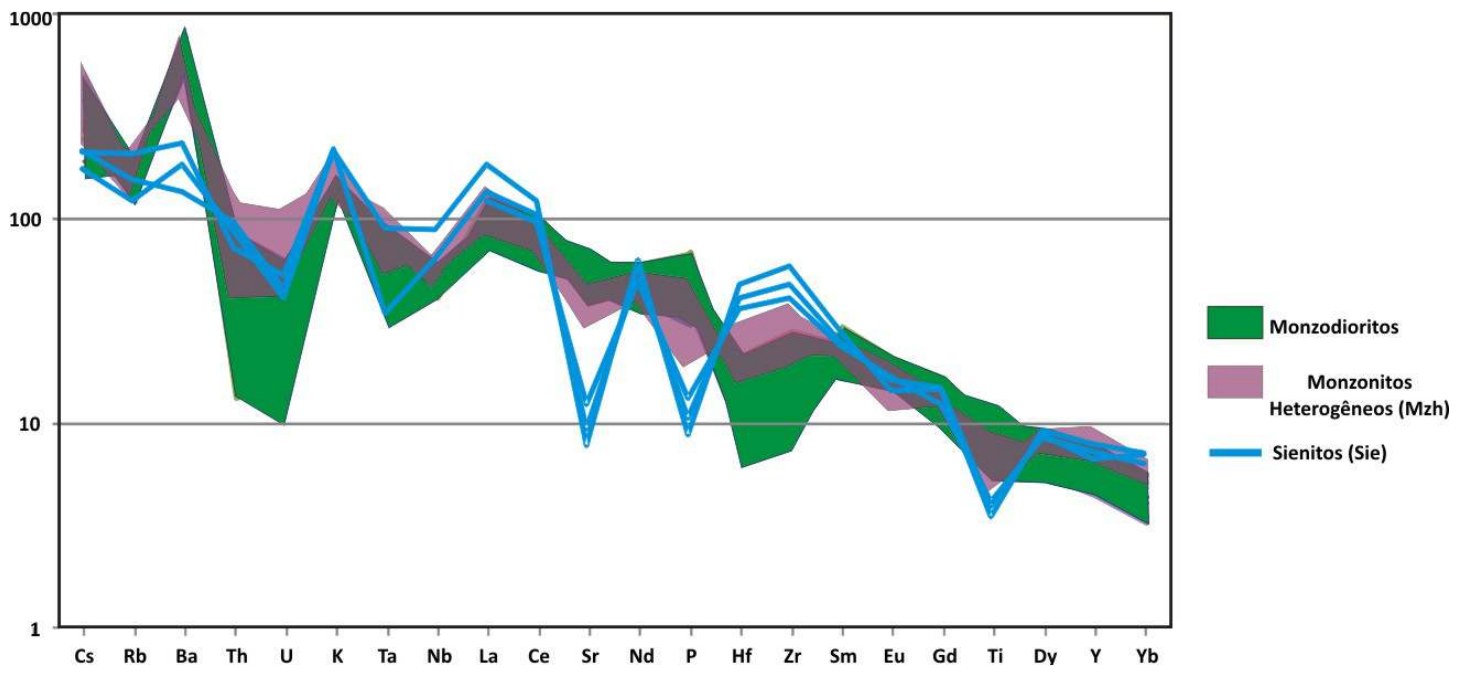

Figura 70. Diagrama multielementar para a unidade $M h$ e unidades $M d f$ e Sie que representam os extremos composicionais da mistura. Normalizado para o Manto Primitivo de Sun \& McDonough (1989).

\subsubsection{Quartzo monzonitos (Qsie)}

Os quartzo monzonitos (Qsie) apresentam composições que predominantemente se situam entre $M d f$ e quartzo sienitos (Qsie) (Figura 71 e 72). Contudo, como no caso anterior, também apresentam elementos destoam deste padrão. Observa-se, em particular, uma grande variação nos conteúdos de ETR, $\mathrm{Rb}, \mathrm{Zr}$, Nb, Th e U, que por vezes são mais elevados em relação aos extremos composicionais inferidos para a mistura. 


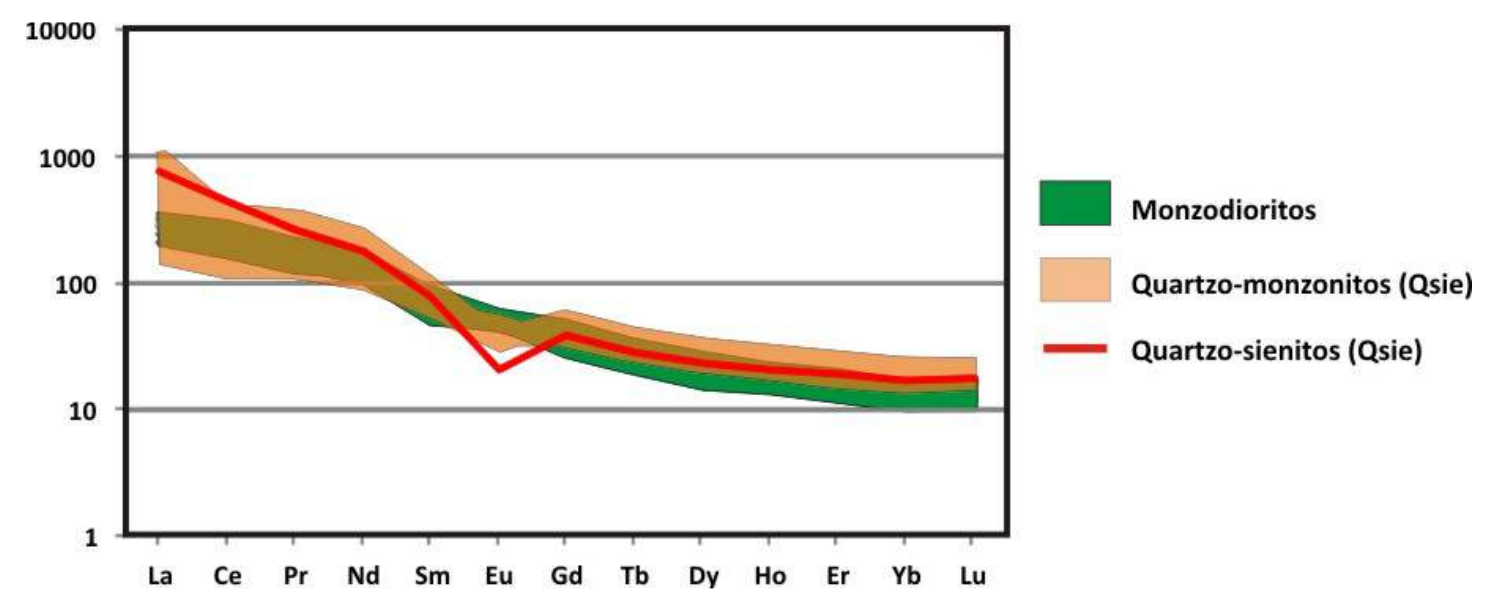

Figura 71. Diagrama de ETR para quartzo monzonitos (Qsie), e $M d f$ e quartzo sienitos (Qsie), que representam os extremos composicionais da mistura. Normalizado para o vondrito de Sun \& McDonough (1989).

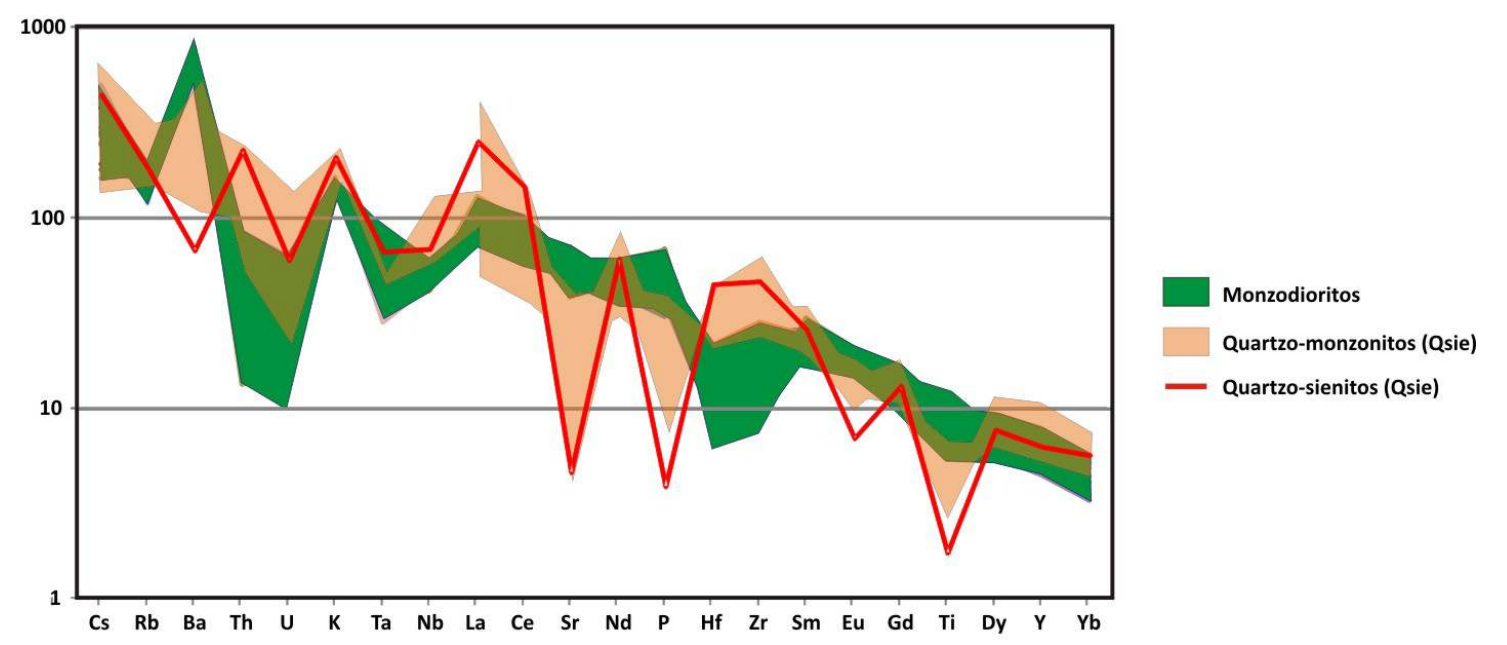

Figura 72. Diagrama multielementar para quartzo monzonitos (Qsie), e $M d f$ e quartzo sienitos (Qsie), que representam os extremos composicionais da mistura. Normalizado para o Manto Primitivo de Sun \& McDonough (1989).

Quando considerada a interação entre magmas monzodioríticos $(M d f)$ e quartzo sieníticos (Qsie), faz-se importante a comparação entre os quartzo monzonitos (Qsie) e as venulações félsicas que ocorrem associadas à $M d f$. Como destacado previamente, algumas venulações apresentam grande variação modal e por vezes apresentam uma gradação composicional entre monzodiorito e quartzo sienito, com porções monzoníticas híbridas.

Estes horizontes monzoníticos híbridos destacam-se pelas suas características composicionais. No que se refere aos elementos maiores, apresentam-se enriquecidos em, $\mathrm{CaO}, \mathrm{MgO}, \mathrm{P}_{2} \mathrm{O}_{5}$ e $\mathrm{FeO}_{\mathrm{t}}$ empobrecidas em $\mathrm{SiO}_{2}$ em relação aos quartzo monzonitos (Qsie), sendo que as concentrações de $\mathrm{CaO}, \mathrm{MgO}$ e $\mathrm{P}_{2} \mathrm{O}_{5}$ são inclusive mais elevadas em relação aos monzodioritos adjacentes às vênulas. Porém as variações mais importantes referem-se aos elementos traços. Os horizontes monzoníticos mostram-se muito ricos em ETR, HFSE, Th e U (Figuras 73 e 74), sendo as concentrações destes 
elementos mais elevadas em relação aos quartzo monzonitos, como também em relação aos quartzo sienitos (Qsie) e as porções sieníticas das vênulas. Por outro lado, os horizontes monzoníticos apresentam baixo conteúdo de elementos LILE, onde as concentrações são menores do que em quartzo monzonitos e quartzo sienitos. As porções sieníticas das vênulas, por sua vez, têm elevado conteúdo de $\mathrm{Ba}$ e $\mathrm{Sr}$, enquanto quartzo monzonito (Qsie) são enriquecidos em $\mathrm{Rb}$.

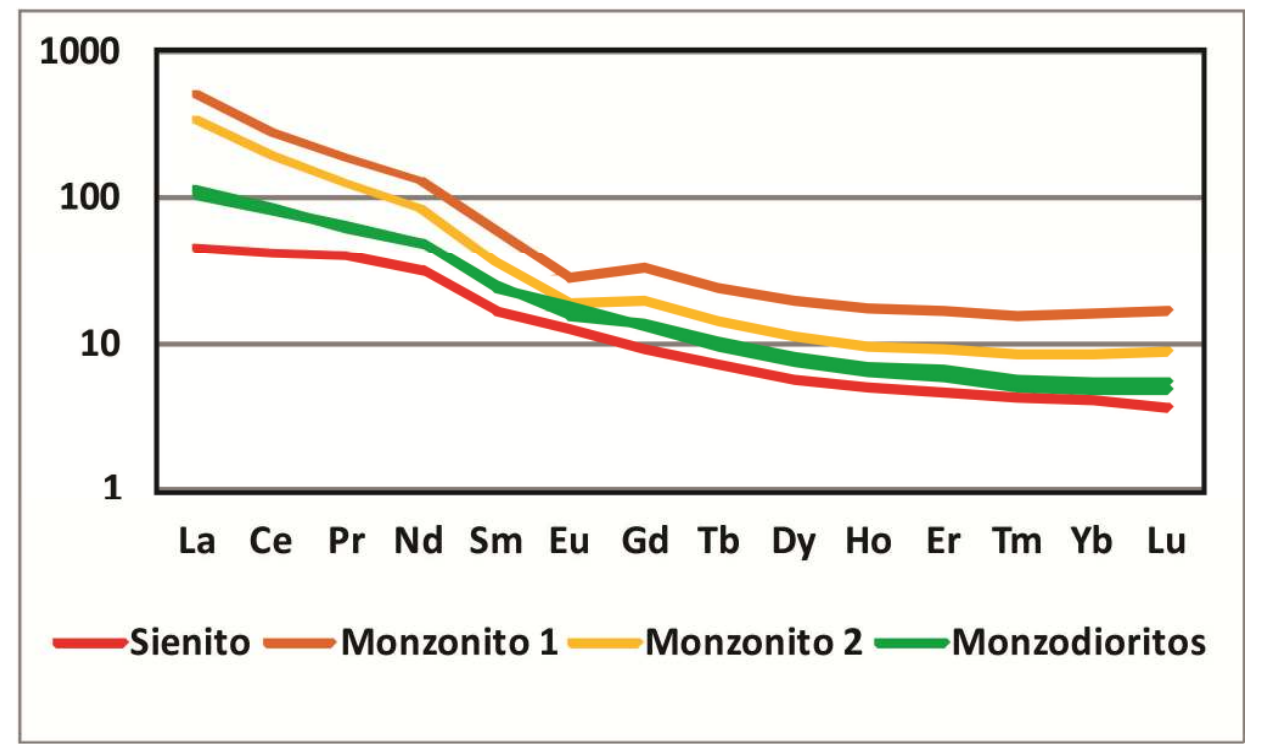

Figura 73. Diagrama de ETR para as diferentes porções de uma vênula félsica e monzodioritos adjacentes (superior e inferior). Normalizado para o condrito de Sun \& McDonough (1989).

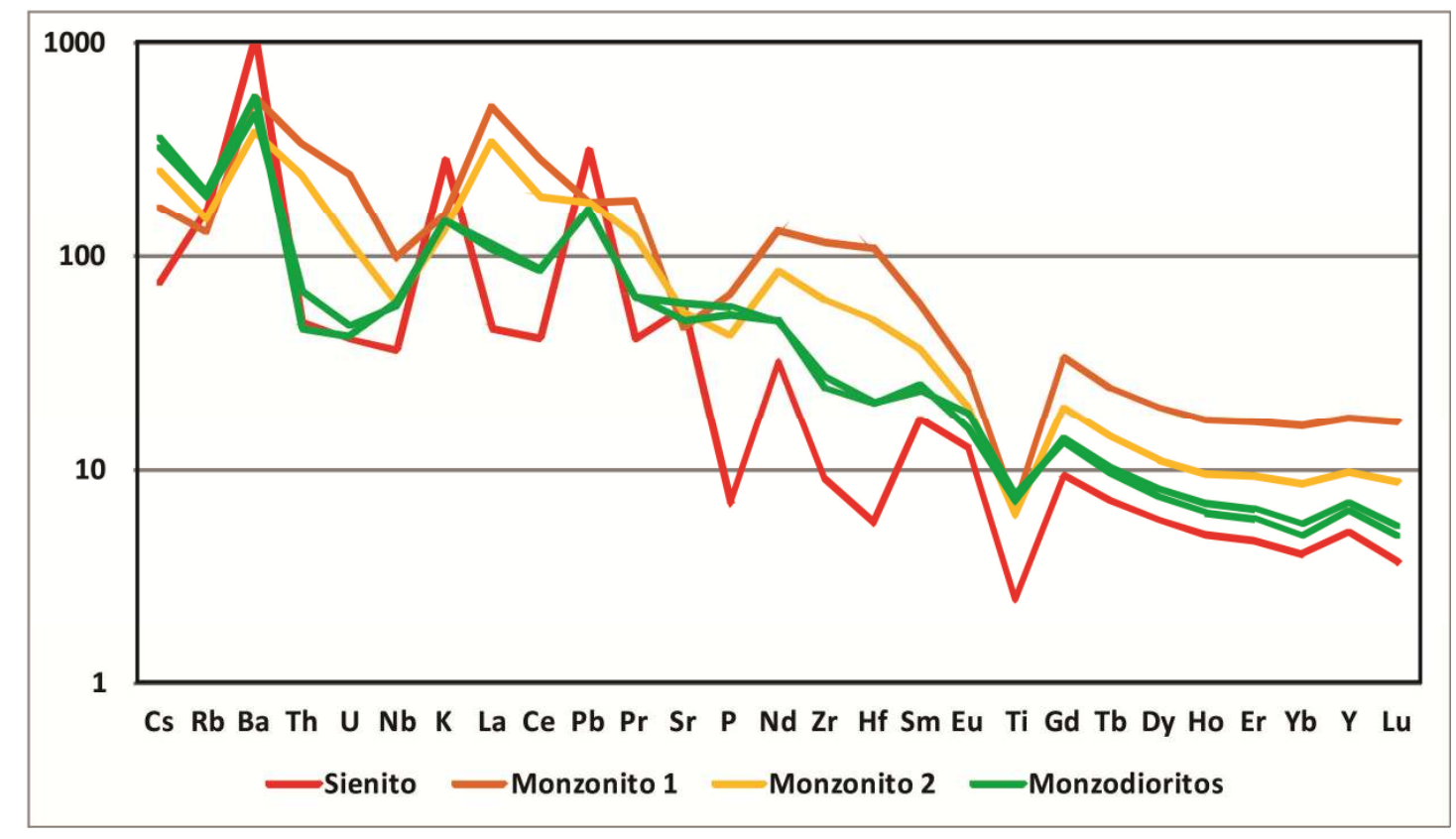

Figura 74. Diagrama multielementar para as diferentes porções da uma vênula félsica e monzodioritos adjacentes (superior e inferior) apresentados na Figura 70, encontrados na Pedreira de Piracaia. Normalizado para o Manto Primitivo de Sun \& McDonough (1989). 


\subsection{Heterogeneidades químicas do processo de mistura de magmas}

As elevadas concentrações de elementos traço das porções monzoníticas híbridas das vênulas, descritas acima, podem em parte estar relacionadas a processos físicos, como discutido por Oliveira (2009). Considerando que se observa uma relativa abundância de minerais que incorporam ETR e HSFE (allanita, zircão, apatita), a acumulação destes poderia ocorrer por processos meramente gravitacionais. Por outro lado, podem estar relacionados à atuação de processos de difusão, que tendem a ocorrer na interface entre os magmas.

Perugini et al. ( 2006) estudaram processos de mistura caótica em sistemas naturais e comparativamente realizaram modelamentos geoquímicos simulando processos difusivos a partir das concentrações de elementos traços dos magmas que representam os extremos da mistura. Os sistemas naturais referem-se a lavas terciárias de composição riolítica e quartzo traquítica, com evidências de rápido resfriamento, cuja mistura resultou em dois produtos típicos: (i) filamentos constituídos por intensa mistura (interdigitação) entre os dois magmas; e (ii) porções coesas do magma menos evoluído, que não se deformou durante a dinâmica de mistura. Esses autores realizaram um grande número de análises pontuais para elementos traço, caracterizando perfis ao longo de zonas de mistura do tipo (i) citadas acima, onde observa-se interdigitação e mistura dos magmas em escala milimétrica. Observaram que a correlação entre os elementos-traço se perde à medida que o coeficiente de difusão dos elementos aumenta. Em especial, observaram uma difusibilidade elevada para os ETR, juntamente com Y, Zr, Nb, Th e U. Coeficientes de difusão ainda mais elevados foram observados para LILE.

Os autores sugerem que processos físicos de mistura associados à difusão química, podem induzir um fracionamento difusivo ("diffusive fractionation”), consequentemente gerando volumes de magma com concentrações de elementos químicos extremamente variáveis, a distâncias relativamente pequenas. Por outro lado, os modelamentos geoquímicos mostram, que os contrastes composicionais existentes na interface entre magmas, do ponto de vista estritamente geoquímico, tendem a se equilibrar à medida que o tempo de interação entre os magmas aumenta. Deste modo, as heterogeneidades geoquímicas estariam diretamente relacionadas aos processos físicos de dispersão, combinadas à diferença de difusibilidade dos elementos. Na visão dos autores, processos de mistura de magmas são governados por uma dinâmica caótica, onde os produtos podem ser altamente variáveis e dependem fundamentalmente das condições iniciais do sistema.

Orsini et al (1991) observaram que sempre há uma correlação química entre enclaves máficos e suas hospedeiras mais félsicas. Para os elementos maiores, a correlação segue padrões lineares, embora sejam frequentes dispersões para $\mathrm{Al}_{2} \mathrm{O}_{3}, \mathrm{CaO}$ e $\mathrm{K}_{2} \mathrm{O}$. Para os elementos-traço, as maiores dispersões referem-se a $\mathrm{Sr}, \mathrm{Rb}, \mathrm{Li}, \mathrm{Nb}$ e $\mathrm{Zr}$. Constataram ainda que sempre há transferência química entre enclaves máficos e hospedeiras mais félsicas, tanto de elementos maiores como traços. A transferência é maior do componente félsico para o máfico, e verifica-se principalmente para $\mathrm{SiO}_{2}$, 
$\mathrm{K}_{2} \mathrm{O}, \mathrm{Rb}, \mathrm{Li}, \mathrm{Zr}, \mathrm{Nb}, \mathrm{Y}$ e ETR. Em contrapartida, observa-se que Ca e $\mathrm{Sr}$ são os principais elementos que migram do componente máfico para o ácido.

Neste contexto, é possível que em Piracaia a atuação de processos difusivos tenha favorecido a cristalização das fases acessórias (allanita, zircão e apatita) que se apresentam em grande quantidade nos horizontes híbridos das venulações félsicas. Debon (1991) identifica a existência de processos como este, que pareceriam improváveis, uma vez que concentrações mais elevadas nos magmas híbridos em relação aos extremos composicionais implicariam na atuação de processos de difusão contra os gradientes de concentração. Para explicar isto, o autor sugere que, à medida que os elementos de maior difusibilidade migram em direção ao magma híbrido, a consequente cristalização de fases que contenham estes elementos abaixaria suas concentrações no magma híbrido (melt); o que por sua vez novamente desencadearia um aumento do processo difusivo dos elementos químicos em questão, favorecendo a cristalização de uma maior quantidade dos determinados minerais.

Quando se comparam os quartzo monzonitos (Qsie) com os horizontes monzoníticos híbridos das vênulas, como descrito previamente, observa-se uma grande diferença composicional, especialmente com relação aos elementos-traço, que são muito mais enriquecidos nos horizontes híbridos. A relativa homogeneidade composicional de quartzo monzonitos possivelmente reflete um estágio mais avançado de mistura, onde heterogeneidades composicionais relacionadas a mecanismos de difusão geradas na interface entre os magmas tenderiam a se dissipar pela evolução do processo de mistura, chegando mais próximo ao equilíbrio, ou seja, de padrões geoquímicos lineares e intermediários entre os extremos composicionais. Ainda assim, sua grande variação composicional e enriquecimento de alguns elementos poderiam mostrar que a homogeneização química do sistema não foi atingida. As vênulas, por outro lado, representariam um estágio inicial de mistura, registrando os processos atuantes na interface entre os magmas em interação, e por isto apresentariam maior heterogeneidade composicional.

No que se refere $M h$, observa-se que a variação química entre as amostras é menor, mesmo sendo inerente à unidade certa dispersão composicional. Deste modo pode-se considerar que a mistura de magmas, do ponto de vista químico, atingiu um grau mais elevado de homogeneização em relação aos quartzo monzonitos (Qsie), possivelmente por uma forte atuação de processos dinâmicos, que propiciaram uma intensa interdigitação entre porções monzodioríticas (Mdf) e sieníticas (Sie). Contudo, aparentemente a homogeneização não foi atingida por completo, como evidenciado pelas elevadas concentrações de U e Th.

Observa-se ainda que algumas amostras de $M h$ destoam das demais, por apresentarem maior similaridade composicional com os monzodioritos mais evoluídos, tanto nas concentrações de elementos traços, como também de elementos maiores. 
O desequilíbrio composicional de quartzo monzonitos e $M h$, em especial no que se relaciona aos elementos traço, é também evidente quando realizados diagramas de correlação propostos por Fourcade \& Allegre (1981) para verificar mistura entre magmas, a partir da equação:

$$
\begin{aligned}
& \mathrm{C}_{\mathrm{H}}=f \mathrm{C}_{\mathrm{F}}+(1-\mathrm{f}) \mathrm{C}_{\mathrm{M}}, \text { ou } \\
& \mathrm{C}_{\mathrm{H}}-\mathrm{C}_{\mathrm{F}}=\mathrm{f}\left(\mathrm{C}_{\mathrm{F}}-\mathrm{C}_{\mathrm{M}}\right) ;
\end{aligned}
$$

onde $\mathrm{C}$ se refere às concentrações elementais no componente híbrido $\mathrm{H}, \mathrm{F}$ corresponde ao componente félsico e $\mathrm{M}$ ao componente máfico da mistura.

Segundo os autores, misturas ideais nestes diagramas seriam verificadas se os diferentes elementos se dispusessem de forma linear $\left(\mathrm{R}^{2}=1\right)$, cuja inclinação aumentaria de acordo com o percentual de mistura. Por outro lado, baixas correlações, evidenciadas por $\mathrm{R}^{2}$ distanciando-se de 1 , não favoreceriam a atuação de processos de mistura. Quando modeladas a mistura entre Sie e $M d f$ para gerar $M h$, assim como entre quartzo sienitos (Qsie) e $M d f$ para gerar quartzo monzonitos (Qsie), a dispersão é geralmente elevada. Para amostras de $M h$, os valores de $\mathrm{R}^{2}$ apenas algumas vezes chegam a 0,85 para elementos maiores, e nunca ultrapassam 0,69 para elementos traço (Figura 75). Para esta amostra (PI-437A) o percentual de mistura a partir da média dos elementos maiores seria de 37\%, enquanto a partir da média dos elementos traço seria de $54 \%$. Já para Qsie, os maiores valores de $\mathrm{R}^{2}$ são de 0,96 para elementos maiores e de 0,88 para elementos traço, onde os percentuais médios de mistura apontados são de $40 \%$ a partir dos maiores e 56\% a partir dos traços (Figura 76).

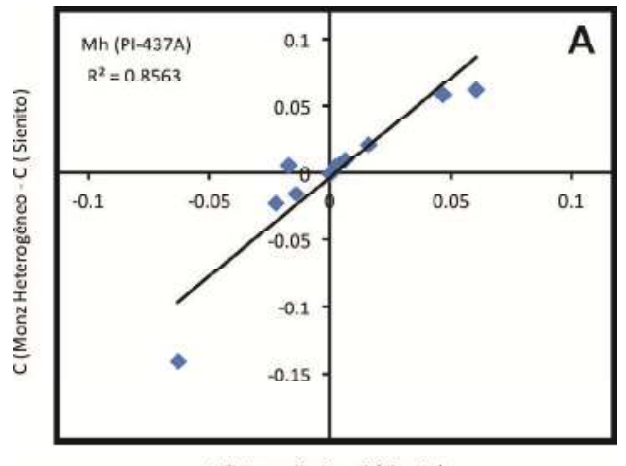

C. (Monzodiorito - C (Sienito)

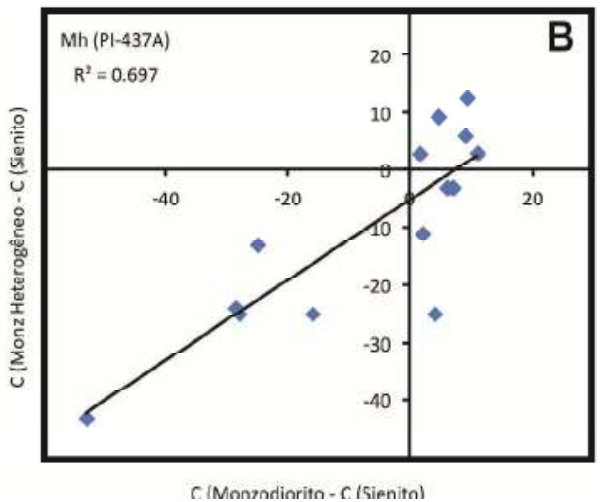

Figura 75. Diagramas de correlação C $(M h-S i e)$ vs. C $(M d f-S i e)$ segundo Fourcade \& Allegre (1981) para a geração de Monzonitos Heterogêneos $(M h)$. Em (A) diagrama para elementos maiores, plotados em wt $(\%)$; em (B) diagrama para elementos traço, onde: $\mathrm{V} / 10 ; \mathrm{Zr} / 10 ; \mathrm{Sr} / 100$ e $\mathrm{Ba} / 1000$. 
Contudo, a abordagem deste método é similar à subtração simples, onde considera-se que a concentração de todos os elementos do magma híbrido seja intermediária entre os extremos composicionais (end members). Assim sendo, a dispersão apontada pelos cálculos pode ser inerente à complexidade dos processos envolvidos na gênese destas rochas.
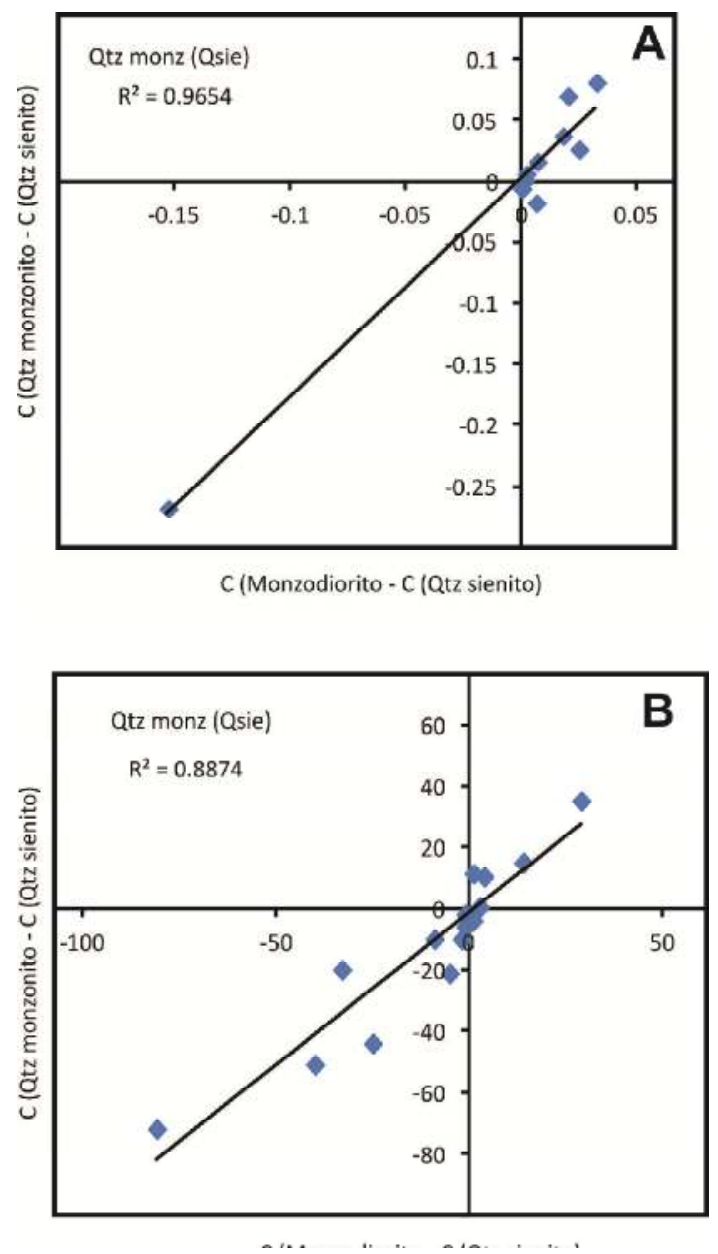

Figura 76. Diagramas de correlação C (quartzo monzonitos - quartzo sienitos) vs. C (Mdf - quartzo sienito) segundo Fourcade \& Allegre (1981) para a geração de Quartzo monzonitos (Qsie). Em (A) diagrama para elementos maiores, plotados em wt(\%); em (B) diagrama para elementos traço, onde: $\mathrm{V} / 10 ; \mathrm{Zr} / 10 ; \mathrm{Sr} / 100 \mathrm{e}$ $\mathrm{Ba} / 1000$.

\subsubsection{Cálculos de balanço de massa}

Complementando a abordagem matemática que visa melhor caracterizar as variações químicas existentes entre as unidades, realizaram-se cálculos de balanço de massa para elementos maiores e para os elementos traço $\mathrm{Ba}$, Sr e Rb.

Verificou-se a possibilidade de geração das rochas híbridas (Mh e quartzo monzonitos) através dos mecanismos de cristalização fracionada e em equilíbrio, assim como por mistura entre os magmas monzodioríticos com magmas sieníticos e quartzo sieníticos. No caso de $M d f$, buscou-se também 
entender as variações intra-unidade, uma vez que a unidade apresenta um grande intervalo composicional.

Para os elementos maiores, utilizou-se o software Petrograph (Petrelli et al., 2005), onde os cálculos de balanço de massa são realizados a partir dos cálculos desenvolvidos por Stormer \& Nichols (1978), que se baseiam no método de Mínimos Quadrados. Com relação aos resultados, embora não seja possível determinar um valor específico para que sejam considerados aceitáveis, os autores salientam que quanto menor for o resultado, ou seja, quanto mais próximo de 0 for a soma dos quadrados dos resíduos $\left(R^{2}\right)$, maior a confiabilidade.

Nos cálculos de mistura é preciso fornecer a composição do líquido inicial (máfico), a do líquido final (híbrido) e a composição do magma que é adicionado (félsico) ao inicial para que se chegue à composição do final. O programa então compara a diferença composicional observada (i.e. verdadeira) com a diferença composicional calculada, onde os cálculos para cada elemento são realizados separadamente.

Para os elementos traço ( $\mathrm{Ba}, \mathrm{Sr}$ e $\mathrm{Rb}$ ), os modelamentos de cristalização fracionada e em equilíbrio também foram realizados através do software Petrograph, que utiliza as equações contidas em Neuman et al. (1954) (1) e Wood \& Frasier (1976) (2), respectivamente. Já os cálculos de mistura são equações simples (3), e baseiam-se no trabalho de Langmuir et al. (1978):

(1) $C_{L}=C_{O} F^{(D-1)}$, onde $\mathrm{C}_{\mathrm{L}}=$ concentração do elemento traço no magma; $\mathrm{C}_{\mathrm{O}}=$ concentração inicial do elemento traço; $\mathrm{D}=$ coeficiente de distribuição; $\mathrm{F}=$ fração de melt restante; $C_{L}=\frac{C o}{[D+F(1-D)]}$, onde $\mathrm{C}_{\mathrm{L}}=$ concentração do elemento traço no magma; $\mathrm{C}_{\mathrm{O}}=$ concentração inicial do elemento traço; $\mathrm{D}=$ coeficiente de distribuição; $\mathrm{F}=$ fração de melt restante;

(3) $A x+B x y+C y+D$ consultar Langmuir et al. (1978) com relação às variáveis que descrevem a equação da hipérbole.

Os coeficientes de partição (Kds) de Ba e Sr para o plagioclásio utilizados nos modelamentos foram calculados a partir do trabalho de Blundy \& Wood (1991), onde pode ser levada em conta a variação de temperatura do magma e o teor de An do plagioclásio. Já os Kds de Rb para o plagioclásio, assim como $\mathrm{Ba}, \mathrm{Sr}$ e $\mathrm{Rb}$ para biotita e clinopiroxênio foram obtidos essencialmente no trabalho de Villemant et al. (1981) ( Tabela 1). Apenas para o Ba na biotita utilizou-se também o $\mathrm{Kd}=6.36$, proposto por McCarthy (1976), para fins de comparação. 
Tabela 1. Coeficientes de partição utilizados nos modelamentos de elementos traço.

\begin{tabular}{|c|c|c|c|c|c|}
\hline & $\begin{array}{l}\text { Plagioclásio } \\
\left(950^{\circ} \mathrm{C} \text { e } \mathrm{An}_{50}\right)\end{array}$ & $\begin{array}{l}\text { Plagioclásio } \\
\left(900^{\circ} \mathrm{C} \text { e } \mathrm{An}_{40}\right)\end{array}$ & Biotita & Augita & $\begin{array}{c}\text { Ortoclásio } \\
\left(\mathrm{Or}_{78}\right)\end{array}$ \\
\hline $\mathrm{Ba}$ & $\mathbf{0 . 4 2} 2^{(1)}$ & $0.59^{(1)}$ & $10^{(2)} ; 6.36^{(3)}$ & $0.04^{(2)}$ & $19.57^{(4)}$ \\
\hline $\mathrm{Sr}$ & $\mathbf{3 . 8}^{(1)}$ & $5.2^{(1)}$ & $0.7^{(2)}$ & $0.16^{(2)}$ & $12^{(4)}$ \\
\hline $\mathrm{Rb}$ & $0.3^{(2)}$ & $0.3^{(1)}$ & $1.9^{(2)}$ & $\mathbf{0 . 1 3}^{(2)}$ & $\mathbf{0 . 8 1} 1^{(4)}$ \\
\hline
\end{tabular}

$\overline{\text { Os coeficientes }}{ }^{(1)}$ foram obtidos em Blundy \& Wood (1991); os coeficientes ${ }^{(2)}$ em Villemant et al. (1981); ${ }^{(3)}$ em McCarthy (1976); e ${ }^{(4)}$ em Icenhower \& London (1996).

\subsubsection{Variações composicionais de $M d f$}

Primeiramente, considerando a importância de $M d f$, por ser um membro final tanto para a geração de monzonitos heterogêneos como para quartzo monzonitos, é preciso investigar a possível atuação de processos de diferenciação internos à unidade, uma vez que ela unidade apresenta um grande intervalo composicional.

A partir de modelamentos de cristalização, inicialmente simulou-se a evolução dos monzodioritos mais primitivos (PI-589B), fracionando os minerais augita, plagioclásio, biotita, magnetita e apatita, que apresentam evidências de cristalização precoce nestas rochas. As composições utilizadas foram as obtidas no presente trabalho através de Microssonda Eletrônica, à exceção augita e apatita, que foram extraídas de Janasi (1986) e Deer et al. (1992), respectivamente.

Nos modelamentos para elementos maiores constata-se que o percentual de cristalização necessário para se chegar aos monzodioritos mais evoluídos é elevada. Pode-se tomar como exemplo o modelamento para o monzodiorito PI-75 (Tabela A13), que representa uma rocha moderadamente diferenciada dentre as que compõem a unidade. Os resultados apontam que são necessários $52 \%$ de magma cristalizado, gerando um sólido com $40,6 \%$ de plagioclásio, $11,2 \%$ de augita, $36 \%$ de biotita, $8,7 \%$ de magnetita e 3,5\% de apatita, sendo a soma dos quadrados dos resíduos de 0,84 .

Os modelamentos de cristalização para elementos traço foram realizados com incrementos de $10 \%$ de percentual de cristalização, fracionando-se augita, biotita e plagioclásio, cujas proporções foram recalculadas para 100\%. Em um primeiro momento, a proporção de fases extraídas corresponde à fornecida pelos cálculos de balanço de massa para elementos maiores para se chegar à amostra PI75, a partir da cristalização fracionada do monzodioritos PI-589B. Os Kds para Ba e Sr do plagioclásio foram calculados inferindo uma temperatura de $950^{\circ} \mathrm{C}$ para o magma e uma composição $\mathrm{An}_{50}$ para o plagioclásio (Tabela 1).

Observa-se no diagrama $\mathrm{Ba} / \mathrm{Sr}$ vs. Rb (Figura 77) que a tendência de evolução difere do comportamento apresentado pelas rochas da unidade, uma vez que as razões $\mathrm{Ba} / \mathrm{Sr}$ diminuem significativamente a cada incremento de cristalização. Esta forte diminuição é atribuída ao 
fracionamento de biotita, e mesmo refazendo os cálculos com um $\mathrm{Kd}=6,36$, considerando que um $\mathrm{Kd}=10$ possa estar superestimado, observa-se que os resultados mantêm-se essencialmente os mesmos (Figura 77B).
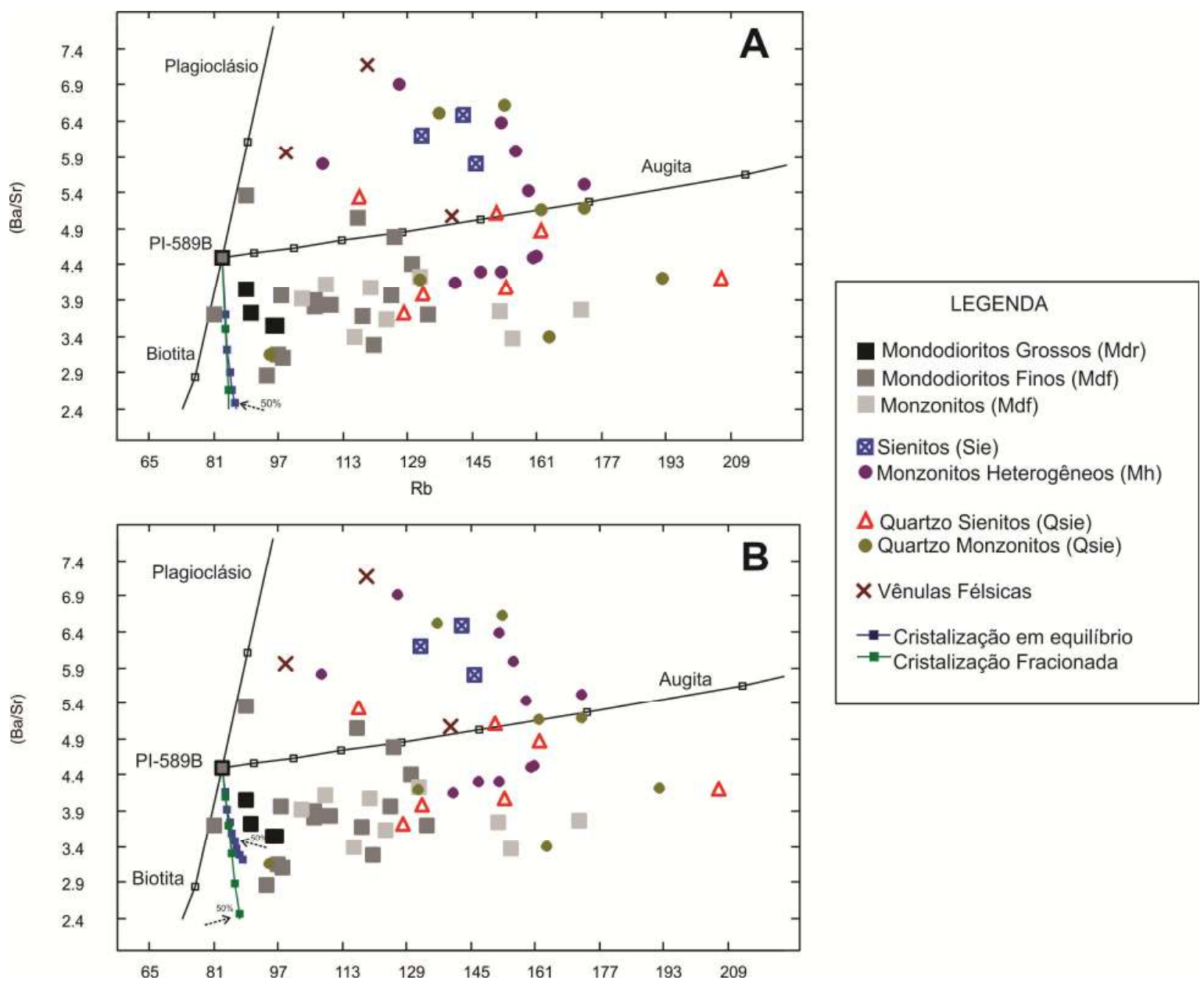

Figura 77. Modelamentos de cristalização fracionada e em equilíbrio, partindo dos monzodioritos (Mdf) mais primitivos (PI-589B), segundo as proporções de minerais fornecidas pelos cálculos de balanço de massa para elementos maiores para se chegar até monzodioritos moderadamente evoluídos (PI-75), que ocorre com aproximadamente $52 \%$ de cristalização. Os modelamentos foram realizados com incrementos de $10 \%$, onde as setas pontilhadas indicam o percentual de cristalização de $50 \%$. As linhas de evolução em azul representam cristalização em equilíbrio e em verde cristalização fracionada. As curvas em preto sinalizam a variação composicional pelo fracionamento de augita, plagioclásio e biotita. Em (A) utilizou-se um $\mathrm{Kd}=10$ para a biotita, enquanto em (B) utilizou-se um $\mathrm{Kd}=6.36$. A proporção de fases fracionadas, recalculadas para $100 \%$, foi de: $46.2 \%$ de plagioclásio, $12.8 \%$ de clinopiroxênio, $41 \%$ de biotita.

Aceitando que qualquer modelo apresenta limitações, buscou-se outra abordagem, baseandose nos modelamentos obtidos através do software MELTS. Neste caso, novamente partiu-se dos monzodioritos mais primitivos (PI-589B), utilizando as proporções de minerais logo após a entrada de plagioclásio no sistema $\left(54,84 \%\right.$ aug; $21,97 \%$ bt; $23,18 \%$ pl), que ocorreu a $911^{\circ} \mathrm{C}$, recalculadas para $100 \%$. Os resultados são mostrados na Figura 78, onde observa-se que a diminuição da razão $\mathrm{Ba} / \mathrm{Sr}$ não é tão forte, porém ainda apresenta-se marcadamente controlada pelo fracionamento de biotita. 


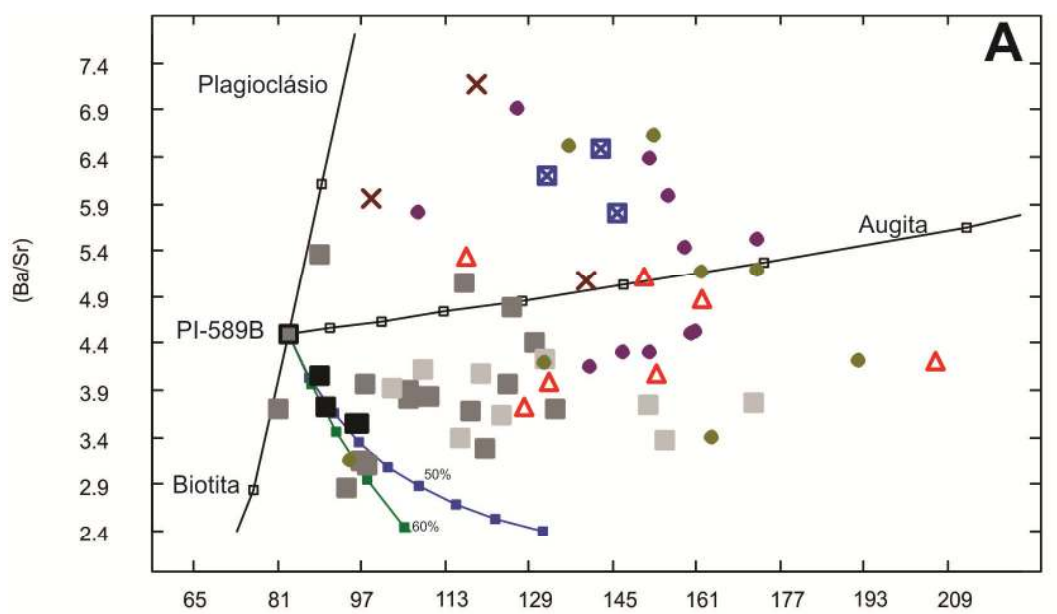

$\mathrm{Rb}$

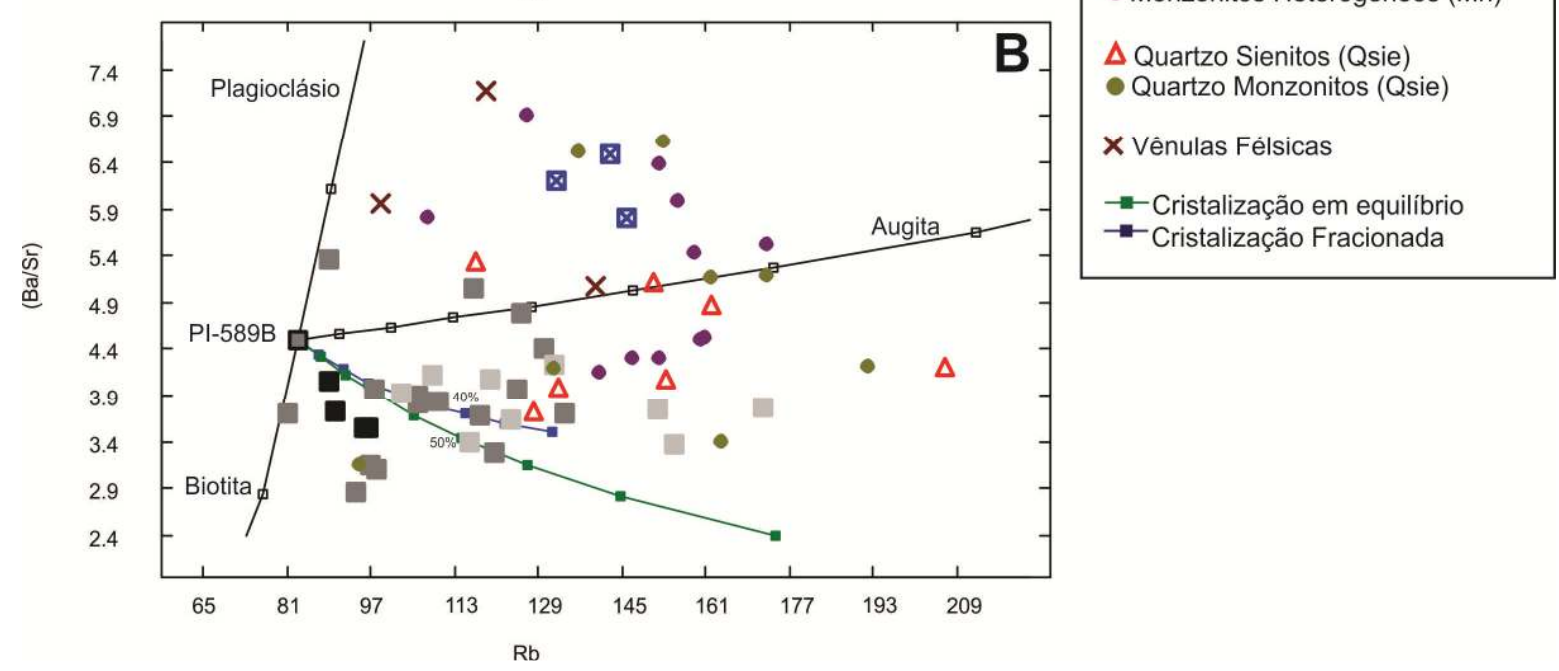

LEGENDA

Mondodioritos Grossos (Mdr)

Mondodioritos Finos (Mdf)

Monzonitos (Mdf)

区Sienitos (Sie)

- Monzonitos Heterogêneos (Mh)

$\triangle$ Quartzo Sienitos (Qsie)

Quartzo Monzonitos (Qsie)

Vênulas Félsicas

- Cristalização em equilíbrio

Cristalização Fracionada

Figura 78. Modelamentos de cristalização fracionada e em equilíbrio a partir dos monzodioritos $(M d f)$ mais primitivos (PI-589B), utilizando as proporções de minerais fornecidas pelos modelamentos realizados através do software MELTS. Em (A) utilizou-se $\mathrm{Kd}=10$ para o $\mathrm{Ba}$ na biotita, enquanto em (B) utilizou-se $\mathrm{Kd}=6,36$.

Mesmo considerando que a composição do magma e os coeficientes de partição mudam à medida que decorre o processo de diferenciação, e que os líquidos gerados por fracionamento devam ter uma composição que se situe entre as fornecidas por modelos de cristalização fracionada e em equilíbrio, observa-se que o fracionamento de biotita não permite o enriquecimento de $\mathrm{Rb}$ nos líquidos mais evoluídos sem que as razões $\mathrm{Ba} / \mathrm{Sr}$ diminuam. Estes resultados sugerem a possível atuação de processos adicionais para a geração das rochas que compõem $M d f$.

\subsubsection{Monzonitos heterogêneos $(M h)$ e quartzo monzonitos ( $Q$ sie)}

Nos que se refere à gênese de monzonitos heterogêneos e quartzo monzonitos, os modelamentos também foram realizados a partir dos monzodioritos mais primitivos, representados pela amostra PI-589B. Nos cálculos de mistura, a amostra PI-602 foi utilizada como o extremo composicional que representa os Sienitos (Sie) e a amostra PI-410 a que representa os quartzo sienitos 
(Qsie). Em ambos os casos, o extremo máfico da mistura foi também a amostra PI-589B. Testou-se a geração de diversas amostras de monzonitos heterogêneos e quartzo monzonitos, porém mostra-se apenas um exemplo de cada unidade.

No que se refere aos elementos maiores, em geral, observou-se que os resultados tanto para a geração de $M h$ como para quartzo monzonitos (Qsie) são melhores nos modelos de cristalização fracionada, do que nos de mistura (Tabelas A14 e A15). Para a geração de $M h$ a partir de cristalização fracionada, a menor soma dos quadrados dos resíduos (daqui para diante chamada apenas de “SQR") foi de 0,90, com a separação de $62 \%$ de sólidos, cujas proporções são de: 43,5\% de plagioclásio, $6,1 \%$ de augita, 39\% de biotita, 7,5\% de magnetita e 3,8\% de apatita. Já a formação da mesma rocha a partir de mistura de magmas fornece uma $S Q R$ de 22,0.

Para a geração dos quartzo monzonitos (Qsie), os resultados para cristalização fracionada são geralmente inferiores a 2,0, sendo 1,1 a menor $S Q R$ encontrada. Neste último caso, tem-se a separação de 78\% de sólidos, nas proporções: $45 \%$ de plagioclásio, 7,8\% de augita, 36,2\% de biotita, 7,9\% de magnetita e $3,7 \%$ de apatita. Os cálculos para a geração da mesma rocha por mistura fornecem uma $S Q R$ de 4,2. Salienta-se que no caso dos quartzo monzonitos, se observa uma maior variação nos resultados para cálculos de mistura, onde as $S Q R$ mais elevadas foram de 53,7.

Foram realizados ainda modelamentos para rochas monzoníticas de $M d f$ (amostra PI-614), localizadas no corpo central da unidade, próximo ao contato com o corpo de quartzo monzonitos (Qsie) ao sul do plúton e que apresentam evidências de mistura em pequena escala. Os resultados para sua geração a partir de cristalização fracionada fornecem uma $S Q R$ de 0,67 , com um percentual de cristalização de $65 \%$, onde a proporção de fases fracionadas é: $43,5 \%$ de plagioclásio, $37,1 \%$ de biotita $8 \%$ de augita, $8 \%$ de magnetita e 3,8\% de apatita (Tabela A16). Enquanto isto, por mistura a SQR é de 1,2. Estas $S Q R$ relativamente baixas, podem em grande parte estar relacionados à pequena diferença composicional em relação à amostra PI-589B, considerada o magma inicial nos modelamentos.

Simulou-se também a geração de Sienitos (Sie) e quartzo sienitos (Qsie) por cristalização fracionada a partir de PI-589B (Tabela A17). Atinge-se a composição sienítica após $76 \%$ de cristalização, onde as proporções de minerais fracionados são: $43 \%$ de plagioclásio, $10 \%$ de augita, $35 \%$ de biotita, $8 \%$ de magnetita e 3\% de apatita; com uma $S Q R$ de 1,2. Já a composição quartzo sienítica é atingida após $82 \%$ de cristalização, gerando um sólido com $45 \%$ de plagioclásio, 4,5\% de augita, $36 \%$ de biotita, $8 \%$ de magnetita e $4 \%$ de apatita, sendo a $S Q R$ de 1,1. Estes resultados representam apenas uma aproximação grosseira do processo de cristalização fracionada, uma vez que a composição dos minerais deve variar grandemente ao longo da evolução de um magma monzodiorítico até que se atinjam composições sieníticas e quartzo sieníticas. Contudo, os resultados são importantes, pois o mostram que o percentual de cristalização necessário para que se atinjam composições tão evoluídas é muito alto, o que implica em um longo processo evolutivo de fracionamento. 
Ainda com relação aos cálculos de mistura, observa-se que a diferença entre a composição observada e a calculada é significativa para alguns elementos, dentre eles o Al, que por vezes mostrase maior do que $1 \%$. Isto implica em imprecisão dos cálculos, uma vez que matematicamente requer a adição de quantidades realisticamente impossíveis de componente félsico para seja atingida a concentração do híbrido. Como argumentado acima, as diferenças observadas para alguns elementos podem ser inerentes ao processo de mistura, de modo que os resultados dos cálculos de balanço de massa, por refletirem uma abordagem linear, não excluem a existência de processos de mistura.

Com relação aos elementos traço, ao analisar as Figuras 77 e 78 observa-se que a geração das unidades félsicas por diferenciação a partir dos $M d f$ mais primitivos não é favorecida. Considerando uma possível diferenciação de $M d f$, modelou-se um segundo estágio de cristalização a partir dos resultados do MELTS para rochas relativamente mais evoluídas da unidade, de composição monzonítica (amostra PI-358A) (Figura 79). Neste caso incluiu-se o feldspato alcalino entre as fases fracionadas, cujos Kds para $\mathrm{Ba}$ e $\mathrm{Rb}$ foram calculados a partir do trabalho de Icenhower \& London (1996), onde demonstra-se que há variação de acordo com o conteúdo do componente ortoclásio. Os Kds calculados para o feldspato alcalino foram de 19,57 para $\mathrm{Ba}$ e 0,81 para $\mathrm{Rb}$, utilizando-se das análises de química mineral obtidas por Janasi (1986). Icenhower \& London (1996) sugerem ainda um $\mathrm{Kd}$ entre 10 e 14 para o $\mathrm{Sr}$, de modo que adotou-se um valor intermediário $(\mathrm{Kd}=12)$ para os modelamentos (Tabela 1). As proporções de minerais fracionados utilizadas representam o momento de início da cristalização do feldspato alcalino, que ocorreu a $911^{\circ} \mathrm{C}$, recalculadas para $100 \%$, e correspondem a: $12 \%$ de augita, $13,61 \%$ de biotita, $54,16 \%$ de plagioclásio e $20,12 \%$ de feldspato alcalino. Se modificaram ainda os coeficientes de partição do plagioclásio para $\mathrm{Ba}$ e $\mathrm{Sr}$, adaptando os parâmetros dos cálculos de Blundy \& Wood (1991) para condições de mais baixa temperatura $\left(900^{\circ}\right.$ C) e uma composição menos cálcica $\left(\mathrm{An}_{40}\right)$.

Ainda assim, a tendência de evolução dos líquidos modelada não propicia o aumento das razões $\mathrm{Ba} / \mathrm{Sr}$ com o fracionamento necessário para que se atinja a composição das unidades mais félsicas presentes no plúton. Por outro lado, os modelamentos de mistura para elementos traço, quando considerados os monzodioritos mais primitivos como o polo máfico, não apontam claramente para uma origem híbrida para monzonitos heterogêneos e quartzo monzonitos (Figura 80).

Na Figura 80 observa-se também que as rochas desta unidade apresentam uma dispersão muito grande neste diagrama, o que talvez decorra da heterogeneidade do processo de mistura e elevada capacidade de difusão dos elementos em questão, como previamente argumentado. Alternativamente, é preciso considerar a possibilidade de que o extremo máfico da mistura não corresponda aos monzodioritos mais primitivos. Deste modo, a possibilidade de que a mistura envolva as rochas mais félsicas de $M d f$, o que é mais viável do ponto de vista físico, precisaria ser investigada com maior detalhamento. 

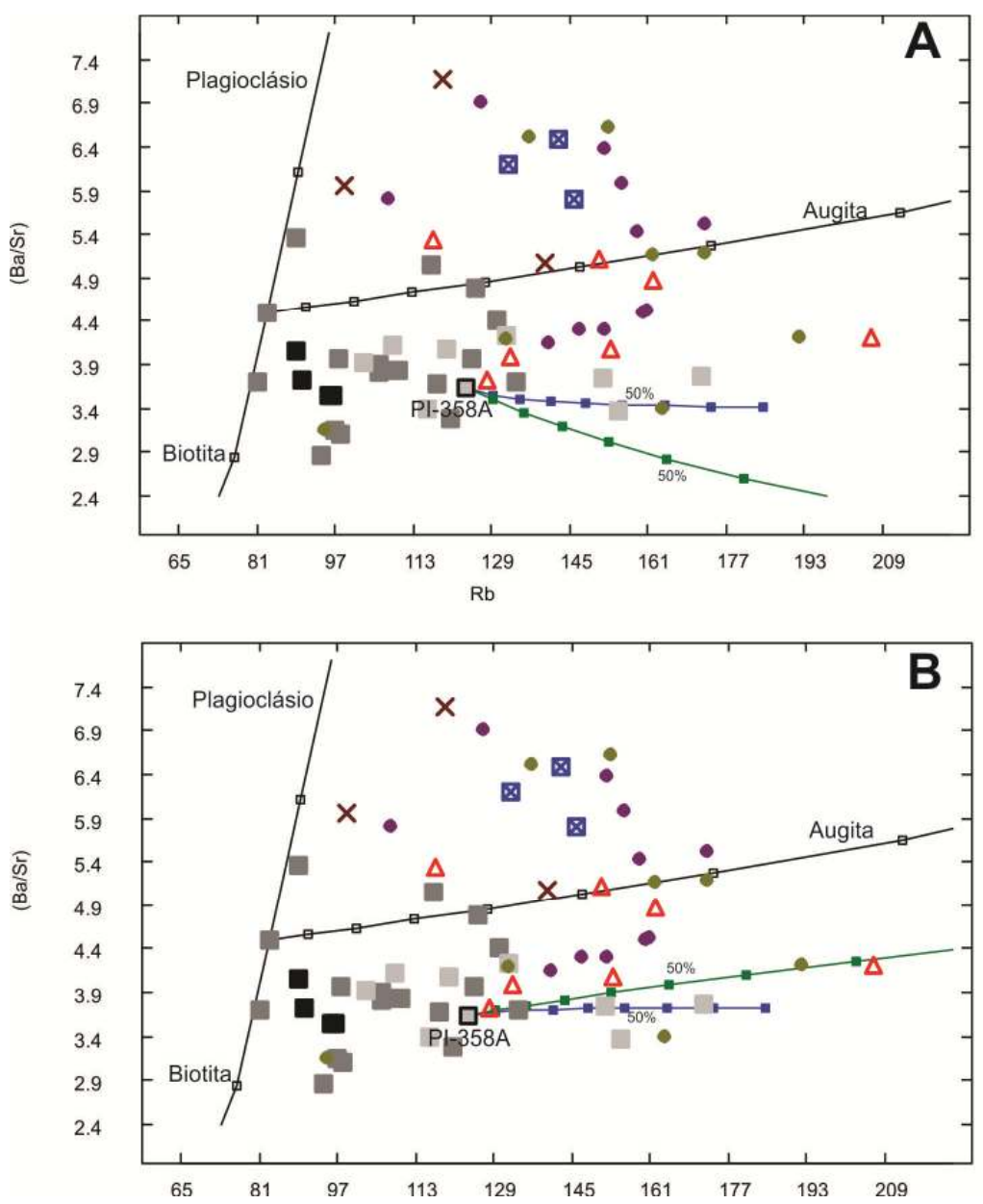

\section{LEGENDA}

Mondodioritos Grossos (Mdr)

Mondodioritos Finos (Mdf) Monzonitos (Mdf)

बSienitos (Sie)

- Monzonitos Heterogêneos (Mh)

$\triangle$ Quartzo Sienitos (Qsie)

- Quartzo Monzonitos (Qsie)

X Vênulas Félsicas

- Cristalização em equilibrio

Cristalização Fracionada

Figura 79. Modelamentos de cristalização fracionada e em equilíbrio a partir das proporções fornecidas pelos modelamentos realizados no software MELTS, para rochas relativamente evoluídas da unidade $M d f$ (monzonito PI-358a). Em (A) utilizou-se $\mathrm{Kd}=10$ para o Ba na biotita, enquanto em (B) utilizou-se $\mathrm{Kd}=6,36$.

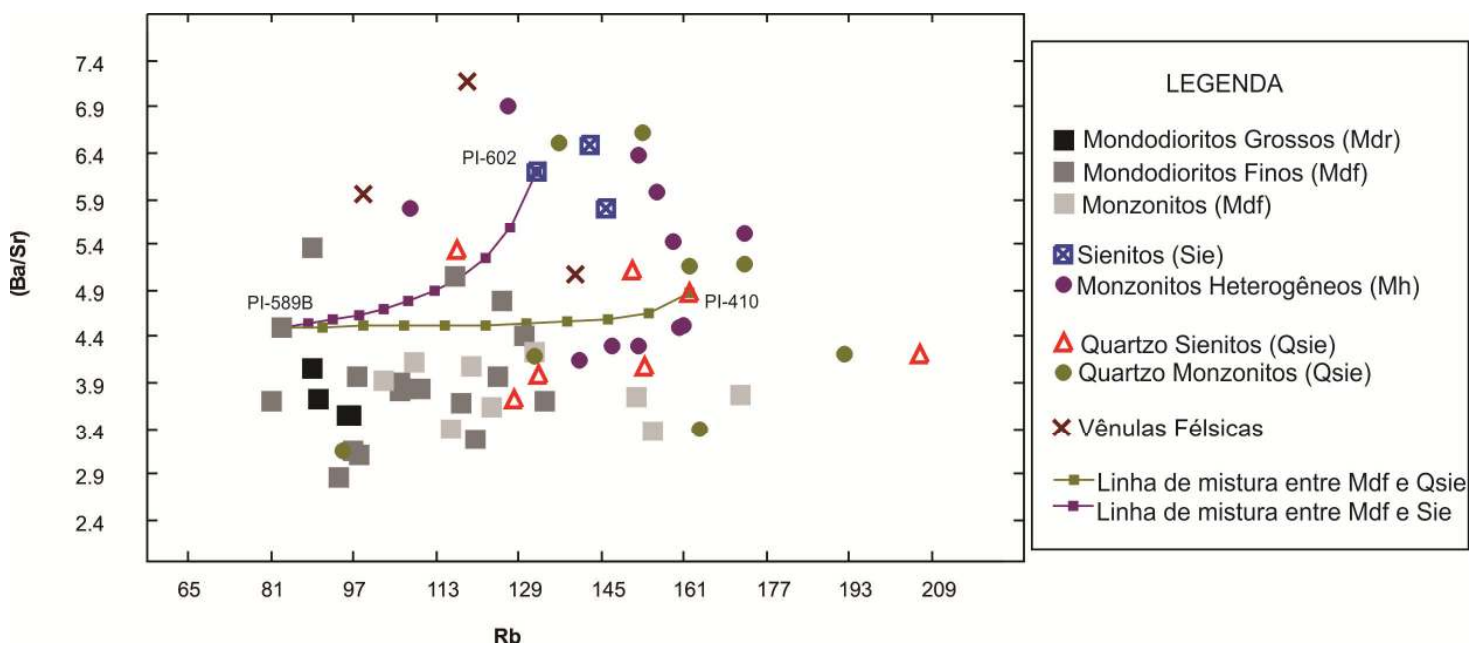

Figura 80. Modelamentos de mistura entre monzodioritos (Mdf) (PI-589B) e a unidade de Sienitos (Sie) e quartzo sienitos da unidade (Qsie). Importante observar a grande dispersão das rochas híbridas (Mh e quartzo monzonitos). 


\section{CAPÍTULO V - CONSIDERAÇÕES FINAIS}

\subsection{Considerações sobre a dinâmica de construção da câmara magmática e cronologia relativa}

Trabalhos anteriores interpretaram a evolução do Plúton Piracaia segundo uma sequência máfico $\rightarrow$ félsica, onde a geração das rochas mais evoluídas estaria vinculada às rochas monzodioríticas.

Janasi (1986) considera que a evolução composicional deve-se a processos de cristalização fracionada dos magmas monzodioríticos, pelo mecanismo de filter pressing. A geração das rochas félsicas estaria relacionada à extração dos líquidos intersticiais dos mushs monzodioríticos em cristalização. A extração destes líquidos teria sido condicionada pela atuação de um campo tensional sobre os magmas, como evidenciado pela forma do plúton e também pela existência de foliação magmática e de estado sólido na maioria das unidades.

Wernick et al. (1997) e Wernick \& Menezes (2001) sugerem que a diferenciação magmática é o principal processo petrogenético responsável pela variação composicional observada no plúton. A partir de uma abordagem baseada em diagramas de fase, propõem que a evolução a partir dos magmas mais primitivos ocorreu em diferentes estágios. Primeiramente, os magmas evoluiriam por cristalização fracionada, cruzando o plano crítico de sílica-insaturação e também o de sílica-saturação. Uma vez atingida uma composição compatível com o sistema Kp-Ne-Q, a evolução se daria segundo dois caminhos distintos: um consolidando-se próximo ao divisor térmico Or-Ab, que representaria as rochas da unidade Sie; e outro, que evoluiria ao longo do vale termal do subsistema Or-Ab-Q, originando as rochas da unidade Qsie. Contudo, os autores propõem a existência de diversos pulsos de magma composicionalmente distintos, gerados por variações no grau de fusão parcial da fonte, assim como a existência de diversas câmaras magmáticas intermediárias, antes da sua colocação final, na câmara que hoje representa o Plúton Piracaia. Estas câmaras intermediárias seriam repreenchidas e drenadas constantemente, e os magmas composicionalmente distintos e sofrendo diferenciação se misturariam em diferentes graus uns com os outros.

Considerando que trabalhos posteriores (Janasi et al. 2007; Salmoni, 2007) identificam a existência de magmas de fontes distintas, e uma vez detalhadas no presente trabalho as feições sugestivas de contemporaneidade e mistura, torna-se interessante a discussão sobre a sequência de pulsos de composição contrastada, i.e. máficos e félsicos, que construíram a câmara magmática e consolidaram o Plúton Piracaia. 


\subsubsection{Relações de corte}

Relações de corte não são abundantes em Piracaia. Um dos principais argumentos utilizados por Janasi (1986) para interpretar as rochas félsicas como mais jovens é a frequente ocorrência de veios e vênulas félsicas (item 2.1.2) cortando as demais unidades, em especial o corpo central de $M d f$.

Diretamente observa-se apenas que grande parte da unidade $M h$ é cortada por quartzo sienitos (Qsie) citando-se como exemplo os pontos PI-512, PI-531, PI-521, PI-515. Embora os contatos sejam predominantemente abruptos, por vezes observam-se contatos irregulares e localmente ocorre mistura entre os magmas.

Com relações às demais unidades, não são observadas relações de corte de maneira clara, ou então se identificam feições de contemporaneidade entre os magmas. Contudo, diversas evidências indiretas permitem inferir uma cronologia relativa entre as unidades.

\subsubsection{Feições de contemporaneidade}

Como descrito neste trabalho, a existência de pillows monzodioríticas próximo ao contato com a unidade Qsie é indicativa de que o corpo central de $M d f$ intrude Qsie. Neste contexto, o formato achatado e o empilhamento das pillows evidenciam a existência de processos de compactação, à medida que o magma monzodiorítico, mais denso, afunda na câmara magmática. Esta compactação pode agir de modo a expulsar o magma félsico residente na câmara. O magma expulso tenderia a subir, cortando os magmas sobrejacentes, que já apresentariam estado mais avançado de cristalização, caracterizando contatos relativamente abruptos. Grande parte das vênulas félsicas que cortam a maioria das rochas de Piracaia pode estar relacionada a processos como este.

Esta hipótese é favorecida pela composição mineralógica e química apresentada por algumas destas venulações. Em diversos locais do corpo central de $M d f$, como por exemplo no ponto PI-598, o monzodiorito é cortado por duas gerações de venulações, sendo que pelo menos uma delas preserva evidências relacionadas a processos de mistura de magmas. A mais espessa, que atinge até $20 \mathrm{~cm}$ em espessura e tem contatos abruptos e predominantemente retilíneos, é modalmente classificada como monzonito, e apresenta elevado conteúdo de allanita, zircão e apatita e enriquecimento nos elementos LREE, HFSE, Th e U. Estas características a tornam muito similar aos horizontes híbridos das venulações descritas na Pedreira, e ela poderia ser interpretada como um magma híbrido que foi expulso pela sobrecarga exercida pelo magma monzodiorítico.

Outra evidência de que o corpo central de $M d f$ intrude $Q$ sie relaciona-se à localização das zonas de interação entre $M d f$ e $Q$ sie. As três zonas com feições de hibrismo ocorrem distribuídas nas bordas do corpo central de $M d f$, o que, associado às suas características estruturais, sugere que a intrusão da unidade central de $M d f$ representa um evento relativamente tardio dentro da dinâmica de construção do plúton. 
Considerando uma origem híbrida para $M h$, e que o corpo central de $M d f$ é intrusivo em Qsie, faz-se necessário pelo menos um pulso mais precoce de $M d f$, para que, após a intrusão de um pulso de magma sienítico (Sie), tenha-se a geração de $M h$. Evidências petrográficas também sugerem um pulso precoce de $M d f$, uma vez que os cristais tabulares (antecristais) de plagioclásio presentes em $M d f$ são maiores em relação aos encontrados no corpo central de $M d f$.

Já a colocação do corpo de Monzodioritos grossos $(M d r)$ localizado na porção SW do plúton em relação às demais unidades não pode ser seguramente definida através de evidências de campo ou petrográficas. Embora em alguns pontos do corpo (PI-609, PI-589) observem-se lentes de monzodiorito fino, ou monzodiorito fino e monzodiorito grosso em contato, a pequena área exposta não permite estabelecer a sequência de intrusão.

O fato de estas rochas não apresentarem foliação de estado sólido, onde por vezes nem mesmo é observada foliação magmática, por si só não comprova sua colocação tardia em relação às demais unidades. Considerando que a distribuição do strain não é homogênea ao longo de zonas de cisalhamento, a porção SW do plúton poderia ter sido simplesmente menos afetada pelo campo tensional, podendo ser considerada uma "sombra de pressão".

Contudo, dados de Anisotropia de Susceptibilidade Magnética (ASM) apresentados por Raposo et al. (2011) auxiliam na interpretação da sequência de eventos e na compreensão da dinâmica de construção do plúton.

\subsubsection{Anisotropia de Susceptibilidade Magnética}

No trabalho realizado por Raposo et al. (2011) foram amostrados cerca de 30 pontos que abrangem as diferentes unidades que compõem o plúton. Os resultados de foliação e lineação magnéticas são apresentados na Figura 81.

Observa-se que a foliação magnética é predominantemente subvertical e sua orientação coincide com a orientação do plúton e também com a direção da foliação magmática e de estado sólido observadas em campo. Nestes locais, o caimento da lineação magnética é de baixo ângulo e sua orientação aponta para S-SW. Este padrão é diferente na porção SW do plúton, onde a orientação da foliação é variável e encontram-se lineações com alto ângulo de caimento, por vezes subverticais. Esta dispersão da orientação da foliação, somada ao alto caimento da lineação, permite inferir que a porção SW representa uma zona de alimentação da câmara magmática, a partir de onde os magmas migrariam para $\mathrm{N}$, condicionados pelo campo tensional atuante na região.

Neste contexto, os monzodioritos grossos poderiam representar a última unidade na sequência de construção do plúton. Ainda assim, é possível que haja pequenos pulsos de magmas monzodioríticos ainda mais tardios, como sugerido pela existência de localizada de $M d f$ associado a $M d r$, como descrito no item 2.1.1. 


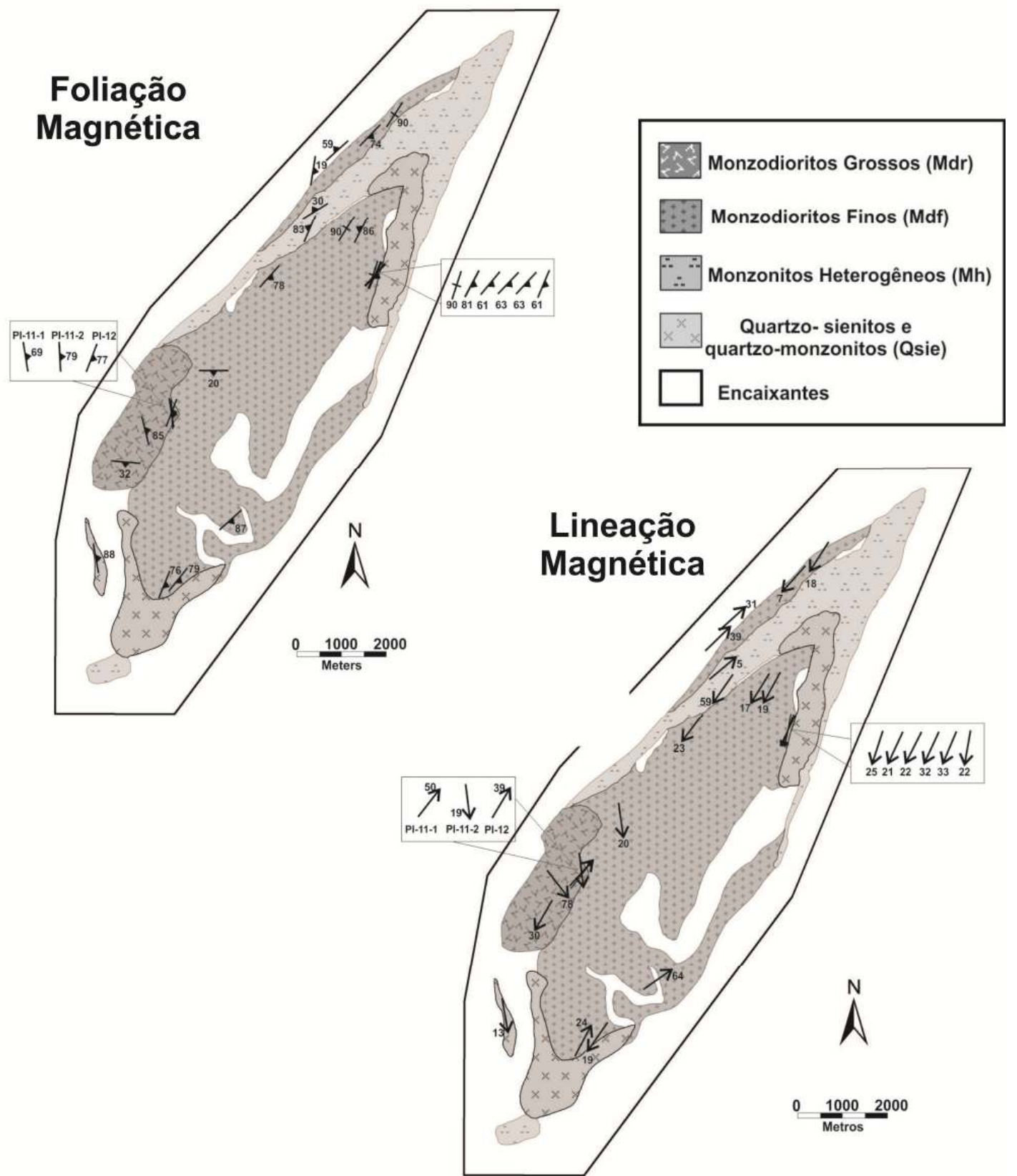

Figura 81. Mapas de foliação e lineação magnética para as diferentes unidades que compõem o Plúton Piracaia (extraído de Raposo et al., 2011). 


\subsection{Fatores condicionantes dos processos de mistura de magmas}

No presente trabalho são discutidas evidências de campo, petrográficas e geoquímicas da existência de dois processos de interação e mistura heterogênea de magmas: (i) entre $M d f$ e Sie, gerando a unidade $M h$; (ii) entre $M d f$ e quartzo sienitos ( $Q$ sie), gerando estruturas de coexistência, mistura localizada, e possivelmente os quartzo monzonitos da unidade Qsie. Dadas as especificidades de qualquer processo de mistura, é interessante considerar os diferentes fatores que exerceram influência sobre os magmas.

Embora o Plúton Piracaia seja de pequena dimensão, o que favoreceria uma câmara magmática com vida relativamente curta, evidências apresentadas no presente trabalho sugerem que sua construção ocorreu gradualmente, pela injeção de vários pulsos de magma, que interagiram entre si em diferentes intensidades. Neste contexto, os últimos eventos de preenchimento da câmara teriam sido de magmas monzodioríticos, correspondentes ao corpo central de $M d f$ e a $M d r$. Esta possibilidade vai de encontro aos modelos petrogenéticos atuais, que consideram a construção de batólitos e plútons como um processo gradual, que se dá pela injeção de múltiplos pulsos de magmas, em um intervalo de tempo relativamente grande (Wiebe \& Collins, 1998; Wiebe et al. 2002).

No que se refere à mistura entre $M d f$ e Sie, evidências sugerem que os magmas apresentavam uma taxa relativamente baixa de cristalização no momento da interação. A principal delas é a intensa interdigitação entre porções monzodioríticas e sieníticas apresentada pelos $M h$. Além disso, a textura média a fina das rochas juntamente com as estimativas de temperaturas liquidus relativamente elevadas para as rochas de Sie e $M d f$, evidenciam um resfriamento rápido. Neste caso, os magmas teriam se comportado como líquidos no momento de seu posicionamento e a intensa interdigitação, que atinge escala milimétrica sem que as porções monzodioríticas e sieníticas percam totalmente sua identidade textural, sugere uma forte atuação de processos mecânicos. Considerando que possa não ter havido tempo suficiente para uma interação mais avançada na câmara magmática de Piracaia, é favorecida a hipótese de que a mistura tenha ocorrido durante ascensão dos magmas, sendo facilitada e intensificada pelo transporte. Diversos trabalhos sugerem que uma mistura mais efetiva é favorecida por processos dinâmicos, desenvolvidos previamente ao posicionamento final dos magmas. Koyaguchi (1986) afirma que mistura mecânica (cisalhamento tectônico, convecção forçada, ascensão em condutos, etc.) parece ser um mecanismo eficiente e necessário para que o mecanismo de hibridização ocorra. Collins et al. (2000) sugerem que a mistura é favorecida em condutos (durante a ascensão) ao invés de ocorrer no local de posicionamento e, segundo os autores, experimentos realizados Blake \& Campbell (1986) corroboram esta hipótese.

É consenso nos trabalhos de Bateman (1995) e Sparks and Marshall (1986) que os magmas sofrem mistura homogênea somente se o contraste de viscosidade for pequeno. No que se refere à mistura entre $M d f$ e quartzo sienitos (Qsie), a grande diferença composicional entre os magmas, juntamente com o avançado estágio de cristalização dos quartzo sienitos, evidenciado pela textura 
grossa dessas rochas, aponta para um grande contraste de viscosidade no momento da interação. Existindo este importante contraste reológico e considerando as evidências apresentadas neste trabalho que apontam os quartzo monzonitos como magmas híbridos, cria-se uma dificuldade, uma vez que se faz necessário algum fator que supere esta barreira de contraste e possibilite a mistura entre quartzo sienitos e $M d f$ em grande escala, suficiente para gerar o grande volume de quartzo monzonitos.

As evidências de campo indicam que a interação entre $M d f$ e quartzo sienitos foi fortemente heterogênea e ocorreu no local final de posicionamento. Neste contexto, as ocorrências sul e norte de Qsie representariam inicialmente um único corpo de magma quartzo sienítico, que uma vez invadido por um grande volume de magma monzodiorítico, teria se misturado parcialmente, gerando os quartzo monzonitos. O corpo de quartzo sienito situado ao norte, representaria então as porções remanescentes e pouco afetadas pelo processo de mistura.

Considerando que os quartzo monzonitos ocupam uma área muito maior do que os quartzo sienitos, o grande volume de magma monzodiorítico pode ter favorecido o processo de mistura. $\mathrm{O}$ aporte de calor proveniente do magma máfico teria facilitado a mistura com os quartzo sienitos, aquecendo-os e desencadeando convecção termal, de modo a compensar o contraste composicional e avançado estágio de cristalização (e.g., Wiebe et al., 2004). Neste contexto, a textura predominantemente fina de $M d f$ estaria relacionada à intensa perda calor, uma vez em contato com o magma residente na câmara. Evidências desta perda de calor são também observadas próximo aos contatos entre $M d f$ e $Q$ sie. Nestes locais, o desenvolvimento de estruturas do tipo pillow sugere que houve inversão reológica entre os magmas (Philpotts \& Ague, 2009). Ou seja, o magma monzodiorítico, inicialmente menos viscoso que o quartzo sienítico em cristalização, uma vez sofrendo resfriamento, passa a ser o magma de maior viscosidade do sistema.

Considerando que a mistura tende a ser mais efetiva quanto menores os contrastes composicionais existentes entre os magmas, uma alternativa para a geração de $M h$ e quartzo sienitos, é a de que o extremo máfico da mistura não corresponda aos magmas mais máficos de $M d f$. Uma possibilidade seria a de que os magmas mais félsicos de $M d f$ estejam relacionados_a variações no grau de fusão de sua fonte, uma vez que os modelamentos geoquímicos para elementos traço (item 4.4.1) já apontam que além da diferenciação, processos adicionais possam ter contribuído para a gênese da unidade Mdf. A alternância de pulsos mais e menos evoluídos é condizente segundo o modelo veinplus-wall-rock melting, admitido para a gênese das rochas mais máficas de Piracaia. Possíveis evidências para esta última hipótese são encontradas no contato entre as unidades $M d r$ e $M d f$. Nesta porção do plúton, onde ocorrem os monzodioritos mais primitivos, foram observados rochas de textura grossa e textura fina em contato (PI-589), composicionalmente idênticas e dentre as menos evoluídas de todo o conjunto, o que sugere a existência de mais de um pulso de composição semelhante. Não distante deste ponto, encontram-se monzonitos associados a monzodioritos finos, onde os monzonitos apresentam a mesma mineralogia, porém apresentam-se muito mais félsicos (PI-588 e PI-358). 
Com relação às características geoquímicas das rochas híbridas, Perugini et al. (2003) consideram que processos difusivos e de mistura dinâmica podem agir conjuntamente de modo a intensificar a mistura química do sistema, uma vez que a efetividade dos processos de difusão é tanto maior quanto mais extensas forem as superfícies de contato (interface) entre os magmas. Por outro lado, Perugini et al. (2006) salientam que, devido à grande diferença nos coeficientes de difusão para elementos traço, é possível que a mistura mecânica promova um "fracionamento por difusão", onde os magmas híbridos adquirem concentrações muito diversas.

Neste contexto, interpreta-se que as variações observadas nos elementos traço das rochas híbridas de Piracaia refletem essencialmente os processos heterogêneos de mistura atuantes no plúton e as menores variações observadas para $M h$ podem ser atribuídas à intensificação do processo de difusão devido à interdigitação entre porções monzodioríticas e sieníticas. No caso da interação entre quartzo sienitos (Qsie) e $M d f$, possíveis variações químicas das rochas félsicas relacionadas a processos de diferenciação prévios ao evento de mistura precisariam ser investigadas em maior detalhe, uma vez que a geração de todo o volume de quartzo monzonitos demandaria uma câmara bastante dinâmica, dados os significativos contrastes existentes entre os magmas quartzo sieníticos e monzodioríticos. 


\section{REFERÊNCIAS BIBLIOGRÁFICAS}

Anderson, J.L. \& Smith, D.R., 1995. The effect of temperature and oxygen fugacity on Al-inhornblende barometry. American. Mineralogist., 80: 549-559.

Anderson, J.L., 1996. Status of thermobarometry in granitic batholiths. Transactions of the Royal Society of Edinburgh: Earth Sciences, 87: 125-138.

Anderson, J.L., Barth, A.P., Wooden, J.L., Mazdab, F., 2008. Thermometers and Thermobarometers in Granitic Systems. Reviews in Mineralogy and geochemistry, 69: 121-142.

Artur, A.C., Wernick, E.; Hormann, P.K. \& Weber-Diebenfach, L. ,1993. Associações plutônicas do Complexo Granitóide Socorro (Estados de São Paulo e Minas Gerais Brasil) Revista Brasileira de Geociências, 23: 262-273.

Artur, A.C., Wernick, E., Weber-Diefenbach, K., Hörmann, P.K., Fahl, F.C., 1994. Caracterização geoquímica e evolução do magmatismo Piracaia, SP. In: Anais do $38^{\circ}$ Congresso Brasileiro de Geologia, 1: 119-120.

Artur, C.A., 2003. Complexo Granitóide Plurisserial Socorro: Geologia, Petrologia e Recursos Minerais. Tese de Livre Docência. Instituto de Geociências e Ciências Exatas, UNESP, 139p.

Azzone, R.G., 2008. Petrogênese do Maciço Alcalino Máfico-ultramáfico Ponte Nova (SP-MG). Tese de doutorado. Instituto de Geociências, Universidade de São Paulo, 240p.

Bacon, C.R. \& Hirschmann, M.M.,1988. Mg/Mn partitioning as a test for equilibrium between coexisting Fe-Ti oxides. American Mineralogist, 73: 57-61

Bachmann, O., Dungan, M. A. \& Lipman, P. W., 2002. The Fish Canyon magma body, San Juan Volcanic Field, Colorado: rejuvenation and eruption of an upper-crustal batholith. Journal of Petrology 43, 1469-1503.

Barbarin B., 1999. A review of the relationships between granitoid types, their origins and their environments. Lithos, 46, 605-626. 
Bastin, G.F., Van Loo, F.J.J., Heijligers, H.J.M., 1984. Evaluation and use of Gaussian $\Phi(\mathrm{pz})$ curves in quantitative electron probe microanalysis: a new optimization. X-Ray Spectrometry, 13: 91-97.

Bateman, R., 1995. The interplay between crystallization, replenishment and hybridization in large felsic magma chambers. Earth-Science Reviews, 39: 91-106.

Best, M.G. 2003. Igneous and Metamorphic Petrology. Blackwell Science Press, Berlim, 729p.

Blake, S. \& Campbell, I. H., 1986. The dynamics of magma-mixing during flow in volcanic conduits. Contributions to Mineralogy and Petrology, 94: 72-81.

Blundy, J. \& Holland, T. 1990. Calcic amphibole equilibria and a new amphibole-plagioclase geothermometer. Contributions to Mineralogy and Petrology, 104: 208-224.

Blundy, J.D. \& Wood, B.J., 1991.Crystal-chemical controls on the partitioning of $\mathrm{Sr}$ and $\mathrm{Ba}$ between plagioclase feldspar, silicate melts, and hydrothermal solutions. Geochimica et Cosmochimica Acta, 55: 193-209.

Buddington, A.F. \& Lindsley, D.H. 1964. Iron-titanium oxide minerals and synthetic equivalents. Journal of Petrology, 5:31-357.

Bunsen, R., 1851. Über die Processe der vulkanischen Gesteinbildung Islands. Annalen der Physik und Chemie, 83(6): 197-272.

Campos Neto M.C., Basei M.A.S., Artur A.C., Silva M.E., Machado R., Dias Neto C.M., Fragoso-Cesar A.R.,1983. Geologia das Folhas Piracaia e Igaratá. In: 1a Jornada sobre a Carta Geológica do Estado de São Paulo em 1:50.000. PRÓ-MINÉRIO, São Paulo, 61-78

Campos Neto M.C., 2000. Orogenic systems from Southwestern Gondwana: An approach to Brasiliano-Pan-African cycle and orogenic collage in Southeastern Brazil. In: U.G. Cordani, E.J. Milani, A. Thomaz Filho and D.A. Campos (eds.): Tectonic Evolution of South America. 31 st International Geological. Congress, Rio de Janeiro, 335-365.

Campos Neto M.C. \& Caby R., 1999. Neoproterozoic high-pressure metamorphism and tectonic constraint from the nappe system south of the São Francisco Craton, southeast Brazil. Precambrian Research, 97:3-26. 
Carmichael, I.S.E., 1991. The redox states of basic and silicic magmas: a reflection of their sources?. Contributions to Mineralogy and Petrology, 106:129-141.

Cavalcante, J.C. \& Kaefer, L.Q., 1974. Complexo de Piracaia - estudos preliminares. In: Anais do $28^{\circ}$ Congresso Brasileiro de Geologia, Porto Alegre, 5: 101-106.

Collins, W.J., Richards, S.R., Healy, B.E., Ellison, P.I., 2000. Origin of heterogeneous mafic enclaves by two-stage hybridization in magma conduits (dykes) below and in granitic magma chambers. Transactions of the Royal Society of Edinburgh: Earth Sciences, 91: 27-45.

Czamanske, G.K.; Mihálik, P., 1972. Oxidation during magmatic differentiation, Finnmarka Complex, Oslo Area, Norway. Part 1. The opaque oxides. Journal. Petrology, 13: 493-503.

Czamanske, G.K.; Wones, D.R., 1973. Oxidation during magmatic differentiation, Finnmarka Complex, Oslo Area, Norway. Part 2. The mafic silicates. JournalPetrology, 14: 349-380.

Dall'Agnol, R., Pichavant, M., Champenois, M., 1997. Iron-titanium oxide mineral of the Jamon Granite, Eastern Amazonian Region, Brazil: implications for the oxygen fugacity in Proterozoic A-type granites. Anais da Academia Brasileira de Ciências, 69: 325-347.

Dall'agnol, R.; Oliveira, D. C., 2007. Oxidized, magnetite-series, rapakivi type granites of Carajás, Brazil: implications for classification and petrogenesis of A-type granites. Lithos. 93: 215-233.

Davidson, J.P., Morgan, D.J., Charlier, B.L.A., Harlou, R. \& Hora, J.M., 2007. Microsampling and isotopic analysis of igneous rocks: implications for the study of magmatic systems. Annual Reviews of Earth and Planetary Sciences, 35:273-311.

Deer, W.A., Howie, R.A. \& Zussman, J., 1992. An Introduction to the Rock-Forming Minerals. Second Edition. Longman Scientific \& Technical, 696p.

Debon, F.,1991. Comparative major element chemistry in various "microgranular enclave - plutonic host” pairs In: Didier, J. \& Barbarin, B. (eds), Enclaves and Granite Petrology. Elsevier: 293312.

De La Roche, H. Leterrier, J., GrandClaude, P., \& Marchal, M.1980. A Classification of Volcanic and Plutonic Rocks using R1R2 - Diagram and major element analysis - its relationships with current nomenclature. Chemical Geology, 29:183-210. 
Frost, B.R., Arculus, R.J., Barnes, C.G., Collins, W.J., Ellis, D.J., Frost, C.D., 2001. A geochemical classification of granitic rocks. Journal of Petrology 42(11): 2033-2048.

Frost, B. R., Frost, C. D., 2008. A geochemical classification for feldspatic igneous rocks. Journal of Petrology, 49(11): 1955-1969.

Foley, S., 1992. Vein-plus-wall-rock melting mechanisms in the lithosphere and the origin of potassic alkaline magmas. In: A. Peccerillo and S. Foley (ed.), Potassic and Ultrapotassic Magmas and their Origin. Lithos, 28: 435-453.

Fourcade, S., Allegre, C.J., 1981. Trace Elements Behavior in Genesis: A case study The CalcAlkaline Plutonic Association from the Querigut Complex (Pyrénées, France). Contributions to Mineralogy and Petrology, 76: 177-195.

Ghiorso, M. \& Evans, W., 2008. Thermodynamics of rhomboedral oxide solid solutions and a revision of the Fe-Ti two-oxide geothermometer and oxygen-barometer. American Journal of Science, 308: 957-1039.

Gomes, E.P. \& Plaetvoet, B., 1994. O complexo ácido-básico de Piracaia, SP- representação de um magmatismo de afinidade shoshonítica do Ciclo Brasiliano. Anais do $38^{\circ}$ Congresso Brasileiro de Geologia, SBG, Balneário de Camburiú, SC, Brasil, 3: 32-34.

Gomes, E.P., 1995. Les intrusions de Piracaia et de Salmão (État de São Paulo, Brésil). Témoins d'un magmatisme potassique en fin d'orogenèse Brasiliano.. Tese de doutorado, Université de ParisSud, Centre D’Orsay, 210p.

Gualda, G.A.R. \& Vlach, S.R.F., 2005. Stoichiometry-based estimates of ferric iron in calcic, sodiccalcic and sodic amphiboles: a comparison of various methods. Anais da Academia Brasileira de Ciências, 77(3):521-534.

Haggerty, S.E., 1976. Opaque mineral oxides in terrestrial igneous rocks. Mineralogical Society of America Reviews in Mineralogy, 3: $\mathrm{Hg} 101-\mathrm{Hg} 300$.

Haggerty, S. E., 1981. Oxidation of opaque mineral oxides in basalts. In: Rumble III (ed.) Oxide Minerals. $2^{\text {nd }}$ ed. Washington, Mineral Society of America. P., Hgl-Hg99. (short course notes). 
Hammarstrom, J.M. \& Zen, E-an, 1986. Aluminium in hornblende, an empirical igneus geobarometer. American Mineralogist, 71: 1297-1313.

Harrison, T.M. \& Watson, E.B. . 1984. The behavior of apatite during crustal anatexis: Equilibrium and kinetic considerations. Geochimica et Cosmochimica Acta. 48: 1468-1477

Heilbron, M.L., Pedrosa-Soares, A.C., Campos Neto, M.C., Silva, L.C., Trouw, R. \& Janasi, V.A., 2004. Província Mantiqueira. In: V.M. Mantesso-Neto, A. Bartorelli, C.D.R. Carneiro \& Brito-Neves, B.B. (orgs.). Geologia do Continente Sul-Americano. São Paulo, Editora Beca. 203-234p.

Hibbard, M.J., 1991. Textural anatomy of twelve magma-mixed granitoid systems. In: Didier, J. \& Barbarin, B. (eds), Enclaves and Granite Petrology. Elsevier: 431-443.

Holland, T. \& Blundy, J., 1994. Non-ideal interactions in calcic amphiboles and their bearing on amphibole-plagioclase thermometry. Contributions to Mineralogy and Petrology, 116: 433-447.

Hollister, L.S.; Grisson, G.C.; Peters, E.K.; Stowell, H.H. \& Sisson, V.B., 1987. Confirmation of the empirical correlation of $\mathrm{Al}$ in hornblende with pressure of solidification of calc-alkaline plutons: Americam Mineralogist, 27: 231-239.

Housh, T.B. \& Luhr, J.F., 1991. Plagioclase-melt equilibria in hydrous systems. American Mineralogist, 76: 477-492.

Icenhower, J. P. \& London, D., 1996. Experimental partitioning of Rb, Cs, Sr, and Ba between alkali feldspar and peraluminous melt. American Mineralogist. 81: 719-734.

Ishihara, S., 1977. The magnetite-series and ilmenite-series granitic rocks. Mining Geology, 27: 293305.

Janasi V.A., 1986. Geologia e petrologia do maciço monzodiorítico monzonítico de Piracaia-SP. Dissertação de Mestrado, Instituto de Geociências, Universidade de São Paulo, 281 p.

Janasi, V.A. \& Ulbricht, H.H.G.J., 1987. Petrogenesis of the monzonitic-monzodioritic Piracaia massif, State of São Paulo, southern Brazil:field and petrographic aspects. Revista Brasileira de Geociências, 17: 524-534. 
Janasi V.A. , 1999. Petrogênese de granitos crustais na Nappe de Empurrão Socorro-Guaxupé (SPMG): uma contribuição da geoquímica elemental e isotópica. Tese de Livre-Docência, Instituto de Geociências, Universidade de São Paulo, 304 p.

Janasi, V.A., Vlach, S.R.F. \& Ulbrich, H.H.G.J., 1993. Enriched-mantle contributions to the Itu granitoid belt, southeastern Brazil: evidence from K-rich diorites and syenites. Anais da Academia Brasileira de Ciências, 65 (supl.1): 107-118.

Janasi, V.A., Leite, R.J. \& Van Schmus, W.R., 2001. U-Pb chronostratigraphy of the granitic magmatism in the Agudos Grandes Batholith (west of São Paulo, Brazil) - implications for the evolution of the Ribeira Belt. Journal of South American Earth Sciences 14: 363-373.

Janasi, V.A., Vlach, S.R.F., Campos Neto, M.C., Ulbrich, H.G.J., 2009. Associated A-type subalkaline and high-K calc-alkaline granites in the Itu Granite Province, southestern Brazil: petrological and tectonic significance. The Canadian Mineralogist, 47: 1505-1526.

Jerram, D.A., Martin, V.M., 2008. Understanding crystal populations and their significance through the magma plumbing system. Geological Society, London, Special Publications, 304: 133-148.

Johnson, M.C. \& Rutherford, M.J. Montel. 1989. Experimental calibration of the aluminium-inhornblende geobarometer with application to Long Valley caldera (California) volcanic rocks. Geology, 17: 137-841.

Klein, C. \& Hurlbut, C.S., 2002. The $22^{\text {nd }}$ edition of the Manual of Mineral Science. $22^{\mathrm{a}}$ ed. John Wiley \& Sons, Inc. New York, 643 p.

Koyaguchi, T., 1986. Textural and compositional evidence for magma mixing and its mechanism, Abu volcano group, southwestern Japan. Contributions to Mineralogy and Petrology, 93(1): 3345.

Lange, R.A., Frey, H.M. \& Hector, J., 2009. A thermodynamic model for the plagioclase-liquid hygrometer/thermometer. American Mineralogist, 94: 494:506.

Langmuir, C.H., Vocke Jr., R.D., Hanson, G.N., 1978. A general mixing equation with applications to Icelandic basalts. Earth and Planetary Science Letters, 37: 380-192. 
Lalonde, A.E., Bernard, P., 1993. Composition and colour of biotite from granites: two useful properties in the characterization of plutonic suites from the Hepburn internal zone of wopmay orogen, northewest territories. The Canadian Mineralogist, 31: 203:217.

Lepage, D.L., 2003. ILMAT: an excel worksheet for ilmenite-magnetite geothermometry and geobarometry. Computers \& Geosciences, 29 (5): 673-678.

Leake, B.E. (Chairman), 1997. Nomenclature of amphiboles, Report of the Subcommittee on Amphiboles of the International Mineralogical Association Comission on New Minerals and Mineral Names. European Journal of Mineralogy, 9: 623-651.

Lindsley, D.H., 1965. Iron-titanium oxides. Carnegie Institution of Washington Yearbook, 64: 144148.

Martins, L., 2001. Condições de cristalização de granitos sin- e tardi-orogênicos da porção central do Batólito Agudos Grandes, SP, com base em geoquímica de minerais e rochas. Dissertação de Mestrado. Instituto de Geociências, Universidade de São Paulo, 127 p.

McCarthy, T.S., 1976. Chemical interrelationship in a low-pressure granulite terrain in Namaqualand, South Africa, and their bearing in on granite genesis and the composition of the lower crust. Geochimica et Cosmochimica Acta, 40: 1057-1068.

Miyashiro, A., 1974. Volcanic rock series in island arcs and active continental margins. American Journal of Science, 274: 321-355.

Navarro, M.S., 2004. A implantação de rotina, e seu refinamento, para determinação de elementos terras raras em materiais geológicos por ICP-OES e ICP-MS. Aplicação ao caso dos granitóides de Piedade-Ibiúna (SP) e Cunhaporanga (PR). Dissertação de Mestrado. Instituto de Geociências, Universidade de São Paulo. 132p.

Neuman, H., Mead, J., Vitaliano, C.J., 1954. Trace-element variation during fractional crystallization as calculated from the distribution law. Geochimica et Cosmochimica Acta, 6: 90-100.

O'Connor, J. T., 1965. A classification for quartz-rich igneous rocks based on feldspar ratios. In: US Geological Survey Professional Paper. USGS, B525. 79-84. 
Oliveira, F.C., 2009. Petrografia e geoquímica de microestruturas magmáticas e implicações para a evolução do Plúton Piracaia. Monografia de Trabalho de Formatura. Instituto de Geociências, Universidade de São Paulo, 44p.

Orsini, J.B., Cocirta, C., Zorpi, M.J., 1991. Genesis of mafic microgranular enclaves through differentiation of basic magmas, mingling and chemical exchanges with their host granitoid magmas. In: Didier, J. \& Barbarin, B. (eds), Enclaves and Granite Petrology. Elsevier: 445464.

Peccerillo, A., Taylor, S.R., 1976. Geochemistry of Eocene calc-alkaline rocks from Kastamonu area, Northern Turkey. Contributions to Mineralogy and Petrology, 58: 63-81.

Perugini, D., Poli, G., Mazzuoli, R., 2003. Chaotic advection, fractals and diffusion during mixing of magmas: evidences from lava flows. Journal of Volcanology and Geothermal Research 124: $255-279$.

Perugini, D., Petrelli, M., Poli, G., 2006. Diffusive fractionation of trace elements by chaotic mixing of magmas. Earth and Planetary Science Letters 243: 669-680.

Petrelli M., Poli G., Perugini D. \& Peccerillo A., 2005. Petrograph: a New Software to Visualize, Model, and Present Geochemical Data in Igneous Petrology, Geochemistry, Geophysics, and Geosystems., 6(7): Q07011, DOI 10.1029/2005GC000932.

Petrelli, M., Perugini, D., Poli, G., 2011. Transition to chaos and implications for time-scales of magma hybridization during mixing processes in magma chambers. Lithos 125: 211-220.

Philpotts, A.R. \& Ague, J.J., 2009. Principles of Igneous and Metamorphic Petrology. Cambridge University Press. Cambridge, UK, 667p.

Prazeres Filho, H.J., Harara, O.M., Basei, M.A.S., Passarelli, C.R. \& Siga Jr, O., 2003. Litoquímica, geocronologia $\mathrm{U}-\mathrm{Pb}$ e geologia isotópica $(\mathrm{Sr}-\mathrm{Nd})$ das rochas graníticas dos batólitos Cunhaporanga e Três Córregos na porção sul do Cinturão Ribeira, Estado do Paraná. Geologia USP, série Científica 3: 51-70.

Pressi, L.F., Oliveira, F.C., Janasi, V.A., 2010. Interação de magmas monzodioríticos e quartzo sieníticos no pluton Piracaia (SP): evidências estruturais e conseqüências geoquímicas. In: 
Anais do $45^{\circ}$ Congresso Brasileiro de Geologia. $45^{\circ}$ Congresso Brasileiro de Geologia, BelémPA.

Putirka K.D., 2005. Igneous thermometers and barometers based on plagioclase + liquid equilibria: Tests of some existing models and new calibrations. American Mineralogist, 90: 336-346.

Salmoni, B., 2007. Evolução magmática do Plúton Monzonítico-Monzodiorítico de Piracaia (SP). Monografia de Trabalho de Formatura. Instituto de Geociências, Universidade de São Paulo, $56 \mathrm{p}$.

Raposo, M.I.B., Pressi, L.F., Janasi, V.A., 2011. Magnetic fabrics and their relationship with the emplacement of the Piracaia pluton, Se Brazil. International Journal of Earth Sciences. DOI: 10.1007/s00531-011-0696-5.

Shand S.J., 1943. Eruptive rocks. their genesis, composition, classification, and their relation to oredeposits. With a chapter on meteorite. New York.

Schmidt, M.W., 1992. Amphibole composition in a tonalite as a function of pressure: An experimental calibration of the Al-in-hornblende barometer. Contributions to Mineralogy and Petrology, 110: 304-310.

Sparks, R.S.J., \& Marshall, L., 1986. Thermal and mechanical constraints on mixing between mafic and silicic magmas. Journal of Volcanology and Geothermal Research, 29, 99-124.

Spencer, K.J. \& Lindsley, D.H., 1981. A solution model for coexisting iron-titanium oxides. American Mineralogist, 66: 1189-1201.

Stormer, J.C., Nicholls, J., 1978. XLFRAC: a program for the interactive testing of magmatic differentiation models. Computers \& Geosciences 4, 143-159.

Stormer, J.C., 1983. The effects of recalculation on estimates of temperature and oxygen fugacity from analyses of multicomponent iron-titanium oxides. American Mineralogist, 68: 586:594.

Sun, S., McDonough, W.F., 1989. Chemical and isotopic systematics of oceanic basalts: implications for mantle composition and processes. In: Saunders, A. D. \& Norry, M.J. (eds.), Magmatism in the Ocean Basins. Geological Society, London, Special Publications, 42: 315:345. 
Töpfner, C., 1996. Brasiliano - Granitoide in den Bundesstaaten São Paulo and Minas Gerais, Brasilien - Eine vergleichende Studie (Zircontypologie, U-(Th)-Pb und $\mathrm{Rb}-\mathrm{Sr}$ Altersbestimmungen). Müncher Geologische Hefte - Reine A (Allgemeine Geologie, 17: 258p.

Turnbull, R., Weaver, S., Tulloch, A., Cole, J., Handler, M., Ireland., T., 2010. Field and Geochemical constraints on mafic-felsic interactions, and processes in high-level arc magma chambers: an example from the halfmoon pluton, New Zealand. Journal of Petrology, 51(7): $1477-1505$.

Vauchez, A., Tommasi, A., Egydio-Silva, M., 1994. Self-indentation of a heterogeneous continental lithosphere. Geology, 22: 967-970.

Villemant, B., Jaffrezic, H., Joron, J.L. and Treuil, M., 1981. Distribution Coefficients of Major and Trace-Elements - Fractional Crystallization in the Alkali Basalt Series of Chaine-Des-Puys (Massif Central, France). Geochimica et Cosmochimica Acta 45(11): 1997-2016.

Watson, E.B. \& Harrison, T.M., 1983. Zircon saturation revisited: temperature and composition effects in a variety of crustal magma types. Earth and Planetary. Science. Letters., 64: 295-304.

Wernick, E., Artur, C.A., Hörman, P.K., Weber-Diefenbach, W., Fahl, F.C., 1997. O magmatismo alcalino potássico Piracaia, SP (SE Brasil): aspectos composicionais e evolutivos. Revista Brasileira de Geociências, 27(1):53-66.

Wernick, E. \& Menezes, A.C., 2001. The late precambrian K-alkaline magmatism in the Ribeira Fold Belt: a case study of the Piracaia Pluton, State of São Paulo, SE Brazil, and its potential mineralization (Cu, Zn, Gd). Journal of Asian Sciences, 19: 347-373.

Whalen, J.B., Currie, K.L., Chappell, B.W., 1987. A-type granites: geochemical characteristics discrimination and petrogenesis. Contributions to Mineralogy and Petrology, 95: 407-419.

Wiebe, R.A., 1988. Structural and Magmatic Evolution of a MagmaChamber: The Newark Island Layered Intrusion, Nain, Labrador. Journal of Petrology, 29 (2): 383 -411.

Wiebe, R.A. e Collins, W.J., 1998. Depositional features and stratigraphic sections in granitic plutons: implications for the emplacement and crystallization of granitic magma. Journal of Structural Geology 20: 1273-1289. 
Wiebe, R. A., Frey, H. \& Hawkins, D. P., 2001. Basaltic pillows mounds in the Vinalhaven intrusion, Maine. Journal of Volcanology and Geothermal Research 10: 171-184.

Wiebe, R.A, Blair, K.D., Hawkins, D.P., Sabine, C.P., 2002. Mafic injections, in situ hybridization, and crystal accumulation in the Pyramid Peak granite, California. GSA Bulletin 114 (7): 909920.

Wiebe, R.A., Manon, M.R., Hawkins, D.P., McDonough, W.F., 2004. Late-Stage Mafic Injection and Thermal Rejuvenation of the Vinalhaven Granite, Coastal Maine. Journal of Petrology 45 (11): 2133-2153.

Wood, B.J., Fraser, D.G., 1976. Elementary thermodynamics for geologists. Oxford University Press, Oxford.

Zorpi, M.J., Coulon, C., Orsini, J.B., Cocirta, C., 1989. Magma mingling, zoning and emplacement in calc-alkaline granitoid plutons. Tectonophysics, 157: 315-329. 
ANEXO 1

TABELAS DE ANÁLISES QUÍMICAS DE MINERAIS 
Tabela A01. Composição química, em percentagem de peso, de anfibólios das rochas do Plúton Piracaia $(\mathrm{O}=23)$

\begin{tabular}{|c|c|c|c|c|c|c|c|c|c|c|c|c|}
\hline $\begin{array}{l}\text { Amostra/cristal } \\
\text { Posição } \\
\text { Unidade }\end{array}$ & $5 \mathrm{c} / 10^{*}$ & $5 \mathrm{c} / 10^{*}$ & $\begin{array}{l}5 \mathrm{c} / 10^{*} \\
\text { borda } \\
M d f\end{array}$ & $5 c / 12 *$ & $\begin{array}{c}5 c / 17^{*} \\
\text { borda } \\
M d f\end{array}$ & $\begin{array}{c}5 \mathrm{c} / 17^{*} \\
\text { centro } \\
M d f\end{array}$ & $358 \mathrm{c} / 12^{*}$ & $358 \mathrm{c} / 12 *$ & $358 \mathrm{c} / 16^{*}$ & $358 \mathrm{c} / 16^{*}$ & $\begin{array}{c}500-71 / 10^{*} \\
\text { borda } \\
M d f\end{array}$ & $\begin{array}{c}500-71 / 10^{*} \\
\text { centro } \\
M d f\end{array}$ \\
\hline $\mathrm{SiO}_{2}$ & 42.97 & 43.07 & 42.54 & 43.46 & 43.25 & 43.30 & 41.07 & 41.85 & 42.97 & 42.47 & 43.89 & 43.68 \\
\hline $\mathrm{TiO}_{2}$ & 1.29 & 0.87 & 1.36 & 1.68 & 1.41 & 1.54 & 1.53 & 0.89 & 1.76 & 1.52 & 1.32 & 0.95 \\
\hline $\mathrm{Al}_{2} \mathrm{O}_{3}$ & 8.80 & 7.60 & 8.64 & 8.70 & 8.55 & 8.66 & 9.44 & 9.13 & 8.99 & 9.07 & 8.97 & 8.09 \\
\hline $\mathrm{FeO}$ & 20.33 & 18.35 & 18.66 & 18.98 & 19.08 & 19.28 & 20.39 & 20.31 & 19.34 & 19.21 & 18.53 & 18.33 \\
\hline $\mathrm{MnO}$ & 0.47 & 0.54 & 0.43 & 0.50 & 0.53 & 0.53 & 0.83 & 0.92 & 0.98 & 1.02 & 0.68 & 0.59 \\
\hline $\mathrm{MgO}$ & 10.09 & 10.57 & 10.35 & 10.36 & 10.27 & 10.26 & 8.84 & 9.09 & 10.07 & 9.73 & 10.00 & 10.60 \\
\hline $\mathrm{CaO}$ & 11.66 & 11.66 & 11.54 & 11.39 & 11.27 & 11.41 & 11.39 & 11.40 & 11.01 & 10.94 & 11.55 & 11.59 \\
\hline $\mathrm{Na}_{2} \mathrm{O}$ & 1.53 & 1.23 & 1.58 & 1.49 & 1.45 & 1.56 & 1.62 & 1.84 & 1.84 & 1.86 & 1.22 & 1.24 \\
\hline $\mathrm{K}_{2} \mathrm{O}$ & 1.12 & 0.89 & 0.98 & 1.08 & 1.04 & 1.07 & 1.41 & 1.27 & 1.32 & 1.32 & 0.90 & 0.94 \\
\hline $\mathrm{F}$ & 0.16 & 0.22 & 0.21 & 0.48 & 0.06 & 0.05 & 0.27 & 0.05 & 0.43 & 0.27 & 0.22 & 0.00 \\
\hline $\mathrm{Cl}$ & 0.07 & 0.06 & 0.06 & 0.08 & 0.06 & 0.10 & 0.57 & 0.52 & 0.25 & 0.23 & 0.04 & 0.04 \\
\hline Total & 98.50 & 95.05 & 96.36 & 98.19 & 96.96 & 97.75 & 97.36 & 97.26 & 98.95 & 97.65 & 97.29 & 96.03 \\
\hline$-\mathrm{O}=\mathrm{F}, \mathrm{Cl}$ & 0.08 & 0.11 & 0.10 & 0.22 & 0.04 & 0.04 & 0.24 & 0.14 & 0.24 & 0.17 & 0.10 & 0.01 \\
\hline Total & 98.42 & 94.94 & 96.26 & 97.97 & 96.92 & 97.71 & 97.12 & 97.12 & 98.71 & 97.48 & 97.19 & 96.02 \\
\hline$\overline{\mathrm{Si}}$ & & 6.648 & 6.496 & 6.516 & 6.531 & 6.507 & 6.335 & 6.432 & 6.429 & 6.44 & 6.603 & 6.638 \\
\hline $\mathrm{Al}$ & 1.554 & 1.352 & 1.504 & 1.484 & 1.469 & 1.493 & 1.665 & 1.568 & 1.571 & 1.56 & 1.397 & 1.362 \\
\hline Soma Sítio T & 8 & 8 & 8 & 8 & 8 & 8 & 8 & 8 & 8 & 8 & 8 & 8 \\
\hline $\mathrm{Al}$ & 0 & 0.028 & 0.05 & 0.053 & 0.051 & 0.039 & 0.05 & 0.084 & 0.012 & 0.06 & 0.192 & 0.085 \\
\hline $\mathrm{Fe}^{+3}$ & 0.863 & 0.725 & 0.707 & 0.753 & 0.825 & 0.773 & 0.734 & 0.727 & 0.85 & 0.798 & 0.657 & 0.741 \\
\hline $\mathrm{Ti}$ & 0.146 & 0.101 & 0.156 & 0.189 & 0.16 & 0.174 & 0.178 & 0.103 & 0.198 & 0.174 & 0.149 & 0.108 \\
\hline $\mathrm{Mg}$ & 2.253 & 2.431 & 2.356 & 2.315 & 2.312 & 2.297 & 2.033 & 2.083 & 2.246 & 2.199 & 2.242 & 2.401 \\
\hline $\mathrm{Fe}^{+2}$ & 1.678 & 1.644 & 1.675 & 1.626 & 1.584 & 1.65 & 1.897 & 1.885 & 1.57 & 1.638 & 1.674 & 1.589 \\
\hline $\mathrm{Mn}$ & 0.059 & 0.071 & 0.056 & 0.064 & 0.068 & 0.067 & 0.109 & 0.12 & 0.124 & 0.131 & 0.086 & 0.076 \\
\hline Soma Sítio C & 5 & 5 & 5 & 5 & 5 & 5 & 5 & 5 & 5 & 5 & 5 & 5 \\
\hline $\mathrm{Ca}$ & 1.873 & 1.928 & 1.888 & 1.83 & 1.824 & 1.838 & 1.883 & 1.877 & 1.764 & 1.776 & 1.861 & 1.887 \\
\hline $\mathrm{Na}$ & 0.127 & 0.072 & 0.112 & 0.17 & 0.176 & 0.162 & 0.117 & 0.123 & 0.236 & 0.224 & 0.139 & 0.113 \\
\hline Soma Sítio B & 2 & 2 & 2 & 2 & 2 & 2 & 2 & 2 & 2 & 2 & 2 & 2 \\
\hline $\mathrm{Ca}$ & 0 & 0 & 0 & 0 & 0 & 0 & 0 & 0 & 0 & 0 & 0 & 0 \\
\hline $\mathrm{Na}$ & 0.317 & 0.295 & 0.355 & 0.263 & 0.248 & 0.291 & 0.366 & 0.426 & 0.296 & 0.323 & 0.216 & 0.251 \\
\hline $\mathrm{K}$ & 0.215 & 0.176 & 0.191 & 0.206 & 0.2 & 0.205 & 0.277 & 0.25 & 0.251 & 0.255 & 0.173 & 0.181 \\
\hline Soma Sítio A & 0.532 & 0.471 & 0.546 & 0.469 & 0.448 & 0.496 & 0.643 & 0.676 & 0.548 & 0.579 & 0.389 & 0.433 \\
\hline Soma Cátions & 15.532 & 15.471 & 15.546 & 15.469 & 15.448 & 15.496 & 15.643 & 15.676 & 15.548 & 15.579 & 15.389 & 15.433 \\
\hline $\mathrm{Fe} /(\mathrm{Fe}+\mathrm{Mg})$ & 0.43 & 0.4 & 0.42 & 0.41 & 0.41 & 0.42 & 0.48 & 0.48 & 0.41 & 0.43 & 0.43 & 0.4 \\
\hline
\end{tabular}

Análises com (*) foram obtidas no presente trabalho, sendo as demais do banco de dados do orientador 
Tabela A01. Continuação. Composição química, em percentagem de peso, de anfibólios das rochas do Plúton Piracaia $(\mathrm{O}=23)$

\begin{tabular}{|c|c|c|c|c|c|c|c|c|c|c|}
\hline $\begin{array}{l}\text { Amostra/cristal } \\
\text { Posição } \\
\text { Unidade }\end{array}$ & $\begin{array}{c}500-71 / 12 * \\
\text { borda } \\
M d f \\
\end{array}$ & $\begin{array}{c}500-71 / 12 * \\
\text { borda } \\
M d f \\
\end{array}$ & $\begin{array}{c}500-71 / 12 * \\
\text { centro } \\
M d f \\
\end{array}$ & $\begin{array}{c}\text { 500-71/13* } \\
M d f \\
\end{array}$ & $\begin{array}{c}500-71 / 13^{*} \\
\text { borda } \\
M d f\end{array}$ & $\begin{array}{c}\text { 500-71/13* } \\
\text { centro } \\
M d f \\
\end{array}$ & $\begin{array}{c}\text { PI-26a } \\
M h \\
\end{array}$ & $\begin{array}{c}\text { PI-26a } \\
\text { tabular } \\
M h \\
\end{array}$ & $\begin{array}{c}\text { PI-26a } \\
\text { tabular } \\
M h \\
\end{array}$ & $\begin{array}{c}\text { PI-26a } \\
\text { tabular } \\
M h \\
\end{array}$ \\
\hline $\mathrm{SiO}_{2}$ & 42.63 & 42.90 & 42.98 & 44.05 & 43.78 & 42.17 & 40.97 & 42.59 & 41.66 & 41.63 \\
\hline $\mathrm{TiO}_{2}$ & 1.36 & 1.07 & 1.29 & 1.20 & 1.01 & 1.32 & 1.42 & 1.35 & 1.44 & 1.40 \\
\hline $\mathrm{Al}_{2} \mathrm{O}_{3}$ & 9.10 & 8.86 & 9.25 & 9.28 & 8.93 & 9.63 & 10.31 & 9.43 & 9.81 & 9.74 \\
\hline $\mathrm{FeO}$ & 19.04 & 19.75 & 18.85 & 19.70 & 18.85 & 20.59 & 24.11 & 24.09 & 24.55 & 24.29 \\
\hline $\mathrm{MnO}$ & 0.67 & 0.64 & 0.64 & 0.65 & 0.64 & 0.61 & 0.62 & 0.58 & 0.59 & 0.59 \\
\hline $\mathrm{MgO}$ & 9.53 & 9.92 & 9.76 & 10.13 & 10.29 & 9.58 & 5.49 & 5.80 & 5.77 & 5.74 \\
\hline $\mathrm{CaO}$ & 11.51 & 11.63 & 11.79 & 11.72 & 11.33 & 11.07 & 11.54 & 11.62 & 11.26 & 11.56 \\
\hline $\mathrm{Na}_{2} \mathrm{O}$ & 1.24 & 1.11 & 1.28 & 1.37 & 1.29 & 1.46 & 1.20 & 1.34 & 1.49 & 1.23 \\
\hline $\mathrm{K}_{2} \mathrm{O}$ & 1.15 & 0.91 & 1.02 & 0.97 & 1.08 & 1.10 & 1.37 & 1.26 & 1.36 & 1.29 \\
\hline $\mathrm{F}$ & 0.11 & 0.00 & 0.05 & 0.00 & 0.00 & 0.00 & 0.14 & 0.50 & 0.26 & 0.15 \\
\hline $\mathrm{Cl}$ & 0.06 & 0.04 & 0.07 & 0.04 & 0.05 & 0.05 & 0.16 & 0.16 & 0.10 & 0.10 \\
\hline Total & 96.38 & 96.82 & 96.98 & 99.10 & 97.25 & 97.58 & 97.33 & 98.71 & 98.29 & 97.73 \\
\hline$-\mathrm{O}=\mathrm{F}, \mathrm{Cl}$ & 0.06 & 0.01 & 0.04 & 0.01 & 0.01 & 0.01 & 0.10 & 0.25 & 0.13 & 0.08 \\
\hline Total & 96.32 & 96.81 & 96.94 & 99.09 & 97.24 & 97.57 & 97.23 & 98.46 & 98.16 & 97.65 \\
\hline $\mathrm{Si}$ & 6.515 & 6.486 & 6.519 & 6.507 & 6.565 & 6.335 & 6.412 & 6.591 & 6.453 & 6.479 \\
\hline $\mathrm{Al}$ & 1.485 & 1.514 & 1.481 & 1.493 & 1.435 & 1.665 & 1.588 & 1.409 & 1.547 & 1.521 \\
\hline Soma Sítio T & 8 & 8 & 8 & 8 & 8 & 8 & 8 & 8 & 8 & 8 \\
\hline $\mathrm{Al}$ & 0.152 & 0.064 & 0.171 & 0.121 & 0.141 & 0.04 & 0.312 & 0.311 & 0.242 & 0.265 \\
\hline $\mathrm{Fe}^{+3}$ & 0.66 & 0.938 & 0.612 & 0.821 & 0.845 & 1.127 & 0.433 & 0.282 & 0.519 & 0.448 \\
\hline $\mathrm{Ti}$ & 0.157 & 0.122 & 0.147 & 0.133 & 0.114 & 0.149 & 0.167 & 0.158 & 0.167 & 0.163 \\
\hline $\mathrm{Mg}$ & 2.171 & 2.236 & 2.208 & 2.23 & 2.3 & 2.146 & 1.282 & 1.338 & 1.333 & 1.332 \\
\hline $\mathrm{Fe}^{+2}$ & 1.774 & 1.559 & 1.779 & 1.613 & 1.519 & 1.459 & 2.724 & 2.836 & 2.662 & 2.713 \\
\hline $\mathrm{Mn}$ & 0.086 & 0.081 & 0.083 & 0.082 & 0.082 & 0.078 & 0.082 & 0.076 & 0.077 & 0.078 \\
\hline Soma Sítio C & 5 & 5 & 5 & 5 & 5 & 5 & 5 & 5 & 5 & 5 \\
\hline $\mathrm{Ca}$ & 1.885 & 1.884 & 1.915 & 1.854 & 1.82 & 1.781 & 1.935 & 1.926 & 1.868 & 1.927 \\
\hline $\mathrm{Na}$ & 0.115 & 0.116 & 0.085 & 0.146 & 0.18 & 0.219 & 0.065 & 0.074 & 0.132 & 0.073 \\
\hline Soma Sítio B & 2 & 2 & 2 & 2 & 2 & 2 & 2 & 2 & 2 & 2 \\
\hline $\mathrm{Ca}$ & 0 & 0 & 0 & 0 & 0 & 0 & 0 & 0 & 0 & 0 \\
\hline $\mathrm{Na}$ & 0.251 & 0.208 & 0.29 & 0.247 & 0.196 & 0.206 & 0.3 & 0.327 & 0.316 & 0.298 \\
\hline K & 0.223 & 0.176 & 0.198 & 0.183 & 0.206 & 0.211 & 0.273 & 0.248 & 0.268 & 0.257 \\
\hline Soma Sítio A & 0.475 & 0.384 & 0.488 & 0.429 & 0.402 & 0.418 & 0.574 & 0.575 & 0.584 & 0.554 \\
\hline Soma Cátions & 15.475 & 15.384 & 15.488 & 15.429 & 15.402 & 15.418 & 15.574 & 15.575 & 15.584 & 15.554 \\
\hline $\mathrm{Fe} /(\mathrm{Fe}+\mathrm{Mg})$ & 0.45 & 0.41 & 0.45 & 0.42 & 0.4 & 0.4 & 0.68 & 0.68 & 0.67 & 0.67 \\
\hline
\end{tabular}

Análises com (*) foram obtidas no presente trabalho, sendo as demais do banco de dados do orientador 
Tabela A01. Continuação. Composição química, em percentagem de peso, de anfibólios das rochas do Plúton Piracaia $(\mathrm{O}=23)$

\begin{tabular}{|c|c|c|c|c|c|c|c|c|c|c|c|}
\hline $\begin{array}{l}\text { Amostra/cristal } \\
\text { Posição } \\
\text { Unidade } \\
\end{array}$ & $\begin{array}{c}\text { PI-26a } \\
\text { borda } \\
M h \\
\end{array}$ & PI-400A & PI-400A & PI-400A & $\begin{array}{c}\text { PI-400A } \\
\text { matriz } \\
M h\end{array}$ & PI-400A & PI-400A & $\begin{array}{c}\text { PI-400A } \\
\text { matriz } \\
M h\end{array}$ & $\begin{array}{c}\text { PI-400A } \\
\text { centro } \\
M h \\
\end{array}$ & $\begin{array}{c}\text { PI-400A } \\
\text { borda } \\
M h \\
\end{array}$ & $\begin{array}{c}\text { PI-400A } \\
\text { centro } \\
M h \\
\end{array}$ \\
\hline $\mathrm{SiO}_{2}$ & 44.74 & 40.33 & 40.60 & 43.16 & 40.56 & 41.53 & 41.20 & 40.89 & 43.82 & 41.45 & 42.19 \\
\hline $\mathrm{TiO}_{2}$ & 0.60 & 1.15 & 1.86 & 1.26 & 0.90 & 1.03 & 1.47 & 0.93 & 0.89 & 1.46 & 1.23 \\
\hline $\mathrm{Al}_{2} \mathrm{O}_{3}$ & 7.28 & 14.30 & 10.09 & 8.75 & 10.77 & 10.15 & 10.11 & 10.28 & 8.10 & 10.38 & 9.37 \\
\hline $\mathrm{FeO}$ & 24.02 & 22.96 & 24.28 & 23.32 & 25.00 & 24.32 & 23.86 & 24.53 & 22.79 & 23.54 & 23.47 \\
\hline $\mathrm{MnO}$ & 0.56 & 0.73 & 0.68 & 0.75 & 0.64 & 0.76 & 0.67 & 0.81 & 0.77 & 0.71 & 0.70 \\
\hline $\mathrm{MgO}$ & 7.14 & 6.69 & 6.31 & 7.09 & 6.08 & 6.55 & 6.41 & 6.12 & 7.58 & 6.33 & 6.66 \\
\hline $\mathrm{CaO}$ & 11.81 & 11.24 & 11.04 & 11.38 & 11.21 & 11.37 & 11.21 & 11.28 & 11.36 & 11.45 & 13.29 \\
\hline $\mathrm{Na}_{2} \mathrm{O}$ & 1.05 & 1.35 & 1.69 & 1.26 & 1.56 & 1.42 & 1.56 & 1.41 & 1.20 & 1.55 & 1.30 \\
\hline $\mathrm{K}_{2} \mathrm{O}$ & 0.91 & 1.27 & 1.38 & 1.19 & 1.41 & 1.28 & 1.39 & 1.34 & 1.02 & 1.38 & 1.36 \\
\hline F & 0.28 & 0.33 & 0.14 & 0.18 & 0.36 & 0.32 & 0.04 & 0.44 & 0.30 & 0.25 & 0.19 \\
\hline $\mathrm{Cl}$ & 0.06 & 0.19 & 0.16 & 0.14 & 0.27 & 0.18 & 0.18 & 0.23 & 0.13 & 0.22 & 0.23 \\
\hline Total & 98.46 & 100.53 & 98.22 & 98.48 & 98.76 & 98.92 & 98.09 & 98.25 & 97.97 & 98.72 & 100.00 \\
\hline$-\mathrm{O}=\mathrm{F}, \mathrm{Cl}$ & 0.13 & 0.18 & 0.10 & 0.11 & 0.21 & 0.18 & 0.06 & 0.23 & 0.15 & 0.16 & 0.13 \\
\hline Total & 98.33 & 100.35 & 98.12 & 98.37 & 98.55 & 98.74 & 98.03 & 98.02 & 97.82 & 98.56 & 99.87 \\
\hline$\overline{\mathrm{Si}}$ & 6.845 & 5.969 & 6.272 & 6.591 & 6.245 & 6.351 & 6.354 & 6.327 & 6.699 & 6.377 & 6.507 \\
\hline $\mathrm{Al}$ & 1.155 & 2.031 & 1.728 & 1.409 & 1.755 & 1.649 & 1.646 & 1.673 & 1.301 & 1.623 & 1.493 \\
\hline Soma Sítio T & 8 & 8 & 8 & 8 & 8 & 8 & 8 & 8 & 8 & 8 & 8 \\
\hline $\mathrm{Al}$ & 0.157 & 0.461 & 0.107 & 0.165 & 0.198 & 0.18 & 0.19 & 0.201 & 0.157 & 0.258 & 0.209 \\
\hline $\mathrm{Fe}^{+3}$ & 0.497 & 1.12 & 0.759 & 0.627 & 0.909 & 0.834 & 0.671 & 0.832 & 0.664 & 0.52 & 0 \\
\hline $\mathrm{Ti}$ & 0.069 & 0.128 & 0.216 & 0.145 & 0.104 & 0.119 & 0.171 & 0.108 & 0.102 & 0.169 & 0.142 \\
\hline $\mathrm{Mg}$ & 1.628 & 1.477 & 1.452 & 1.615 & 1.395 & 1.493 & 1.474 & 1.411 & 1.727 & 1.452 & 1.531 \\
\hline $\mathrm{Fe}^{+2}$ & 2.575 & 1.722 & 2.377 & 2.351 & 2.31 & 2.275 & 2.406 & 2.343 & 2.249 & 2.509 & 3.026 \\
\hline $\mathrm{Mn}$ & 0.072 & 0.091 & 0.089 & 0.097 & 0.084 & 0.098 & 0.088 & 0.106 & 0.1 & 0.092 & 0.092 \\
\hline Soma Sítio C & 5 & 5 & 5 & 5 & 5 & 5 & 5 & 5 & 5 & 5 & 5 \\
\hline $\mathrm{Ca}$ & 1.936 & 1.783 & 1.827 & 1.862 & 1.849 & 1.863 & 1.852 & 1.869 & 1.86 & 1.888 & 2 \\
\hline $\mathrm{Na}$ & 0.064 & 0.217 & 0.173 & 0.138 & 0.151 & 0.137 & 0.148 & 0.131 & 0.14 & 0.112 & 0 \\
\hline Soma Sítio B & 2 & 2 & 2 & 2 & 2 & 2 & 2 & 2 & 2 & 2 & 2 \\
\hline $\mathrm{Ca}$ & 0 & 0 & 0 & 0 & 0 & 0 & 0 & 0 & 0 & 0 & 0.196 \\
\hline $\mathrm{Na}$ & 0.248 & 0.17 & 0.332 & 0.235 & 0.315 & 0.283 & 0.317 & 0.291 & 0.217 & 0.349 & 0.39 \\
\hline $\mathrm{K}$ & 0.178 & 0.239 & 0.272 & 0.232 & 0.277 & 0.25 & 0.274 & 0.264 & 0.199 & 0.27 & 0.267 \\
\hline Soma Sítio A & 0.426 & 0.41 & 0.604 & 0.466 & 0.592 & 0.534 & 0.591 & 0.555 & 0.416 & 0.619 & 0.854 \\
\hline Soma Cátions & 15.426 & 15.41 & 15.604 & 15.466 & 15.592 & 15.534 & 15.591 & 15.555 & 15.416 & 15.619 & 15.854 \\
\hline $\mathrm{Fe} /(\mathrm{Fe}+\mathrm{Mg})$ & 0.61 & 0.54 & 0.62 & 0.59 & 0.62 & 0.6 & 0.62 & 0.62 & 0.57 & 0.63 & 0.66 \\
\hline
\end{tabular}

Análises com (*) foram obtidas no presente trabalho, sendo as demais do banco de dados do orientador 
Tabela A01. Continuação. Composição química, em percentagem de peso, de anfibólios das rochas do Plúton Piracaia $(\mathrm{O}=23)$

\begin{tabular}{|c|c|c|c|c|c|c|c|c|c|c|}
\hline $\begin{array}{l}\text { Amostra/cristal } \\
\text { Posição } \\
\text { Unidade } \\
\end{array}$ & $\begin{array}{c}\text { PI-400A } \\
\text { borda } \\
M h \\
\end{array}$ & PI-400A & PI-400A & PI-400A & $\begin{array}{c}\text { PI-400D } \\
\text { centro } \\
M h \\
\end{array}$ & $\begin{array}{c}\text { PI-400D } \\
\text { centro } \\
M h \\
\end{array}$ & $\begin{array}{c}\text { PI-400D } \\
\text { centro } \\
M h \\
\end{array}$ & $\begin{array}{c}\text { PI-400D } \\
\text { centro } \\
M h \\
\end{array}$ & $\begin{array}{c}\text { PI-400D } \\
\text { borda } \\
M h \\
\end{array}$ & $\begin{array}{c}\text { PI-400D } \\
M h \\
\end{array}$ \\
\hline $\mathrm{SiO}_{2}$ & 40.14 & 42.31 & 44.26 & 43.09 & 43.38 & 41.71 & 48.62 & 46.53 & 41.61 & 41.77 \\
\hline $\mathrm{Al}_{2} \mathrm{O}_{3}$ & 9.33 & 9.13 & 7.90 & 8.62 & 8.46 & 10.60 & 4.56 & 7.88 & 9.27 & 8.40 \\
\hline $\mathrm{FeO}$ & 23.26 & 23.60 & 23.50 & 23.29 & 23.51 & 24.61 & 20.01 & 19.98 & 24.32 & 23.29 \\
\hline $\mathrm{MnO}$ & 0.61 & 0.60 & 0.64 & 0.66 & 0.49 & 0.55 & 0.52 & 0.51 & 0.61 & 0.65 \\
\hline $\mathrm{Na}_{2} \mathrm{O}$ & 1.44 & 1.34 & 1.31 & 1.34 & 1.23 & 1.25 & 0.56 & 0.65 & 1.57 & 1.22 \\
\hline $\mathrm{K}_{2} \mathrm{O}$ & 1.39 & 1.39 & 1.17 & 1.24 & 1.14 & 1.28 & 0.42 & 0.52 & 1.22 & 1.17 \\
\hline $\mathrm{F}$ & 0.00 & 0.19 & 0.41 & 0.16 & 0.22 & 0.44 & 0.15 & 0.07 & 0.32 & 0.14 \\
\hline $\mathrm{Cl}$ & 0.21 & 0.22 & 0.09 & 0.23 & 0.11 & 0.14 & 0.07 & 0.02 & 0.20 & 0.18 \\
\hline Total & 95.23 & 98.21 & 99.15 & 97.06 & 97.46 & 98.31 & 96.86 & 96.82 & 98.25 & 96.20 \\
\hline Soma Sítio T & 8 & 8 & 8 & 8 & 8 & 8 & 8 & 8 & 8 & 8 \\
\hline $\mathrm{Al}$ & 0.166 & 0.206 & 0.129 & 0.153 & 0.234 & 0.361 & 0.206 & 0.406 & 0.146 & 0.129 \\
\hline $\mathrm{Fe}^{+3}$ & 0.523 & 0.438 & 0.612 & 1.02 & 0.566 & 0.694 & 0.149 & 0.507 & 0.554 & 0.527 \\
\hline $\mathrm{Ti}$ & 0.143 & 0.15 & 0.111 & 0.155 & 0.087 & 0.039 & 0.002 & 0.022 & 0.185 & 0.165 \\
\hline $\mathrm{Mg}$ & 1.503 & 1.513 & 1.695 & 1.623 & 1.58 & 1.353 & 2.182 & 1.991 & 1.435 & 1.554 \\
\hline $\mathrm{Fe}^{+2}$ & 2.583 & 2.615 & 2.37 & 1.963 & 2.47 & 2.48 & 2.394 & 2.009 & 2.6 & 2.538 \\
\hline $\mathrm{Mn}$ & 0.082 & 0.079 & 0.082 & 0.086 & 0.064 & 0.072 & 0.067 & 0.065 & 0.081 & 0.086 \\
\hline Soma Sítio C & 5 & 5 & 5 & 5 & 5 & 5 & 5 & 5 & 5 & 5 \\
\hline $\mathrm{Ca}$ & 1.942 & 1.92 & 1.854 & 1.64 & 1.87 & 1.902 & 2 & 1.873 & 1.882 & 1.916 \\
\hline $\mathrm{Na}$ & 0.058 & 0.08 & 0.146 & 0.36 & 0.13 & 0.098 & 0 & 0.127 & 0.118 & 0.084 \\
\hline Soma Sítio B & 2 & 2 & 2 & 2 & 2 & 2 & 2 & 2 & 2 & 2 \\
\hline
\end{tabular}

Análises com (*) foram obtidas no presente trabalho, sendo as demais do banco de dados do orientador 
Tabela A01. Continuação. Composição química, em percentagem de peso, de anfibólios das rochas do Plúton Piracaia $(\mathrm{O}=23)$

\begin{tabular}{|c|c|c|c|c|c|c|c|c|c|c|c|}
\hline $\begin{array}{l}\text { Amostra/cristal } \\
\text { Posição }\end{array}$ & $\begin{array}{l}\text { PI-400D } \\
\text { centro }\end{array}$ & $\begin{array}{l}\text { PI-400D } \\
\text { borda }\end{array}$ & PI-400D & $\begin{array}{l}\text { PI-400D } \\
\text { matriz }\end{array}$ & $\begin{array}{l}\text { PI-400D } \\
\text { matriz }\end{array}$ & $\begin{array}{c}\text { PI-400D } \\
\text { aglomerado }\end{array}$ & $\begin{array}{c}\text { PI-419 } \\
\text { aglomerado }\end{array}$ & PI-419 & PI-419 & PI-419 & PI-419 \\
\hline Unidade & $M h$ & $M h$ & $M h$ & $M h$ & $M h$ & $M h$ & $M h$ & $M h$ & $M h$ & $M h$ & $M h$ \\
\hline $\mathrm{SiO}_{2}$ & 40.65 & 41.47 & 41.48 & 42.51 & 41.80 & 41.61 & 42.18 & 42.03 & 41.71 & 42.05 & 43.27 \\
\hline $\mathrm{TiO}_{2}$ & 0.34 & 1.41 & 1.62 & 1.36 & 1.58 & 1.22 & 1.03 & 1.31 & 1.23 & 1.19 & 1.07 \\
\hline $\mathrm{Al}_{2} \mathrm{O}_{3}$ & 10.80 & 9.04 & 9.28 & 9.97 & 9.18 & 9.84 & 9.87 & 9.58 & 9.68 & 9.05 & 8.50 \\
\hline $\mathrm{FeO}$ & 23.80 & 23.52 & 24.34 & 23.06 & 24.40 & 25.05 & 24.66 & 23.85 & 24.10 & 23.34 & 23.20 \\
\hline $\mathrm{MnO}$ & 0.49 & 0.51 & 0.51 & 0.62 & 0.58 & 0.52 & 0.54 & 0.63 & 0.63 & 0.58 & 0.55 \\
\hline $\mathrm{MgO}$ & 6.41 & 6.60 & 6.21 & 6.93 & 6.28 & 6.02 & 5.94 & 6.38 & 6.16 & 6.87 & 6.99 \\
\hline $\mathrm{CaO}$ & 11.25 & 11.13 & 11.32 & 11.35 & 11.12 & 11.44 & 11.65 & 11.15 & 11.27 & 11.35 & 11.76 \\
\hline $\mathrm{Na}_{2} \mathrm{O}$ & 1.15 & 1.47 & 1.55 & 1.30 & 1.68 & 1.29 & 1.28 & 1.68 & 1.49 & 1.29 & 1.21 \\
\hline $\mathrm{K}_{2} \mathrm{O}$ & 1.09 & 1.20 & 1.25 & 1.08 & 1.22 & 1.30 & 1.24 & 1.26 & 1.23 & 1.13 & 1.11 \\
\hline $\mathrm{F}$ & 0.11 & 0.00 & 0.00 & 0.22 & 0.18 & 0.43 & 0.22 & 0.04 & 0.00 & 0.19 & 0.33 \\
\hline $\mathrm{Cl}$ & 0.13 & 0.16 & 0.16 & 0.10 & 0.24 & 0.20 & 0.14 & 0.16 & 0.12 & 0.13 & 0.10 \\
\hline Total & 96.21 & 96.52 & 97.72 & 98.49 & 98.25 & 98.91 & 98.77 & 98.07 & 97.62 & 97.16 & 98.09 \\
\hline$-\mathrm{O}=\mathrm{F}, \mathrm{Cl}$ & 0.07 & 0.04 & 0.04 & 0.11 & 0.13 & 0.22 & 0.13 & 0.05 & 0.03 & 0.11 & 0.16 \\
\hline Total & 96.14 & 96.48 & 97.68 & 98.38 & 98.12 & 98.69 & 98.64 & 98.02 & 97.59 & 97.05 & 97.93 \\
\hline$\overline{\mathrm{Si}}$ & 6.329 & 6.485 & 6.445 & 6.47 & 6.466 & 6.404 & 6.488 & 6.483 & 6.463 & 6.519 & 6.666 \\
\hline $\mathrm{Al}$ & 1.671 & 1.515 & 1.555 & 1.53 & 1.534 & 1.596 & 1.512 & 1.517 & 1.537 & 1.481 & 1.334 \\
\hline Soma Sítio T & 8 & 8 & 8 & 8 & 8 & 8 & 8 & 8 & 8 & 8 & 8 \\
\hline $\mathrm{Al}$ & 0.309 & 0.151 & 0.143 & 0.257 & 0.137 & 0.187 & 0.276 & 0.222 & 0.23 & 0.172 & 0.21 \\
\hline $\mathrm{Fe}^{+3}$ & 0.965 & 0.617 & 0.55 & 0.67 & 0.6 & 0.714 & 0.53 & 0.556 & 0.591 & 0.648 & 0.411 \\
\hline $\mathrm{Ti}$ & 0.04 & 0.166 & 0.189 & 0.155 & 0.183 & 0.142 & 0.12 & 0.152 & 0.143 & 0.139 & 0.124 \\
\hline $\mathrm{Mg}$ & 1.487 & 1.539 & 1.438 & 1.573 & 1.449 & 1.381 & 1.362 & 1.468 & 1.423 & 1.587 & 1.606 \\
\hline $\mathrm{Fe}^{+2}$ & 2.133 & 2.459 & 2.612 & 2.265 & 2.556 & 2.509 & 2.641 & 2.52 & 2.532 & 2.379 & 2.578 \\
\hline $\mathrm{Mn}$ & 0.065 & 0.068 & 0.067 & 0.08 & 0.075 & 0.067 & 0.07 & 0.082 & 0.082 & 0.076 & 0.071 \\
\hline Soma Sítio C & 5 & 5 & 5 & 5 & 5 & 5 & 5 & 5 & 5 & 5 & 5 \\
\hline $\mathrm{Ca}$ & 1.877 & 1.865 & 1.884 & 1.85 & 1.843 & 1.887 & 1.92 & 1.842 & 1.871 & 1.886 & 1.942 \\
\hline $\mathrm{Na}$ & 0.123 & 0.135 & 0.116 & 0.15 & 0.157 & 0.113 & 0.08 & 0.158 & 0.129 & 0.114 & 0.058 \\
\hline Soma Sítio B & 2 & 2 & 2 & 2 & 2 & 2 & 2 & 2 & 2 & 2 & 2 \\
\hline $\mathrm{Ca}$ & 0 & 0 & 0 & 0 & 0 & 0 & 0 & 0 & 0 & 0 & 0 \\
\hline $\mathrm{Na}$ & 0.224 & 0.311 & 0.351 & 0.233 & 0.348 & 0.271 & 0.303 & 0.344 & 0.318 & 0.274 & 0.304 \\
\hline $\mathrm{K}$ & 0.216 & 0.239 & 0.248 & 0.21 & 0.24 & 0.254 & 0.243 & 0.248 & 0.242 & 0.224 & 0.219 \\
\hline Soma Sítio A & 0.44 & 0.55 & 0.599 & 0.443 & 0.588 & 0.525 & 0.546 & 0.593 & 0.56 & 0.498 & 0.522 \\
\hline Soma Cátions & 15.44 & 15.55 & 15.599 & 15.443 & 15.588 & 15.525 & 15.546 & 15.593 & 15.56 & 15.498 & 15.522 \\
\hline $\mathrm{Fe} /(\mathrm{Fe}+\mathrm{Mg})$ & 0.59 & 0.62 & 0.64 & 0.59 & 0.64 & 0.64 & 0.66 & 0.63 & 0.64 & 0.6 & 0.62 \\
\hline
\end{tabular}

Análises com (*) foram obtidas no presente trabalho, sendo as demais do banco de dados do orientador 
Tabela A01. Continuação. Composição química, em percentagem de peso, de anfibólios das rochas do Plúton Piracaia $(\mathrm{O}=23)$

\begin{tabular}{|c|c|c|c|c|c|c|c|c|c|c|c|}
\hline $\begin{array}{l}\text { Amostra/cristal } \\
\text { Posição }\end{array}$ & PI-419 & $\begin{array}{c}\text { PI-419 } \\
\text { borda }\end{array}$ & PI-419 & PI-419 & $\begin{array}{l}\text { PI-419 } \\
\text { centro }\end{array}$ & PI-426B & PI-426B & $\begin{array}{l}\text { PI-426B } \\
\text { matriz }\end{array}$ & $\begin{array}{l}\text { PI-426B } \\
\text { centro }\end{array}$ & $\begin{array}{c}\text { PI-426B } \\
\text { borda }\end{array}$ & PI-426B \\
\hline Unidade & $M h$ & $M h$ & $M h$ & $M h$ & $M h$ & $M h$ & $M h$ & $M h$ & $M h$ & $M h$ & $M h$ \\
\hline $\mathrm{SiO}_{2}$ & 42.01 & 42.01 & 41.64 & 41.99 & 46.60 & 41.32 & 41.50 & 42.04 & 42.67 & 41.93 & 41.58 \\
\hline $\mathrm{TiO}_{2}$ & 1.27 & 1.19 & 1.04 & 1.33 & 0.37 & 0.73 & 1.10 & 1.16 & 0.72 & 1.17 & 1.54 \\
\hline $\mathrm{Al}_{2} \mathrm{O}_{3}$ & 8.83 & 9.12 & 9.75 & 9.69 & 6.32 & 10.17 & 10.12 & 9.39 & 9.06 & 9.08 & 9.16 \\
\hline $\mathrm{FeO}$ & 22.83 & 22.34 & 24.23 & 24.14 & 21.22 & 23.46 & 24.13 & 24.23 & 24.02 & 24.15 & 23.83 \\
\hline $\mathrm{MnO}$ & 0.60 & 0.57 & 0.54 & 0.58 & 0.48 & 0.68 & 0.65 & 0.78 & 0.60 & 0.54 & 0.68 \\
\hline $\mathrm{MgO}$ & 6.76 & 7.02 & 6.25 & 6.17 & 9.08 & 5.67 & 5.80 & 6.19 & 6.49 & 6.25 & 6.15 \\
\hline $\mathrm{CaO}$ & 11.37 & 11.30 & 11.24 & 11.43 & 12.09 & 11.50 & 11.11 & 11.28 & 11.61 & 11.29 & 11.14 \\
\hline $\mathrm{Na}_{2} \mathrm{O}$ & 1.37 & 1.35 & 1.37 & 1.46 & 0.87 & 1.14 & 1.61 & 1.39 & 1.18 & 1.42 & 1.50 \\
\hline $\mathrm{K}_{2} \mathrm{O}$ & 1.10 & 1.25 & 1.24 & 1.30 & 0.73 & 1.35 & 1.34 & 1.29 & 1.11 & 1.22 & 1.22 \\
\hline $\mathrm{F}$ & 0.04 & 0.00 & 0.07 & 0.22 & 0.08 & 0.22 & 0.26 & 0.00 & 0.29 & 0.33 & 0.11 \\
\hline $\mathrm{Cl}$ & 0.12 & 0.11 & 0.17 & 0.14 & 0.04 & 0.19 & 0.13 & 0.12 & 0.12 & 0.12 & 0.10 \\
\hline Total & 96.30 & 96.26 & 97.54 & 98.44 & 97.88 & 96.44 & 97.75 & 97.85 & 97.87 & 97.49 & 97.00 \\
\hline$-\mathrm{O}=\mathrm{F}, \mathrm{Cl}$ & 0.04 & 0.02 & 0.07 & 0.13 & 0.04 & 0.14 & 0.14 & 0.03 & 0.15 & 0.16 & 0.07 \\
\hline Total & 96.26 & 96.24 & 97.47 & 98.31 & 97.84 & 96.30 & 97.61 & 97.82 & 97.72 & 97.33 & 96.93 \\
\hline$\overline{\mathrm{Si}}$ & 6.577 & 6.559 & 6.45 & 6.478 & 7.044 & 6.511 & 6.452 & 6.497 & 6.592 & 6.53 & 6.497 \\
\hline $\mathrm{Al}$ & 1.423 & 1.441 & 1.55 & 1.522 & 0.956 & 1.489 & 1.548 & 1.503 & 1.408 & 1.47 & 1.503 \\
\hline Soma Sítio T & 8 & 8 & 8 & 8 & 8 & 8 & 8 & 8 & 8 & 8 & 8 \\
\hline $\mathrm{Al}$ & 0.204 & 0.234 & 0.227 & 0.237 & 0.169 & 0.398 & 0.305 & 0.206 & 0.24 & 0.195 & 0.182 \\
\hline $\mathrm{Fe}^{+3}$ & 0.469 & 0.49 & 0.694 & 0.504 & 0.388 & 0.416 & 0.534 & 0.622 & 0.584 & 0.565 & 0.532 \\
\hline $\mathrm{Ti}$ & 0.15 & 0.14 & 0.121 & 0.154 & 0.043 & 0.086 & 0.129 & 0.135 & 0.083 & 0.136 & 0.181 \\
\hline $\mathrm{Mg}$ & 1.578 & 1.634 & 1.443 & 1.419 & 2.046 & 1.333 & 1.344 & 1.426 & 1.495 & 1.452 & 1.433 \\
\hline $\mathrm{Fe}^{+2}$ & 2.52 & 2.426 & 2.444 & 2.61 & 2.294 & 2.676 & 2.603 & 2.51 & 2.519 & 2.58 & 2.582 \\
\hline $\mathrm{Mn}$ & 0.079 & 0.076 & 0.07 & 0.076 & 0.061 & 0.091 & 0.086 & 0.102 & 0.079 & 0.071 & 0.089 \\
\hline Soma Sítio C & 5 & 5 & 5 & 5 & 5 & 5 & 5 & 5 & 5 & 5 & 5 \\
\hline $\mathrm{Ca}$ & 1.907 & 1.891 & 1.865 & 1.89 & 1.959 & 1.942 & 1.85 & 1.867 & 1.922 & 1.883 & 1.864 \\
\hline $\mathrm{Na}$ & 0.093 & 0.109 & 0.135 & 0.11 & 0.041 & 0.058 & 0.15 & 0.133 & 0.078 & 0.117 & 0.136 \\
\hline Soma Sítio B & 2 & 2 & 2 & 2 & 2 & 2 & 2 & 2 & 2 & 2 & 2 \\
\hline $\mathrm{Ca}$ & 0 & 0 & 0 & 0 & 0 & 0 & 0 & 0 & 0 & 0 & 0 \\
\hline $\mathrm{Na}$ & 0.324 & 0.298 & 0.276 & 0.327 & 0.214 & 0.291 & 0.336 & 0.284 & 0.276 & 0.312 & 0.318 \\
\hline $\mathrm{K}$ & 0.219 & 0.249 & 0.246 & 0.256 & 0.142 & 0.27 & 0.266 & 0.254 & 0.219 & 0.242 & 0.244 \\
\hline Soma Sítio A & 0.543 & 0.547 & 0.522 & 0.583 & 0.356 & 0.561 & 0.601 & 0.537 & 0.495 & 0.554 & 0.562 \\
\hline Soma Cátions & 15.543 & 15.547 & 15.522 & 15.583 & 15.356 & 15.561 & 15.601 & 15.537 & 15.495 & 15.554 & 15.562 \\
\hline $\mathrm{Fe} /(\mathrm{Fe}+\mathrm{Mg})$ & 0.61 & 0.6 & 0.63 & 0.65 & 0.53 & 0.67 & 0.66 & 0.64 & 0.63 & 0.64 & 0.64 \\
\hline
\end{tabular}

Análises com (*) foram obtidas no presente trabalho, sendo as demais do banco de dados do orientador 
Tabela A01. Continuação. Composição química, em percentagem de peso, de anfibólios das rochas do Plúton Piracaia $(\mathrm{O}=23)$

\begin{tabular}{|c|c|c|c|c|c|c|c|c|c|c|c|}
\hline $\begin{array}{l}\text { Amostra/cristal } \\
\text { Posição } \\
\text { Unidade } \\
\end{array}$ & $\begin{array}{c}\text { PI-426B } \\
\text { matriz } \\
M h \\
\end{array}$ & $\begin{array}{c}\text { PI-426B } \\
\text { aglomerado } \\
M h \\
\end{array}$ & $\begin{array}{c}\text { PI-437a } \\
\text { centro } \\
M h\end{array}$ & $\begin{array}{c}\text { PI-437a } \\
\text { centro } \\
M h\end{array}$ & $\begin{array}{c}\text { PI-437a } \\
\text { borda } \\
M h\end{array}$ & $\begin{array}{c}\text { PI-437a } \\
\text { borda } \\
M h \\
\end{array}$ & $\begin{array}{c}\text { PI-437a } \\
\text { matriz } \\
M h\end{array}$ & $\begin{array}{c}\text { PI-437a } \\
\text { Mh }\end{array}$ & $\begin{array}{c}\text { PI-437a } \\
\text { borda } \\
M h\end{array}$ & $\begin{array}{c}\text { PI-437a } \\
\text { borda } \\
M h\end{array}$ & $\begin{array}{c}\text { PI-437a } \\
\text { matriz } \\
M h\end{array}$ \\
\hline $\mathrm{SiO}_{2}$ & 43.40 & 42.41 & 47.38 & 48.60 & 44.38 & 44.08 & 42.49 & 43.39 & 43.95 & 44.09 & 43.68 \\
\hline $\mathrm{TiO}_{2}$ & 0.93 & 1.19 & 0.47 & 0.34 & 1.33 & 1.38 & 0.74 & 1.23 & 1.57 & 1.36 & 1.08 \\
\hline $\mathrm{Al}_{2} \mathrm{O}_{3}$ & 8.63 & 9.02 & 6.76 & 5.45 & 8.50 & 8.67 & 10.27 & 8.80 & 8.73 & 8.69 & 8.74 \\
\hline $\mathrm{FeO}$ & 23.99 & 23.54 & 20.05 & 19.21 & 21.13 & 21.37 & 22.80 & 20.37 & 20.77 & 21.00 & 21.85 \\
\hline $\mathrm{MnO}$ & 0.74 & 0.66 & 0.36 & 0.36 & 0.43 & 0.46 & 0.39 & 0.41 & 0.42 & 0.36 & 0.42 \\
\hline $\mathrm{MgO}$ & 6.83 & 6.27 & 10.21 & 11.08 & 8.71 & 8.77 & 7.45 & 8.50 & 8.78 & 8.70 & 8.00 \\
\hline $\mathrm{CaO}$ & 11.31 & 11.29 & 10.52 & 12.15 & 11.94 & 11.74 & 10.75 & 10.48 & 11.34 & 11.87 & 11.60 \\
\hline $\mathrm{Na}_{2} \mathrm{O}$ & 1.33 & 1.40 & 0.95 & 0.85 & 1.29 & 1.42 & 1.48 & 1.46 & 1.53 & 1.30 & 1.43 \\
\hline $\mathrm{K}_{2} \mathrm{O}$ & 1.10 & 1.15 & 0.76 & 0.54 & 1.09 & 1.14 & 1.50 & 1.27 & 1.15 & 1.11 & 1.15 \\
\hline $\mathrm{F}$ & 0.15 & 0.30 & 0.20 & 0.00 & 0.26 & 0.15 & 0.15 & 0.16 & 0.12 & 0.46 & 0.61 \\
\hline $\mathrm{Cl}$ & 0.10 & 0.10 & 0.08 & 0.09 & 0.15 & 0.18 & 0.13 & 0.14 & 0.17 & 0.18 & 0.19 \\
\hline Total & 98.49 & 97.32 & 97.73 & 98.67 & 99.20 & 99.35 & 98.14 & 96.21 & 98.52 & 99.11 & 98.74 \\
\hline$-\mathrm{O}=\mathrm{F}, \mathrm{Cl}$ & 0.08 & 0.15 & 0.10 & 0.02 & 0.14 & 0.10 & 0.09 & 0.10 & 0.09 & 0.23 & 0.30 \\
\hline Total & 98.41 & 97.17 & 97.63 & 98.65 & 99.06 & 99.25 & 98.05 & 96.11 & 98.43 & 98.88 & 98.44 \\
\hline $\mathrm{Si}$ & 6.629 & 6.601 & 7.002 & 7.165 & 6.677 & 6.613 & 6.451 & 6.657 & 6.626 & 6.651 & 6.654 \\
\hline $\mathrm{Al}$ & 1.371 & 1.399 & 0.998 & 0.835 & 1.323 & 1.387 & 1.549 & 1.343 & 1.374 & 1.349 & 1.346 \\
\hline Soma Sítio T & 8 & 8 & 8 & 8 & 8 & 8 & 8 & 8 & 8 & 8 & 8 \\
\hline $\mathrm{Al}$ & 0.18 & 0.255 & 0.177 & 0.112 & 0.182 & 0.145 & 0.287 & 0.247 & 0.176 & 0.195 & 0.221 \\
\hline $\mathrm{Fe}^{+3}$ & 0.666 & 0.45 & 0.969 & 0.466 & 0.408 & 0.527 & 0.87 & 0.687 & 0.511 & 0.413 & 0.446 \\
\hline $\mathrm{Ti}$ & 0.107 & 0.139 & 0.052 & 0.038 & 0.15 & 0.156 & 0.085 & 0.141 & 0.179 & 0.155 & 0.124 \\
\hline $\mathrm{Mg}$ & 1.554 & 1.455 & 2.248 & 2.435 & 1.954 & 1.961 & 1.685 & 1.945 & 1.973 & 1.956 & 1.816 \\
\hline $\mathrm{Fe}^{+2}$ & 2.398 & 2.614 & 1.509 & 1.903 & 2.25 & 2.155 & 2.025 & 1.927 & 2.108 & 2.235 & 2.338 \\
\hline $\mathrm{Mn}$ & 0.095 & 0.087 & 0.045 & 0.045 & 0.055 & 0.058 & 0.05 & 0.053 & 0.054 & 0.045 & 0.054 \\
\hline Soma Sítio C & 5 & 5 & 5 & 5 & 5 & 5 & 5 & 5 & 5 & 5 & 5 \\
\hline $\mathrm{Ca}$ & 1.852 & 1.883 & 1.666 & 1.919 & 1.924 & 1.887 & 1.748 & 1.722 & 1.831 & 1.918 & 1.893 \\
\hline $\mathrm{Na}$ & 0.148 & 0.117 & 0.272 & 0.081 & 0.076 & 0.113 & 0.252 & 0.278 & 0.169 & 0.082 & 0.107 \\
\hline Soma Sítio B & 2 & 2 & 1.938 & 2 & 2 & 2 & 2 & 2 & 2 & 2 & 2 \\
\hline $\mathrm{Ca}$ & 0 & 0 & 0 & 0 & 0 & 0 & 0 & 0 & 0 & 0 & $\overline{0}$ \\
\hline $\mathrm{Na}$ & 0.247 & 0.305 & 0 & 0.161 & 0.299 & 0.299 & 0.185 & 0.155 & 0.277 & 0.299 & 0.314 \\
\hline $\mathrm{K}$ & 0.214 & 0.228 & 0.144 & 0.101 & 0.209 & 0.219 & 0.291 & 0.249 & 0.221 & 0.214 & 0.223 \\
\hline Soma Sítio A & 0.461 & 0.534 & 0.144 & 0.262 & 0.508 & 0.517 & 0.475 & 0.405 & 0.499 & 0.513 & 0.538 \\
\hline Soma Cátions & 15.461 & 15.534 & 15.082 & 15.262 & 15.508 & 15.517 & 15.475 & 15.405 & 15.499 & 15.513 & 15.538 \\
\hline $\mathrm{Fe} /(\mathrm{Fe}+\mathrm{Mg})$ & 0.61 & 0.64 & 0.4 & 0.44 & 0.54 & 0.52 & 0.55 & 0.5 & 0.52 & 0.53 & 0.56 \\
\hline
\end{tabular}

Análises com (*) foram obtidas no presente trabalho, sendo as demais do banco de dados do orientador 
Tabela A01. Continuação. Composição química, em percentagem de peso, de anfibólios das rochas do Plúton Piracaia $(\mathrm{O}=23)$

\begin{tabular}{|c|c|c|c|c|c|c|c|c|c|c|c|}
\hline $\begin{array}{l}\text { Amostra/cristal } \\
\text { Posição } \\
\text { Unidade }\end{array}$ & $\begin{array}{c}\text { PI-437a } \\
\text { matriz } \\
M h\end{array}$ & PI-437a & $\begin{array}{c}\text { PI-437a } \\
\text { centro } \\
M h\end{array}$ & $\begin{array}{c}\text { PI-437a } \\
\text { centro } \\
M h\end{array}$ & $\begin{array}{c}26 \mathrm{~b} 1 \text { borda } \\
\text { borda } \\
\text { Sie } \\
\end{array}$ & $\begin{array}{c}\text { 26b } 1 \text { centro } \\
\text { centro } \\
\text { Sie } \\
\end{array}$ & $\begin{array}{c}26 \mathrm{~b} 4 \\
\text { Sie }\end{array}$ & $\begin{array}{c}26 \mathrm{~b} 4 \\
\text { Sie }\end{array}$ & $\begin{array}{l}\text { PI-429 } \\
\text { Qsie } \\
\end{array}$ & $\begin{array}{l}\text { PI-429 } \\
\text { incl. Bt } \\
\text { Qsie }\end{array}$ & $\begin{array}{c}\text { PI-429 } \\
\text { tabular } \\
\text { Qsie } \\
\end{array}$ \\
\hline $\mathrm{SiO}_{2}$ & 43.89 & 45.28 & 43.36 & 48.97 & 39.45 & 39.62 & 40.30 & 40.20 & 38.82 & 40.77 & 40.43 \\
\hline $\mathrm{TiO}_{2}$ & 1.29 & 1.28 & 0.73 & 0.47 & 1.28 & 1.62 & 1.27 & 1.22 & 1.71 & 1.97 & 1.82 \\
\hline $\mathrm{Al}_{2} \mathrm{O}_{3}$ & 8.76 & 7.71 & 8.09 & 5.21 & 9.81 & 9.38 & 9.43 & 9.27 & 9.38 & 9.65 & 10.15 \\
\hline $\mathrm{FeO}$ & 21.07 & 20.42 & 19.69 & 19.13 & 26.47 & 27.20 & 27.03 & 27.06 & 23.95 & 24.93 & 24.14 \\
\hline $\mathrm{MnO}$ & 0.44 & 0.40 & 0.36 & 0.38 & 0.80 & 0.91 & 0.77 & 0.88 & 0.68 & 0.65 & 0.70 \\
\hline $\mathrm{MgO}$ & 8.14 & 9.28 & 9.08 & 11.08 & 3.89 & 4.22 & 4.02 & 3.96 & 5.69 & 5.59 & 5.61 \\
\hline $\mathrm{CaO}$ & 11.74 & 10.64 & 11.71 & 12.49 & 11.24 & 10.88 & 11.07 & 11.02 & 10.82 & 11.31 & 10.78 \\
\hline $\mathrm{Na}_{2} \mathrm{O}$ & 1.32 & 1.34 & 1.13 & 0.80 & 1.35 & 1.57 & 1.26 & 1.42 & 1.51 & 1.48 & 1.65 \\
\hline $\mathrm{K}_{2} \mathrm{O}$ & 1.12 & 1.15 & 0.97 & 0.53 & 1.61 & 1.48 & 1.43 & 1.38 & 1.21 & 1.28 & 1.29 \\
\hline $\mathrm{F}$ & 0.27 & 0.23 & 0.01 & 0.20 & 0.05 & 0.00 & 0.16 & 0.16 & 0.11 & 0.18 & 0.25 \\
\hline $\mathrm{Cl}$ & 0.17 & 0.16 & 0.14 & 0.09 & 0.11 & 0.16 & 0.10 & 0.13 & 0.13 & 0.18 & 0.13 \\
\hline Total & 98.20 & 97.89 & 95.26 & 99.34 & 96.05 & 97.04 & 96.82 & 96.69 & 94.01 & 97.97 & 96.94 \\
\hline$-\mathrm{O}=\mathrm{F}, \mathrm{Cl}$ & 0.15 & 0.13 & 0.03 & 0.10 & 0.05 & 0.04 & 0.09 & 0.10 & 0.08 & 0.12 & 0.13 \\
\hline Total & 98.05 & 97.76 & 95.23 & 99.24 & 96.00 & 97.00 & 96.73 & 96.59 & 93.93 & 97.85 & 96.81 \\
\hline$\overline{\mathrm{Si}}$ & 6.688 & 6.799 & 6.732 & 7.21 & 6.365 & 6.305 & 6.42 & 6.428 & 6.289 & 6.358 & 6.341 \\
\hline $\mathrm{Al}$ & 1.312 & 1.201 & 1.268 & 0.79 & 1.635 & 1.695 & 1.58 & 1.572 & 1.711 & 1.642 & 1.659 \\
\hline Soma Sítio T & 8 & 8 & 8 & 8 & 8 & 8 & 8 & 8 & 8 & 8 & 8 \\
\hline $\mathrm{Al}$ & 0.26 & 0.163 & 0.21 & 0.113 & 0.229 & 0.063 & 0.189 & 0.173 & 0.079 & 0.131 & 0.216 \\
\hline $\mathrm{Fe}^{+3}$ & 0.316 & 0.716 & 0.459 & 0.304 & 0.455 & 0.749 & 0.63 & 0.612 & 0.737 & 0.57 & 0.632 \\
\hline $\mathrm{Ti}$ & 0.147 & 0.145 & 0.085 & 0.052 & 0.155 & 0.193 & 0.152 & 0.146 & 0.208 & 0.231 & 0.214 \\
\hline $\mathrm{Mg}$ & 1.85 & 2.077 & 2.101 & 2.433 & 0.935 & 1.002 & 0.955 & 0.944 & 1.374 & 1.3 & 1.311 \\
\hline $\mathrm{Fe}^{+2}$ & 2.37 & 1.849 & 2.097 & 2.051 & 3.116 & 2.871 & 2.97 & 3.006 & 2.508 & 2.683 & 2.534 \\
\hline $\mathrm{Mn}$ & 0.057 & 0.051 & 0.048 & 0.047 & 0.11 & 0.122 & 0.104 & 0.119 & 0.094 & 0.086 & 0.093 \\
\hline Soma Sítio C & 5 & 5 & 5 & 5 & 5 & 5 & 5 & 5 & 5 & 5 & 5 \\
\hline $\mathrm{Ca}$ & 1.917 & 1.712 & 1.948 & 1.97 & 1.943 & 1.855 & 1.889 & 1.888 & 1.877 & 1.889 & 1.812 \\
\hline $\mathrm{Na}$ & 0.083 & 0.288 & 0.052 & 0.03 & 0.057 & 0.145 & 0.111 & 0.112 & 0.123 & 0.111 & 0.188 \\
\hline Soma Sítio B & 2 & 2 & 2 & 2 & 2 & 2 & 2 & 2 & 2 & 2 & 2 \\
\hline $\mathrm{Ca}$ & 0 & 0 & 0 & 0 & 0 & 0 & 0 & 0 & 0 & 0 & 0 \\
\hline $\mathrm{Na}$ & 0.306 & 0.102 & 0.288 & 0.199 & 0.366 & 0.341 & 0.279 & 0.327 & 0.352 & 0.336 & 0.314 \\
\hline K & 0.218 & 0.219 & 0.193 & 0.099 & 0.331 & 0.301 & 0.29 & 0.281 & 0.25 & 0.254 & 0.258 \\
\hline Soma Sítio A & 0.524 & 0.322 & 0.481 & 0.299 & 0.697 & 0.642 & 0.569 & 0.608 & 0.602 & 0.59 & 0.571 \\
\hline Soma Cátions & 15.524 & 15.322 & 15.481 & 15.299 & 15.697 & 15.642 & 15.569 & 15.608 & 15.602 & 15.59 & 15.571 \\
\hline $\mathrm{Fe} /(\mathrm{Fe}+\mathrm{Mg})$ & 0.56 & 0.47 & 0.5 & 0.46 & 0.77 & 0.74 & 0.76 & 0.76 & 0.65 & 0.67 & 0.66 \\
\hline
\end{tabular}

Análises com (*) foram obtidas no presente trabalho, sendo as demais do banco de dados do orientador 
Tabela A01. Continuação. Composição química, em percentagem de peso, de anfibólios das rochas do Plúton Piracaia $(\mathrm{O}=23)$

\begin{tabular}{|c|c|c|c|c|c|c|c|c|c|c|c|}
\hline $\begin{array}{l}\text { Amostra/cristal } \\
\text { Posição } \\
\text { Unidade } \\
\end{array}$ & PI-429 & PI-429 & PI-429 & PI-429 & PI-429 & PI-427 & $\begin{array}{l}\text { PI-427 } \\
\text { centro } \\
\text { Qsie } \\
\end{array}$ & $\begin{array}{l}\text { PI-427 } \\
\text { borda } \\
\text { Qsie } \\
\end{array}$ & PI-427 & $\begin{array}{c}\text { PI-427 } \\
\text { aglomera } \\
\text { Qsie } \\
\end{array}$ & PI-427 \\
\hline $\mathrm{SiO}_{2}$ & 41.13 & 40.71 & 40.10 & 41.12 & 40.77 & 42.38 & 42.04 & 42.22 & 43.06 & 43.44 & 42.89 \\
\hline $\mathrm{TiO}_{2}$ & 1.78 & 1.97 & 2.17 & 2.24 & 1.71 & 1.52 & 1.57 & 1.56 & 1.24 & 1.24 & 1.34 \\
\hline $\mathrm{Al}_{2} \mathrm{O}_{3}$ & 9.55 & 10.39 & 11.41 & 10.03 & 9.64 & 8.86 & 9.13 & 8.63 & 8.06 & 8.21 & 8.32 \\
\hline $\mathrm{FeO}$ & 24.19 & 23.80 & 24.20 & 24.56 & 24.40 & 24.51 & 23.98 & 24.50 & 25.36 & 24.84 & 24.81 \\
\hline $\mathrm{MnO}$ & 0.76 & 0.81 & 0.73 & 0.78 & 0.72 & 0.82 & 0.84 & 0.85 & 0.92 & 0.83 & 0.79 \\
\hline $\mathrm{MgO}$ & 5.77 & 5.68 & 5.28 & 5.77 & 5.71 & 6.04 & 6.29 & 6.02 & 6.09 & 6.39 & 6.27 \\
\hline $\mathrm{CaO}$ & 10.89 & 10.59 & 10.79 & 11.06 & 10.88 & 11.01 & 10.81 & 11.09 & 11.05 & 11.46 & 11.19 \\
\hline $\mathrm{Na}_{2} \mathrm{O}$ & 1.68 & 1.92 & 1.76 & 1.53 & 1.75 & 1.78 & 1.51 & 1.55 & 1.33 & 1.31 & 1.42 \\
\hline $\mathrm{K}_{2} \mathrm{O}$ & 1.18 & 1.26 & 1.36 & 1.26 & 1.24 & 1.12 & 1.02 & 1.14 & 1.06 & 0.99 & 1.00 \\
\hline $\mathrm{F}$ & 0.29 & 0.29 & 0.04 & 0.00 & 0.23 & 0.15 & 0.33 & 0.04 & 0.04 & 0.08 & 0.15 \\
\hline $\mathrm{Cl}$ & 0.17 & 0.13 & 0.19 & 0.14 & 0.14 & 0.13 & 0.12 & 0.14 & 0.12 & 0.08 & 0.13 \\
\hline Total & 97.38 & 97.55 & 98.02 & 98.48 & 97.19 & 98.30 & 97.63 & 97.72 & 98.32 & 98.88 & 98.30 \\
\hline$-\mathrm{O}=\mathrm{F}, \mathrm{Cl}$ & 0.16 & 0.15 & 0.06 & 0.03 & 0.13 & 0.09 & 0.16 & 0.05 & 0.04 & 0.05 & 0.09 \\
\hline Total & 97.22 & 97.40 & 97.96 & 98.45 & 97.06 & 98.21 & 97.47 & 97.67 & 98.28 & 98.83 & 98.21 \\
\hline $\begin{array}{l}\mathrm{Si} \\
\end{array}$ & 6.428 & 6.339 & 6.215 & 6.332 & 6.391 & 6.547 & 6.497 & 6.555 & 6.621 & 6.639 & 6.601 \\
\hline $\mathrm{Al}$ & 1.572 & 1.661 & 1.785 & 1.668 & 1.609 & 1.453 & 1.503 & 1.445 & 1.379 & 1.361 & 1.399 \\
\hline Soma Sítio T & 8 & 8 & 8 & 8 & 8 & 8 & 8 & 8 & 8 & 8 & 8 \\
\hline $\mathrm{Al}$ & 0.185 & 0.245 & 0.296 & 0.151 & 0.17 & 0.158 & 0.159 & 0.133 & 0.081 & 0.118 & 0.109 \\
\hline $\mathrm{Fe}^{+3}$ & 0.576 & 0.593 & 0.602 & 0.644 & 0.602 & 0.544 & 0.744 & 0.567 & 0.765 & 0.623 & 0.672 \\
\hline $\mathrm{Ti}$ & 0.209 & 0.231 & 0.252 & 0.259 & 0.201 & 0.176 & 0.182 & 0.182 & 0.144 & 0.143 & 0.155 \\
\hline $\mathrm{Mg}$ & 1.343 & 1.317 & 1.219 & 1.324 & 1.334 & 1.392 & 1.45 & 1.392 & 1.395 & 1.456 & 1.439 \\
\hline $\mathrm{Fe}^{+2}$ & 2.586 & 2.506 & 2.534 & 2.52 & 2.597 & 2.622 & 2.355 & 2.615 & 2.496 & 2.553 & 2.521 \\
\hline $\mathrm{Mn}$ & 0.1 & 0.107 & 0.096 & 0.101 & 0.096 & 0.107 & 0.11 & 0.111 & 0.119 & 0.108 & 0.103 \\
\hline Soma Sítio C & 5 & 5 & 5 & 5 & 5 & 5 & 5 & 5 & 5 & 5 & 5 \\
\hline $\mathrm{Ca}$ & 1.824 & 1.766 & 1.792 & 1.825 & 1.827 & 1.822 & 1.79 & 1.846 & 1.821 & 1.876 & 1.844 \\
\hline $\mathrm{Na}$ & 0.176 & 0.234 & 0.208 & 0.175 & 0.173 & 0.178 & 0.21 & 0.154 & 0.179 & 0.124 & 0.156 \\
\hline Soma Sítio B & 2 & 2 & 2 & 2 & 2 & 2 & 2 & 2 & 2 & 2 & 2 \\
\hline $\mathrm{Ca}$ & 0 & 0 & 0 & 0 & 0 & 0 & 0 & 0 & 0 & 0 & 0 \\
\hline $\mathrm{Na}$ & 0.333 & 0.345 & 0.322 & 0.281 & 0.36 & 0.356 & 0.243 & 0.311 & 0.217 & 0.265 & 0.268 \\
\hline $\mathrm{K}$ & 0.235 & 0.25 & 0.268 & 0.248 & 0.247 & 0.22 & 0.202 & 0.225 & 0.207 & 0.193 & 0.196 \\
\hline Soma Sítio A & 0.567 & 0.595 & 0.59 & 0.529 & 0.607 & 0.576 & 0.445 & 0.536 & 0.424 & 0.459 & 0.463 \\
\hline Soma Cátions & 15.567 & 15.595 & 15.59 & 15.529 & 15.607 & 15.576 & 15.445 & 15.536 & 15.424 & 15.459 & 15.463 \\
\hline $\mathrm{Fe} /(\mathrm{Fe}+\mathrm{Mg})$ & 0.66 & 0.66 & 0.68 & 0.66 & 0.66 & 0.65 & 0.62 & 0.65 & 0.64 & 0.64 & 0.64 \\
\hline
\end{tabular}

Análises com (*) foram obtidas no presente trabalho, sendo as demais do banco de dados do orientador 
Tabela A01. Continuação. Composição química, em percentagem de peso, de anfibólios das rochas do Plúton Piracaia $(\mathrm{O}=23)$

\begin{tabular}{|c|c|c|c|}
\hline $\begin{array}{l}\text { Amostra/cristal } \\
\text { Posição } \\
\text { Unidade }\end{array}$ & PI-427 & PI-427 & PI-427 \\
\hline $\mathrm{SiO}_{2}$ & 42.08 & 43.76 & 42.76 \\
\hline $\mathrm{TiO}_{2}$ & 1.37 & 1.37 & 1.22 \\
\hline $\mathrm{Al}_{2} \mathrm{O}_{3}$ & 9.32 & 7.74 & 8.05 \\
\hline $\mathrm{FeO}$ & 24.14 & 24.03 & 24.62 \\
\hline $\mathrm{MnO}$ & 0.82 & 0.91 & 0.81 \\
\hline $\mathrm{MgO}$ & 5.95 & 6.91 & 6.45 \\
\hline $\mathrm{CaO}$ & 10.92 & 10.80 & 11.23 \\
\hline $\mathrm{Na}_{2} \mathrm{O}$ & 1.52 & 1.58 & 1.32 \\
\hline $\mathrm{K}_{2} \mathrm{O}$ & 1.12 & 0.98 & 1.05 \\
\hline $\mathrm{F}$ & 0.18 & 0.37 & 0.15 \\
\hline $\mathrm{Cl}$ & 0.11 & 0.12 & 0.10 \\
\hline Total & 97.54 & 98.56 & 97.75 \\
\hline$-\mathrm{O}=\mathrm{F}, \mathrm{Cl}$ & 0.10 & 0.18 & 0.09 \\
\hline Total & 97.44 & 98.38 & 97.66 \\
\hline$\overline{\mathrm{Si}}$ & 6.525 & 6.687 & 6.614 \\
\hline $\mathrm{Al}$ & 1.475 & 1.313 & 1.386 \\
\hline Soma Sítio T & 8 & 8 & 8 \\
\hline $\mathrm{Al}$ & 0.227 & 0.079 & 0.081 \\
\hline $\mathrm{Fe}^{+3}$ & 0.621 & 0.722 & 0.693 \\
\hline $\mathrm{Ti}$ & 0.16 & 0.158 & 0.142 \\
\hline $\mathrm{Mg}$ & 1.376 & 1.574 & 1.487 \\
\hline $\mathrm{Fe}^{+2}$ & 2.51 & 2.349 & 2.492 \\
\hline $\mathrm{Mn}$ & 0.107 & 0.118 & 0.105 \\
\hline Soma Sítio C & 5 & 5 & 5 \\
\hline $\mathrm{Ca}$ & 1.815 & 1.769 & 1.862 \\
\hline $\mathrm{Na}$ & 0.185 & 0.231 & 0.138 \\
\hline Soma Sítio B & 2 & 2 & 2 \\
\hline $\mathrm{Ca}$ & 0 & 0 & 0 \\
\hline $\mathrm{Na}$ & 0.271 & 0.237 & 0.259 \\
\hline K & 0.221 & 0.19 & 0.207 \\
\hline Soma Sítio A & 0.493 & 0.427 & 0.465 \\
\hline Soma Cátions & 15.493 & 15.427 & 15.465 \\
\hline $\mathrm{Fe} /(\mathrm{Fe}+\mathrm{Mg})$ & 0.65 & 0.6 & 0.63 \\
\hline
\end{tabular}

Análises com (*) foram obtidas no presente trabalho, sendo as demais do banco de dados do orientador 
Tabela A02. Composição química, em percentagem de peso, de biotitas das rochas do Plúton Piracaia

\begin{tabular}{|c|c|c|c|c|c|c|c|c|c|c|c|c|c|}
\hline $\begin{array}{l}\text { Amostra / Cristal } \\
\text { Posição }\end{array}$ & $\begin{array}{c}257 / 10^{*} \\
\text { borda }\end{array}$ & $\begin{array}{c}257 / 10^{*} \\
\text { centro }\end{array}$ & $\begin{array}{c}257 / 12 * \\
\text { centro }\end{array}$ & $257 / 8^{*}$ & $\begin{array}{c}257 / 8^{*} \\
\text { centro }\end{array}$ & $358 \mathrm{c} / 11 *$ & $58 \mathrm{c} / 17 *$ & $358 \mathrm{c} / 17 *$ & $5 \mathrm{c} / 14^{*}$ & $5 \mathrm{c} / 14^{*}$ & $5 \mathrm{c} / 16^{*}$ & $5 c / 16^{*}$ & $500-71 / 12 *$ \\
\hline Unidade & $M d r$ & $M d r$ & $M d r$ & $M d r$ & $M d r$ & $M d f$ & $M d f$ & $M d f$ & $M d f$ & $M d f$ & $M d f$ & $M d f$ & $M d f$ \\
\hline $\mathrm{SiO}_{2}$ & 35.54 & 34.69 & 35.12 & 35.03 & 35.05 & 36.40 & 37.43 & 36.91 & 36.20 & 36.18 & 36.56 & 36.98 & 35.58 \\
\hline $\mathrm{TiO}_{2}$ & 3.41 & 3.70 & 3.90 & 3.55 & 3.98 & 3.76 & 3.44 & 3.11 & 1.96 & 2.07 & 2.60 & 2.09 & 2.69 \\
\hline $\mathrm{Al}_{2} \mathrm{O}_{3}$ & 15.32 & 14.68 & 14.93 & 15.08 & 15.52 & 15.16 & 15.27 & 15.60 & 14.97 & 14.71 & 15.31 & 15.45 & 15.41 \\
\hline $\mathrm{FeO}$ & 15.97 & 18.05 & 17.29 & 16.75 & 16.92 & 22.76 & 21.46 & 21.42 & 20.23 & 20.69 & 19.10 & 19.72 & 20.50 \\
\hline $\mathrm{MnO}$ & 0.17 & 0.24 & 0.18 & 0.16 & 0.20 & 0.27 & 0.32 & 0.28 & 0.30 & 0.24 & 0.27 & 0.26 & 0.41 \\
\hline $\mathrm{MgO}$ & 13.31 & 12.50 & 12.50 & 12.72 & 12.80 & 8.75 & 9.52 & 9.89 & 12.08 & 11.91 & 11.75 & 11.87 & 10.28 \\
\hline $\mathrm{BaO}$ & 1.96 & 2.74 & 2.35 & 2.49 & 2.11 & 0.11 & 0.06 & 0.07 & 0.65 & 0.58 & 0.93 & 0.48 & 0.80 \\
\hline $\mathrm{CaO}$ & 0.01 & 0.01 & 0.00 & 0.00 & 0.01 & 0.03 & 0.02 & 0.01 & 0.04 & 0.04 & 0.00 & 0.01 & 0.00 \\
\hline $\mathrm{Na}_{2} \mathrm{O}$ & 0.10 & 0.11 & 0.11 & 0.10 & 0.06 & 0.02 & 0.01 & 0.08 & 0.06 & 0.03 & 0.02 & 0.06 & 0.09 \\
\hline $\mathrm{K}_{2} \mathrm{O}$ & 9.14 & 8.94 & 8.90 & 9.01 & 9.09 & 9.66 & 9.93 & 9.66 & 9.73 & 9.58 & 9.53 & 10.04 & 9.33 \\
\hline $\mathrm{F}$ & 0.46 & 0.16 & 0.31 & 0.05 & 0.51 & 0.47 & 0.16 & 0.16 & 0.30 & 0.50 & 0.26 & 0.26 & 0.26 \\
\hline $\mathrm{Cl}$ & 0.12 & 0.08 & 0.14 & 0.07 & 0.07 & 0.31 & 0.29 & 0.32 & 0.09 & 0.14 & 0.10 & 0.11 & 0.05 \\
\hline Total & 95.49 & 95.89 & 95.74 & 95 & 96.32 & 97.7 & 97.91 & 97.5 & 96.6 & 96.67 & 96.41 & 97.33 & 95.39 \\
\hline$-\mathrm{O}=\mathrm{F}, \mathrm{Cl}$ & 0.22 & 0.08 & 0.16 & 0.04 & 0.23 & 0.27 & 0.13 & 0.14 & 0.15 & 0.24 & 0.13 & 0.13 & 0.12 \\
\hline Total & 95.27 & 95.81 & 95.58 & 94.96 & 96.09 & 97.43 & 97.78 & 97.36 & 96.45 & 96.43 & 96.28 & 97.2 & 95.27 \\
\hline \multicolumn{14}{|c|}{ Fórmula estrutural calculada na base de 22 oxigênios } \\
\hline $\mathrm{Si}$ & 5.455 & 5.385 & 5.423 & 5.428 & 5.368 & 5.568 & 5.647 & 5.591 & 5.547 & 5.56 & 5.575 & 5.592 & 5.528 \\
\hline $\mathrm{Al}^{\mathrm{IV}}$ & 2.545 & 2.615 & 2.577 & 2.572 & 2.632 & 2.432 & 2.353 & 2.409 & 2.453 & 2.44 & 2.425 & 2.408 & 2.472 \\
\hline $\mathrm{Al}^{\mathrm{VI}}$ & 0.224 & 0.068 & 0.138 & 0.179 & 0.168 & 0.299 & 0.36 & 0.373 & 0.249 & 0.223 & 0.324 & 0.344 & 0.347 \\
\hline $\mathrm{Ti}$ & 0.393 & 0.432 & 0.453 & 0.414 & 0.459 & 0.432 & 0.391 & 0.354 & 0.226 & 0.24 & 0.298 & 0.238 & 0.314 \\
\hline $\mathrm{Fe}^{2+}$ & 2.05 & 2.344 & 2.233 & 2.171 & 2.167 & 2.912 & 2.708 & 2.714 & 2.592 & 2.659 & 2.435 & 2.493 & 2.663 \\
\hline $\mathrm{Mn}$ & 0.022 & 0.031 & 0.023 & 0.021 & 0.025 & 0.035 & 0.041 & 0.036 & 0.039 & 0.031 & 0.035 & 0.033 & 0.054 \\
\hline $\mathrm{Mg}$ & 3.045 & 2.893 & 2.877 & 2.938 & 2.924 & 1.995 & 2.141 & 2.233 & 2.759 & 2.728 & 2.672 & 2.674 & 2.38 \\
\hline $\mathrm{Ba}$ & 0.118 & 0.167 & & 0.151 & 0.127 & 0.007 & 0.003 & 0.004 & 0.039 & 0.035 & 0.055 & 0.029 & 0.048 \\
\hline $\mathrm{Ca}$ & 0.001 & 0.002 & 0 & 0 & 0.002 & 0.005 & 0.003 & 0.002 & 0.007 & 0.006 & 0 & 0.002 & 0 \\
\hline $\mathrm{Na}$ & 0.03 & 0.033 & 0.034 & 0.029 & 0.017 & 0.007 & 0.001 & 0.022 & 0.017 & 0.009 & 0.005 & 0.016 & 0.028 \\
\hline$\underline{\mathrm{K}}$ & 1.79 & 1.77 & 1.754 & 1.781 & 1.777 & 1.884 & 1.911 & 1.866 & 1.903 & 1.878 & 1.853 & 1.937 & 1.849 \\
\hline Soma cátions & 15.673 & 15.74 & 15.512 & 15.684 & 15.666 & 15.576 & 15.559 & 15.604 & 15.831 & 15.809 & 15.677 & 15.766 & 15.683 \\
\hline $\mathrm{Fe} /(\mathrm{Fe}+\mathrm{Mg})$ & 0.4 & 0.45 & 0.44 & 0.42 & 0.43 & 0.59 & 0.56 & 0.55 & 0.48 & 0.49 & 0.48 & 0.48 & 0.53 \\
\hline
\end{tabular}

Análises com (*) foram obtidas no presente trabalho, sendo as demais do banco de dados do orientador 
Tabela A02. Continuação. Composição química, em percentagem de peso, de biotitas das rochas do Plúton Piracaia

\begin{tabular}{|c|c|c|c|c|c|c|c|c|c|c|c|c|c|c|}
\hline $\begin{array}{l}\text { Amostra / Cristal } \\
\text { Posição } \\
\text { Unidade }\end{array}$ & $500-71 / 12 *$ & $500-71 / 5 *$ & $500-71 / 5^{*}$ & $500-71 / 6^{*}$ & $500-71 / 6^{*}$ & $26 \mathrm{~b} / 3^{*}$ & $26 \mathrm{~b} / 7^{*}$ & $26 \mathrm{~b} / 7 *$ & $26 \mathrm{~b} / 7 *$ & $26 \mathrm{~b} / 8^{*}$ & $26 \mathrm{~b} / 8^{*}$ & $26 \mathrm{~b} / 9 *$ & $26 \mathrm{~b} / 9 *$ & $26 \mathrm{~b} / 9 *$ \\
\hline $\mathrm{SiO}_{2}$ & 35.90 & 36.36 & 36.37 & 36.40 & 36.55 & 34.96 & 39.22 & 34.77 & 35.50 & 35.21 & 34.91 & 41.79 & 41.68 & 34.51 \\
\hline $\mathrm{TiO}_{2}$ & 2.19 & 1.97 & 1.61 & 2.24 & 2.23 & 1.20 & 0.49 & 1.13 & 1.50 & 1.39 & 1.34 & 1.43 & 1.18 & 1.02 \\
\hline $\mathrm{Al}_{2} \mathrm{O}_{3}$ & 15.56 & 15.76 & 15.54 & 15.08 & 15.57 & 14.55 & 10.92 & 15.09 & 14.49 & 14.62 & 14.78 & 8.24 & 8.45 & 14.53 \\
\hline $\mathrm{FeO}$ & 20.66 & 20.14 & 19.95 & 20.24 & 19.54 & 28.52 & 27.09 & 28.74 & 27.70 & 28.36 & 28.80 & 26.31 & 25.95 & 28.29 \\
\hline $\mathrm{MnO}$ & 0.45 & 0.42 & 0.40 & 0.37 & 0.39 & 0.43 & 0.80 & 0.46 & 0.52 & 0.52 & 0.43 & 0.91 & 0.87 & 0.40 \\
\hline $\mathrm{MgO}$ & 10.70 & 10.77 & 10.76 & 10.52 & 10.50 & 5.93 & 3.56 & 5.57 & 5.81 & 5.85 & 5.78 & 4.48 & 4.40 & 6.16 \\
\hline $\mathrm{BaO}$ & 0.52 & 0.40 & 0.58 & 0.19 & 0.35 & 0.09 & 0.00 & 0.00 & 0.15 & 0.06 & 0.04 & 0.00 & 0.00 & 0.10 \\
\hline $\mathrm{CaO}$ & 0.01 & 0.01 & 0.01 & 0.00 & 0.00 & 0.11 & 11.24 & 0.02 & 0.00 & 0.03 & 0.01 & 11.20 & 10.87 & 0.04 \\
\hline $\mathrm{Na}_{2} \mathrm{O}$ & 0.06 & 0.07 & 0.03 & 0.05 & 0.04 & 0.07 & 1.34 & 0.01 & 0.09 & 0.07 & 0.04 & 1.39 & 1.43 & 0.01 \\
\hline $\mathrm{K}_{2} \mathrm{O}$ & 9.78 & 9.61 & 9.55 & 9.67 & 9.79 & 9.07 & 1.74 & 9.43 & 9.49 & 9.32 & 9.36 & 1.30 & 1.18 & 9.43 \\
\hline $\mathrm{F}$ & 0.00 & 0.00 & 0.00 & 0.11 & 0.16 & 0.29 & 0.11 & 0.20 & 0.68 & 0.15 & 0.28 & 0.36 & 0.00 & 0.10 \\
\hline $\mathrm{Cl}$ & 0.10 & 0.05 & 0.03 & 0.07 & 0.03 & 0.12 & 0.13 & 0.09 & 0.10 & 0.07 & 0.07 & 0.13 & 0.08 & 0.07 \\
\hline Total & 95.93 & 95.55 & 94.83 & 94.94 & 95.15 & 95.35 & 96.64 & 95.51 & 96.03 & 95.64 & 95.85 & 97.55 & 96.08 & 94.65 \\
\hline$-\mathrm{O}=\mathrm{F}, \mathrm{Cl}$ & 0.02 & 0.01 & 0.01 & 0.06 & 0.07 & 0.15 & 0.07 & 0.1 & 0.31 & 0.08 & 0.14 & 0.18 & 0.02 & 0.06 \\
\hline Total & 95.91 & 95.54 & 94.82 & 94.88 & 95.08 & 95.2 & 96.57 & 95.41 & 95.72 & 95.56 & 95.71 & 97.37 & 96.06 & 94.59 \\
\hline \multicolumn{15}{|c|}{ Fórmula estrutural calculada na base de 22 oxigênios } \\
\hline $\mathrm{Si}$ & 5.534 & 5.587 & 5.632 & 5.638 & 5.634 & 5.634 & 6.094 & 5.596 & 5.687 & 5.642 & 5.603 & 6.388 & 6.419 & 5.602 \\
\hline $\mathrm{Al}^{\mathrm{IV}}$ & 2.466 & 2.413 & 2.368 & 2.362 & 2.366 & 2.366 & 1.906 & 2.404 & 2.313 & 2.358 & 2.397 & 1.483 & 1.532 & 2.398 \\
\hline $\mathrm{Al}^{\mathrm{VI}}$ & 0.358 & 0.44 & 0.467 & 0.388 & 0.46 & 0.395 & 0.093 & 0.456 & 0.42 & 0.4 & 0.396 & 0 & 0 & 0.379 \\
\hline $\mathrm{Ti}$ & 0.254 & 0.227 & 0.188 & 0.261 & 0.259 & 0.145 & 0.057 & 0.136 & 0.181 & 0.167 & 0.161 & 0.164 & 0.136 & 0.124 \\
\hline $\mathrm{Fe}^{2+}$ & 2.664 & 2.588 & 2.583 & 2.622 & 2.518 & 3.843 & 3.521 & 3.868 & 3.711 & 3.801 & 3.865 & 3.363 & 3.343 & 3.841 \\
\hline Mn & 0.058 & 0.055 & 0.052 & 0.048 & 0.051 & 0.059 & 0.105 & 0.063 & 0.07 & 0.071 & 0.058 & 0.117 & 0.113 & 0.055 \\
\hline $\mathrm{Mg}$ & 2.459 & 2.467 & 2.485 & 2.429 & 2.412 & 1.425 & 0.825 & 1.336 & 1.387 & 1.397 & 1.383 & 1.021 & 1.009 & 1.49 \\
\hline $\mathrm{Ba}$ & 0.031 & 0.024 & 0.035 & 0.011 & 0.021 & 0.006 & 0 & 0 & 0.009 & 0.004 & 0.003 & 0 & 0 & 0.006 \\
\hline $\mathrm{Ca}$ & 0.002 & 0.001 & 0.001 & 0 & 0 & 0.02 & 1.871 & 0.004 & 0 & 0.004 & 0.002 & 1.835 & 1.794 & 0.007 \\
\hline $\mathrm{Na}$ & 0.017 & 0.02 & 0.008 & 0.015 & 0.011 & 0.023 & 0.403 & 0.004 & 0.029 & 0.022 & 0.013 & 0.413 & 0.426 & 0.004 \\
\hline K & 1.923 & 1.883 & 1.887 & 1.91 & 1.925 & 1.864 & 0.346 & 1.936 & 1.94 & 1.905 & 1.917 & 0.253 & 0.232 & 1.954 \\
\hline Soma cátions & 15.766 & 15.705 & 15.706 & 15.684 & 15.657 & 15.78 & 15.221 & 15.803 & 15.747 & 15.771 & 15.798 & 15.037 & 15.004 & 15.86 \\
\hline $\mathrm{Fe} /(\mathrm{Fe}+\mathrm{Mg})$ & 0.52 & 0.51 & 0.51 & 0.52 & 0.51 & 0.73 & 0.81 & 0.74 & 0.73 & 0.73 & 0.74 & 0.77 & 0.77 & 0.72 \\
\hline
\end{tabular}

Análises com (*) foram obtidas no presente trabalho, sendo as demais do banco de dados do orientador 
Tabela A02. Continuação. Composição química, em percentagem de peso, de biotitas das rochas do Plúton Piracaia

\begin{tabular}{|c|c|c|c|c|c|c|c|c|c|c|c|c|c|c|c|c|}
\hline $\begin{array}{l}\text { Amostra / Cristal } \\
\text { Posição } \\
\text { Unidade } \\
\end{array}$ & $26 \mathrm{~b} / 9 *$ & $270 / 12 *$ & $270 / 3^{*}$ & $270 / 3^{*}$ & $270 / 5^{*}$ & $270 / 5^{*}$ & $270 / 5^{*}$ & $270 / 5^{*}$ & $270 / 9 *$ & $270 / 9 *$ & & $\begin{array}{c}\text { PI-5 } \\
\text { centro } \\
M d f \\
\end{array}$ & $M d f$ & $M d f$ & PI-56 & PI-56 \\
\hline $\mathrm{SiO}_{2}$ & 35.36 & 35.15 & 34.25 & 34.12 & 34.28 & 34.64 & 34.28 & 34.64 & 33.65 & 34.30 & & 36.13 & 36.13 & 36.57 & 36.74 & 36.44 \\
\hline $\mathrm{TiO}_{2}$ & 1.22 & 3.63 & 1.90 & 1.66 & 1.22 & 1.26 & 1.22 & 1.26 & 1.82 & 1.49 & & 3.44 & 3.10 & 2.76 & 2.12 & 2.35 \\
\hline $\mathrm{Al}_{2} \mathrm{O}_{3}$ & 14.17 & 14.79 & 15.58 & 15.65 & 15.69 & 15.87 & 15.69 & 15.87 & 15.32 & 15.56 & & 13.71 & 13.79 & 13.49 & 14.74 & 14.28 \\
\hline $\mathrm{FeO}$ & 27.56 & 18.09 & 28.16 & 27.94 & 28.07 & 28.00 & 28.07 & 28.00 & 28.72 & 28.28 & & 19.85 & 21.32 & 17.79 & 20.02 & 20.84 \\
\hline $\mathrm{MnO}$ & 0.44 & 0.21 & 0.92 & 0.87 & 0.84 & 0.83 & 0.84 & 0.83 & 0.84 & 0.81 & & 0.29 & 0.33 & 0.23 & 0.38 & 0.43 \\
\hline $\mathrm{MgO}$ & 6.20 & 12.48 & 4.67 & 4.84 & 5.14 & 5.14 & 5.14 & 5.14 & 4.89 & 4.93 & & 11.48 & 11.08 & 13.09 & 11.28 & 10.93 \\
\hline $\mathrm{BaO}$ & 0.06 & 2.16 & 0.13 & 0.05 & 0.00 & 0.00 & 0.00 & 0.00 & 0.02 & 0.05 & & & & & 0.28 & 0.35 \\
\hline $\mathrm{CaO}$ & 0.04 & 0.00 & 0.00 & 0.00 & 0.00 & 0.00 & 0.00 & 0.00 & 0.08 & 0.13 & & 0.02 & 0.07 & 0.10 & 0.19 & 0.13 \\
\hline $\mathrm{Na}_{2} \mathrm{O}$ & 0.02 & 0.06 & 0.06 & 0.06 & 0.03 & 0.02 & 0.03 & 0.02 & 0.04 & 0.04 & & 0.05 & 0.08 & 0.03 & 0.08 & 0.05 \\
\hline $\mathrm{K}_{2} \mathrm{O}$ & 9.55 & 9.33 & 9.57 & 9.64 & 9.61 & 9.63 & 9.61 & 9.63 & 9.24 & 8.65 & & 9.35 & 9.49 & 9.71 & 9.53 & 9.77 \\
\hline $\mathrm{F}$ & 0.30 & 0.20 & 0.30 & 0.63 & 0.10 & 0.16 & 0.10 & 0.16 & 0.20 & 0.15 & & & & & 0.39 & 0.38 \\
\hline $\mathrm{Cl}$ & 0.07 & 0.12 & 0.09 & 0.06 & 0.07 & 0.12 & 0.07 & 0.12 & 0.11 & 0.07 & & & & & 0.09 & 0.13 \\
\hline Total & 94.97 & 96.22 & 95.62 & 95.5 & 95.06 & 95.67 & 95.06 & 95.67 & 94.92 & 94.47 & & 94.32 & 95.39 & 93.77 & 95.84 & 96.08 \\
\hline$-\mathrm{O}=\mathrm{F}, \mathrm{Cl}$ & 0.14 & 0.11 & 0.14 & 0.28 & 0.06 & 0.09 & 0.06 & 0.09 & 0.11 & 0.08 & & & & & 0.18 & 0.19 \\
\hline Total & 94.83 & 96.11 & 95.48 & 95.22 & 95 & 95.58 & 95 & 95.58 & 94.81 & 94.39 & 0 & 94.32 & 95.39 & 93.77 & 95.66 & 95.89 \\
\hline \multicolumn{17}{|c|}{ Fórmula estrutural calculada na base de 22 oxigênios } \\
\hline $\mathrm{Si}$ & 5.701 & 5.419 & 5.524 & 5.522 & 5.539 & 5.555 & 5.539 & 5.555 & 5.477 & 5.559 & & 5.611 & 5.592 & 5.663 & 5.649 & 5.633 \\
\hline $\mathrm{Al}^{\mathrm{IV}}$ & 2.299 & 2.581 & 2.476 & 2.478 & 2.461 & 2.445 & 2.461 & 2.445 & 2.523 & 2.441 & & 2.389 & 2.408 & 2.337 & 2.351 & 2.367 \\
\hline $\mathrm{Al}^{\mathrm{VI}}$ & 0.392 & 0.105 & 0.483 & 0.504 & 0.524 & 0.551 & 0.524 & 0.551 & 0.414 & 0.528 & & 0.118 & 0.106 & 0.123 & 0.318 & 0.233 \\
\hline $\mathrm{Ti}$ & 0.147 & 0.421 & 0.231 & 0.202 & 0.149 & 0.152 & 0.149 & 0.152 & 0.223 & 0.181 & & 0.402 & 0.361 & 0.322 & 0.245 & 0.273 \\
\hline $\mathrm{Fe}^{2+}$ & 3.717 & 2.333 & 3.797 & 3.781 & 3.793 & 3.755 & 3.793 & 3.755 & 3.909 & 3.833 & & 2.578 & 2.76 & 2.304 & 2.574 & 2.694 \\
\hline $\mathrm{Mn}$ & 0.06 & 0.028 & 0.126 & 0.12 & 0.115 & 0.113 & 0.115 & 0.113 & 0.116 & 0.111 & & 0.038 & 0.043 & 0.03 & 0.049 & 0.056 \\
\hline $\mathrm{Mg}$ & 1.489 & 2.869 & 1.122 & 1.167 & 1.239 & 1.229 & 1.239 & 1.229 & 1.186 & 1.192 & & 2.658 & 2.557 & 3.022 & 2.586 & 2.519 \\
\hline $\mathrm{Ba}$ & 0.004 & 0.13 & 0.008 & 0.003 & 0 & 0 & 0 & 0 & 0.001 & 0.003 & & 0 & 0 & 0 & 0.017 & 0.021 \\
\hline $\mathrm{Ca}$ & 0.007 & 0 & 0.001 & 0 & 0 & 0 & 0 & 0 & 0.013 & 0.023 & & 0.003 & 0.012 & 0.017 & 0.031 & 0.022 \\
\hline $\mathrm{Na}$ & 0.006 & 0.018 & 0.019 & 0.018 & 0.01 & 0.007 & 0.01 & 0.007 & 0.013 & 0.014 & & 0.015 & 0.024 & 0.009 & 0.024 & 0.015 \\
\hline K & 1.965 & 1.835 & 1.969 & 1.989 & 1.982 & 1.971 & 1.982 & 1.971 & 1.918 & 1.789 & & 1.852 & 1.874 & 1.918 & 1.869 & 1.927 \\
\hline Soma cátions & 15.787 & 15.739 & 15.756 & 15.784 & 15.812 & 15.778 & 15.812 & 15.778 & 15.793 & 15.674 & 0 & 15.66 & 15.74 & 15.75 & 15.71 & 15.76 \\
\hline $\mathrm{Fe} /(\mathrm{Fe}+\mathrm{Mg})$ & 0.71 & 0.45 & 0.77 & 0.76 & 0.75 & 0.75 & 0.75 & 0.75 & 0.77 & 0.76 & & 0.49 & 0.52 & 0.43 & 0.5 & 0.52 \\
\hline
\end{tabular}

Análises com (*) foram obtidas no presente trabalho, sendo as demais do banco de dados do orientador 
Tabela A02. Continuação. Composição química, em percentagem de peso, de biotitas das rochas do Plúton Piracaia

\begin{tabular}{|c|c|c|c|c|c|c|c|c|c|c|c|c|c|c|c|c|}
\hline $\begin{array}{l}\text { Amostra / Cristal } \\
\text { Posição } \\
\text { Unidade }\end{array}$ & $M d f$ & $\begin{array}{c}\text { PI-75 } \\
\text { borda } \\
M d f \\
\end{array}$ & $M d f$ & $M d f$ & $M d f$ & $\begin{array}{c}\text { PI-170a } \\
\text { centro } \\
M d f \\
\end{array}$ & $\begin{array}{c}\text { PI-170a } \\
\text { borda } \\
M d f \\
\end{array}$ & $\begin{array}{c}\text { PI-170a } \\
\text { centro } \\
M d f \\
\end{array}$ & $\begin{array}{c}\text { PI-170a } \\
\text { centro } \\
M d f \\
\end{array}$ & $M d f$ & $M d f$ & $\begin{array}{c}\text { PI-172 } \\
\text { centro } \\
M d f \\
\end{array}$ & $\begin{array}{c}\text { PI-172 } \\
\text { borda } \\
M d f \\
\end{array}$ & $M d f$ & $M d f$ & $\begin{array}{c}\text { PI-175 } \\
\text { centro } \\
M d f \\
\end{array}$ \\
\hline $\mathrm{TiO}_{2}$ & 3.72 & 4.07 & 3.68 & 1.75 & 3.42 & 4.21 & 4.20 & 4.20 & 3.76 & 3.36 & 4.19 & 4.46 & 4.21 & 3.10 & 4.13 & 4.13 \\
\hline $\mathrm{Al}_{2} \mathrm{O}_{3}$ & 13.65 & 13.11 & 13.34 & 15.52 & 15.45 & 13.97 & 13.46 & 13.21 & 13.10 & 14.14 & 13.63 & 13.57 & 13.11 & 13.28 & 13.31 & 13.16 \\
\hline $\mathrm{FeO}$ & 20.50 & 20.96 & 19.42 & 20.18 & 20.10 & 18.75 & 18.47 & 19.68 & 18.47 & 17.42 & 19.39 & 20.42 & 19.67 & 19.24 & 20.45 & 22.54 \\
\hline $\mathrm{BaO}$ & .42 & 0.52 & 0.47 & 0.17 & 0.82 & 1.34 & 0.53 & 1.06 & 0.89 & 0.42 & 0.68 & 0.32 & 0.19 & 0.16 & 0.41 & 0.15 \\
\hline $\mathrm{CaO}$ & 0.24 & 0.07 & 0.20 & 0.08 & 0.07 & 0.00 & 0.06 & 0.08 & 0.09 & 0.14 & 0.20 & 0.07 & 0.14 & 0.01 & 0.10 & 0.10 \\
\hline $\mathrm{Na}_{2} \mathrm{O}$ & 0.10 & 0.06 & 0.11 & 0.08 & 0.06 & 0.09 & 0.12 & 0.10 & 0.09 & 0.07 & 0.12 & 0.11 & 0.11 & 0.05 & 0.10 & 0.08 \\
\hline $\mathrm{K}_{2} \mathrm{O}$ & .17 & 9.52 & 9.27 & 9.09 & 9.32 & 9.47 & 9.46 & 9.15 & 9.58 & 9.14 & 8.96 & 9.34 & 9.52 & 9.46 & 9.61 & 9.50 \\
\hline $\mathrm{F}$ & .06 & 0.07 & 0.06 & 0.31 & 0.28 & & & & & & & & & & & \\
\hline 1 & 0.48 & 0.44 & 0.46 & 0.01 & 0.04 & & & & & & & & & & & \\
\hline \multicolumn{17}{|c|}{ Fórmula estrutural calculada na base de 22 oxigênios } \\
\hline $\mathrm{Si}$ & 5.622 & 5.663 & 5.635 & 5.659 & 5.447 & 5.575 & 5.611 & 5.582 & 5.657 & 5.663 & 5.617 & 5.615 & 5.65 & 5.741 & 5.644 & 5.666 \\
\hline $\mathrm{Al}^{\mathrm{IV}}$ & 2.378 & 2.337 & 2.365 & 2.341 & 2.553 & 2.425 & 2.389 & 2.38 & 2.343 & 2.337 & 2.383 & 2.385 & 2.35 & 2.259 & 2.356 & 2.334 \\
\hline $\mathrm{Al}^{\mathrm{VI}}$ & 082 & 0.032 & 0.083 & 0.476 & 0.203 & 0.065 & 0.024 & 0 & 0.017 & 0.187 & 0.063 & 0.05 & 0.015 & 0.15 & 0.021 & 0.061 \\
\hline $\mathrm{Ti}$ & 0.428 & 0.47 & 0.431 & 0.203 & 0.39 & 0.479 & 0.481 & 0.483 & 0.433 & 0.383 & 0.48 & 0.511 & 0.485 & 0.359 & 0.471 & 0.48 \\
\hline $\mathrm{Fe}^{2+}$ & 624 & 2.689 & & 2.601 & 2.546 & 2.373 & 2.351 & 2.518 & 2.363 & 2.208 & 2.471 & 2.602 & 2.52 & 2.479 & 2.593 & 2.913 \\
\hline $\mathrm{Mn}$ & 043 & 0.039 & 0.045 & 0.048 & .055 & 0.021 & 0.028 & 0.031 & 0.027 & 0.021 & 0.027 & 0.031 & 0.034 & 0.033 & 0.028 & 0.034 \\
\hline $\mathrm{Mg}$ & 564 & 2.468 & 2.617 & 2.468 & 2.619 & 2.754 & 2.837 & 2.762 & 2.871 & 2.948 & 2.674 & 2.503 & 2.644 & 2.721 & 2.595 & 2.191 \\
\hline $\mathrm{Ba}$ & 025 & 0.031 & 0.029 & 0.01 & .049 & 0.079 & 0.032 & 0.064 & 0.053 & 0.025 & 0.041 & 0.019 & 0.011 & 0.01 & 0.024 & 0.009 \\
\hline $\mathrm{Ca}$ & 039 & 012 & 0.033 & 0.013 & & 0 & 0.01 & 0.013 & 0.015 & 0.023 & 0.033 & 0.011 & 0.023 & 0.002 & 0.016 & 0.017 \\
\hline $\mathrm{Na}$ & .03 & 0.018 & 0.033 & 0.024 & & 026 & 0.035 & 0.03 & 0.027 & 0.021 & 0.035 & 0.033 & 0.033 & 0.015 & 0.029 & 0.024 \\
\hline
\end{tabular}

Análises com (*) foram obtidas no presente trabalho, sendo as demais do banco de dados do orientador 
Tabela A02. Continuação. Composição química, em percentagem de peso, de biotitas das rochas do Plúton Piracaia

\begin{tabular}{|c|c|c|c|c|c|c|c|c|c|c|c|c|c|c|c|}
\hline $\begin{array}{l}\text { Amostra / Cristal } \\
\text { Posição } \\
\text { Unidade }\end{array}$ & $\begin{array}{l}\text { PI-175 } \\
\text { borda } \\
M d f\end{array}$ & $\begin{array}{c}\text { PI-175 } \\
\text { centro } \\
M d f\end{array}$ & $\begin{array}{c}\text { PI-175 } \\
\text { borda } \\
M d f\end{array}$ & $M d f$ & $M d f$ & $M d r$ & $M h$ & $M h$ & $M h$ & $M h$ & $M h$ & $M h$ & $M h$ & $M h$ & $\begin{array}{c}\text { PI-400A } \\
\text { borda } \\
M h\end{array}$ \\
\hline $\mathrm{SiO}_{2}$ & 37.27 & 36.59 & 37.12 & 36.70 & 36.62 & 37.21 & 35.63 & 35.92 & 29.83 & 30.04 & 30.52 & 30.25 & 32.03 & 33.04 & 31.69 \\
\hline $\mathrm{TiO}_{2}$ & 4.04 & 4.26 & 3.57 & 3.69 & 5.01 & 3.53 & 1.73 & 1.45 & 1.48 & 1.59 & 1.50 & 1.40 & 1.61 & 1.59 & 1.63 \\
\hline $\mathrm{Al}_{2} \mathrm{O}_{3}$ & 13.83 & 13.14 & 13.19 & 13.14 & 12.71 & 13.97 & 14.25 & 15.07 & 29.05 & 27.82 & 26.54 & 27.28 & 23.47 & 19.74 & 24.92 \\
\hline $\mathrm{FeO}$ & 21.63 & 21.67 & 21.20 & 21.30 & 20.17 & 19.62 & 25.61 & 23.87 & 19.68 & 20.25 & 21.63 & 20.44 & 22.00 & 22.51 & 22.53 \\
\hline $\mathrm{BaO}$ & 0.24 & 0.24 & 0.24 & 0.12 & 0.55 & & & 0.01 & 0.14 & 0.24 & 0.21 & 0.28 & 0.12 & 0.09 & 0.08 \\
\hline $\mathrm{CaO}$ & 0.22 & 0.10 & 0.12 & 0.05 & 0.22 & 0.09 & 0.02 & 0.00 & 0.09 & 0.08 & 0.04 & 0.04 & 0.00 & 0.00 & 0.04 \\
\hline $\mathrm{Na}_{2} \mathrm{O}$ & 0.11 & 0.09 & 0.10 & 0.04 & 0.11 & 0.10 & 0.06 & 0.07 & 0.08 & 0.07 & 0.08 & 0.07 & 0.10 & 0.06 & 0.05 \\
\hline $\mathrm{K}_{2} \mathrm{O}$ & 9.14 & 9.56 & 9.41 & 9.72 & 9.44 & 9.73 & 9.39 & 9.53 & 8.21 & 8.38 & 8.57 & 8.32 & 8.88 & 10.54 & 8.83 \\
\hline $\mathrm{F}$ & & & & & 0.08 & & & 0.82 & 0.40 & 0.29 & 0.55 & 0.11 & 0.33 & 0.58 & 0.12 \\
\hline $\mathrm{Cl}$ & & & & & 0.65 & & & 0.20 & 0.19 & 0.16 & 0.15 & 0.22 & 0.20 & 0.20 & 0.20 \\
\hline \multicolumn{16}{|c|}{ Fórmula estrutural calculada na base de 22 oxigênios } \\
\hline $\mathrm{Si}$ & 5.703 & 5.651 & 5.702 & 5.669 & 5.637 & 5.665 & 5.644 & 5.631 & 4.505 & 4.563 & 4.632 & 4.61 & 4.914 & 5.164 & 4.801 \\
\hline $\mathrm{Al}^{\mathrm{IV}}$ & 2.297 & 2.349 & 2.298 & 2.331 & 2.304 & 2.335 & 2.356 & 2.369 & 3.495 & 3.437 & 3.368 & 3.39 & 3.086 & 2.836 & 3.199 \\
\hline $\mathrm{Al}^{\mathrm{VI}}$ & 0.195 & 0.041 & 0.088 & 0.06 & 0 & 0.17 & 0.302 & 0.414 & 1.672 & 1.54 & 1.375 & 1.507 & 1.155 & 0.797 & 1.247 \\
\hline $\mathrm{Ti}$ & 0.465 & 0.495 & 0.413 & 0.429 & 0.58 & 0.404 & 0.206 & 0.171 & 0.168 & 0.182 & 0.171 & 0.161 & 0.185 & 0.187 & 0.185 \\
\hline $\mathrm{Fe}^{2+}$ & 2.768 & 2.799 & 2.724 & 2.752 & 2.596 & 2.498 & 3.393 & 3.131 & 2.486 & 2.573 & 2.745 & 2.605 & 2.822 & 2.942 & 2.854 \\
\hline $\mathrm{Mn}$ & 0.03 & 0.051 & 0.052 & 0.051 & 0.027 & 0.032 & 0.055 & 0.061 & 0.051 & 0.06 & 0.055 & 0.06 & 0.054 & 0.058 & 0.052 \\
\hline $\mathrm{Mg}$ & 2.167 & 2.284 & 2.441 & 2.432 & 2.471 & 2.594 & 1.899 & 2.06 & 1.534 & 1.556 & 1.613 & 1.599 & 1.666 & 1.779 & 1.573 \\
\hline $\mathrm{Ba}$ & 0.014 & 0.015 & 0.014 & 0.007 & 0.033 & 0 & 0 & 0.001 & 0.008 & 0.014 & 0.012 & 0.016 & 0.007 & 0.005 & 0.005 \\
\hline $\mathrm{Ca}$ & 0.036 & 0.017 & 0.02 & 0.008 & 0.036 & 0.015 & 0.003 & 0.001 & 0.014 & 0.012 & 0.006 & 0.006 & 0 & 0 & 0.007 \\
\hline $\mathrm{Na}$ & 0.033 & 0.027 & 0.03 & 0.012 & 0.033 & 0.03 & 0.018 & 0.02 & 0.024 & 0.022 & 0.024 & 0.02 & 0.028 & 0.018 & 0.014 \\
\hline
\end{tabular}

Análises com (*) foram obtidas no presente trabalho, sendo as demais do banco de dados do orientador 
Tabela A02. Continuação. Composição química, em percentagem de peso, de biotitas das rochas do Plúton Piracaia

\begin{tabular}{|c|c|c|c|c|c|c|c|c|c|c|c|c|c|}
\hline $\begin{array}{l}\text { Amostra / Cristal } \\
\text { Posição } \\
\text { Unidade } \\
\end{array}$ & $\begin{array}{c}\text { PI-400A } \\
\text { matriz } \\
M h \\
\end{array}$ & PI-400A & $\begin{array}{c}\text { PI-400A } \\
\text { matriz } \\
M h \\
\end{array}$ & PI-400A & $\begin{array}{l}\text { PI-400D } \\
\qquad M h \\
\end{array}$ & $\begin{array}{c}\text { PI-400D } \\
\qquad h \\
\end{array}$ & $\begin{array}{c}\text { PI-400D } \\
\text { matriz } \\
M h \\
\end{array}$ & $\begin{array}{c}\text { PI-400D } \\
\text { matriz } \\
M h \\
\end{array}$ & $\begin{array}{c}\text { PI-400D } \\
\text { matriz } \\
M h \\
\end{array}$ & $\begin{array}{c}\text { PI-400D } \\
\qquad h \\
\end{array}$ & $\begin{array}{c}\text { PI-437a } \\
\text { Mh }\end{array}$ & $\begin{array}{c}\text { PI-437a } \\
\text { Mh }\end{array}$ & $\begin{array}{c}\text { PI-437a } \\
\text { Mh }\end{array}$ \\
\hline $\mathrm{SiO}_{2}$ & 44.08 & 33.27 & 36.38 & 34.44 & 35.57 & 35.32 & 35.16 & 35.13 & 35.19 & 34.92 & 36.49 & 36.35 & 35.83 \\
\hline $\mathrm{TiO}_{2}$ & 1.00 & 1.71 & 1.29 & 2.62 & 2.08 & 1.76 & 1.92 & 2.42 & 1.99 & 1.95 & 1.96 & 1.81 & 2.32 \\
\hline $\mathrm{Al}_{2} \mathrm{O}_{3}$ & 18.17 & 20.14 & 15.29 & 18.22 & 14.28 & 15.23 & 14.39 & 15.04 & 14.76 & 14.59 & 14.70 & 14.89 & 16.62 \\
\hline $\mathrm{FeO}$ & 17.76 & 23.47 & 23.96 & 22.34 & 24.65 & 23.68 & 24.90 & 24.01 & 25.14 & 24.67 & 21.60 & 21.97 & 21.97 \\
\hline $\mathrm{MnO}$ & 0.31 & 0.44 & 0.43 & 0.41 & 0.39 & 0.33 & 0.42 & 0.25 & 0.28 & 0.36 & 0.25 & 0.27 & 0.34 \\
\hline $\mathrm{MgO}$ & 5.54 & 7.74 & 7.96 & 8.00 & 7.53 & 7.84 & 7.34 & 7.48 & 7.26 & 7.28 & 9.94 & 9.80 & 8.23 \\
\hline $\mathrm{BaO}$ & 0.11 & 0.14 & 0.16 & 0.16 & 0.24 & 0.30 & 0.27 & 0.14 & 0.26 & 0.26 & 0.26 & 0.23 & 0.44 \\
\hline $\mathrm{CaO}$ & 1.27 & 0.00 & 0.03 & 0.03 & 0.01 & 0.00 & 0.00 & 0.04 & 0.02 & 0.02 & 0.04 & 0.02 & 0.00 \\
\hline $\mathrm{Na}_{2} \mathrm{O}$ & 3.10 & 0.06 & 0.06 & 0.09 & 0.04 & 0.05 & 0.06 & 0.10 & 0.02 & 0.06 & 0.07 & 0.07 & 0.05 \\
\hline $\mathrm{K}_{2} \mathrm{O}$ & 6.89 & 9.21 & 9.29 & 9.44 & 9.50 & 9.52 & 9.24 & 9.42 & 9.53 & 9.11 & 9.48 & 9.73 & 9.81 \\
\hline $\mathrm{F}$ & 0.29 & 0.59 & 0.45 & 0.35 & 0.61 & 0.45 & 0.72 & 0.35 & 0.37 & 0.34 & 0.47 & 0.58 & 0.55 \\
\hline $\mathrm{Cl}$ & 0.13 & 0.14 & 0.20 & 0.20 & 0.20 & 0.18 & 0.15 & 0.18 & 0.20 & 0.14 & 0.15 & 0.11 & 0.16 \\
\hline Total & 98.65 & 96.92 & 95.49 & 96.29 & 95.1 & 94.67 & 94.56 & 94.54 & 95 & 93.69 & 95.39 & 95.84 & 96.31 \\
\hline$-\mathrm{O}=\mathrm{F}, \mathrm{Cl}$ & 0.15 & 0.28 & 0.23 & 0.19 & 0.3 & 0.23 & 0.34 & 0.19 & 0.2 & 0.18 & 0.23 & 0.27 & 0.27 \\
\hline Total & 98.5 & 96.64 & 95.26 & 96.1 & 94.8 & 94.44 & 94.22 & 94.35 & 94.8 & 93.51 & 95.16 & 95.57 & 96.04 \\
\hline \multicolumn{14}{|c|}{ Fórmula estrutural calculada na base de 22 oxigênios } \\
\hline $\mathrm{Si}$ & 6.299 & 5.145 & 5.714 & 5.329 & 5.675 & 5.621 & 5.653 & 5.595 & 5.62 & 5.634 & 5.682 & 5.658 & 5.553 \\
\hline $\mathrm{Al}^{\mathrm{IV}}$ & 1.701 & 2.855 & 2.286 & 2.671 & 2.325 & 2.379 & 2.347 & 2.405 & 2.38 & 2.366 & 2.318 & 2.342 & 2.447 \\
\hline $\mathrm{Al}^{\mathrm{VI}}$ & 1.356 & 0.813 & 0.541 & 0.648 & 0.359 & 0.475 & 0.377 & 0.417 & 0.396 & 0.406 & 0.379 & 0.387 & 0.587 \\
\hline $\mathrm{Ti}$ & 0.108 & 0.199 & 0.153 & 0.305 & 0.25 & 0.211 & 0.232 & 0.29 & 0.239 & 0.237 & 0.229 & 0.212 & 0.271 \\
\hline $\mathrm{Fe}^{2+}$ & 2.122 & 3.036 & 3.146 & 2.89 & 3.289 & 3.152 & 3.349 & 3.199 & 3.357 & 3.329 & 2.813 & 2.86 & 2.847 \\
\hline $\mathrm{Mn}$ & 0.038 & 0.058 & 0.057 & 0.054 & 0.052 & 0.045 & 0.057 & 0.033 & 0.038 & 0.049 & 0.033 & 0.036 & 0.044 \\
\hline $\mathrm{Mg}$ & 1.18 & 1.784 & 1.864 & 1.845 & 1.79 & 1.861 & 1.758 & 1.775 & 1.727 & 1.752 & 2.309 & 2.273 & 1.901 \\
\hline $\mathrm{Ba}$ & 0.006 & 0.009 & 0.01 & 0.009 & 0.015 & 0.019 & 0.017 & 0.008 & 0.016 & 0.017 & 0.016 & 0.014 & 0.026 \\
\hline $\mathrm{Ca}$ & 0.194 & 0 & 0.005 & 0.005 & 0.001 & 0 & 0 & 0.006 & 0.003 & 0.003 & 0.006 & 0.003 & 0 \\
\hline $\mathrm{Na}$ & 0.858 & 0.017 & 0.018 & 0.026 & 0.011 & 0.015 & 0.02 & 0.03 & 0.005 & 0.019 & 0.02 & 0.02 & 0.016 \\
\hline $\mathrm{K}$ & 1.256 & 1.817 & 1.861 & 1.863 & 1.933 & 1.934 & 1.895 & 1.915 & 1.942 & 1.875 & 1.884 & 1.932 & 1.94 \\
\hline Soma cátions & 15.118 & 15.733 & 15.655 & 15.645 & 15.7 & 15.712 & 15.705 & 15.673 & 15.723 & 15.687 & 15.689 & 15.737 & 15.632 \\
\hline $\mathrm{Fe} /(\mathrm{Fe}+\mathrm{Mg})$ & 0.64 & 0.63 & 0.63 & 0.61 & 0.65 & 0.63 & 0.66 & 0.64 & 0.66 & 0.66 & 0.55 & 0.56 & 0.6 \\
\hline
\end{tabular}

Análises com (*) foram obtidas no presente trabalho, sendo as demais do banco de dados do orientador 
Tabela A02. Continuação. Composição química, em percentagem de peso, de biotitas das rochas do Plúton Piracaia

\begin{tabular}{|c|c|c|c|c|c|c|c|c|c|c|c|c|c|c|c|c|}
\hline $\begin{array}{l}\text { Amostra / Cristal } \\
\text { Posição }\end{array}$ & PI-437a & PI-437a & PI-437a & $\begin{array}{l}\text { PI-26a } \\
\text { inclusa }\end{array}$ & PI-26a & PI-26a & $\begin{array}{l}\text { PI-26a } \\
\text { matriz }\end{array}$ & $\begin{array}{l}\text { PI-26a } \\
\text { matriz }\end{array}$ & PI-426B & $\begin{array}{l}\text { PI-426B } \\
\text { inclusa }\end{array}$ & PI-426B & PI-426B & PI-426B & PI-26b & PI-26b & PI-26b \\
\hline Unidade & $M h$ & $M h$ & $M h$ & $M h$ & $M h$ & $M h$ & $M h$ & $M h$ & $M h$ & $M h$ & $M h$ & $M h$ & $M h$ & $M h$ & $M h$ & $M h$ \\
\hline $\mathrm{SiO}_{2}$ & 36.60 & 36.04 & 34.33 & 34.64 & 35.23 & 39.59 & 35.04 & 34.59 & 35.39 & 35.84 & 35.56 & 35.28 & 34.87 & 35.71 & 35.87 & 36.00 \\
\hline $\mathrm{TiO}_{2}$ & 1.34 & 1.43 & 1.19 & 1.06 & 1.83 & 1.41 & 2.59 & 1.48 & 1.53 & 1.35 & 2.43 & 1.85 & 1.98 & 2.27 & 1.22 & 2.74 \\
\hline $\mathrm{Al}_{2} \mathrm{O}_{3}$ & 14.94 & 14.75 & 15.64 & 14.39 & 14.91 & 14.21 & 14.85 & 14.52 & 14.76 & 14.44 & 14.83 & 14.65 & 14.96 & 14.09 & 13.65 & 13.36 \\
\hline $\mathrm{FeO}$ & 22.25 & 22.15 & 29.90 & 25.25 & 25.74 & 23.01 & 25.79 & 24.54 & 25.22 & 25.03 & 24.63 & 24.71 & 24.86 & 29.33 & 28.96 & 29.14 \\
\hline $\mathrm{MnO}$ & 0.25 & 0.30 & 0.94 & 0.37 & 0.36 & 0.30 & 0.39 & 0.36 & 0.43 & 0.48 & 0.42 & 0.49 & 0.48 & 0.65 & 0.55 & 0.58 \\
\hline $\mathrm{MgO}$ & 10.73 & 10.09 & 4.15 & 7.76 & 7.23 & 6.71 & 6.62 & 7.73 & 8.05 & 8.19 & 7.09 & 7.40 & 7.35 & 5.27 & 6.09 & 5.05 \\
\hline $\mathrm{BaO}$ & 0.33 & 0.15 & 0.02 & 0.14 & 0.96 & 0.10 & 0.15 & 0.26 & 0.35 & 0.16 & 0.27 & 0.34 & 0.34 & & & \\
\hline $\mathrm{CaO}$ & 0.19 & 0.00 & 0.07 & 0.07 & 0.00 & 0.03 & 0.00 & 0.02 & 0.01 & 0.01 & 0.00 & 0.00 & 0.01 & 0.03 & 0.07 & 0.33 \\
\hline $\mathrm{Na}_{2} \mathrm{O}$ & 0.08 & 0.04 & 0.04 & 0.34 & 0.11 & 0.14 & 0.07 & 0.13 & 0.03 & 0.06 & 0.04 & 0.02 & 0.03 & 0.04 & 0.05 & 0.10 \\
\hline $\mathrm{K}_{2} \mathrm{O}$ & 9.22 & 9.51 & 9.23 & 9.28 & 9.26 & 9.11 & 9.32 & 9.51 & 9.63 & 9.38 & 9.63 & 9.53 & 9.42 & 9.76 & 9.76 & 8.84 \\
\hline $\mathrm{F}$ & 0.44 & 0.33 & 0.52 & 0.40 & 0.58 & 0.39 & 0.45 & 0.78 & 0.49 & 0.66 & 0.42 & 0.65 & 0.46 & & & \\
\hline $\mathrm{Cl}$ & 0.15 & 0.24 & 0.11 & 0.13 & 0.12 & 0.10 & 0.12 & 0.14 & 0.10 & 0.10 & 0.12 & 0.12 & 0.14 & & & \\
\hline Total & 96.51 & 95.02 & 96.14 & 93.83 & 96.32 & 95.09 & 95.4 & 94.05 & 95.99 & 95.7 & 95.43 & 95.05 & 94.87 & 97.15 & 96.22 & 96.14 \\
\hline$-\mathrm{O}=\mathrm{F}, \mathrm{Cl}$ & 0.22 & 0.19 & 0.24 & 0.2 & 0.27 & 0.18 & 0.22 & 0.36 & 0.23 & 0.3 & 0.2 & 0.3 & 0.22 & & & \\
\hline Total & 96.29 & 94.83 & 95.9 & 93.63 & 96.05 & 94.91 & 95.18 & 93.69 & 95.76 & 95.4 & 95.23 & 94.75 & 94.65 & 97.15 & 96.22 & 96.14 \\
\hline \multicolumn{17}{|c|}{ Fórmula estrutural calculada na base de 22 oxigênios } \\
\hline $\mathrm{Si}$ & 5.641 & 5.652 & 5.55 & 5.616 & 5.593 & 6.136 & 5.583 & 5.606 & 5.603 & 5.677 & 5.636 & 5.641 & 5.579 & 5.653 & 5.726 & 5.73 \\
\hline $\mathrm{Al}^{\mathrm{IV}}$ & 2.359 & 2.348 & 2.45 & 2.384 & 2.407 & 1.864 & 2.417 & 2.394 & 2.397 & 2.323 & 2.364 & 2.359 & 2.421 & 2.347 & 2.274 & 2.27 \\
\hline $\mathrm{Al}^{\mathrm{VI}}$ & 0.352 & 0.375 & 0.528 & 0.364 & 0.381 & 0.73 & 0.368 & 0.378 & 0.354 & 0.37 & 0.405 & 0.4 & 0.399 & 0.28 & 0.292 & 0.234 \\
\hline $\mathrm{Ti}$ & 0.156 & 0.168 & 0.145 & 0.13 & 0.218 & 0.165 & 0.31 & 0.18 & 0.183 & 0.16 & 0.289 & 0.223 & 0.238 & 0.27 & 0.146 & 0.328 \\
\hline $\mathrm{Fe}^{2+}$ & 2.868 & 2.904 & 4.042 & 3.423 & 3.417 & 2.982 & 3.437 & 3.326 & 3.339 & 3.315 & 3.265 & 3.304 & 3.326 & 3.883 & 3.866 & 3.879 \\
\hline $\mathrm{Mn}$ & 0.033 & 0.039 & 0.128 & 0.051 & 0.049 & 0.039 & 0.052 & 0.05 & 0.058 & 0.064 & 0.056 & 0.067 & 0.064 & 0.087 & 0.074 & 0.078 \\
\hline $\mathrm{Mg}$ & 2.465 & 2.359 & 1 & 1.875 & 1.71 & 1.55 & 1.573 & 1.868 & 1.901 & 1.934 & 1.675 & 1.763 & 1.753 & 1.244 & 1.449 & 1.198 \\
\hline $\mathrm{Ba}$ & 0.02 & 0.009 & 0.001 & 0.009 & 0.06 & 0.006 & 0.009 & 0.016 & 0.022 & 0.01 & 0.017 & 0.021 & 0.021 & 0 & 0 & 0 \\
\hline $\mathrm{Ca}$ & 0.031 & 0 & 0.012 & 0.013 & 0 & 0.005 & 0.001 & 0.003 & 0.001 & 0.001 & 0 & 0 & 0.002 & 0.005 & 0.012 & 0.056 \\
\hline $\mathrm{Na}$ & 0.025 & 0.012 & 0.012 & 0.106 & 0.035 & 0.042 & 0.023 & 0.04 & 0.01 & 0.019 & 0.012 & 0.006 & 0.008 & 0.012 & 0.015 & 0.031 \\
\hline $\mathrm{K}$ & 1.814 & 1.903 & 1.903 & 1.92 & 1.875 & 1.8 & 1.894 & 1.967 & 1.944 & 1.896 & 1.947 & 1.943 & 1.922 & 1.971 & 1.988 & 1.795 \\
\hline Soma cátions & 15.764 & 15.769 & 15.771 & 15.89 & 15.75 & 15.319 & 15.67 & 15.83 & 15.812 & 15.769 & 15.666 & 15.727 & 15.733 & 15.75 & 15.84 & 15.6 \\
\hline $\mathrm{Fe} /(\mathrm{Fe}+\mathrm{Mg})$ & 0.54 & 0.55 & 0.8 & 0.65 & 0.67 & 0.66 & 0.69 & 0.64 & 0.64 & 0.63 & 0.66 & 0.65 & 0.65 & 0.76 & 0.73 & 0.76 \\
\hline
\end{tabular}

Análises com (*) foram obtidas no presente trabalho, sendo as demais do banco de dados do orientador 
Tabela A02. Continuação. Composição química, em percentagem de peso, de biotitas das rochas do Plúton Piracaia

\begin{tabular}{|c|c|c|c|c|c|c|c|c|c|c|c|c|c|c|c|c|c|}
\hline \multirow{2}{*}{$\begin{array}{l}\text { Amostra / Cristal } \\
\text { Posição } \\
\text { Unidade } \\
\end{array}$} & \multicolumn{2}{|c|}{ PI-419 PI-419 } & \multicolumn{2}{|c|}{$\begin{array}{l}\text { PI-419 PI-419 } \\
\text { centro aglomera }\end{array}$} & PI-419 & \multirow{2}{*}{$\begin{array}{c}\text { PI-419 } \\
M h \\
\end{array}$} & \multirow{2}{*}{$\begin{array}{l}\text { PI-429 } \\
\text { Qsie } \\
\end{array}$} & \multirow{2}{*}{$\begin{array}{l}\text { PI-429 } \\
\text { Qsie } \\
\end{array}$} & \multicolumn{2}{|c|}{ PI-429 PI-429 } & PI-429 & \multicolumn{6}{|c|}{$\begin{array}{l}\text { PI-429 PI-429 PI-270E PI-270E PI-270E PI-8/1 } \\
\text { inclusa inclusa }\end{array}$} \\
\hline & $M h$ & $M h$ & $M h$ & $M h$ & $M h$ & & & & Qsie & Qsie & Qsie & Qsie & Qsie & Qsie & Qsie & Qsie & Qsie \\
\hline $\mathrm{SiO}_{2}$ & 35.56 & 35.28 & 35.70 & 35.63 & 32.12 & 35.66 & 35.02 & 34.82 & 35.46 & 34.95 & 35.41 & 34.89 & 35.85 & 36.38 & 35.85 & 35.88 & 35.72 \\
\hline $\mathrm{TiO}_{2}$ & 1.64 & 1.67 & 1.20 & 1.79 & 2.26 & 2.63 & 1.87 & 1.79 & 1.91 & 2.76 & 1.99 & 2.16 & 1.98 & 1.35 & 1.39 & 1.68 & 1.28 \\
\hline $\mathrm{Al}_{2} \mathrm{O}_{3}$ & 14.51 & 14.71 & 14.58 & 14.42 & 14.79 & 14.54 & 14.44 & 15.05 & 14.63 & 14.47 & 14.93 & 14.38 & 14.30 & 15.70 & 15.50 & 15.03 & 14.95 \\
\hline $\mathrm{FeO}$ & 24.74 & 25.75 & 24.81 & 25.48 & 24.63 & 24.43 & 23.86 & 25.32 & 24.49 & 26.06 & 24.53 & 24.88 & 24.55 & 28.13 & 28.82 & 27.40 & 25.91 \\
\hline $\mathrm{MnO}$ & 0.40 & 0.41 & 0.39 & 0.31 & 0.39 & 0.44 & 0.30 & 0.44 & 0.41 & 0.32 & 0.37 & 0.40 & 0.51 & 0.72 & 0.70 & 0.70 & 0.50 \\
\hline $\mathrm{MgO}$ & 8.21 & 7.65 & 8.27 & 7.79 & 7.52 & 7.61 & 7.29 & 7.64 & 7.91 & 6.88 & 7.30 & 7.24 & 7.68 & 5.36 & 5.44 & 5.51 & 7.54 \\
\hline $\mathrm{BaO}$ & 0.22 & 0.27 & 0.24 & 0.11 & 1.12 & 0.38 & 0.23 & 0.16 & 0.26 & 0.26 & 0.24 & 0.19 & 0.21 & 0.04 & 0.08 & 0.04 & 0.10 \\
\hline $\mathrm{CaO}$ & 0.03 & 0.09 & 0.03 & 0.01 & 0.04 & 0.00 & 0.03 & 0.00 & 0.00 & 0.00 & 0.00 & 0.00 & 0.00 & 0.05 & 0.00 & 0.01 & 0.04 \\
\hline $\mathrm{Na}_{2} \mathrm{O}$ & 0.04 & 0.10 & 0.07 & 0.05 & 0.08 & 0.04 & 0.05 & 0.04 & 0.04 & 0.07 & 0.05 & 0.05 & 0.03 & 0.06 & 0.03 & 0.04 & 0.08 \\
\hline $\mathrm{K}_{2} \mathrm{O}$ & 9.50 & 9.13 & 9.51 & 9.58 & 9.01 & 9.63 & 9.09 & 9.20 & 9.36 & 9.23 & 9.59 & 9.17 & 9.48 & 9.95 & 9.72 & 9.81 & 9.50 \\
\hline $\mathrm{F}$ & 0.96 & 0.75 & 0.58 & 0.61 & 0.45 & 0.35 & 0.58 & 0.52 & 0.72 & 0.28 & 0.48 & 0.42 & 0.65 & 0.82 & 0.71 & 0.73 & 0.66 \\
\hline $\mathrm{Cl}$ & 0.14 & 0.30 & 0.15 & 0.13 & 0.15 & 0.08 & 0.15 & 0.15 & 0.15 & 0.12 & 0.15 & 0.15 & 0.18 & 0.12 & 0.11 & 0.04 & 0.14 \\
\hline Total & 95.94 & 96.11 & 95.53 & 95.91 & 92.54 & 95.78 & 92.91 & 95.14 & 95.34 & 95.4 & 95.05 & 93.92 & 95.42 & 98.66 & 98.36 & 96.86 & 96.43 \\
\hline$-\mathrm{O}=\mathrm{F}, \mathrm{Cl}$ & 0.44 & 0.38 & 0.28 & 0.29 & 0.22 & 0.16 & 0.28 & 0.25 & 0.34 & 0.14 & 0.24 & 0.21 & 0.32 & 0.37 & 0.33 & 0.32 & 0.31 \\
\hline Total & 95.5 & 95.73 & 95.25 & 95.62 & 92.32 & 95.62 & 92.63 & 94.89 & 95 & 95.26 & 94.81 & 93.71 & 95.1 & 98.29 & 98.03 & 96.54 & 96.12 \\
\hline \multicolumn{18}{|c|}{ Fórmula estrutural calculada na base de 22 oxigênios } \\
\hline $\mathrm{Si}$ & 5.639 & 5.604 & 5.665 & 5.646 & 5.344 & 5.625 & 5.689 & 5.556 & 5.638 & 5.57 & 5.637 & 5.628 & 5.694 & 5.67 & 5.623 & 5.683 & 5.639 \\
\hline $\mathrm{Al}^{\mathrm{IV}}$ & 2.361 & 2.396 & 2.335 & 2.354 & 2.656 & 2.375 & 2.311 & 2.444 & 2.362 & 2.43 & 2.363 & 2.372 & 2.306 & 2.33 & 2.377 & 2.317 & 2.361 \\
\hline $\mathrm{Al}^{\mathrm{VI}}$ & 0.348 & 0.356 & 0.39 & 0.337 & 0.242 & 0.327 & 0.452 & 0.385 & 0.377 & 0.287 & 0.436 & 0.361 & 0.368 & 0.552 & 0.486 & 0.486 & 0.419 \\
\hline $\mathrm{Ti}$ & 0.196 & 0.199 & 0.143 & 0.213 & 0.283 & 0.313 & 0.229 & 0.215 & 0.228 & 0.331 & 0.239 & 0.262 & 0.237 & 0.159 & 0.164 & 0.201 & 0.152 \\
\hline $\mathrm{Fe}^{2+}$ & 3.281 & 3.422 & 3.292 & 3.376 & 3.427 & 3.223 & 3.241 & 3.379 & 3.256 & 3.473 & 3.266 & 3.357 & 3.26 & 3.667 & 3.78 & 3.629 & 3.42 \\
\hline $\mathrm{Mn}$ & 0.054 & 0.055 & 0.052 & 0.042 & 0.056 & 0.059 & 0.042 & 0.059 & 0.055 & 0.043 & 0.05 & 0.054 & 0.069 & 0.095 & 0.092 & 0.093 & 0.067 \\
\hline $\mathrm{Mg}$ & 1.942 & 1.811 & 1.957 & 1.839 & 1.864 & 1.789 & 1.766 & 1.818 & 1.873 & 1.636 & 1.732 & 1.741 & 1.818 & 1.244 & 1.272 & 1.301 & 1.774 \\
\hline $\mathrm{Ba}$ & 0.013 & 0.017 & 0.015 & 0.007 & 0.073 & 0.024 & 0.014 & 0.01 & 0.016 & 0.016 & 0.015 & 0.012 & 0.013 & 0.002 & 0.005 & 0.003 & 0.006 \\
\hline $\mathrm{Ca}$ & 0.005 & 0.015 & 0.005 & 0.002 & 0.006 & 0 & 0.005 & 0 & 0 & 0 & 0 & 0 & 0 & 0.008 & 0 & 0.001 & 0.006 \\
\hline $\mathrm{Na}$ & 0.013 & 0.029 & 0.021 & 0.015 & 0.024 & 0.011 & 0.016 & 0.012 & 0.011 & 0.02 & 0.017 & 0.015 & 0.008 & 0.019 & 0.009 & 0.012 & 0.025 \\
\hline $\mathrm{K}$ & 1.921 & 1.851 & 1.924 & 1.936 & 1.912 & 1.937 & 1.884 & 1.874 & 1.898 & 1.877 & 1.948 & 1.888 & 1.92 & 1.978 & 1.945 & 1.982 & 1.914 \\
\hline Soma cátions & 15.77 & 15.76 & 15.8 & 15.767 & 15.89 & 15.68 & 15.65 & 15.75 & 15.71 & 15.68 & 15.703 & 15.69 & 15.69 & 15.724 & 15.753 & 15.708 & 15.78 \\
\hline $\mathrm{Fe} /(\mathrm{Fe}+\mathrm{Mg})$ & 0.63 & 0.65 & 0.63 & 0.65 & 0.65 & 0.64 & 0.65 & 0.65 & 0.63 & 0.68 & 0.65 & 0.66 & 0.64 & 0.75 & 0.75 & 0.74 & 0.66 \\
\hline
\end{tabular}

Análises com (*) foram obtidas no presente trabalho, sendo as demais do banco de dados do orientador 
Tabela A02. Continuação. Composição química, em percentagem de peso, de biotitas das rochas do Plúton Piracaia

\begin{tabular}{|c|c|c|c|c|c|c|c|c|c|c|c|c|c|c|c|c|c|}
\hline \multirow{2}{*}{$\begin{array}{l}\text { Amostra / Cristal } \\
\text { Posição } \\
\text { Unidade } \\
\end{array}$} & \multirow{2}{*}{$\begin{array}{l}\text { PI-8/1 } \\
\text { Qsie } \\
\end{array}$} & \multirow{2}{*}{$\begin{array}{l}\text { PI-8/1 } \\
\text { Qsie } \\
\end{array}$} & \multirow{2}{*}{$\begin{array}{l}\text { PI-8/1 } \\
\text { Qsie } \\
\end{array}$} & \multirow{2}{*}{$\begin{array}{l}\text { PI-8/1 } \\
\text { Qsie } \\
\end{array}$} & \multirow{2}{*}{$\begin{array}{l}\text { PI-8/1 } \\
\text { Qsie } \\
\end{array}$} & \multirow{2}{*}{$\begin{array}{l}\text { PI-8/1 } \\
\text { Qsie } \\
\end{array}$} & \multirow{2}{*}{$\begin{array}{l}\text { PI-8/1 } \\
\text { Qsie } \\
\end{array}$} & \multirow{2}{*}{$\begin{array}{l}\text { PI-384B } \\
\text { Qsie } \\
\end{array}$} & \multirow{2}{*}{$\begin{array}{l}\text { PI-384B } \\
\text { Qsie } \\
\end{array}$} & \multirow{2}{*}{$\begin{array}{l}\text { PI-384B P } \\
\text { Qsie }\end{array}$} & \multirow{2}{*}{$\begin{array}{l}\text { PI-384B } \\
\text { Qsie } \\
\end{array}$} & \multicolumn{2}{|c|}{ PI-384B PI-384B } & \multirow{2}{*}{$\begin{array}{l}\text { PI-410 } \\
\text { Qsie } \\
\end{array}$} & \multicolumn{3}{|c|}{ PI-410 PI-410 PI-410 } \\
\hline & & & & & & & & & & & & Qsie & Qsie & & Qsie & Qsie & Qsie \\
\hline $\mathrm{SiO}_{2}$ & 35.87 & 36.41 & 35.52 & 35.79 & 35.41 & 35.23 & 35.73 & 35.56 & 34.45 & 34.70 & 34.28 & 34.70 & 35.06 & 34.26 & 34.33 & 34.61 & 34.05 \\
\hline $\mathrm{TiO}_{2}$ & 1.64 & 1.59 & 1.43 & 3.21 & 3.19 & 2.68 & 2.24 & 1.54 & 1.39 & 1.44 & 1.22 & 1.53 & 1.49 & 1.54 & 1.19 & 1.61 & 1.45 \\
\hline $\mathrm{Al}_{2} \mathrm{O}_{3}$ & 14.95 & 14.59 & 14.67 & 14.72 & 14.39 & 14.26 & 14.45 & 15.69 & 15.54 & 15.61 & 16.06 & 15.52 & 15.84 & 15.59 & 15.64 & 15.36 & 15.76 \\
\hline $\mathrm{FeO}$ & 25.15 & 24.58 & 25.36 & 25.71 & 26.30 & 26.33 & 26.12 & 29.06 & 28.81 & 28.91 & 29.64 & 29.29 & 28.68 & 29.02 & 29.90 & 29.65 & 29.95 \\
\hline $\mathrm{MnO}$ & 0.49 & 0.49 & 0.48 & 0.44 & 0.48 & 0.49 & 0.57 & 0.73 & 0.83 & 0.84 & 0.78 & 0.88 & 0.77 & 0.75 & 0.94 & 0.91 & 0.89 \\
\hline $\mathrm{MgO}$ & 7.32 & 8.22 & 8.11 & 6.60 & 6.41 & 6.73 & 7.69 & 4. & 4.14 & 4.33 & 4.22 & 4.19 & 4.16 & 4.16 & 4.15 & 4.21 & 4.01 \\
\hline $\mathrm{BaO}$ & 0.13 & 0.14 & 0.00 & 0.23 & 0.12 & 0.08 & 0.06 & & 0.07 & 0.03 & & & 0.00 & 0.06 & 0.02 & 0.14 & 0.12 \\
\hline $\mathrm{CaO}$ & 0.01 & 0.01 & 0.07 & 0.00 & 0.20 & 0.00 & 0.00 & & 0.00 & 0.02 & 0.02 & 0.02 & 0.00 & 0.07 & 0.07 & 0.00 & 0.12 \\
\hline $\mathrm{Na}_{2} \mathrm{O}$ & 0.04 & 0.01 & 0.06 & 0.05 & 0.07 & 0.03 & 0.04 & 0.04 & 0.06 & 0.06 & 0.02 & 0.04 & 0.02 & 0.02 & 0.04 & 0.02 & 0.06 \\
\hline $\mathrm{K}_{2} \mathrm{O}$ & 9.75 & 9.68 & 9.42 & 9.94 & 9.48 & 9.80 & 9.77 & 9.6 & 9.68 & 9.69 & 9.60 & 9.7 & 9.77 & 9.24 & 9.23 & 9.55 & 9.66 \\
\hline F & .75 & 0.86 & 0.83 & 0.63 & 0.75 & 0.40 & 0.74 & & 0 . & 0.2 & & & 0.35 & 0.25 & 0.52 & 0.39 & 0.56 \\
\hline $\mathrm{Cl}$ & 17 & 0.16 & 0.15 & 0.13 & 0.12 & 0.14 & 0.11 & & & & & & 0.11 & .13 & 0.11 & 0.10 & 0.08 \\
\hline Total & 96.25 & 96.72 & 96.09 & 97.44 & 96.92 & 96.16 & 97.52 & & 95.2 & 95.92 & & & 96.26 & 95.09 & 96.14 & 96.54 & 96.7 \\
\hline$-\mathrm{O}=\mathrm{F}$, & 35 & 0.39 & 0.38 & 0.29 & 0.34 & 0.2 & 0.34 & 0.09 & 0. & 0.11 & 0. & & 0.17 & 0.13 & 0.24 & 0.19 & 0.25 \\
\hline Total & 95.9 & 96.33 & 95.71 & 97.15 & 96.58 & 95.96 & 97.18 & 96.85 & 95.12 & 95.81 & 96.1 & 96.14 & 96.09 & 94.96 & 95.9 & 96.35 & 96.45 \\
\hline \multicolumn{18}{|c|}{ Fórmula estrutural calculada na base de 22 oxigênios } \\
\hline $\mathrm{Si}$ & 5.665 & 5.701 & 5.623 & 5.599 & 5.588 & 5.596 & 5.596 & 5.64 & 5.586 & 5.581 & 5.515 & 5.575 & 5.612 & 5.561 & 5.55 & 5.566 & 5.495 \\
\hline $\mathrm{Al}^{\mathrm{IV}}$ & 2.335 & 2.299 & 2.377 & 2.401 & 2.412 & 2.404 & 2.404 & 2.36 & 2.414 & 2.419 & 2.485 & 2.425 & 2.388 & 2.439 & 2.45 & 2.434 & 2.505 \\
\hline $\mathrm{Al}^{\mathrm{VI}}$ & 445 & 0.392 & 0.358 & 0.311 & 0.263 & 0.264 & 0.261 & 0.57 & 0.553 & 0.537 & 0.558 & 0.512 & 0.597 & 0.541 & 0.528 & 0.475 & 0.49 \\
\hline $\mathrm{Ti}$ & 0.194 & 0.187 & 0.17 & 0.377 & 0.379 & 0.321 & 0.264 & 0.183 & 0.169 & 0.174 & 0.147 & & 0.179 & 0.188 & 0.145 & 0.194 & 0.176 \\
\hline $\mathrm{Fe}^{2+}$ & 321 & 219 & 3.357 & 3.364 & 3.471 & 3.498 & 2401 & & & & & & & 3.94 & 4.042 & & 4.043 \\
\hline $\mathrm{Mn}$ & 065 & 0.064 & 0.064 & 0.059 & 0.064 & 0.066 & 0.075 & 0.0 & & & & & 0.105 & 0.104 & 0.128 & 0.124 & 0.122 \\
\hline $\mathrm{Mg}$ & 723 & 1.92 & 1.914 & 1.539 & 1.509 & 1.594 & 1.796 & 1.011 & 1.001 & 1.0 & & & 0.992 & 1.007 & 1 & 1.01 & 0.964 \\
\hline $\mathrm{Ba}$ & 008 & 0.008 & 0 & 0.014 & 0.007 & 0.005 & 0.004 & 0.007 & 0.004 & 0.00 & & 0.006 & 0 & 0.004 & 0.001 & 0.009 & 0.008 \\
\hline $\mathrm{Ca}$ & 002 & 002 & 012 & 0 & 0.034 & 0 & 0 & 0 & 0 & & & & 0 & 0.011 & 0.012 & 0 & 0.02 \\
\hline $\mathrm{Na}$ & 013 & 004 & 018 & 0.015 & 0.022 & 0.008 & 0.011 & & & & & & & 0.007 & 0.012 & 0.005 & 0.018 \\
\hline $\mathrm{K}$ & 965 & 1.934 & 1.902 & 1.984 & 1.909 & 1.986 & 1.951 & 1.955 & 2.002 & 1.989 & 1.97 & 1.997 & 1.995 & 1.914 & 1.903 & 1.96 & 1.989 \\
\hline Soma cátions & 15.74 & 15.73 & 15.8 & 15.66 & 15.66 & 15.74 & 15.78 & 15.69 & 15.767 & 15.765 & 15.798 & 15.771 & 15.712 & 15.716 & 15.77 & 15.77 & 15.83 \\
\hline $\mathrm{Fe} /(\mathrm{Fe}+\mathrm{Mg})$ & 0.66 & 0.63 & 0.64 & 0.69 & 0.7 & 0.69 & 0.66 & 0.79 & 0.8 & 0.79 & 0.8 & 0.8 & 0.79 & 0.8 & 0.8 & 0.8 & 0.81 \\
\hline
\end{tabular}

Análises com (*) foram obtidas no presente trabalho, sendo as demais do banco de dados do orientador 
Tabela A02. Continuação. Composição química, em percentagem de peso, de biotitas das rochas do Plúton Piracaia

\begin{tabular}{|c|c|c|c|c|c|c|c|c|c|c|c|c|c|c|c|c|}
\hline \multirow{2}{*}{$\begin{array}{l}\text { Amostra / Cristal } \\
\text { Posição } \\
\text { Unidade } \\
\end{array}$} & \multicolumn{2}{|c|}{ PI-410 PI-413 } & $\begin{array}{l}\text { PI-413 } \\
\text { aglomera }\end{array}$ & PI-413 & \multicolumn{2}{|c|}{ PI-413 PI-413 } & PI-426 & \multicolumn{2}{|c|}{ PI-426 PI-426 } & \multicolumn{2}{|c|}{$\begin{array}{c}\text { PI-426 PI-426 } \\
\text { aglomera aglomera }\end{array}$} & PI-426 & \multirow{2}{*}{$\begin{array}{c}\text { PI-427 } \\
\text { aglomera } \\
\text { Qsie } \\
\end{array}$} & PI-427 & \multirow{2}{*}{$\begin{array}{l}\text { PI-427 } \\
\text { Qsie } \\
\end{array}$} & \multirow{2}{*}{$\begin{array}{c}\text { PI-427 } \\
\text { borda } \\
\text { Qsie } \\
\end{array}$} \\
\hline & Qsie & Qsie & Qsie & Qsie & Qsie & Qsie & Qsie & Qsie & Qsie & Qsie & Qsie & Qsie & & Qsie & & \\
\hline $\mathrm{SiO}_{2}$ & 34.39 & 35.58 & 35.67 & 35.98 & 35.34 & 35.74 & 34.87 & 34.92 & 35.60 & 34.74 & 38.01 & 35.84 & 33.84 & 35.21 & 35.79 & 35.87 \\
\hline $\mathrm{TiO}_{2}$ & 1.03 & 1.89 & 1.62 & 2.06 & 1.43 & 1.38 & 1.97 & 2.24 & 2.52 & 2.02 & 1.80 & 3.31 & 1.70 & 2.56 & 1.68 & 1.73 \\
\hline $\mathrm{Al}_{2} \mathrm{O}_{3}$ & 16.19 & 15.43 & 15.83 & 15.93 & 15.79 & 15.93 & 15.16 & 14.93 & 15.33 & 15.58 & 16.11 & 14.99 & 17.91 & 14.63 & 14.64 & 14.67 \\
\hline $\mathrm{FeO}$ & 29.46 & 25.99 & 25.95 & 26.24 & 26.36 & 26.10 & 26.62 & 26.75 & 25.89 & 26.96 & 23.84 & 26.28 & 25.55 & 26.52 & 25.80 & 26.36 \\
\hline $\mathrm{MnO}$ & 0.94 & 0.79 & 0.79 & 0.77 & 0.87 & 0.75 & 0.34 & 0.39 & 0.33 & 0.27 & 0.27 & 0.35 & 0.48 & 0.53 & 0.45 & 0.54 \\
\hline $\mathrm{MgO}$ & 4.22 & 6.21 & 5.88 & 6.37 & 6.34 & 6.26 & 6.14 & 5.97 & 6.49 & 5.25 & 5.42 & 5.93 & 7.09 & 6.37 & 7.53 & 7.19 \\
\hline $\mathrm{BaO}$ & 0.02 & 0.02 & 0.00 & 0.07 & 0.03 & 0.02 & 0.20 & 0.39 & 0.17 & 0.15 & 0.20 & 0.21 & 0.19 & 0.10 & 0.09 & 0.05 \\
\hline $\mathrm{CaO}$ & 0.00 & 0.00 & 0.03 & 0.00 & 0.02 & 0.00 & 0.00 & 0.00 & 0.00 & 0.02 & 0.00 & 0.00 & 0.00 & 0.04 & 0.00 & 0.06 \\
\hline $\mathrm{Na}_{2} \mathrm{O}$ & 0.00 & 0.02 & 0.06 & 0.06 & 0.01 & 0.03 & 0.08 & 0.08 & 0.07 & 0.07 & 0.09 & 0.04 & 0.03 & 0.02 & 0.06 & 0.01 \\
\hline $\mathrm{K}_{2} \mathrm{O}$ & 8.81 & 9.74 & 9.47 & 9.74 & 9.60 & 9.67 & 9.30 & 9.68 & 9.74 & 8.90 & 9.88 & 9.60 & 9.01 & 9.20 & 9.27 & 8.99 \\
\hline F & 0.18 & 0.52 & 0.56 & 0.45 & 0.38 & 0.6 & 0.61 & 0.41 & 0.42 & 0.3 & 0.04 & 0.17 & 0.44 & 0.31 & 0.18 & 0.31 \\
\hline $\mathrm{Cl}$ & 0.18 & 0.12 & 0.15 & 0.11 & 0.12 & 0.10 & 0.12 & 0.06 & 0.06 & 0.09 & 0.13 & 0.10 & 0.05 & 0.09 & 0.07 & 0.06 \\
\hline Total & 95.39 & 96.32 & 96.01 & 97.77 & 96.29 & 96.59 & 95.41 & 95.83 & 96.62 & 94.41 & 95.8 & 96.82 & 96.28 & 95.58 & 95.55 & 95.82 \\
\hline$-\mathrm{O}=\mathrm{F}, \mathrm{Cl}$ & 0.11 & 0.25 & 0.27 & 0.21 & 0.19 & 0.28 & 0.28 & 0.19 & 0.19 & 0.17 & 0.05 & 0.1 & 0.2 & 0.15 & 0.09 & 0.14 \\
\hline Total & 95.28 & 96.07 & 95.74 & 97.56 & 96.1 & 96.31 & 95.13 & 95.64 & 96.43 & 94.24 & 95.75 & 96.72 & 96.08 & 95.43 & 95.46 & 95.68 \\
\hline \multicolumn{17}{|c|}{ Fórmula estrutural calculada na base de 22 oxigênios } \\
\hline $\mathrm{Si}$ & 5.551 & 5.624 & 5.643 & 5.59 & 5.587 & 5.627 & 5.587 & 5.582 & 5.593 & 5.6 & 5.892 & 5.611 & 5.314 & 5.603 & 5.658 & 5.664 \\
\hline $\mathrm{Al}^{\mathrm{IV}}$ & 2.449 & 2.376 & 2.357 & 2.41 & 2.413 & 2.373 & 2.413 & 2.418 & 2.407 & 2.4 & 2.108 & 2.389 & 2.686 & 2.397 & 2.342 & 2.336 \\
\hline $\mathrm{Al}^{\mathrm{VI}}$ & 0.628 & 0.495 & 0.593 & 0.504 & 0.528 & 0.582 & 0.448 & 0.393 & 0.429 & 0.556 & 0.833 & 0.375 & 0.627 & 0.345 & 0.383 & 0.392 \\
\hline $\mathrm{Ti}$ & 0.124 & 0.225 & 0.193 & 0.241 & 0.17 & 0.164 & 0.238 & 0.27 & 0.298 & 0.245 & 0.21 & 0.39 & 0.201 & 0.306 & 0.199 & 0.205 \\
\hline $\mathrm{Fe}^{2+}$ & 3.977 & 3.436 & 3.434 & & 3.486 & 3.437 & 3.567 & 3.576 & 3.401 & 3.634 & 3.09 & 3.441 & 3.356 & 3.53 & 3.411 & 3.481 \\
\hline $\mathrm{Mn}$ & 0.128 & 0.106 & 0.106 & 0.101 & 0.117 & 0.1 & 0.046 & 0.053 & 0.043 & 0.037 & 0.036 & 0.046 & 0.064 & 0.072 & 0.061 & 0.072 \\
\hline $\mathrm{Mg}$ & 1.016 & 1.463 & 1.388 & 1.475 & 1.493 & 1.468 & 1.468 & 1.422 & 1.519 & 1.26 & 1.253 & 1.383 & 1.659 & 1.511 & 1.775 & 1.692 \\
\hline $\mathrm{Ba}$ & 0.001 & 0.001 & 0 & 0.004 & 0.002 & 0.001 & 0.013 & 0.025 & 0.01 & 0.01 & 0.012 & 0.013 & 0.012 & 0.006 & 0.006 & 0.003 \\
\hline $\mathrm{Ca}$ & 0 & 0 & 0.005 & 0 & 0.003 & 0.001 & 0 & 0 & 0 & 0.004 & 0 & 0 & 0 & 0.007 & 0.001 & 0.01 \\
\hline $\mathrm{Na}$ & 0 & 0.006 & 0.018 & 0.017 & 0.004 & 0.009 & 0.023 & 0.025 & 0.022 & 0.021 & 0.026 & 0.012 & 0.009 & 0.007 & 0.017 & 0.004 \\
\hline $\mathrm{K}$ & 1.814 & 1.965 & 1.912 & 1.93 & 1.937 & 1.942 & 1.9 & 1.974 & 1.952 & 1.831 & 1.953 & 1.917 & 1.804 & 1.868 & 1.868 & 1.81 \\
\hline Soma cátions & 15.69 & 15.7 & 15.649 & 15.682 & 15.74 & 15.7 & 15.703 & 15.74 & 15.67 & 15.598 & 15.413 & 15.58 & 15.732 & 15.65 & 15.721 & 15.67 \\
\hline $\mathrm{Fe} /(\mathrm{Fe}+\mathrm{Mg})$ & 0.8 & 0.7 & 0.71 & 0.7 & 0.7 & 0.7 & 0.71 & 0.72 & 0.69 & 0.74 & 0.71 & 0.71 & 0.67 & 0.7 & 0.66 & 0.67 \\
\hline
\end{tabular}

Análises com (*) foram obtidas no presente trabalho, sendo as demais do banco de dados do orientador 
Tabela A02. Continuação. Composição química, em percentagem de peso, de biotitas das rochas do Plúton Piracaia

\begin{tabular}{|c|c|c|c|c|c|c|c|c|c|c|c|c|c|c|c|}
\hline $\begin{array}{l}\text { Amostra / Cristal } \\
\text { Posição } \\
\text { Unidade }\end{array}$ & $\begin{array}{c}\text { PI-427 } \\
\text { nucleo } \\
\text { Qsie }\end{array}$ & $\begin{array}{l}\text { PI-427 } \\
\text { inclusa } \\
\text { Qsie }\end{array}$ & PI-43a & PI-43a & $\begin{array}{l}\text { PI-43a } \\
\text { Qsie }\end{array}$ & $\begin{array}{l}\text { PI-440 } \\
\text { aglomera } \\
\text { Qsie }\end{array}$ & $\begin{array}{l}\text { PI-440 } \\
\text { Qsie }\end{array}$ & PI-440 & PI-440 & PI-440 & PI-440 & PI-440 & PI-440 & PI-112AA & PI-112AA \\
\hline $\mathrm{SiO}_{2}$ & 33.54 & 36.01 & 36.30 & 36.39 & 36.26 & 34.17 & 34.62 & 32.86 & 33.24 & 33.70 & 33.75 & 34.67 & 33.92 & 36.33 & 36.13 \\
\hline $\mathrm{TiO}_{2}$ & 2.17 & 1.54 & 2.62 & 2.57 & 2.13 & 1.44 & 1.71 & 2.00 & 1.97 & 1.73 & 0.87 & 1.75 & 1.63 & 2.30 & 0.75 \\
\hline $\mathrm{Al}_{2} \mathrm{O}_{3}$ & 17.81 & 14.45 & 14.24 & 14.11 & 13.72 & 16.11 & 16.37 & 15.82 & 17.91 & 15.83 & 16.37 & 16.16 & 15.91 & 16.01 & 15.27 \\
\hline $\mathrm{FeO}$ & 25.52 & 26.07 & 23.98 & 23.22 & 22.17 & 30.34 & 31.15 & 29.91 & 29.39 & 30.49 & 30.73 & 30.52 & 30.42 & 20.85 & 23.15 \\
\hline $\mathrm{MnO}$ & 0.56 & 0.57 & 0.62 & 0.59 & 0.60 & 0.75 & 0.72 & 0.70 & 0.68 & 0.64 & 0.73 & 0.74 & 0.74 & 0.36 & 0.42 \\
\hline $\mathrm{MgO}$ & 6.57 & 7.42 & 8.37 & 8.79 & 10.58 & 3.08 & 3.05 & 2.84 & 2.71 & 3.19 & 3.12 & 3.00 & 3.02 & 9.82 & 10.19 \\
\hline $\mathrm{BaO}$ & 0.16 & 0.19 & & & & 0.05 & 0.00 & 0.00 & 0.14 & 0.02 & 0.01 & 0.01 & 0.00 & 0.40 & 0.14 \\
\hline $\mathrm{CaO}$ & 0.03 & 0.04 & 0.09 & 0.08 & 0.05 & 0.01 & 0.00 & 0.06 & 0.11 & 0.02 & 0.01 & 0.00 & 0.02 & 0.00 & 0.02 \\
\hline $\mathrm{Na}_{2} \mathrm{O}$ & 0.02 & 0.05 & 0.01 & 0.06 & 0.05 & 0.00 & 0.05 & 0.10 & 0.19 & 0.04 & 0.02 & 0.03 & 0.05 & 0.03 & 0.08 \\
\hline $\mathrm{K}_{2} \mathrm{O}$ & 9.05 & 8.97 & 9.73 & 9.76 & 9.57 & 9.55 & 9.50 & 9.01 & 8.57 & 9.13 & 9.45 & 9.36 & 9.18 & 9.89 & 9.68 \\
\hline $\mathrm{F}$ & 0.21 & 0.67 & & & & 0.17 & 0.00 & 0.17 & 0.00 & 0.07 & 0.00 & 0.13 & 0.03 & 0.44 & 0.45 \\
\hline $\mathrm{Cl}$ & 0.06 & 0.10 & & & & 0.12 & 0.10 & 0.14 & 0.15 & 0.13 & 0.09 & 0.14 & 0.09 & 0.10 & 0.18 \\
\hline Total & 95.69 & 96.08 & 95.96 & 95.57 & 95.13 & 95.79 & 97.26 & 93.59 & 95.07 & 94.99 & 95.14 & 96.51 & 95 & 96.53 & 96.47 \\
\hline$-\mathrm{O}=\mathrm{F}, \mathrm{Cl}$ & 0.1 & 0.31 & & & & 0.1 & 0.02 & 0.11 & 0.04 & 0.06 & 0.02 & 0.09 & 0.03 & 0.21 & 0.23 \\
\hline Total & 95.59 & 95.77 & 95.96 & 95.57 & 95.13 & 95.69 & 97.24 & 93.48 & 95.03 & 94.93 & 95.12 & 96.42 & 94.97 & 96.32 & 96.24 \\
\hline \multicolumn{16}{|c|}{ Fórmula estrutural calculada na base de 22 oxigênios } \\
\hline $\mathrm{Si}$ & 5.296 & 5.694 & 5.66 & 5.678 & 5.657 & 5.538 & 5.516 & 5.459 & 5.372 & 5.505 & 5.51 & 5.561 & 5.532 & 5.577 & 5.612 \\
\hline $\mathrm{Al}^{\mathrm{IV}}$ & 2.704 & 2.306 & 2.34 & 2.322 & 2.343 & 2.462 & 2.484 & 2.541 & 2.628 & 2.495 & 2.49 & 2.439 & 2.468 & 2.423 & 2.388 \\
\hline $\mathrm{Al}^{\mathrm{VI}}$ & 0.608 & 0.386 & 0.275 & 0.271 & 0.178 & 0.613 & 0.588 & 0.553 & 0.78 & 0.55 & 0.656 & 0.612 & 0.588 & 0.472 & 0.404 \\
\hline $\mathrm{Ti}$ & 0.257 & 0.184 & 0.307 & 0.302 & 0.25 & 0.176 & 0.205 & 0.25 & 0.24 & 0.213 & 0.107 & 0.211 & 0.199 & 0.266 & 0.088 \\
\hline $\mathrm{Fe}^{2+}$ & 3.37 & 3.448 & 3.127 & 3.03 & 2.893 & 4.113 & 4.151 & 4.155 & 3.972 & 4.165 & 4.195 & 4.093 & 4.149 & 2.677 & 3.008 \\
\hline $\mathrm{Mn}$ & 0.075 & 0.076 & 0.082 & 0.078 & 0.079 & 0.103 & 0.097 & 0.098 & 0.093 & 0.089 & 0.101 & 0.1 & 0.102 & 0.047 & 0.056 \\
\hline $\mathrm{Mg}$ & 1.546 & 1.748 & 1.946 & 2.045 & 2.461 & 0.745 & 0.724 & 0.703 & 0.654 & 0.778 & 0.759 & 0.718 & 0.733 & 2.247 & 2.359 \\
\hline $\mathrm{Ba}$ & 0.01 & 0.012 & 0 & 0 & 0 & 0.003 & 0 & 0 & 0.009 & 0.001 & 0.001 & 0.001 & 0 & 0.024 & 0.009 \\
\hline $\mathrm{Ca}$ & 0.005 & 0.006 & 0.015 & 0.013 & 0.008 & 0.002 & 0 & 0.01 & 0.019 & 0.003 & 0.001 & 0 & 0.003 & 0 & 0.004 \\
\hline $\mathrm{Na}$ & 0.006 & 0.014 & 0.003 & 0.018 & 0.015 & 0 & 0.017 & 0.032 & 0.06 & 0.012 & 0.006 & 0.01 & 0.016 & 0.008 & 0.025 \\
\hline $\mathrm{K}$ & 1.822 & 1.81 & 1.936 & 1.943 & 1.905 & 1.974 & 1.93 & 1.909 & 1.766 & 1.903 & 1.967 & 1.915 & 1.91 & 1.937 & 1.918 \\
\hline Soma cátions & 15.7 & 15.68 & 15.69 & 15.7 & 15.79 & 15.729 & 15.712 & 15.71 & 15.593 & 15.714 & 15.793 & 15.66 & 15.7 & 15.678 & 15.871 \\
\hline $\mathrm{Fe} /(\mathrm{Fe}+\mathrm{Mg})$ & 0.69 & 0.66 & 0.62 & 0.6 & 0.54 & 0.85 & 0.85 & 0.86 & 0.86 & 0.84 & 0.85 & 0.85 & 0.85 & 0.54 & 0.56 \\
\hline
\end{tabular}

Análises com (*) foram obtidas no presente trabalho, sendo as demais do banco de dados do orientador 
Tabela A02. Continuação. Composição química, em percentagem de peso, de biotitas das rochas do Plúton Piracaia

\begin{tabular}{|c|c|c|c|c|c|c|c|c|c|c|c|}
\hline $\begin{array}{l}\text { Amostra / Cristal } \\
\text { Posição }\end{array}$ & PI-112AA & PI-112AA & PI-112AA & PI-112AA & PI-112AA & PI-112AB & PI-112AB & PI-112AB & PI-112AB & PI-112AB & PI-112AB \\
\hline Unidade & Vênula & Vênula & Vênula & Vênula & Vênula & Vênula & Vênula & Vênula & Vênula & Vênula & Vênula \\
\hline $\mathrm{SiO}_{2}$ & 35.89 & 35.96 & 36.61 & 36.21 & 36.09 & 36.35 & 36.55 & 36.30 & 36.60 & 36.34 & 36.14 \\
\hline $\mathrm{TiO}_{2}$ & 0.56 & 1.92 & 1.90 & 2.05 & 1.91 & 2.67 & 2.22 & 1.67 & 1.67 & 2.83 & 2.11 \\
\hline $\mathrm{Al}_{2} \mathrm{O}_{3}$ & 15.16 & 15.00 & 14.55 & 15.34 & 15.28 & 14.63 & 14.57 & 15.03 & 15.39 & 15.30 & 15.33 \\
\hline $\mathrm{FeO}$ & 22.30 & 21.37 & 21.15 & 20.93 & 20.90 & 21.67 & 21.44 & 20.04 & 18.73 & 20.01 & 20.33 \\
\hline $\mathrm{MnO}$ & 0.38 & 0.32 & 0.30 & 0.32 & 0.35 & 0.48 & 0.49 & 0.48 & 0.45 & 0.40 & 0.41 \\
\hline $\mathrm{MgO}$ & 10.15 & 11.13 & 11.24 & 10.39 & 10.32 & 10.59 & 10.98 & 11.56 & 12.11 & 10.34 & 10.92 \\
\hline $\mathrm{BaO}$ & 0.23 & 0.17 & 0.31 & 0.28 & 0.23 & 0.35 & 0.35 & 0.22 & 0.20 & 0.28 & 0.69 \\
\hline $\mathrm{CaO}$ & 0.00 & 0.00 & 0.00 & 0.01 & 0.00 & 0.00 & 0.01 & 0.02 & 0.05 & 0.00 & 0.00 \\
\hline $\mathrm{Na}_{2} \mathrm{O}$ & 0.06 & 0.06 & 0.06 & 0.08 & 0.04 & 0.06 & 0.06 & 0.06 & 0.06 & 0.04 & 0.03 \\
\hline $\mathrm{K}_{2} \mathrm{O}$ & 9.93 & 9.84 & 9.75 & 10.01 & 9.75 & 9.73 & 9.70 & 9.80 & 9.89 & 9.71 & 9.57 \\
\hline $\mathrm{F}$ & 0.21 & 0.27 & 0.35 & 0.39 & 0.40 & 0.31 & 0.43 & 0.30 & 0.43 & 0.25 & 0.34 \\
\hline $\mathrm{Cl}$ & 0.20 & 0.10 & 0.16 & 0.09 & 0.07 & 0.03 & 0.04 & 0.08 & 0.06 & 0.05 & 0.04 \\
\hline Total & 95.08 & 96.12 & 96.36 & 96.08 & 95.32 & 96.86 & 96.82 & 95.54 & 95.63 & 95.55 & 95.91 \\
\hline$-\mathrm{O}=\mathrm{F}, \mathrm{Cl}$ & 0.14 & 0.13 & 0.18 & 0.18 & 0.18 & 0.14 & 0.19 & 0.14 & 0.19 & 0.12 & 0.15 \\
\hline Total & 94.94 & 95.99 & 96.18 & 95.9 & 95.14 & 96.72 & 96.63 & 95.4 & 95.44 & 95.43 & 95.76 \\
\hline \multicolumn{12}{|c|}{ Fórmula estrutural calculada na base de 22 oxigênios } \\
\hline $\mathrm{Si}$ & 5.639 & 5.553 & 5.637 & 5.592 & 5.608 & 5.581 & 5.612 & 5.605 & 5.61 & 5.598 & 5.576 \\
\hline $\mathrm{Al}^{\mathrm{IV}}$ & 2.361 & 2.447 & 2.363 & 2.408 & 2.392 & 2.419 & 2.388 & 2.395 & 2.39 & 2.402 & 2.424 \\
\hline $\mathrm{Al}^{\mathrm{VI}}$ & 0.444 & 0.28 & 0.275 & 0.382 & 0.404 & 0.226 & 0.246 & 0.337 & 0.388 & 0.373 & 0.361 \\
\hline $\mathrm{Ti}$ & 0.066 & 0.223 & 0.22 & 0.238 & 0.223 & 0.309 & 0.256 & 0.193 & 0.193 & 0.327 & 0.244 \\
\hline $\mathrm{Fe}^{2+}$ & 2.931 & 2.76 & 2.723 & 2.703 & 2.716 & 2.782 & 2.752 & 2.588 & 2.401 & 2.578 & 2.623 \\
\hline $\mathrm{Mn}$ & 0.051 & 0.042 & 0.039 & 0.042 & 0.046 & 0.062 & 0.064 & 0.062 & 0.059 & 0.052 & 0.054 \\
\hline $\mathrm{Mg}$ & 2.378 & 2.562 & 2.58 & 2.392 & 2.391 & 2.424 & 2.513 & 2.661 & 2.767 & 2.374 & 2.512 \\
\hline $\mathrm{Ba}$ & 0.014 & 0.01 & 0.018 & 0.017 & 0.014 & 0.021 & 0.021 & 0.013 & 0.012 & 0.017 & 0.042 \\
\hline $\mathrm{Ca}$ & 0 & 0 & 0 & 0.001 & 0 & 0 & 0.001 & 0.003 & 0.008 & 0 & 0 \\
\hline $\mathrm{Na}$ & 0.019 & 0.017 & 0.017 & 0.022 & 0.013 & 0.017 & 0.017 & 0.019 & 0.019 & 0.013 & 0.01 \\
\hline $\mathrm{K}$ & 1.991 & 1.938 & 1.914 & 1.971 & 1.933 & 1.906 & 1.9 & 1.93 & 1.935 & 1.908 & 1.883 \\
\hline Soma cátions & 15.894 & 15.832 & 15.786 & 15.768 & 15.74 & 15.747 & 15.77 & 15.806 & 15.782 & 15.642 & 15.729 \\
\hline $\mathrm{Fe} /(\mathrm{Fe}+\mathrm{Mg})$ & 0.55 & 0.52 & 0.51 & 0.53 & 0.53 & 0.53 & 0.52 & 0.49 & 0.46 & 0.52 & 0.51 \\
\hline
\end{tabular}

Análises com (*) foram obtidas no presente trabalho, sendo as demais do banco de dados do orientador 
Tabela A02. Continuação. Composição química, em percentagem de peso, de biotitas das rochas do Plúton Piracaia

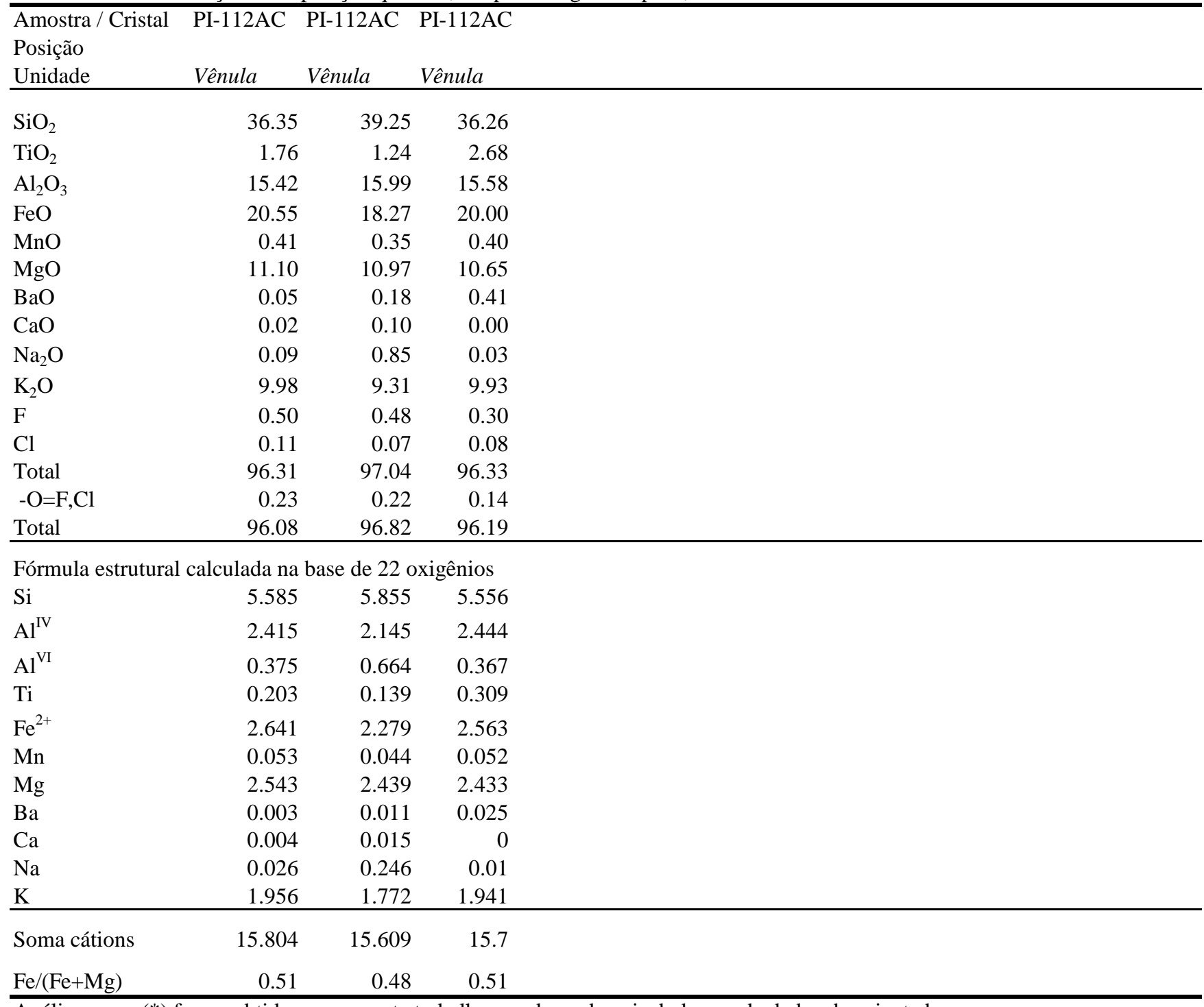

Análises com (*) foram obtidas no presente trabalho, sendo as demais do banco de dados do orientador 
Tabela A03. Composição química, em percentagem de peso, para plagioclásios das rochas do Plúton Piracaia.

\begin{tabular}{|c|c|c|c|c|c|c|c|c|c|c|c|c|c|c|c|}
\hline $\begin{array}{c}\text { Amostra / cristal } \\
\text { Posição } \\
\text { Unidade } \\
\end{array}$ & $256 \mathrm{c} / 10^{*}$ & $256 \mathrm{c} / 10^{*}$ & $\begin{array}{c}256 \mathrm{c} / 10^{*} \\
\text { centro } \\
M d r\end{array}$ & $\begin{array}{c}256 \mathrm{c} / 10^{*} \\
\text { centro } \\
M d r\end{array}$ & $\begin{array}{c}256 \mathrm{c} / 8^{*} \\
\text { borda } \\
M d r\end{array}$ & $\begin{array}{c}256 \mathrm{c} / 8^{*} \\
\text { borda } \\
M d r\end{array}$ & $\begin{array}{c}256 \mathrm{c} / 8^{*} \\
\text { borda } \\
M d r\end{array}$ & $\begin{array}{c}256 \mathrm{c} / 8^{*} \\
\text { borda } \\
M d r\end{array}$ & $\begin{array}{c}256 \mathrm{c} / 8^{*} \\
\text { centro } \\
M d r\end{array}$ & $\begin{array}{c}256 \mathrm{c} / 8^{*} \\
\text { centro } \\
M d r\end{array}$ & $\begin{array}{c}256 \mathrm{c} / 9^{*} \\
\text { borda } \\
M d r\end{array}$ & $\begin{array}{c}256 \mathrm{c} / 9^{*} \\
\text { borda } \\
M d r\end{array}$ & $\begin{array}{c}256 \mathrm{c} / 9 * \\
\text { centro } \\
M d r\end{array}$ & $\begin{array}{c}256 \mathrm{c} / 9 * \\
\text { interm } \\
M d r\end{array}$ & $\begin{array}{c}257 / 11^{*} \\
\text { borda } \\
M d r \\
\end{array}$ \\
\hline $\mathrm{SiO}_{2}$ & 61.15 & 61.15 & 59.17 & 61.17 & 54.93 & 53.87 & 57.04 & 56.99 & 54.40 & 55.36 & 59.91 & 61.36 & 54.53 & 54.58 & 59.52 \\
\hline $\mathrm{TiO}_{2}$ & 0.00 & 0.00 & 0.03 & 0.00 & 0.00 & 0.05 & 0.05 & 0.01 & 0.00 & 0.00 & 0.00 & 0.00 & 0.08 & 0.00 & 0.00 \\
\hline $\mathrm{Al}_{2} \mathrm{O}_{3}$ & 24.79 & 24.66 & 26.39 & 24.87 & 29.05 & 29.44 & 27.06 & 27.17 & 28.79 & 28.69 & 25.74 & 24.78 & 28.80 & 29.23 & 26.35 \\
\hline $\mathrm{Fe}_{2} \mathrm{O}_{3}$ & 0.22 & 0.14 & 0.10 & 0.06 & 0.00 & 0.26 & 0.09 & 0.18 & 0.10 & 0.15 & 0.16 & 0.11 & 0.17 & 0.09 & 0.35 \\
\hline $\mathrm{MnO}$ & 0.01 & 0.02 & 0.00 & 0.00 & 0.00 & 0.00 & 0.00 & 0.00 & 0.01 & 0.00 & 0.02 & 0.00 & 0.00 & 0.01 & 0.01 \\
\hline $\mathrm{MgO}$ & 0.00 & 0.00 & 0.00 & 0.01 & 0.01 & 0.01 & 0.00 & 0.01 & 0.01 & 0.00 & 0.01 & 0.00 & 0.00 & 0.00 & 0.07 \\
\hline $\mathrm{BaO}$ & 0.00 & 0.04 & 0.17 & 0.06 & 0.22 & 0.10 & 0.09 & 0.12 & 0.23 & 0.14 & 0.07 & 0.05 & 0.00 & 0.02 & 0.13 \\
\hline $\mathrm{CaO}$ & 5.35 & 5.55 & 7.66 & 5.29 & 10.97 & 11.23 & 7.80 & 8.20 & 10.02 & 10.13 & 6.78 & 5.57 & 9.82 & 10.82 & 6.82 \\
\hline $\mathrm{Na}_{2} \mathrm{O}$ & 8.61 & 8.66 & 7.22 & 8.38 & 5.36 & 5.43 & 6.91 & 6.62 & 5.57 & 5.94 & 7.94 & 8.26 & 6.01 & 5.81 & 7.55 \\
\hline $\mathrm{K}_{2} \mathrm{O}$ & 0.14 & 0.18 & 0.20 & 0.12 & 0.14 & 0.11 & 0.31 & 0.23 & 0.38 & 0.19 & 0.08 & 0.27 & 0.06 & 0.06 & 0.11 \\
\hline Total & 100.26 & 100.40 & 100.93 & 99.96 & 100.69 & 100.50 & 99.35 & 99.53 & 99.49 & 100.60 & 100.69 & 100.40 & 99.47 & 100.62 & 100.91 \\
\hline
\end{tabular}

Fórmula estrutural calculada na base de 32 oxigênios

\begin{tabular}{|c|c|c|c|c|c|c|c|c|c|c|c|c|c|c|c|}
\hline $\mathrm{Si}$ & 10.838 & 10.837 & 10.486 & 10.857 & 9.855 & 9.708 & 10.29 & 10.265 & 9.875 & 9.929 & 10.617 & 10.858 & 9.876 & 9.8 & 10.529 \\
\hline $\mathrm{Al}$ & 5.173 & 5.147 & 5.509 & 5.198 & 6.138 & 6.247 & 5.748 & 5.764 & 6.153 & 6.06 & 5.372 & 5.165 & 6.142 & 6.18 & 5.49 \\
\hline $\mathrm{Fe}^{3+}$ & 0.029 & 0.018 & 0.013 & 0.008 & 0 & 0.035 & 0.012 & 0.024 & 0.013 & 0.02 & 0.021 & 0.014 & 0.024 & 0.013 & 0.047 \\
\hline $\mathrm{Ti}$ & 0 & 0 & 0.004 & 0 & 0 & 0.007 & 0.007 & 0.002 & 0 & 0 & 0 & 0 & 0.011 & 0 & 0 \\
\hline $\mathrm{Mn}$ & 0.001 & 0.003 & 0 & 0 & 0 & 0 & 0 & 0 & 0.001 & 0.001 & 0.003 & 0 & 0 & 0.001 & 0.001 \\
\hline $\mathrm{Mg}$ & 0 & 0.001 & 0 & 0.003 & 0.002 & 0.002 & 0 & 0.002 & 0.003 & 0 & 0.002 & 0.001 & 0.001 & 0 & 0.019 \\
\hline $\mathrm{Ba}$ & 0 & 0.003 & 0.012 & 0.004 & 0.015 & 0.007 & 0.006 & 0.009 & 0.016 & 0.01 & 0.005 & 0.004 & 0 & 0.001 & 0.009 \\
\hline $\mathrm{Ca}$ & 1.016 & 1.054 & 1.454 & 1.005 & 2.108 & 2.169 & 1.507 & 1.582 & 1.948 & 1.947 & 1.286 & 1.057 & 1.906 & 2.081 & 1.292 \\
\hline $\mathrm{Na}$ & 2.957 & 2.978 & 2.481 & 2.885 & 1.865 & 1.897 & 2.417 & 2.312 & 1.961 & 2.066 & 2.727 & 2.834 & 2.111 & 2.021 & 2.591 \\
\hline $\mathrm{K}$ & 0.031 & 0.04 & 0.045 & 0.027 & 0.032 & 0.024 & 0.071 & 0.053 & 0.087 & 0.043 & 0.019 & 0.06 & 0.014 & 0.014 & 0.025 \\
\hline$\Sigma_{\mathrm{T}}$ & 16.04 & 16.002 & 16.012 & 16.063 & 15.993 & 15.997 & 16.057 & 16.055 & 16.041 & 16.009 & 16.01 & 16.037 & 16.053 & 15.993 & 16.066 \\
\hline$\underline{\Sigma_{M}}$ & 4.005 & 4.079 & 3.992 & 3.924 & 4.022 & 4.099 & 4.001 & 3.958 & 4.016 & 4.067 & 4.042 & 3.956 & 4.032 & 4.118 & 3.937 \\
\hline$\Sigma$ cátions & 20.045 & 20.081 & 20.004 & 19.987 & 20.015 & 20.096 & 20.058 & 20.013 & 20.057 & 20.076 & 20.052 & 19.993 & 20.085 & 20.111 & 20.003 \\
\hline $\mathrm{Ab}$ & 73.9 & 73.1 & 62.3 & 73.7 & 46.6 & 46.4 & 60.5 & 58.6 & 49.1 & 50.9 & 67.6 & 71.7 & 52.4 & 49.1 & 66.3 \\
\hline An & 25.4 & 25.9 & 36.5 & 25.7 & 52.6 & 53 & 37.7 & 40.1 & 48.7 & 48 & 31.9 & 26.8 & 47.3 & 50.6 & 33.1 \\
\hline Or & 0.8 & 1 & 1.1 & 0.7 & 0.8 & 0.6 & 1.8 & 1.3 & 2.2 & 1.1 & 0.5 & 1.5 & 0.3 & 0.3 & 0.6 \\
\hline
\end{tabular}

Análises com (*) foram obtidas no presente trabalho, sendo as demais do banco de dados do orientador 
Tabela A03. Continuação. Composição química, em percentagem de peso, para plagioclásios das rochas do Plúton Piracaia.

\begin{tabular}{|c|c|c|c|c|c|c|c|c|c|c|c|c|c|c|c|}
\hline $\begin{array}{c}\text { Amostra / cristal } \\
\text { Posição } \\
\text { Unidade } \\
\end{array}$ & $\begin{array}{c}257 / 11 * \\
\text { centro } \\
M d r\end{array}$ & $\begin{array}{c}257 / 11^{*} \\
\text { interm } \\
M d r\end{array}$ & $\begin{array}{c}257 / 12 * \\
\text { borda } \\
M d r \\
\end{array}$ & $\begin{array}{c}257 / 12^{*} \\
\text { borda } \\
M d r \\
\end{array}$ & $\begin{array}{c}257 / 12^{*} \\
\text { centro } \\
M d r \\
\end{array}$ & $\begin{array}{c}257 / 12^{*} \\
\text { centro } \\
M d r \\
\end{array}$ & $\begin{array}{c}257 / 12^{*} \\
\text { centro } \\
M d r \\
\end{array}$ & $\begin{array}{c}257 / 12^{*} \\
\text { interm } \\
M d r\end{array}$ & $\begin{array}{c}257 / 12 * \\
\text { interm } \\
M d r\end{array}$ & $\begin{array}{c}257 / 12 * \\
\text { superior } \\
M d r\end{array}$ & $\begin{array}{c}257 / 12 * \\
\text { superior } \\
M d r\end{array}$ & $\begin{array}{c}257 / 12^{*} \\
\text { superior } \\
M d r\end{array}$ & $\begin{array}{c}257 / 8 \_2 * \\
\text { centro } \\
M d r \\
\end{array}$ & $\begin{array}{c}257 / 8 \_2 * \\
\text { borda } \\
M d r \\
\end{array}$ & $\begin{array}{c}257 / 8 \_2 * \\
\text { interm } \\
M d r\end{array}$ \\
\hline $\mathrm{SiO}_{2}$ & 55.60 & 54.73 & 55.09 & 55.93 & 54.48 & 54.58 & 54.53 & 55.21 & 55.29 & 53.64 & 54.86 & 54.73 & 55.16 & 59.85 & 56.26 \\
\hline $\mathrm{TiO}_{2}$ & 0.08 & 0.05 & 0.00 & 0.00 & 0.00 & 0.04 & 0.01 & 0.05 & 0.03 & 0.03 & 0.04 & 0.04 & 0.07 & 0.00 & 0.04 \\
\hline $\mathrm{Al}_{2} \mathrm{O}_{3}$ & 28.83 & 29.17 & 29.19 & 28.45 & 27.97 & 29.55 & 29.37 & 28.65 & 29.04 & 28.24 & 28.76 & 28.37 & 29.05 & 20.47 & 27.35 \\
\hline $\mathrm{Fe}_{2} \mathrm{O}_{3}$ & 0.55 & 0.16 & 0.20 & 0.09 & 0.27 & 0.08 & 0.08 & 0.40 & 0.55 & 0.02 & 0.09 & 0.19 & 0.17 & 0.04 & 0.29 \\
\hline $\mathrm{MnO}$ & 0.00 & 0.00 & 0.00 & 0.00 & 0.02 & 0.00 & 0.01 & 0.00 & 0.00 & 0.00 & 0.00 & 0.00 & 0.02 & 0.00 & 0.03 \\
\hline $\mathrm{MgO}$ & 0.00 & 0.01 & 0.00 & 0.00 & 0.06 & 0.01 & 0.00 & 0.00 & 0.01 & 0.00 & 0.00 & 0.01 & 0.01 & 0.00 & 0.12 \\
\hline $\mathrm{BaO}$ & 0.07 & 0.11 & 0.04 & 0.08 & 0.12 & 0.06 & 0.03 & 0.18 & 0.20 & 0.09 & 0.09 & 0.06 & 0.16 & 6.01 & 0.16 \\
\hline $\mathrm{CaO}$ & 10.46 & 10.47 & 10.62 & 9.53 & 9.77 & 10.88 & 10.83 & 10.44 & 10.55 & 10.24 & 10.40 & 10.30 & 10.40 & 0.07 & 8.41 \\
\hline $\mathrm{Na}_{2} \mathrm{O}$ & 6.00 & 5.72 & 5.74 & 6.21 & 5.92 & 5.74 & 5.54 & 5.62 & 6.00 & 5.47 & 5.79 & 5.67 & 5.76 & 1.29 & 6.17 \\
\hline $\mathrm{K}_{2} \mathrm{O}$ & 0.13 & 0.20 & 0.12 & 0.15 & 0.14 & 0.06 & 0.04 & 0.18 & 0.13 & 0.14 & 0.11 & 0.11 & 0.16 & 13.00 & 0.22 \\
\hline Total & 101.72 & 100.61 & 100.99 & 100.44 & 98.74 & 101.00 & 100.44 & 100.74 & 101.80 & 97.86 & 100.13 & 99.47 & 100.94 & 100.72 & 99.05 \\
\hline \multicolumn{16}{|c|}{ Fórmula estrutural calculada na base de 32 oxigênios } \\
\hline $\mathrm{Si}$ & 9.882 & 9.826 & 9.846 & 10.019 & 9.953 & 9.765 & 9.796 & 9.902 & 9.835 & 9.883 & 9.886 & 9.922 & 9.868 & 11.407 & 10.191 \\
\hline $\mathrm{Al}$ & 6.033 & 6.167 & 6.143 & 6.003 & 6.017 & 6.226 & 6.213 & 6.05 & 6.084 & 6.128 & 6.102 & 6.056 & 6.119 & 4.594 & 5.833 \\
\hline $\mathrm{Fe}^{3+}$ & 0.073 & 0.021 & 0.027 & 0.012 & 0.037 & 0.011 & 0.011 & 0.054 & 0.073 & 0.002 & 0.012 & 0.025 & 0.023 & 0.005 & 0.04 \\
\hline $\mathrm{Ti}$ & 0.011 & 0.007 & 0 & 0 & 0 & 0.005 & 0.002 & 0.007 & 0.003 & 0.004 & 0.005 & 0.005 & 0.009 & 0 & 0.005 \\
\hline Mn & 0.001 & 0 & 0 & 0 & 0.002 & 0 & 0.002 & 0 & 0 & 0 & 0 & 0 & 0.002 & 0 & 0.005 \\
\hline $\mathrm{Mg}$ & 0 & 0.002 & 0 & 0 & 0.017 & 0.002 & 0.001 & 0 & 0.004 & 0 & 0 & 0.003 & 0.002 & 0 & 0.032 \\
\hline $\mathrm{Ba}$ & 0.005 & 0.008 & 0.003 & 0.005 & 0.008 & 0.004 & 0.002 & 0.013 & 0.014 & 0.006 & 0.006 & 0.004 & 0.011 & 0.449 & 0.012 \\
\hline $\mathrm{Ca}$ & 1.992 & 2.013 & 2.033 & 1.829 & 1.912 & 2.085 & 2.085 & 2.006 & 2.012 & 2.022 & 2.008 & 1.999 & 1.993 & 0.015 & 1.631 \\
\hline $\mathrm{Na}$ & 2.068 & 1.991 & 1.988 & 2.158 & 2.097 & 1.991 & 1.93 & 1.954 & 2.068 & 1.956 & 2.022 & 1.991 & 1.996 & 0.475 & 2.167 \\
\hline K & 0.029 & 0.045 & 0.028 & 0.035 & 0.033 & 0.015 & 0.008 & 0.042 & 0.029 & 0.033 & 0.025 & 0.026 & 0.035 & 3.16 & 0.051 \\
\hline$\Sigma_{\mathrm{T}}$ & 15.999 & 16.021 & 16.016 & 16.034 & 16.007 & 16.007 & 16.022 & 16.013 & 15.995 & 16.017 & 16.005 & 16.008 & 16.019 & 16.006 & 16.069 \\
\hline$\Sigma_{\mathrm{M}}$ & 4.095 & 4.059 & 4.052 & 4.027 & 4.069 & 4.097 & 4.028 & 4.015 & 4.127 & 4.017 & 4.061 & 4.023 & 4.039 & 4.099 & 3.898 \\
\hline$\Sigma$ cátions & 20.094 & 20.08 & 20.068 & 20.061 & 20.076 & 20.104 & 20.05 & 20.028 & 20.122 & 20.034 & 20.066 & 20.031 & 20.058 & 20.105 & 19.967 \\
\hline $\mathrm{Ab}$ & 50.6 & 49.2 & 49.1 & 53.7 & 51.9 & 48.7 & 48 & 48.8 & 50.3 & 48.8 & 49.9 & 49.6 & 49.6 & 13 & 56.3 \\
\hline An & 48.7 & 49.7 & 50.2 & 45.5 & 47.3 & 51 & 51.8 & 50.1 & 49 & 50.4 & 49.5 & 49.8 & 49.5 & 0.4 & 42.4 \\
\hline Or & 0.7 & 1.1 & 0.7 & 0.9 & 0.8 & 0.4 & 0.2 & 1 & 0.7 & 0.8 & 0.6 & 0.6 & 0.9 & 86.6 & 1.3 \\
\hline
\end{tabular}

Análises com (*) foram obtidas no presente trabalho, sendo as demais do banco de dados do orientador 
Tabela A03. Continuação. Composição química, em percentagem de peso, para plagioclásios das rochas do Plúton Piracaia.

\begin{tabular}{|c|c|c|c|c|c|c|c|c|c|c|c|c|c|c|c|c|}
\hline $\begin{array}{c}\text { Amostra / cristal } \\
\text { Posição } \\
\text { Unidade } \\
\end{array}$ & $\begin{array}{c}5 \mathrm{c} / 13^{*} \\
\text { borda } \\
M d f \\
\end{array}$ & $\begin{array}{c}5 \mathrm{c} / 13^{*} \\
\text { centro } \\
M d f \\
\end{array}$ & $\begin{array}{c}\mathrm{c} / 13^{*} \\
\text { centro } \\
M d f \\
\end{array}$ & $\begin{array}{c}\mathrm{c} / 16^{*} \\
\text { borda } \\
M d f\end{array}$ & $\begin{array}{c}\mathrm{c} / 16^{*} \\
\text { borda } \\
M d f \\
\end{array}$ & $\begin{array}{c}\mathrm{c} / 16^{*} \\
\text { borda } \\
M d f \\
\end{array}$ & $\begin{array}{c}\mathrm{c} / 16^{*} \\
\text { centro } \\
M d f \\
\end{array}$ & $\begin{array}{c}\mathrm{c} / 16^{*} \\
\text { centro } \\
M d f\end{array}$ & $75 \mathrm{c} / 8 *$ & $75 \mathrm{c} / 8^{*}$ & $75 \mathrm{c} / 9^{*}$ & $\begin{array}{c}75 \mathrm{c} / 9 \\
M d f\end{array}$ & $\begin{array}{c}75 \mathrm{c} / 10^{*} \\
\text { borda } \\
M d f \\
\end{array}$ & $\begin{array}{c}75 \mathrm{c} / 10^{*} \\
\text { borda } \\
M d f\end{array}$ & $\begin{array}{c}75 \mathrm{c} / 10^{*} \\
\text { borda } \\
M d f\end{array}$ & $\begin{array}{c}75 \mathrm{c} / 10^{*} \\
\text { centro } \\
M d f \\
\end{array}$ \\
\hline $\mathrm{SiO}_{2}$ & 61.62 & 61.01 & 59.67 & 65.00 & 64.36 & 62.62 & 61.89 & 63.26 & 61.18 & 62.02 & 62.07 & 61.52 & 58.00 & 64.05 & 63.00 & 55.55 \\
\hline $\mathrm{TiO}_{2}$ & 0.04 & 0.00 & 0.00 & 0.00 & 0.00 & 0.00 & 0.00 & 0.00 & 0.09 & 0.00 & 0.00 & 0.00 & 0.00 & 0.00 & 0.07 & 0.08 \\
\hline $\mathrm{Al}_{2} \mathrm{O}_{3}$ & 23.66 & 24.12 & 24.88 & 19.61 & 19.19 & 23.95 & 23.56 & 23.55 & 24.17 & 23.85 & 23.73 & 24.11 & 26.97 & 19.56 & 19.48 & 27.53 \\
\hline $\mathrm{Fe}_{2} \mathrm{O}_{3}$ & 0.24 & 0.16 & 0.30 & 0.22 & 0.06 & 0.15 & 0.07 & 0.17 & 0.12 & 0.15 & 0.18 & 0.16 & 0.03 & 0.08 & 0.03 & 0.04 \\
\hline $\mathrm{MnO}$ & 0.00 & 0.02 & 0.01 & 0.00 & 0.00 & 0.00 & 0.00 & 0.00 & 0.00 & 0.00 & 0.00 & 0.03 & 0.01 & 0.02 & 0.00 & 0.00 \\
\hline $\mathrm{MgO}$ & 0.00 & 0.00 & 0.00 & 0.00 & 0.01 & 0.00 & 0.00 & 0.00 & 0.01 & 0.00 & 0.00 & 0.01 & 0.00 & 0.00 & 0.00 & 0.00 \\
\hline $\mathrm{BaO}$ & 0.00 & 0.00 & 0.05 & 2.60 & 2.50 & 0.05 & 0.00 & 0.05 & 0.00 & 0.02 & 0.06 & 0.03 & 0.00 & 0.86 & 1.21 & 0.15 \\
\hline $\mathrm{CaO}$ & 4.81 & 5.45 & 6.37 & 0.12 & 0.01 & 4.93 & 6.07 & 4.55 & 4.83 & 5.08 & 4.65 & 4.92 & 8.10 & 0.75 & 0.30 & 8.80 \\
\hline $\mathrm{Na}_{2} \mathrm{O}$ & 8.60 & 8.29 & 7.93 & 4.49 & 1.05 & 8.74 & 8.51 & 9.07 & 8.94 & 8.86 & 9.09 & 8.88 & 7.33 & 2.90 & 2.13 & 6.65 \\
\hline $\mathrm{K}_{2} \mathrm{O}$ & 0.15 & 0.15 & 0.07 & 9.89 & 14.65 & 0.14 & 0.09 & 0.13 & 0.16 & 0.11 & 0.22 & 0.15 & 0.14 & 12.57 & 13.14 & 0.15 \\
\hline Total & 99.12 & 99.19 & 99.28 & 101.93 & 101.82 & 100.58 & 100.20 & 100.77 & 99.49 & 100.09 & 99.99 & 99.81 & 100.57 & 100.80 & 99.34 & 98.95 \\
\hline
\end{tabular}

Fórmula estrutural calculada na base de 32 oxigênios

\begin{tabular}{|c|c|c|c|c|c|c|c|c|c|c|c|c|c|c|c|c|}
\hline $\mathrm{Si}$ & 11.016 & 10.917 & 10.711 & 11.769 & 11.831 & 11.033 & 10.982 & 11.115 & 10.917 & 10.995 & 11.02 & 10.944 & 10.334 & 11.728 & 11.734 & 10.101 \\
\hline $\mathrm{Al}$ & 4.982 & 5.083 & 5.26 & 4.182 & 4.154 & 4.969 & 4.923 & 4.873 & 5.08 & 4.98 & 4.961 & 5.051 & 5.659 & 4.217 & 4.272 & 5.896 \\
\hline $\mathrm{Fe}^{3+}$ & 0.032 & 0.022 & 0.04 & 0.029 & 0.008 & 0.02 & 0.009 & 0.023 & 0.017 & 0.021 & 0.024 & 0.021 & 0.003 & 0.01 & 0.005 & 0.005 \\
\hline $\mathrm{Ti}$ & 0.005 & 0 & 0 & 0 & 0 & 0 & 0 & 0 & 0.013 & 0 & 0 & 0 & 0 & 0 & 0.009 & 0.011 \\
\hline $\mathrm{Mn}$ & 0.001 & 0.003 & 0.002 & 0 & 0 & 0 & 0 & 0 & 0 & 0 & 0 & 0.005 & 0.002 & 0.004 & 0 & 0 \\
\hline $\mathrm{Mg}$ & 0.001 & 0 & 0 & 0 & 0.002 & 0.001 & 0 & 0.001 & 0.001 & 0 & 0 & 0.003 & 0 & 0.001 & 0 & 0 \\
\hline $\mathrm{Ba}$ & 0 & 0 & 0.003 & 0.184 & 0.18 & 0.004 & 0 & 0.003 & 0 & 0.002 & 0.004 & 0.002 & 0 & 0.062 & 0.088 & 0.011 \\
\hline $\mathrm{Ca}$ & 0.921 & 1.044 & 1.226 & 0.024 & 0.002 & 0.931 & 1.155 & 0.857 & 0.923 & 0.964 & 0.884 & 0.938 & 1.546 & 0.147 & 0.06 & 1.714 \\
\hline $\mathrm{Na}$ & 2.981 & 2.877 & 2.76 & 1.577 & 0.373 & 2.985 & 2.929 & 3.089 & 3.092 & 3.045 & 3.128 & 3.064 & 2.532 & 1.031 & 0.768 & 2.345 \\
\hline $\mathrm{K}$ & 0.033 & 0.033 & 0.016 & 2.285 & 3.436 & 0.031 & 0.019 & 0.028 & 0.036 & 0.026 & 0.049 & 0.034 & 0.031 & 2.937 & 3.121 & 0.035 \\
\hline$\Sigma_{\mathrm{T}}$ & 16.035 & 16.022 & 16.011 & 15.98 & 15.993 & 16.022 & 15.914 & 16.011 & 16.027 & 15.996 & 16.005 & 16.016 & 15.996 & 15.955 & 16.02 & 16.013 \\
\hline$\underline{\Sigma_{M}}$ & 3.937 & 3.957 & 4.007 & 4.07 & 3.993 & 3.952 & 4.103 & 3.978 & 4.052 & 4.037 & 4.065 & 4.046 & 4.111 & 4.182 & 4.037 & 4.105 \\
\hline$\sum$ cátions & 19.972 & 19.979 & 20.018 & 20.05 & 19.986 & 19.974 & 20.017 & 19.989 & 20.079 & 20.033 & 20.07 & 20.062 & 20.107 & 20.137 & 20.057 & 20.118 \\
\hline $\mathrm{Ab}$ & 75.8 & 72.8 & 69 & 40.6 & 9.8 & 75.6 & 71.4 & 77.7 & 76.3 & 75.5 & 77 & 75.9 & 61.6 & 25.1 & 19.4 & 57.3 \\
\hline An & 23.4 & 26.4 & 30.6 & 0.6 & 0.1 & 23.6 & 28.2 & 21.6 & 22.8 & 23.9 & 21.8 & 23.2 & 37.6 & 3.6 & 1.5 & 41.9 \\
\hline Or & 0.8 & 0.8 & 0.4 & 58.8 & 90.2 & 0.8 & 0.5 & 0.7 & 0.9 & 0.6 & 1.2 & 0.8 & 0.8 & 71.4 & 79 & 0.9 \\
\hline
\end{tabular}

Análises com (*) foram obtidas no presente trabalho, sendo as demais do banco de dados do orientador 
Tabela A03. Continuação. Composição química, em percentagem de peso, para plagioclásios das rochas do Plúton Piracaia.

\begin{tabular}{|c|c|c|c|c|c|c|c|c|c|c|c|c|c|c|}
\hline $\begin{array}{c}\text { Amostra / cristal } \\
\text { Posição } \\
\text { Unidade } \\
\end{array}$ & $\begin{array}{c}75 \mathrm{c} / 10^{*} \\
\text { interm } \\
M d f \\
\end{array}$ & $\begin{array}{c}500-7 / 6^{*} \\
\text { borda } \\
M d f \\
\end{array}$ & $\begin{array}{c}500-7 / 6^{*} \\
\text { centro } \\
M d f \\
\end{array}$ & $\begin{array}{c}500-7 / 7^{*} \\
\text { borda } \\
M d f \\
\end{array}$ & $\begin{array}{c}500-7 / 7^{*} \\
\text { centro } \\
M d f \\
\end{array}$ & $\begin{array}{c}358 \mathrm{c} / 3 * \\
\text { centro } \\
M d f\end{array}$ & $\begin{array}{c}358 \mathrm{c} / 3^{*} \\
\text { centro } \\
M d f \\
\end{array}$ & $\begin{array}{c}358 \mathrm{c} / 14^{*} \\
\text { borda } \\
M d f \\
\end{array}$ & $\begin{array}{c}358 \mathrm{c} / 10^{*} \\
\text { borda } \\
M d f \\
\end{array}$ & $\begin{array}{c}358 \mathrm{c} / 10^{*} \\
\text { borda } \\
M d f \\
\end{array}$ & $\begin{array}{c}358 \mathrm{c} / 10 * \\
\text { centro } \\
M d f \\
\end{array}$ & $\begin{array}{c}358 \mathrm{c} / 10^{*} \\
\text { centro } \\
M d f \\
\end{array}$ & $358 \mathrm{c} / 11 *$ & $358 \mathrm{c} / 11 *$ \\
\hline $\mathrm{SiO}_{2}$ & 57.60 & 62.80 & 63.56 & 62.86 & 63.03 & 65.11 & 65.24 & 64.42 & 65.24 & 62.37 & 60.40 & 62.38 & 63.57 & 62.95 \\
\hline $\mathrm{TiO}_{2}$ & 0.05 & 0.04 & 0.03 & 0.15 & 0.08 & 0.08 & 0.03 & 0.01 & 0.05 & 0.00 & 0.04 & 0.01 & 0.07 & 0.04 \\
\hline $\mathrm{Al}_{2} \mathrm{O}_{3}$ & 26.74 & 22.65 & 22.48 & 22.76 & 22.70 & 22.51 & 21.90 & 23.39 & 22.83 & 24.05 & 25.83 & 24.75 & 23.83 & 23.76 \\
\hline $\mathrm{Fe}_{2} \mathrm{O}_{3}$ & 0.09 & 0.09 & 0.06 & 0.08 & 0.00 & 0.00 & 0.16 & 0.19 & 0.05 & 0.00 & 0.02 & 0.00 & 0.12 & 0.04 \\
\hline $\mathrm{MnO}$ & 0.00 & 0.00 & 0.00 & 0.00 & 0.01 & 0.00 & 0.01 & 0.00 & 0.00 & 0.02 & 0.01 & 0.01 & 0.00 & 0.00 \\
\hline $\mathrm{MgO}$ & 0.00 & 0.00 & 0.01 & 0.00 & 0.00 & 0.00 & 0.01 & 0.01 & 0.00 & 0.01 & 0.00 & 0.00 & 0.00 & 0.01 \\
\hline $\mathrm{BaO}$ & 0.08 & 0.02 & 0.01 & 0.04 & 0.08 & 0.04 & 0.00 & 0.00 & 0.08 & 0.00 & 0.05 & 0.00 & 0.00 & 0.00 \\
\hline $\mathrm{CaO}$ & 7.66 & 4.10 & 3.90 & 4.07 & 4.18 & 2.78 & 2.33 & 4.59 & 3.36 & 4.89 & 7.06 & 5.77 & 4.60 & 5.03 \\
\hline $\mathrm{Na}_{2} \mathrm{O}$ & 7.07 & 9.14 & 9.58 & 8.94 & 9.06 & 10.30 & 10.66 & 9.08 & 9.83 & 8.74 & 7.41 & 8.22 & 8.97 & 8.58 \\
\hline $\mathrm{K}_{2} \mathrm{O}$ & 0.22 & 0.12 & 0.09 & 0.10 & 0.07 & 0.11 & 0.12 & 0.16 & 0.06 & 0.19 & 0.18 & 0.13 & 0.13 & 0.18 \\
\hline Total & 99.51 & 98.96 & 99.71 & 98.98 & 99.21 & 100.92 & 100.44 & 101.84 & 101.50 & 100.28 & 100.99 & 101.28 & 101.29 & 100.59 \\
\hline
\end{tabular}

Fórmula estrutural calculada na base de 32 oxigênios

\begin{tabular}{|c|c|c|c|c|c|c|c|c|c|c|c|c|c|c|}
\hline $\mathrm{Si}$ & 10.361 & 11.217 & 11.267 & 11.214 & 11.227 & 11.374 & 11.449 & 11.187 & 11.335 & 11.018 & 10.652 & 10.92 & 11.103 & 11.076 \\
\hline $\mathrm{Al}$ & 5.665 & 4.765 & 4.693 & 4.781 & 4.761 & 4.63 & 4.527 & 4.785 & 4.672 & 5.003 & 5.365 & 5.103 & 4.901 & 4.925 \\
\hline $\mathrm{Fe}^{3+}$ & 0.012 & 0.012 & 0.008 & 0.011 & 0 & 0 & 0.021 & 0.025 & 0.007 & 0 & 0.003 & 0 & 0.016 & 0.005 \\
\hline $\mathrm{Ti}$ & 0.007 & 0.005 & 0.003 & 0.02 & 0.011 & 0.01 & 0.003 & 0.002 & 0.007 & 0 & 0.005 & 0.002 & 0.009 & 0.005 \\
\hline $\mathrm{Mn}$ & 0 & 0 & 0 & 0 & 0.001 & 0 & 0.001 & 0 & 0 & 0.003 & 0.001 & 0.001 & 0 & 0.001 \\
\hline $\mathrm{Mg}$ & 0 & 0.001 & 0.002 & 0 & 0 & 0 & 0.002 & 0.001 & 0 & 0.004 & 0.001 & 0.001 & 0 & 0.002 \\
\hline $\mathrm{Ba}$ & 0.006 & 0.001 & 0.001 & 0.002 & 0.006 & 0.003 & 0 & 0 & 0.005 & 0 & 0.003 & 0 & 0 & 0 \\
\hline $\mathrm{Ca}$ & 1.476 & 0.784 & 0.741 & 0.778 & 0.797 & 0.521 & 0.438 & 0.853 & 0.625 & 0.926 & 1.333 & 1.083 & 0.861 & 0.949 \\
\hline $\mathrm{Na}$ & 2.466 & 3.164 & 3.292 & 3.091 & 3.129 & 3.487 & 3.627 & 3.057 & 3.31 & 2.995 & 2.533 & 2.791 & 3.037 & 2.928 \\
\hline $\mathrm{K}$ & 0.05 & 0.027 & 0.02 & 0.023 & 0.017 & 0.024 & 0.026 & 0.034 & 0.013 & 0.043 & 0.04 & 0.028 & 0.03 & 0.041 \\
\hline$\Sigma_{\mathrm{T}}$ & 16.045 & 15.999 & 15.971 & 16.026 & 15.999 & 16.014 & 16 & 15.999 & 16.021 & 16.021 & 16.025 & 16.025 & 16.029 & 16.011 \\
\hline$\Sigma_{\mathrm{M}}$ & 3.998 & 3.977 & 4.056 & 3.894 & 3.95 & 4.035 & 4.094 & 3.945 & 3.953 & 3.971 & 3.911 & 3.904 & 3.928 & 3.921 \\
\hline$\sum$ cátions & 20.043 & 19.976 & 20.027 & 19.92 & 19.949 & 20.049 & 20.094 & 19.944 & 19.974 & 19.992 & 19.936 & 19.929 & 19.957 & 19.932 \\
\hline $\mathrm{Ab}$ & 61.8 & 79.6 & 81.2 & 79.4 & 79.4 & 86.5 & 88.7 & 77.5 & 83.8 & 75.6 & 64.8 & 71.5 & 77.3 & 74.7 \\
\hline An & 37 & 19.7 & 18.3 & 20 & 20.2 & 12.9 & 10.7 & 21.6 & 15.8 & 23.4 & 34.1 & 27.8 & 21.9 & 24.2 \\
\hline Or & 1.3 & 0.7 & 0.5 & 0.6 & 0.4 & 0.6 & 0.6 & 0.9 & 0.3 & 1.1 & 1 & 0.7 & 0.8 & 1 \\
\hline
\end{tabular}

Análises com (*) foram obtidas no presente trabalho, sendo as demais do banco de dados do orientador 
Tabela A03. Continuação. Composição química, em percentagem de peso, para plagioclásios das rochas do Plúton Piracaia.

\begin{tabular}{|c|c|c|c|c|c|c|c|c|c|c|c|c|c|}
\hline $\begin{array}{c}\text { Amostra / cristal } \\
\text { Posição } \\
\text { Unidade } \\
\end{array}$ & $\begin{array}{c}358 \mathrm{c} / 14^{*} \\
\text { borda } \\
M d f\end{array}$ & $\begin{array}{c}358 \mathrm{c} / 14^{*} \\
\text { centro } \\
M d f\end{array}$ & $\begin{array}{c}358 \mathrm{c} / 14^{*} \\
\text { centro } \\
M d f \\
\end{array}$ & $\begin{array}{c}26 \mathrm{~b} / 10^{*} \\
\text { borda } \\
\text { Sie } \\
\end{array}$ & $\begin{array}{c}26 \mathrm{~b} / 10^{*} \\
\text { borda } \\
\text { Sie } \\
\end{array}$ & $\begin{array}{c}26 \mathrm{~b} / 10 * \\
\text { centro } \\
\text { Sie }\end{array}$ & $\begin{array}{c}26 \mathrm{~b} / 10^{*} \\
\text { centro } \\
\text { Sie } \\
\end{array}$ & $\begin{array}{c}26 \mathrm{~b} / 11^{*} \\
\text { borda } \\
\text { Sie }\end{array}$ & $\begin{array}{c}26 \mathrm{~b} / 11^{*} \\
\text { borda } \\
\mathrm{Sie}\end{array}$ & $\begin{array}{c}\text { 26b/11_1* } \\
\text { centro } \\
\text { Sie }\end{array}$ & $\begin{array}{c}26 \mathrm{~b} / 11_{-} 1^{*} \\
\text { centro } \\
\text { Sie }\end{array}$ & $\begin{array}{c}\text { 26b/11_2* } \\
\text { centro } \\
\text { Sie } \\
\end{array}$ & $\begin{array}{c}\text { 26b/11_2* } \\
\text { borda } \\
\text { Sie }\end{array}$ \\
\hline $\mathrm{TiO}_{2}$ & 0.05 & 0.00 & 0.04 & 0.00 & 0.00 & 0.00 & 0.00 & 0.00 & 0.00 & 0.09 & 0.05 & 0.06 & 0.00 \\
\hline $\mathrm{Al}_{2} \mathrm{O}_{3}$ & 22.79 & 24.07 & 23.95 & 19.94 & 19.90 & 20.54 & 20.83 & 21.26 & 20.40 & 21.39 & 21.26 & 21.24 & 20.11 \\
\hline $\mathrm{Fe}_{2} \mathrm{O}_{3}$ & 0.09 & 0.10 & 0.00 & 0.00 & 0.07 & 0.05 & 0.00 & 0.20 & 0.00 & 0.10 & 0.12 & 0.14 & 0.10 \\
\hline $\mathrm{MgO}$ & 0.00 & 0.00 & 0.00 & 0.00 & 0.00 & 0.00 & 0.00 & 0.00 & 0.01 & 0.00 & 0.00 & 0.00 & 0.00 \\
\hline $\mathrm{BaO}$ & 0.01 & 0.06 & 0.00 & 0.05 & 0.01 & 0.00 & 0.00 & 0.04 & 0.00 & 0.00 & 0.00 & 0.00 & 0.03 \\
\hline $\mathrm{CaO}$ & 3.55 & 4.81 & 4.79 & 0.55 & 0.67 & 1.70 & 1.74 & 2.18 & 1.31 & 2.06 & 2.14 & 2.25 & 0.98 \\
\hline $\mathrm{Na}_{2} \mathrm{O}$ & 9.52 & 8.56 & 8.70 & 11.42 & 11.21 & 10.88 & 10.54 & 10.33 & 10.95 & 10.24 & 10.37 & 10.37 & 11.02 \\
\hline $\mathrm{K}_{2} \mathrm{O}$ & 0.16 & 0.25 & 0.17 & 0.08 & 0.08 & 0.08 & 0.05 & 0.13 & 0.05 & 0.09 & 0.10 & 0.14 & 0.08 \\
\hline Total & 102.73 & 101.32 & 101.55 & 99.85 & 99.65 & 99.21 & 99.15 & 100.21 & 100.24 & 99.44 & 99.88 & 100.32 & 99.76 \\
\hline $\mathrm{Fe}^{3+}$ & 0.012 & 0.014 & 0 & 0 & 0.009 & 0.006 & 0 & 0.026 & 0 & 0.013 & 0.016 & 0.019 & 0.013 \\
\hline $\mathrm{Ti}$ & 0.007 & 0 & 0.005 & 0 & 0 & 0 & 0 & 0 & 0 & 0.012 & 0.007 & 0.007 & 0 \\
\hline $\mathrm{Mn}$ & 0 & 0 & 0 & 0 & 0 & 0.002 & 0 & 0 & 0 & 0.001 & 0 & 0.001 & 0 \\
\hline $\mathrm{Mg}$ & 0 & 0 & 0.001 & 0 & 0 & 0.001 & 0.001 & 0 & 0.003 & 0 & 0 & 0 & 0.001 \\
\hline $\mathrm{Ba}$ & 0.001 & 0.004 & 0 & 0.004 & 0.001 & 0 & 0 & 0.003 & 0 & 0 & 0 & 0 & 0.002 \\
\hline $\mathrm{Ca}$ & 0.651 & 0.899 & 0.892 & 0.104 & 0.125 & 0.323 & 0.33 & 0.411 & 0.245 & 0.389 & 0.404 & 0.423 & 0.185 \\
\hline $\mathrm{Na}$ & 3.165 & 2.897 & 2.935 & 3.879 & 3.815 & 3.735 & 3.615 & 3.512 & 3.708 & 3.507 & 3.537 & 3.522 & 3.748 \\
\hline $\mathrm{K}$ & 0.034 & 0.055 & 0.037 & 0.018 & 0.018 & 0.018 & 0.011 & 0.029 & 0.011 & 0.02 & 0.021 & 0.031 & 0.018 \\
\hline$\Sigma_{\mathrm{T}}$ & 16.024 & 16.048 & 16.034 & 15.998 & 16.006 & 15.968 & 16.009 & 16.009 & 15.992 & 16.035 & 16.01 & 15.997 & 16.004 \\
\hline$\underline{\Sigma_{M}}$ & 3.851 & 3.855 & 3.865 & 4.005 & 3.959 & 4.079 & 3.957 & 3.955 & 3.967 & 3.917 & 3.962 & 3.977 & 3.954 \\
\hline$\Sigma$ cátions & 19.875 & 19.903 & 19.899 & 20.003 & 19.965 & 20.047 & 19.966 & 19.964 & 19.959 & 19.952 & 19.972 & 19.974 & 19.958 \\
\hline
\end{tabular}

Análises com (*) foram obtidas no presente trabalho, sendo as demais do banco de dados do orientador 
Tabela A03. Continuação. Composição química, em percentagem de peso, para plagioclásios das rochas do Plúton Piracaia.

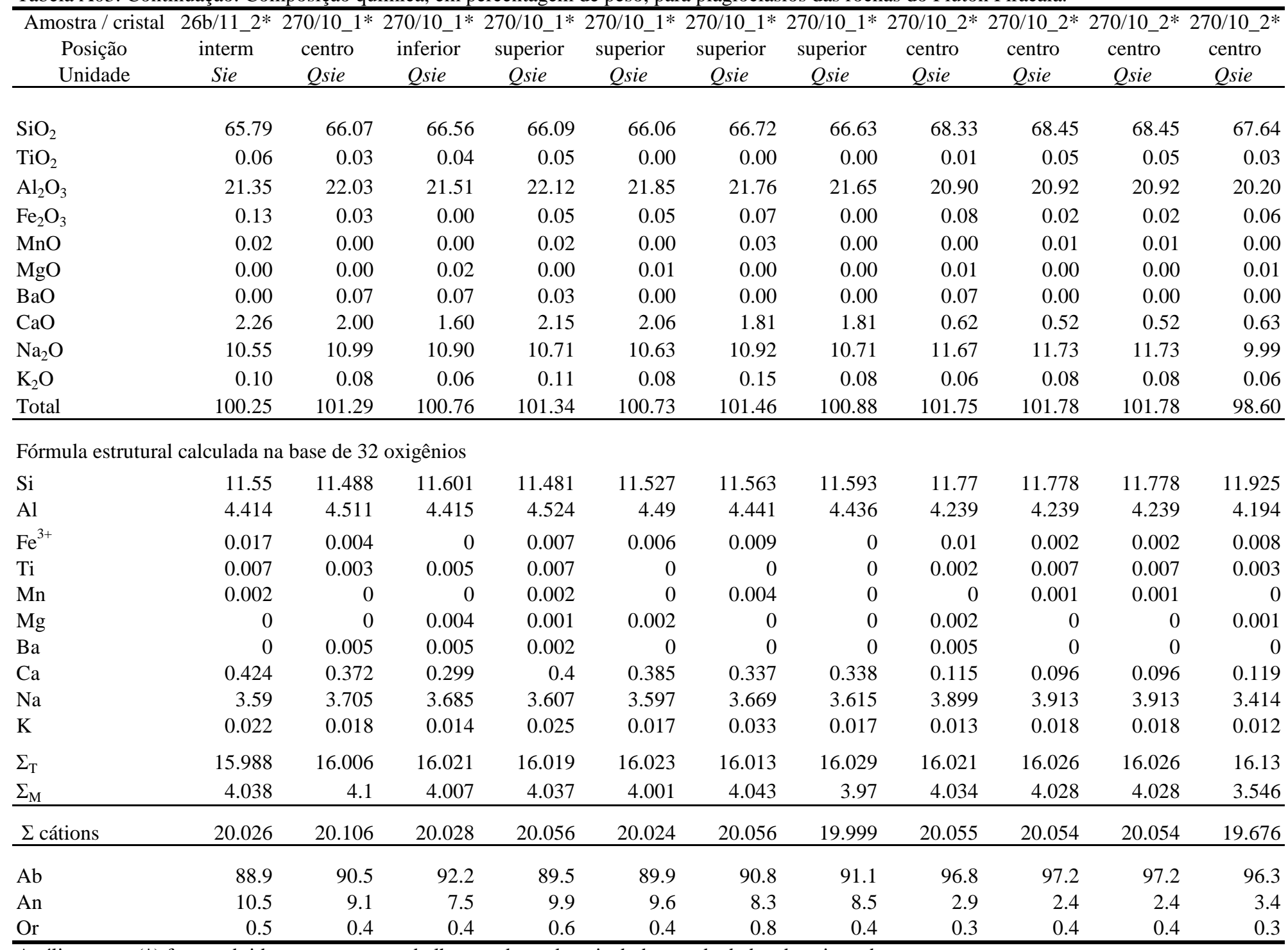

Análises com (*) foram obtidas no presente trabalho, sendo as demais do banco de dados do orientador 
Tabela A03. Continuação. Composição química, em percentagem de peso, para plagioclásios das rochas do Plúton Piracaia.

\begin{tabular}{|c|c|c|c|c|c|c|c|c|c|c|c|}
\hline $\begin{array}{c}\text { Amostra / cristal } \\
\text { Posição } \\
\text { Unidade } \\
\end{array}$ & $\begin{array}{c}\text { 270/10_2* } \\
\text { centro } \\
\text { Qsie }\end{array}$ & $\begin{array}{c}\text { 270/10_2* } \\
\text { inferior } \\
\text { Qsie }\end{array}$ & $\begin{array}{c}270 / 10 \_2 * \\
\text { superior } \\
\text { Qsie }\end{array}$ & $\begin{array}{c}\text { 270/10_2* } \\
\text { superior } \\
\text { Qsie }\end{array}$ & $\begin{array}{c}\text { 270/10_2* } \\
\text { superior } \\
\text { Qsie }\end{array}$ & $\begin{array}{c}\text { 270/10_2* } \\
\text { superior } \\
\text { Qsie }\end{array}$ & $\begin{array}{c}270 / 3^{*} \\
\text { borda } \\
\text { Qsie }\end{array}$ & $\begin{array}{c}270 / 3^{*} \\
\text { borda } \\
\text { Qsie } \\
\end{array}$ & $\begin{array}{c}270 / 3^{*} \\
\text { borda } \\
\text { Qsie }\end{array}$ & $\begin{array}{c}270 / 3^{*} \\
\text { borda } \\
\text { Qsie }\end{array}$ & $\begin{array}{c}270 / 3^{*} \\
\text { borda } \\
\text { Qsie }\end{array}$ \\
\hline $\mathrm{SiO}_{2}$ & 67.72 & 68.00 & 66.16 & 66.29 & 68.08 & 68.08 & 66.85 & 68.36 & 66.42 & 66.63 & 67.85 \\
\hline $\mathrm{TiO}_{2}$ & 0.01 & 0.00 & 0.00 & 0.05 & 0.00 & 0.00 & 0.03 & 0.04 & 0.00 & 0.07 & 0.01 \\
\hline $\mathrm{Al}_{2} \mathrm{O}_{3}$ & 20.14 & 20.57 & 20.69 & 20.87 & 20.81 & 20.81 & 21.78 & 20.95 & 21.58 & 21.54 & 21.00 \\
\hline $\mathrm{Fe}_{2} \mathrm{O}_{3}$ & 0.12 & 0.12 & 0.24 & 0.19 & 0.06 & 0.06 & 0.03 & 0.00 & 0.06 & 0.10 & 0.04 \\
\hline $\mathrm{MnO}$ & 0.00 & 0.02 & 0.00 & 0.00 & 0.00 & 0.00 & 0.00 & 0.00 & 0.00 & 0.00 & 0.00 \\
\hline $\mathrm{MgO}$ & 0.01 & 0.01 & 0.00 & 0.01 & 0.02 & 0.02 & 0.00 & 0.00 & 0.02 & 0.00 & 0.00 \\
\hline $\mathrm{BaO}$ & 0.01 & 0.00 & 0.05 & 0.00 & 0.00 & 0.00 & 0.00 & 0.00 & 0.00 & 0.03 & 0.01 \\
\hline $\mathrm{CaO}$ & 0.58 & 0.55 & 1.25 & 1.16 & 0.73 & 0.73 & 1.92 & 0.66 & 2.05 & 1.90 & 0.67 \\
\hline $\mathrm{Na}_{2} \mathrm{O}$ & 11.52 & 11.64 & 9.66 & 11.02 & 11.80 & 11.80 & 10.99 & 11.58 & 10.58 & 10.83 & 11.47 \\
\hline $\mathrm{K}_{2} \mathrm{O}$ & 0.09 & 0.13 & 0.09 & 0.12 & 0.06 & 0.06 & 0.08 & 0.11 & 0.09 & 0.05 & 0.06 \\
\hline Total & 100.21 & 101.04 & 98.14 & 99.69 & 101.55 & 101.55 & 101.67 & 101.69 & 100.80 & 101.15 & 101.11 \\
\hline \multicolumn{12}{|c|}{ Fórmula estrutural calculada na base de 32 oxigênios } \\
\hline $\mathrm{Si}$ & 11.837 & 11.794 & 11.764 & 11.669 & 11.756 & 11.756 & 11.56 & 11.771 & 11.577 & 11.579 & 11.751 \\
\hline $\mathrm{Al}$ & 4.145 & 4.201 & 4.333 & 4.327 & 4.232 & 4.232 & 4.436 & 4.249 & 4.43 & 4.408 & 4.282 \\
\hline $\mathrm{Fe}^{3+}$ & 0.016 & 0.016 & 0.033 & 0.025 & 0.008 & 0.008 & 0.003 & 0 & 0.007 & 0.013 & 0.005 \\
\hline $\mathrm{Ti}$ & 0.002 & 0 & 0 & 0.007 & 0 & 0 & 0.003 & 0.005 & 0 & 0.009 & 0.002 \\
\hline $\mathrm{Mn}$ & 0 & 0.002 & 0 & 0 & 0 & 0 & 0 & 0 & 0 & 0 & 0 \\
\hline $\mathrm{Mg}$ & 0.001 & 0.003 & 0 & 0.002 & 0.004 & 0.004 & 0 & 0.001 & 0.004 & 0 & 0 \\
\hline $\mathrm{Ba}$ & 0.001 & 0 & 0.003 & 0 & 0 & 0 & 0 & 0 & 0 & 0.002 & 0.001 \\
\hline $\mathrm{Ca}$ & 0.109 & 0.103 & 0.238 & 0.218 & 0.135 & 0.135 & 0.356 & 0.121 & 0.382 & 0.355 & 0.125 \\
\hline $\mathrm{Na}$ & 3.906 & 3.914 & 3.332 & 3.76 & 3.952 & 3.952 & 3.684 & 3.868 & 3.577 & 3.648 & 3.85 \\
\hline K & 0.02 & 0.029 & 0.02 & 0.026 & 0.013 & 0.013 & 0.019 & 0.023 & 0.02 & 0.012 & 0.012 \\
\hline$\Sigma_{\mathrm{T}}$ & 16 & 16.011 & 16.13 & 16.028 & 15.996 & 15.996 & 16.002 & 16.025 & 16.014 & 16.009 & 16.04 \\
\hline$\Sigma_{M}$ & 4.037 & 4.051 & 3.593 & 4.006 & 4.104 & 4.104 & 4.059 & 4.013 & 3.983 & 4.017 & 3.988 \\
\hline$\Sigma$ cátions & 20.037 & 20.062 & 19.723 & 20.034 & 20.1 & 20.1 & 20.061 & 20.038 & 19.997 & 20.026 & 20.028 \\
\hline $\mathrm{Ab}$ & 96.8 & 96.7 & 92.8 & 93.9 & 96.4 & 96.4 & 90.8 & 96.4 & 89.9 & 90.9 & 96.6 \\
\hline An & 2.7 & 2.5 & 6.6 & 5.4 & 3.3 & 3.3 & 8.8 & 3 & 9.6 & 8.8 & 3.1 \\
\hline Or & 0.5 & 0.7 & 0.6 & 0.6 & 0.3 & 0.3 & 0.5 & 0.6 & 0.5 & 0.3 & 0.3 \\
\hline
\end{tabular}

Análises com (*) foram obtidas no presente trabalho, sendo as demais do banco de dados do orientador 
Tabela A03. Continuação. Composição química, em percentagem de peso, para plagioclásios das rochas do Plúton Piracaia.

\begin{tabular}{|c|c|c|c|c|c|c|c|c|c|c|c|}
\hline $\begin{array}{c}\text { Amostra / cristal } \\
\text { Posição } \\
\text { Unidade } \\
\end{array}$ & PI-400A & PI-400A & PI-400A & $\begin{array}{c}\text { PI-400A } \\
M h \\
\end{array}$ & $\begin{array}{c}\text { PI-400A } \\
\text { tabular } \\
M h \\
\end{array}$ & $\begin{array}{c}\text { PI-400A } \\
\text { matriz } \\
M h \\
\end{array}$ & $\begin{array}{c}\text { PI-400A } \\
\text { matriz } \\
M h \\
\end{array}$ & $\begin{array}{c}\text { PI-400A } \\
\text { matriz } \\
M h\end{array}$ & $\begin{array}{c}\text { PI-400A } \\
\text { tabular } \\
M h \\
\end{array}$ & $\begin{array}{c}\text { PI-400A } \\
\text { matriz } \\
M h\end{array}$ & $\begin{array}{c}\text { PI-400D } \\
\text { tabular } \\
M h \\
\end{array}$ \\
\hline $\mathrm{SiO}_{2}$ & 56.70 & 62.88 & 64.13 & 64.60 & 59.97 & 59.19 & 64.68 & 60.78 & 57.31 & 56.13 & 63.85 \\
\hline $\mathrm{TiO}_{2}$ & 0.00 & 0.00 & 0.00 & 0.02 & 0.00 & 0.00 & 0.05 & 0.05 & 0.00 & 0.00 & 0.05 \\
\hline $\mathrm{Al}_{2} \mathrm{O}_{3}$ & 28.44 & 23.00 & 22.69 & 23.10 & 25.45 & 26.40 & 22.76 & 24.96 & 27.36 & 29.15 & 22.92 \\
\hline $\mathrm{Fe}_{2} \mathrm{O}_{3}$ & 0.06 & 0.00 & 0.05 & 0.00 & 0.01 & 0.17 & 0.13 & 0.20 & 0.00 & 0.16 & 0.06 \\
\hline $\mathrm{MnO}$ & 0.00 & 0.00 & 0.00 & 0.00 & 0.00 & 0.00 & 0.00 & 0.06 & 0.00 & 0.00 & 0.00 \\
\hline $\mathrm{MgO}$ & 0.00 & 0.01 & 0.01 & 0.00 & 0.02 & 0.00 & 0.00 & 0.00 & 0.01 & 0.01 & 0.00 \\
\hline \multicolumn{12}{|l|}{$\mathrm{BaO}$} \\
\hline $\mathrm{CaO}$ & 9.76 & 4.17 & 3.84 & 3.78 & 7.26 & 3.52 & 3.70 & 4.15 & 8.96 & 3.38 & 4.11 \\
\hline $\mathrm{Na}_{2} \mathrm{O}$ & 6.10 & 9.29 & 9.46 & 9.41 & 7.57 & 8.85 & 9.59 & 9.09 & 6.77 & 8.95 & 9.14 \\
\hline $\mathrm{K}_{2} \mathrm{O}$ & 0.10 & 0.13 & 0.06 & 0.10 & 0.08 & 0.12 & 0.16 & 0.12 & 0.05 & 0.17 & 0.11 \\
\hline Total & 101.16 & 99.48 & 100.24 & 101.00 & 100.36 & 98.25 & 101.06 & 99.42 & 100.46 & 97.95 & 100.23 \\
\hline \multicolumn{12}{|c|}{ Fórmula estrutural calculada na base de 32 oxigênios } \\
\hline $\mathrm{Si}$ & 10.069 & 11.178 & 11.289 & 11.278 & 10.652 & 10.66 & 11.299 & 10.842 & 10.233 & 10.183 & 11.245 \\
\hline $\mathrm{Al}$ & 5.947 & 4.815 & 4.704 & 4.749 & 5.324 & 5.599 & 4.682 & 5.244 & 5.754 & 6.228 & 4.753 \\
\hline $\mathrm{Fe}^{3+}$ & 0.008 & 0 & 0.007 & 0 & 0.002 & 0.023 & 0.017 & 0.027 & 0 & 0.021 & 0.008 \\
\hline $\mathrm{Ti}$ & 0 & 0 & 0 & 0.002 & 0 & 0 & 0.007 & 0.007 & 0 & 0 & 0.006 \\
\hline $\mathrm{Mn}$ & 0 & 0 & 0 & 0 & 0 & 0 & 0 & 0.01 & 0 & 0 & 0.001 \\
\hline $\mathrm{Mg}$ & 0 & 0.002 & 0.002 & 0 & 0.005 & 0.001 & 0 & 0 & 0.002 & 0.001 & 0 \\
\hline \multicolumn{12}{|l|}{$\mathrm{Ba}$} \\
\hline $\mathrm{Ca}$ & 1.858 & 0.795 & 0.724 & 0.707 & 1.382 & 0.68 & 0.693 & 0.793 & 1.715 & 0.656 & 0.776 \\
\hline $\mathrm{Na}$ & 2.102 & 3.204 & 3.229 & 3.186 & 2.606 & 3.09 & 3.249 & 3.145 & 2.344 & 3.147 & 3.12 \\
\hline K & 0.022 & 0.03 & 0.014 & 0.022 & 0.019 & 0.028 & 0.035 & 0.028 & 0.011 & 0.04 & 0.024 \\
\hline$\Sigma_{\mathrm{T}}$ & 16.024 & 15.993 & 16 & 16.029 & 15.978 & 16.282 & 16.005 & 16.12 & 15.987 & 16.432 & 16.012 \\
\hline$\Sigma_{\mathrm{M}}$ & 3.982 & 4.031 & 3.969 & 3.915 & 4.012 & 3.799 & 3.977 & 3.976 & 4.072 & 3.844 & 3.921 \\
\hline$\sum$ cátions & 20.006 & 20.024 & 19.969 & 19.944 & 19.99 & 20.081 & 19.982 & 20.096 & 20.059 & 20.276 & 19.933 \\
\hline $\mathrm{Ab}$ & 52.8 & 79.5 & 81.4 & 81.4 & 65 & 81.4 & 81.7 & 79.3 & 57.6 & 81.9 & 79.6 \\
\hline An & 46.7 & 19.7 & 18.3 & 18.1 & 34.5 & 17.9 & 17.4 & 20 & 42.1 & 17.1 & 19.8 \\
\hline Or & 0.6 & 0.7 & 0.4 & 0.6 & 0.5 & 0.7 & 0.9 & 0.7 & 0.3 & 1 & 0.6 \\
\hline
\end{tabular}

Análises com (*) foram obtidas no presente trabalho, sendo as demais do banco de dados do orientador 
Tabela A03. Continuação. Composição química, em percentagem de peso, para plagioclásios das rochas do Plúton Piracaia.

\begin{tabular}{|c|c|c|c|c|c|c|c|c|c|c|c|}
\hline $\begin{array}{c}\text { Amostra / cristal } \\
\text { Posição } \\
\text { Unidade } \\
\end{array}$ & $\begin{array}{c}\text { PI-400D } \\
\text { tabular } \\
M h\end{array}$ & $\begin{array}{l}\text { PI-400D } \\
\qquad M h\end{array}$ & $\begin{array}{c}\text { PI-400D } \\
\text { tabular } \\
M h\end{array}$ & $\begin{array}{c}\text { PI-400D } \\
\text { matriz } \\
M h\end{array}$ & $\begin{array}{l}\text { PI-400D } \\
\qquad M h\end{array}$ & $\begin{array}{l}\text { PI-400D } \\
\qquad M h\end{array}$ & $\begin{array}{l}\text { PI-413 } \\
\text { Qsie }\end{array}$ & $\begin{array}{l}\text { PI-413 } \\
\text { Qsie } \\
\end{array}$ & $\begin{array}{l}\text { PI-413 } \\
\text { Qsie }\end{array}$ & $\begin{array}{l}\text { PI-413 } \\
\text { Qsie }\end{array}$ & $\begin{array}{l}\text { PI-413 } \\
\text { Qsie }\end{array}$ \\
\hline $\mathrm{SiO}_{2}$ & 59.81 & 64.31 & 59.44 & 63.92 & 59.24 & 62.10 & 64.44 & 65.26 & 65.47 & 68.16 & 63.78 \\
\hline $\mathrm{TiO}_{2}$ & 0.00 & 0.02 & 0.01 & 0.02 & 0.02 & 0.00 & 0.00 & 0.02 & 0.03 & 0.07 & 0.02 \\
\hline $\mathrm{Al}_{2} \mathrm{O}_{3}$ & 24.88 & 21.85 & 25.29 & 22.27 & 22.22 & 22.41 & 21.79 & 21.90 & 21.78 & 20.05 & 23.46 \\
\hline $\mathrm{Fe}_{2} \mathrm{O}_{3}$ & 0.00 & 0.02 & 0.06 & 0.12 & 0.09 & 0.09 & 0.07 & 0.03 & 0.08 & 0.02 & 0.02 \\
\hline $\mathrm{MnO}$ & 0.04 & 0.00 & 0.05 & 0.01 & 0.00 & 0.00 & 0.00 & 0.02 & 0.01 & 0.03 & 0.00 \\
\hline $\mathrm{MgO}$ & 0.00 & 0.00 & 0.00 & 0.00 & 0.00 & 0.00 & 0.00 & 0.00 & 0.00 & 0.00 & 0.01 \\
\hline $\mathrm{BaO}$ & & & & & & & & & & & \\
\hline $\mathrm{CaO}$ & 6.27 & 2.88 & 7.04 & 3.40 & 3.60 & 3.66 & 2.90 & 2.89 & 2.62 & 0.83 & 2.80 \\
\hline $\mathrm{Na}_{2} \mathrm{O}$ & 7.95 & 9.65 & 7.63 & 9.66 & 9.51 & 9.32 & 10.06 & 10.15 & 10.33 & 11.69 & 10.08 \\
\hline $\mathrm{K}_{2} \mathrm{O}$ & 0.14 & 0.26 & 0.15 & 0.08 & 0.09 & 0.17 & 0.12 & 0.10 & 0.03 & 0.06 & 0.07 \\
\hline Total & 99.10 & 98.97 & 99.67 & 99.47 & 94.76 & 97.74 & 99.39 & 100.36 & 100.34 & 100.90 & 100.25 \\
\hline \multicolumn{12}{|c|}{ Fórmula estrutural calculada na base de 32 oxigênios } \\
\hline $\mathrm{Si}$ & 10.742 & 11.439 & 10.641 & 11.336 & 11.084 & 11.228 & 11.429 & 11.454 & 11.484 & 11.842 & 11.218 \\
\hline $\mathrm{Al}$ & 5.263 & 4.577 & 5.332 & 4.65 & 4.895 & 4.772 & 4.552 & 4.527 & 4.5 & 4.102 & 4.86 \\
\hline $\mathrm{Fe}^{3+}$ & 0 & 0.002 & 0.008 & 0.016 & 0.013 & 0.012 & 0.009 & 0.004 & 0.01 & 0.003 & 0.003 \\
\hline $\mathrm{Ti}$ & 0 & 0.002 & 0.001 & 0.002 & 0.002 & 0 & 0 & 0.002 & 0.003 & 0.01 & 0.002 \\
\hline $\mathrm{Mn}$ & 0.006 & 0 & 0.007 & 0.002 & 0 & 0 & 0 & 0.003 & 0.001 & 0.004 & 0.001 \\
\hline $\mathrm{Mg}$ & 0 & 0 & 0.001 & 0 & 0 & 0 & 0 & 0 & 0 & 0 & 0.003 \\
\hline \multicolumn{12}{|l|}{$\mathrm{Ba}$} \\
\hline $\mathrm{Ca}$ & 1.207 & 0.548 & 1.351 & 0.646 & 0.722 & 0.708 & 0.55 & 0.543 & 0.493 & 0.154 & 0.528 \\
\hline $\mathrm{Na}$ & 2.77 & 3.327 & 2.647 & 3.321 & 3.452 & 3.268 & 3.459 & 3.455 & 3.513 & 3.936 & 3.438 \\
\hline K & 0.031 & 0.059 & 0.033 & 0.018 & 0.021 & 0.039 & 0.028 & 0.022 & 0.006 & 0.013 & 0.016 \\
\hline$\Sigma_{\mathrm{T}}$ & 16.005 & 16.02 & 15.982 & 16.004 & 15.994 & 16.012 & 15.99 & 15.987 & 15.997 & 15.957 & 16.083 \\
\hline$\underline{\Sigma_{M}}$ & 4.014 & 3.934 & 4.039 & 3.987 & 4.195 & 4.015 & 4.037 & 4.023 & 4.013 & 4.107 & 3.986 \\
\hline$\Sigma$ cátions & 20.019 & 19.954 & 20.021 & 19.991 & 20.189 & 20.027 & 20.027 & 20.01 & 20.01 & 20.064 & 20.069 \\
\hline $\mathrm{Ab}$ & 69.1 & 84.6 & 65.7 & 83.3 & 82.3 & 81.4 & 85.7 & 85.9 & 87.6 & 95.9 & 86.3 \\
\hline An & 30.1 & 13.9 & 33.5 & 16.2 & 17.2 & 17.6 & 13.6 & 13.5 & 12.3 & 3.8 & 13.3 \\
\hline Or & 0.8 & 1.5 & 0.8 & 0.5 & 0.5 & 1 & 0.7 & 0.5 & 0.1 & 0.3 & 0.4 \\
\hline
\end{tabular}

Análises com (*) foram obtidas no presente trabalho, sendo as demais do banco de dados do orientador 
Tabela A03. Continuação. Composição química, em percentagem de peso, para plagioclásios das rochas do Plúton Piracaia.

\begin{tabular}{|c|c|c|c|c|c|c|c|c|c|c|}
\hline $\begin{array}{c}\text { Amostra / cristal } \\
\text { Posição } \\
\text { Unidade } \\
\end{array}$ & Qsie & Qsie & $\begin{array}{c}\text { PI-413 } \\
\text { tabular } \\
\text { Qsie } \\
\end{array}$ & $\begin{array}{l}\text { PI-413 } \\
\text { borda } \\
\text { Qsie } \\
\end{array}$ & $\begin{array}{c}\text { PI-419 } \\
\text { centro } \\
M h \\
\end{array}$ & $\begin{array}{l}\text { PI-419 } \\
\text { Mh } \\
\end{array}$ & $\begin{array}{l}\text { PI-426 } \\
\text { Mh } \\
\end{array}$ & $\begin{array}{c}\text { PI-426 } \\
\text { tabular } \\
M h \\
\end{array}$ & $\begin{array}{c}\text { PI-426B } \\
\text { borda } \\
M h \\
\end{array}$ & $\begin{array}{l}\text { PI-426B } \\
\qquad M h \\
\end{array}$ \\
\hline $\mathrm{SiO}_{2}$ & 67.98 & 65.06 & 65.49 & 64.72 & 59.06 & 64.42 & 64.71 & 64.08 & 64.17 & 63.48 \\
\hline $\mathrm{TiO}_{2}$ & 0.00 & 0.00 & 0.00 & 0.06 & 0.02 & 0.00 & 0.00 & 0.06 & 0.03 & 0.00 \\
\hline $\mathrm{Al}_{2} \mathrm{O}_{3}$ & 19.95 & 21.96 & 21.96 & 21.61 & 25.77 & 22.59 & 22.40 & 22.33 & 22.91 & 22.62 \\
\hline $\mathrm{Fe}_{2} \mathrm{O}_{3}$ & 0.04 & 0.07 & 0.11 & 0.04 & 0.02 & 0.10 & 0.10 & 0.14 & 0.06 & 0.00 \\
\hline $\mathrm{MnO}$ & 0.00 & 0.00 & 0.02 & 0.01 & 0.00 & 0.00 & 0.00 & 0.00 & 0.03 & 0.00 \\
\hline $\mathrm{MgO}$ & 0.00 & 0.00 & 0.02 & 0.00 & 0.01 & 0.00 & 0.00 & 0.00 & 0.01 & 0.00 \\
\hline $\mathrm{BaO}$ & & & & & & & & & & \\
\hline $\mathrm{CaO}$ & 0.57 & 2.77 & 2.74 & 2.87 & 7.16 & 3.50 & 3.33 & 3.63 & 3.09 & 3.53 \\
\hline $\mathrm{Na}_{2} \mathrm{O}$ & 11.46 & 10.35 & 10.34 & 10.20 & 7.75 & 9.70 & 9.73 & 9.52 & 9.48 & 9.61 \\
\hline $\mathrm{K}_{2} \mathrm{O}$ & 0.06 & 0.13 & 0.07 & 0.08 & 0.08 & 0.06 & 0.07 & 0.05 & 0.09 & 0.09 \\
\hline Total & 100.06 & 100.34 & 100.75 & 99.58 & 99.85 & 100.37 & 100.33 & 99.81 & 99.86 & 99.34 \\
\hline \multicolumn{11}{|c|}{ Fórmula estrutural calculada na base de 32 oxigênios } \\
\hline $\mathrm{Si}$ & 11.885 & 11.432 & 11.453 & 11.455 & 10.559 & 11.321 & 11.366 & 11.326 & 11.31 & 11.278 \\
\hline $\mathrm{Al}$ & 4.108 & 4.544 & 4.523 & 4.503 & 5.426 & 4.676 & 4.633 & 4.648 & 4.756 & 4.733 \\
\hline $\mathrm{Fe}^{3+}$ & 0.005 & 0.009 & 0.014 & 0.005 & 0.003 & 0.013 & 0.013 & 0.019 & 0.008 & 0 \\
\hline $\mathrm{Ti}$ & 0 & 0 & 0 & 0.008 & 0.002 & 0 & 0 & 0.008 & 0.004 & 0 \\
\hline $\mathrm{Mn}$ & 0 & 0.001 & 0.002 & 0.001 & 0 & 0 & 0 & 0 & 0.005 & 0 \\
\hline $\mathrm{Mg}$ & 0 & 0 & 0.004 & 0.001 & 0.002 & 0 & 0.001 & 0 & 0.002 & 0 \\
\hline \multicolumn{11}{|l|}{$\mathrm{Ba}$} \\
\hline $\mathrm{Ca}$ & 0.106 & 0.521 & 0.513 & 0.544 & 1.372 & 0.658 & 0.627 & 0.688 & 0.583 & 0.672 \\
\hline $\mathrm{Na}$ & 3.884 & 3.525 & 3.507 & 3.5 & 2.686 & 3.306 & 3.314 & 3.262 & 3.238 & 3.311 \\
\hline K & 0.014 & 0.03 & 0.015 & 0.018 & 0.018 & 0.013 & 0.017 & 0.01 & 0.02 & 0.021 \\
\hline$\Sigma_{\mathrm{T}}$ & 15.998 & 15.985 & 15.99 & 15.971 & 15.99 & 16.01 & 16.012 & 16.001 & 16.078 & 16.011 \\
\hline$\Sigma_{M}$ & 4.004 & 4.077 & 4.041 & 4.064 & 4.078 & 3.977 & 3.959 & 3.96 & 3.848 & 4.004 \\
\hline$\Sigma$ cátions & 20.002 & 20.062 & 20.031 & 20.035 & 20.068 & 19.987 & 19.971 & 19.961 & 19.926 & 20.015 \\
\hline $\mathrm{Ab}$ & 97 & 86.5 & 86.9 & 86.2 & 65.9 & 83.1 & 83.7 & 82.4 & 84.3 & 82.7 \\
\hline An & 2.6 & 12.8 & 12.7 & 13.4 & 33.7 & 16.5 & 15.8 & 17.4 & 15.2 & 16.8 \\
\hline Or & 0.3 & 0.7 & 0.4 & 0.4 & 0.4 & 0.3 & 0.4 & 0.3 & 0.5 & 0.5 \\
\hline
\end{tabular}

Análises com (*) foram obtidas no presente trabalho, sendo as demais do banco de dados do orientador 
Tabela A03. Continuação. Composição química, em percentagem de peso, para plagioclásios das rochas do Plúton Piracaia.

\begin{tabular}{|c|c|c|c|c|c|c|c|c|c|c|c|}
\hline $\begin{array}{c}\text { Amostra / cristal } \\
\text { Posição } \\
\text { Unidade } \\
\end{array}$ & $\begin{array}{c}\text { PI-437a } \\
\text { matriz } \\
M h \\
\end{array}$ & $\begin{array}{c}\text { PI-437a } \\
\text { matriz } \\
M h \\
\end{array}$ & $\begin{array}{l}\text { PI-437a } \\
\qquad M h \\
\end{array}$ & $\begin{array}{c}\text { PI-437a } \\
\text { borda } \\
M h \\
\end{array}$ & $\begin{array}{c}\text { PI-437a } \\
\text { centro } \\
M h \\
\end{array}$ & $\begin{array}{c}\text { PI-437a } \\
\text { borda } \\
M h \\
\end{array}$ & $\begin{array}{c}\text { PI-437a } \\
\text { borda } \\
M h \\
\end{array}$ & $\begin{array}{l}\text { PI-429 } \\
\text { Qsie } \\
\end{array}$ & $\begin{array}{l}\text { PI-429 } \\
\text { borda } \\
\text { Qsie } \\
\end{array}$ & $\begin{array}{c}\text { PI-429 } \\
\text { tabular } \\
\text { Qsie } \\
\end{array}$ & $\begin{array}{l}\text { PI-427 } \\
\text { Qsie } \\
\end{array}$ \\
\hline $\mathrm{SiO}_{2}$ & 63.67 & 64.77 & 56.10 & 61.52 & 57.83 & 60.91 & 62.91 & 63.22 & 61.80 & 57.51 & 65.90 \\
\hline $\mathrm{TiO}_{2}$ & 0.10 & 0.01 & 0.08 & 0.00 & 0.00 & 0.04 & 0.00 & 0.01 & 0.01 & 0.02 & 0.00 \\
\hline $\mathrm{Al}_{2} \mathrm{O}_{3}$ & 22.70 & 21.84 & 27.42 & 24.09 & 26.48 & 24.74 & 21.82 & 23.13 & 22.42 & 25.82 & 21.50 \\
\hline $\mathrm{Fe}_{2} \mathrm{O}_{3}$ & 0.17 & 0.12 & 0.13 & 0.01 & 0.10 & 0.11 & 0.07 & 0.08 & 0.11 & 0.02 & 0.01 \\
\hline $\mathrm{MnO}$ & 0.00 & 0.00 & 0.02 & 0.00 & 0.01 & 0.00 & 0.00 & 0.02 & 0.02 & 0.00 & 0.00 \\
\hline $\mathrm{MgO}$ & 0.00 & 0.00 & 0.02 & 0.00 & 0.00 & 0.00 & 0.00 & 0.01 & 0.00 & 0.01 & 0.00 \\
\hline \multicolumn{12}{|l|}{$\mathrm{BaO}$} \\
\hline $\mathrm{CaO}$ & 3.05 & 2.31 & 8.34 & 4.93 & 7.47 & 5.32 & 2.55 & 4.06 & 3.70 & 6.96 & 2.42 \\
\hline $\mathrm{Na}_{2} \mathrm{O}$ & 9.68 & 10.11 & 6.18 & 8.55 & 6.63 & 8.36 & 10.28 & 9.34 & 9.47 & 7.30 & 10.37 \\
\hline $\mathrm{K}_{2} \mathrm{O}$ & 0.13 & 0.06 & 0.15 & 0.16 & 0.11 & 0.13 & 0.10 & 0.10 & 0.14 & 0.10 & 0.07 \\
\hline Total & 99.49 & 99.21 & 98.42 & 99.26 & 98.62 & 99.61 & 97.74 & 99.97 & 97.67 & 97.73 & 100.28 \\
\hline \multicolumn{12}{|c|}{ Fórmula estrutural calculada na base de 32 oxigênios } \\
\hline $\mathrm{Si}$ & 11.284 & 11.475 & 10.2 & 10.979 & 10.449 & 10.85 & 11.357 & 11.181 & 11.196 & 10.497 & 11.552 \\
\hline $\mathrm{Al}$ & 4.738 & 4.556 & 5.87 & 5.062 & 5.636 & 5.19 & 4.64 & 4.818 & 4.783 & 5.55 & 4.44 \\
\hline $\mathrm{Fe}^{3+}$ & 0.023 & 0.016 & 0.017 & 0.002 & 0.013 & 0.014 & 0.009 & 0.011 & 0.015 & 0.002 & 0.002 \\
\hline $\mathrm{Ti}$ & 0.013 & 0.001 & 0.01 & 0 & 0 & 0.005 & 0 & 0.001 & 0.001 & 0.002 & 0 \\
\hline Mn & 0 & 0 & 0.003 & 0 & 0.001 & 0 & 0 & 0.003 & 0.003 & 0 & 0 \\
\hline $\mathrm{Mg}$ & 0 & 0 & 0.005 & 0 & 0.001 & 0 & 0.001 & 0.003 & 0 & 0.002 & 0 \\
\hline \multicolumn{12}{|l|}{$\mathrm{Ba}$} \\
\hline $\mathrm{Ca}$ & 0.579 & 0.439 & 1.625 & 0.942 & 1.446 & 1.016 & 0.493 & 0.769 & 0.718 & 1.361 & 0.455 \\
\hline $\mathrm{Na}$ & 3.327 & 3.473 & 2.178 & 2.957 & 2.322 & 2.887 & 3.597 & 3.202 & 3.326 & 2.583 & 3.526 \\
\hline $\mathrm{K}$ & 0.029 & 0.014 & 0.035 & 0.036 & 0.024 & 0.03 & 0.024 & 0.022 & 0.032 & 0.023 & 0.016 \\
\hline$\Sigma_{\mathrm{T}}$ & 16.058 & 16.048 & 16.097 & 16.043 & 16.098 & 16.059 & 16.006 & 16.011 & 15.995 & 16.051 & 15.994 \\
\hline$\underline{\Sigma_{M}}$ & 3.935 & 3.926 & 3.846 & 3.935 & 3.794 & 3.933 & 4.115 & 3.999 & 4.079 & 3.969 & 3.997 \\
\hline$\Sigma$ cátions & 19.993 & 19.974 & 19.943 & 19.978 & 19.892 & 19.992 & 20.121 & 20.01 & 20.074 & 20.02 & 19.991 \\
\hline $\mathrm{Ab}$ & 84.5 & 88.5 & 56.7 & 75.1 & 61.2 & 73.4 & 87.4 & 80.2 & 81.6 & 65.1 & 88.2 \\
\hline An & 14.7 & 11.2 & 42.3 & 23.9 & 38.1 & 25.8 & 12 & 19.3 & 17.6 & 34.3 & 11.4 \\
\hline Or & 0.7 & 0.4 & 0.9 & 0.9 & 0.6 & 0.8 & 0.6 & 0.6 & 0.8 & 0.6 & 0.4 \\
\hline
\end{tabular}

Análises com (*) foram obtidas no presente trabalho, sendo as demais do banco de dados do orientador 
Tabela A03. Continuação. Composição química, em percentagem de peso, para plagioclásios das rochas do Plúton Piracaia.

\begin{tabular}{|c|c|c|c|c|c|c|c|c|c|c|c|}
\hline $\begin{array}{c}\text { Amostra / cristal } \\
\text { Posição } \\
\text { Unidade } \\
\end{array}$ & $\begin{array}{l}\text { PI-427 } \\
\text { centro } \\
\text { Qsie } \\
\end{array}$ & PI-427 & $\begin{array}{l}\text { PI-427 } \\
\text { Qsie } \\
\end{array}$ & $\begin{array}{l}\text { PI-427 } \\
\text { Qsie } \\
\end{array}$ & $\begin{array}{l}\text { PI-427 } \\
\text { Qsie } \\
\end{array}$ & $\begin{array}{l}\text { PI-427 } \\
\text { Qsie } \\
\end{array}$ & $\begin{array}{l}\text { PI-440 } \\
\text { Qsie } \\
\end{array}$ & $\begin{array}{l}\text { PI-440 } \\
\text { Qsie } \\
\end{array}$ & $\begin{array}{l}\text { PI-440 } \\
\text { Qsie } \\
\end{array}$ & $\begin{array}{l}\text { PI-440 } \\
\text { centro } \\
\text { Qsie } \\
\end{array}$ & $\begin{array}{c}\text { PI-440 } \\
\text { borda } \\
\text { Qsie } \\
\end{array}$ \\
\hline $\mathrm{SiO}_{2}$ & 67.50 & 65.01 & 62.95 & 64.57 & 65.26 & 66.94 & 67.96 & 68.01 & 66.68 & 68.09 & 68.00 \\
\hline $\mathrm{TiO}_{2}$ & 0.00 & 0.08 & 0.05 & 0.01 & 0.01 & 0.03 & 0.00 & 0.02 & 0.00 & 0.02 & 0.05 \\
\hline $\mathrm{Al}_{2} \mathrm{O}_{3}$ & 20.32 & 21.45 & 21.94 & 22.84 & 21.61 & 20.68 & 20.10 & 20.22 & 19.88 & 19.94 & 20.21 \\
\hline $\mathrm{Fe}_{2} \mathrm{O}_{3}$ & 0.07 & 0.12 & 0.00 & 0.06 & 0.15 & 0.03 & 0.04 & 0.00 & 0.03 & 0.01 & 0.09 \\
\hline $\mathrm{MnO}$ & 0.00 & 0.00 & 0.00 & 0.02 & 0.03 & 0.02 & 0.00 & 0.00 & 0.01 & 0.02 & 0.01 \\
\hline $\mathrm{MgO}$ & 0.00 & 0.00 & 0.02 & 0.01 & 0.01 & 0.00 & 0.00 & 0.00 & 0.00 & 0.00 & 0.00 \\
\hline $\mathrm{BaO}$ & & & & & & & & & & & \\
\hline $\mathrm{CaO}$ & 0.54 & 2.42 & 1.84 & 2.15 & 2.56 & 1.18 & 0.56 & 0.83 & 0.41 & 0.60 & 0.57 \\
\hline $\mathrm{Na}_{2} \mathrm{O}$ & 11.13 & 10.39 & 9.96 & 10.18 & 10.26 & 11.01 & 11.49 & 11.11 & 11.40 & 11.27 & 11.36 \\
\hline $\mathrm{K}_{2} \mathrm{O}$ & 0.09 & 0.08 & 0.09 & 0.08 & 0.14 & 0.07 & 0.12 & 0.05 & 0.10 & 0.07 & 0.09 \\
\hline Total & 99.65 & 99.55 & 96.86 & 99.91 & 100.02 & 99.94 & 100.26 & 100.23 & 98.52 & 100.02 & 100.37 \\
\hline \multicolumn{12}{|c|}{ Fórmula estrutural calculada na base de 32 oxigênios } \\
\hline $\mathrm{Si}$ & 11.839 & 11.499 & 11.413 & 11.363 & 11.491 & 11.737 & 11.863 & 11.861 & 11.847 & 11.899 & 11.853 \\
\hline $\mathrm{Al}$ & 4.198 & 4.467 & 4.685 & 4.732 & 4.481 & 4.27 & 4.132 & 4.152 & 4.16 & 4.104 & 4.147 \\
\hline $\mathrm{Fe}^{3+}$ & 0.009 & 0.016 & 0 & 0.008 & 0.02 & 0.003 & 0.005 & 0 & 0.004 & 0.002 & 0.012 \\
\hline $\mathrm{Ti}$ & 0 & 0.01 & 0.007 & 0.001 & 0.001 & 0.003 & 0 & 0.002 & 0 & 0.002 & 0.006 \\
\hline $\mathrm{Mn}$ & 0 & 0 & 0 & 0.004 & 0.005 & 0.003 & 0 & 0 & 0.001 & 0.003 & 0.001 \\
\hline $\mathrm{Mg}$ & 0 & 0 & 0.006 & 0.001 & 0.001 & 0 & 0 & 0 & 0.001 & 0 & 0 \\
\hline \multicolumn{12}{|l|}{$\mathrm{Ba}$} \\
\hline $\mathrm{Ca}$ & 0.101 & 0.459 & 0.357 & 0.405 & 0.484 & 0.221 & 0.104 & 0.154 & 0.077 & 0.112 & 0.106 \\
\hline $\mathrm{Na}$ & 3.785 & 3.563 & 3.503 & 3.472 & 3.504 & 3.743 & 3.889 & 3.757 & 3.927 & 3.819 & 3.839 \\
\hline K & 0.021 & 0.018 & 0.021 & 0.018 & 0.03 & 0.016 & 0.027 & 0.011 & 0.023 & 0.015 & 0.019 \\
\hline$\Sigma_{\mathrm{T}}$ & 16.046 & 15.992 & 16.105 & 16.104 & 15.993 & 16.013 & 16 & 16.015 & 16.011 & 16.007 & 16.018 \\
\hline$\underline{\Sigma_{M}}$ & 3.907 & 4.04 & 3.887 & 3.9 & 4.024 & 3.983 & 4.02 & 3.922 & 4.029 & 3.949 & 3.965 \\
\hline$\Sigma$ cátions & 19.953 & 20.032 & 19.992 & 20.004 & 20.017 & 19.996 & 20.02 & 19.937 & 20.04 & 19.956 & 19.983 \\
\hline $\mathrm{Ab}$ & 96.9 & 88.2 & 90.3 & 89.1 & 87.2 & 94 & 96.7 & 95.8 & 97.5 & 96.8 & 96.8 \\
\hline An & 2.6 & 11.4 & 9.2 & 10.4 & 12 & 5.6 & 2.6 & 3.9 & 1.9 & 2.8 & 2.7 \\
\hline Or & 0.5 & 0.4 & 0.5 & 0.5 & 0.7 & 0.4 & 0.7 & 0.3 & 0.6 & 0.4 & 0.5 \\
\hline
\end{tabular}

Análises com (*) foram obtidas no presente trabalho, sendo as demais do banco de dados do orientador 
Tabela A03. Continuação. Composição química, em percentagem de peso, para plagioclásios das rochas do Plúton Piracaia.

\begin{tabular}{|c|c|c|c|c|c|}
\hline $\begin{array}{c}\text { Amostra / cristal } \\
\text { Posição } \\
\text { Unidade }\end{array}$ & $\begin{array}{l}\text { PI-440 } \\
\text { Qsie }\end{array}$ & $\begin{array}{l}\text { PI-440 } \\
\text { Qsie }\end{array}$ & $\begin{array}{c}\text { PI-440 } \\
\text { Qsie }\end{array}$ & $\begin{array}{l}\text { PI-440 } \\
\text { Qsie }\end{array}$ & $\begin{array}{c}\text { PI-440 } \\
\text { Qsie }\end{array}$ \\
\hline $\mathrm{SiO}_{2}$ & 67.23 & 67.39 & 66.01 & 65.73 & 67.59 \\
\hline $\mathrm{TiO}_{2}$ & 0.01 & 0.00 & 0.02 & 0.00 & 0.03 \\
\hline $\mathrm{Al}_{2} \mathrm{O}_{3}$ & 19.92 & 19.85 & 20.02 & 19.42 & 19.93 \\
\hline $\mathrm{Fe}_{2} \mathrm{O}_{3}$ & 0.05 & 0.13 & 0.01 & 0.06 & 0.02 \\
\hline $\mathrm{MnO}$ & 0.01 & 0.02 & 0.02 & 0.01 & 0.03 \\
\hline $\mathrm{MgO}$ & 0.01 & 0.00 & 0.00 & 0.01 & 0.00 \\
\hline \multicolumn{6}{|l|}{$\mathrm{BaO}$} \\
\hline $\mathrm{CaO}$ & 0.41 & 0.49 & 0.52 & 0.26 & 0.52 \\
\hline $\mathrm{Na}_{2} \mathrm{O}$ & 11.26 & 11.43 & 11.22 & 11.57 & 11.43 \\
\hline $\mathrm{K}_{2} \mathrm{O}$ & 0.08 & 0.14 & 0.07 & 0.07 & 0.09 \\
\hline Total & 98.99 & 99.46 & 97.88 & 97.13 & 99.64 \\
\hline \multicolumn{6}{|c|}{ Fórmula estrutural calculada na base de 32 oxigênios } \\
\hline $\mathrm{Si}$ & 11.874 & 11.866 & 11.804 & 11.854 & 11.871 \\
\hline $\mathrm{Al}$ & 4.142 & 4.116 & 4.216 & 4.125 & 4.121 \\
\hline $\mathrm{Fe}^{3+}$ & 0.006 & 0.017 & 0.001 & 0.008 & 0.003 \\
\hline $\mathrm{Ti}$ & 0.001 & 0 & 0.002 & 0 & 0.003 \\
\hline $\mathrm{Mn}$ & 0.002 & 0.004 & 0.002 & 0.001 & 0.004 \\
\hline $\mathrm{Mg}$ & 0.003 & 0 & 0 & 0.004 & 0 \\
\hline \multicolumn{6}{|l|}{$\mathrm{Ba}$} \\
\hline $\mathrm{Ca}$ & 0.078 & 0.093 & 0.1 & 0.05 & 0.098 \\
\hline $\mathrm{Na}$ & 3.856 & 3.902 & 3.891 & 4.047 & 3.893 \\
\hline K & 0.018 & 0.031 & 0.016 & 0.017 & 0.019 \\
\hline$\Sigma_{\mathrm{T}}$ & 16.023 & 15.999 & 16.023 & 15.987 & 15.998 \\
\hline$\Sigma_{\mathrm{M}}$ & 3.957 & 4.03 & 4.009 & 4.119 & 4.014 \\
\hline$\Sigma$ cátions & 19.98 & 20.029 & 20.032 & 20.106 & 20.012 \\
\hline $\mathrm{Ab}$ & 97.6 & 96.9 & 97.1 & 98.4 & 97.1 \\
\hline An & 2 & 2.3 & 2.5 & 1.2 & 2.4 \\
\hline Or & 0.5 & 0.8 & 0.4 & 0.4 & 0.5 \\
\hline
\end{tabular}

Análises com (*) foram obtidas no presente trabalho, sendo as demais do banco de dados do orientador 


\begin{tabular}{|c|c|c|c|c|c|c|c|c|c|c|c|c|c|}
\hline Amostra & $257 \mathrm{c}$ & $257 c$ & $257 c$ & $257 \mathrm{c}$ & $257 \mathrm{c}$ & $257 \mathrm{c}$ & $257 \mathrm{c}$ & $257 c$ & $257 c$ & $257 \mathrm{c}$ & $257 c$ & $257 \mathrm{c}$ & $257 c$ \\
\hline Cristal & 5 & 5 & 7_3 & 7_3 & 7_2 & 7_2 & 7_2 & 7_4 & 7_4 & 5 & 5 & 3 & 3 \\
\hline Associação & Comp & Comp & Treliça (cpx) & Treliça (cpx) & Sand (cpx) & Sand (cpx) & Sand (cpx) & Sand (cpx) & Sand (cpx) & Comp & Comp & Isolado & Isolado \\
\hline Unidade & $M d r$ & $M d r$ & $M d r$ & $M d r$ & $M d r$ & $M d r$ & $M d r$ & $M d r$ & $M d r$ & $M d r$ & $M d r$ & $M d r$ & $M d r$ \\
\hline $\mathrm{SiO}_{2}$ & 0.01 & 0.03 & 0.00 & 0.02 & 0.03 & 0.03 & 0.16 & 0.02 & 0.03 & 0.03 & 0.02 & 0.02 & 0.02 \\
\hline $\mathrm{TiO}_{2}$ & 0.00 & 0.01 & 0.08 & 0.07 & 0.16 & 0.16 & 0.05 & 0.04 & 0.11 & 0.07 & 0.01 & 0.04 & 0.05 \\
\hline $\mathrm{Al}_{2} \mathrm{O}_{3}$ & 0.23 & 0.19 & 0.30 & 0.24 & 0.19 & 0.19 & 0.28 & 0.26 & 0.25 & 0.20 & 0.19 & 0.13 & 0.26 \\
\hline $\mathrm{FeOt}$ & 90.82 & 94.40 & 96.47 & 98.71 & 95.24 & 92.09 & 91.62 & 92.14 & 95.70 & 97.72 & 97.34 & 94.54 & 94.48 \\
\hline $\mathrm{MnO}$ & 0.05 & 0.02 & 0.04 & 0.01 & 0.04 & 0.04 & 0.02 & 0.02 & 0.06 & 0.05 & 0.02 & 0.13 & 0.04 \\
\hline $\mathrm{MgO}$ & 0.00 & 0.01 & 0.07 & 0.00 & 0.02 & 0.02 & 0.03 & 0.06 & 0.12 & 0.02 & 0.02 & 0.00 & 0.00 \\
\hline $\mathrm{CaO}$ & 0.02 & 0.01 & 0.03 & 0.08 & 0.00 & 0.00 & 0.00 & 0.00 & 0.03 & 0.00 & 0.04 & 0.00 & 0.01 \\
\hline $\mathrm{Cr}_{2} \mathrm{O}_{3}$ & 0.04 & 0.04 & 0.00 & 0.03 & 0.01 & 0.01 & 0.00 & 0.00 & 0.01 & 0.00 & 0.00 & 0.00 & 0.00 \\
\hline $\mathrm{ZnO}$ & 0.08 & 0.00 & 0.07 & 0.00 & 0.02 & 0.02 & 0.04 & 0.00 & 0.00 & 0.04 & 0.00 & 0.03 & 0.00 \\
\hline $\mathrm{NiO}$ & 0.00 & 0.00 & 0.00 & 0.00 & 0.03 & 0.03 & 0.02 & 0.00 & 0.00 & 0.02 & 0.02 & 0.02 & 0.00 \\
\hline $\mathrm{Nb}_{2} \mathrm{O}_{3}$ & 0.01 & 0.00 & 0.00 & 0.00 & 0.05 & 0.05 & 0.01 & 0.02 & 0.00 & 0.04 & 0.02 & 0.00 & 0.00 \\
\hline Total & 91.26 & 94.70 & 97.07 & 99.15 & 95.79 & 92.63 & 92.23 & 92.57 & 96.30 & 98.18 & 97.66 & 94.90 & 94.86 \\
\hline $\mathrm{Fe}_{2} \mathrm{O}_{3}$ wt. $\% *$ & 67.24 & 69.80 & 71.40 & 72.95 & 70.27 & 67.93 & 67.46 & 68.13 & 70.80 & 72.24 & 72.04 & 70.00 & 69.80 \\
\hline $\mathrm{FeO}$ wt. $\%$ & 30.32 & 31.59 & 32.23 & 33.07 & 32.01 & 30.96 & 30.91 & 30.83 & 31.99 & 32.72 & 32.51 & 31.55 & 31.67 \\
\hline Total: & 98.00 & 101.69 & 104.23 & 106.46 & 102.83 & 99.44 & 98.99 & 99.39 & 103.39 & 105.41 & 104.88 & 101.92 & 101.85 \\
\hline \multicolumn{14}{|l|}{ Cations } \\
\hline $\mathrm{Si}$ & 0.000 & 0.001 & 0.000 & 0.001 & 0.001 & 0.001 & 0.006 & 0.001 & 0.001 & 0.001 & 0.001 & 0.001 & 0.001 \\
\hline $\mathrm{Ti}$ & 0.000 & 0.000 & 0.002 & 0.002 & 0.004 & 0.005 & 0.002 & 0.001 & 0.003 & 0.002 & 0.000 & 0.001 & 0.001 \\
\hline $\mathrm{Al}$ & 0.011 & 0.008 & 0.013 & 0.010 & 0.008 & 0.009 & 0.013 & 0.012 & 0.011 & 0.009 & 0.008 & 0.006 & 0.011 \\
\hline $\mathrm{Fe}^{+3}$ & 1.987 & 1.988 & 1.982 & 1.984 & 1.979 & 1.978 & 1.971 & 1.984 & 1.981 & 1.985 & 1.989 & 1.990 & 1.984 \\
\hline $\mathrm{Fe}^{+2}$ & 0.996 & 1.000 & 0.994 & 1.000 & 1.002 & 1.002 & 1.004 & 0.997 & 0.994 & 0.999 & 0.998 & 0.997 & 1.000 \\
\hline $\mathrm{Mn}$ & 0.002 & 0.000 & 0.001 & 0.000 & 0.001 & 0.001 & 0.001 & 0.001 & 0.002 & 0.001 & 0.001 & 0.004 & 0.001 \\
\hline $\mathrm{Mg}$ & 0.000 & 0.001 & 0.004 & 0.000 & 0.001 & 0.001 & 0.002 & 0.004 & 0.007 & 0.001 & 0.001 & 0.000 & 0.000 \\
\hline $\mathrm{Ca}$ & 0.001 & 0.000 & 0.001 & 0.003 & 0.000 & 0.000 & 0.000 & 0.000 & 0.001 & 0.000 & 0.001 & 0.000 & 0.001 \\
\hline $\mathrm{Cr}$ & 0.001 & 0.001 & 0.000 & 0.001 & 0.000 & 0.000 & 0.000 & 0.000 & 0.000 & 0.000 & 0.000 & 0.000 & 0.000 \\
\hline $\mathrm{Zn}$ & 0.002 & 0.000 & 0.002 & 0.000 & 0.000 & 0.001 & 0.001 & 0.000 & 0.000 & 0.001 & 0.000 & 0.001 & 0.000 \\
\hline $\mathrm{Ni}$ & 0.000 & 0.000 & 0.000 & 0.000 & 0.001 & 0.001 & 0.001 & 0.000 & 0.000 & 0.001 & 0.001 & 0.001 & 0.000 \\
\hline $\mathrm{Nb}$ & 0.000 & 0.000 & 0.000 & 0.000 & 0.001 & 0.001 & 0.000 & 0.000 & 0.000 & 0.001 & 0.000 & 0.000 & 0.000 \\
\hline Total: & 3.000 & 3.000 & 3.000 & 3.000 & 3.000 & 3.000 & 3.000 & 3.000 & 3.000 & 3.000 & 3.000 & 3.000 & 3.000 \\
\hline \multicolumn{14}{|c|}{ Ulvoespinélio (\%) } \\
\hline$*$ & 0.06 & 0.13 & 0.24 & 0.28 & 0.54 & 0.56 & 0.78 & 0.20 & 0.40 & 0.30 & 0.09 & 0.20 & 0.22 \\
\hline$* *$ & 0.01 & 0.02 & 0.23 & 0.20 & 0.44 & 0.45 & 0.16 & 0.13 & 0.30 & 0.20 & 0.02 & 0.12 & 0.14 \\
\hline
\end{tabular}




\begin{tabular}{|c|c|c|c|c|c|c|c|c|c|c|c|c|c|c|c|c|}
\hline Amostra & $257 \mathrm{c}$ & $257 \mathrm{c}$ & $256 \mathrm{c}$ & $256 c$ & $256 c$ & $256 c$ & $256 \mathrm{c}$ & $256 \mathrm{c}$ & $256 \mathrm{c}$ & $256 c$ & $256 c$ & $256 c$ & $256 c$ & $256 c$ & $256 c$ & $256 c$ \\
\hline Cristal & 7_4 & 4 & 1 & 1 & 1 & 1 & 1 & 2 & 2 & 3 & 3 & 4 & 4 & 4 & 5 & 5 \\
\hline Associação & Comp (cpx) & & Comp & Comp & Comp & Comp & Comp & Comp & Comp & Próximos & Próximos & Treliça & Treliça & Treliça & Comp & Comp \\
\hline Unidade & $M d r$ & $M d r$ & $M d r$ & $M d r$ & $M d r$ & $M d r$ & $M d r$ & $M d r$ & $M d r$ & $M d r$ & $M d r$ & $M d r$ & $M d r$ & $M d r$ & $M d r$ & $M d r$ \\
\hline $\mathrm{SiO}_{2}$ & 0.02 & 0.05 & 0.02 & 0.02 & 0.02 & 0.02 & 0.02 & 0.04 & 0.01 & 0.03 & 0.16 & 0.03 & 0.02 & 0.03 & 0.01 & 0.01 \\
\hline $\mathrm{TiO}_{2}$ & 0.13 & 0.12 & 0.38 & 0.16 & 0.02 & 0.43 & 0.22 & 0.16 & 0.39 & 0.22 & 0.00 & 0.06 & 0.00 & 0.06 & 0.00 & 0.05 \\
\hline $\mathrm{Al}_{2} \mathrm{O}_{3}$ & 0.28 & 0.17 & 0.09 & 0.09 & 0.09 & 0.08 & 0.10 & 0.16 & 0.16 & 0.21 & 0.24 & 0.20 & 0.28 & 0.20 & 0.13 & 0.12 \\
\hline $\mathrm{FeOt}$ & 90.58 & 93.31 & 91.49 & 95.24 & 91.52 & 93.31 & 94.09 & 96.76 & 90.86 & 93.16 & 92.86 & 94.14 & 89.96 & 94.14 & 95.36 & 92.89 \\
\hline $\mathrm{MnO}$ & 0.04 & 0.02 & 0.05 & 0.03 & 0.03 & 0.03 & 0.06 & 0.05 & 0.04 & 0.03 & 0.05 & 0.07 & 0.03 & 0.07 & 0.07 & 0.07 \\
\hline $\mathrm{MgO}$ & 0.02 & 0.05 & 0.02 & 0.02 & 0.00 & 0.00 & 0.03 & 0.02 & 0.00 & 0.02 & 0.07 & 0.03 & 0.00 & 0.03 & 0.00 & 0.00 \\
\hline $\mathrm{CaO}$ & 0.04 & 0.00 & 0.03 & 0.03 & 0.00 & 0.01 & 0.00 & 0.00 & 0.00 & 0.04 & 0.00 & 0.01 & 0.01 & 0.01 & 0.00 & 0.02 \\
\hline $\mathrm{Cr}_{2} \mathrm{O}_{3}$ & 0.00 & 0.04 & 0.01 & 0.01 & 0.02 & 0.01 & 0.00 & 0.00 & 0.00 & 0.02 & 0.00 & 0.02 & 0.00 & 0.02 & 0.00 & 0.02 \\
\hline $\mathrm{ZnO}$ & 0.00 & 0.00 & 0.01 & 0.05 & 0.00 & 0.08 & 0.00 & 0.00 & 0.00 & 0.00 & 0.04 & 0.00 & 0.03 & 0.00 & 0.00 & 0.06 \\
\hline $\mathrm{NiO}$ & 0.02 & 0.00 & 0.00 & 0.06 & 0.04 & 0.01 & 0.05 & 0.00 & 0.00 & 0.01 & 0.01 & 0.02 & 0.00 & 0.02 & 0.01 & 0.02 \\
\hline $\mathrm{Nb}_{2} \mathrm{O}_{3}$ & 0.00 & 0.01 & 0.00 & 0.00 & 0.00 & 0.00 & 0.00 & 0.00 & 0.00 & 0.00 & 0.01 & 0.00 & 0.00 & 0.00 & 0.00 & 0.05 \\
\hline Total & 91.13 & 93.76 & 92.08 & 95.71 & 91.73 & 93.98 & 94.56 & 97.18 & 91.46 & 93.72 & 93.45 & 94.58 & 90.32 & 94.58 & 95.58 & 93.31 \\
\hline $\mathrm{Fe}_{2} \mathrm{O}_{3}$ wt. $\% *$ & 66.86 & 68.88 & 67.28 & 70.39 & 67.71 & 68.56 & 69.42 & 71.37 & 66.74 & 68.64 & 68.55 & 69.61 & 66.52 & 69.61 & 70.62 & 68.79 \\
\hline $\mathrm{FeO}$ wt. $\%$ & 30.42 & 31.33 & 30.94 & 31.91 & 30.59 & 31.61 & 31.62 & 32.53 & 30.81 & 31.39 & 31.18 & 31.50 & 30.10 & 31.50 & 31.81 & 31.00 \\
\hline Total: & 97.82 & 100.66 & 98.82 & 102.77 & 98.51 & 100.85 & 101.51 & 104.33 & 98.15 & 100.59 & 100.32 & 101.56 & 96.99 & 101.56 & 102.65 & 100.20 \\
\hline \multicolumn{17}{|l|}{ Cations } \\
\hline $\mathrm{Si}$ & 0.001 & 0.002 & 0.001 & 0.001 & 0.001 & 0.001 & 0.001 & 0.002 & 0.000 & 0.001 & 0.006 & 0.001 & 0.001 & 0.001 & 0.000 & 0.000 \\
\hline $\mathrm{Ti}$ & 0.004 & 0.003 & 0.011 & 0.004 & 0.001 & 0.012 & 0.006 & 0.004 & 0.011 & 0.006 & 0.000 & 0.002 & 0.000 & 0.002 & 0.000 & 0.001 \\
\hline $\mathrm{Al}$ & 0.013 & 0.007 & 0.004 & 0.004 & 0.004 & 0.004 & 0.004 & 0.007 & 0.007 & 0.009 & 0.011 & 0.009 & 0.013 & 0.009 & 0.006 & 0.005 \\
\hline $\mathrm{Fe}^{+3}$ & 1.978 & 1.981 & 1.972 & 1.985 & 1.992 & 1.970 & 1.981 & 1.981 & 1.969 & 1.975 & 1.977 & 1.984 & 1.986 & 1.984 & 1.993 & 1.990 \\
\hline $\mathrm{Fe}^{+2}$ & 1.000 & 1.001 & 1.008 & 1.000 & 1.000 & 1.009 & 1.003 & 1.004 & 1.010 & 1.004 & 0.999 & 0.998 & 0.998 & 0.998 & 0.998 & 0.996 \\
\hline $\mathrm{Mn}$ & 0.001 & 0.001 & 0.002 & 0.001 & 0.001 & 0.001 & 0.002 & 0.002 & 0.001 & 0.001 & 0.002 & 0.002 & 0.001 & 0.002 & 0.002 & 0.002 \\
\hline $\mathrm{Mg}$ & 0.001 & 0.003 & 0.001 & 0.001 & 0.000 & 0.000 & 0.002 & 0.001 & 0.000 & 0.001 & 0.004 & 0.002 & 0.000 & 0.002 & 0.000 & 0.000 \\
\hline $\mathrm{Ca}$ & 0.002 & 0.000 & 0.001 & 0.001 & 0.000 & 0.001 & 0.000 & 0.000 & 0.000 & 0.001 & 0.000 & 0.000 & 0.000 & 0.000 & 0.000 & 0.001 \\
\hline $\mathrm{Cr}$ & 0.000 & 0.001 & 0.000 & 0.000 & 0.001 & 0.000 & 0.000 & 0.000 & 0.000 & 0.001 & 0.000 & 0.001 & 0.000 & 0.001 & 0.000 & 0.001 \\
\hline $\mathrm{Zn}$ & 0.000 & 0.000 & 0.000 & 0.001 & 0.000 & 0.002 & 0.000 & 0.000 & 0.000 & 0.000 & 0.001 & 0.000 & 0.001 & 0.000 & 0.000 & 0.002 \\
\hline $\mathrm{Ni}$ & 0.001 & 0.000 & 0.000 & 0.002 & 0.001 & 0.000 & 0.001 & 0.000 & 0.000 & 0.000 & 0.000 & 0.001 & 0.000 & 0.001 & 0.000 & 0.001 \\
\hline $\mathrm{Nb}$ & 0.000 & 0.000 & 0.000 & 0.000 & 0.000 & 0.000 & 0.000 & 0.000 & 0.000 & 0.000 & 0.000 & 0.000 & 0.000 & 0.000 & 0.000 & 0.001 \\
\hline Total: & 3.000 & 3.000 & 3.000 & 3.000 & 3.000 & 3.000 & 3.000 & 3.000 & 3.000 & 3.000 & 3.000 & 3.000 & 3.000 & 3.000 & 3.000 & 3.000 \\
\hline \multicolumn{17}{|c|}{ Ulvoespinélio (\%) } \\
\hline$*$ & 0.44 & 0.51 & 1.18 & 0.51 & 0.13 & 1.31 & 0.69 & 0.59 & 1.16 & 0.72 & 0.62 & 0.28 & 0.07 & 0.28 & 0.03 & 0.18 \\
\hline$* *$ & 0.38 & 0.34 & 1.13 & 0.44 & 0.06 & 1.23 & 0.63 & 0.44 & 1.15 & 0.62 & 0.00 & 0.18 & 0.00 & 0.18 & 0.00 & 0.14 \\
\hline
\end{tabular}

*Valores calculados pelo método de Carmichael (1967); ** Valores calculados pelos métodos de Lindsley \& Spencer (1982) 
Tabela A04. Continuação. Composição química, em percentagem de peso, para magnetitas das rochas do Plúton Piracaia $(\mathrm{O}=4)$;

\begin{tabular}{|c|c|c|c|c|c|c|c|c|c|c|c|c|c|c|c|}
\hline Amostra & $256 c$ & $75 c$ & $75 c$ & $75 c$ & $75 c$ & $75 c$ & $75 c$ & $5 c$ & $5 c$ & $5 c$ & $358 \mathrm{c}$ & $358 \mathrm{c}$ & $358 \mathrm{c}$ & $358 \mathrm{c}$ & $358 \mathrm{c}$ \\
\hline Cristal & 5 & 7 & 7 & 2 & 2 & 4 & 4 & 8 & 8 & 8 & 8 & 8 & 8 & 1 & 1 \\
\hline Unidade & $M d r$ & $M d f$ & $M d f$ & $M d f$ & $M d f$ & $M d f$ & $M d f$ & $M d f$ & $M d f$ & $M d f$ & $M d f$ & $M d f$ & $M d f$ & $M d f$ & $M d f$ \\
\hline $\mathrm{TiO}_{2}$ & 0.32 & 0.28 & 0.38 & 0.11 & 0.22 & 0.16 & 0.10 & 0.24 & 0.06 & 0.36 & 0.05 & 0.66 & 0.08 & 0.04 & 0.05 \\
\hline $\mathrm{Al}_{2} \mathrm{O}_{3}$ & 0.10 & 0.13 & 0.10 & 0.21 & 0.20 & 0.28 & 0.26 & 0.09 & 0.13 & 0.10 & 0.11 & 0.07 & 0.07 & 0.05 & 0.03 \\
\hline $\mathrm{FeOt}$ & 92.99 & 90.91 & 91.68 & 86.64 & 93.78 & 92.10 & 91.55 & 94.90 & 93.74 & 93.39 & 93.87 & 91.24 & 93.78 & 94.32 & 94.82 \\
\hline $\mathrm{CaO}$ & 0.02 & 0.01 & 0.04 & 0.00 & 0.09 & 0.03 & 0.02 & 0.08 & 0.13 & 0.05 & 0.06 & 0.10 & 0.08 & 0.01 & 0.05 \\
\hline $\mathrm{Cr}_{2} \mathrm{O}_{3}$ & 0.00 & 0.04 & 0.01 & 0.04 & 0.02 & 0.02 & 0.06 & 0.00 & 0.03 & 0.01 & 0.09 & 0.13 & 0.09 & 0.14 & 0.11 \\
\hline $\mathrm{ZnO}$ & 0.00 & 0.00 & 0.00 & 0.00 & 0.00 & 0.00 & 0.04 & 0.03 & 0.04 & 0.01 & 0.00 & 0.04 & 0.00 & 0.00 & 0.00 \\
\hline $\mathrm{NiO}$ & 0.01 & 0.00 & 0.00 & 0.01 & 0.03 & 0.00 & 0.00 & 0.02 & 0.00 & 0.00 & 0.00 & 0.00 & 0.03 & 0.07 & 0.00 \\
\hline $\mathrm{Nb}_{2} \mathrm{O}_{3}$ & 0.00 & 0.00 & 0.05 & 0.00 & 0.00 & 0.00 & 0.00 & 0.00 & 0.00 & 0.01 & 0.00 & 0.00 & 0.00 & 0.00 & 0.00 \\
\hline Total & 93.52 & 91.72 & 92.31 & 87.14 & 94.42 & 92.68 & 92.12 & 95.42 & 94.18 & 93.97 & 94.22 & 92.37 & 94.21 & 94.71 & 95.10 \\
\hline $\mathrm{Si}$ & 001 & 0.008 & 0.001 & 0.001 & 0.001 & 0.002 & 0.002 & 0.001 & 0.001 & 0.000 & 0.001 & 0.002 & 0.001 & 0.002 & 0.001 \\
\hline $\mathrm{Ti}$ & 0.009 & 0.008 & 0.011 & 0.003 & 0.006 & 0.005 & 0.003 & 0.007 & 0.002 & 0.010 & 0.001 & 0.019 & 0.002 & 0.001 & 0.001 \\
\hline $\mathrm{Al}$ & 0.005 & 0.006 & 0.004 & 0.010 & 0.009 & 0.013 & 0.012 & 0.004 & 0.006 & 0.005 & 0.005 & 0.003 & 0.003 & 0.002 & 0.001 \\
\hline $\mathrm{Fe}^{+3}$ & 1.975 & 1.960 & 1.970 & 1.979 & 1.975 & 1.974 & 1.977 & 1.980 & 1.988 & 1.974 & 1.987 & 1.949 & 1.987 & 1.986 & 1.990 \\
\hline $\mathrm{Fe}^{+2}$ & 1.007 & 1.009 & 1.009 & 1.000 & 1.001 & 1.003 & 1.001 & 1.003 & 0.996 & 1.007 & 1.000 & 1.014 & 0.998 & 1.001 & 1.000 \\
\hline $\mathrm{Mn}$ & 0.002 & 0.001 & 0.001 & 0.002 & 0.001 & 0.002 & 0.001 & 0.001 & 0.001 & 0.001 & 0.000 & 0.002 & 0.001 & 0.001 & 0.001 \\
\hline $\mathrm{Mg}$ & 0.000 & 0.006 & 0.000 & 0.002 & 0.001 & 0.000 & 0.001 & 0.000 & 0.000 & 0.000 & 0.000 & 0.001 & 0.001 & 0.000 & 0.000 \\
\hline $\mathrm{Ca}$ & 0.001 & 0.001 & 0.002 & 0.000 & 0.003 & 0.001 & 0.001 & 0.003 & 0.005 & 0.002 & 0.003 & 0.004 & 0.003 & 0.001 & 0.002 \\
\hline $\mathrm{Cr}$ & 0.000 & 0.001 & 0.000 & 0.001 & 0.000 & 0.001 & 0.002 & 0.000 & 0.001 & 0.000 & 0.003 & 0.004 & 0.003 & 0.004 & 0.003 \\
\hline $\mathrm{Zn}$ & 0.000 & 0.000 & 0.000 & 0.000 & 0.000 & 0.000 & 0.001 & 0.001 & 0.001 & 0.000 & 0.000 & 0.001 & 0.000 & 0.000 & 0.000 \\
\hline $\mathrm{Ni}$ & 0.000 & 0.000 & 0.000 & 0.000 & 0.001 & 0.000 & 0.000 & 0.001 & 0.000 & 0.000 & 0.000 & 0.000 & 0.001 & 0.002 & 0.000 \\
\hline
\end{tabular}




\begin{tabular}{|c|c|c|c|c|c|c|c|c|c|c|c|c|c|c|c|c|}
\hline Amostra & $358 \mathrm{c}$ & $358 \mathrm{c}$ & $358 \mathrm{c}$ & $500-71$ & $500-71$ & $500-71$ & $500-71$ & $500-71$ & $500-71$ & $400 a$ & $400 a$ & $400 a$ & $400 \mathrm{a}$ & $400 \mathrm{a}$ & $400 a$ & $400 \mathrm{a}$ \\
\hline Cristal & 1 & 3 & 3 & 3 & 3 & 3 & 2 & 3 & 3 & 1_1 & 1_1 & 1_2 & $1 \_2$ & $1 \_2$ & $1 \_2$ & $1 \_3$ \\
\hline Associação & Comp & Próx Ilm & Próx Ilm & Isolado & Isolado & Isolado & Isolado & Isolado & Isolado & Comp & Comp & Sand & Sand & Sand & Sand & Sand \\
\hline Unidade & $M d f$ & $M d f$ & $M d f$ & $M d f$ & $M d f$ & $M d f$ & $M d f$ & $M d f$ & $M d f$ & $M h$ & $M h$ & $M h$ & $M h$ & $M h$ & $M h$ & $M h$ \\
\hline $\mathrm{SiO}_{2}$ & 0.03 & 0.00 & 0.03 & 0.00 & 0.01 & 10.62 & 0.01 & 2.12 & 0.02 & 0.03 & 0.02 & 0.04 & 25.21 & 0.06 & 0.03 & 0.03 \\
\hline $\mathrm{TiO}_{2}$ & 0.35 & 0.05 & 0.06 & 0.02 & 0.00 & 0.58 & 0.00 & 0.04 & 0.15 & 0.13 & 0.10 & 0.19 & 28.55 & 0.28 & 0.12 & 0.09 \\
\hline $\mathrm{Al}_{2} \mathrm{O}_{3}$ & 0.09 & 0.07 & 0.11 & 0.14 & 0.13 & 6.14 & 0.05 & 0.50 & 0.08 & 0.09 & 0.06 & 0.06 & 3.51 & 0.08 & 0.08 & 0.10 \\
\hline $\mathrm{FeOt}$ & 91.56 & 93.68 & 95.68 & 94.57 & 94.54 & 75.97 & 98.45 & 94.77 & 93.44 & 91.69 & 92.95 & 92.53 & 14.81 & 93.43 & 93.09 & 92.59 \\
\hline $\mathrm{MnO}$ & 0.07 & 0.01 & 0.09 & 0.10 & 0.16 & 0.20 & 0.05 & 0.08 & 0.17 & 0.03 & 0.04 & 0.02 & 0.16 & 0.00 & 0.05 & 0.07 \\
\hline $\mathrm{MgO}$ & 0.03 & 0.06 & 0.00 & 0.02 & 0.01 & 4.39 & 0.00 & 0.04 & 0.00 & 0.00 & 0.00 & 0.02 & 0.01 & 0.00 & 0.02 & 0.02 \\
\hline $\mathrm{CaO}$ & 0.12 & 0.05 & 0.01 & 0.03 & 0.01 & 0.04 & 0.00 & 0.06 & 0.00 & 0.03 & 0.02 & 0.13 & 23.71 & 0.09 & 0.06 & 0.02 \\
\hline $\mathrm{Cr}_{2} \mathrm{O}_{3}$ & 0.12 & 0.06 & 0.05 & 0.00 & 0.03 & 0.00 & 0.05 & 0.01 & 0.02 & 0.02 & 0.01 & 0.05 & 0.00 & 0.04 & 0.03 & 0.00 \\
\hline $\mathrm{ZnO}$ & 0.00 & 0.01 & 0.00 & 0.00 & 0.03 & 0.06 & 0.00 & 0.00 & 0.00 & 0.10 & 0.00 & 0.00 & 0.00 & 0.01 & 0.00 & 0.00 \\
\hline $\mathrm{NiO}$ & 0.00 & 0.01 & 0.05 & 0.01 & 0.03 & 0.00 & 0.01 & 0.00 & 0.00 & 0.00 & 0.00 & 0.02 & 0.03 & 0.04 & 0.00 & 0.00 \\
\hline $\mathrm{Nb}_{2} \mathrm{O}_{3}$ & 0.00 & 0.01 & 0.00 & 0.00 & 0.00 & 0.06 & 0.01 & 0.00 & 0.02 & 0.00 & 0.00 & 0.00 & 0.14 & 0.00 & 0.01 & 0.02 \\
\hline Total & 92.37 & 94.00 & 96.09 & 94.90 & 94.93 & 98.05 & 98.63 & 97.61 & 93.89 & 92.11 & 93.20 & 93.04 & 96.12 & 94.04 & 93.47 & 92.94 \\
\hline $\mathrm{Fe}_{2} \mathrm{O}_{3}$ wt. $\% *$ & 67.44 & 69.41 & 70.76 & 70.10 & 70.10 & 39.51 & 72.92 & 66.32 & 69.08 & 67.78 & 68.71 & 68.37 & -50.95 & 68.79 & 68.84 & 68.47 \\
\hline FeO wt. $\%$ & 30.88 & 31.23 & 32.01 & 31.49 & 31.46 & 40.42 & 32.84 & 35.10 & 31.27 & 30.71 & 31.13 & 31.01 & 60.66 & 31.53 & 31.15 & 30.98 \\
\hline Total: & 99.12 & 100.95 & 103.18 & 101.92 & 101.95 & 102.01 & 105.93 & 104.26 & 100.81 & 98.90 & 100.09 & 99.90 & 91.02 & 100.93 & 100.37 & 99.80 \\
\hline \multicolumn{17}{|l|}{ Cations } \\
\hline $\mathrm{Si}$ & 0.001 & 0.000 & 0.001 & 0.000 & 0.000 & 0.359 & 0.000 & 0.077 & 0.001 & 0.001 & 0.001 & 0.001 & 0.851 & 0.002 & 0.001 & 0.001 \\
\hline $\mathrm{Ti}$ & 0.010 & 0.001 & 0.002 & 0.001 & 0.000 & 0.015 & 0.000 & 0.001 & 0.004 & 0.004 & 0.003 & 0.005 & 0.725 & 0.008 & 0.003 & 0.003 \\
\hline $\mathrm{Al}$ & 0.004 & 0.003 & 0.005 & 0.006 & 0.006 & 0.245 & 0.002 & 0.021 & 0.003 & 0.004 & 0.003 & 0.003 & 0.140 & 0.004 & 0.004 & 0.005 \\
\hline $\mathrm{Fe}^{+3}$ & 1.970 & 1.992 & 1.987 & 1.992 & 1.992 & 1.006 & 1.995 & 1.822 & 1.986 & 1.986 & 1.989 & 1.982 & -1.294 & 1.974 & 1.987 & 1.988 \\
\hline $\mathrm{Fe}^{+2}$ & 1.002 & 0.996 & 0.999 & 0.995 & 0.994 & 1.144 & 0.999 & 1.071 & 0.999 & 1.000 & 1.002 & 0.999 & 1.713 & 1.006 & 0.999 & 0.999 \\
\hline $\mathrm{Mn}$ & 0.002 & 0.000 & 0.003 & 0.003 & 0.005 & 0.006 & 0.002 & 0.003 & 0.005 & 0.001 & 0.001 & 0.001 & 0.004 & 0.000 & 0.002 & 0.002 \\
\hline $\mathrm{Mg}$ & 0.002 & 0.003 & 0.000 & 0.001 & 0.000 & 0.222 & 0.000 & 0.002 & 0.000 & 0.000 & 0.000 & 0.001 & 0.001 & 0.000 & 0.001 & 0.001 \\
\hline $\mathrm{Ca}$ & 0.005 & 0.002 & 0.001 & 0.001 & 0.000 & 0.001 & 0.000 & 0.002 & 0.000 & 0.001 & 0.001 & 0.005 & 0.857 & 0.004 & 0.002 & 0.001 \\
\hline $\mathrm{Cr}$ & 0.004 & 0.002 & 0.002 & 0.000 & 0.001 & 0.000 & 0.002 & 0.000 & 0.001 & 0.001 & 0.000 & 0.001 & 0.000 & 0.001 & 0.001 & 0.000 \\
\hline $\mathrm{Zn}$ & 0.000 & 0.000 & 0.000 & 0.000 & 0.001 & 0.001 & 0.000 & 0.000 & 0.000 & 0.003 & 0.000 & 0.000 & 0.000 & 0.000 & 0.000 & 0.000 \\
\hline $\mathrm{Ni}$ & 0.000 & 0.000 & 0.001 & 0.000 & 0.001 & 0.000 & 0.000 & 0.000 & 0.000 & 0.000 & 0.000 & 0.001 & 0.001 & 0.001 & 0.000 & 0.000 \\
\hline $\mathrm{Nb}$ & 0.000 & 0.000 & 0.000 & 0.000 & 0.000 & 0.001 & 0.000 & 0.000 & 0.000 & 0.000 & 0.000 & 0.000 & 0.002 & 0.000 & 0.000 & 0.000 \\
\hline Total: & 3.000 & 3.000 & 3.000 & 3.000 & 3.000 & 3.000 & 3.000 & 3.000 & 3.000 & 3.000 & 3.000 & 3.000 & 3.000 & 3.000 & 3.000 & 3.000 \\
\hline \multicolumn{17}{|l|}{ Ulvoespinélio (\%) } \\
\hline$*$ & 1.13 & 0.14 & 0.29 & 0.07 & 0.03 & 37.42 & 0.04 & 7.83 & 0.49 & 0.47 & 0.38 & 0.68 & 157.62 & 1.02 & 0.43 & 0.37 \\
\hline$* *$ & 1.02 & 0.14 & 0.17 & 0.07 & 0.00 & 1.85 & 0.00 & 0.10 & 0.42 & 0.37 & 0.30 & 0.54 & 190.15 & 0.81 & 0.34 & 0.26 \\
\hline
\end{tabular}

*Valores calculados pelo método de Carmichael (1967); ** Valores calculados pelos métodos de Lindsley \& Spencer (1982) 


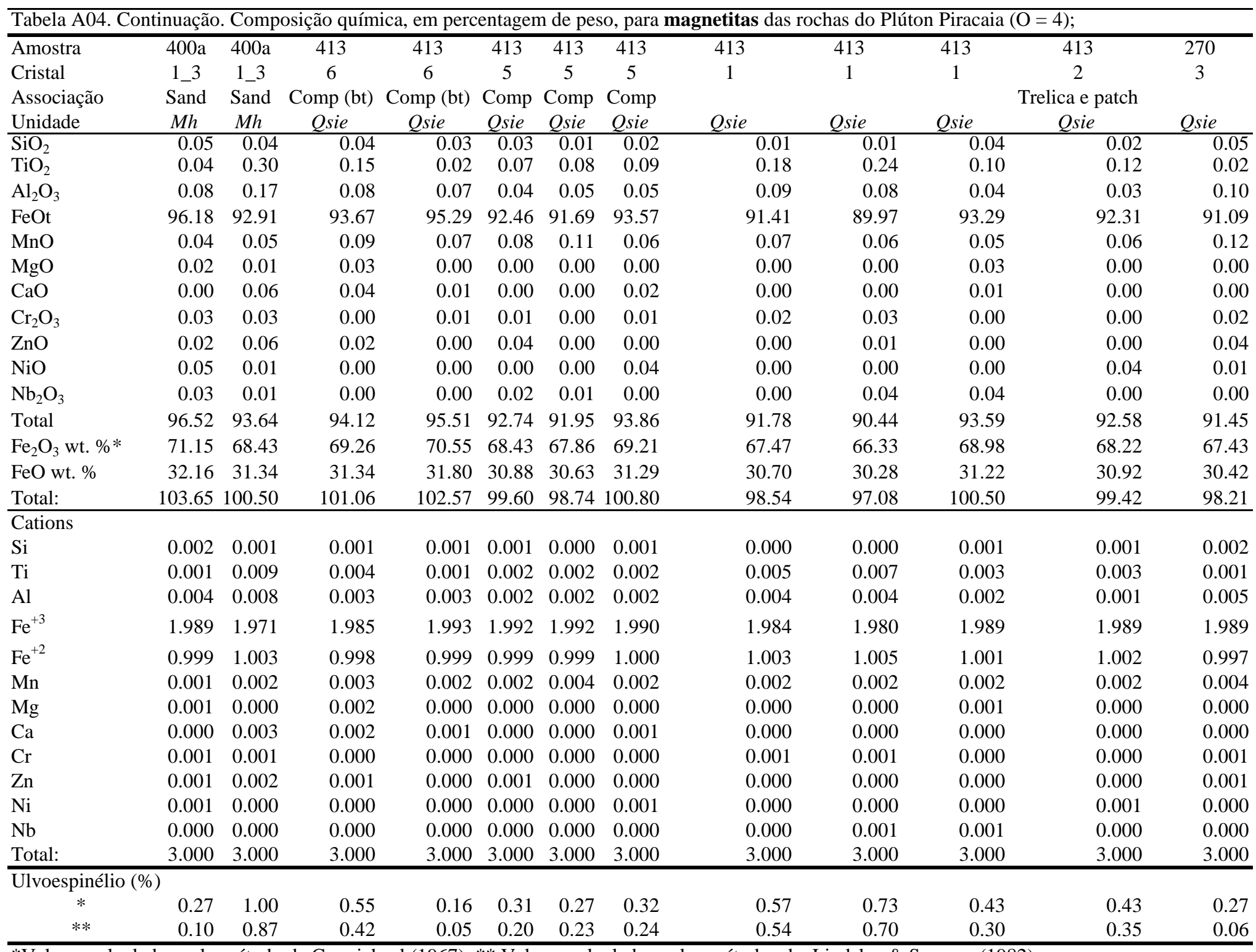

*Valores calculados pelo método de Carmichael (1967); ** Valores calculados pelos métodos de Lindsley \& Spencer (1982) 


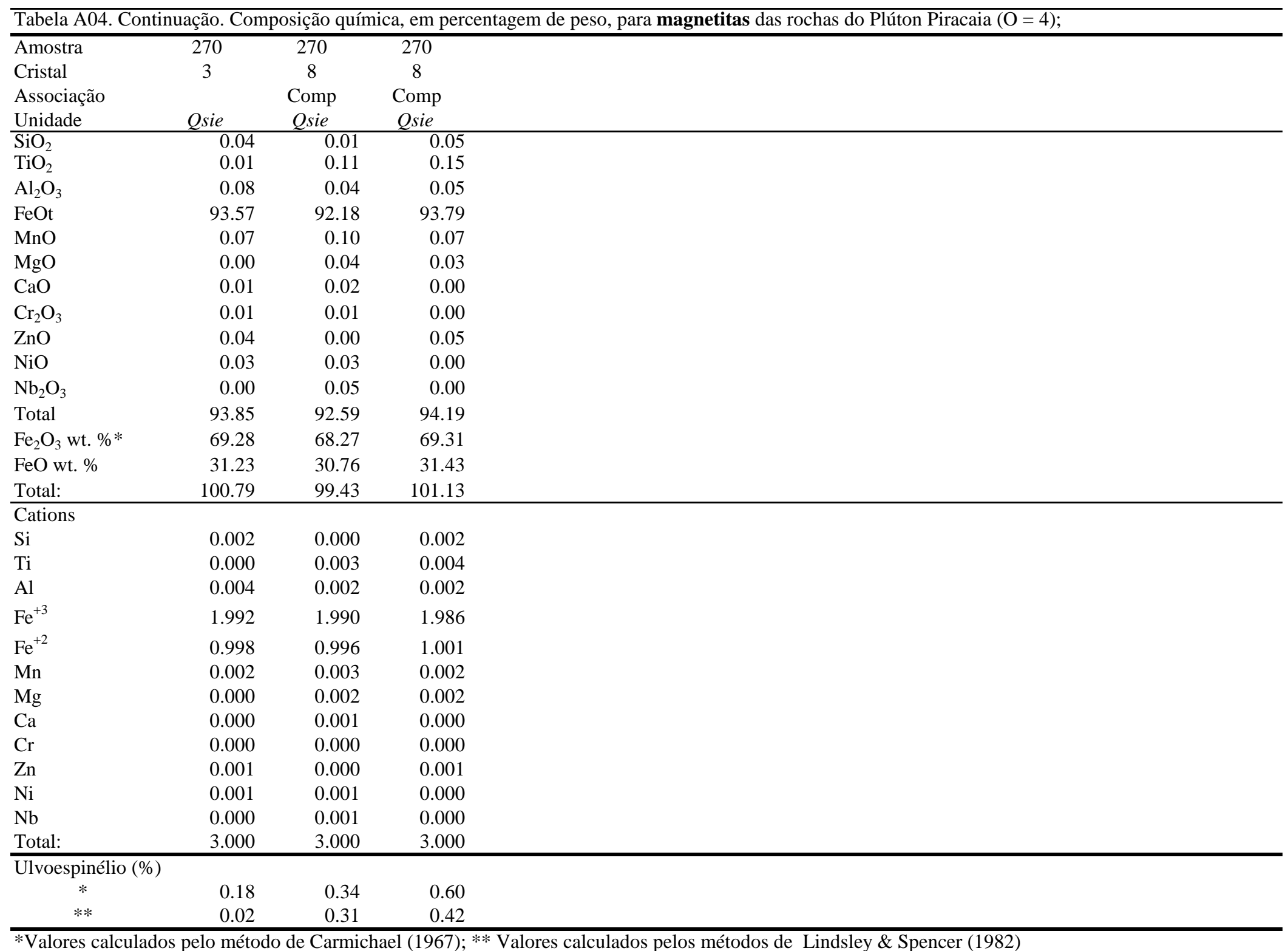




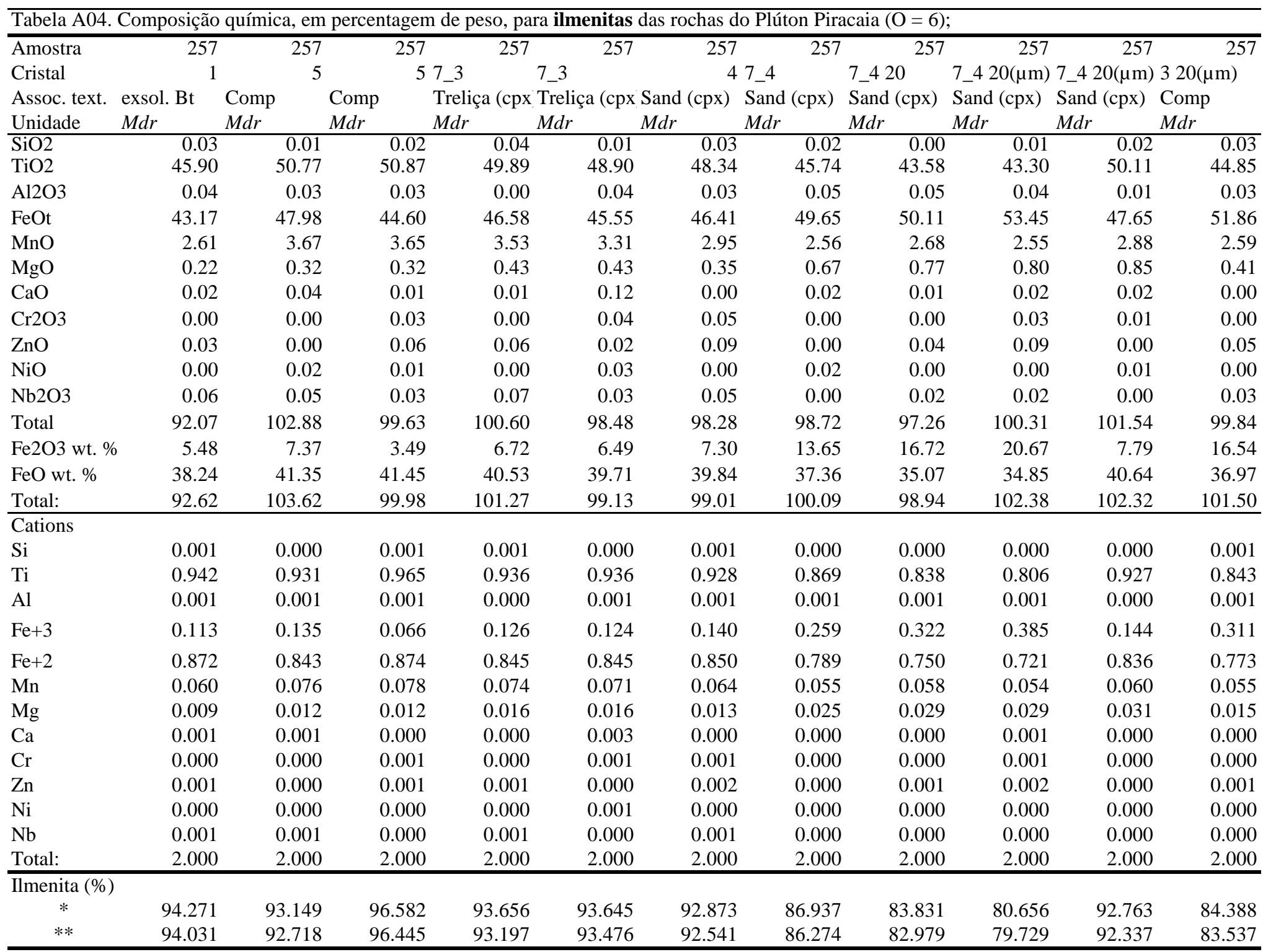

*Valores calculados pelo método de Carmichael (1967); ** Valores calculados pelos métodos de Lindsley \& Spencer (1982) 


\begin{tabular}{|c|c|c|c|c|c|c|c|c|c|c|c|}
\hline Amostra & 257 & 257 & $256 c$ & $256 c$ & $256 c$ & $256 c$ & $256 c$ & $256 \mathrm{c}$ & $256 c$ & $256 c$ & $256 c$ \\
\hline Cristal & $320(\mu \mathrm{m})$ & $320(\mu \mathrm{m})$ & 1 & 1 & 1 & 2 & 2 & 2 & 2 & 3 & 3 \\
\hline $\begin{array}{l}\text { Assoc. text. } \\
\text { Unidade }\end{array}$ & $\begin{array}{l}\text { Comp } \\
M d r\end{array}$ & $\begin{array}{l}\text { Comp } \\
M d r\end{array}$ & $\begin{array}{l}\text { Comp } \\
M d r\end{array}$ & $\begin{array}{l}\text { Comp } \\
M d r\end{array}$ & $\begin{array}{l}\text { Comp } \\
M d r\end{array}$ & $\begin{array}{l}\text { Comp } \\
M d r\end{array}$ & $\begin{array}{l}\text { Comp } \\
M d r\end{array}$ & $\begin{array}{l}\text { Comp } \\
M d r\end{array}$ & $\begin{array}{l}\text { Comp } \\
M d r\end{array}$ & $\begin{array}{l}\text { Proximos } \\
M d r\end{array}$ & $\begin{array}{l}\text { Proximos } \\
M d r\end{array}$ \\
\hline $\mathrm{SiO} 2$ & 0.01 & 0.03 & 0.01 & 0.00 & 0.01 & 0.00 & 0.00 & 0.00 & 0.02 & 0.03 & 0.00 \\
\hline $\mathrm{TiO} 2$ & 46.18 & 44.95 & 49.09 & 50.61 & 49.23 & 50.09 & 50.12 & 46.19 & 46.38 & 51.73 & 48.89 \\
\hline $\mathrm{A} 12 \mathrm{O} 3$ & 0.05 & 0.01 & 0.03 & 0.02 & 0.04 & 0.05 & 0.01 & 0.03 & 0.05 & 0.04 & 0.04 \\
\hline $\mathrm{FeOt}$ & 48.62 & 49.59 & 47.68 & 47.02 & 44.88 & 45.69 & 45.00 & 47.18 & 43.64 & 44.40 & 43.93 \\
\hline $\mathrm{MnO}$ & 2.63 & 2.58 & 3.57 & 3.76 & 3.83 & 3.68 & 3.96 & 3.63 & 4.00 & 3.62 & 3.53 \\
\hline $\mathrm{MgO}$ & 0.33 & 0.43 & 0.20 & 0.15 & 0.23 & 0.24 & 0.25 & 0.19 & 0.23 & 0.23 & 0.18 \\
\hline $\mathrm{CaO}$ & 0.00 & 0.00 & 0.00 & 0.00 & 0.00 & 0.01 & 0.05 & 0.00 & 0.00 & 0.04 & 0.01 \\
\hline $\mathrm{Cr} 2 \mathrm{O} 3$ & 0.03 & 0.01 & 0.03 & 0.00 & 0.00 & 0.00 & 0.04 & 0.00 & 0.03 & 0.00 & 0.01 \\
\hline $\mathrm{ZnO}$ & 0.00 & 0.00 & 0.00 & 0.00 & 0.00 & 0.00 & 0.00 & 0.01 & 0.00 & 0.06 & 0.06 \\
\hline $\mathrm{NiO}$ & 0.00 & 0.00 & 0.00 & 0.00 & 0.00 & 0.03 & 0.00 & 0.02 & 0.00 & 0.01 & 0.02 \\
\hline $\mathrm{Nb} 2 \mathrm{O} 3$ & 0.07 & 0.02 & 0.16 & 0.11 & 0.16 & 0.19 & 0.18 & 0.14 & 0.13 & 0.04 & 0.02 \\
\hline Total & 97.93 & 97.61 & 100.75 & 101.67 & 98.39 & 99.97 & 99.61 & 97.39 & 94.49 & 100.20 & 96.68 \\
\hline $\mathrm{Fe} 2 \mathrm{O} 3$ wt. \%: & 11.45 & 13.88 & 8.30 & 6.18 & 5.41 & 5.32 & 4.92 & 10.72 & 7.07 & 2.25 & 4.33 \\
\hline $\mathrm{FeO}$ wt. \% & 38.32 & 37.10 & 40.21 & 41.46 & 40.01 & 40.90 & 40.57 & 37.54 & 37.27 & 42.38 & 40.03 \\
\hline Total: & 99.07 & 98.99 & 101.58 & 102.29 & 98.93 & 100.50 & 100.10 & 98.47 & 95.20 & 100.43 & 97.11 \\
\hline \multicolumn{12}{|l|}{$\overline{\text { Cations }}$} \\
\hline $\mathrm{Si}$ & 0.000 & 0.001 & 0.000 & 0.000 & 0.000 & 0.000 & 0.000 & 0.000 & 0.000 & 0.001 & 0.000 \\
\hline $\mathrm{Ti}$ & 0.888 & 0.865 & 0.920 & 0.942 & 0.946 & 0.948 & 0.952 & 0.895 & 0.927 & 0.977 & 0.957 \\
\hline $\mathrm{Al}$ & 0.001 & 0.000 & 0.001 & 0.000 & 0.001 & 0.001 & 0.000 & 0.001 & 0.002 & 0.001 & 0.001 \\
\hline $\mathrm{Fe}+3$ & 0.220 & 0.267 & 0.156 & 0.115 & 0.104 & 0.101 & 0.093 & 0.208 & 0.141 & 0.042 & 0.085 \\
\hline $\mathrm{Fe}+2$ & 0.819 & 0.794 & 0.838 & 0.857 & 0.855 & 0.860 & 0.856 & 0.808 & 0.828 & 0.890 & 0.871 \\
\hline $\mathrm{Mn}$ & 0.057 & 0.056 & 0.075 & 0.079 & 0.083 & 0.078 & 0.085 & 0.079 & 0.090 & 0.077 & 0.078 \\
\hline $\mathrm{Mg}$ & 0.012 & 0.016 & 0.007 & 0.005 & 0.009 & 0.009 & 0.009 & 0.007 & 0.009 & 0.008 & 0.007 \\
\hline $\mathrm{Ca}$ & 0.000 & 0.000 & 0.000 & 0.000 & 0.000 & 0.000 & 0.001 & 0.000 & 0.000 & 0.001 & 0.000 \\
\hline $\mathrm{Cr}$ & 0.001 & 0.000 & 0.001 & 0.000 & 0.000 & 0.000 & 0.001 & 0.000 & 0.001 & 0.000 & 0.000 \\
\hline $\mathrm{Zn}$ & 0.000 & 0.000 & 0.000 & 0.000 & 0.000 & 0.000 & 0.000 & 0.000 & 0.000 & 0.001 & 0.001 \\
\hline $\mathrm{Ni}$ & 0.000 & 0.000 & 0.000 & 0.000 & 0.000 & 0.001 & 0.000 & 0.000 & 0.000 & 0.000 & 0.000 \\
\hline $\mathrm{Nb}$ & 0.001 & 0.000 & 0.002 & 0.001 & 0.002 & 0.002 & 0.002 & 0.002 & 0.002 & 0.001 & 0.000 \\
\hline Total: & 2.000 & 2.000 & 2.000 & 2.000 & 2.000 & 2.000 & 2.000 & 2.000 & 2.000 & 2.000 & 2.000 \\
\hline \multicolumn{12}{|l|}{ Ilmenita (\%) } \\
\hline$*$ & 88.836 & 86.604 & 92.048 & 94.151 & 94.634 & 94.758 & 95.157 & 89.463 & 92.725 & 97.776 & 95.667 \\
\hline$* *$ & 88.293 & 85.807 & 91.561 & 93.750 & 94.308 & 94.540 & 94.951 & 88.717 & 92.197 & 97.781 & 95.467 \\
\hline
\end{tabular}

*Valores calculados pelo método de Carmichael (1967); ** Valores calculados pelos métodos de Lindsley \& Spencer (1982) 




*Valores calculados pelo método de Carmichael (1967); ** Valores calculados pelos métodos de Lindsley \& Spencer (1982) 


\begin{tabular}{|c|c|c|c|c|c|c|c|c|c|c|c|}
\hline Amostra & $5 c$ & $5 c$ & $5 c$ & $5 c$ & $5 c$ & $5 c$ & $5 c$ & $5 c$ & $5 c$ & $5 c$ & $5 c$ \\
\hline Cristal & $9(20 \mu \mathrm{m})$ & $8(20 \mu \mathrm{m})$ & $8(20 \mu \mathrm{m})$ & $6(20 \mu \mathrm{m})$ & $6(20 \mu \mathrm{m})$ & $620(\mu \mathrm{m})$ & $620(\mu \mathrm{m})$ & $620(\mu \mathrm{m})$ & $620(\mu \mathrm{m})$ & $920(\mu \mathrm{m})$ & $920(\mu \mathrm{m})$ \\
\hline Assoc. text. & & Comp & Comp & Comp & Comp & Comp & Comp & Comp & Comp & & \\
\hline Unidade & $M d f$ & $M d f$ & $M d f$ & $M d f$ & $M d f$ & $M d f^{*}$ & $M d f$ & $M d f$ & $M d f$ & $M d f$ & $M d f$ \\
\hline$\overline{\mathrm{SiO} 2}$ & 0.25 & 0.03 & 7.86 & 0.00 & 0.03 & 0.01 & 0.02 & 0.02 & 0.01 & 0.00 & 0.00 \\
\hline $\mathrm{TiO} 2$ & 45.38 & 49.95 & 42.70 & 43.23 & 47.75 & 44.25 & 36.08 & 40.99 & 39.73 & 44.36 & 43.47 \\
\hline $\mathrm{A} 12 \mathrm{O} 3$ & 0.11 & 0.03 & 2.32 & 0.02 & 0.05 & 0.00 & 0.01 & 0.01 & 0.03 & 0.02 & 0.04 \\
\hline $\mathrm{FeOt}$ & 52.07 & 49.02 & 38.24 & 48.37 & 47.91 & 48.72 & 51.34 & 46.49 & 48.02 & 48.25 & 50.42 \\
\hline $\mathrm{MnO}$ & 2.22 & 3.24 & 2.42 & 2.55 & 2.68 & 2.69 & 2.33 & 2.66 & 2.75 & 2.32 & 2.19 \\
\hline $\mathrm{MgO}$ & 0.25 & 0.26 & 0.19 & 0.26 & 0.26 & 0.27 & 0.26 & 0.24 & 0.27 & 0.28 & 0.22 \\
\hline $\mathrm{CaO}$ & 0.04 & 0.10 & 6.30 & 0.02 & 0.00 & 0.02 & 0.03 & 0.03 & 0.01 & 0.00 & 0.02 \\
\hline $\mathrm{Cr} 2 \mathrm{O} 3$ & 0.03 & 0.01 & 0.00 & 0.00 & 0.04 & 0.00 & 0.00 & 0.04 & 0.00 & 0.04 & 0.02 \\
\hline $\mathrm{ZnO}$ & 0.00 & 0.00 & 0.02 & 0.04 & 0.00 & 0.02 & 0.06 & 0.02 & 0.02 & 0.00 & 0.00 \\
\hline $\mathrm{NiO}$ & 0.06 & 0.05 & 0.00 & 0.02 & 0.00 & 0.00 & 0.03 & 0.00 & 0.00 & 0.00 & 0.00 \\
\hline $\mathrm{Nb} 2 \mathrm{O} 3$ & 0.16 & 0.13 & 0.14 & 0.10 & 0.11 & 0.15 & 0.13 & 0.15 & 0.11 & 0.24 & 0.16 \\
\hline Total & 100.55 & 102.82 & 100.19 & 94.61 & 98.83 & 96.14 & 90.28 & 90.64 & 90.95 & 95.52 & 96.56 \\
\hline $\mathrm{Fe} 2 \mathrm{O} 3$ wt. $\%$ & 15.20 & 8.80 & 1.46 & 13.97 & 8.99 & 13.52 & 24.20 & 14.19 & 17.30 & 12.44 & 15.51 \\
\hline $\mathrm{FeO}$ wt. $\%$ & 38.39 & 41.11 & 36.93 & 35.79 & 39.82 & 36.56 & 29.57 & 33.72 & 32.45 & 37.05 & 36.47 \\
\hline Total: & 102.07 & 103.70 & 100.33 & 96.01 & 99.73 & 97.49 & 92.71 & 92.06 & 92.68 & 96.76 & 98.11 \\
\hline \multicolumn{12}{|l|}{$\overline{\text { Cations }}$} \\
\hline $\mathrm{Si}$ & 0.0061 & 0.0007 & 0.1874 & 0.0001 & 0.0008 & 0.0003 & 0.0006 & 0.0004 & 0.0002 & 0.0000 & 0.0000 \\
\hline $\mathrm{Ti}$ & 0.8485 & 0.9169 & 0.7661 & 0.8598 & 0.9116 & 0.8663 & 0.7474 & 0.8506 & 0.8199 & 0.8749 & 0.8470 \\
\hline $\mathrm{Al}$ & 0.0032 & 0.0008 & 0.0651 & 0.0007 & 0.0013 & 0.0000 & 0.0003 & 0.0004 & 0.0010 & 0.0005 & 0.0012 \\
\hline $\mathrm{Fe}+3$ & 0.2842 & 0.1615 & 0.0261 & 0.2780 & 0.1716 & 0.2648 & 0.5014 & 0.2945 & 0.3572 & 0.2455 & 0.3023 \\
\hline $\mathrm{Fe}+2$ & 0.7979 & 0.8388 & 0.7365 & 0.7913 & 0.8451 & 0.7957 & 0.6810 & 0.7779 & 0.7445 & 0.8123 & 0.7898 \\
\hline $\mathrm{Mn}$ & 0.0466 & 0.0669 & 0.0488 & 0.0571 & 0.0575 & 0.0594 & 0.0543 & 0.0621 & 0.0640 & 0.0516 & 0.0481 \\
\hline $\mathrm{Mg}$ & 0.0091 & 0.0093 & 0.0069 & 0.0102 & 0.0098 & 0.0106 & 0.0107 & 0.0098 & 0.0109 & 0.0110 & 0.0085 \\
\hline $\mathrm{Ca}$ & 0.0009 & 0.0025 & 0.1610 & 0.0004 & 0.0000 & 0.0006 & 0.0010 & 0.0009 & 0.0004 & 0.0001 & 0.0006 \\
\hline $\mathrm{Cr}$ & 0.0006 & 0.0002 & 0.0000 & 0.0000 & 0.0007 & 0.0000 & 0.0000 & 0.0009 & 0.0000 & 0.0009 & 0.0004 \\
\hline $\mathrm{Zn}$ & 0.0000 & 0.0000 & 0.0003 & 0.0008 & 0.0000 & 0.0004 & 0.0011 & 0.0003 & 0.0003 & 0.0000 & 0.0000 \\
\hline $\mathrm{Ni}$ & 0.0012 & 0.0010 & 0.0000 & 0.0004 & 0.0001 & 0.0000 & 0.0006 & 0.0000 & 0.0000 & 0.0000 & 0.0000 \\
\hline $\mathrm{Nb}$ & 0.0020 & 0.0016 & 0.0017 & 0.0013 & 0.0015 & 0.0020 & 0.0018 & 0.0022 & 0.0015 & 0.0032 & 0.0022 \\
\hline Total: & 2.0004 & 2.0003 & 2.0000 & 2.0001 & 2.0000 & 2.0000 & 2.0002 & 2.0000 & 2.0000 & 2.0000 & 2.0000 \\
\hline \multicolumn{12}{|l|}{ Ilmenita (\%) } \\
\hline$*$ & 85.4612 & 91.7600 & 95.3558 & 85.9878 & 91.2426 & 86.6584 & 74.8014 & 85.1031 & 82.0157 & 87.4934 & 84.6952 \\
\hline$* *$ & 84.7424 & 91.4172 & 96.6335 & 85.2967 & 90.8377 & 85.9359 & 73.4986 & 84.3002 & 80.9223 & 87.0331 & 84.1285 \\
\hline
\end{tabular}

*Valores calculados pelo método de Carmichael (1967); ** Valores calculados pelos métodos de Lindsley \& Spencer (1982) 


\begin{tabular}{|c|c|c|c|c|c|c|c|c|c|c|c|}
\hline Amostra & $5 c$ & $5 c$ & $75 c$ & $75 c$ & $75 c$ & $75 c$ & $75 c$ & $75 c$ & $75 c$ & $75 c$ & $75 c$ \\
\hline Cristal & $920(\mu \mathrm{m})$ & $920(\mu \mathrm{m})$ & 7 & 7 & 7 & 4 & 6 & 6 & 6 & 6 & 2 \\
\hline $\begin{array}{l}\text { Assoc. text. } \\
\text { Unidade }\end{array}$ & $M d f$ & $M d f$ & $\begin{array}{l}\text { Treliça } \\
M d f\end{array}$ & $\begin{array}{l}\text { Treliça } \\
M d f\end{array}$ & $\begin{array}{l}\text { Treliça } \\
M d f\end{array}$ & $M d f$ & $\begin{array}{l}\text { Isolado } \\
M d f\end{array}$ & $\begin{array}{l}\text { Isolado } \\
M d f\end{array}$ & $\begin{array}{l}\text { Isolado } \\
M d f\end{array}$ & $\begin{array}{l}\text { Isolado } \\
M d f\end{array}$ & $\begin{array}{l}\text { Comp } \\
M d f\end{array}$ \\
\hline $\mathrm{SiO} 2$ & $\overline{0}$ & 0 & 0.011 & 0.02 & 0.24 & 0.03 & 0 & 0 & 0.01 & 0 & 0.03 \\
\hline $\mathrm{TiO} 2$ & 47.31 & 47.31 & 52.92 & 49.48 & 49.62 & 48.03 & 47.21 & 47.88 & 45.69 & 47.21 & 48.98 \\
\hline $\mathrm{A} 12 \mathrm{O} 3$ & 0.02 & 0.02 & 0.00 & 0.00 & 0.65 & 0.01 & 0.00 & 0.02 & 0.04 & 0.00 & 0.02 \\
\hline $\mathrm{FeOt}$ & 48.50 & 48.50 & 42.69 & 42.95 & 41.93 & 46.06 & 47.81 & 47.12 & 48.45 & 47.81 & 43.76 \\
\hline $\mathrm{MnO}$ & 2.26 & 2.26 & 4.05 & 4.13 & 4.10 & 2.43 & 2.40 & 2.42 & 2.05 & 2.40 & 3.10 \\
\hline $\mathrm{MgO}$ & 0.20 & 0.20 & 0.12 & 0.13 & 0.17 & 0.12 & 0.10 & 0.12 & 0.14 & 0.10 & 0.18 \\
\hline $\mathrm{CaO}$ & 0.02 & 0.02 & 0.03 & 0.37 & 0.03 & 0.03 & 0.03 & 0.01 & 0.00 & 0.03 & 0.03 \\
\hline $\mathrm{Cr} 2 \mathrm{O} 3$ & 0.00 & 0.00 & 0.03 & 0.00 & 0.01 & 0.02 & 0.05 & 0.00 & 0.05 & 0.05 & 0.03 \\
\hline $\mathrm{ZnO}$ & 0.00 & 0.00 & 0.03 & 0.02 & 0.06 & 0.00 & 0.02 & 0.07 & 0.03 & 0.02 & 0.07 \\
\hline $\mathrm{NiO}$ & 0.03 & 0.03 & 0.03 & 0.01 & 0.02 & 0.00 & 0.00 & 0.02 & 0.05 & 0.00 & 0.02 \\
\hline $\mathrm{Nb} 2 \mathrm{O} 3$ & 0.17 & 0.17 & 0.09 & 0.12 & 0.10 & 0.12 & 0.21 & 0.29 & 0.31 & 0.21 & 0.29 \\
\hline Total & 98.51 & 98.51 & 100.01 & 97.22 & 96.94 & 96.86 & 97.83 & 97.95 & 96.80 & 97.83 & 96.51 \\
\hline $\mathrm{Fe} 2 \mathrm{O} 3$ wt. $\%$ & 9.56 & 9.56 & -0.61 & 3.69 & 1.75 & 6.14 & 8.89 & 7.54 & 10.77 & 8.89 & 3.59 \\
\hline $\mathrm{FeO}$ wt. \% & 39.90 & 39.90 & 43.24 & 39.63 & 40.36 & 40.54 & 39.81 & 40.33 & 38.76 & 39.81 & 40.54 \\
\hline Total: & 99.47 & 99.47 & 99.94 & 97.59 & 97.11 & 97.47 & 98.71 & 98.70 & 97.88 & 98.71 & 96.87 \\
\hline \multicolumn{12}{|l|}{ Cations } \\
\hline $\mathrm{Si}$ & 0 & 0 & 0.0002775 & 0.0005431 & 0.0061075 & 0.0008825 & 0 & 0 & 0.0001297 & 0 & 0.0007565 \\
\hline $\mathrm{Ti}$ & 0.907 & 0.907 & 1.004 & 0.963 & 0.966 & 0.938 & 0.912 & 0.925 & 0.891 & 0.912 & 0.961 \\
\hline $\mathrm{Al}$ & 0.000 & 0.000 & 0.000 & 0.000 & 0.020 & 0.000 & 0.000 & 0.001 & 0.001 & 0.000 & 0.001 \\
\hline $\mathrm{Fe}+3$ & 0.183 & 0.183 & -0.012 & 0.072 & 0.034 & 0.120 & 0.172 & 0.146 & 0.210 & 0.172 & 0.070 \\
\hline $\mathrm{Fe}+2$ & 0.850 & 0.850 & 0.912 & 0.857 & 0.873 & 0.880 & 0.855 & 0.866 & 0.841 & 0.855 & 0.884 \\
\hline $\mathrm{Mn}$ & 0.049 & 0.049 & 0.086 & 0.090 & 0.090 & 0.053 & 0.052 & 0.053 & 0.045 & 0.052 & 0.068 \\
\hline $\mathrm{Mg}$ & 0.007 & 0.007 & 0.004 & 0.005 & 0.007 & 0.005 & 0.004 & 0.005 & 0.005 & 0.004 & 0.007 \\
\hline $\mathrm{Ca}$ & 0.001 & 0.001 & 0.001 & 0.010 & 0.001 & 0.001 & 0.001 & 0.000 & 0.000 & 0.001 & 0.001 \\
\hline $\mathrm{Cr}$ & 0.000 & 0.000 & 0.001 & 0.000 & 0.000 & 0.000 & 0.001 & 0.000 & 0.001 & 0.001 & 0.001 \\
\hline $\mathrm{Zn}$ & 0.000 & 0.000 & 0.001 & 0.000 & 0.001 & 0.000 & 0.000 & 0.001 & 0.000 & 0.000 & 0.001 \\
\hline $\mathrm{Ni}$ & 0.001 & 0.001 & 0.001 & 0.000 & 0.000 & 0.000 & 0.000 & 0.000 & 0.001 & 0.000 & 0.000 \\
\hline $\mathrm{Nb}$ & 0.002 & 0.002 & 0.001 & 0.002 & 0.001 & 0.002 & 0.003 & 0.004 & 0.004 & 0.003 & 0.004 \\
\hline Total: & 2.000 & 2.000 & 2.000 & 2.000 & 2.000 & 2.000 & 2.000 & 2.000 & 2.000 & 2.000 & 2.000 \\
\hline \multicolumn{12}{|l|}{ Ilmenita (\%) } \\
\hline * & 90.677 & 90.677 & 100.468 & 96.322 & 97.219 & 93.890 & 91.220 & 92.476 & 89.149 & 91.220 & 96.212 \\
\hline$* *$ & 90.379 & 90.379 & 100.700 & 96.575 & 97.895 & 93.652 & 90.965 & 92.365 & 88.979 & 90.965 & 96.288 \\
\hline
\end{tabular}

*Valores calculados pelo método de Carmichael (1967); ** Valores calculados pelos métodos de Lindsley \& Spencer (1982) 


\begin{tabular}{|c|c|c|c|c|c|c|c|c|c|c|c|}
\hline Amostra & $75 c$ & $75 \mathrm{c}$ & $75 c$ & $75 c$ & $75 \mathrm{c}$ & $75 c$ & $358 \mathrm{c}$ & $358 \mathrm{c}$ & $358 \mathrm{c}$ & $358 \mathrm{c}$ & $358 \mathrm{c}$ \\
\hline Cristal & 2 & 2 & 4 & 4 & 4 & 4 & 8 & 8 & 1 & 1 & 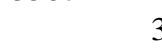 \\
\hline $\begin{array}{l}\text { Assoc. text. } \\
\text { Unidade }\end{array}$ & $\begin{array}{l}\text { Comp } \\
M d f\end{array}$ & $\begin{array}{l}\text { Comp } \\
M d f\end{array}$ & $\begin{array}{l}\text { Sand } \\
M d f\end{array}$ & $\begin{array}{l}\text { Sand } \\
M d f\end{array}$ & $\begin{array}{l}\text { Sand } \\
M d f\end{array}$ & $\begin{array}{l}\text { Sand } \\
M d f\end{array}$ & $\begin{array}{l}\text { Comp } \\
M d f\end{array}$ & $\begin{array}{l}\text { Comp } \\
M d f\end{array}$ & $\begin{array}{l}\text { Comp } \\
M d f\end{array}$ & $\begin{array}{l}\text { Comp } \\
M d f\end{array}$ & $\begin{array}{l}\text { Prox Mt } \\
M d f\end{array}$ \\
\hline $\mathrm{SiO} 2$ & 0.22 & 0.00 & 0.01 & 0.01 & 0.01 & 0.01 & 0.02 & 0.01 & 0.00 & 0.03 & 0.00 \\
\hline $\mathrm{TiO} 2$ & 49.59 & 47.90 & 48.96 & 48.81 & 53.89 & 49.39 & 50.39 & 44.09 & 49.41 & 45.00 & 50.99 \\
\hline $\mathrm{A} 12 \mathrm{O} 3$ & 0.10 & 0.04 & 0.02 & 0.04 & 0.03 & 0.04 & 0.00 & 0.04 & 0.02 & 0.03 & 0.05 \\
\hline $\mathrm{FeOt}$ & 44.48 & 46.55 & 44.89 & 45.89 & 45.23 & 45.31 & 42.12 & 42.64 & 43.37 & 42.93 & 45.85 \\
\hline $\mathrm{MnO}$ & 2.90 & 2.84 & 2.77 & 2.65 & 2.86 & 2.71 & 5.24 & 5.20 & 4.63 & 4.75 & 2.94 \\
\hline $\mathrm{MgO}$ & 0.35 & 0.21 & 0.25 & 0.16 & 0.23 & 0.15 & 0.05 & 0.03 & 0.09 & 0.07 & 0.05 \\
\hline $\mathrm{CaO}$ & 0.13 & 0.02 & 0.04 & 0.02 & 0.00 & 0.06 & 0.22 & 0.17 & 0.17 & 0.09 & 0.02 \\
\hline $\mathrm{Cr} 2 \mathrm{O} 3$ & 0.00 & 0.00 & 0.00 & 0.01 & 0.00 & 0.00 & 0.01 & 0.01 & 0.00 & 0.03 & 0.05 \\
\hline $\mathrm{ZnO}$ & 0.00 & 0.03 & 0.00 & 0.00 & 0.00 & 0.04 & 0.04 & 0.02 & 0.00 & 0.00 & 0.10 \\
\hline $\mathrm{NiO}$ & 0.00 & 0.00 & 0.00 & 0.00 & 0.01 & 0.01 & 0.00 & 0.00 & 0.00 & 0.05 & 0.02 \\
\hline $\mathrm{Nb} 2 \mathrm{O} 3$ & 0.19 & 0.12 & 0.21 & 0.20 & 0.21 & 0.18 & 0.16 & 0.26 & 0.36 & 0.34 & 0.99 \\
\hline Total & 97.95 & 97.71 & 97.16 & 97.79 & 102.46 & 97.91 & 98.24 & 92.47 & 98.04 & 93.32 & 101.04 \\
\hline $\mathrm{Fe} 2 \mathrm{O} 3$ wt. \% & 3.70 & 7.50 & 4.58 & 5.51 & 0.03 & 4.44 & 2.75 & 9.46 & 4.44 & 8.30 & 3.51 \\
\hline $\mathrm{FeO}$ wt. \% & 41.15 & 39.80 & 40.76 & 40.93 & 45.20 & 41.32 & 39.65 & 34.13 & 39.38 & 35.46 & 42.69 \\
\hline Total: & 98.32 & 98.46 & 97.62 & 98.34 & 102.47 & 98.35 & 98.52 & 93.42 & 98.48 & 94.15 & 101.39 \\
\hline \multicolumn{12}{|l|}{ Cations } \\
\hline $\mathrm{Si}$ & 0.006 & 0.000 & 0.000 & 0.000 & 0.000 & 0.000 & 0.000 & 0.000 & 0.000 & 0.001 & 0.000 \\
\hline $\mathrm{Ti}$ & 0.956 & 0.926 & 0.953 & 0.944 & 0.998 & 0.955 & 0.972 & 0.900 & 0.955 & 0.912 & 0.959 \\
\hline $\mathrm{Al}$ & 0.003 & 0.001 & 0.001 & 0.001 & 0.001 & 0.001 & 0.000 & 0.001 & 0.000 & 0.001 & 0.001 \\
\hline $\mathrm{Fe}+3$ & 0.071 & 0.145 & 0.089 & 0.107 & 0.001 & 0.086 & 0.053 & 0.193 & 0.086 & 0.168 & 0.066 \\
\hline $\mathrm{Fe}+2$ & 0.882 & 0.855 & 0.882 & 0.880 & 0.930 & 0.888 & 0.850 & 0.775 & 0.846 & 0.798 & 0.893 \\
\hline $\mathrm{Mn}$ & 0.063 & 0.062 & 0.061 & 0.058 & 0.060 & 0.059 & 0.114 & 0.120 & 0.101 & 0.108 & 0.062 \\
\hline $\mathrm{Mg}$ & 0.013 & 0.008 & 0.009 & 0.006 & 0.008 & 0.006 & 0.002 & 0.001 & 0.003 & 0.003 & 0.002 \\
\hline $\mathrm{Ca}$ & 0.004 & 0.001 & 0.001 & 0.001 & 0.000 & 0.002 & 0.006 & 0.005 & 0.005 & 0.003 & 0.001 \\
\hline $\mathrm{Cr}$ & 0.000 & 0.000 & 0.000 & 0.000 & 0.000 & 0.000 & 0.000 & 0.000 & 0.000 & 0.001 & 0.001 \\
\hline $\mathrm{Zn}$ & 0.000 & 0.000 & 0.000 & 0.000 & 0.000 & 0.001 & 0.001 & 0.000 & 0.000 & 0.000 & 0.002 \\
\hline $\mathrm{Ni}$ & 0.000 & 0.000 & 0.000 & 0.000 & 0.000 & 0.000 & 0.000 & 0.000 & 0.000 & 0.001 & 0.000 \\
\hline $\mathrm{Nb}$ & 0.003 & 0.002 & 0.003 & 0.003 & 0.003 & 0.002 & 0.002 & 0.004 & 0.005 & 0.005 & 0.013 \\
\hline Total: & 2.000 & 2.000 & 2.000 & 2.000 & 2.000 & 2.000 & 2.000 & 2.000 & 2.000 & 2.000 & 2.000 \\
\hline \multicolumn{12}{|l|}{ Ilmenita (\%) } \\
\hline$*$ & 96.160 & 92.604 & 95.358 & 94.470 & 99.789 & 95.523 & 97.232 & 90.087 & 95.452 & 91.227 & 95.934 \\
\hline$* *$ & 96.064 & 92.312 & 95.279 & 94.350 & 99.959 & 95.544 & 97.350 & 89.249 & 95.465 & 90.623 & 96.570 \\
\hline
\end{tabular}

*Valores calculados pelo método de Carmichael (1967); ** Valores calculados pelos métodos de Lindsley \& Spencer (1982) 


\begin{tabular}{|c|c|c|c|c|c|c|c|c|c|c|c|}
\hline Amostra & $358 \mathrm{c}$ & $358 \mathrm{c}$ & $358 \mathrm{c}$ & $358 \mathrm{c}$ & $358 \mathrm{c}$ & $358 \mathrm{c}$ & $400 \mathrm{a}$ & $400 \mathrm{a}$ & $400 \mathrm{a}$ & $400 a$ & $400 \mathrm{a}$ \\
\hline Cristal & 3 & & 3820 & 820 & 120 & 120 & $1 \_1$ & $1 \_1$ & $1 \_1$ & $1 \_1$ & $1 \_2$ \\
\hline Assoc. text. & Prox Mt & Prox Mt & Comp & Comp & Comp & Comp & Comp & Comp & Comp & Comp & Sand \\
\hline Unidade & $M d f$ & $M d f$ & $M d f$ & $M d f$ & $M d f$ & $M d f$ & $M h$ & $M h$ & $M h$ & $M h$ & $M h$ \\
\hline $\mathrm{SiO} 2$ & 0 & 0.01 & 0.299 & 0.299 & 0.042 & 0.04 & 0.018 & 0.005 & 0.02 & 1.714 & 0.03 \\
\hline $\mathrm{TiO} 2$ & 50.55 & 50.86 & 50.89 & 50.89 & 43.05 & 47.18 & 50.17 & 51.09 & 49.61 & 48.56 & 51.30 \\
\hline $\mathrm{A} 12 \mathrm{O} 3$ & 0.02 & 0.06 & 0.20 & 0.20 & 0.02 & 0.03 & 0.02 & 0.01 & 0.03 & 0.25 & 0.04 \\
\hline $\mathrm{FeOt}$ & 48.37 & 45.59 & 42.78 & 42.78 & 40.49 & 39.04 & 43.49 & 44.80 & 44.89 & 40.33 & 43.89 \\
\hline $\mathrm{MnO}$ & 3.11 & 3.33 & 4.98 & 4.98 & 4.53 & 4.98 & 4.81 & 4.59 & 4.61 & 4.97 & 5.28 \\
\hline $\mathrm{MgO}$ & 0.10 & 0.14 & 0.00 & 0.00 & 0.10 & 0.02 & 0.08 & 0.00 & 0.09 & 0.05 & 0.03 \\
\hline $\mathrm{CaO}$ & 0.00 & 0.01 & 0.31 & 0.31 & 1.40 & 1.56 & 0.01 & 0.01 & 0.00 & 1.61 & 0.17 \\
\hline $\mathrm{Cr} 2 \mathrm{O} 3$ & 0.03 & 0.00 & 0.02 & 0.02 & 0.00 & 0.00 & 0.00 & 0.00 & 0.00 & 0.01 & 0.00 \\
\hline $\mathrm{ZnO}$ & 0.04 & 0.05 & 0.00 & 0.00 & 0.00 & 0.02 & 0.00 & 0.04 & 0.03 & 0.10 & 0.04 \\
\hline $\mathrm{NiO}$ & 0.00 & 0.02 & 0.00 & 0.00 & 0.03 & 0.03 & 0.03 & 0.02 & 0.00 & 0.00 & 0.00 \\
\hline $\mathrm{Nb} 2 \mathrm{O} 3$ & 0.73 & 0.52 & 0.14 & 0.14 & 0.32 & 0.41 & 0.21 & 0.24 & 0.18 & 0.05 & 0.10 \\
\hline Total & 102.95 & 100.57 & 99.62 & 99.62 & 89.97 & 93.29 & 98.84 & 100.79 & 99.46 & 97.64 & 100.87 \\
\hline Fe2O3 wt. \% & 6.96 & 3.88 & 2.32 & 2.32 & 9.20 & 4.03 & 3.73 & 3.93 & 5.66 & 2.06 & 3.72 \\
\hline $\mathrm{FeO}$ wt. $\%$ & 42.11 & 42.09 & 40.69 & 40.69 & 32.21 & 35.41 & 40.13 & 41.27 & 39.80 & 38.48 & 40.54 \\
\hline Total: & 103.65 & 100.96 & 99.85 & 99.85 & 90.90 & 93.69 & 99.21 & 101.18 & 100.03 & 97.84 & 101.24 \\
\hline \multicolumn{12}{|l|}{$\overline{\text { Cations }}$} \\
\hline $\mathrm{Si}$ & 0 & 0.000 & 0.008 & 0.008 & 0.001 & 0.001 & 0.000 & 0.000 & 0.001 & 0.044 & 0.001 \\
\hline $\mathrm{Ti}$ & 0.931 & 0.959 & 0.966 & 0.966 & 0.900 & 0.955 & 0.962 & 0.961 & 0.944 & 0.932 & 0.963 \\
\hline $\mathrm{Al}$ & 0.001 & 0.002 & 0.006 & 0.006 & 0.001 & 0.001 & 0.001 & 0.000 & 0.001 & 0.008 & 0.001 \\
\hline $\mathrm{Fe}+3$ & 0.128 & 0.073 & 0.044 & 0.044 & 0.192 & 0.082 & 0.072 & 0.074 & 0.108 & 0.039 & 0.070 \\
\hline $\mathrm{Fe}+2$ & 0.862 & 0.882 & 0.859 & 0.859 & 0.748 & 0.797 & 0.855 & 0.863 & 0.842 & 0.821 & 0.846 \\
\hline $\mathrm{Mn}$ & 0.064 & 0.071 & 0.107 & 0.107 & 0.107 & 0.113 & 0.104 & 0.097 & 0.099 & 0.107 & 0.112 \\
\hline $\mathrm{Mg}$ & 0.004 & 0.005 & 0.000 & 0.000 & 0.004 & 0.001 & 0.003 & 0.000 & 0.003 & 0.002 & 0.001 \\
\hline $\mathrm{Ca}$ & 0 & 0.000 & 0.008 & 0.008 & 0.042 & 0.045 & 0.000 & 0.000 & 0.000 & 0.044 & 0.004 \\
\hline $\mathrm{Cr}$ & 0.001 & 0.000 & 0.000 & 0.000 & 0.000 & 0.000 & 0.000 & 0.000 & 0.000 & 0.000 & 0.000 \\
\hline $\mathrm{Zn}$ & 0.001 & 0.001 & 0.000 & 0.000 & 0.000 & 0.000 & 0.000 & 0.001 & 0.001 & 0.002 & 0.001 \\
\hline $\mathrm{Ni}$ & 0.000 & 0.000 & 0.000 & 0.000 & 0.001 & 0.001 & 0.001 & 0.000 & 0.000 & 0.000 & 0.000 \\
\hline $\mathrm{Nb}$ & 0.009 & 0.007 & 0.002 & 0.002 & 0.005 & 0.006 & 0.003 & 0.003 & 0.002 & 0.001 & 0.001 \\
\hline Total: & 2.000 & 2.000 & 2.000 & 2.000 & 2.000 & 2.000 & 2.000 & 2.000 & 2.000 & 2.000 & 2.000 \\
\hline \multicolumn{12}{|l|}{ Ilmenita (\%) } \\
\hline$*$ & 93.072 & 95.913 & 97.393 & 97.393 & 90.105 & 95.581 & 96.232 & 96.126 & 94.450 & 97.604 & 96.391 \\
\hline$* *$ & 93.157 & 96.097 & 97.561 & 97.561 & 91.271 & 97.829 & 95.996 & 95.941 & 94.020 & 97.791 & 96.302 \\
\hline
\end{tabular}

*Valores calculados pelo método de Carmichael (1967); ** Valores calculados pelos métodos de Lindsley \& Spencer (1982) 


\begin{tabular}{|c|c|c|c|c|c|c|c|c|c|c|c|}
\hline Amostra & $400 \mathrm{a}$ & $400 \mathrm{a}$ & $400 \mathrm{a}$ & $400 \mathrm{a}$ & $26 b$ & $26 b$ & $26 \mathrm{~b}$ & $26 \mathrm{~b}$ & 413 & 413 & $\begin{array}{r}413 \\
5\end{array}$ \\
\hline Cristal & $1 \_3$ & $1 \_3$ & $1 \_3$ & $1 \_3$ & 1 & 1 & 4 & 4 & 6 & 6 & 5 \\
\hline $\begin{array}{l}\text { Assoc. text. } \\
\text { Unidade }\end{array}$ & $\begin{array}{l}\text { Sand } \\
M h\end{array}$ & $\begin{array}{l}\text { Sand } \\
M h\end{array}$ & $\begin{array}{l}\text { Sand } \\
M h\end{array}$ & $\begin{array}{l}\text { Sand } \\
M h\end{array}$ & $\begin{array}{l}\text { Isolado } \\
\text { Sie }\end{array}$ & $\begin{array}{l}\text { Isolado } \\
\text { Sie }\end{array}$ & $\begin{array}{l}\text { Isolado } \\
\text { Sie }\end{array}$ & $\begin{array}{l}\text { Isolado } \\
\text { Sie }\end{array}$ & $\begin{array}{l}\text { Comp (bt) } \\
\text { Qsie }\end{array}$ & $\begin{array}{l}\text { Comp (bt) } \\
\text { Qsie }\end{array}$ & $\begin{array}{l}\text { Comp } \\
\text { Qsie }\end{array}$ \\
\hline $\mathrm{SiO} 2$ & 0.01 & 0.01 & 0.01 & 0.02 & 0.00 & 0.01 & 0.03 & 0.01 & 0.00 & 0.02 & 0.00 \\
\hline $\mathrm{TiO} 2$ & 44.98 & 48.13 & 48.20 & 47.17 & 51.50 & 49.78 & 52.23 & 50.07 & 52.47 & 51.23 & 52.07 \\
\hline $\mathrm{A} 12 \mathrm{O} 3$ & 0.04 & 0.04 & 0.03 & 0.01 & 0.04 & 0.02 & 0.02 & 0.01 & 0.03 & 0.01 & 0.02 \\
\hline $\mathrm{FeOt}$ & 43.44 & 44.46 & 45.96 & 45.32 & 41.60 & 41.28 & 40.79 & 42.86 & 36.22 & 36.67 & 41.66 \\
\hline $\mathrm{MnO}$ & 4.31 & 4.26 & 4.44 & 4.56 & 6.35 & 7.12 & 6.03 & 5.91 & 11.99 & 11.67 & 8.35 \\
\hline $\mathrm{MgO}$ & 0.08 & 0.05 & 0.08 & 0.11 & 0.00 & 0.03 & 0.03 & 0.05 & 0.03 & 0.01 & 0.00 \\
\hline $\mathrm{CaO}$ & 0.01 & 0.00 & 0.04 & 0.00 & 0.06 & 0.08 & 0.05 & 0.00 & 0.01 & 0.01 & 0.10 \\
\hline $\mathrm{Cr} 2 \mathrm{O} 3$ & 0.00 & 0.05 & 0.01 & 0.00 & 0.00 & 0.00 & 0.01 & 0.00 & 0.00 & 0.00 & 0.00 \\
\hline $\mathrm{ZnO}$ & 0.00 & 0.00 & 0.00 & 0.08 & 0.04 & 0.07 & 0.02 & 0.00 & 0.00 & 0.03 & 0.19 \\
\hline $\mathrm{NiO}$ & 0.06 & 0.01 & 0.05 & 0.02 & 0.04 & 0.01 & 0.00 & 0.00 & 0.01 & 0.00 & 0.00 \\
\hline $\mathrm{Nb} 2 \mathrm{O} 3$ & 0.22 & 0.21 & 0.19 & 0.27 & 0.51 & 0.50 & 0.54 & 0.52 & 0.15 & 0.26 & 0.09 \\
\hline Total & 93.16 & 97.21 & 99.02 & 97.55 & 100.13 & 98.91 & 99.74 & 99.43 & 100.90 & 99.91 & 102.46 \\
\hline Fe2O3 wt. \% & 8.32 & 6.17 & 8.10 & 8.60 & 2.02 & 4.35 & 0.00 & 4.30 & 1.37 & 2.70 & 3.96 \\
\hline $\mathrm{FeO}$ wt. $\%$ & 35.96 & 38.90 & 38.67 & 37.58 & 39.78 & 37.37 & 40.79 & 38.99 & 34.99 & 34.24 & 38.09 \\
\hline Total: & 93.99 & 97.83 & 99.83 & 98.41 & 100.34 & 99.35 & 99.74 & 99.86 & 101.04 & 100.18 & 102.86 \\
\hline \multicolumn{12}{|l|}{ Cations } \\
\hline $\mathrm{Si}$ & 0.000 & 0.000 & 0.000 & 0.001 & 0.000 & 0.000 & 0.001 & 0.000 & 0.000 & 0.001 & 0.000 \\
\hline $\mathrm{Ti}$ & 0.913 & 0.937 & 0.920 & 0.914 & 0.977 & 0.954 & 0.995 & 0.955 & 0.986 & 0.972 & 0.963 \\
\hline $\mathrm{Al}$ & 0.001 & 0.001 & 0.001 & 0.000 & 0.001 & 0.001 & 0.001 & 0.000 & 0.001 & 0.000 & 0.001 \\
\hline $\mathrm{Fe}+3$ & 0.169 & 0.120 & 0.155 & 0.167 & 0.038 & 0.083 & 0.000 & 0.082 & 0.026 & 0.051 & 0.073 \\
\hline $\mathrm{Fe}+2$ & 0.811 & 0.842 & 0.821 & 0.810 & 0.839 & 0.796 & 0.864 & 0.827 & 0.731 & 0.722 & 0.783 \\
\hline $\mathrm{Mn}$ & 0.099 & 0.093 & 0.096 & 0.099 & 0.136 & 0.154 & 0.129 & 0.127 & 0.254 & 0.249 & 0.174 \\
\hline $\mathrm{Mg}$ & 0.003 & 0.002 & 0.003 & 0.004 & 0.000 & 0.001 & 0.001 & 0.002 & 0.001 & 0.000 & 0.000 \\
\hline $\mathrm{Ca}$ & 0.000 & 0.000 & 0.001 & 0.000 & 0.002 & 0.002 & 0.001 & 0.000 & 0.000 & 0.000 & 0.003 \\
\hline $\mathrm{Cr}$ & 0.000 & 0.001 & 0.000 & 0.000 & 0.000 & 0.000 & 0.000 & 0.000 & 0.000 & 0.000 & 0.000 \\
\hline $\mathrm{Zn}$ & 0.000 & 0.000 & 0.000 & 0.002 & 0.001 & 0.001 & 0.000 & 0.000 & 0.000 & 0.001 & 0.003 \\
\hline $\mathrm{Ni}$ & 0.001 & 0.000 & 0.001 & 0.000 & 0.001 & 0.000 & 0.000 & 0.000 & 0.000 & 0.000 & 0.000 \\
\hline $\mathrm{Nb}$ & 0.003 & 0.003 & 0.003 & 0.004 & 0.007 & 0.007 & 0.007 & 0.007 & 0.002 & 0.003 & 0.001 \\
\hline Total: & 2.000 & 2.000 & 2.000 & 2.000 & 2.000 & 2.000 & 2.000 & 2.000 & 2.000 & 2.000 & 2.000 \\
\hline \multicolumn{12}{|l|}{ Ilmenita (\%) } \\
\hline$*$ & 91.303 & 93.732 & 92.048 & 91.458 & 97.674 & 95.461 & 99.609 & 95.540 & 98.574 & 97.254 & 96.254 \\
\hline$* *$ & 90.607 & 93.337 & 91.467 & 90.767 & 97.911 & 95.229 & 100.060 & 95.263 & 98.297 & 96.592 & 95.912 \\
\hline
\end{tabular}

*Valores calculados pelo método de Carmichael (1967); ** Valores calculados pelos métodos de Lindsley \& Spencer (1982) 


\begin{tabular}{|c|c|c|c|c|c|c|c|c|c|}
\hline Amostra & 413 & 413 & 413 & 270 & 270 & 270 & 270 & 270 & 270 \\
\hline Cristal & 5 & 5 & 3 & 3 & 3 & 8 & 8 & 8 & 8 \\
\hline $\begin{array}{l}\text { Assoc. text. } \\
\text { Unidade }\end{array}$ & $\begin{array}{l}\text { Comp } \\
\text { Qsie }\end{array}$ & $\begin{array}{l}\text { Comp } \\
\text { Qsie } \\
\end{array}$ & $\begin{array}{l}\text { Patch } \\
\text { Qsie }\end{array}$ & Qsie & Qsie & $\begin{array}{l}\text { Comp } \\
\text { Qsie }\end{array}$ & $\begin{array}{l}\text { Comp } \\
\text { Qsie }\end{array}$ & $\begin{array}{l}\text { Comp } \\
\text { Qsie }\end{array}$ & $\begin{array}{l}\text { Comp } \\
\text { Qsie } \\
\end{array}$ \\
\hline $\mathrm{SiO} 2$ & 0.00 & 0.01 & 0.04 & 0.01 & 0.18 & 0.02 & 0.02 & 0.02 & 0.02 \\
\hline $\mathrm{TiO} 2$ & 51.60 & 52.73 & 50.67 & 51.06 & 50.03 & 52.66 & 50.94 & 52.66 & 52.66 \\
\hline $\mathrm{Al} 2 \mathrm{O} 3$ & 0.02 & 0.02 & 0.05 & 0.01 & 0.04 & 0.04 & 0.04 & 0.04 & 0.04 \\
\hline $\mathrm{FeOt}$ & 38.37 & 39.24 & 37.53 & 39.69 & 38.09 & 40.23 & 40.47 & 40.23 & 40.23 \\
\hline $\mathrm{MnO}$ & 8.14 & 8.25 & 12.15 & 8.69 & 9.48 & 8.70 & 8.52 & 8.76 & 8.76 \\
\hline $\mathrm{MgO}$ & 0.00 & 0.02 & 0.03 & 0.02 & 0.05 & 0.02 & 0.04 & 0.02 & 0.02 \\
\hline $\mathrm{CaO}$ & 0.05 & 0.03 & 0.01 & 0.01 & 0.04 & 0.00 & 0.01 & 0.00 & 0.00 \\
\hline $\mathrm{Cr} 2 \mathrm{O} 3$ & 0.03 & 0.00 & 0.00 & 0.03 & 0.00 & 0.01 & 0.00 & 0.01 & 0.01 \\
\hline $\mathrm{ZnO}$ & 0.24 & 0.15 & 0.01 & 0.00 & 0.23 & 0.06 & 0.04 & 0.06 & 0.06 \\
\hline $\mathrm{NiO}$ & 0.00 & 0.01 & 0.02 & 0.04 & 0.00 & 0.00 & 0.00 & 0.00 & 0.00 \\
\hline $\mathrm{Nb} 2 \mathrm{O} 3$ & 0.09 & 0.07 & 0.09 & 0.57 & 0.68 & 0.48 & 0.39 & 0.48 & 0.48 \\
\hline Total & 98.54 & 100.53 & 100.57 & 100.12 & 98.81 & 102.21 & 100.47 & 102.27 & 102.27 \\
\hline Fe2O3 wt. \% & 0.52 & 0.40 & 4.74 & 2.88 & 3.11 & 1.93 & 3.75 & 2.00 & 2.00 \\
\hline $\mathrm{FeO}$ wt. $\%$ & 37.90 & 38.88 & 33.26 & 37.10 & 35.29 & 38.49 & 37.10 & 38.43 & 38.43 \\
\hline Total: & 98.60 & 100.57 & 101.04 & 100.41 & 99.12 & 102.40 & 100.84 & 102.47 & 102.47 \\
\hline \multicolumn{10}{|l|}{$\overline{\text { Cations }}$} \\
\hline $\mathrm{Si}$ & 0.000 & 0.000 & 0.001 & 0.000 & 0.005 & 0.000 & 0.001 & 0.000 & 0.000 \\
\hline $\mathrm{Ti}$ & 0.994 & 0.995 & 0.953 & 0.968 & 0.960 & 0.978 & 0.961 & 0.977 & 0.977 \\
\hline $\mathrm{Al}$ & 0.001 & 0.001 & 0.001 & 0.000 & 0.001 & 0.001 & 0.001 & 0.001 & 0.001 \\
\hline $\mathrm{Fe}+3$ & 0.010 & 0.008 & 0.089 & 0.055 & 0.060 & 0.036 & 0.071 & 0.037 & 0.037 \\
\hline $\mathrm{Fe}+2$ & 0.811 & 0.816 & 0.696 & 0.782 & 0.753 & 0.795 & 0.778 & 0.793 & 0.793 \\
\hline $\mathrm{Mn}$ & 0.177 & 0.175 & 0.257 & 0.185 & 0.205 & 0.182 & 0.181 & 0.183 & 0.183 \\
\hline $\mathrm{Mg}$ & 0.000 & 0.001 & 0.001 & 0.001 & 0.002 & 0.001 & 0.001 & 0.001 & 0.001 \\
\hline $\mathrm{Ca}$ & 0.001 & 0.001 & 0.000 & 0.000 & 0.001 & 0.000 & 0.000 & 0.000 & 0.000 \\
\hline $\mathrm{Cr}$ & 0.001 & 0.000 & 0.000 & 0.001 & 0.000 & 0.000 & 0.000 & 0.000 & 0.000 \\
\hline $\mathrm{Zn}$ & 0.004 & 0.003 & 0.000 & 0.000 & 0.004 & 0.001 & 0.001 & 0.001 & 0.001 \\
\hline $\mathrm{Ni}$ & 0.000 & 0.000 & 0.000 & 0.001 & 0.000 & 0.000 & 0.000 & 0.000 & 0.000 \\
\hline $\mathrm{Nb}$ & 0.001 & 0.001 & 0.001 & 0.007 & 0.009 & 0.006 & 0.005 & 0.006 & 0.006 \\
\hline Total: & 2.000 & 2.000 & 2.000 & 2.000 & 2.000 & 2.000 & 2.000 & 2.000 & 2.000 \\
\hline \multicolumn{10}{|l|}{ Ilmenita (\%) } \\
\hline$*$ & 99.380 & 99.541 & 95.401 & 96.836 & 96.502 & 97.837 & 96.161 & 97.773 & 97.773 \\
\hline$* *$ & 99.743 & 99.744 & 93.947 & 96.622 & 96.248 & 97.843 & 95.701 & 97.762 & 97.762 \\
\hline
\end{tabular}

*Valores calculados pelo método de Carmichael (1967); ** Valores calculados pelos métodos de Lindsley \& Spencer (1982) 
ANEXO 2

TABELAS DE ANÁLISES QUÍMICAS DE ROCHA TOTAL 
Tabela A05. Composição química (óxidos \% peso; traços, ppm) das rochas do Plúton Piracaia por Fluorescência de Raios X

\begin{tabular}{|c|c|c|c|c|c|c|c|c|c|c|c|c|c|c|c|}
\hline $\begin{array}{l}\text { Amostra } \\
\text { Unidade }\end{array}$ & $\begin{array}{c}\text { PIA-01* } \\
\text { Qsie }\end{array}$ & $\begin{array}{l}\text { PIA-02* } \\
\quad M d f\end{array}$ & $\begin{array}{c}\text { PIA- } 03^{*} \\
\quad M d f\end{array}$ & $\begin{array}{c}\text { PIA-04* } \\
\quad M d f\end{array}$ & $\begin{array}{c}\text { PIA-07* } \\
M d f\end{array}$ & $\begin{array}{c}\text { PI-574* } \\
\quad M d f\end{array}$ & $\begin{array}{c}\text { PI-576* } \\
M d f\end{array}$ & $\begin{array}{c}\text { PI-582* } \\
\text { Mdf }\end{array}$ & $\begin{array}{c}\text { PI-589A* } \\
M d f\end{array}$ & $\begin{array}{c}\text { PI-589B* } \\
\quad M d f\end{array}$ & $\begin{array}{l}\text { PI-598A* } \\
\quad M d f\end{array}$ & $\begin{array}{c}\text { PI-598B* } \\
\text { Qsie }\end{array}$ & $\begin{array}{c}\mathrm{PI}-602 * \\
\text { Sie }\end{array}$ & $\begin{array}{c}\text { PI-605* } \\
M d r\end{array}$ & $\begin{array}{c}\mathrm{PI}-609^{*} \\
M d r\end{array}$ \\
\hline $\mathrm{SiO}_{2}$ & 61.74 & 51.46 & 51.20 & 53.95 & 51.00 & 57.76 & 54.63 & 60.91 & 46.41 & 45.50 & 52.18 & 57.50 & 59.55 & 50.33 & 47.99 \\
\hline $\mathrm{Al}_{2} \mathrm{O}_{3}$ & 18.00 & 17.66 & 17.54 & 18.37 & 17.48 & 17.30 & 17.55 & 16.91 & 17.57 & 17.43 & 17.88 & 19.22 & 17.79 & 17.97 & 17.73 \\
\hline $\mathrm{FeO}_{\mathrm{t}}$ & 3.88 & 8.62 & 8.66 & 7.64 & 9.19 & 6.80 & 7.15 & 5.34 & 11.49 & 11.89 & 8.46 & 5.42 & 5.54 & 9.87 & 10.53 \\
\hline $\mathrm{MnO}$ & 0.07 & 0.15 & 0.15 & 0.13 & 0.16 & 0.14 & 0.14 & 0.11 & 0.16 & 0.16 & 0.16 & 0.08 & 0.14 & 0.16 & 0.17 \\
\hline $\mathrm{MgO}$ & 0.77 & 3.04 & 3.04 & 2.20 & 3.31 & 1.68 & 2.47 & 1.31 & 4.43 & 4.84 & 2.84 & 1.35 & 0.88 & 3.42 & 3.79 \\
\hline $\mathrm{CaO}$ & 2.32 & 5.74 & 5.86 & 4.20 & 5.44 & 3.15 & 4.48 & 2.78 & 7.20 & 7.35 & 5.00 & 3.24 & 2.33 & 5.98 & 6.64 \\
\hline $\mathrm{Na}_{2} \mathrm{O}$ & 4.41 & 4.45 & 4.14 & 4.64 & 4.44 & 4.56 & 4.21 & 3.94 & 3.49 & 3.37 & 4.37 & 5.36 & 4.91 & 4.08 & 3.89 \\
\hline $\mathrm{K}_{2} \mathrm{O}$ & 6.83 & 3.91 & 4.44 & 4.97 & 4.29 & 5.32 & 4.94 & 5.86 & 3.70 & 3.40 & 4.73 & 4.82 & 6.59 & 3.87 & 3.77 \\
\hline $\mathrm{TiO}_{2}$ & 0.61 & 1.82 & 1.79 & 1.50 & 1.61 & 0.94 & 1.49 & 0.96 & 2.24 & 2.66 & 1.54 & 0.97 & 0.90 & 1.86 & 2.13 \\
\hline $\mathrm{P}_{2} \mathrm{O}_{5}$ & 0.22 & 1.00 & 0.99 & 0.63 & 1.27 & 0.65 & 0.82 & 0.36 & 1.48 & 1.43 & 1.11 & 0.44 & 0.29 & 1.14 & 1.47 \\
\hline $\mathrm{PF}$ & 0.57 & 0.78 & 0.56 & 0.40 & 0.46 & 0.40 & 0.64 & 0.72 & 0.98 & 0.76 & 0.76 & 0.38 & 0.42 & 0.66 & 0.83 \\
\hline Total & 99.42 & 98.64 & 98.36 & 98.63 & 98.65 & 98.71 & 98.51 & 99.20 & 99.15 & 98.78 & 99.02 & 98.78 & 99.35 & 99.35 & 98.93 \\
\hline mg\# & 16.56 & 26.07 & 25.98 & 22.36 & 26.48 & 19.81 & 25.68 & 19.70 & 27.83 & 28.93 & 25.13 & 19.94 & 13.71 & 25.73 & 26.47 \\
\hline $\mathrm{Ba}$ & 3077 & 4270 & 4590 & 4452 & 3759 & 2981 & 4754 & 2663 & 5486 & 6044 & 3772 & 3726 & 1634 & 4672 & 4982 \\
\hline $\mathrm{Rb}$ & 128 & 110 & 106 & 107 & 97 & 152 & 117 & 173 & 90 & 84 & 121 & 95 & 132 & 97 & 97 \\
\hline $\mathrm{Sr}$ & 825 & 1114 & 1203 & 1162 & 1182 & 693 & 943 & 513 & 1471 & 1352 & 1147 & 1186 & 264 & 1317 & 1253 \\
\hline $\mathrm{Zr}$ & 367 & 228 & 228 & 279 & 290 & 313 & 329 & 478 & 147 & 81 & 274 & 628 & 462 & 212 & 121 \\
\hline $\mathrm{Ni}$ & $<5$ & $<5$ & $<5$ & $<5$ & $<5$ & $<5$ & $<5$ & $<5$ & 6.3 & 10.1 & $<5$ & $<5$ & $<5$ & $<5$ & \\
\hline Co & $<6$ & 17.3 & 14.4 & 9 & 15.4 & 7.6 & 11.5 & 8.5 & 24.8 & 28.8 & 12.7 & 6 & & 11.5 & 16.6 \\
\hline $\mathrm{Cr}$ & $<13$ & $<13$ & $<13$ & $<13$ & $<13$ & $<13$ & $<13$ & $<13$ & $<13$ & $<13$ & $<13$ & $<13$ & $<13$ & $<13$ & $<13$ \\
\hline $\mathrm{Cu}$ & $<5$ & 10.4 & 13.5 & 7.3 & 10.1 & 5.4 & 6.2 & 6.9 & 20.2 & 29.3 & 8.6 & 6 & $<5$ & 17.3 & 11 \\
\hline $\mathrm{Ga}$ & 16 & 15 & 15 & 16 & 17 & 18 & 16 & 19 & 15 & 16 & 18 & 16 & 19 & 17 & 17 \\
\hline $\mathrm{Nb}$ & 15.7 & 28.6 & 27.9 & 19 & 32.5 & 46.4 & 34.5 & 39.5 & 24.6 & 21.1 & 37.8 & 28.0 & 49.0 & 25.8 & 26.3 \\
\hline Sc & $<14$ & 16 & 15 & $<14$ & 17 & $<14$ & 16 & $<14$ & 23 & 23 & 14 & $<14$ & $<14$ & 16 & 20 \\
\hline V & 45 & 118 & 118 & 63 & 110 & 35 & 83 & 59 & 215 & 270 & 85 & 44 & $<9$ & 136 & 126 \\
\hline$Y$ & 20 & 26 & 26 & 14 & 29 & 34 & 29 & 31 & 27 & 28 & 32 & 29 & 35 & 27 & 36 \\
\hline $\mathrm{Zn}$ & 49 & 78 & 76 & 74 & 92 & 87 & 79 & 76 & 102 & 112 & 91 & 63 & 85 & 91 & 107 \\
\hline $\mathrm{U}$ & $<3$ & $<3$ & $<3$ & $<3$ & $<3$ & $<3$ & $<3$ & 2.7 & $<3$ & $<3$ & $<3$ & $<3$ & & & $<3$ \\
\hline Th & 13.9 & 8.2 & 8.9 & 7.1 & 8.6 & 10.6 & 6.9 & $<7$ & 9.6 & 8.3 & 9.2 & 20 & $<7$ & $<7$ & 8.2 \\
\hline $\mathrm{Pb}$ & 15.1 & 12.1 & 14.2 & 11.3 & 16.7 & 13.4 & 13.6 & 14.1 & 15.8 & 15.6 & $<5$ & 16.0 & 12.4 & 16.5 & 15.6 \\
\hline $\mathrm{La}$ & 143.2 & 56.0 & 44.2 & 75.7 & 56.9 & 120.9 & 62.3 & $<28$ & 44.1 & 70.0 & 82.9 & 256.0 & 95.8 & 64.7 & 73.4 \\
\hline $\mathrm{Ce}$ & 247.9 & 116.9 & 109.7 & 132.3 & 85.8 & 185.6 & 119.9 & 58.0 & 120.8 & 97.8 & 155.8 & 424.0 & 153.7 & 100.1 & 127.6 \\
\hline $\mathrm{Nd}$ & 52.7 & 51.4 & 44.3 & 36.4 & 64.2 & 58.4 & 47.1 & 41.2 & 71.1 & 80.8 & 51.4 & 47.0 & 54.9 & 65.3 & 74.9 \\
\hline $\mathrm{Ba} / \mathrm{Sr}$ & 4 & 3.8 & 3.8 & 3.8 & 3.2 & 4.3 & 5.0 & 5.2 & 3.7 & 4.5 & 3.3 & 3.1 & 6.2 & 3.5 & 4.0 \\
\hline
\end{tabular}

Análises com (*) foram obtidas no presente trabalho, sendo as demais do banco de dados do orientador 
Tabela A05. Continuação. Composição química (óxidos \% peso; traços, ppm) para as rochas do Plúton Piracaia (XRF)

\begin{tabular}{|c|c|c|c|c|c|c|c|c|c|c|c|c|}
\hline $\begin{array}{l}\text { Amostra } \\
\text { Unidade }\end{array}$ & $\begin{array}{c}\text { PI-614* } \\
\text { Mdf }\end{array}$ & $\begin{array}{c}\mathrm{PI}-621^{*} \\
M d f\end{array}$ & $\begin{array}{l}\text { MIX-01* } \\
\text { Qz sienito }\end{array}$ & $\begin{array}{l}\text { MIX-02* } \\
\text { monzonito }\end{array}$ & $\begin{array}{l}\text { MIX-03* } \\
\text { monzonito }\end{array}$ & $\begin{array}{c}\text { MIX-04* } \\
\text { monzodiorito }\end{array}$ & $\begin{array}{c}\text { MIX-05* } \\
\text { monzodiorito }\end{array}$ & $\begin{array}{c}\mathrm{PI}-257 \mathrm{c} \\
M d r \\
\end{array}$ & $\begin{array}{l}\mathrm{PI}-256 \\
M d r\end{array}$ & $\begin{array}{l}\text { PI-41c } \\
M d f\end{array}$ & $\begin{array}{l}\text { PI-75 } \\
M d f \\
\end{array}$ & $\begin{array}{l}\text { PI-15 } \\
M d f\end{array}$ \\
\hline$\overline{\mathrm{SiO}_{2}}$ & 54.80 & 49.90 & 61.69 & 52.71 & 54.04 & 52.26 & 50.94 & 43.63 & 54.44 & 48.92 & 50.85 & 50.85 \\
\hline $\mathrm{Al}_{2} \mathrm{O}_{3}$ & 16.91 & 17.42 & 18.23 & 15.53 & 18.07 & 17.92 & 17.79 & 17.74 & 19.15 & 17.42 & 18.19 & 17.84 \\
\hline $\mathrm{FeO}_{\mathrm{t}}$ & 7.79 & 9.92 & 2.30 & 7.75 & 6.62 & 7.81 & 8.14 & 11.70 & 6.62 & 10.34 & 8.99 & 9.04 \\
\hline $\mathrm{MnO}$ & 0.14 & 0.16 & 0.03 & 0.21 & 0.15 & 0.17 & 0.16 & 0.18 & 0.12 & 0.17 & 0.16 & 0.16 \\
\hline $\mathrm{MgO}$ & 2.63 & 3.51 & 0.47 & 3.12 & 2.43 & 2.95 & 3.11 & 4.85 & 1.94 & 3.76 & 3.09 & 2.90 \\
\hline $\mathrm{CaO}$ & 4.68 & 5.94 & 2.10 & 6.57 & 5.02 & 5.06 & 5.56 & 8.18 & 4.87 & 6.57 & 5.52 & 5.31 \\
\hline $\mathrm{Na}_{2} \mathrm{O}$ & 4.13 & 4.24 & 3.64 & 3.62 & 5.01 & 4.55 & 4.34 & 3.18 & 4.54 & 3.80 & 4.01 & 3.99 \\
\hline $\mathrm{K}_{2} \mathrm{O}$ & 4.56 & 4.29 & 8.54 & 4.71 & 3.96 & 4.42 & 4.36 & 3.21 & 4.57 & 4.10 & 4.59 & 4.85 \\
\hline $\mathrm{TiO}_{2}$ & 1.54 & 1.75 & 0.55 & 1.47 & 1.32 & 1.56 & 1.64 & 2.69 & 1.17 & 2.05 & 1.66 & 1.54 \\
\hline $\mathrm{P}_{2} \mathrm{O}_{5}$ & 0.91 & 1.49 & 0.15 & 1.44 & 0.92 & 1.17 & 1.25 & 1.85 & 0.65 & 1.40 & 0.97 & 1.09 \\
\hline $\mathrm{PF}$ & 0.48 & 0.76 & 0.64 & 0.70 & 0.62 & 0.64 & 0.92 & 1.06 & 0.74 & & 0.82 & 0.69 \\
\hline Total & 98.57 & 99.38 & 98.35 & 97.83 & 98.16 & 98.50 & 98.21 & 98.26 & 98.82 & 98.53 & 98.84 & 98.26 \\
\hline mg\# & 25.24 & 26.14 & 0.17 & 0.29 & 0.27 & 0.27 & 0.28 & 29.31 & 22.66 & 26.67 & 25.58 & 24.29 \\
\hline $\mathrm{Ba}$ & 3617 & 3772 & 7434 & 3846 & 2674 & 3204 & 3871 & 6195 & 3574 & 4958 & 4181 & 3944 \\
\hline $\mathrm{Rb}$ & 132 & 98 & 103 & 82 & 94 & 120 & 128 & 89 & & & 118 & 134 \\
\hline $\mathrm{Sr}$ & 854 & 1218 & 103 & 82 & 94 & 120 & 128 & 1530 & 1115 & 1262 & 1138 & 1067 \\
\hline $\mathrm{Zr}$ & 269 & 258 & 101 & 1288 & 697 & 268 & 302 & 92 & 215 & 237 & 302 & 328 \\
\hline $\mathrm{Ni}$ & $<5$ & $<5$ & $<5$ & $<5$ & $<5$ & $<5$ & $<5$ & $<5$ & & & $<5$ & \\
\hline Co & 13 & 16.4 & & 12.9 & 10.0 & 14.9 & 16.3 & 39 & & & 20 & 18 \\
\hline $\mathrm{Cr}$ & $<13$ & $<13$ & $<13$ & $<13$ & $<13$ & $<13$ & $<13$ & $<13$ & & & $<13$ & \\
\hline $\mathrm{Cu}$ & 8.7 & 12.8 & $<5$ & 11 & 6 & 9 & 9 & 6 & & & 20 & 9 \\
\hline $\mathrm{Ga}$ & 17 & 16 & 13 & 17 & 20 & 18 & 16 & 17 & & & 19 & 19 \\
\hline $\mathrm{Nb}$ & 34.6 & 30.7 & 24.5 & 63.9 & 39.1 & 36.1 & 33.2 & 20.0 & & & 33.0 & 37.0 \\
\hline $\mathrm{Sc}$ & 16 & 16 & $<14$ & 26 & 15 & 15 & 17 & 22 & & & 15 & 15 \\
\hline V & 120 & 128 & 33 & 96 & 92 & 102 & 122 & 173 & & & 125 & 116 \\
\hline $\mathrm{Y}$ & 27 & 29 & 22 & 85 & 45 & 32 & 30 & 30 & & & 30 & 33 \\
\hline $\mathrm{Zn}$ & 81 & 93 & 21 & 89 & 80 & 96 & 91 & 109 & & & 93 & 96 \\
\hline $\mathrm{U}$ & $<3$ & $<3$ & $<3$ & 7 & $<3$ & $<3$ & $<3$ & $<3$ & & & $<3$ & 12 \\
\hline Th & 8.4 & 8.9 & 7.1 & 29.0 & 21.9 & 10.2 & 9.2 & 14.0 & & & 10.0 & 11.0 \\
\hline $\mathrm{Pb}$ & 13.4 & 14.7 & 19.1 & 22.7 & 16.8 & 16.3 & 17.0 & 13.0 & & & 14.0 & 16.0 \\
\hline $\mathrm{La}$ & 55.9 & 77.5 & $<28$ & 249.3 & 168.3 & 55.2 & 82.1 & 61.0 & & & 72.0 & 78.0 \\
\hline $\mathrm{Ce}$ & 100.6 & 130.6 & $<35$ & 439.9 & 336.8 & 91.2 & 127.6 & 126.0 & & & 114.0 & 110.0 \\
\hline $\mathrm{Nd}$ & 50.6 & 60.0 & 26.9 & 150.3 & 77.7 & 63.5 & 64.4 & 56.0 & & & 59.0 & 65.0 \\
\hline $\mathrm{Ba} / \mathrm{Sr}$ & 4.2 & 3.1 & 71.9 & 47.0 & 28.4 & 26.6 & 30.4 & 4.0 & 3.2 & 3.9 & 3.7 & 3.7 \\
\hline
\end{tabular}

Análises com (*) foram obtidas no presente trabalho, sendo as demais do banco de dados do orientador 
Tabela A05. Continuação. Composição química (óxidos \% peso; traços, ppm) para as rochas do Plúton Piracaia (XRF)

\begin{tabular}{|c|c|c|c|c|c|c|c|c|c|c|c|c|c|c|c|}
\hline $\begin{array}{l}\text { Amostra } \\
\text { Unidade }\end{array}$ & $\begin{array}{l}\text { PI-5c } \\
M d f\end{array}$ & $\begin{array}{c}\text { PI-436 } \\
M d f\end{array}$ & $\begin{array}{c}\text { PI-112 } \\
M d f\end{array}$ & $\begin{array}{c}\text { PI-171a } \\
M d f\end{array}$ & $\begin{array}{c}\mathrm{PI}-256 \mathrm{c} \\
M d f\end{array}$ & $\begin{array}{c}\text { PI-172b } \\
M d f\end{array}$ & $\begin{array}{l}\text { PI-18a } \\
M d f\end{array}$ & $\begin{array}{c}\text { PI-428 } \\
M d f\end{array}$ & $\begin{array}{c}\mathrm{PI}-405 \\
M d f\end{array}$ & $\begin{array}{c}\text { PI-179b } \\
M d f\end{array}$ & $\begin{array}{c}\text { PI-176 } \\
M d f\end{array}$ & $\begin{array}{c}\text { PI-358a } \\
M d f\end{array}$ & $\begin{array}{c}\text { PI-171b } \\
M d f\end{array}$ & $\begin{array}{c}\text { PI-47b } \\
M d f\end{array}$ & $\begin{array}{c}\text { PI-281a } \\
M d f\end{array}$ \\
\hline $\mathrm{SiO}_{2}$ & 52.50 & 52.91 & 53.08 & 46.78 & 52.53 & 50.69 & 51.19 & 52.63 & 53.82 & 53.89 & 54.51 & 55.04 & 56.75 & 53.08 & 55.63 \\
\hline $\mathrm{Al}_{2} \mathrm{O}_{3}$ & 17.90 & 17.44 & 17.38 & 17.91 & 17.21 & 17.75 & 17.39 & 17.75 & 17.29 & 17.85 & 17.27 & 17.91 & 18.75 & 17.30 & 17.10 \\
\hline $\mathrm{FeO}_{\mathrm{t}}$ & 8.57 & 8.69 & 7.84 & 10.57 & 8.44 & 8.84 & 8.80 & 8.39 & 7.83 & 7.83 & 7.85 & 7.35 & 6.57 & 7.99 & 7.36 \\
\hline $\mathrm{MnO}$ & 0.14 & 0.14 & 0.15 & 0.15 & 0.18 & 0.14 & 0.16 & 0.16 & 0.16 & 0.15 & 0.14 & 0.14 & 0.08 & 0.16 & 0.12 \\
\hline $\mathrm{MgO}$ & 3.50 & 2.76 & 2.82 & 4.47 & 2.75 & 3.54 & 2.95 & 2.53 & 2.35 & 2.44 & 2.61 & 2.18 & 1.50 & 2.63 & 2.26 \\
\hline $\mathrm{CaO}$ & 5.60 & 4.56 & 5.33 & 6.64 & 5.19 & 5.41 & 5.35 & 4.46 & 4.54 & 4.57 & 4.57 & 4.28 & 3.65 & 4.80 & 4.19 \\
\hline $\mathrm{Na}_{2} \mathrm{O}$ & 4.00 & 3.77 & 4.11 & 4.13 & 3.98 & 4.41 & 4.61 & 4.61 & 4.70 & 4.32 & 4.05 & 4.70 & 4.49 & 4.37 & 3.98 \\
\hline $\mathrm{K}_{2} \mathrm{O}$ & 4.50 & 4.67 & 4.34 & 3.46 & 4.37 & 4.15 & 4.06 & 4.55 & 4.63 & 4.71 & 4.86 & 4.95 & 5.17 & 4.99 & 5.17 \\
\hline $\mathrm{TiO}_{2}$ & 1.80 & 1.64 & 1.91 & 2.27 & 1.45 & 1.69 & 1.95 & 1.80 & 1.71 & 1.43 & 1.36 & 1.33 & 0.92 & 1.42 & 1.39 \\
\hline $\mathrm{P}_{2} \mathrm{O}_{5}$ & 0.93 & 1.08 & 0.78 & 0.99 & 1.09 & 0.83 & 1.10 & 0.89 & 0.80 & 0.85 & 0.72 & 0.74 & 0.47 & 1.06 & 0.76 \\
\hline $\mathrm{PF}$ & 0.77 & 0.72 & 0.90 & 1.50 & 1.37 & 1.42 & 0.75 & 0.62 & 0.62 & 0.88 & 0.87 & 0.66 & 0.92 & 1.14 & 0.60 \\
\hline Total & 100.21 & 98.38 & 98.65 & 98.87 & 98.55 & 98.86 & 98.31 & 98.38 & 98.45 & 98.92 & 98.81 & 99.29 & 99.27 & 98.94 & 98.56 \\
\hline $\mathrm{mg} \#$ & 29.01 & 24.10 & 26.45 & 29.72 & 24.58 & 28.59 & 25.11 & 23.17 & 23.08 & 23.76 & 24.95 & 22.88 & 18.59 & 24.76 & 23.49 \\
\hline $\mathrm{Ba}$ & 4468 & 4218 & 4505 & 4835 & 3576 & 4408 & 5339 & 4410 & 4677 & 3877 & 3818 & 3479 & 3897 & 3509 & 3499 \\
\hline $\mathrm{Rb}$ & & 130 & 106 & 81 & 96 & 125 & 89 & 126 & 108 & 120 & 152 & 124 & 103 & 116 & 172 \\
\hline $\mathrm{Sr}$ & 1271 & 957 & 1157 & 1307 & 1007 & 1111 & 998 & 920 & 805 & 950 & 1018 & 954 & 992 & 1033 & 928 \\
\hline $\mathrm{Zr}$ & 235 & 219 & 97 & 124 & 101 & 290 & 239 & 294 & 317 & 233 & 257 & 238 & 709 & 290 & 301 \\
\hline $\mathrm{Ni}$ & & $<5$ & $<5$ & 18 & & 14 & & $<5$ & & $<5$ & & 5 & $<5$ & $<5$ & \\
\hline Co & & 17 & 11 & 35 & 15 & 43 & 15 & 11 & 11 & 13 & 17 & 11 & 43 & 24 & 13 \\
\hline $\mathrm{Cr}$ & & $<13$ & $<13$ & $<13$ & & $<13$ & & $<13$ & & $<13$ & & $<13$ & $<13$ & $<13$ & \\
\hline $\mathrm{Cu}$ & & 15 & 21 & 26 & 7 & 17 & $<5$ & 5 & 5 & 21 & 10 & 20 & 5 & 7 & 9 \\
\hline $\mathrm{Ga}$ & & 20 & 17 & 19 & 17 & 18 & 19 & 19 & 20 & 18 & 17 & 20 & 20 & 17 & 21 \\
\hline $\mathrm{Nb}$ & & 31.0 & 26.0 & 24.0 & 25.0 & 29.0 & 34.0 & 38.0 & 38.0 & 32.0 & 33.0 & 25.0 & 17.0 & 35.0 & 43.0 \\
\hline $\mathrm{Sc}$ & & $<14$ & 19 & 20 & & 18 & 15 & $<14$ & 16 & 17 & & $<14$ & $<14$ & 16 & \\
\hline V & & 109 & 77 & 211 & 85 & 155 & 81 & 81 & 55 & 74 & 113 & 70 & 43 & 75 & 89 \\
\hline $\mathrm{Y}$ & & 35 & 21 & 23 & 31 & 26 & 30 & 32 & 33 & 21 & 30 & 27 & 22 & 32 & 46 \\
\hline $\mathrm{Zn}$ & & 96 & 89 & 98 & 93 & 96 & 96 & 95 & 97 & 89 & 74 & 99 & 70 & 88 & 82 \\
\hline $\mathrm{U}$ & & 9 & $<3$ & $<3$ & 10.0 & $<3$ & 8.0 & 8.0 & 8.0 & $<3$ & 11.0 & $<3$ & 3.0 & $<3$ & 9.0 \\
\hline Th & & 12.0 & 12.0 & 11.0 & 11.0 & 9.0 & 11.0 & $<7$ & 14.0 & 10.0 & 16.0 & $<7$ & 9.0 & 11.0 & 21.0 \\
\hline $\mathrm{Pb}$ & & 17.0 & 11.0 & 11.0 & 14.0 & 15.0 & 13.0 & 17.0 & 14.0 & 16.0 & 19.0 & 12.0 & 17.0 & 12.0 & 20.0 \\
\hline $\mathrm{La}$ & & 72.0 & 52.0 & 63.0 & 61.0 & 86.0 & 67.0 & 60.0 & 72.0 & 81.0 & 57.0 & 57.0 & 44.0 & 74.0 & 87.0 \\
\hline $\mathrm{Ce}$ & & 120.0 & 124.0 & 85.0 & 100.0 & 108.0 & 95.0 & 98.0 & 92.0 & 94.0 & 90.0 & 95.0 & 84.0 & 138.0 & 136.0 \\
\hline $\mathrm{Nd}$ & & 61.0 & 49.0 & 41.0 & 62.0 & 56.0 & 48.0 & 54.0 & 53.0 & 56.0 & 43.0 & 40.0 & 48.0 & 77.0 & 75.0 \\
\hline $\mathrm{Ba} / \mathrm{Sr}$ & 3.5 & 4.4 & 3.9 & 3.7 & 3.6 & 4.0 & 5.3 & 4.8 & 5.8 & 4.1 & 3.8 & 3.6 & 3.9 & 3.4 & 3.8 \\
\hline
\end{tabular}

Análises com (*) foram obtidas no presente trabalho, sendo as demais do banco de dados do orientador 
Tabela A05. Continuação. Composição química (óxidos \% peso; traços, ppm) para as rochas do Plúton Piracaia (XRF)

\begin{tabular}{|c|c|c|c|c|c|c|c|c|c|c|c|c|c|c|c|c|}
\hline $\begin{array}{l}\text { Amostra } \\
\text { Unidade }\end{array}$ & $\begin{array}{c}\text { PI-175 } \\
M d f\end{array}$ & $\begin{array}{c}\text { PI-437c } \\
M h\end{array}$ & $\begin{array}{c}\text { PI-437a } \\
M h\end{array}$ & $\begin{array}{c}\text { PI-400d } \\
M h\end{array}$ & $\begin{array}{c}\text { PI-40 } \\
M h\end{array}$ & $\begin{array}{c}\text { PI-400a } \\
M h\end{array}$ & $\begin{array}{c}\text { PI-437d } \\
M h\end{array}$ & $\begin{array}{c}\text { PI-419 } \\
M h\end{array}$ & $\begin{array}{c}\text { PI-402 } \\
M h\end{array}$ & $\begin{array}{c}\text { PI-443 } \\
\text { Sie }\end{array}$ & $\begin{array}{c}\text { PI-26b } \\
\text { Sie }\end{array}$ & $\begin{array}{c}\text { PI-429 } \\
\text { Qsie }\end{array}$ & $\begin{array}{l}\text { PI-8a } \\
\text { Qsie }\end{array}$ & $\begin{array}{l}\text { PI-66 } \\
\text { Qsie }\end{array}$ & $\begin{array}{c}\text { PI-270e } \\
\text { Qsie }\end{array}$ & $\begin{array}{c}\text { PI-43b } \\
\text { Qsie }\end{array}$ \\
\hline $\mathrm{SiO}_{2}$ & 59.16 & 54.07 & 55.35 & 56.44 & 57.00 & 57.86 & 57.57 & 58.21 & 58.31 & 59.86 & 59.57 & 57.78 & 59.40 & 61.88 & 63.10 & 58.82 \\
\hline $\mathrm{Al}_{2} \mathrm{O}_{3}$ & 17.60 & 16.51 & 15.85 & 17.86 & 18.20 & 18.13 & 17.04 & 17.46 & 17.59 & 17.90 & 17.71 & 18.06 & 17.80 & 17.00 & 16.57 & 16.58 \\
\hline $\mathrm{FeO}_{\mathrm{t}}$ & 5.39 & 8.28 & 8.04 & 6.86 & 6.59 & 6.24 & 6.62 & 5.97 & 6.09 & 5.48 & 5.62 & 5.94 & 5.30 & 4.52 & 4.41 & 6.45 \\
\hline $\mathrm{MnO}$ & 0.13 & 0.14 & 0.16 & 0.13 & 0.12 & 0.12 & 0.13 & 0.11 & 0.14 & 0.16 & 0.16 & 0.16 & 0.15 & 0.09 & 0.13 & 0.13 \\
\hline $\mathrm{MgO}$ & 1.48 & 2.70 & 2.60 & 1.46 & 1.28 & 1.19 & 1.50 & 1.33 & 1.02 & 0.65 & 0.77 & 1.09 & 0.97 & 1.17 & 0.60 & 1.78 \\
\hline $\mathrm{CaO}$ & 3.16 & 5.68 & 5.40 & 3.56 & 3.47 & 3.37 & 2.94 & 3.18 & 2.48 & 1.89 & 2.11 & 2.82 & 2.50 & 2.69 & 1.67 & 3.46 \\
\hline $\mathrm{Na}_{2} \mathrm{O}$ & 4.80 & 4.14 & 4.04 & 4.37 & 4.37 & 4.53 & 4.18 & 4.22 & 4.91 & 5.05 & 4.94 & 4.34 & 4.80 & 4.01 & 4.42 & 4.44 \\
\hline $\mathrm{K}_{2} \mathrm{O}$ & 5.68 & 4.48 & 4.54 & 6.01 & 5.83 & 5.68 & 5.89 & 5.93 & 6.27 & 6.55 & 6.67 & 6.76 & 7.20 & 6.13 & 6.74 & 4.87 \\
\hline $\mathrm{TiO}_{2}$ & 0.90 & 1.41 & 1.34 & 1.12 & 1.02 & 0.97 & 1.19 & 1.06 & 0.95 & 0.77 & 0.87 & 0.89 & 0.80 & 0.79 & 0.62 & 1.03 \\
\hline $\mathrm{P}_{2} \mathrm{O}_{5}$ & 0.46 & 0.57 & 0.55 & 0.49 & 0.41 & 0.39 & 0.60 & 0.42 & 0.32 & 0.19 & 0.23 & 0.34 & 0.24 & 0.28 & 0.17 & 0.65 \\
\hline $\mathrm{PF}$ & 0.88 & 0.74 & 0.90 & 0.62 & 2.57 & 0.50 & 0.73 & 0.58 & 0.52 & 0.50 & 0.58 & 0.54 & 0.79 & 0.84 & 0.90 & 0.60 \\
\hline Total & 99.65 & 98.71 & 98.76 & 98.92 & 100.86 & 98.99 & 98.39 & 98.46 & 98.60 & 99.00 & 99.23 & 98.71 & 99.95 & 99.40 & 99.34 & 98.80 \\
\hline $\mathrm{mg} \#$ & 21.54 & 24.59 & 24.44 & 17.55 & 16.26 & 16.02 & 18.47 & 18.22 & 14.35 & 10.60 & 12.05 & 15.50 & 15.47 & 20.56 & 11.98 & 21.63 \\
\hline $\mathrm{Ba}$ & 2905 & 3087 & 2825 & 3558 & 3120 & 2902 & 3110 & 3373 & 2965 & 957 & 1290 & 3154 & 1880 & 2797 & 774 & 2273 \\
\hline $\mathrm{Rb}$ & 109 & 141 & 147 & 159 & 160 & 161 & 156 & 173 & 127 & 146 & 143 & 137 & & 162 & & 164 \\
\hline $\mathrm{Sr}$ & 704 & 744 & 658 & 655 & 693 & 642 & 520 & 611 & 430 & 165 & 199 & 484 & 420 & 541 & 97 & 668 \\
\hline $\mathrm{Zr}$ & 248 & 267 & 255 & 410 & 424 & 391 & 579 & 397 & 507 & 664 & 541 & 463 & 540 & 375 & 701 & 330 \\
\hline $\mathrm{Ni}$ & $<5$ & 11 & 10 & & $<5$ & & & & & & $<5$ & & & $<5$ & & $<5$ \\
\hline Co & 33 & 21 & 23 & 12 & 11 & 10 & 12 & 11 & 6 & & 14 & $<6$ & & 40 & & 13 \\
\hline $\mathrm{Cr}$ & $<13$ & & & & $<13$ & & & & & & $<13$ & & & $<13$ & & $<13$ \\
\hline $\mathrm{Cu}$ & $<5$ & 12 & 18 & 10 & 41 & 7 & 6 & 7 & & & $<5$ & 5 & & 6 & & 22 \\
\hline $\mathrm{Ga}$ & 18 & 18 & 20 & 20 & 19 & 21 & 20 & 20 & 21 & 22 & 20 & 20 & & 19 & & 20 \\
\hline $\mathrm{Nb}$ & 21.0 & 34.0 & 42.0 & 42.0 & 44.0 & 41.0 & 48.0 & 40.0 & 50.0 & 59.0 & 58.0 & 41.0 & & 34.0 & & 44.0 \\
\hline $\mathrm{Sc}$ & $<14$ & & & & $<14$ & & & & & & $<14$ & 14 & & $<14$ & & $<14$ \\
\hline V & 41 & 100 & 93 & 33 & 48 & 32 & 58 & 40 & 11 & 17 & $<9$ & 22 & & 27 & & 68 \\
\hline $\mathrm{Y}$ & 24 & 32 & 40 & 39 & 30 & 36 & 122 & 46 & 39 & 43 & 33 & 35 & & 27 & & 28 \\
\hline $\mathrm{Zn}$ & 70 & 107 & 106 & 98 & 111 & 95 & 99 & 89 & 93 & 108 & 104 & 87 & & 65 & & 91 \\
\hline $\mathrm{U}$ & 5.0 & 10.0 & 9.0 & 8.0 & 4.0 & 10.0 & 8.0 & 9.0 & 9.0 & 7.0 & 9.0 & 7.0 & & 7.0 & & 3.0 \\
\hline Th & 7.0 & 16.0 & 18.0 & 12.0 & 8.0 & 12.0 & 14.0 & 17.0 & 9.0 & 11.0 & 7.0 & 11.0 & & 9.0 & & 10.0 \\
\hline $\mathrm{Pb}$ & 21.0 & 21.0 & 23.0 & 23.0 & 22.0 & 24.0 & 22.0 & 26.0 & 19.0 & 22.0 & 17.0 & 19.0 & & 15.0 & & 18.0 \\
\hline $\mathrm{La}$ & 60.0 & 63.0 & 62.0 & 70.0 & 72.0 & 74.0 & 115.0 & 102.0 & 81.0 & 120.0 & 115.0 & 83.0 & & 80.0 & & 56.0 \\
\hline $\mathrm{Ce}$ & 82.0 & 92.0 & 111.0 & 123.0 & 124.0 & 98.0 & 123.0 & 119.0 & 117.0 & 160.0 & 139.0 & 105.0 & & 126.0 & & 109.0 \\
\hline $\mathrm{Nd}$ & 43.0 & 43.0 & 47.0 & 60.0 & 59.0 & 54.0 & 75.0 & 57.0 & 64.0 & 84.0 & 72.0 & 46.0 & & 55.0 & & 47.0 \\
\hline $\mathrm{Ba} / \mathrm{Sr}$ & 4.1 & 4.1 & 4.3 & 5.4 & 4.5 & 4.5 & 6.0 & 5.5 & 6.9 & 5.8 & 6.5 & 6.5 & 4.5 & 5.2 & 8.0 & 3.4 \\
\hline
\end{tabular}

Análises com (*) foram obtidas no presente trabalho, sendo as demais do banco de dados do orientador 
Tabela A05. Continuação. Composição química (óxidos \% peso; traços, ppm) para as rochas do Plúton Piracaia (XRF)

\begin{tabular}{|c|c|c|c|c|c|c|c|c|c|c|c|}
\hline $\begin{array}{l}\text { Amostra } \\
\text { Unidade }\end{array}$ & $\begin{array}{l}\text { PI-104 } \\
\text { Qsie }\end{array}$ & $\begin{array}{l}\text { PI-116 } \\
\text { Qsie }\end{array}$ & $\begin{array}{c}\text { PI-427 } \\
\text { Qsie } \\
\end{array}$ & $\begin{array}{c}\text { PI-136a } \\
\text { Qsie }\end{array}$ & $\begin{array}{c}\text { PI-410 } \\
\text { Qsie }\end{array}$ & $\begin{array}{l}\text { PI-17 } \\
\text { Qsie }\end{array}$ & $\begin{array}{l}\text { PI-413 } \\
\text { Qsie }\end{array}$ & $\begin{array}{c}\text { PI-440 } \\
\text { Qsie }\end{array}$ & $\begin{array}{l}\text { PI-112AB } \\
\text { Vênula }\end{array}$ & $\begin{array}{l}\text { PI-112AA } \\
\text { Vênula }\end{array}$ & $\begin{array}{l}\text { PI-256d } \\
\text { Vênula }\end{array}$ \\
\hline $\mathrm{SiO}_{2}$ & 59.02 & 61.03 & 65.29 & 66.45 & 67.37 & 68.40 & 68.97 & 73.86 & 58.97 & 62.50 & 62.95 \\
\hline $\mathrm{Al}_{2} \mathrm{O}_{3}$ & 17.43 & 15.73 & 16.30 & 17.02 & 15.71 & 16.40 & 15.15 & 12.39 & 16.45 & 18.78 & 18.97 \\
\hline $\mathrm{FeO}_{\mathrm{t}}$ & 5.75 & 5.90 & 3.35 & 1.23 & 3.20 & 2.30 & 2.85 & 1.93 & 3.99 & 1.46 & 2.80 \\
\hline $\mathrm{MnO}$ & 0.13 & 0.11 & 0.08 & 0.04 & 0.10 & 0.04 & 0.07 & 0.07 & 0.10 & 0.02 & 0.02 \\
\hline $\mathrm{MgO}$ & 1.14 & 1.69 & 0.59 & 0.26 & 0.31 & 0.66 & 0.27 & 0.09 & 1.47 & 0.30 & 0.08 \\
\hline $\mathrm{CaO}$ & 2.61 & 3.26 & 1.64 & 0.88 & 1.06 & 0.99 & 1.01 & 0.63 & 3.18 & 1.55 & 2.13 \\
\hline $\mathrm{Na}_{2} \mathrm{O}$ & 4.40 & 3.99 & 4.58 & 4.99 & 4.38 & 3.00 & 3.95 & 3.33 & 2.59 & 4.14 & 4.57 \\
\hline $\mathrm{K}_{2} \mathrm{O}$ & 6.31 & 4.71 & 6.03 & 8.18 & 6.24 & 7.20 & 6.22 & 5.55 & 8.71 & 8.19 & 6.61 \\
\hline $\mathrm{TiO}_{2}$ & 1.03 & 1.09 & 0.51 & 0.29 & 0.38 & 0.36 & 0.33 & 0.18 & 0.89 & 0.17 & 0.19 \\
\hline $\mathrm{P}_{2} \mathrm{O}_{5}$ & 0.35 & 0.57 & 0.20 & 0.05 & 0.09 & & 0.08 & 0.01 & 0.76 & 0.05 & 0.01 \\
\hline $\mathrm{PF}$ & 0.61 & 0.64 & 0.48 & 0.36 & 0.42 & 0.33 & 0.46 & 0.40 & 0.62 & 0.48 & 0.40 \\
\hline Total & 98.78 & 98.71 & 99.05 & 99.75 & 99.25 & 99.68 & 99.36 & 98.44 & 97.73 & 97.64 & 98.73 \\
\hline mg\# & 16.55 & 22.27 & 14.97 & 17.45 & 8.83 & 22.33 & 8.65 & 4.46 & 26.92 & 17.05 & 2.78 \\
\hline $\mathrm{Ba}$ & 2888 & 2960 & 1693 & 1200 & 472 & 820 & 568 & 199 & 7847 & 8247 & 3939 \\
\hline $\mathrm{Rb}$ & 153 & 132 & 117 & 207 & 162 & & 151 & 133 & 119 & 99 & 140 \\
\hline $\mathrm{Sr}$ & 437 & 707 & 317 & 285 & 97 & & 111 & 50 & 1094 & 1387 & 778 \\
\hline $\mathrm{Zr}$ & 690 & 219 & 381 & 90 & 514 & 430 & 385 & 229 & 692 & 113 & 109 \\
\hline $\mathrm{Ni}$ & & & & $<5$ & & & & & & & \\
\hline Co & 7 & 11 & & 39 & & & & & 8 & & \\
\hline $\mathrm{Cr}$ & & & & $<13$ & & & & 22 & & & \\
\hline $\mathrm{Cu}$ & & 5 & & 5 & & & & & & & \\
\hline $\mathrm{Ga}$ & 20 & 19 & 19 & 20 & 21 & & 19 & 17 & 13 & 13 & 20 \\
\hline $\mathrm{Nb}$ & 51.0 & 36.0 & 29.0 & 29.0 & 43.0 & & 30.0 & 20.0 & 31.0 & $<9$ & 10.0 \\
\hline Sc & & & & $<14$ & & & & & & & \\
\hline V & 34 & 69 & 27 & 12 & 11 & & 20 & $<9$ & 47 & 9 & 31 \\
\hline $\mathrm{Y}$ & 38 & 36 & 30 & 30 & 34 & & 25 & 21 & 37 & 1 & 8 \\
\hline $\mathrm{Zn}$ & 94 & 64 & 50 & 21 & 58 & & 47 & 33 & 45 & 21 & 18 \\
\hline $\mathrm{U}$ & 8.0 & 9.0 & 6.0 & 19.0 & 6.0 & & 5.0 & 4.0 & 11.0 & 11.0 & 12.0 \\
\hline Th & 15.0 & 15.0 & 18.0 & 21.0 & 20.0 & & 16.0 & 25.0 & 22.0 & $<7$ & 9.0 \\
\hline $\mathrm{Pb}$ & 22.0 & 16.0 & 18.0 & $<4$ & 20.0 & & 19.0 & 15.0 & 24.0 & 22.0 & 21.0 \\
\hline $\mathrm{La}$ & 105.0 & 65.0 & 99.0 & 38.0 & 123.0 & & 85.0 & 175.0 & 104.0 & $<28$ & \\
\hline $\mathrm{Ce}$ & 145.0 & 91.0 & 161.0 & 62.0 & 186.0 & & 144.0 & 207.0 & 128.0 & $<35$ & \\
\hline $\mathrm{Nd}$ & 51.0 & 42.0 & 46.0 & 27.0 & 79.0 & & 41.0 & 62.0 & 56.0 & $<14$ & \\
\hline $\mathrm{Ba} / \mathrm{Sr}$ & 6.6 & 4.2 & 5.3 & 4.2 & 4.9 & & 5.1 & 4.0 & 7.2 & 5.9 & 5.1 \\
\hline
\end{tabular}

Análises com (*) foram obtidas no presente trabalho, sendo as demais do banco de dados do orientador 
Tabela A06. Composição química de elementos traços para as rochas do Plúton Piracaia pelo método de ICPMS

\begin{tabular}{|c|c|c|c|c|c|c|c|c|c|c|}
\hline $\begin{array}{l}\text { Amostra } \\
\text { Unidade }\end{array}$ & $\begin{array}{c}\text { PI-537* } \\
\text { Qsie }\end{array}$ & $\begin{array}{c}\text { PI-582* } \\
\text { Qsie }\end{array}$ & $\begin{array}{c}\text { PI-589A* } \\
M d r\end{array}$ & $\begin{array}{c}\text { PI-589B* } \\
M d f\end{array}$ & $\begin{array}{c}\text { PI-598A* } \\
M d f\end{array}$ & $\begin{array}{c}\text { PI-598B* } \\
\text { Qsie }\end{array}$ & $\begin{array}{c}\text { PI-602* } \\
\text { Sie }\end{array}$ & $\begin{array}{c}\text { PI-605* } \\
M d r\end{array}$ & $\begin{array}{c}\text { PI-609* } \\
M d r\end{array}$ & $\begin{array}{c}\text { PI-614* } \\
M d f\end{array}$ \\
\hline $\mathrm{Rb}$ & 193 & 171 & 73 & 69 & 98 & 78 & 104 & 78 & 80 & 103 \\
\hline \multicolumn{11}{|l|}{$\mathrm{Zr}$} \\
\hline Cs & 4 & 4 & 2 & 2 & 3 & 2 & 2 & 1 & 1 & 5 \\
\hline $\mathrm{Y}$ & 53 & 29 & 26 & 28 & 32 & 28 & 34 & 27 & 36 & 27 \\
\hline \multicolumn{11}{|l|}{$\mathrm{Ta}$} \\
\hline $\mathrm{U}$ & 2.8 & 1.7 & 0.5 & 0.2 & 1.1 & 3.0 & 1.1 & 0.4 & 0.3 & 2.9 \\
\hline Th & 20.4 & 4.6 & 2.8 & 1.1 & 5.2 & 24.2 & 6.2 & 1.2 & 1.1 & 7.4 \\
\hline $\mathrm{Pb}$ & 19.8 & 18.8 & 6.9 & 5.5 & 10.9 & 19.5 & 19.3 & 8.6 & 7.3 & 11.7 \\
\hline $\mathrm{La}$ & 267.07 & 35.31 & 65.47 & 69.03 & 81.00 & 366.12 & 84.42 & 69.36 & 79.76 & 61.83 \\
\hline $\mathrm{Ce}$ & 240.44 & 69.08 & 146.00 & 152.99 & 179.05 & 425.89 & 172.71 & 150.17 & 177.67 & 133.58 \\
\hline Gd & 11.73 & 6.78 & 7.39 & 8.40 & 8.18 & 6.47 & 7.38 & 7.01 & 9.81 & 6.74 \\
\hline $\mathrm{Tb}$ & 1.56 & 0.93 & 0.95 & 1.04 & 1.10 & 0.96 & 1.11 & 0.96 & 1.29 & 0.91 \\
\hline Dy & 8.75 & 5.17 & 5.19 & 5.63 & 6.01 & 5.50 & 6.26 & 5.23 & 6.86 & 5.09 \\
\hline Ho & 1.71 & 1.02 & 0.95 & 1.04 & 1.14 & 0.99 & 1.22 & 0.98 & 1.28 & 0.96 \\
\hline $\mathrm{Er}$ & 4.56 & 2.73 & 2.42 & 2.60 & 3.00 & 2.75 & 3.29 & 2.52 & 3.25 & 2.56 \\
\hline $\mathrm{Tm}$ & 0.66 & 0.40 & 0.32 & 0.35 & 0.43 & 0.41 & 0.48 & 0.35 & 0.43 & 0.37 \\
\hline $\mathrm{Yb}$ & 4.09 & 2.58 & 2.00 & 2.15 & 2.73 & 2.86 & 3.18 & 2.15 & 2.56 & 2.43 \\
\hline $\mathrm{Lu}$ & 0.62 & 0.40 & 0.29 & 0.31 & 0.39 & 0.45 & 0.48 & 0.31 & 0.36 & 0.37 \\
\hline$(\mathrm{La} / \mathrm{Yb})_{\mathrm{N}}$ & 46.88 & 9.81 & 23.44 & 23.04 & 21.25 & 91.73 & 19.06 & 23.17 & 22.37 & 18.24 \\
\hline
\end{tabular}

Análises com (*) foram obtidas no presente trabalho, sendo as demais do banco de dados do orientador 
Tabela A06. Continuação. Composição química de elementos traços para as rochas do Plúton Piracaia pelo método de ICPMS

\begin{tabular}{|c|c|c|c|c|c|c|c|c|c|c|c|}
\hline $\begin{array}{l}\text { Amostra } \\
\text { Unidade }\end{array}$ & $\begin{array}{l}\text { PI-MIX-01* } \\
\text { Qz sienito }\end{array}$ & $\begin{array}{l}\text { PI-MIX-02* } \\
\text { monzonito }\end{array}$ & $\begin{array}{l}\text { PI-MIX-03* } \\
\text { monzonito }\end{array}$ & $\begin{array}{l}\text { PI-MIX-04* } \\
\text { monzodiorito }\end{array}$ & $\begin{array}{l}\text { PI-MIX-05* } \\
\text { monzodiorito }\end{array}$ & $\begin{array}{l}\mathrm{PI}-256 \\
M d r\end{array}$ & $\begin{array}{l}\text { PI-41c } \\
M d f\end{array}$ & $\begin{array}{l}\mathrm{PI}-75 \\
M d f\end{array}$ & $\begin{array}{l}\mathrm{PI}-5 \mathrm{c} \\
M d f\end{array}$ & $\begin{array}{l}\text { PI-436 } \\
M d f\end{array}$ & $\begin{array}{l}\mathrm{PI}-112 \\
M d f\end{array}$ \\
\hline $\mathrm{Ba}$ & 7867 & 4177 & 2810 & 3329 & 4160 & & 5117 & & & 4404 & \\
\hline $\mathrm{Rb}$ & 88 & 79 & 89 & 110 & 125 & 91 & 100 & 106 & 113 & 102 & 100 \\
\hline $\mathrm{Sr}$ & 1202 & 980 & 1142 & 1063 & 1273 & & 1179 & & & 922 & \\
\hline $\mathrm{Zr}$ & 61 & 1506 & 686 & 273 & 292 & 215 & 169 & 305 & 235 & 225 & 107 \\
\hline Cs & 1 & 1 & 2 & 3 & 3 & 2 & 2 & 2 & 2 & 2 & 4 \\
\hline Y & 23 & 79 & 44 & 32 & 29 & 21 & 33 & 29 & 25 & 32 & 20 \\
\hline $\mathrm{Nb}$ & 26.2 & 69.4 & 42.8 & 41.6 & 46.0 & 31.1 & 29.1 & 41.8 & 38.3 & 32.6 & 35.9 \\
\hline Hf & 1.74 & 33.26 & 15.40 & 6.34 & 6.42 & & 3.93 & 6.18 & 5.13 & 5.00 & 2.66 \\
\hline $\mathrm{Ta}$ & & & & & & 1.34 & 2.44 & 2.43 & 2.24 & 2.91 & 1.74 \\
\hline $\mathrm{U}$ & 0.8 & 5.0 & 2.4 & 1.0 & 0.9 & 0.4 & 0.5 & 0.4 & 0.8 & 1.0 & 1.3 \\
\hline Th & 4.2 & 28.6 & 20.3 & 5.8 & 4.0 & 1.6 & 2.3 & 2.7 & 3.7 & 5.8 & 7.1 \\
\hline $\mathrm{Pb}$ & 22.2 & 12.8 & 12.8 & 11.7 & 11.8 & 9.1 & 8.8 & 8.6 & 8.9 & 14.4 & 7.7 \\
\hline $\mathrm{La}$ & 31.36 & 341.25 & 235.20 & 72.74 & 78.73 & 49.30 & 75.76 & 69.00 & 66.15 & 87.80 & 65.90 \\
\hline $\mathrm{Ce}$ & 73.47 & 500.42 & 338.33 & 150.76 & 154.00 & 100.00 & 138.16 & 141.00 & 132.16 & 165.58 & 133.00 \\
\hline $\operatorname{Pr}$ & 11.31 & 51.05 & 33.96 & 17.76 & 17.69 & 11.60 & 16.55 & 17.10 & 16.12 & 17.88 & 15.10 \\
\hline $\mathrm{Nd}$ & 43.79 & 176.30 & 113.47 & 67.92 & 66.85 & 53.80 & 69.74 & 63.70 & 61.52 & 72.14 & 54.30 \\
\hline $\mathrm{Sm}$ & 7.59 & 26.51 & 16.23 & 11.11 & 10.55 & 7.35 & 11.44 & 10.20 & 10.33 & 11.55 & 8.48 \\
\hline $\mathrm{Eu}$ & 2.10 & 4.77 & 3.25 & 2.62 & 3.08 & 2.59 & 3.30 & 2.68 & 2.98 & 3.33 & 2.60 \\
\hline $\mathrm{Gd}$ & 5.54 & 19.86 & 11.55 & 8.22 & 7.93 & 5.60 & 8.13 & 7.45 & 7.11 & 8.21 & 6.42 \\
\hline $\mathrm{Tb}$ & 0.77 & 2.62 & 1.53 & 1.11 & 1.03 & 0.73 & 1.08 & 0.99 & 1.15 & 1.08 & 0.77 \\
\hline Dy & 4.22 & 14.44 & 8.19 & 5.94 & 5.47 & 3.87 & 5.96 & 5.54 & 5.98 & 5.95 & 4.07 \\
\hline Ho & 0.82 & 2.83 & 1.57 & 1.14 & 1.04 & 0.78 & 1.25 & 1.12 & 1.17 & 1.24 & 0.78 \\
\hline Er & 2.26 & 8.13 & 4.50 & 3.17 & 2.85 & 1.97 & 3.27 & 2.96 & 2.99 & 3.13 & 1.95 \\
\hline $\mathrm{Tm}$ & 0.31 & 1.15 & 0.62 & 0.42 & 0.38 & 0.28 & 0.43 & 0.41 & & 0.40 & 0.25 \\
\hline $\mathrm{Yb}$ & 2.02 & 7.95 & 4.21 & 2.73 & 2.45 & 1.74 & 2.77 & 2.77 & 2.50 & 2.52 & 1.60 \\
\hline $\mathrm{Lu}$ & 0.28 & 1.25 & 0.64 & 0.40 & 0.36 & 0.26 & 0.41 & 0.40 & 0.38 & 0.36 & 0.24 \\
\hline$(\mathrm{La} / \mathrm{Yb})_{\mathrm{N}}$ & 11.16 & 30.81 & 40.09 & 19.15 & 23.05 & 19.10 & 18.45 & 16.79 & 17.82 & 23.48 & 27.77 \\
\hline
\end{tabular}

Análises com (*) foram obtidas no presente trabalho, sendo as demais do banco de dados do orientador 
Tabela A06. Continuação. Composição química de elementos traços para as rochas do Plúton Piracaia pelo método de ICPMS

\begin{tabular}{|c|c|c|c|c|c|c|c|c|c|c|c|c|c|c|}
\hline $\begin{array}{l}\text { Amostra } \\
\text { Unidade }\end{array}$ & $\begin{array}{c}\text { PI-18a } \\
M d f\end{array}$ & $\begin{array}{c}\text { PI-405 } \\
M d f\end{array}$ & $\begin{array}{c}\text { PI-179b } \\
M d f\end{array}$ & $\begin{array}{c}\text { PI-358a } \\
M d f\end{array}$ & $\begin{array}{c}\text { PI-437a } \\
M h\end{array}$ & $\begin{array}{c}\text { PI-40 } \\
M h\end{array}$ & $\begin{array}{l}\text { PI-419 } \\
M h\end{array}$ & $\begin{array}{c}\text { PI-443 } \\
\text { Sie }\end{array}$ & $\begin{array}{c}\text { PI-26b } \\
\text { Sie }\end{array}$ & $\begin{array}{c}\text { PI-429 } \\
\text { Qsie }\end{array}$ & $\begin{array}{l}\text { PI-270e } \\
\text { Qsie }\end{array}$ & $\begin{array}{l}\text { PI-410 } \\
\text { Qsie }\end{array}$ & $\begin{array}{l}\text { PI-440 } \\
\text { Qsie }\end{array}$ & $\begin{array}{c}\text { PI-112AB } \\
\text { Vênula }\end{array}$ \\
\hline $\mathrm{Ba}$ & 5483 & 4609 & & & 2912 & & 3227 & 754 & & 3061 & & 404 & 158 & 7554 \\
\hline $\mathrm{Rb}$ & 77 & 81 & 109 & 112 & 117 & 136 & 126 & 100 & 78 & 96 & 94 & 114 & 110 & 69 \\
\hline $\mathrm{Sr}$ & 1009 & 773 & & & 641 & & 604 & 156 & & 463 & 97 & 83 & 41 & 1028 \\
\hline $\mathrm{Zr}$ & 230 & 280 & 219 & 216 & 249 & 305 & 364 & 641 & 630 & 434 & 701 & 511 & 238 & 614 \\
\hline Cs & 3 & 2 & 4 & 1 & 4 & 2 & 2 & 2 & 1 & 1 & 2 & 3 & 1 & 2 \\
\hline Y & 31 & 30 & 27 & 25 & 36 & 31 & 43 & 37 & 31 & 29 & 35 & 29 & 17 & 31 \\
\hline $\mathrm{Nb}$ & 38.8 & 37.1 & 42.7 & 31.4 & 44.6 & 46.2 & 45.6 & 63.0 & 46.2 & 43.1 & 94.6 & 48.5 & 21.3 & 33.0 \\
\hline Hf & 5.54 & 6.59 & 5.16 & 4.76 & 6.33 & 9.31 & 9.00 & 14.94 & 12.70 & 10.03 & 14.10 & 13.80 & 6.10 & 15.55 \\
\hline Ta & 3.69 & 2.62 & 2.42 & 1.15 & 4.57 & 2.26 & 3.92 & 3.71 & 1.42 & 1.91 & 2.08 & 2.70 & 1.00 & 3.91 \\
\hline $\mathrm{U}$ & 0.9 & 0.9 & 1.2 & 1.0 & 2.3 & 1.7 & 1.2 & 1.0 & 0.9 & 0.5 & 1.5 & 1.3 & 0.8 & 2.0 \\
\hline Th & 3.5 & 4.8 & 5.2 & 2.2 & 10.1 & 7.8 & 11.6 & 8.3 & 7.5 & 4.4 & 8.6 & 19.2 & 25.8 & 10.5 \\
\hline $\mathrm{Pb}$ & 8.7 & 11.6 & 10.0 & 10.9 & 20.2 & 19.8 & 21.7 & 21.3 & 15.9 & 16.5 & 17.5 & 22.2 & 20.7 & 19.4 \\
\hline $\mathrm{La}$ & 59.03 & 72.26 & 66.40 & 57.10 & 65.83 & 74.90 & 97.48 & 126.47 & 93.60 & 84.42 & 92.60 & 171.57 & 193.09 & 132.53 \\
\hline $\mathrm{Ce}$ & 125.91 & 143.12 & 128.00 & 112.00 & 129.46 & 147.00 & 166.06 & 218.33 & 186.00 & 161.52 & 194.00 & 259.16 & 307.59 & 215.63 \\
\hline $\operatorname{Pr}$ & 13.96 & 15.49 & 15.60 & 13.00 & 13.90 & 16.30 & 18.39 & 22.85 & 21.50 & 16.36 & 21.30 & 24.02 & 27.49 & 21.57 \\
\hline $\mathrm{Nd}$ & 59.17 & 62.91 & 58.70 & 47.40 & 54.53 & 57.90 & 69.99 & 84.91 & 73.40 & 63.19 & 71.90 & 81.56 & 85.46 & 78.35 \\
\hline $\mathrm{Sm}$ & 10.26 & 10.64 & 9.60 & 7.60 & 9.76 & 9.65 & 11.54 & 12.88 & 11.40 & 10.23 & 11.60 & 11.51 & 9.80 & 10.77 \\
\hline $\mathrm{Eu}$ & 3.04 & 2.94 & 3.17 & 2.49 & 1.98 & 2.11 & 2.49 & 2.43 & 2.76 & 3.12 & 1.70 & 1.16 & 0.64 & 2.47 \\
\hline Gd & 7.64 & 7.90 & 7.56 & 6.16 & 7.50 & 7.60 & 8.68 & 8.78 & 8.93 & 7.39 & 9.36 & 7.79 & 5.98 & 7.45 \\
\hline $\mathrm{Tb}$ & 1.01 & 1.04 & 0.97 & 0.80 & 1.08 & 1.02 & 1.22 & 1.24 & 1.19 & 1.01 & 1.31 & 1.03 & 0.70 & 0.94 \\
\hline Dy & 5.45 & 5.68 & 5.21 & 4.44 & 6.14 & 5.69 & 6.75 & 6.91 & 6.53 & 5.54 & 7.38 & 5.62 & 3.61 & 5.25 \\
\hline Но & 1.15 & 1.18 & 1.03 & 0.94 & 1.31 & 1.17 & 1.43 & 1.46 & 1.33 & 1.16 & 1.54 & 1.15 & 0.68 & 1.14 \\
\hline $\mathrm{Er}$ & 2.93 & 3.04 & 2.66 & 2.60 & 3.55 & 3.16 & 3.77 & 3.93 & 3.61 & 3.04 & 4.18 & 3.08 & 1.84 & 3.20 \\
\hline $\mathrm{Tm}$ & 0.40 & 0.41 & 0.37 & 0.40 & 0.51 & 0.45 & 0.51 & 0.53 & 0.52 & 0.42 & 0.61 & 0.42 & 0.23 & 0.46 \\
\hline $\mathrm{Yb}$ & 2.53 & 2.62 & 2.38 & 2.59 & 3.41 & 3.03 & 3.29 & 3.57 & 3.48 & 2.71 & 4.01 & 2.80 & 1.52 & 3.30 \\
\hline $\mathrm{Lu}$ & 0.38 & 0.40 & 0.36 & 0.40 & 0.50 & 0.45 & 0.49 & 0.55 & 0.54 & 0.41 & 0.62 & 0.44 & 0.23 & 0.53 \\
\hline$(\mathrm{La} / \mathrm{Yb})_{\mathrm{N}}$ & 15.73 & 18.56 & 18.81 & 14.86 & 13.00 & 16.67 & 19.99 & 23.90 & 18.13 & 21.04 & 15.57 & 41.37 & 85.52 & 27.06 \\
\hline
\end{tabular}

Análises com (*) foram obtidas no presente trabalho, sendo as demais do banco de dados do orientador 
ANEXO 3

TABELA DE ANÁLISES ISOTÓPICAS DE Sr E Nd 
Tabela A07. Dados de isótopos de Sr e Nd para as rochas do Plúton Piracaia. Razões iniciais calculadas para $580 \mathrm{Ma}$

\begin{tabular}{|c|c|c|c|c|c|c|c|c|c|c|c|c|c|}
\hline Amostra & $\begin{array}{c}\mathrm{Rb} \\
(\mathrm{ppm})\end{array}$ & $\begin{array}{c}\mathrm{Sr} \\
(\mathrm{ppm})\end{array}$ & $\begin{array}{l}{ }^{87} \mathrm{Rb} / \\
{ }^{86} \mathrm{Sr}\end{array}$ & $\begin{array}{c}{ }^{87} \mathrm{Sr} / \\
{ }^{86} \mathrm{Sr} \\
\end{array}$ & SE & $\begin{array}{l}{ }^{87} \mathrm{Sr} / \\
{ }^{86} \mathrm{Sr}_{\mathrm{i}(\mathrm{i})}\end{array}$ & $\begin{array}{c}\mathrm{Sm} \\
(\mathrm{ppm})\end{array}$ & $\begin{array}{c}\mathrm{Nd} \\
(\mathrm{ppm})\end{array}$ & $\begin{array}{l}{ }^{147} \mathrm{Sm} / \\
{ }^{144} \mathrm{Nd} \\
\end{array}$ & $\begin{array}{l}{ }^{143} \mathrm{Nd} / \\
{ }^{144} \mathrm{Nd}_{(\mathrm{t}=0)}\end{array}$ & SE & $\begin{array}{l}{ }^{143} \mathrm{Nd} / \\
{ }^{144} \mathrm{Nd}_{(\mathrm{t})}\end{array}$ & $\varepsilon N d_{(t)}$ \\
\hline PI-41c & 105 & 1277 & 0.24 & 0.70737 & & 0.70540 & 10.03 & 63.98 & 0.095 & 0.51182 & & 0.51146 & -8.50 \\
\hline PI-5c & 151 & 1054 & 0.41 & 0.70901 & & 0.70558 & 10.24 & 63.82 & 0.097 & 0.51182 & & 0.51146 & -8.50 \\
\hline PI-437a & 147 & 658 & 0.65 & 0.71147 & 0.00003 & 0.70612 & 9.76 & 54.50 & 0.109 & 0.51184 & 0.00001 & 0.51143 & -9.07 \\
\hline PI-400a & 161 & 642 & 0.73 & 0.71254 & 0.00004 & 0.70653 & & & & 0.51183 & 0.00002 & & -8.70 \\
\hline PI-419 & 173 & 611 & 0.72 & 0.71350 & 0.00005 & 0.70673 & 11.50 & 70.00 & 0.100 & 0.51178 & 0.00001 & 0.51140 & -9.59 \\
\hline PI-26b & 134 & 190 & 2.05 & 0.72282 & & 0.70590 & 11.06 & 72.75 & 0.092 & 0.51170 & & 0.51135 & -10.50 \\
\hline PI-429 & 137 & 484 & 0.82 & 0.71254 & 0.00003 & 0.70576 & 10.20 & 63.20 & 0.098 & 0.51196 & 0.00001 & 0.51158 & -6.00 \\
\hline PI-270e & 167 & 152 & 3.18 & 0.73171 & & 0.70544 & 10.80 & 70.55 & 0.093 & 0.51187 & & 0.51152 & -7.30 \\
\hline PI-410 & 162 & 97 & 4.83 & 0.74571 & 0.00003 & 0.70575 & 11.50 & 81.60 & 0.086 & 0.51185 & 0.00001 & 0.51152 & -7.15 \\
\hline
\end{tabular}




\begin{abstract}
ANEXO 4
TABELAS DE ESTIMATIVAS DE PARÂMETROS FÍSICO QUÍMICOS DE CRISTALIZAÇÃO DOS MAGMAS
\end{abstract}


Tabela A08. Estimativas de pressão e temperatura de cristalização para as rochas do Plúton Piracaia.

\begin{tabular}{|c|c|c|c|c|c|c|c|c|c|c|c|}
\hline $\begin{array}{l}\text { Amostra / cristal } \\
\text { Unidade }\end{array}$ & $\begin{array}{l}26 \mathrm{~b} / 1 \\
\text { Sie }\end{array}$ & $\begin{array}{l}358 / 12 \\
M d f\end{array}$ & $\begin{array}{l}358 / 12 \\
M d f\end{array}$ & $\begin{array}{l}358 \mathrm{c} / 16 \\
M d f\end{array}$ & $\begin{array}{l}358 \mathrm{c} / 16 \\
M d f\end{array}$ & $\begin{array}{l}\mathrm{c} / 10 \\
M d f\end{array}$ & $\begin{array}{l}5 c / 10 \\
M d f\end{array}$ & $\begin{array}{l}\mathrm{c} / 10 \\
M d f\end{array}$ & $\begin{array}{l}\mathrm{c} / 12 \\
M d f\end{array}$ & $\begin{array}{l}\text { 5c/17 } \\
M d f\end{array}$ & $\begin{array}{l}\mathrm{c} / 17 \\
M d f\end{array}$ \\
\hline Anfibólio & centro & matriz & matriz & matriz & matriz & borda & borda & matriz & matriz & borda & centro \\
\hline $\mathrm{SiO}_{2}$ & 39.62 & 41.07 & 41.07 & 41.85 & 41.85 & 42.54 & 42.54 & 43.07 & 43.46 & 43.25 & 43.30 \\
\hline $\mathrm{TiO}_{2}$ & 1.62 & 1.53 & 1.53 & 0.89 & 0.89 & 1.36 & 1.36 & 0.87 & 1.68 & 1.41 & 1.54 \\
\hline $\mathrm{Al}_{2} \mathrm{O}_{3}$ & 9.38 & 9.44 & 9.44 & 9.13 & 9.13 & 8.64 & 8.64 & 7.60 & 8.70 & 8.55 & 8.66 \\
\hline $\mathrm{FeOt}$ & 27.20 & 20.39 & 20.39 & 20.31 & 20.31 & 18.66 & 18.66 & 18.35 & 18.98 & 19.08 & 19.28 \\
\hline $\mathrm{MgO}$ & 4.22 & 8.84 & 8.84 & 9.09 & 9.09 & 10.35 & 10.35 & 10.57 & 10.36 & 10.27 & 10.26 \\
\hline $\mathrm{MnO}$ & 0.91 & 0.83 & 0.83 & 0.92 & 0.92 & 0.43 & 0.43 & 0.54 & 0.50 & 0.53 & 0.53 \\
\hline $\mathrm{CaO}$ & 10.88 & 11.39 & 11.39 & 11.40 & 11.40 & 11.54 & 11.54 & 11.66 & 11.39 & 11.27 & 11.41 \\
\hline $\mathrm{Na}_{2} \mathrm{O}$ & 1.57 & 1.62 & 1.62 & 1.84 & 1.84 & 1.58 & 1.58 & 1.23 & 1.49 & 1.45 & 1.56 \\
\hline $\mathrm{K}_{2} \mathrm{O}$ & 1.48 & 1.41 & 1.41 & 1.27 & 1.27 & 0.98 & 0.98 & 0.89 & 1.08 & 1.04 & 1.07 \\
\hline $\mathrm{F}$ & 0.00 & 0.27 & 0.27 & 0.05 & 0.05 & 0.21 & 0.21 & 0.22 & 0.48 & 0.06 & 0.05 \\
\hline $\mathrm{Cl}$ & 0.16 & 0.57 & 0.57 & 0.52 & 0.52 & 0.06 & 0.06 & 0.06 & 0.08 & 0.06 & 0.10 \\
\hline Total & 97.04 & 97.36 & 97.36 & 97.26 & 97.26 & 96.36 & 96.36 & 95.05 & 98.19 & 96.96 & 97.75 \\
\hline Plagioclásio & centro & borda & centro & borda & centro & centro & borda & borda & borda & centro & borda \\
\hline $\mathrm{Ab}$ & 0.89 & 0.76 & 0.72 & 0.82 & 0.76 & 0.78 & 0.76 & 0.82 & 0.76 & 0.69 & 0.76 \\
\hline An & 0.11 & 0.23 & 0.28 & 0.17 & 0.23 & 0.22 & 0.24 & 0.17 & 0.24 & 0.31 & 0.24 \\
\hline
\end{tabular}

Fórmula segundo Holland and Blundy (1994) Sítios T

\begin{tabular}{|c|c|c|c|c|c|c|c|c|c|c|c|}
\hline $\mathrm{Si}$ & 6.311 & 6.340 & 6.340 & 6.433 & 6.433 & 6.500 & 6.500 & 6.651 & 6.531 & 6.548 & 6.525 \\
\hline $\mathrm{Al}$ (IV) & 1.689 & 1.660 & 1.660 & 1.567 & 1.567 & 1.500 & 1.500 & 1.349 & 1.469 & 1.452 & 1.475 \\
\hline $\mathrm{Al}($ total $)$ & 1.762 & 1.718 & 1.718 & 1.654 & 1.654 & 1.556 & 1.556 & 1.383 & 1.542 & 1.526 & 1.539 \\
\hline $\mathrm{Fe} /(\mathrm{Fe}+\mathrm{Mg})$ & 0.78 & 0.56 & 0.56 & 0.56 & 0.56 & 0.50 & 0.50 & 0.49 & 0.51 & 0.51 & 0.51 \\
\hline
\end{tabular}

Resultados de pressão baseiam-se nas iterações de Anderson \& Smith (1995) a partir da temperatura fornecida por diferentes termômetros

$\begin{array}{lllllllllll}\mathrm{T}(\mathrm{C}) \mathrm{HB} 1 & 856 & 946 & 982 & 862 & 896 & 862 & 872 & 812 & 830 & 849\end{array}$

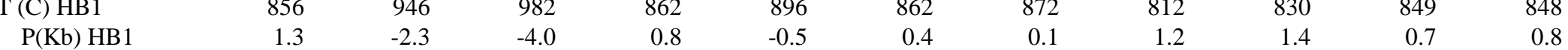

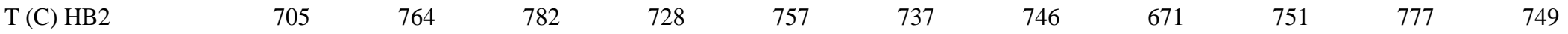

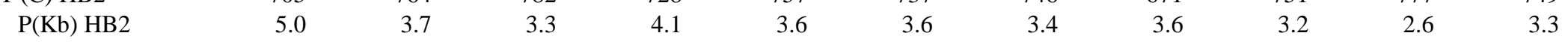

$\mathrm{T}(\mathrm{C}) \mathrm{BH}$

$\begin{array}{rrrrrrr}5.0 & 3.7 & 3.3 & 4.1 & 3.6 & 3.6 & 3.4 \\ 770 & 818 & 840 & 765 & 789 & 771 & 779\end{array}$

$\mathrm{P}(\mathrm{Kb}) \mathrm{BH}$

$\begin{array}{llll}2.4 & 1.7 & 3.4 & 2.9\end{array}$

2.9

$\begin{array}{ll}2.7 & 2.9\end{array}$

2.9 
Tabela A08. Continuação. Estimativas de pressão e temperatura de cristalização para as rochas do Plúton Piracaia.

\begin{tabular}{|c|c|c|c|c|c|c|c|c|c|c|c|}
\hline $\begin{array}{l}\text { Amostra / cristal } \\
\text { Unidade }\end{array}$ & $\begin{array}{l}5 \mathrm{c} / 17 \\
M d f\end{array}$ & $\begin{array}{l}71 / 12 \\
M d f\end{array}$ & $\begin{array}{r}71 / 13 \\
M d f \\
\end{array}$ & $\begin{array}{c}\text { PI-400A } \\
M h \\
\end{array}$ & $\begin{array}{c}\text { PI-400A } \\
M h \\
\end{array}$ & $\begin{array}{c}\text { PI-400A } \\
M h \\
\end{array}$ & $\begin{array}{c}\text { PI-400D } \\
M h \\
\end{array}$ & $\begin{array}{c}\text { PI-400D } \\
M h \\
\end{array}$ & $\begin{array}{c}\text { PI-400D } \\
M h \\
\end{array}$ & $\begin{array}{c}\text { PI-400D } \\
M h \\
\end{array}$ & $\begin{array}{c}\text { PI-400D } \\
M h \\
\end{array}$ \\
\hline Anfibólio & borda & borda & borda & matriz & matriz & centro & centro & borda & borda & agregado & bolsão \\
\hline $\mathrm{SiO}_{2}$ & 43.25 & 42.90 & 43.78 & 40.56 & 40.89 & 43.82 & 43.38 & 41.47 & 41.61 & 41.61 & 41.77 \\
\hline $\mathrm{TiO}_{2}$ & 1.41 & 1.07 & 1.01 & 0.90 & 0.93 & 0.89 & 0.75 & 1.41 & 1.59 & 1.22 & 1.40 \\
\hline $\mathrm{Al}_{2} \mathrm{O}_{3}$ & 8.55 & 8.86 & 8.93 & 10.77 & 10.28 & 8.10 & 8.46 & 9.04 & 9.27 & 9.84 & 8.40 \\
\hline $\mathrm{FeOt}$ & 19.08 & 19.75 & 18.85 & 25.00 & 24.53 & 22.79 & 23.51 & 23.52 & 24.32 & 25.05 & 23.29 \\
\hline $\mathrm{MgO}$ & 10.27 & 9.92 & 10.29 & 6.08 & 6.12 & 7.58 & 6.87 & 6.60 & 6.21 & 6.02 & 6.63 \\
\hline $\mathrm{MnO}$ & 0.53 & 0.64 & 0.64 & 0.64 & 0.81 & 0.77 & 0.49 & 0.51 & 0.61 & 0.52 & 0.65 \\
\hline $\mathrm{CaO}$ & 11.27 & 11.63 & 11.33 & 11.21 & 11.28 & 11.36 & 11.31 & 11.13 & 11.33 & 11.44 & 11.36 \\
\hline $\mathrm{Na}_{2} \mathrm{O}$ & 1.45 & 1.11 & 1.29 & 1.56 & 1.41 & 1.20 & 1.23 & 1.47 & 1.57 & 1.29 & 1.22 \\
\hline $\mathrm{K}_{2} \mathrm{O}$ & 1.04 & 0.91 & 1.08 & 1.41 & 1.34 & 1.02 & 1.14 & 1.20 & 1.22 & 1.30 & 1.17 \\
\hline F & 0.06 & 0.00 & 0.00 & 0.36 & 0.44 & 0.30 & 0.22 & 0.00 & 0.32 & 0.43 & 0.14 \\
\hline $\mathrm{Cl}$ & 0.06 & 0.04 & 0.05 & 0.27 & 0.23 & 0.13 & 0.11 & 0.16 & 0.20 & 0.20 & 0.18 \\
\hline Total & 96.96 & 96.82 & 97.25 & 98.76 & 98.25 & 97.97 & 97.46 & 96.52 & 98.26 & 98.91 & 96.20 \\
\hline
\end{tabular}

Plagioclásio borda borda matriz matriz matriz antecristal antecristal antecristal matriz matriz ocelo

$\begin{array}{llllllllllll}\mathrm{Ab} & 0.76 & 0.80 & 0.79 & 0.82 & 0.81 & 0.65 & 0.80 & 0.58 & 0.83 & 0.82 & 0.82\end{array}$

\begin{tabular}{lllllllllll} 
An & 0.24 & 0.20 & 0.20 & 0.17 & 0.18 & 0.35 & 0.20 & 0.42 & 0.16 & 0.17 \\
\hline
\end{tabular}

Fórmula segundo Holland and Blundy (1994) Sítios T

\begin{tabular}{|c|c|c|c|c|c|c|c|c|c|c|c|}
\hline $\mathrm{Si}$ & 6.548 & 6.486 & 6.579 & 6.252 & 6.330 & 6.704 & 6.698 & 6.489 & 6.452 & 6.403 & 6.566 \\
\hline $\mathrm{Al}$ (IV) & 1.452 & 1.514 & 1.421 & 1.748 & 1.670 & 1.296 & 1.302 & 1.511 & 1.548 & 1.597 & 1.434 \\
\hline $\mathrm{Al}($ total $)$ & 1.526 & 1.580 & 1.582 & 1.958 & 1.876 & 1.461 & 1.541 & 1.668 & 1.695 & 1.785 & 1.556 \\
\hline $\mathrm{Fe} /(\mathrm{Fe}+\mathrm{Mg})$ & 0.51 & 0.53 & 0.51 & 0.70 & 0.69 & 0.63 & 0.66 & 0.67 & 0.69 & 0.70 & 0.66 \\
\hline
\end{tabular}

Resultados de pressão baseiam-se nas iterações de Anderson \& Smith (1995) a partir da temperatura fornecida por diferentes termômetros

\begin{tabular}{|c|c|c|c|c|c|c|c|c|c|c|c|}
\hline $\mathrm{T}(\mathrm{C}) \mathrm{HB} 1$ & 823 & 803 & 749 & 796 & 775 & 765 & 703 & 869 & 789 & 763 & 766 \\
\hline $\mathrm{P}(\mathrm{Kb}) \mathrm{HB} 1$ & 1.5 & 2.2 & 3.5 & 3.9 & 4.1 & 2.6 & 4.0 & 0.6 & 3.1 & 4.0 & 3.0 \\
\hline $\mathrm{T}(\mathrm{C}) \mathrm{HB} 2$ & 749 & 721 & 709 & 720 & 709 & 740 & 665 & 798 & 701 & 696 & 683 \\
\hline $\mathrm{P}(\mathrm{Kb}) \mathrm{HB} 2$ & 3.2 & 3.9 & 4.1 & 5.6 & 5.5 & 3.1 & 4.4 & 2.7 & 4.7 & 5.2 & 4.3 \\
\hline $\mathrm{T}(\mathrm{C}) \mathrm{BH}$ & 766 & 766 & 740 & 795 & 779 & 766 & 712 & 872 & 752 & 764 & 737 \\
\hline $\mathrm{P}(\mathrm{Kb}) \mathrm{BH}$ & 2.9 & 3.1 & 3.6 & 3.9 & 4.0 & 2.6 & 3.9 & 0.5 & 3.9 & 4.0 & \\
\hline
\end{tabular}


Tabela A08. Continuação. Estimativas de pressão e temperatura de cristalização para as rochas do Plúton Piracaia.

\begin{tabular}{|c|c|c|c|c|c|c|c|c|c|c|}
\hline $\begin{array}{l}\text { Amostra / cristal } \\
\text { Unidade }\end{array}$ & $\begin{array}{c}\mathrm{PI}-400 \mathrm{D} \\
M h \\
\end{array}$ & $\begin{array}{c}\text { PI-419 } \\
M h \\
\end{array}$ & $\begin{array}{c}\mathrm{PI}-419 \\
M h\end{array}$ & $\begin{array}{c}\mathrm{PI}-426 \mathrm{~B} \\
M h \\
\end{array}$ & $\begin{array}{c}\text { PI-426B } \\
M h \\
\end{array}$ & $\begin{array}{c}\text { PI-437a } \\
M h \\
\end{array}$ & $\begin{array}{c}\text { PI-437a } \\
M h \\
\end{array}$ & $\begin{array}{c}\text { PI-437a } \\
M h \\
\end{array}$ & $\begin{array}{c}\mathrm{PI}-437 \mathrm{a} \\
M h \\
\end{array}$ & $\begin{array}{c}\text { PI-427 } \\
\text { Qsie (qz sie) } \\
\end{array}$ \\
\hline Anfibólio & bolsão & matriz & centro & matriz & matriz & centro & borda & matriz & borda & matriz \\
\hline $\mathrm{SiO}_{2}$ & 41.48 & 41.64 & 46.60 & 42.04 & 43.40 & 47.38 & 44.38 & 42.49 & 43.95 & 43.06 \\
\hline $\mathrm{TiO}_{2}$ & 1.62 & 1.04 & 0.37 & 1.16 & 0.93 & 0.47 & 1.33 & 0.74 & 1.57 & 1.24 \\
\hline $\mathrm{Al}_{2} \mathrm{O}_{3}$ & 9.28 & 9.75 & 6.32 & 9.39 & 8.63 & 6.76 & 8.50 & 10.27 & 8.73 & 8.06 \\
\hline $\mathrm{FeOt}$ & 24.34 & 24.23 & 21.22 & 24.23 & 23.99 & 20.05 & 21.13 & 22.80 & 20.77 & 25.36 \\
\hline $\mathrm{MgO}$ & 6.21 & 6.25 & 9.08 & 6.19 & 6.83 & 10.21 & 8.71 & 7.45 & 8.78 & 6.09 \\
\hline $\mathrm{MnO}$ & 0.51 & 0.54 & 0.48 & 0.78 & 0.74 & 0.36 & 0.43 & 0.39 & 0.42 & 0.92 \\
\hline $\mathrm{CaO}$ & 11.32 & 11.24 & 12.09 & 11.28 & 11.31 & 10.52 & 11.94 & 10.75 & 11.34 & 11.05 \\
\hline $\mathrm{Na}_{2} \mathrm{O}$ & 1.55 & 1.37 & 0.87 & 1.39 & 1.33 & 0.95 & 1.29 & 1.48 & 1.53 & 1.33 \\
\hline $\mathrm{K}_{2} \mathrm{O}$ & 1.25 & 1.24 & 0.73 & 1.29 & 1.10 & 0.76 & 1.09 & 1.50 & 1.15 & 1.06 \\
\hline $\mathrm{F}$ & 0.00 & 0.07 & 0.08 & 0.00 & 0.15 & 0.20 & 0.26 & 0.15 & 0.12 & 0.04 \\
\hline $\mathrm{Cl}$ & 0.16 & 0.17 & 0.04 & 0.12 & 0.10 & 0.08 & 0.15 & 0.13 & 0.17 & 0.12 \\
\hline Total & 97.72 & 97.54 & 97.88 & 97.85 & 98.49 & 97.73 & 99.20 & 98.14 & 98.52 & 98.32 \\
\hline Plagioclásio & ocelo & matriz & antecristal & matriz & borda & antecristal & borda & matriz & borda & matriz \\
\hline $\mathrm{Ab}$ & 0.85 & 0.83 & 0.66 & 0.83 & 0.84 & 0.61 & 0.73 & 0.85 & 0.87 & 0.88 \\
\hline $\mathrm{An}$ & 0.14 & 0.17 & 0.34 & 0.17 & 0.15 & 0.38 & 0.26 & 0.15 & 0.12 & 0.11 \\
\hline \multicolumn{11}{|c|}{$\begin{array}{l}\text { Fórmula segundo Holland and Blundy (1994) } \\
\text { Sítios T }\end{array}$} \\
\hline $\mathrm{Si}$ & 6.444 & 6.454 & 7.027 & 6.501 & 6.636 & 7.091 & 6.668 & 6.480 & 6.637 & 6.635 \\
\hline $\mathrm{Al}$ (IV) & 1.556 & 1.546 & 0.973 & 1.499 & 1.364 & 0.909 & 1.332 & 1.520 & 1.363 & 1.365 \\
\hline $\mathrm{Al}($ total $)$ & 1.700 & 1.781 & 1.123 & 1.711 & 1.555 & 1.192 & 1.505 & 1.846 & 1.554 & 1.464 \\
\hline $\mathrm{Fe} /(\mathrm{Fe}+\mathrm{Mg})$ & 0.687 & 0.685 & 0.567 & 0.687 & 0.664 & 0.524 & 0.577 & 0.632 & 0.570 & 0.700 \\
\hline \multicolumn{11}{|c|}{ Resultados de pressão baseiam-se nas iterações de Anderson \& Smith (1995) a partir da temperatura fornecida por diferentes termômetros } \\
\hline $\mathrm{T}(\mathrm{C}) \mathrm{HB} 1$ & 787 & 738 & 713 & 740 & 724 & 651 & 755 & 691 & 722 & 750 \\
\hline $\mathrm{P}(\mathrm{Kb}) \mathrm{HB} 1$ & 3.1 & 4.5 & 2.0 & 4.2 & 3.8 & 2.8 & 3.0 & 5.6 & 3.8 & 2.9 \\
\hline $\mathrm{T}(\mathrm{C}) \mathrm{HB} 2$ & 690 & 682 & 671 & 683 & 666 & 687 & 696 & 671 & 655 & 670 \\
\hline $\mathrm{P}(\mathrm{Kb}) \mathrm{HB} 2$ & 4.9 & 5.4 & 2.4 & 5.0 & 4.5 & 2.6 & 3.9 & 5.8 & 4.6 & 4.0 \\
\hline $\mathrm{T}(\mathrm{C}) \mathrm{BH}$ & 750 & 745 & 700 & 739 & 713 & 692 & 741 & 727 & 705 & 711 \\
\hline $\mathrm{P}(\mathrm{Kb}) \mathrm{BH}$ & 3.9 & 4.4 & 2.1 & 4.2 & 3.9 & 2.5 & 3.3 & 5.0 & 4.0 & 3.6 \\
\hline
\end{tabular}


Tabela A08. Continuação. Estimativas de pressão e temperatura de cristalização para as rochas do Plúton Piracaia.

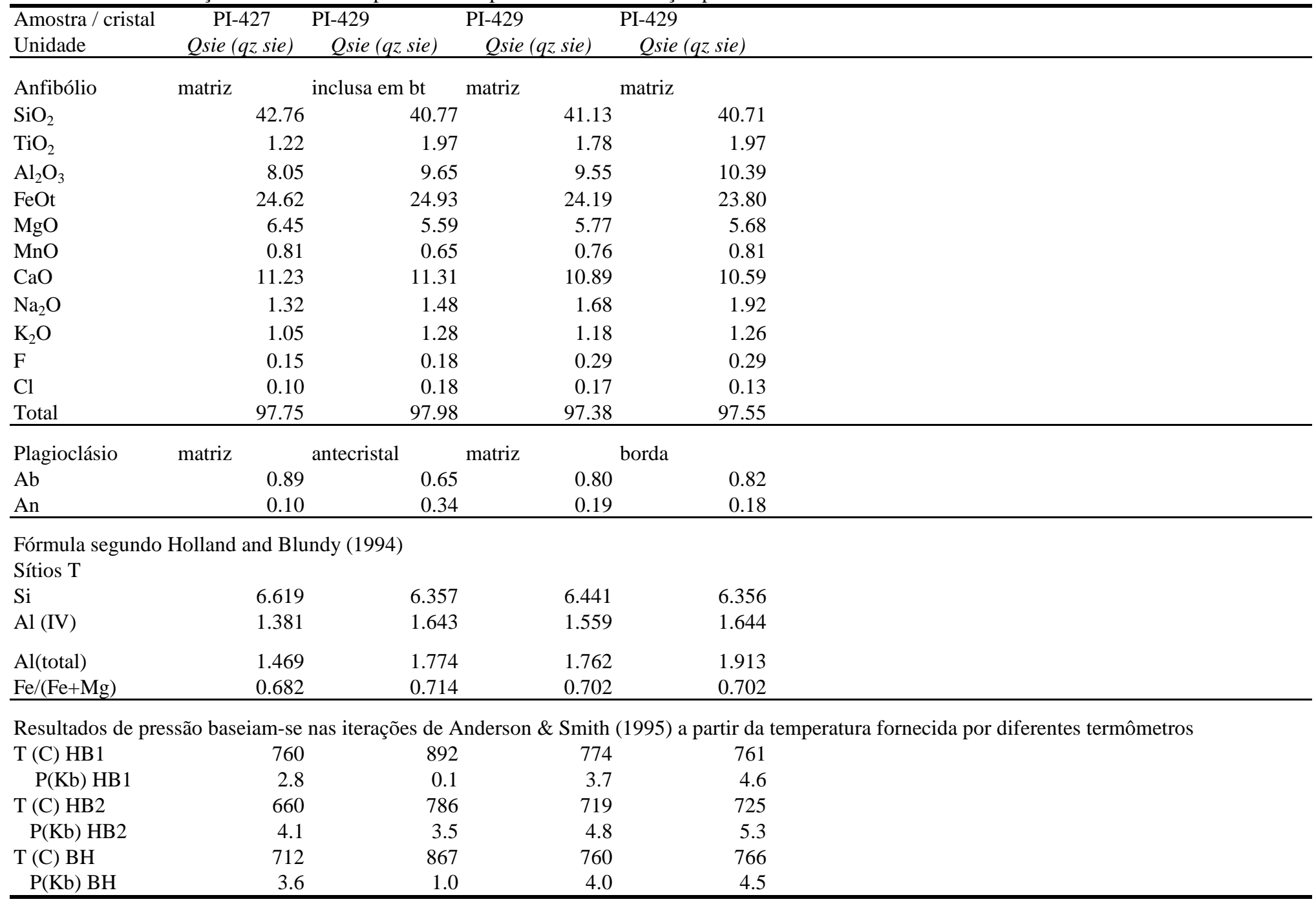


Tabela A09. Estimativas de concentração de $\mathrm{H}_{2} \mathrm{O}$ para as rochas do Plúton Piracaia

\begin{tabular}{|c|c|c|c|c|c|c|c|c|}
\hline & P (3kbar) & $\mathrm{P}(5 \mathrm{kbar})$ & P (3kbar) & $\mathrm{P}(5 \mathrm{kbar})$ & P (3kbar) & $\mathrm{P}(5 \mathrm{kbar})$ & P (3kbar) & $\mathrm{P}(5 \mathrm{kbar})$ \\
\hline Unidade & $M d r$ & $M d r$ & $M d r$ & $M d r$ & $M d r$ & $M d r$ & $M d r$ & $M d r$ \\
\hline Amostra & PI-256 & PI-256 & PI-256 & PI-256 & PI-256 & PI-256 & PI-256 & PI-256 \\
\hline An & 0.41 & 0.41 & 0.506 & 0.506 & 0.48 & 0.48 & 0.59 & 0.59 \\
\hline $\mathrm{Ab}$ & 0.59 & 0.59 & 0.494 & 0.494 & 0.52 & 0.52 & 0.41 & 0.41 \\
\hline T liquidus $\left({ }^{\circ} \mathrm{C}\right.$ & 963 & 963 & 963 & 963 & 963 & 963 & 963 & 963 \\
\hline $\mathrm{A} \mathrm{H} 2 \mathrm{O}(\%)$ & 3.4 & 3.6 & 3.9 & 4.1 & 3.7 & 3.9 & 4.4 & 4.6 \\
\hline & P (3kbar) & $\mathrm{P}(5 \mathrm{kbar})$ & P (3kbar) & $\mathrm{P}(5 \mathrm{kbar})$ & P (3kbar) & $\mathrm{P}(5 \mathrm{kbar})$ & P (3kbar) & $\mathrm{P}(5 \mathrm{kbar})$ \\
\hline Unidadade & $M d r$ & $M d r$ & $M d r$ & $M d r$ & $M d f$ & $M d f$ & $M d f$ & $M d f$ \\
\hline Amostra & PI-257c & PI-257c & PI-257c & PI-257c & PI-75 & PI-75 & PI-75 & PI-75 \\
\hline An & 0.423 & 0.423 & 0.494 & 0.494 & 0.39 & 0.39 & 0.52 & 0.52 \\
\hline $\mathrm{Ab}$ & 0.564 & 0.564 & 0.496 & 0.496 & 0.61 & 0.61 & 0.48 & 0.48 \\
\hline T liquidus $\left({ }^{\circ} \mathrm{C}\right.$ & 996 & 996 & 996 & 996 & 984 & 984 & 984 & 984 \\
\hline A H2O (\%) & 2.0 & 2.2 & 2.3 & 2.5 & 2.5 & 2.7 & 3.2 & 3.4 \\
\hline & P (3kbar) & $\mathrm{P}(5 \mathrm{kbar})$ & P (3kbar) & $\mathrm{P}(5 \mathrm{kbar})$ & P (3kbar) & $\mathrm{P}(5 \mathrm{kbar})$ & P (3kbar) & $\mathrm{P}(5 \mathrm{kbar})$ \\
\hline Unidade & $M d f$ & $M d f$ & $M d f$ & $M d f$ & $M d f$ & $M d f$ & $M d f$ & $M d f$ \\
\hline Amostra & PI-358a & PI-358a & PI-358a & PI-358a & PI-5c & PI-5c & PI-5c & PI-5c \\
\hline An & 0.42 & 0.42 & 0.48 & 0.48 & 0.45 & 0.45 & 0.61 & 0.61 \\
\hline $\mathrm{Ab}$ & 0.58 & 0.58 & 0.52 & 0.52 & 0.55 & 0.55 & 0.49 & 0.49 \\
\hline $\mathrm{T}$ liquidus $\left({ }^{\circ} \mathrm{C}\right.$ & 994 & 994 & 994 & 994 & 989 & 989 & 989 & 989 \\
\hline A H2O (\%) & 2.9 & 3.1 & 3.2 & 3.4 & 2.6 & 2.8 & 3.1 & 3.3 \\
\hline & P (3kbar) & $\mathrm{P}(5 \mathrm{kbar})$ & P (3kbar) & $\mathrm{P}(5 \mathrm{kbar})$ & P (3kbar) & $\mathrm{P}(5 \mathrm{kbar})$ & P (3kbar) & $\mathrm{P}(5 \mathrm{kbar})$ \\
\hline Unidade & $M h$ & $M h$ & $M h$ & $M h$ & $M h$ & $M h$ & $M h$ & $M h$ \\
\hline Amostra & PI-437a & PI-437a & PI-437a & PI-437a & PI-400a & PI-400a & PI-400a & PI-400a \\
\hline An & 0.38 & 0.38 & 0.42 & 0.42 & 0.42 & 0.42 & 0.47 & 0.47 \\
\hline $\mathrm{Ab}$ & 0.62 & 0.62 & 0.58 & 0.58 & 0.58 & 0.58 & 0.53 & 0.53 \\
\hline $\mathrm{T}$ liquidus $\left({ }^{\circ} \mathrm{C}\right.$ & 959 & 959 & 959 & 959 & 939 & 939 & 939 & 939 \\
\hline A H2O (\%) & 2.51 & 2.72 & 2.73 & 2.94 & 4.13 & 4.35 & 4.39 & 4.61 \\
\hline
\end{tabular}


Tabela A09. Continuação. Estimativas de concentração de $\mathrm{H}_{2} \mathrm{O}$ para as rochas do Plúton Piracaia

\begin{tabular}{|c|c|c|c|c|c|c|c|c|}
\hline & $\mathrm{P}$ (3kbar) & $\mathrm{P}(5 \mathrm{kbar})$ & $\mathrm{P}(3 \mathrm{kbar})$ & $\mathrm{P}(5 \mathrm{kbar})$ & & & & \\
\hline Unidade & $M h$ & $M h$ & $M h$ & $M h$ & & & & \\
\hline Amostra & PI-427 & PI-427 & PI-427 & PI-427 & & & & \\
\hline An & 0.12 & 0.12 & 0.06 & 0.06 & & & & \\
\hline $\mathrm{Ab}$ & 0.87 & 0.87 & 0.94 & 0.94 & & & & \\
\hline $\mathrm{T}$ liquidus $\left({ }^{\circ} \mathrm{C}\right)$ & 940 & 940 & 940 & 940 & & & & \\
\hline $\mathrm{A} \mathrm{H} 2 \mathrm{O}(\%)$ & 3.11 & 3.33 & 2.72 & 2.94 & & & & \\
\hline \multicolumn{9}{|c|}{ Cristais com composição inadequada } \\
\hline & P (3kbar) & $\mathrm{P}(5 \mathrm{kbar})$ & P (3kbar) & $\mathrm{P}(5 \mathrm{kbar})$ & P (3kbar) & $\mathrm{P}(5 \mathrm{kbar})$ & P (3kbar) & $\mathrm{P}(5 \mathrm{kbar})$ \\
\hline Unidade & $M h$ (matriz) & $M h$ (matriz) & $M h$ (matriz) & $M h$ (matriz) & $M h$ (matriz) & $M h$ (matriz) & $M h$ (matriz) & $M h$ (matriz) \\
\hline Amostra & PI-437a & PI-437a & PI-437a & PI-437a & PI-400a & PI-400a & PI-400a & PI-400a \\
\hline An & 0.15 & 0.15 & 0.11 & 0.11 & 0.18 & 0.18 & 0.20 & 0.20 \\
\hline $\mathrm{Ab}$ & 0.85 & 0.85 & 0.89 & 0.89 & 0.84 & 0.84 & 0.80 & 0.80 \\
\hline $\mathrm{T}$ liquidus $\left({ }^{\circ} \mathrm{C}\right)$ & 959 & 959 & 959 & 959 & 939 & 939 & 939 & 939 \\
\hline A H2O (\%) & 1.3 & 1.5 & 1.1 & 1.3 & 2.8 & 3.0 & 3.0 & 3.2 \\
\hline \multicolumn{9}{|c|}{ Cristais com composição inadequada } \\
\hline & $\mathrm{P}$ (3kbar) & $\mathrm{P}(5 \mathrm{kbar})$ & $\mathrm{P}(3 \mathrm{kbar})$ & $\mathrm{P}(5 \mathrm{kbar})$ & P (3kbar) & $\mathrm{P}(5 \mathrm{kbar})$ & $\mathrm{P}(3 \mathrm{kbar})$ & $\mathrm{P}(5 \mathrm{kbar})$ \\
\hline Unidade & Qsie (monz) & Qsie (monz) & Qsie (monz) & Qsie (monz) & Qsie (sien) & Qsie (sien) & Qsie (sien) & Qsie (sien) \\
\hline Amostra & PI-270e & PI-270e & PI-270e & PI-270e & PI-413 & PI-413 & PI-413 & PI-413 \\
\hline An & 0.13 & 0.13 & 0.11 & 0.11 & 0.14 & 0.14 & 0.12 & 0.12 \\
\hline $\mathrm{Ab}$ & 0.87 & 0.87 & 0.89 & 0.89 & 0.86 & 0.86 & 0.88 & 0.88 \\
\hline $\mathrm{T}$ liquidus $\left({ }^{\circ} \mathrm{C}\right)$ & 884 & 884 & 884 & 884 & 877 & 877 & 877 & 877 \\
\hline $\mathrm{A} \mathrm{H} 2 \mathrm{O}(\%)$ & 4.0 & 4.3 & 3.9 & 4.1 & 4.7 & 4.8 & 4.6 & 4.9 \\
\hline \multicolumn{9}{|c|}{ Cristais com composição inadequada } \\
\hline & P (3kbar) & $\mathrm{P}(5 \mathrm{kbar})$ & P (3kbar) & $\mathrm{P}(5 \mathrm{kbar})$ & $\mathrm{P}(3 \mathrm{kbar})$ & $\mathrm{P}(5 \mathrm{kbar})$ & $\mathrm{P}(3 \mathrm{kbar})$ & $\mathrm{P}(5 \mathrm{kbar})$ \\
\hline Unidade & $M d f($ matriz) & $M d f($ matriz) & $M d f($ matriz) & $M d f($ matriz) & Sie & Sie & Sie & Sie \\
\hline Amostra & PI-5c & PI-5c & PI-5c & PI-5c & PI-26b & PI-26b & PI-26b & PI-26b \\
\hline An & 0.24 & 0.24 & 0.32 & 0.32 & 0.11 & 0.11 & 0.03 & 0.03 \\
\hline $\mathrm{Ab}$ & 0.76 & 0.76 & 0.68 & 0.68 & 0.89 & 0.89 & 0.96 & 0.96 \\
\hline $\mathrm{T}$ liquidus $\left({ }^{\circ} \mathrm{C}\right)$ & 989 & 989 & 989 & 989 & 892 & 892 & 892 & 892 \\
\hline A H2O $(\%)$ & 1.5 & 1.7 & 1.9 & 2.1 & 4.0 & 4.2 & 3.7 & 3.9 \\
\hline
\end{tabular}


Tabela A10. Estimativas de $\mathrm{fO}_{2}$ a partir de cristais de magnetita e ilmenita de rochas do Plúton Piracaia

\begin{tabular}{|c|c|c|c|c|c|c|c|c|c|c|}
\hline $\begin{array}{l}\text { Mineral } \\
\text { Amostra / cristal } \\
\text { Unidade }\end{array}$ & $\begin{array}{l}\text { Magnetita } \\
270 / 8 \\
\text { Qsie } \\
\end{array}$ & $\begin{array}{l}\text { Ilmenita } \\
270 / 8 \\
\text { Qsie }\end{array}$ & $\begin{array}{l}\text { Magnetita } \\
413 / 2 \\
\text { Qsie }\end{array}$ & $\begin{array}{l}\text { Ilmenita } \\
413 / 2 \\
\text { Qsie }\end{array}$ & $\begin{array}{l}\text { Magnetita } \\
413 \text { / } 5 \\
\text { Qsie } \\
\end{array}$ & $\begin{array}{l}\text { Ilmenita } \\
413 \text { / } 5 \\
\text { Qsie }\end{array}$ & $\begin{array}{l}\text { Magnetita } \\
413 \text { / } 6 \\
\text { Qsie } \\
\end{array}$ & $\begin{array}{l}\text { Ilmenita } \\
413 \text { / } 6 \\
\text { Qsie }\end{array}$ & $\begin{array}{l}\text { Magnetita } \\
257 / 3 \\
M d r\end{array}$ & $\begin{array}{l}\text { Ilmenita } \\
257 / 320 \mu \mathrm{m} \\
M d r\end{array}$ \\
\hline $\mathrm{SiO}_{2}$ & 0.01 & 0.02 & 0.02 & 0.04 & 0.03 & 0.00 & 0.04 & 0.02 & 0.02 & 0.01 \\
\hline $\mathrm{TiO}_{2}$ & 0.11 & 50.94 & 0.12 & 50.67 & 0.07 & 51.60 & 0.15 & 51.23 & 0.05 & 46.18 \\
\hline $\mathrm{Al}_{2} \mathrm{O}_{3}$ & 0.04 & 0.04 & 0.03 & 0.05 & 0.04 & 0.02 & 0.08 & 0.01 & 0.26 & 0.05 \\
\hline $\mathrm{Fe}_{2} \mathrm{O}_{3}$ & 68.28 & 3.75 & 68.25 & 4.74 & 68.43 & 0.52 & 69.27 & 2.70 & 69.80 & 11.45 \\
\hline $\mathrm{Cr}_{2} \mathrm{O}_{3}$ & 0.01 & 0.00 & 0.00 & 0.00 & 0.01 & 0.03 & 0.00 & 0.00 & 0.00 & 0.03 \\
\hline $\mathrm{FeO}$ & 30.75 & 37.10 & 30.89 & 33.26 & 30.89 & 37.90 & 31.34 & 34.24 & 31.67 & 38.32 \\
\hline $\mathrm{MnO}$ & 0.10 & 8.52 & 0.06 & 12.15 & 0.08 & 8.14 & 0.09 & 11.67 & 0.04 & 2.63 \\
\hline $\mathrm{MgO}$ & 0.04 & 0.04 & 0.00 & 0.03 & 0.00 & 0.00 & 0.03 & 0.01 & 0.00 & 0.33 \\
\hline $\mathrm{CaO}$ & 0.02 & 0.01 & 0.00 & 0.01 & 0.00 & 0.05 & 0.04 & 0.01 & 0.01 & 0.00 \\
\hline $\mathrm{ZnO}$ & 0.00 & 0.04 & 0.00 & 0.01 & 0.04 & 0.24 & 0.02 & 0.03 & 0.00 & 0.00 \\
\hline $\mathrm{NiO}$ & 0.03 & 0.00 & 0.04 & 0.02 & 0.00 & 0.00 & 0.00 & 0.00 & 0.00 & 0.00 \\
\hline $\mathrm{Nb}_{2} \mathrm{O}_{3}$ & 0.05 & 0.39 & 0.00 & 0.09 & 0.02 & 0.09 & 0.00 & 0.26 & 0.00 & 0.07 \\
\hline Total & 99.43 & 100.84 & 99.42 & 101.04 & 99.60 & 98.60 & 101.06 & 100.18 & 101.85 & 99.07 \\
\hline
\end{tabular}

Geotermobarômetro de Spencer \& Lindsley (1981)

$\begin{array}{lrr}\text { X'Usp \& X'Ilm de: } & \text { Temp }\left({ }^{\circ} \mathrm{C}\right) & \text { Temp }\left({ }^{\circ} \mathrm{C}\right) \\ \text { Carmichael }(1967) & 468 & 488 \\ \text { Stormer }(1983) & 466 & 488\end{array}$

$\begin{array}{rr}488 & \text { Temp }\left({ }^{\circ} \mathrm{C}\right) \\ 357\end{array}$

357
341

Temp $\left({ }^{\circ} \mathrm{C}\right)$
462

Temp $\left({ }^{\circ} \mathrm{C}\right)$

$\log 10 \mathrm{fO} 2$

$-22.26$

$\log 10 \mathrm{fO} 2$

$-35.77$

$\log 10 \mathrm{fO} 2$

$-25.32$

$\log 10 \mathrm{fO} 2$

$-36.89$

$-25.03$

$-17.84$

Stormer (1983)

$-23.49$ 
Tabela A10. Continuação. Estimativas de $\mathrm{fO}_{2}$ a partir de cristais de magnetita e ilmenita de rochas do Plúton Piracaia

\begin{tabular}{|c|c|c|c|c|c|c|c|c|c|c|c|}
\hline $\begin{array}{l}\text { Mineral } \\
\text { Amostra / cristal } \\
\text { Unidade }\end{array}$ & $\begin{array}{l}\text { Magnetita } \\
257 / 7 \_2 \\
M d r\end{array}$ & $\begin{array}{l}\text { Ilmenita } \\
257 / 7 \_2 \\
M d r\end{array}$ & $\begin{array}{l}\text { Magnetita } \\
400 / 1 \_1 \\
\text { Mh }\end{array}$ & $\begin{array}{l}\text { Ilmenita } \\
400 / 1 \_1 \\
M h \\
\end{array}$ & $\begin{array}{l}\text { Magnetita } \\
400 / 1 \_2 \\
M h\end{array}$ & $\begin{array}{l}\text { Ilmenita } \\
400 / 1 \_2 \\
M h \\
\end{array}$ & $\begin{array}{l}\text { Magnetita } \\
358 \mathrm{c} / 1 \\
\text { Mdf } \\
\end{array}$ & $\begin{array}{l}\text { Ilmenita } \\
358 / 1 \\
M d f \\
\end{array}$ & $\begin{array}{l}\text { Magnetita } \\
358 \mathrm{c} / 8 \\
M d f \\
\end{array}$ & $\begin{array}{l}\text { Ilmenita } \\
358 \mathrm{c} 8 \\
M d f\end{array}$ & $\begin{array}{l}\text { Magnetita } \\
75 \mathrm{c} / 2 \\
M d f \\
\end{array}$ \\
\hline $\mathrm{TiO}_{2}$ & 0.16 & 51.02 & 0.10 & 50.17 & 0.28 & 51.30 & 0.35 & 49.41 & 0.05 & 50.39 & 0.22 \\
\hline $\mathrm{Al}_{2} \mathrm{O}_{3}$ & 0.19 & 0.04 & 0.06 & 0.02 & 0.08 & 0.04 & 0.09 & 0.02 & 0.11 & 0.00 & 0.20 \\
\hline $\mathrm{Fe}_{2} \mathrm{O}_{3}$ & 67.94 & 6.26 & 68.71 & 3.73 & 68.82 & 3.72 & 67.44 & 4.44 & 69.40 & 2.75 & 69.18 \\
\hline $\mathrm{FeO}$ & 30.96 & 42.30 & 31.13 & 40.13 & 31.51 & 40.54 & 30.88 & 39.38 & 31.43 & 39.65 & 31.53 \\
\hline $\mathrm{MnO}$ & 0.04 & 2.84 & 0.04 & 4.81 & 0.00 & 5.28 & 0.07 & 4.63 & 0.01 & 5.24 & 0.04 \\
\hline $\mathrm{MgO}$ & 0.02 & 0.36 & 0.00 & 0.08 & 0.00 & 0.03 & 0.03 & 0.09 & 0.00 & 0.05 & 0.02 \\
\hline $\mathrm{CaO}$ & 0.00 & 0.02 & 0.02 & 0.01 & 0.09 & 0.17 & 0.12 & 0.17 & 0.06 & 0.22 & 0.09 \\
\hline $\mathrm{ZnO}$ & 0.02 & 0.10 & 0.00 & 0.00 & 0.01 & 0.04 & 0.00 & 0.00 & 0.00 & 0.04 & 0.00 \\
\hline $\mathrm{NiO}$ & 0.03 & 0.02 & 0.00 & 0.03 & 0.04 & 0.00 & 0.00 & 0.00 & 0.00 & 0.00 & 0.03 \\
\hline $\mathrm{Nb}_{2} \mathrm{O}_{3}$ & 0.05 & 0.06 & 0.00 & 0.21 & 0.00 & 0.10 & 0.00 & 0.36 & 0.00 & 0.16 & 0.00 \\
\hline Total & 99.44 & 103.04 & 100.09 & 99.21 & 100.93 & 101.24 & 99.12 & 98.48 & 101.17 & 98.52 & 101.35 \\
\hline
\end{tabular}

Geotermobarômetro de Spencer \& Lindsley (1981)

$\begin{array}{lrr}\text { X'Usp \& X'Ilm de: } & \text { Temp }\left({ }^{\circ} \mathrm{C}\right) & \text { Temp }\left({ }^{\circ} \mathrm{C}\right) \\ \text { Carmichael }(1967) & 515 & 470 \\ \text { Stormer }(1983) & 508 & 463\end{array}$

Temp $\left({ }^{\circ} \mathrm{C}\right)$
5010

Temp $\left({ }^{\circ} \mathrm{C}\right)$
501

522
518

Temp $\left({ }^{\circ} \mathrm{C}\right)$
439

Temp $\left({ }^{\circ} \mathrm{C}\right)$

495

420

495

$\log 10 \mathrm{fO} 2$

$-23.11$

$\log 10 \mathrm{fO} 2$

$-21.60$

$\log 10 \mathrm{fO} 2$

$-25.81$

$\log 10 \mathrm{fO} 2$

$-23.59514$

$-21.66$

$-26.20$

$-23.27$

$-20.62$ 
Tabela A10. Continuação. Estimativas de $\mathrm{fO}_{2}$ a partir de cristais de magnetita e ilmenita de rochas do Plúton Piracaia

\begin{tabular}{|c|c|c|c|c|c|c|c|c|c|c|c|}
\hline $\begin{array}{l}\text { Mineral } \\
\text { Amostra / cristal } \\
\text { Unidade }\end{array}$ & $\begin{array}{l}\text { Ilmenita } \\
75 \mathrm{c} / 2 \\
M d f\end{array}$ & $\begin{array}{l}\text { Magnetita } \\
75 \mathrm{c} / 4 \\
M d f \\
\end{array}$ & $\begin{array}{l}\text { Ilmenita } \\
75 \mathrm{c} / 4 \\
M d f \\
\end{array}$ & $\begin{array}{l}\text { Magnetita } \\
75 \mathrm{c} / 7 \\
M d f \\
\end{array}$ & $\begin{array}{l}\text { Ilmenita } \\
75 \mathrm{c} / 7 \\
M d f \\
\end{array}$ & $\begin{array}{l}\text { Magnetita } \\
256 \mathrm{c} / 2 \\
M d r \\
\end{array}$ & $\begin{array}{l}\text { Ilmenita } \\
256 \mathrm{c} / 2 \\
M d r\end{array}$ & $\begin{array}{l}\text { Magnetita } \\
256 \mathrm{c} / 4 \\
M d r \\
\end{array}$ & $\begin{array}{l}\text { Ilmenita } \\
256 \mathrm{c} / 4 \\
M d r \\
\end{array}$ & $\begin{array}{l}\text { Magnetita } \\
256 \mathrm{c} 1 \\
M d r \\
\end{array}$ & $\begin{array}{l}\text { Ilmenita } \\
256 \mathrm{c} 1 \\
M d r\end{array}$ \\
\hline $\mathrm{TiO}_{2}$ & 49.59 & 0.10 & 48.96 & 0.28 & 49.48 & 0.39 & 50.12 & 0.06 & 52.33 & 0.43 & 49.23 \\
\hline $\mathrm{Al}_{2} \mathrm{O}_{3}$ & 0.10 & 0.26 & 0.02 & 0.13 & 0.00 & 0.16 & 0.01 & 0.20 & 0.07 & 0.08 & 0.04 \\
\hline $\mathrm{Fe}_{2} \mathrm{O}_{3}$ & 3.70 & 67.54 & 4.58 & 66.71 & 3.69 & 66.74 & 4.92 & 69.62 & 1.33 & 68.57 & 5.41 \\
\hline $\mathrm{FeO}$ & 41.15 & 30.77 & 40.76 & 30.88 & 39.63 & 30.81 & 40.57 & 31.49 & 43.92 & 31.61 & 40.01 \\
\hline $\mathrm{MnO}$ & 2.90 & 0.03 & 2.77 & 0.04 & 4.13 & 0.04 & 3.96 & 0.07 & 2.95 & 0.03 & 3.83 \\
\hline $\mathrm{MgO}$ & 0.35 & 0.01 & 0.25 & 0.10 & 0.13 & 0.00 & 0.25 & 0.03 & 0.09 & 0.00 & 0.23 \\
\hline $\mathrm{CaO}$ & 0.13 & 0.02 & 0.04 & 0.01 & 0.37 & 0.00 & 0.05 & 0.01 & 0.02 & 0.01 & 0.00 \\
\hline $\mathrm{ZnO}$ & 0.00 & 0.04 & 0.00 & 0.00 & 0.02 & 0.00 & 0.00 & 0.00 & 0.00 & 0.08 & 0.00 \\
\hline $\mathrm{NiO}$ & 0.00 & 0.00 & 0.00 & 0.00 & 0.01 & 0.00 & 0.00 & 0.02 & 0.00 & 0.01 & 0.00 \\
\hline $\mathrm{Nb}_{2} \mathrm{O}_{3}$ & 0.19 & 0.00 & 0.21 & 0.00 & 0.12 & 0.00 & 0.18 & 0.00 & 0.05 & 0.00 & 0.16 \\
\hline Total & 98.32 & 98.89 & 97.62 & 98.40 & 97.59 & 98.15 & 100.10 & 101.56 & 100.80 & 100.85 & 98.93 \\
\hline
\end{tabular}

Geotermobarômetro de Spencer \& Lindsley (1981)

$\begin{array}{lr}\text { X'Usp \& X'Ilm de: } & \text { Temp }\left({ }^{\circ} \mathrm{C}\right) \\ \text { Carmichael }(1967) & 492 \\ \text { Stormer }(1983) & 475\end{array}$

Temp $\left({ }^{\circ} \mathrm{C}\right)$
519
498

$\log 10 \mathrm{fO} 2$

$-22.13$

$-22.51$ $\log 10 \mathrm{fO} 2$

$-22.65$

$-22.92$
Temp $\left({ }^{\circ} \mathrm{C}\right)$

528

529

$\log 10 \mathrm{fO} 2$

$-21.19$

$-21.10$
Temp $\left({ }^{\circ} \mathrm{C}\right)$
399

383

$\log 10 \mathrm{fO} 2$

$-30.31$

$-31.15$

$-20.50$ 



\begin{tabular}{|c|c|c|c|c|c|c|c|c|c|c|}
\hline Amostra / Cristal & $270 / 8$ & $413 / 2$ & $413 / 5$ & $413 / 6$ & $257 / 3$ & $257 / 2$ & $400 / 1 \_1$ & $400 / 1 \_2$ & $\mathrm{Pi}-358 / 1$ & Pi-358 / 8 \\
\hline Unidade & Qsie & Qsie & Qsie & Qsie & $M d r$ & $M d r$ & $M h$ & $M h$ & $M d f$ & $M d f$ \\
\hline $\mathrm{SiO}_{2}$ & 0.01 & 0.03 & 0.02 & 0.03 & 0.02 & 0.03 & 0.02 & 0.05 & 0.01 & 0.12 \\
\hline $\mathrm{TiO}_{2}$ & 20.85 & 14.47 & 12.59 & 9.19 & 13.47 & 6.31 & 34.30 & 13.55 & 40.62 & 12.06 \\
\hline $\mathrm{Al} 2 \mathrm{O} 3$ & 0.04 & 0.03 & 0.03 & 0.06 & 0.20 & 0.17 & 0.03 & 0.07 & 0.03 & 0.10 \\
\hline $\mathrm{FeOt}$ & 71.09 & 76.75 & 79.32 & 83.58 & 81.13 & 86.75 & 59.17 & 80.55 & 52.00 & 80.24 \\
\hline $\mathrm{MnO}$ & 3.53 & 3.50 & 2.04 & 2.14 & 0.79 & 0.38 & 3.29 & 1.37 & 3.82 & 1.18 \\
\hline $\mathrm{MgO}$ & 0.04 & 0.01 & 0.00 & 0.03 & 0.09 & 0.06 & 0.05 & 0.01 & 0.08 & 0.01 \\
\hline $\mathrm{CaO}$ & 0.02 & 0.00 & 0.01 & 0.04 & 0.01 & 0.00 & 0.01 & 0.11 & 0.16 & 0.14 \\
\hline $\mathrm{Cr}_{2} \mathrm{O}_{3}$ & 0.00 & 0.00 & 0.01 & 0.00 & 0.01 & 0.01 & 0.00 & 0.03 & 0.02 & 0.11 \\
\hline $\mathrm{ZnO}$ & 0.02 & 0.00 & 0.09 & 0.03 & 0.00 & 0.03 & 0.00 & 0.02 & 0.00 & 0.03 \\
\hline $\mathrm{Nb}_{2} \mathrm{O}_{3}$ & 0.19 & 0.03 & 0.04 & 0.05 & 0.02 & 0.05 & 0.14 & 0.02 & 0.29 & 0.03 \\
\hline Total & 95.78 & 94.81 & 94.15 & 95.14 & 95.75 & 93.79 & 97.03 & 95.78 & 97.02 & 94.02 \\
\hline Carmichael (1967) & & & & & & & & & & \\
\hline $\mathrm{Fe}_{2} \mathrm{O}_{3}$ wt. $\%$ & 27.56 & 40.14 & 43.52 & 51.27 & 42.74 & 56.10 & 0.62 & 42.65 & -12.60 & 44.12 \\
\hline $\mathrm{FeO}$ wt. $\%$ & 46.28 & 40.63 & 40.15 & 37.44 & 42.67 & 36.27 & 58.61 & 42.17 & 63.34 & 40.54 \\
\hline Total: & 98.55 & 98.84 & 98.51 & 100.28 & 100.03 & 99.41 & 97.09 & 100.06 & 95.76 & 98.44 \\
\hline \multicolumn{11}{|c|}{ Fórmula estrutural calculada na base de 4 Oxigênios } \\
\hline Cátions & & & & & & & & & & \\
\hline $\mathrm{Si}$ & 0.001 & 0.001 & 0.001 & 0.001 & 0.001 & 0.001 & 0.001 & 0.002 & 0.000 & 0.005 \\
\hline $\mathrm{Ti}$ & 0.600 & 0.418 & 0.366 & 0.263 & 0.385 & 0.183 & 0.988 & 0.387 & 1.179 & 0.350 \\
\hline $\mathrm{Al}$ & 0.002 & 0.002 & 0.001 & 0.003 & 0.009 & 0.008 & 0.002 & 0.003 & 0.001 & 0.004 \\
\hline $\mathrm{Fe}+3$ & 0.794 & 1.160 & 1.265 & 1.468 & 1.220 & 1.624 & 0.018 & 1.218 & -0.366 & 1.282 \\
\hline $\mathrm{Fe}+2$ & 1.481 & 1.305 & 1.296 & 1.191 & 1.354 & 1.167 & 1.878 & 1.339 & 2.043 & 1.309 \\
\hline $\mathrm{Mn}$ & 0.115 & 0.114 & 0.067 & 0.069 & 0.025 & 0.012 & 0.107 & 0.044 & 0.125 & 0.039 \\
\hline $\mathrm{Mg}$ & 0.002 & 0.000 & 0.000 & 0.001 & 0.005 & 0.003 & 0.003 & 0.000 & 0.004 & 0.001 \\
\hline $\mathrm{Ca}$ & 0.001 & 0.000 & 0.001 & 0.001 & 0.000 & 0.000 & 0.001 & 0.005 & 0.007 & 0.006 \\
\hline $\mathrm{Cr}$ & 0.000 & 0.000 & 0.000 & 0.000 & 0.000 & 0.000 & 0.000 & 0.001 & 0.001 & 0.003 \\
\hline $\mathrm{Zn}$ & 0.000 & 0.000 & 0.003 & 0.001 & 0.000 & 0.001 & 0.000 & 0.001 & 0.000 & 0.001 \\
\hline $\mathrm{Nb}$ & 0.004 & 0.001 & 0.001 & 0.001 & 0.000 & 0.001 & 0.003 & 0.000 & 0.006 & 0.001 \\
\hline Total: & 3 & 3 & 3 & 3 & 3 & 3 & 3 & 3 & 3 & 3 \\
\hline \multicolumn{11}{|l|}{ Ulvosespinélio (\%) } \\
\hline Carmichael (1967) & 60.08 & 41.91 & 36.65 & 26.42 & 38.53 & 18.36 & 98.91 & 38.87 & 117.91 & 35.49 \\
\hline Stormer (1983) & 58.40 & 39.90 & 35.47 & 25.28 & 38.30 & 18.22 & 99.13 & 38.06 & 119.96 & 34.69 \\
\hline
\end{tabular}




\begin{tabular}{|c|c|c|c|c|c|}
\hline Amostra / Cristal & $\begin{array}{r}\mathrm{Pi}-75 / 2 \\
M d f\end{array}$ & $\begin{array}{r}\text { Pi-75 / } 7 \\
M d f\end{array}$ & $\begin{array}{r}256 / 1 \\
M d r\end{array}$ & $\begin{array}{r}256 / 2 \\
M d r\end{array}$ & $\begin{array}{r}256 / 4 \\
M d r\end{array}$ \\
\hline $\mathrm{SiO}_{2}$ & 0.02 & 0.18 & 0.01 & 0.00 & 0.02 \\
\hline $\mathrm{TiO}_{2}$ & 27.11 & 36.42 & 27.00 & 24.54 & 13.32 \\
\hline $\mathrm{Al} 2 \mathrm{O} 3$ & 0.11 & 0.50 & 0.05 & 0.11 & 0.15 \\
\hline $\mathrm{FeOt}$ & 67.15 & 55.26 & 68.39 & 69.00 & 81.64 \\
\hline $\mathrm{MnO}$ & 1.62 & 3.01 & 1.96 & 1.81 & 0.82 \\
\hline $\mathrm{MgO}$ & 0.13 & 0.13 & 0.11 & 0.11 & 0.04 \\
\hline $\mathrm{CaO}$ & 0.05 & 0.03 & 0.01 & 0.00 & 0.02 \\
\hline $\mathrm{Cr}_{2} \mathrm{O}_{3}$ & 0.01 & 0.01 & 0.02 & 0.00 & 0.02 \\
\hline $\mathrm{ZnO}$ & 0.01 & 0.05 & 0.03 & 0.00 & 0.00 \\
\hline $\mathrm{Nb}_{2} \mathrm{O}_{3}$ & 0.07 & 0.08 & 0.09 & 0.09 & 0.03 \\
\hline Total & 96.26 & 95.68 & 97.67 & 95.67 & 96.05 \\
\hline \multicolumn{6}{|l|}{ Carmichael (1967) } \\
\hline $\mathrm{Fe}_{2} \mathrm{O}_{3}$ wt. $\%$ & 14.940 & -5.719 & 16.248 & 19.835 & 43.281 \\
\hline FeO wt. \% & 53.702 & 60.411 & 53.770 & 51.151 & 42.695 \\
\hline Total: & 97.761 & 95.111 & 99.295 & 97.658 & 100.391 \\
\hline \multicolumn{6}{|l|}{ Cátions } \\
\hline $\mathrm{Si}$ & 0.001 & 0.007 & 0.000 & 0.000 & 0.001 \\
\hline $\mathrm{Ti}$ & 0.781 & 1.064 & 0.767 & 0.710 & 0.379 \\
\hline $\mathrm{Al}$ & 0.005 & 0.023 & 0.002 & 0.005 & 0.007 \\
\hline $\mathrm{Fe}+3$ & 0.430 & -0.167 & 0.461 & 0.574 & 1.232 \\
\hline $\mathrm{Fe}+2$ & 1.719 & 1.962 & 1.697 & 1.644 & 1.351 \\
\hline $\mathrm{Mn}$ & 0.052 & 0.099 & 0.063 & 0.059 & 0.026 \\
\hline $\mathrm{Mg}$ & 0.007 & 0.007 & 0.006 & 0.007 & 0.002 \\
\hline $\mathrm{Ca}$ & 0.002 & 0.001 & 0.000 & 0.000 & 0.001 \\
\hline $\mathrm{Cr}$ & 0.000 & 0.000 & 0.001 & 0.000 & 0.001 \\
\hline $\mathrm{Zn}$ & 0.000 & 0.001 & 0.001 & 0.000 & 0.000 \\
\hline $\mathrm{Nb}$ & 0.001 & 0.002 & 0.002 & 0.002 & 0.001 \\
\hline Total: & 3 & 3 & 3 & 3 & 3 \\
\hline \multicolumn{6}{|l|}{ Ulvosespinélio (\%) } \\
\hline Carmichael (1967) & 78.15 & 107.11 & 76.70 & 70.98 & 37.99 \\
\hline Stormer (1983) & 77.99 & 110.66 & 76.25 & 70.58 & 37.74 \\
\hline
\end{tabular}


Tabela A12. Estimativas de $f \mathrm{O}_{2}$ a partir de cristais reconstituídos de magnetita e ilmenita de rochas do Plúton Piracaia

\begin{tabular}{|c|c|c|c|c|c|c|c|c|c|c|}
\hline Mineral & Magnetita & Ilmenita & Magnetita & Ilmenita & Magnetita & Ilmenita & Magnetita & Ilmenita & Magnetita & Ilmenita \\
\hline Amostra / Cristal & Pi-358 / 8 & $\mathrm{Pi}-358$ / 3 & Pi-358 / 8 & $\mathrm{Pi}-358$ / 8 & $\mathrm{Pi}-358$ / 1 & Pi-358/ 3 & $\mathrm{Pi}-75$ / 2 & Pi-75 / 6 & Pi-75 / 7 & Pi-75 / 6 \\
\hline Unidade & $M d f$ & $M d f$ & $M d f$ & $M d f$ & $M d f$ & $M d f$ & $M d f$ & $M d f$ & $M d f$ & $M d f$ \\
\hline $\mathrm{SiO}_{2}$ & 0.12 & 0.01 & 0.12 & 0.30 & 0.01 & 0.01 & 0.02 & 0.00 & 0.18 & 0.00 \\
\hline $\mathrm{TiO}_{2}$ & 12.06 & 50.86 & 12.06 & 50.89 & 40.62 & 50.86 & 27.11 & 47.21 & 36.42 & 47.21 \\
\hline $\mathrm{Al}_{2} \mathrm{O}_{3}$ & 0.10 & 0.06 & 0.10 & 0.20 & 0.03 & 0.06 & 0.11 & 0.00 & 0.50 & 0.00 \\
\hline $\mathrm{Fe}_{2} \mathrm{O}_{3}$ & 44.12 & 3.88 & 44.12 & 2.32 & -12.60 & 3.88 & 14.94 & 8.89 & -5.72 & 8.89 \\
\hline $\mathrm{Cr}_{2} \mathrm{O}_{3}$ & 0.11 & 0.00 & 0.11 & 0.02 & 0.02 & 0.00 & 0.01 & 0.05 & 0.01 & 0.05 \\
\hline $\mathrm{FeO}$ & 40.54 & 42.09 & 40.54 & 40.69 & 63.34 & 42.09 & 53.70 & 39.81 & 60.41 & 39.81 \\
\hline $\mathrm{MnO}$ & 1.18 & 3.33 & 1.18 & 4.98 & 3.82 & 3.33 & 1.62 & 2.40 & 3.01 & 2.40 \\
\hline $\mathrm{MgO}$ & 0.01 & 0.14 & 0.01 & 0.00 & 0.08 & 0.14 & 0.13 & 0.10 & 0.13 & 0.10 \\
\hline $\mathrm{CaO}$ & 0.14 & 0.01 & 0.14 & 0.31 & 0.16 & 0.01 & 0.05 & 0.03 & 0.03 & 0.03 \\
\hline $\mathrm{ZnO}$ & 0.03 & 0.05 & 0.03 & 0.00 & 0.00 & 0.05 & 0.01 & 0.02 & 0.05 & 0.02 \\
\hline \multicolumn{11}{|l|}{$\mathrm{NiO}$} \\
\hline $\mathrm{Nb}_{2} \mathrm{O}_{3}$ & 0.03 & 0.52 & 0.03 & 0.14 & 0.29 & 0.52 & 0.07 & 0.21 & 0.08 & 0.21 \\
\hline Total & 98.44 & 100.94 & 98.44 & 99.85 & 95.76 & 100.94 & 97.76 & 98.71 & 95.11 & 98.71 \\
\hline \multicolumn{11}{|c|}{ Geotermobarômetro de Spencer \& Lindsley (1981) } \\
\hline X'Usp \& X'Ilm de: & Temp $\left({ }^{\circ} \mathrm{C}\right)$ & & Temp $\left({ }^{\circ} \mathrm{C}\right)$ & \multicolumn{2}{|r|}{ Temp $\left({ }^{\circ} \mathrm{C}\right)$} & \multicolumn{2}{|r|}{ Temp $\left({ }^{\circ} \mathrm{C}\right)$} & \multicolumn{3}{|c|}{ Temp $\left({ }^{\circ} \mathrm{C}\right)$} \\
\hline Carmichael (1967) & \multicolumn{2}{|l|}{639} & 563 & \multicolumn{2}{|r|}{-} & \multicolumn{2}{|r|}{1427.7} & \multicolumn{3}{|c|}{ - } \\
\hline Stormer (1983) & 626 & & 547 & & - & & 1430.1 & \multicolumn{3}{|c|}{-} \\
\hline \multicolumn{3}{|c|}{$\log 10 \mathrm{fO} 2$} & $\log 10 \mathrm{fO} 2$ & \multicolumn{2}{|r|}{$\log 10 \mathrm{fO} 2$} & \multicolumn{2}{|r|}{$\log 10 \mathrm{fO} 2$} & \multicolumn{3}{|c|}{$\log 10 \mathrm{fO} 2$} \\
\hline Carmichael (1967) & -19.70 & & -23.27 & \multicolumn{2}{|r|}{-} & \multicolumn{2}{|r|}{-6.30} & \multicolumn{3}{|c|}{-} \\
\hline Stormer (1983) & -20.22 & & -24.10 & \multicolumn{2}{|r|}{ - } & \multicolumn{2}{|r|}{-6.26} & \multicolumn{3}{|c|}{ - } \\
\hline
\end{tabular}

Campos com o símbolo ( - ) representam erro no cálculo 
Tabela A12. Estimativas de $\mathrm{fO}_{2}$ a partir de cristais reconstituídos de magnetita e ilmenita de rochas do Plúton Piracaia

\begin{tabular}{lrrrrrr}
\hline Mineral & Magnetita & Ilmenita & \multicolumn{3}{c}{ Magnetita } & Ilmenita \\
Amostra / Cristal & $256 / 1$ & $256 / 3$ & $256 / 2$ & $256 / 3$ & $256 / 4$ & $256 / 3$ \\
Unidade & $M d r$ & $M d r$ & $M d r$ & $M d r$ & $M d r$ & $M d r$ \\
\hline & & & & & & \\
$\mathrm{SiO}_{2}$ & 0.01 & 0.03 & 0.00 & 0.03 & 0.02 & 0.03 \\
$\mathrm{TiO}_{2}$ & 27.00 & 51.73 & 24.54 & 51.73 & 13.32 & 51.73 \\
$\mathrm{Al}_{2} \mathrm{O}_{3}$ & 0.05 & 0.04 & 0.11 & 0.04 & 0.15 & 0.04 \\
$\mathrm{Fe}_{2} \mathrm{O}_{3}$ & 31.70 & 2.25 & 19.84 & 2.25 & 43.28 & 2.25 \\
$\mathrm{Cr}_{2} \mathrm{O}_{3}$ & 0.02 & 0.00 & 0.00 & 0.00 & 0.02 & 0.00 \\
$\mathrm{FeO}$ & 60.72 & 42.38 & 51.15 & 42.38 & 42.70 & 42.38 \\
$\mathrm{MnO}$ & 1.96 & 3.62 & 1.81 & 3.62 & 0.82 & 3.62 \\
$\mathrm{MgO}$ & 0.11 & 0.23 & 0.11 & 0.23 & 0.04 & 0.23 \\
$\mathrm{CaO}$ & 0.01 & 0.04 & 0.00 & 0.04 & 0.02 & 0.04 \\
$\mathrm{ZnO}$ & 0.03 & 0.06 & 0.00 & 0.06 & 0.00 & 0.06 \\
$\mathrm{NiO}$ & & & & & & \\
$\mathrm{Nb}$ & 0.09 & 0.04 & 0.09 & 0.04 & 0.03 & 0.04 \\
$\mathrm{Total}$ & 121.70 & 100.42 & 97.66 & 100.42 & 100.39 & 100.42 \\
\hline
\end{tabular}

Geotermobarômetro de Spencer \& Lindsley (1981)

$\begin{array}{lrrr}\text { X'Usp \& X'Ilm de: } & \text { Temp }\left({ }^{\circ} \mathrm{C}\right) & \text { Temp }\left({ }^{\circ} \mathrm{C}\right) & \text { Temp }\left({ }^{\circ} \mathrm{C}\right) \\ \text { Carmichael }(1967) & 570 & 609 & 538 \\ \text { Stormer }(1983) & 569 & 609 & 539\end{array}$

Stormer (1983)

$\begin{array}{lrrr} & \log 10 \mathrm{fO} 2 & \log 10 \mathrm{fO} 2 & \log 10 \mathrm{fO} 2 \\ \text { Carmichael (1967) } & -23.56 & -22.31 & -24.62 \\ \text { Stormer (1983) } & -23.57 & -22.32 & -24.57\end{array}$

Campos com o símbolo ( - ) representam erro no cálculo 


\begin{abstract}
ANEXO 5
TABELAS DE MODELAMENTOS DE CRISTALIZAÇÃO FRACIONADA E DE MISTURA DE MAGMAS A PARTIR DE ELEMENTOS MAIORES
\end{abstract}


Tabela A13. Modelamento de cristalização fracionada para $M d f$ a partir elementos maiores

\begin{tabular}{|c|c|c|c|c|c|c|c|c|}
\hline \multicolumn{9}{|c|}{ MODELAMENTO DE CRISTALIZAÇÃO FRACIONADA } \\
\hline \multirow{2}{*}{\multicolumn{2}{|c|}{$\begin{array}{l}\text { Magma Inicial } \\
\text { PI-589B }\end{array}$}} & \multirow{2}{*}{$\begin{array}{l}\text { Magma Final } \\
\text { PI-75 }\end{array}$} & & \multicolumn{5}{|c|}{ Minerais Fracionados } \\
\hline & & & & Plag & $\mathrm{Cpx}$ & Magnetita & Apatita & biotita \\
\hline $\mathrm{SiO} 2$ & 46.99 & 52.36 & & 55.15 & 58.97 & 0.02 & 0.03 & 36.61 \\
\hline $\mathrm{TiO} 2$ & 2.75 & 1.71 & & 0.04 & 0.1 & 13.9 & 0 & 4.16 \\
\hline $\mathrm{A} 12 \mathrm{O} 3$ & 18.00 & 18.73 & & 28.58 & 0.96 & 0.16 & 0 & 16.21 \\
\hline FeOtot & 11.04 & 8.32 & & 0.03 & 0.19 & 85 & 0.32 & 17.67 \\
\hline $\mathrm{MnO}$ & 0.16 & 0.16 & & 0 & 0.78 & 0.86 & 0.02 & 0.2 \\
\hline $\mathrm{MgO}$ & 5.00 & 3.18 & & 0.01 & 12.42 & 0.04 & 0.05 & 13.38 \\
\hline $\mathrm{CaO}$ & 7.59 & 5.68 & & 10.37 & 25.99 & 0.02 & 56.24 & 2.21 \\
\hline $\mathrm{Na} 2 \mathrm{O}$ & 3.48 & 4.13 & & 5.7 & 0.59 & 0 & 0.04 & 0.06 \\
\hline $\mathrm{K} 2 \mathrm{O}$ & 3.51 & 4.73 & & 0.11 & 0 & 0 & 0.01 & 9.5 \\
\hline $\mathrm{P} 2 \mathrm{O} 5$ & 1.47 & 0.99 & & 0 & 0 & 0 & 43.29 & 0 \\
\hline TOTAL & 100 & 100 & & 100 & 100 & 100 & 100 & 100 \\
\hline \multicolumn{9}{|c|}{ RESULTADOS } \\
\hline & $\begin{array}{l}\text { Composição } \\
\text { subtraída }\end{array}$ & $\begin{array}{l}\text { Diferença observada } \\
\text { entre os magmas }\end{array}$ & $\begin{array}{c}\text { Diferença calculada } \\
\text { entre os magmas }\end{array}$ & \multicolumn{5}{|c|}{ Resíduo = Observado - Calculado } \\
\hline $\mathrm{SiO} 2$ & 42.19 & 5.37 & 5.33 & \multicolumn{5}{|c|}{0.04} \\
\hline $\mathrm{TiO} 2$ & 2.74 & -1.04 & -0.54 & \multicolumn{5}{|c|}{-0.50} \\
\hline $\mathrm{A} 12 \mathrm{O} 3$ & 17.55 & 0.73 & 0.62 & \multicolumn{5}{|c|}{0.11} \\
\hline FeOtot & 13.82 & -2.72 & -2.88 & \multicolumn{5}{|c|}{0.16} \\
\hline $\mathrm{MnO}$ & 0.24 & 0.00 & -0.04 & \multicolumn{5}{|c|}{0.04} \\
\hline $\mathrm{MgO}$ & 6.22 & -1.82 & -1.59 & \multicolumn{5}{|c|}{-0.23} \\
\hline $\mathrm{CaO}$ & 9.87 & -1.91 & -2.19 & \multicolumn{5}{|c|}{0.29} \\
\hline $\mathrm{Na} 2 \mathrm{O}$ & 2.40 & 0.65 & 0.90 & \multicolumn{5}{|c|}{-0.26} \\
\hline $\mathrm{K} 2 \mathrm{O}$ & 3.47 & 1.22 & 0.66 & \multicolumn{5}{|c|}{0.56} \\
\hline $\mathrm{P} 2 \mathrm{O} 5$ & 1.50 & -0.48 & -0.27 & \multicolumn{5}{|c|}{-0.21} \\
\hline \multicolumn{9}{|c|}{ Soma dos Quadrados dos Resíduos $=0.84$} \\
\hline Mineral & $\begin{array}{l}\text { Quantidade em relação } \\
\text { ao magma inicial (wt\%) }\end{array}$ & $\begin{array}{c}\text { Quantidade de } \\
\text { cada mineral (wt } \%)\end{array}$ & \multicolumn{6}{|l|}{$\begin{array}{l}\text { Quantidade em relação } \\
\text { às fases subtraídas (wt\%) }\end{array}$} \\
\hline Plag & -21.25 & 40.57 & \multicolumn{6}{|l|}{40.57} \\
\hline Cpx & -5.89 & 11.24 & 11.24 & & & & & \\
\hline Magnetita & -4.57 & 8.72 & 8.72 & & & & & \\
\hline Apatita & -1.81 & 3.47 & 3.47 & & & & & \\
\hline biotita & -18.85 & 36 & 36 & & & & & \\
\hline
\end{tabular}


Tabela A14. Modelamentos de elementos maiores para a geração de Monzonitos heterogêneos $(M h)$ por cristalização fracionada e mistura de magmas.

\begin{tabular}{|c|c|c|c|c|c|c|c|}
\hline \multirow[b]{3}{*}{ Amostra } & \multicolumn{7}{|c|}{ MODELAMENTO DE CRISTALIZAÇÃO FRACIONADA } \\
\hline & Magma Inicial & Magma Final & & & erais Fracior & & \\
\hline & PI-589B & PI-437C & Plag & $\mathrm{Cpx}$ & Magnetita & Apatita & biotita \\
\hline $\mathrm{SiO} 2$ & 46.99 & 55.66 & 55.15 & 58.97 & 0.02 & 0.03 & 36.61 \\
\hline $\mathrm{TiO} 2$ & 2.75 & 1.45 & 0.04 & 0.1 & 13.9 & 0 & 4.16 \\
\hline $\mathrm{Al} 2 \mathrm{O} 3$ & 18.00 & 17.00 & 28.58 & 0.96 & 0.16 & 0 & 16.21 \\
\hline FeOtot & 11.04 & 7.66 & 0.03 & 0.19 & 85 & 0.32 & 17.67 \\
\hline $\mathrm{MnO}$ & 0.16 & 0.14 & 0 & 0.78 & 0.86 & 0.02 & 0.2 \\
\hline $\mathrm{MgO}$ & 5.00 & 2.78 & 0.01 & 12.42 & 0.04 & 0.05 & 13.38 \\
\hline $\mathrm{CaO}$ & 7.59 & 5.85 & 10.37 & 25.99 & 0.02 & 56.24 & 2.21 \\
\hline $\mathrm{Na} 2 \mathrm{O}$ & 3.48 & 4.26 & 5.7 & 0.59 & 0 & 0.04 & 0.06 \\
\hline $\mathrm{K} 2 \mathrm{O}$ & 3.51 & 4.61 & 0.11 & 0 & 0 & 0.01 & 9.5 \\
\hline $\mathrm{P} 2 \mathrm{O} 5$ & 1.47 & 0.59 & 0 & 0 & 0 & 43.29 & 0 \\
\hline TOTAL & 100 & 100 & 100 & 100 & 100 & 100 & 100 \\
\hline
\end{tabular}

Composição Diferença observada Diferença calculada

Resíduo = Observado - Calculado

$\begin{array}{lcccc}\mathrm{SiO} 2 & 41.85 & 8.67 & 8.62 & 0.05 \\ \mathrm{TiO} 2 & 2.70 & -1.30 & -0.78 & -0.52 \\ \mathrm{Al} 2 \mathrm{O} 3 & 18.82 & -1.01 & -1.14 & 0.13 \\ \mathrm{FeOtot} & 13.36 & -3.38 & -3.56 & 0.18 \\ \mathrm{MnO} & 0.19 & -0.02 & -0.03 & 0.01 \\ \mathrm{MgO} & 5.98 & -2.22 & -2.00 & -0.22 \\ \mathrm{CaO} & 9.13 & -1.74 & -2.05 & 0.30 \\ \mathrm{Na} 2 \mathrm{O} & 2.54 & 0.78 & 1.07 & -0.29 \\ \mathrm{~K} 2 \mathrm{O} & 3.75 & 1.10 & 0.54 & 0.56 \\ \mathrm{P} 2 \mathrm{O} 5 & 1.67 & -0.89 & -0.68 & -0.21\end{array}$

Soma dos Quadrados dos Resíduos $=0.907$

Mineral Quantidade em relação Quantidade de Quantidade em relação ao magma inicial (wt\%) cada mineral (wt\%) às fases subtraídas (wt\%)

$\begin{array}{lrrr}\text { Plag } & -27.14 & 43.48 & 43.48 \\ \text { Cpx } & -3.81 & 6.1 & 6.1 \\ \text { Magnetita } & -4.72 & 7.57 & 7.57 \\ \text { Apatita } & -2.41 & 3.86 & 3.86 \\ \text { biotita } & -24.33 & 38.99 & 38.99\end{array}$

biotita- $-24.33 \quad 38.99 \quad 38.99$

Total em relação ao magma inicial $=62.41 \%$ 
Tabela A14. Cont. Modelamentos de elementos maiores para a geração de Monzonitos heterogêneos $(M h)$ por cristalização fracionada e mistura de magmas.

\begin{tabular}{lccc}
\hline & \multicolumn{3}{c}{ MODELAMENTO DE MISTURA } \\
\hline & Magma inicial & ma final (híbgma adicionado \\
& PI-589B & PI-437C & PI-602 \\
$\mathrm{SiO} 2$ & 46.99 & 55.66 & 60.54 \\
$\mathrm{TiO} 2$ & 2.75 & 1.45 & 0.92 \\
$\mathrm{Al2O} 3$ & 18.00 & 17.00 & 18.09 \\
$\mathrm{FeOtot}$ & 11.04 & 7.66 & 5.06 \\
$\mathrm{MnO}$ & 0.16 & 0.14 & 0.15 \\
$\mathrm{MgO}$ & 5.00 & 2.78 & 0.89 \\
$\mathrm{CaO}$ & 7.59 & 5.85 & 2.37 \\
$\mathrm{Na} 2 \mathrm{O}$ & 3.48 & 4.26 & 4.99 \\
$\mathrm{~K} 2 \mathrm{O}$ & 3.51 & 4.61 & 6.7 \\
$\mathrm{P} 2 \mathrm{O5}$ & 1.47 & 0.59 & 0.3 \\
TOTAL & 100 & 100 & 100 \\
\hline \multicolumn{1}{c}{ RESULTADOS } & & \\
\hline
\end{tabular}

RESULTADOS

$\begin{array}{cl}\text { Composição } & \text { Diferença ol Diferença calculada } \\ \text { adicionada } & \text { entre os maş entre os magmas }\end{array}$

Resíduo = Observado - Calculado

$\begin{array}{lcccc}\text { OXIDE } & \text { adicionada } & \text { entre os mą̧ entre os magmas } & \\ \mathrm{SiO} 2 & 60.54 & 8.67 & 5.93 & 2.74 \\ \mathrm{TiO} 2 & 0.92 & -1.30 & -0.64 & -0.65 \\ \mathrm{Al2O} 3 & 18.09 & -1.01 & 1.32 & -2.33 \\ \mathrm{FeOtot} & 5.06 & -3.38 & -3.16 & -0.21 \\ \mathrm{MnO} & 0.15 & -0.02 & 0.01 & -0.03 \\ \mathrm{MgO} & 0.90 & -2.22 & -2.29 & 0.07 \\ \mathrm{CaO} & 2.37 & -1.74 & -4.23 & 2.49 \\ \mathrm{Na} 2 \mathrm{O} & 4.99 & 0.78 & 0.89 & -0.11 \\ \mathrm{~K} 2 \mathrm{O} & 6.70 & 1.10 & 2.54 & -1.44 \\ \mathrm{P} 2 \mathrm{O} 5 & 0.30 & -0.89 & -0.35 & -0.53\end{array}$

Soma dos Quadrados dos resíduos $=21.9709$
Fase
Quantidade em relação
Quantidade Quantidade de fases
(magma)
ao magma inicial (wt\%)
as fases (wt' adicionadas (wt \%)
PI-602
121.65
100
100

Total em relação ao magma inicial $=121.65 \%$ 
Tabela A15. Modelamentos de elementos maiores para a geração de quarto monzonitos (Qsie) por cristalização fracionada e mistura de magmas

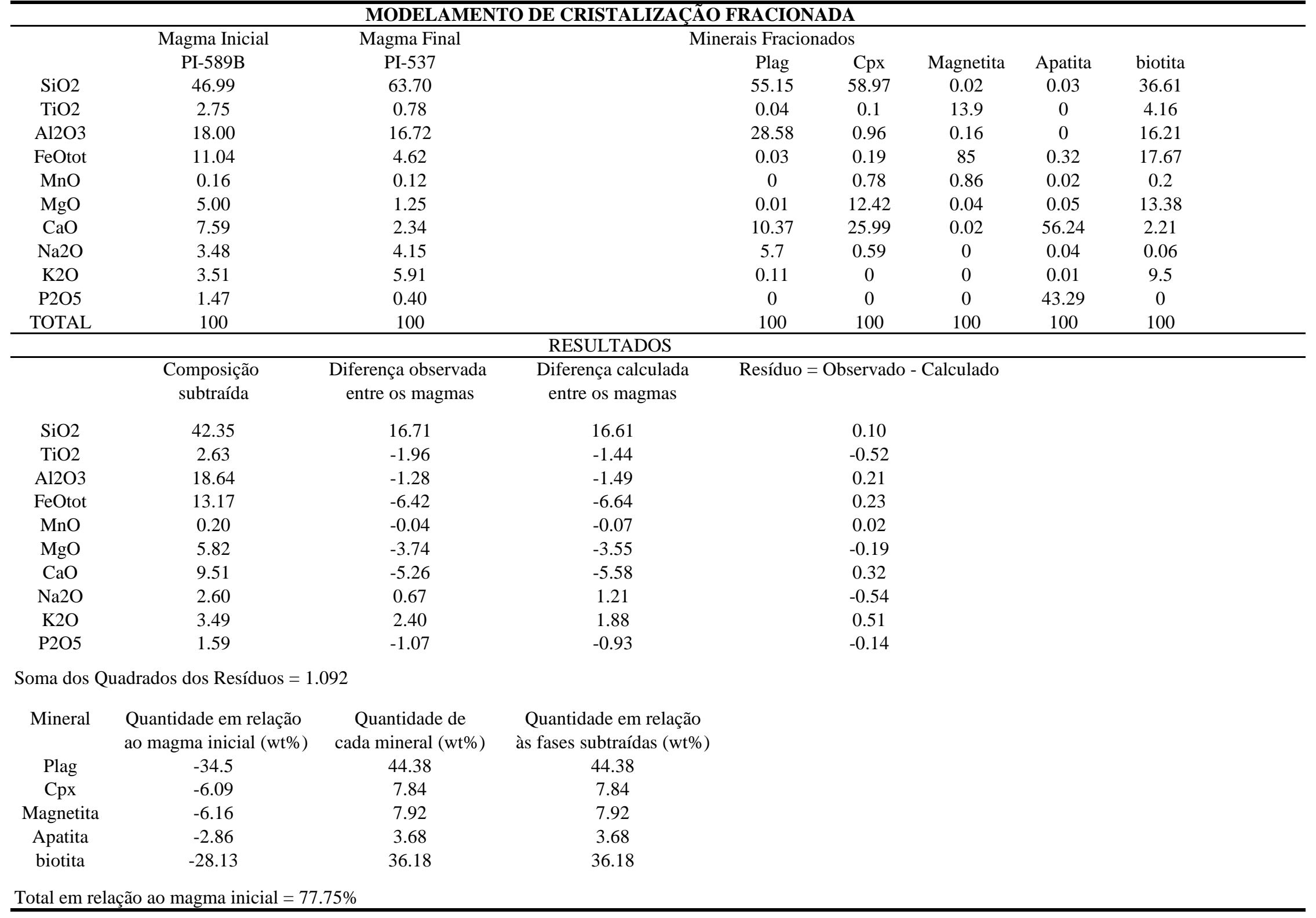


Tabela A15.Cont. Modelamentos de elementos maiores para a geração de quarto monzonitos (Qsie) por cristalização fracionada e mistura de magmas

\begin{tabular}{|c|c|c|c|c|}
\hline \multicolumn{5}{|c|}{ MODELAMENTO DE MISTURA DE MAGMAS } \\
\hline & Magma inicial & Magma final & Magma adicionado & \\
\hline & PI-589B & PI-537 & PI-410 & \\
\hline $\mathrm{SiO} 2$ & 46.99 & 63.70 & 68.39 & \\
\hline $\mathrm{TiO} 2$ & 2.75 & 0.78 & 0.38 & \\
\hline $\mathrm{Al} 2 \mathrm{O} 3$ & 18.00 & 16.72 & 15.95 & \\
\hline FeOtot & 11.04 & 4.62 & 2.92 & \\
\hline $\mathrm{MnO}$ & 0.16 & 0.12 & 0.10 & \\
\hline $\mathrm{MgO}$ & 5.00 & 1.25 & 0.31 & \\
\hline $\mathrm{CaO}$ & 7.59 & 2.34 & 1.08 & \\
\hline $\mathrm{Na} 2 \mathrm{O}$ & 3.48 & 4.15 & 4.45 & \\
\hline $\mathrm{K} 2 \mathrm{O}$ & 3.51 & 5.91 & 6.33 & \\
\hline $\mathrm{P} 2 \mathrm{O} 5$ & 1.47 & 0.40 & 0.09 & \\
\hline TOTAL & 100 & 100 & 100 & \\
\hline \multicolumn{5}{|c|}{ RESULTADOS } \\
\hline & $\begin{array}{c}\text { Composição } \\
\text { adicionada }\end{array}$ & $\begin{array}{c}\text { Diferença observada } \\
\text { entre os magmas }\end{array}$ & $\begin{array}{c}\text { Diferença calculada } \\
\text { entre os magmas }\end{array}$ & Resíduo = Observado - Calculado \\
\hline $\mathrm{SiO} 2$ & 68.39 & 16.71 & 16.92 & -0.21 \\
\hline $\mathrm{TiO} 2$ & 0.39 & -1.96 & -1.44 & -0.53 \\
\hline $\mathrm{A} 12 \mathrm{O} 3$ & 15.95 & -1.28 & -2.78 & 1.50 \\
\hline FeOtot & 2.92 & -6.42 & -6.14 & -0.28 \\
\hline $\mathrm{MnO}$ & 0.10 & -0.04 & -0.07 & 0.03 \\
\hline $\mathrm{MgO}$ & 0.32 & -3.74 & -3.39 & -0.35 \\
\hline $\mathrm{CaO}$ & 1.08 & -5.26 & -4.55 & -0.71 \\
\hline $\mathrm{Na} 2 \mathrm{O}$ & 4.45 & 0.67 & 1.06 & -0.39 \\
\hline $\mathrm{K} 2 \mathrm{O}$ & 6.34 & 2.40 & 1.55 & 0.85 \\
\hline $\mathrm{P} 2 \mathrm{O} 5$ & 0.09 & -1.07 & -1.15 & 0.08 \\
\hline
\end{tabular}

Soma dos Quadrados dos Resíduos = 4.153
Fase Quantidade em relação
Quantidade de todas
Quantidade de fases
(magma) ao magma inicial (wt\%)
as fases (wt $\%)$
adicionadas (wt\%)
PI-410
100

360.96

100

Total em relação ao magma inicial $=360.96 \%$ 
Tabela A16. Modelamentos de elementos maiores para a geração de monzonitos $(M d f)$ por cristalização fracionada e mistura de magmas

\begin{tabular}{|c|c|c|c|c|c|c|c|c|}
\hline \multicolumn{9}{|c|}{ MODELAMENTO DE CRISTALIZAÇÃO FRACIONADA } \\
\hline & \multirow{2}{*}{$\begin{array}{l}\text { Magma Inicial } \\
\text { PI-589B }\end{array}$} & \multirow{2}{*}{$\begin{array}{l}\text { Magma Final } \\
\text { PI-614 }\end{array}$} & & \multicolumn{4}{|c|}{ Minerais Fracionados } & \multirow[b]{2}{*}{ biotita } \\
\hline & & & & Plag & Cpx & Magnetita & Apatita & \\
\hline $\mathrm{SiO} 2$ & 46.99 & 56.32 & & 55.15 & 58.97 & 0.02 & 0.03 & 36.61 \\
\hline $\mathrm{TiO} 2$ & 2.75 & 1.58 & & 0.04 & 0.1 & 13.9 & 0 & 4.16 \\
\hline $\mathrm{Al} 2 \mathrm{O} 3$ & 18.00 & 17.38 & & 28.58 & 0.96 & 0.16 & 0 & 16.21 \\
\hline FeOtot & 11.04 & 7.20 & & 0.03 & 0.19 & 85 & 0.32 & 17.67 \\
\hline $\mathrm{MnO}$ & 0.16 & 0.14 & & 0 & 0.78 & 0.86 & 0.02 & 0.2 \\
\hline $\mathrm{MgO}$ & 5.00 & 2.70 & & 0.01 & 12.42 & 0.04 & 0.05 & 13.38 \\
\hline $\mathrm{CaO}$ & 7.59 & 4.81 & & 10.37 & 25.99 & 0.02 & 56.24 & 2.21 \\
\hline $\mathrm{Na} 2 \mathrm{O}$ & 3.48 & 4.24 & & 5.7 & 0.59 & 0 & 0.04 & 0.06 \\
\hline $\mathrm{K} 2 \mathrm{O}$ & 3.51 & 4.69 & & 0.11 & 0 & 0 & 0.01 & 9.5 \\
\hline P2O5 & 1.47 & 0.93 & & 0 & 0 & 0 & 43.29 & 0 \\
\hline \multirow[t]{3}{*}{ TOTAL } & 100 & 100 & & 100 & 100 & 100 & 100 & 100 \\
\hline & & & RESULTADOS & & & & & \\
\hline & $\begin{array}{l}\text { Composição } \\
\text { subtraída }\end{array}$ & $\begin{array}{c}\text { Diferença observada } \\
\text { entre os magmas }\end{array}$ & $\begin{array}{c}\text { Diferença calculada } \\
\text { entre os magmas }\end{array}$ & & Resíduo & Observado - & Calculado & \\
\hline $\mathrm{SiO} 2$ & 42.14 & 9.33 & 9.24 & & & 0.10 & & \\
\hline $\mathrm{TiO} 2$ & 2.68 & -1.16 & -0.71 & & & -0.45 & & \\
\hline $\mathrm{A} 12 \mathrm{O} 3$ & 18.52 & -0.62 & -0.74 & & & 0.12 & & \\
\hline FeOtot & 13.36 & -3.84 & -4.02 & & & 0.18 & & \\
\hline $\mathrm{MnO}$ & 0.21 & -0.02 & -0.04 & & & 0.02 & & \\
\hline $\mathrm{MgO}$ & 5.94 & -2.30 & -2.11 & & & -0.19 & & \\
\hline $\mathrm{CaO}$ & 9.43 & -2.78 & -3.01 & & & 0.23 & & \\
\hline $\mathrm{Na} 2 \mathrm{O}$ & 2.55 & 0.76 & 1.11 & & & -0.34 & & \\
\hline $\mathrm{K} 2 \mathrm{O}$ & 3.58 & 1.18 & 0.72 & & & 0.45 & & \\
\hline $\mathrm{P} 2 \mathrm{O} 5$ & 1.60 & -0.54 & -0.44 & & & -0.10 & & \\
\hline \multicolumn{9}{|c|}{ Soma dos Quadrados dos Resíduos $=0.67$} \\
\hline Mineral & $\begin{array}{l}\text { Quantidade em relação } \\
\text { ao magma inicial (wt\%) }\end{array}$ & $\begin{array}{c}\text { Quantidade de } \\
\text { cada mineral (wt\%) }\end{array}$ & $\begin{array}{l}\text { Quantidade em relação } \\
\text { às fases subtraídas (wt\%) }\end{array}$ & & & & & \\
\hline Plag & -28.3 & 43.43 & 43.43 & & & & & \\
\hline Cpx & -5.07 & 7.78 & 7.78 & & & & & \\
\hline Magnetita & -5.18 & 7.95 & 7.95 & & & & & \\
\hline Apatita & -2.41 & 3.71 & 3.71 & & & & & \\
\hline biotita & -24.2 & 37.13 & 37.13 & & & & & \\
\hline
\end{tabular}


Tabela A16. Cont. Modelamentos de elementos maiores para a geração de monzonitos $(M d f)$ por cristalização fracionada e mistura de magmas

\begin{tabular}{|c|c|c|c|c|}
\hline \multicolumn{5}{|c|}{ MODELAMENTO DE MISTURA DE MAGMAS } \\
\hline & Magma inicial & Magma final & Magma adicionado & \\
\hline & PI-589B & PI-614 & PI-410 & \\
\hline $\mathrm{SiO} 2$ & 46.99 & 56.32 & 68.39 & \\
\hline $\mathrm{TiO} 2$ & 2.75 & 1.58 & 0.38 & \\
\hline $\mathrm{A} 12 \mathrm{O} 3$ & 18.00 & 17.38 & 15.95 & \\
\hline FeOtot & 11.04 & 7.20 & 2.92 & \\
\hline $\mathrm{MnO}$ & 0.16 & 0.14 & 0.10 & \\
\hline $\mathrm{MgO}$ & 5.00 & 2.70 & 0.31 & \\
\hline $\mathrm{CaO}$ & 7.59 & 4.81 & 1.08 & \\
\hline $\mathrm{Na} 2 \mathrm{O}$ & 3.48 & 4.24 & 4.45 & \\
\hline $\mathrm{K} 2 \mathrm{O}$ & 3.51 & 4.69 & 6.33 & \\
\hline $\mathrm{P} 2 \mathrm{O} 5$ & 1.47 & 0.93 & 0.09 & \\
\hline TOT & 100 & 100 & 100 & \\
\hline \multicolumn{5}{|c|}{ RESULTADOS } \\
\hline & $\begin{array}{c}\text { Composição } \\
\text { adicionada }\end{array}$ & $\begin{array}{c}\text { Diferença observada } \\
\text { entre os magmas }\end{array}$ & $\begin{array}{l}\text { Diferença calculada } \\
\text { entre os magmas }\end{array}$ & Resíduo = Observado - Calculado \\
\hline $\mathrm{SiO} 2$ & 68.39 & 9.33 & 9.48 & -0.16 \\
\hline $\mathrm{TiO} 2$ & 0.39 & -1.16 & -0.94 & -0.22 \\
\hline $\mathrm{A} 12 \mathrm{O} 3$ & 15.95 & -0.62 & -1.12 & 0.50 \\
\hline FeOtot & 2.92 & -3.84 & -3.36 & -0.48 \\
\hline $\mathrm{MnO}$ & 0.10 & -0.02 & -0.03 & 0.02 \\
\hline $\mathrm{MgO}$ & 0.32 & -2.30 & -1.88 & -0.42 \\
\hline $\mathrm{CaO}$ & 1.08 & -2.78 & -2.93 & 0.15 \\
\hline $\mathrm{Na} 2 \mathrm{O}$ & 4.45 & 0.76 & 0.16 & 0.61 \\
\hline $\mathrm{K} 2 \mathrm{O}$ & 6.34 & 1.18 & 1.29 & -0.12 \\
\hline $\mathrm{P} 2 \mathrm{O} 5$ & 0.09 & -0.54 & -0.67 & 0.13 \\
\hline
\end{tabular}

Soma dos Quadrados dos Resíduos = 1.15
Fase Quantidade em relação
Quantidade de todas as fases (wt\%)
Quantidade de fases (magma) ao magma inicial (wt\%)
100 adicionadas (wt $\%$ )
PI-410$$
78.54
$$$$
100
$$$$
100
$$

Total em relação ao magma inicial $=78.54 \%$ 
Tabela A17. Modelamentos de elementos maiores para a geração de Sienitos (Sie) e quartzo sienitos (Qsie) por cristalização fracionada.

\begin{tabular}{|c|c|c|c|c|c|c|c|c|}
\hline \multicolumn{9}{|c|}{ MODELAMENTO DE CRISTALIZAÇÃO FRACIONADA } \\
\hline & Magma Inicial & Magma Final & & \multicolumn{5}{|c|}{ Minerais Fracionados } \\
\hline & PI-589B & PI-602 & & Plag & $\mathrm{Cpx}$ & Magnetita & Apatita & biotita \\
\hline $\mathrm{SiO} 2$ & 46.99 & 60.54 & & 55.15 & 58.97 & 0.02 & 0.03 & 36.61 \\
\hline $\mathrm{TiO} 2$ & 2.75 & 0.92 & & 0.04 & 0.1 & 13.9 & 0 & 4.16 \\
\hline $\mathrm{Al} 2 \mathrm{O} 3$ & 18.00 & 18.09 & & 28.58 & 0.96 & 0.16 & 0 & 16.21 \\
\hline FeOtot & 11.04 & 5.06 & & 0.03 & 0.19 & 85 & 0.32 & 17.67 \\
\hline $\mathrm{MnO}$ & 0.16 & 0.15 & & 0 & 0.78 & 0.86 & 0.02 & 0.2 \\
\hline $\mathrm{MgO}$ & 5.00 & 0.89 & & 0.01 & 12.42 & 0.04 & 0.05 & 13.38 \\
\hline $\mathrm{CaO}$ & 7.59 & 2.37 & & 10.37 & 25.99 & 0.02 & 56.24 & 2.21 \\
\hline $\mathrm{Na} 2 \mathrm{O}$ & 3.48 & 4.99 & & 5.7 & 0.59 & 0 & 0.04 & 0.06 \\
\hline $\mathrm{K} 2 \mathrm{O}$ & 3.51 & 6.70 & & 0.11 & 0 & 0 & 0.01 & 9.5 \\
\hline $\mathrm{P} 2 \mathrm{O} 5$ & 1.47 & 0.30 & & 0 & 0 & 0 & 43.29 & 0 \\
\hline TOTAL & 100 & 100 & & 100 & 100 & 100 & 100 & 100 \\
\hline \multicolumn{9}{|c|}{ RESULTADOS } \\
\hline & $\begin{array}{l}\text { Composição } \\
\text { subtraída }\end{array}$ & $\begin{array}{l}\text { Diferença observada } \\
\text { entre os magmas }\end{array}$ & $\begin{array}{l}\text { Diferença calculada } \\
\text { entre os magmas }\end{array}$ & \multicolumn{5}{|c|}{ Resíduo = Observado - Calculado } \\
\hline $\mathrm{SiO} 2$ & 42.73 & 13.54 & 13.52 & \multicolumn{5}{|c|}{0.02} \\
\hline $\mathrm{TiO} 2$ & 2.62 & -1.83 & -1.29 & \multicolumn{5}{|c|}{-0.53} \\
\hline $\mathrm{A} 12 \mathrm{O} 3$ & 18.19 & 0.08 & -0.08 & \multicolumn{5}{|c|}{0.16} \\
\hline FeOtot & 13.17 & -5.98 & -6.16 & \multicolumn{5}{|c|}{0.18} \\
\hline $\mathrm{MnO}$ & 0.22 & -0.02 & -0.06 & \multicolumn{5}{|c|}{0.04} \\
\hline $\mathrm{MgO}$ & 5.95 & -4.10 & -3.84 & \multicolumn{5}{|c|}{-0.27} \\
\hline $\mathrm{CaO}$ & 9.76 & -5.22 & -5.61 & \multicolumn{5}{|c|}{0.39} \\
\hline $\mathrm{Na} 2 \mathrm{O}$ & 2.56 & 1.51 & 1.85 & \multicolumn{5}{|c|}{-0.34} \\
\hline $\mathrm{K} 2 \mathrm{O}$ & 3.38 & 3.19 & 2.53 & \multicolumn{5}{|c|}{0.66} \\
\hline $\mathrm{P} 2 \mathrm{O} 5$ & 1.42 & -1.18 & -0.86 & \multicolumn{5}{|c|}{-0.32} \\
\hline \multicolumn{9}{|c|}{ Soma dos Quadrados dos Resíduos $=1.22$} \\
\hline Mineral & $\begin{array}{l}\text { Quantidade em relação } \\
\text { ao magma inicial (wt\%) }\end{array}$ & $\begin{array}{c}\text { Quantidade de } \\
\text { cada mineral (wt } \%)\end{array}$ & $\begin{array}{l}\text { Quantidade em relação } \\
\text { às fases subtraídas (wt\%) }\end{array}$ & & & & & \\
\hline Plag & -33.0 & 43.4 & 43.4 & & & & & \\
\hline $\mathrm{Cpx}$ & -7.7 & 10.1 & 10.1 & & & & & \\
\hline Magnetita & -6.2 & 8.2 & 8.2 & & & & & \\
\hline Apatita & -2.5 & 3.3 & 3.3 & & & & & \\
\hline biotita & -26.6 & 35.0 & 35.0 & & & & & \\
\hline
\end{tabular}


Tabela A17. Continuação. Modelamentos de elementos maiores para a geração de Sienitos (Sie) e quartzo sienitos (Qsie) por cristalização fracionada

\begin{tabular}{|c|c|c|c|c|c|c|c|c|}
\hline \multicolumn{9}{|c|}{ MODELAMENTO DE CRISTALIZAÇÃO FRACIONADA } \\
\hline & \multirow{2}{*}{$\begin{array}{l}\text { Magma Inicial } \\
\text { PI-589B }\end{array}$} & \multirow{2}{*}{$\begin{array}{l}\text { Magma Final } \\
\text { PI-410 }\end{array}$} & & \multicolumn{4}{|c|}{ Minerais Fracionados } & \multirow[b]{2}{*}{ biotita } \\
\hline & & & & Plag & $\mathrm{Cpx}$ & Magnetita & Apatita & \\
\hline $\mathrm{SiO} 2$ & 46.99 & 68.39 & & 55.15 & 58.97 & 0.02 & 0.03 & 36.61 \\
\hline $\mathrm{TiO} 2$ & 2.75 & 0.38 & & 0.04 & 0.1 & 13.9 & 0 & 4.16 \\
\hline $\mathrm{Al} 2 \mathrm{O} 3$ & 18.00 & 15.95 & & 28.58 & 0.96 & 0.16 & 0 & 16.21 \\
\hline FeOtot & 11.04 & 2.92 & & 0.03 & 0.19 & 85 & 0.32 & 17.67 \\
\hline $\mathrm{MnO}$ & 0.16 & 0.10 & & 0 & 0.78 & 0.86 & 0.02 & 0.2 \\
\hline $\mathrm{MgO}$ & 5.00 & 0.31 & & 0.01 & 12.42 & 0.04 & 0.05 & 13.38 \\
\hline $\mathrm{CaO}$ & 7.59 & 1.08 & & 10.37 & 25.99 & 0.02 & 56.24 & 2.21 \\
\hline $\mathrm{Na} 2 \mathrm{O}$ & 3.48 & 4.45 & & 5.7 & 0.59 & 0 & 0.04 & 0.06 \\
\hline $\mathrm{K} 2 \mathrm{O}$ & 3.51 & 6.33 & & 0.11 & 0 & 0 & 0.01 & 9.5 \\
\hline $\mathrm{P} 2 \mathrm{O} 5$ & 1.47 & 0.09 & & 0 & 0 & 0 & 43.29 & 0 \\
\hline \multirow[t]{3}{*}{ TOTAL } & 100 & 100 & & 100 & 100 & 100 & 100 & 100 \\
\hline & & & RESULTADOS & & & & & \\
\hline & $\begin{array}{l}\text { Composição } \\
\text { subtraída }\end{array}$ & $\begin{array}{l}\text { Diferença observada } \\
\text { entre os magmas }\end{array}$ & $\begin{array}{c}\text { Diferença calculada } \\
\text { entre os magmas }\end{array}$ & & \multicolumn{3}{|c|}{ Resíduo = Observado - Calculado } & \\
\hline $\mathrm{SiO} 2$ & 42.32 & 21.40 & 21.29 & & & 0.10 & & \\
\hline $\mathrm{TiO} 2$ & 2.63 & -2.36 & -1.84 & & & -0.53 & & \\
\hline $\mathrm{A} 12 \mathrm{O} 3$ & 18.72 & -2.06 & -2.26 & & & 0.21 & & \\
\hline FeOtot & 13.14 & -8.12 & -8.35 & & & 0.23 & & \\
\hline $\mathrm{MnO}$ & 0.20 & -0.06 & -0.08 & & & 0.02 & & \\
\hline $\mathrm{MgO}$ & 5.81 & -4.68 & -4.49 & & & -0.19 & & \\
\hline $\mathrm{CaO}$ & 9.45 & -6.52 & -6.84 & & & 0.33 & & \\
\hline $\mathrm{Na} 2 \mathrm{O}$ & 2.61 & 0.97 & 1.50 & & & -0.54 & & \\
\hline $\mathrm{K} 2 \mathrm{O}$ & 3.51 & 2.82 & 2.30 & & & 0.52 & & \\
\hline $\mathrm{P} 2 \mathrm{O} 5$ & 1.61 & -1.39 & -1.24 & & & -0.15 & & \\
\hline \multicolumn{9}{|c|}{ Soma dos Quadrados dos Resíduos $=1.10$} \\
\hline Mineral & $\begin{array}{l}\text { Quantidade em relação } \\
\text { ao magma inicial (wt\%) }\end{array}$ & $\begin{array}{c}\text { Quantidade de } \\
\text { cada mineral (wt } \%)\end{array}$ & $\begin{array}{l}\text { Quantidade em relação } \\
\text { às fases subtraídas (wt\%) }\end{array}$ & & & & & \\
\hline Plag & -36.4 & 44.5 & 44.5 & & & & & \\
\hline Cpx & -6.1 & 7.5 & 7.5 & & & & & \\
\hline Magnetita & -6.4 & 7.8 & 7.8 & & & & & \\
\hline Apatita & -3.0 & 3.7 & 3.7 & & & & & \\
\hline biotita & -29.8 & 36.4 & 36.4 & & & & & \\
\hline
\end{tabular}




\begin{abstract}
ANEXO 6
MAPA COM A LOCALIZAÇÃO DOS PONTOS COM ANÁLISES DE QUÍMICA MINERAL E QUÍMICA ROCHA TOTAL
\end{abstract}




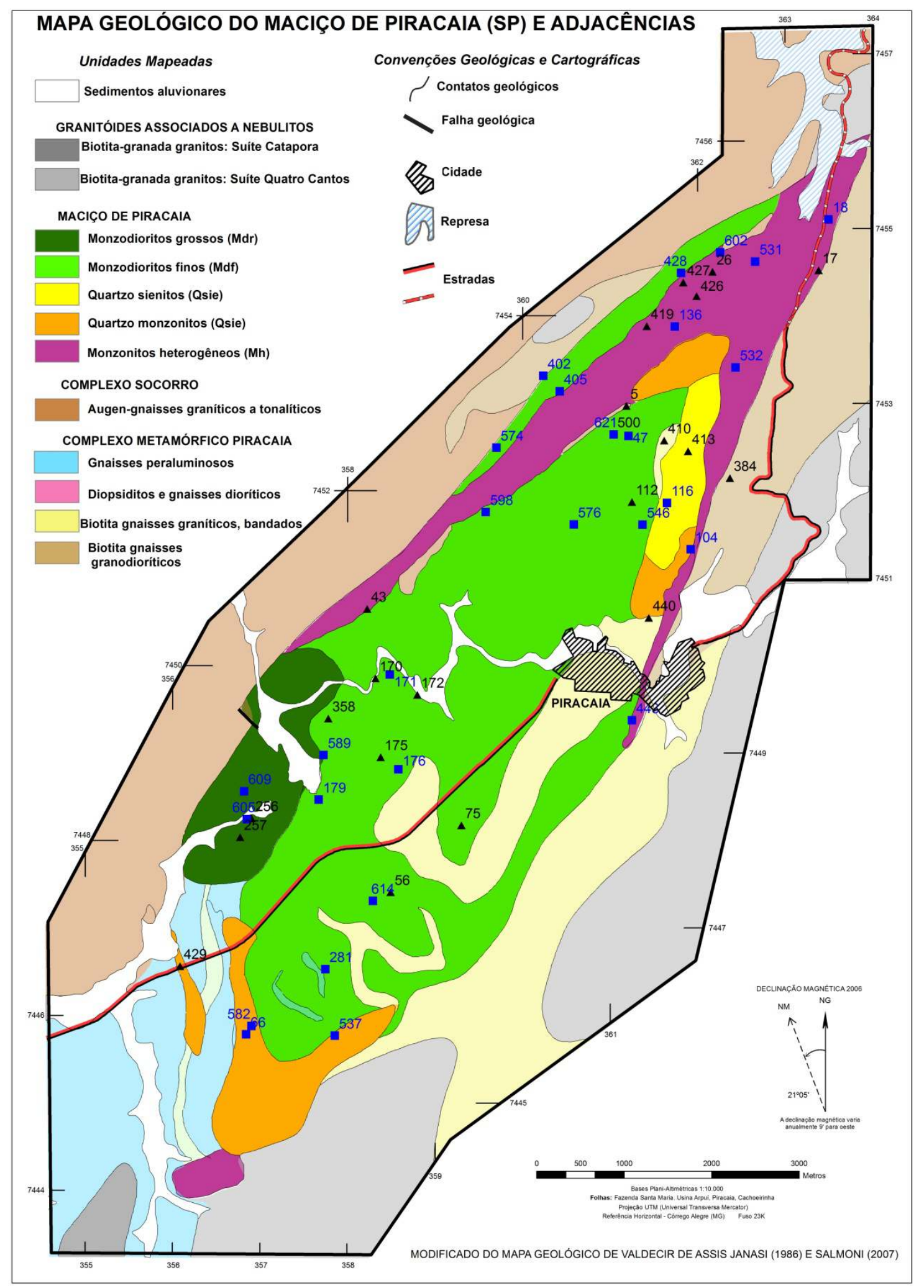

Figura A01. Mapa com a localização dos pontos com análises de química mineral e química de rocha total. Os triângulos pretos representam os pontos com análises de química mineral e rocha total, e os quadrados em azul os pontos apenas com análises químicas de rocha total. 